UNIVERSIDADE DE SÃO PAULO

FACULDADE DE FILOSOFIA, LETRAS E CIÊNCIAS HUMANAS

DEPARTAMENTO DE LETRAS CLÁSSICAS E VERNÁCULAS

PROGRAMA DE FILOLOGIA E LÍNGUA PORTUGUESA

\title{
SINTATICIZAÇÃO, DISCURSIVIZAÇÃO E SEMANTICIZAÇÃO DAS ORAÇÕES DE GERÚNDIO NO PORTUGUÊS BRASILEIRO
}

José da Silva Simões

\begin{abstract}
Tese apresentada ao Programa de Pós-Graduação em Filologia e Língua Portuguesa, do Departamento de Letras Clássicas e Vernáculas da Faculdade de Filosofia, Letras e Ciências Humanas da Universidade de São Paulo, para obtenção do título de Doutor em Letras.
\end{abstract}

Orientador: Prof. Dr. Ataliba Teixeira de Castilho 
UNIVERSIDADE DE SÃO PAULO

FACULDADE DE FILOSOFIA, LETRAS E CIÊNCIAS HUMANAS

DEPARTAMENTO DE LETRAS CLÁSSICAS E VERNÁCULAS PROGRAMA FILOLOGIA E LÍNGUA PORTUGUESA

\title{
SINTATICIZAÇÃO, DISCURSIVIZAÇÃO E SEMANTICIZAÇÃO DAS ORAÇÕES DE GERÚNDIO NO PORTUGUÊS BRASILEIRO
}

\author{
José da Silva Simões
}

Vol. I

São Paulo 


\section{DEDICATÓRIA}

Dedico este trabalho à memória de meus pais, Antonio Gama Simões e Deolinda da Silva, fonte de continuada inspiração e fé. 


\section{AGRADECIMENTOS}

Registro aqui os meus agradecimentos às pessoas que participaram do processo de redação desta tese.

Quero agradecer especialmente ao meu orientador, o Prof. Dr. Ataliba Teixeira de Castilho, que acreditou neste projeto e o abrigou em seu grande projeto de pesquisa. Agradeço-lhe particularmente pela paciência e dedicação, presencial e à distância, mas sobretudo pela maneira tão bem humorada de fazer suas contribuições.

Aos grandes amigos da área de Língua Portuguesa, membros do seleto grupo dos "encontros duvidosos", com quem aprendi muito. Em especial a Verena Kewitz pelo incentivo inesgotável, pela troca desinteressada de conhecimento, pela ajuda constante. Agradeço também ao Celso Kobashi, esse lutador que tanto nos inspira a todos com suas contribuições acadêmicas e lições de vida. À Alessandra Castilho da Costa pela ajuda na finalização deste trabalho. A Deize Rui e Dayane Cristina Pal.

Ao Prof. Dr. Johannes Kabatek, da Universidade de Tübingen /Alemanha, com quem fiz meu estágio de doutoramento e por quem fui recebido como um membro da instituição, ao lado de outras pessoas tão queridas. Aos amigos de Tübingen, pelas críticas, sugestões de leitura e, principalmente, pelo acolhimento e pelos bons momentos divididos entre lingüística e "la asociación gastronómica". À Valentina Vincis e à Beatriz López Giménez, pela generosidade e brilhantismo acadêmicos. À Vitoria Gondim Jacoby, pela recepção em Tübingen e pela gentileza. A Philipp Obrist, Matthias Heinz, Christine Blauth, Paul Gévaudan, Reinhard Meisterfeld e Klaus Böckle pelo companheirismo. A Lony Dauber, pela freqüente ajuda e atenção. Aos companheiros de Espanha em Tübingen, Aitor Rivas Rodríguez, Lola Pons Rodríguez, Mónica Castillo Lluch e a Óscar Loureda, pela leitura do capítulo sobre tradições discursivas.

Ao Prof. Dr. Afranio Gonçalves Barbosa pelas contribuições para este trabalho e para a equipe paulista do Projeto PHPB, por ocasião da coleta de material na Biblioteca Nacional do Rio de Janeiro.

À CAPES pelo financiamento de meus estudos no Brasil e na Alemanha (Processo BEX-131105-0), sem o qual esta tese não seria possível. 


\section{RESUMO}

Este trabalho insere-se nos recentes estudos sobre a história do português brasileiro e tem por objetivo demonstrar os estágios de mudança das orações de gerúndio. Foram recolhidas ocorrências dos séculos XVIII, XIX e XX em tipologia textual diferenciada, organizada por critérios associados à teoria das Tradições Discursivas, e analisadas qualitativa e quantitativamente. Defende-se aqui a adoção do modelo sociocognitivista de Análise Multissistêmica da Língua (Castilho 2006), que prevê que os itens da língua atuam de maneira multilinear e dinâmica, sendo suas propriedades ativadas, reativadas e desativadas nos quatro subsistemas concomitantemente. Neste trabalho concentro-me nos processos de sintaticização, discursivização e semanticização do gerúndio no português brasileiro. Defende-se que é possível descrever os processos de mudança das orações de gerúndio no português brasileiro a partir da análise isolada dos subsistemas da Gramática, do Discurso e da Semântica. Nos capítulos de análise, faz-se uma descrição qualitativa das ocorrências que leva em conta também a quantificação dos dados.

Palavras-chave: mudança lingüística - português brasileiro - tradições discursivas orações de gerúndio - gramática funcional 


\begin{abstract}
The present work pertains to the recent studies on the History of Brazilian Portuguese and aims at presenting the change stages of gerund clauses. Based on qualitative and quantitative analysis, the data were selected from diverse textual typology, which was organized following the criteria associated with the Discourse Traditions Theory (Diskurstraditionen). I adopt the Multissystemic approach to language (Castilho 2006), which envisages that the linguistic items occur in a multilinear and dynamic way, so that its features are activated, reactivated and deactivated simultaneously. I focus on the grammaticalization, semantization and discoursivization processes of the gerund clauses in Brazilian Portuguese. I assume that it is quite feasible to describe the change processes of gerund independently of the Grammar, Semantics and Discourse subsystems of language. In the analysis chapters, I describe the data in a qualitative way, but I also take into account the quantitative results.
\end{abstract}

Keywords: linguistic change - brazilian portuguese - discourse tradition - gerund clauses - functional grammar 


\section{ÍNDICE GERAL}

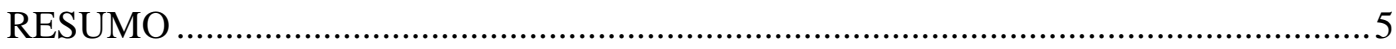

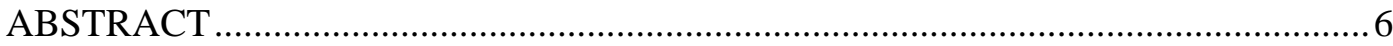

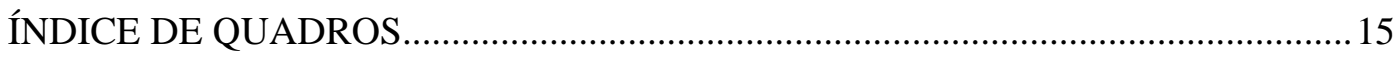

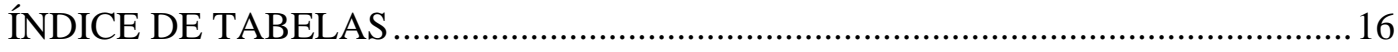

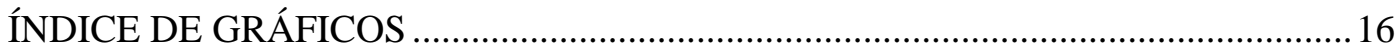

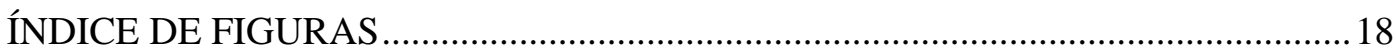

ÍNDICE DO CORPUS BÁSICO E DO CORPUS DIFERENCIAL ............................... 19

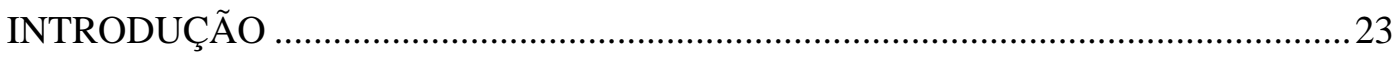

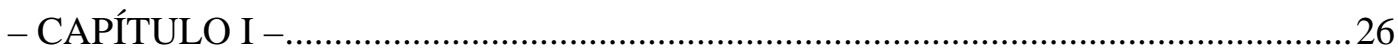

A dicronia do gerúndio do latim às línguas românicas ...................................................2 26

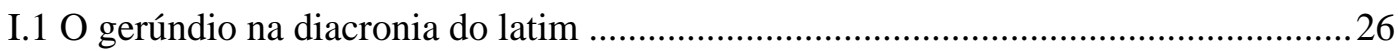

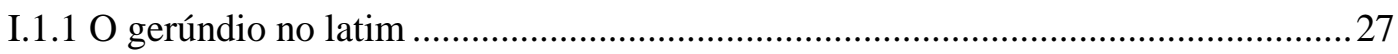

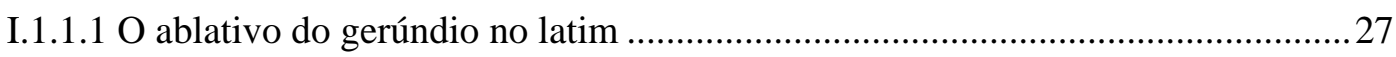

I.1.1.2 As orações adverbiais com gerúndio no latim ..............................................28

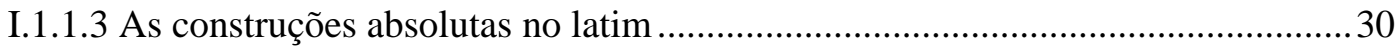

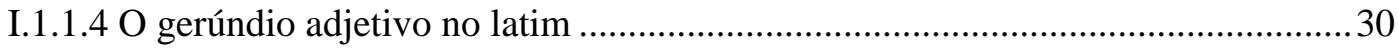

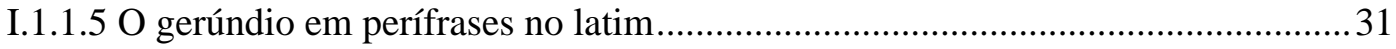

I.1.2 O gerúndio e suas formas concorrentes no latim ................................................. 31

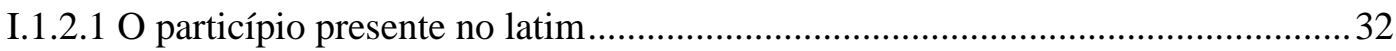

I.1.2.2 A natureza adverbial dos particípios: o particípio conjunto e o particípio

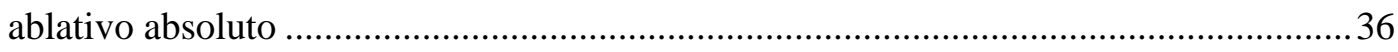

I.1.2.3 A competição entre o particípio presente e o gerúndio no latim ......................... 38

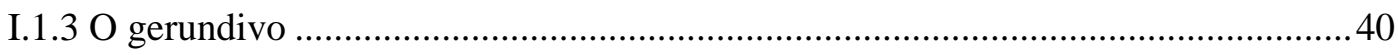

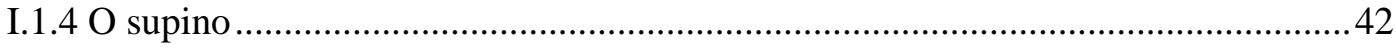

I.1.5 Considerações finais a respeito dos estudos sobre gerúndio no latim ....................43

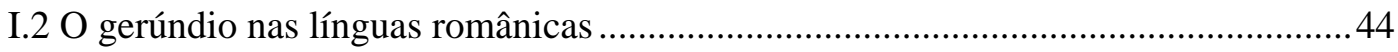

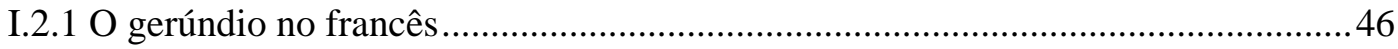

I.2.1.1 As construções absolutas no francês............................................................. 47

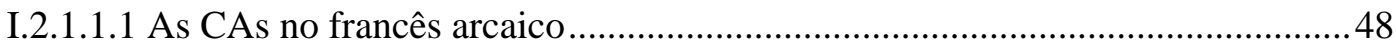




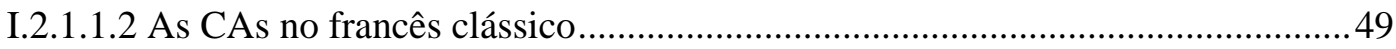

I.2.1.1.3 As CAs no francês moderno .......................................................................... 51

I.2.1.1.4 Considerações finais a respeito dos estudos sobre o gerúndio no francês ........54

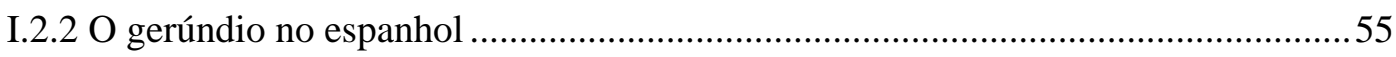

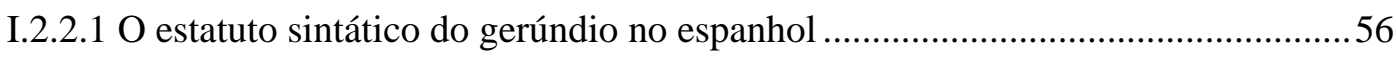

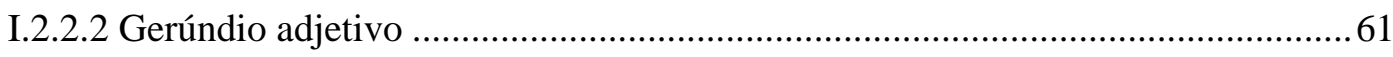

I.2.2.3 Gerúndio referido ao sujeito da oração matriz................................................ 61

I.2.2.4 Gerúndio referido ao objeito direto da oração matriz ........................................... 64

I.2.2.5 Gerúndio referido a outros sintagmas nominais da oração matriz........................66

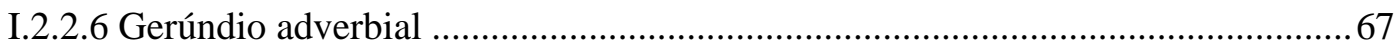

I.2.2.7 O gerúndio em construções perifrásticas e semi-perifrásticas ............................ 71

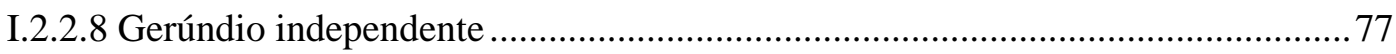

1.2.2.9 Considerações finais a respeito dos estudos sobre o gerúndio no espanhol .......78

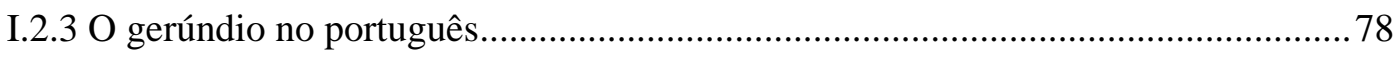

I.2.3.1 O particípio presente no português ................................................................... 80

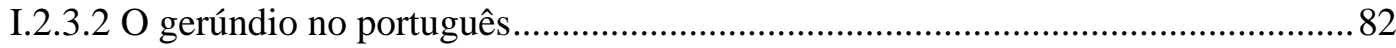

I.2.3.2.1 Estudos descritivos do gerúndio em português................................................. 84

I.2.3.2.1.1 O gerúndio no português - A descrição de Brandão (1933)............................ 84

I.2.3.2.1.2 O estudo histórico-descritivo de Odette Campos (1972)............................... 85

I.2.3.2.2 Gerúndio adjetivo: uma discussão de longa data.......................................... 86

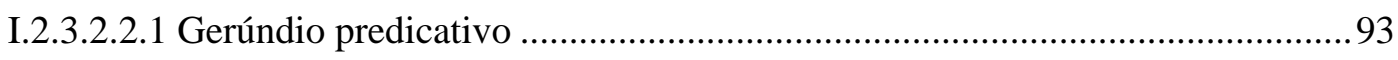

I.2.3.2.2.2 Gerúndio predicativo do sujeito............................................................. 94

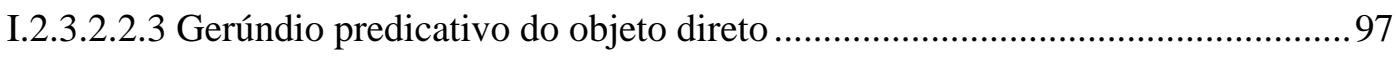

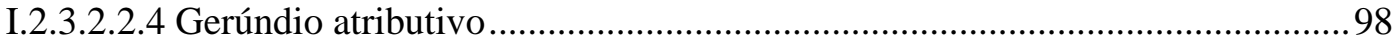

I.2.3.2.2.5 Considerações finais sobre o gerúndio adjetivo ....................................... 102

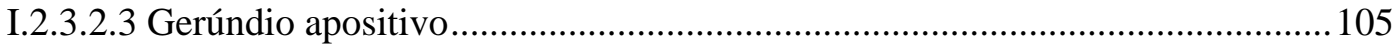

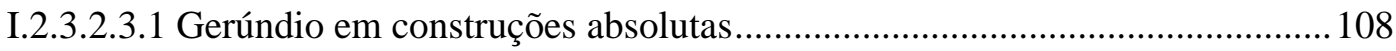

I.2.3.2.3.2 Gerúndio circunstancial (Campos, 1972) ................................................ 109

I.2.3.2.3.3 Gerúndio adverbial (Odette Campos) ou gerúndio coordenativo

(Brandão):

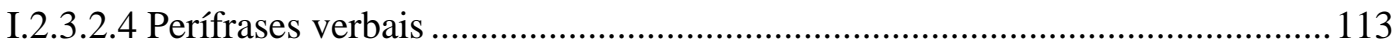

I.2.3.2.5 Gerúndio coordenado (Campos, 1972) ................................................... 114

I.2.3.2.6 Gerúndio narrativo (Campos, 1972) …...................................................... 115

I.2.3.2.7 Gerúndios exclamativos, interrogativos e imperativos ................................ 115 
I.2.3.2.8 Orações reduzidas: coordenação, subordinação ou fórmulas com um estatuto sintático distinto? 116

I.2.3.2.9 Gerúndios flexionados no português 117

I.2.3.2.10 Considerações finais a respeito dos estudos sobre o gerúndio no português: questões em aberto

- CAPÍTULO II 121

Revisão da literatura sobre os modelos teóricos adotados 121

II.1 A teoria da gramaticalização revista. 121

II.1.1 A análise multissistêmica da língua 125

II.1.1.1 Os princípios sociocognitivos. 126

II.1.1.2 Os processos e os produtos da língua como um multissistema. 127

II.1.1.3 Contribuições da abordagem multissistêmica à análise do gerúndio 131

II.2 O modelo das Tradições Discursivas

II.2.2.1 O conceito de linguagem segundo Coseriu 132

II.2.2.2 A ampliação da noção de tradições discursivas segundo Peter Koch

II.2.2.2.5 Oralidade e escrita 138

II.2.2.2.6 A história da língua e o início da escrituralização

II.2.2.3 A historicidade das tradições discursivas . 141

II.2.2.4 As tradições discursivas como tradições culturais entre conservadorismo e dinamismo 142

II.2.2.5 A definição do conceito de tradições discursivas 148

II.2.2.6 Como aplicar o modelo das tradições discursivas à análise da mudança lingüística?

II.2.2.6.1 As variáveis da difusão da mudança lingüística segundo Company

Company (2005).

II.2.2.6.2 A interface Análise do Discurso vs. Tradições Discursivas e sua importância para a constituição da Língüística de Texto... 162

II.3 Considerações finais a respeito dos modelos adotados 164

- CAPÍTULO III 165

A constituição de um corpus diacrônico do português brasileiro dos séculos XVIII, XIX e XX e seus traços lingüístico-discursivos......................................................... 165

III.1 O gênero Carta e a tradição bolonhesa da Ars dictandi. 170 
III.1.1 A arte de escrever cartas e sua popularização na França 171

III.1.2 A tradição epistolar em Portugal e seus ecos no Brasil: os secretários de cartas173

III.2 Estratégias de constituição de um corpus de análise 178

III.2.1 Cartas brasileiras do séc. XVIII ao séc. XX. 179

III.2.2 As categorias discursivas das cartas brasileiras e os traços definidores de seus subgêneros 181

III.2.3 Cartas da Administração Pública e da Administração Privada............................. 185

III.2.3.1 Cartas da Administração privada do século XVIII......................................... 187

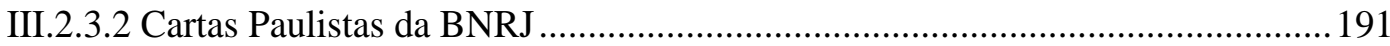

III.2.3.3 Cartas Particulares da Correspondência Passiva de Washington Luiz ............... 192

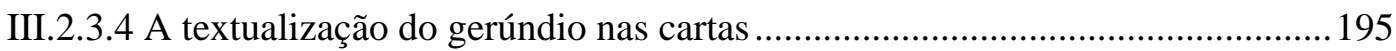

III.2.4 Conclusões prévias sobre a constituição do corpus .......................................... 197

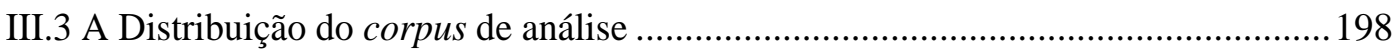

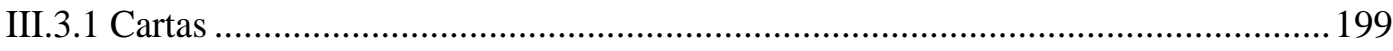

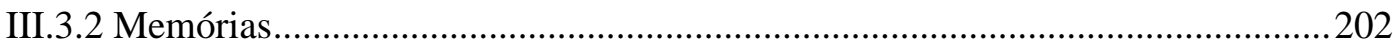

III.3.2.1 Alguns traços lingüísticos das memórias .......................................................204

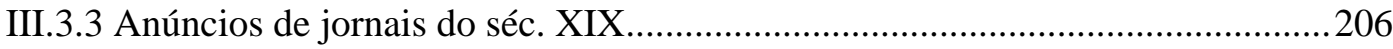

III.3.4 Entremezes, peças teatrais, elocuções formais e diálogos entre informantes ....208

III.3.4.1 Os Entremezes do século XVIII ..................................................................208

III.3.4.2 O Teatro Brasileiro dos séculos XIX e XX.....................................................2.209

III.3.5 Diálogos de norma culta e popular do séc. XX.............................................210

III.3.6 Considerações finais sobre os corpora analisados .......................................212

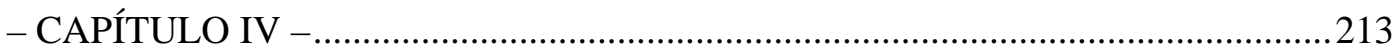

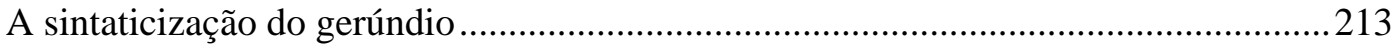

IV.0. Observações preliminares a respeito da sintaticização do gerúndio ....................213

IV.1 A questão do sujeito nas orações reduzidas de gerúndio ....................................214

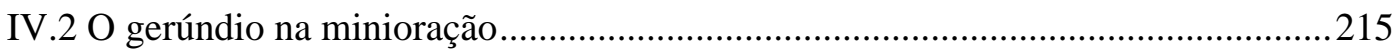

IV.3 Proposta de classificação do gerúndio em português .........................................220

IV.4 Apresentando o quadro geral de ocorrências .....................................................222

IV.5 O gerúndio como núcleo de predicação secundária (dependente) ........................225

IV.5.1 O gerúndio em orações adverbiais dependentes ...........................................225

IV.5.1.1 As propriedades sintáticas das orações adverbiais.........................................225 
IV.5.1.2 A natureza do sujeito compartilhado nas orações gerundiais adverbiais gerundiais 230

IV .5.1.2.1 Sujeito nulo 231

IV.5.1.2.2 Sujeito expresso por um substantivo....................................................231

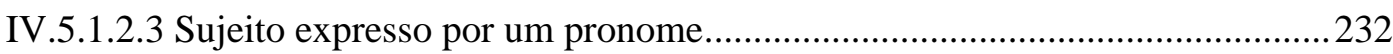

IV.5.1.3 Gerúndio em estruturas de redobro sintático ..............................................232

IV.5.2 Gerúndio em orações sintaticamente ambíguas .............................................233

IV.5.2.1 As propriedades sintáticas das OGs ligadas ao sujeito ...............................2234

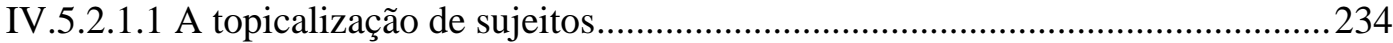

IV.5.2.1.2 A aposição de OGs a outros constituintes de valor adjetivo.......................235

IV.5.2.1.3 O gerúndio ligado ao sujeito posposto na OM............................................2...235

IV.5.2.2 Variações sobre o mesmo tema..................................................................2. 236

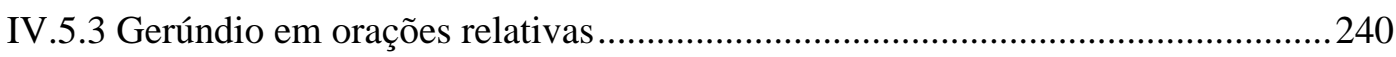

IV.5.3.1 A diacronia das orações com gerúndio adjetivo .......................................240

IV.5.3.2 Tipos de orações de gerúndio adjetivo.......................................................241

IV .5.3.2.1 Gerúndio ligado ao objeto direto da OM .................................................2. 241

IV.5.3.2.2 Gerúndio ligado ao objeto indireto da OM .................................................242

IV.5.3.2.3 Gerúndio ligado ao complemento oblíquo da OM ...................................243

IV.5.3.2.4 Gerúndio ligado ao complemento de um sintagma preposicionado ............243

IV.5.3.2.5 Gerúndio ligado ao absolutivo de verbos existenciais ................................244

IV 5.3.2.5.1 As propriedades sintáticas do absolutivo ............................................244

IV.5.3.2.6 Gerúndio ligado ao absolutivo de verbos ergativos ..................................245

IV.5.3.2.7 Gerúndio ligado ao predicativo da $\mathrm{OM}$..................................................246

IV .5.3.3 As propriedades sintáticas das orações relativas ............................................2. 247

IV.5.4 Conclusões parciais a respeito do gerúndio na minioração (dependente) .........247

IV.6 O gerúndio como núcleo de predicação primária (independente) ........................248

IV.6.1 Gerúndio em oração adverbial independente (construção absoluta) .................249

IV.6.1.1 As propriedades sintáticas das construções absolutas ...................................249

IV.6.1.2 A natureza do sujeito nas orações adverbiais absolutas...............................251

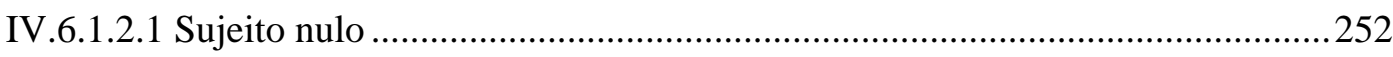

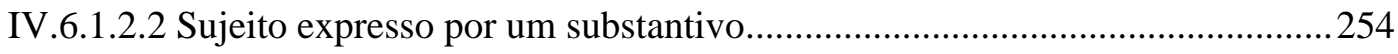

IV.6.1.2.3 Sujeito expresso por um pronome ......................................................25

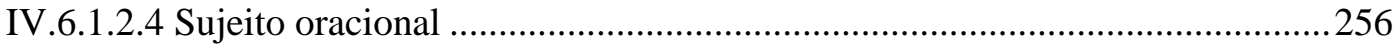

IV.6.1.3 Construções Absolutas sem sujeito gramatical ............................................256 


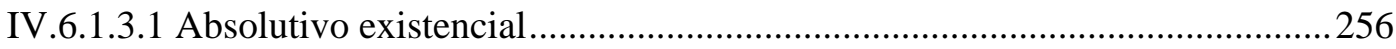

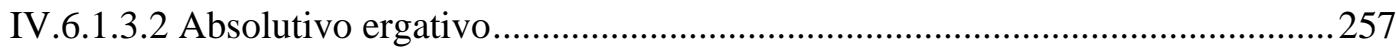

IV.6.1.3.3 Construções com se indeterminador e se apassivador: sujeito

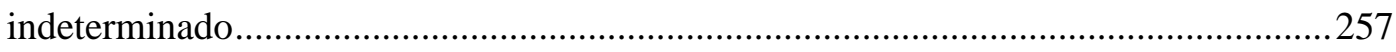

IV.6.1.3.3.1 Construções com se apassivador ou se indeterminador explícito ..............257

IV.6.1.3.3.2 Construções com se apassivador e indeterminador nulo ...........................258

IV.6.1.4 A posição das orações adverbiais ................................................................25

IV.6.2 Gerúndio adjetivo ligado a um SN em sentença plena .......................................261

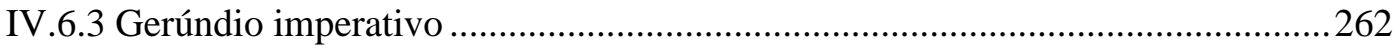

IV.6.4 Gerúndio como articulador discursivo: o lado sintático ......................................262

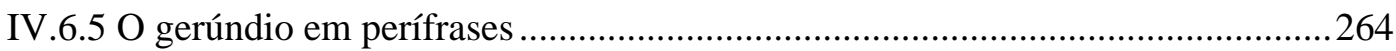

Conclusões sobre a sintaticização do gerúndio em português .........................................266

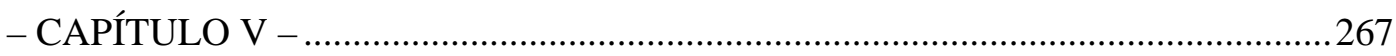

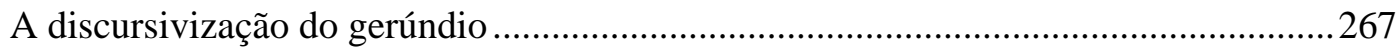

0. Observações preliminares sobre o papel discursivo do gerúndio ................................267

V.1. A ativação, reativação e desativação do gerúndio no subsistema do Discurso .....271

V.1.1 A ativação do gerúndio no discurso ………………………………………….....2 271

V.1.2 A reativação do gerúndio no discurso ................................................................272

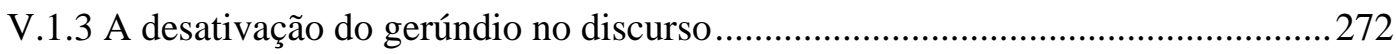

V.2. O gerúndio na articulação do tópico discursivo......................................273

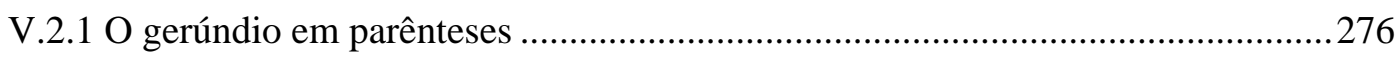

V.2.2 Gerúndio em parênteses focalizadores da elaboração tópica ................................277

V.2.2.1 Gerúndio em parênteses focalizadores do conteúdo tópico ................................277

V.2.2.2 Gerúndio em parênteses focalizadores da estrutura tópica .................................277

V.2.3 Gerúndio em parênteses que focalizam o locutor/autor e o interlocutor/leitor ...280

V.2.3.1 Marcador voltado para os participantes da relação diádica................................280

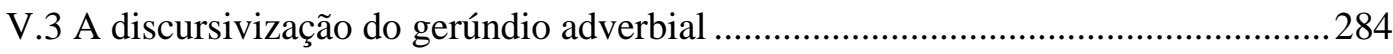

V.3.1 As orações gerundiais adverbiais (OGadvs) nos textos ........................................28

V.3.2 As construções absolutas de gerúndio (CAs) nos textos.......................................28

V.3.3 A dessintaticização das orações adverbiais gerundiais .........................................290

V.4 A discursivização das perífrases verbais ...............................................................293

V.5 A discursivização do gerúndio ambíguo .................................................................297

V.6 A discursivização do gerúndio adjetivo ..................................................................299 
V.7 A discursivização do gerúndio em nominalizações ..............................................301

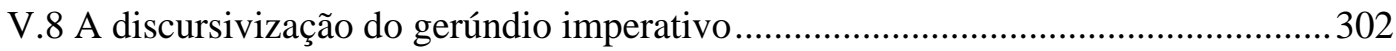

Conclusões sobre a discursivização do gerúndio no português brasileiro .....................302

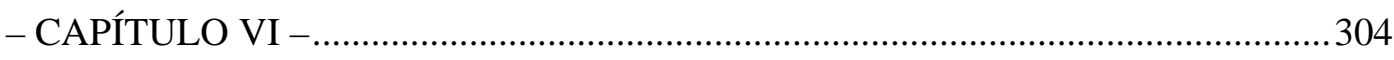

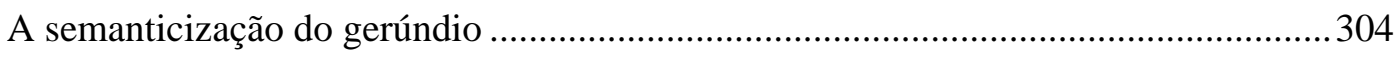

VI.1. O gerúndio como item sintático que evidencia o relevo no processamento da

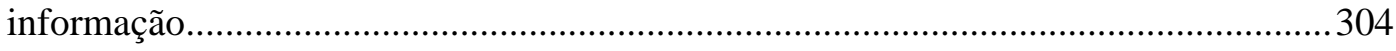

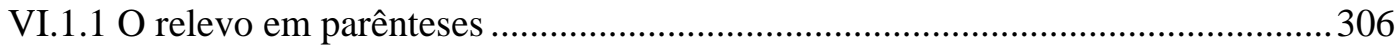

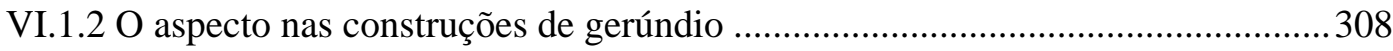

VI.1.3 O papel das orações de gerúndio na construção do relevo ................................309

VI.1.4 O relevo como processo de focalização de partes do texto ............................... 310

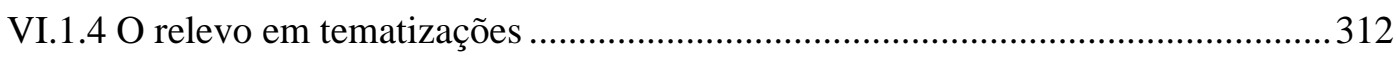

VI.1.4.1 A tematização do gerúndio como estratégia de relevo .................................. 317

VI.1.4.2 Fatos de focalização na narração, na descrição, na dissertação e na injunção 318

VI.2. As propriedades semânticas específicas das orações de gerúndio ....................... 321

VI.2.1 A semântica das orações adverbiais de gerúndio (dependente e independente) 321

VI.2.2 A distribuição semântica das orações adverbiais de gerúndio............................324

VI.2.3 As relações proposicionais das OGadvs e das CAs ..........................................327

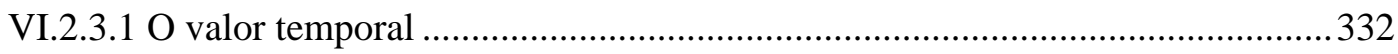

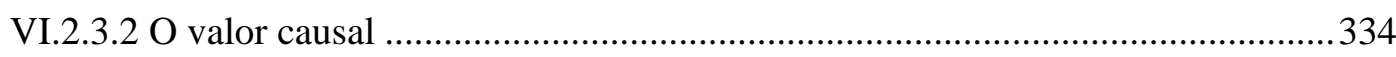

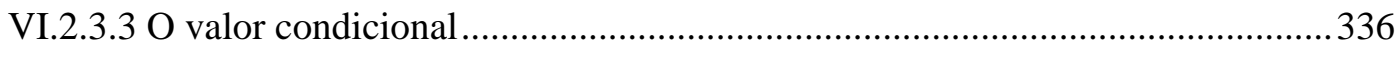

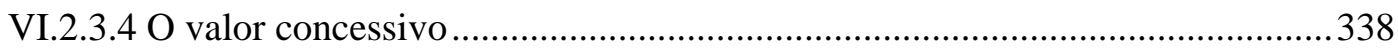

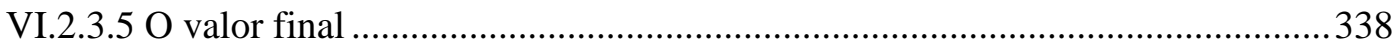

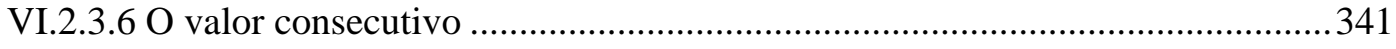

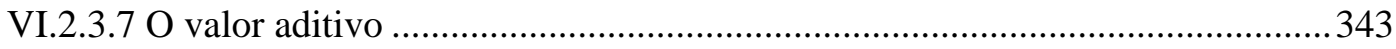

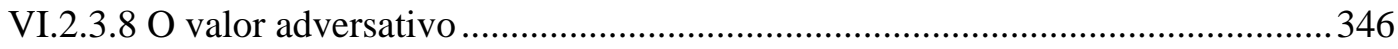

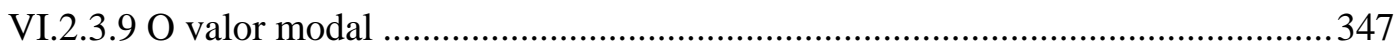

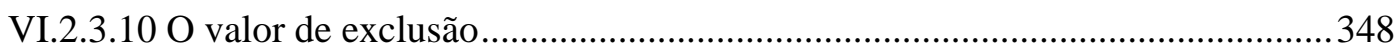

VI.2.4 A semântica das CAs segundo a natureza dos verbos ......................................349

VI.2.5 A semântica das orações de gerúndio ambíguo ............................................... 354

VI.2.6 A semântica do gerúndio em orações relativas .................................................359

VI.2.7 A semântica do gerúndio em nominalizações e do gerúndio imperativo ...........361

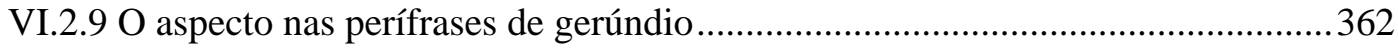




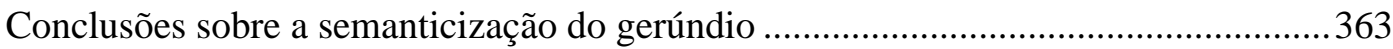

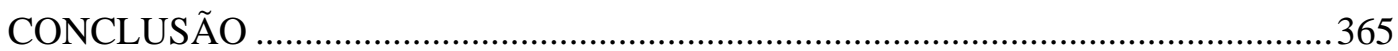

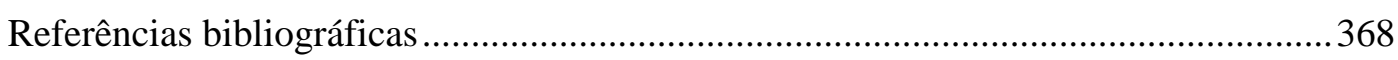




\section{ÍNDICE DE QUADROS}

Quadro 1. As funções do ablativo do gerúndio e do particípio presente no período clássico do latim (Campos, 1972:19).

Quadro 2. Evolução dos usos do gerúndio na diacronia do português, baseado em Campos (1972)

Quadro 3. O níveis da língua segundo Coseriu (1988:73) ..................................... 132

Quadro 4. Os níveis da língua segundo Coseriu (1988:74) ................................... 133

Quadro 5. Os níveis universal, histórico e individual da língua segundo Coseriu

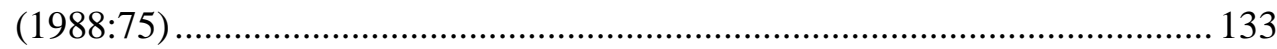

Quadro 6. O redobramento do nível histórico da língua segundo Koch (1997....... 134

Quadro 7. A tradição dos secretários de cartas e suas evocações........................... 175

Quadro 8. Categorias comunicativo-pragmáticas da escrita adaptadas de Henne \& Rehbock (1982) e Allwood (1976) .................................................................. 182

Quadro 9. A tensão proximidade/distância segundo Koch \& Oesterreicher (1985) 183

Quadro 10. Corpus Básico e Corpus Diferencial de cartas. ................................... 201

Quadro 11. Corpus de memórias históricas .......................................................... 206

Quadro 12. Corpus de anúncios de jornal do séc. XIX .......................................... 207

Quadro 13. Corpus Básico de Entremezes e Peças Teatrais .................................... 210

Quadro 14. Corpus Diferencial de Diálogos de Norma Culta e Popular do séc. XX

Quadro 15. Quadro geral de palavras dos Corpora Básico e Diferencial................ 211

Quadro 16. Escala de dessentencialização proposta por Lehmann (1988:200) ........ 226

Quadro 17. A escala de de agregação e integração (adaptado de Raible, 1992) .... 228

Quadro 18. Escala de sentencialidade segundo Müller-Lancé (1994:76)................ 229

Quadro 19. Propriedades sintáticas das orações gerundiais adverbiais ................... 230

Quadro 20. Propriedades sintáticas das orações gerundiais ambíguas .................... 236

Quadro 21. Propriedades sintáticas das orações relativas ....................................... 247

Quadro 22. Seqüências tema-rema, baseado em Koch (2006a:361-66) .................. 313

Quadro 23. As técnicas de junção segundo Raible (1992), adaptado. ..................... 323

Quadro 24. Propriedades semânticas das OGadvs e das CAs................................. 351

Quadro 25. Propriedades semânticas das orações gerundiais ambíguas .................. 358

Quadro 26. Propriedades sintáticas das orações relativas ....................................... 360 


\section{ÍNDICE DE TABELAS}

Tabela 1. Distribuição dos sujeitos dos gerúndios circunstanciais, conforme Campos, 1972. 110

Tabela 2. Total de ocorrências analisadas no Corpus Básico 222

Tabela 3. Distribuição dos tipos de gerúndio por século no Corpus Básico............ 223

Tabela 4. A natureza do sujeito nas orações gerundiais adverbiais (OGadvs). ....... 230

Tabela 5. Distribuição do gerúndio adjetivo nos três séculos analisados ................ 240

Tabela 6. Frequiência de gerúndios adjetivos nas duas metades do séc. XIX .......... 241

Tabela 7. Natureza do sujeito na construção absoluta (CA) ................................. 251

Tabela 8. Distribuição das construções absolutas sem sujeito gramatical ................ 256

Tabela 9. O gerúndio como articulador discursivo na tipologia textual ................. 281

Tabela 10. Distribuição dos tipos de gerúndios nos três séculos por tipologia textual (Corpus Básico).

Tabela 11. Quadro geral dos tipos de gerúndio por tipologia textual e por século.. 285

Tabela 12. Distribuição das orações adverbiais gerundiais $(\mathrm{G})$ e conjuncionais (C) no Corpus Básico (séc. XVIII, XIX e XX) ................................................... 325

Tabela 13. Distribuição semântica das OGadvs nos séculos XVIII, XIX e XX por tipologia textual.

Tabela 14. Distribuição semântica das CAs nos séculos XVIII, XIX e XX por tipologia textual.

Tabela 15. Distribuição semântica das orações gerundiais ambíguas nos séculos XVIII, XIX e XX por tipologia textual.

Tabela 16. O gerúndio adjetivo na $2^{\mathrm{a}}$. metade do séc. XIX 359

\section{ÍNDICE DE GRÁFICOS}

Gráfico 1. Frequiência de construções absolutas na diacronia do latim ao francês moderno (Cf. Müller-Lancé,1994:308).

Gráfico 2. Distribuição dos tipos de gerúndio por século no Corpus Básico por número de ocorrências.

Gráfico 3. Distribuição geral das orações adverbiais no Corpus Básico por número de ocorrências . 224

Gráfico 4.Orações ambíguas com gerúndio ligado ao sujeito. 233 
Gráfico 5. Distribuição do gerúndio ligado a um SN da OM (gerúndio ambíguo +

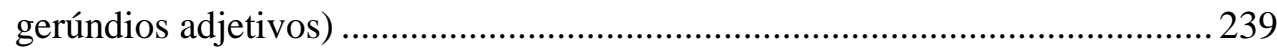

Gráfico 6. Comparação entre orações adverbiais e OG ambíguas .......................... 239

Gráfico 7. Posição das orações adverbiais gerundiais e conjuncionais .................. 259

Gráfico 8. Frequiência de perífrases de gerúndio e das orações adverbiais gerundiais

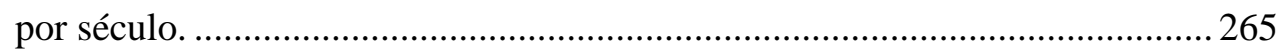

Gráfico 9. Freqüência de OGadvs por tipo de texto no séc. XX............................228

Gráfico 10. Freqüência de CAs por tipo de texto no séc. XX................................. 290

Gráfico 11. Orações adverbiais gerundiais e conjuncionais no Corpus Básico....... 291

Gráfico 12. Média ponderada de orações adverbiais gerundiais e conjuncionais no Corpus Básico.

Gráfico 13. Orações adverbiais gerundiais e conjuncionais nos Corpora (Básico e

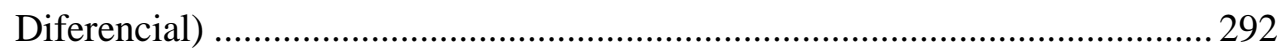

Gráfico 14. A evolução das perífrases de gerúndio no Corpus Básico.................... 293

Gráfico 15. Perífrases de gerúndio na língua falada da $2^{\mathrm{a}}$. metade do séc. XX....... 296

Gráfico 16. O gerúndio ambíguo no Corpus Básico.............................................. 298

Gráfico 17. Freqüência de orações de gerúndio adjetivo por século no Corpus Básico. 300

Gráfico 18. Gerúndios adjetivos no século XIX. 301

Gráfico 19. Distribuição geral das orações adverbiais gerundiais (OGadvs e CAs) por valor semântico no Corpus Básico (total de três séculos)

Gráfico 20. Distribuição de frequiências das circunstâncias adverbiais nas orações gerundiais (OGadvs e CAs) do Corpus Básico (séc. XVIII, XIX e XX)........ 327

Gráfico 21. Frequiência das OGadvs nos séculos XVIII, XIX e XX (Corpus Básico e Corpus Diferencial). 328

Gráfico 22. Frequiência das CAs nos séculos XVIII, XIX e XX (Corpus Básico e Corpus Diferencial) 


\section{ÍNDICE DE FIGURAS}

Figura 1. A reduplicação do nível histórico (Kabatek, 2004) ................................. 135

Figura 2. O contínuo de filiação das tradições discursivas (Cf. Koch, 1997:60)..... 141

Figura 3. Tradições discursivas nos panfletos [Flugschriften] italianos de 1500-1500 (Wilhelm, 1996 apud Koch, 1997:63) .......................................................... 143

Figura 4. 1.a Via - Alguns sucessos, desde Março de [1]634 até ode[1]635.(BNL,

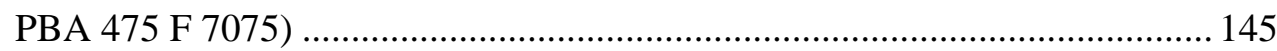

Figura 5. Alguns sucessos, desde Março de [1]634 até ode[1]635.(BNL, PBA 475 F 7075) 145

Figura 6. Alguns sucessos, desde Março de [1]634 até ode[1]635.(BNL, PBA 475 F 7075) 146 


\title{
ÍNDICE DO CORPUS BÁSICO E DO CORPUS DIFERENCIAL
}

\author{
I. Corpus Básico ${ }^{1}$
}

\section{Documentos manuscritos editados pelo pesquisador}

Ald "Aldeamento de índios (Fundo C00228 - AHESP)" -. In: SIMÕES, José da Silva / KEWITZ, Verena (2006). Cartas paulistas dos séculos XVIII e XIX: uma contribuição para os corpora do PHPB, org. São Paulo: Humanitas / FFLCH / USP.

BNRJ "Cartas Paulistas da Biblioteca Nacional do Rio de Janeiro(BNRJ)". In: SIMÕES, José da Silva / KEWITZ, Verena (2006). Cartas paulistas dos séculos XVIII e XIX: uma contribuição para os corpora do PHPB, org. São Paulo: Humanitas / FFLCH / USP.

WL "Correspondência passiva de Washington Luiz (Fundo AP 185 AHESP)”. In: SIMÕES, José da Silva / KEWITZ, Verena (2006). Cartas paulistas dos séculos XVIII e XIX: uma contribuição para os corpora do PHPB, ed. e org. São Paulo: Humanitas / FFLCH / USP.

Lor Capitão Mór de Lorena e Areas - 1721-1822 (Fundo C00335 - AHESP)

Gen Cartas Títulos de Sesmarias Capitães Generais - 1646-1822 (Fundo C00230 - AHESP)

Sim Correspondência passiva da família Simões.

MRI Correspondência passiva de Prudente de Morais / Coleção Clube Republicano / Correspondência passiva de Paulino Lima (MRI).

MPC Dizertaçã̃ a respeito da Capitania de S. Paulo - Marcelino Pereira Cleto - 1781 (BNL).

BON Memoria Economica e Metallurgica sobre a Fabrica de Ferro de Ypanema Sorocaba (BNRJ) - José Bonifácio de Andrada e Silva (1820).

MCA Memoria Historica da Capitania de São Paulo (AHESP) - Manuel Cardoso de Abreu (1797?), plágio da obra Memória para a História da Capitania de São Vicente de Frei Gaspar da Madre de Deus (1798).

Gen Militares - General Arouche - Vale do Paraíba - 1816-1821 (Fundo C00265 - AHESP)

\footnotetext{
${ }^{1}$ Os exemplos retirados dos corpora seguem o seguinte sistema de notação: [C 18 1 NP1 1]: (a) as primeiras letras referem-se ao gênero textual: carta (C), peça teatral (TEA), memória histórica (M), anúncio (A), inquérito do Projeto Filoband (FB) e inquérito do Projeto Português Brasileiro Popular (PBpop); (b) o primeiro número refere-se ao século; (c) o segundo número indica a $1^{\mathrm{a}}$. ou $2^{\mathrm{a}}$. metade do século em questão; (d) a notação em letras indica o documento de origem e (e) o último algarismo indica o número da ocorrência nesse documento. Para os exemplos retirados dos inquéritos do projeto NURC foi utilizada a notação costumeira para esses documentos.
} 
BAN Militares Comandantes - Capitão Mór de Bragança, Atibaia e Nazaré 1723-1822 (Fundo C00262 - AHESP).

Seb Militares e Capitão Mór de São Sebastião e Vila Bela - 1721-1819 (Fundo C0255 - AHESP).

RDN Plano, emque sepropoem omelhoramento daSorte dos Indios (Memória sobre as aldeas de indios da província de S. Paulo) José Arouche de Toledo Rendon (1802) (AHU).

\section{Outros documentos utilizados}

HC ABREU, Capistrano (2000). Capítulos de história colonial, 1500-1800. 7ª ed. rev. anotada e prefaciada por José Honório Rodrigues. Belo Horizonte: Itatiaia; São Paulo: Publifolha. (Grandes nomes do pensamento brasileiro).

Tel ANDRADE, Jorge (1976). Pedreira das almas : O telescópio. Rio de Janeiro : AGIR.

RV ANDRADE, Oswald de (1976). Teatro / Oswald de Andrade - A morta: ato lírico em três quadros; $\mathrm{O}$ rei da vela: peça em três atos; $\mathrm{O}$ homem e o cavalo: espetáculo em nove quadros. Rio de Janeiro : Civilização Brasileira. (Coleção Vera Cruz. Literatura Brasileira)

Mac AZEVEDO, Álvares de (1988). Macário. 3.ed. Rio de Janeiro : Francisco Alves, 1988.

Alm AZEVEDO, ARTUR (1987). "Almanjarra”. In: Teatro de Artur Azevedo Tomo III - Coleção Clássicos do Teatro Brasileiro vol. 7 INACEN, A _ Biblioteca - Virtual de Literatura, http://www. biblio.com.br/Templates/ArturAzevedo/malmanjarra.h tm, acesso em 25.01 .2007 .

SL EIRÓ, Paulo (1998). "Sangue limpo. Drama original em três atos e um prólogo". In: MOURA, Eugênio Marcondes de Moura (org.). Vida Cotidiana em São Paulo no século XIX: memórias, depoimentos, evocações. São Paulo: Ateliê Editorial / Fundação Editora da Unesp / Imprensa Oficial do Estado / Secretaria de Estado da Cultura, p. 313-39.

Ern ÉRNICA, Maurício (2004). "Uma metrópole multicultural na terra paulista". Centro de Estudos e Pesquisas em Educação, Cultura e Ação Comunitária. Terra paulista : história, arte e costumes / coordenação de Maria Alice Setubal [et al.]. São Paulo : CENPEC: Imprensa Oficial, 2004, p. 157-168.

CLis JACINTHO, Valéria Franco (1997). Cartas a Clarice Lispector. Correspondência passiva da escritora depositada na Fundação Casa de Rui Barbosa. São Paulo: FFLCH-USP. Tese de doutorado.

FE LOPES, Célia (s/d, ed.). As filhozes do entrudo feitas em caza de Antufo Rombo Sapateiro, e sua mulher, Mona Xorina, com asistencia de 
seus compadres Sergio Caroso, barbeiro, e sua mulher Ramoia Morena. Rio de Janeiro: Laboratório de História do Português Brasileiro / UFRJ /Projeto "Rearranjos no quadro pronominal do português: variação sincrônica e mudança diacrônica", http://www.letras.ufrj.br/\% 7Eceliarh, acesso em 25.01.2007.

DH LOPES, Célia (s/d, ed.). Novo entremez intitulado dezengados para os homens, nam se fiarem em mulheres. Rio de Janeiro: Laboratório de História do Português Brasileiro / UFRJ /Projeto "Rearranjos no quadro pronominal do português: variação sincrônica e mudança . . diacrônica", 'http://www.letras.ufrj.br/\% $\%$ 7Eceliar/pecasport 09.htm,', acesso em 25.01 .2007 .

WLC LUÍS, Washington (1980 [1918]). Na capitania de S. Vicente (1918). São Paulo: Editora Itatiaia / Editora da Universidade de São Paulo.

MA MORAES, Marcos Antonio (2001, org.). Correspondência Mário de Andrade \& Manuel Bandeira. São Paulo: Editora da Universidade de São Paulo / Instituto de Estudos Brasileiros, Universidade de São Paulo. (Coleção Correspondência de Mário de Andrade: I).

MA MORAES, Marcos Antonio (2001a, org.). Correspondência Mário de Andrade \& Tarsila do Amaral. São Paulo: Editora da Universidade de São Paulo / Instituto de Estudos Brasileiros, Universidade de São Paulo. (Coleção Correspondência de Mário de Andrade: II).

NP1 Notícia - 1 ${ }^{a}$ Prática - Que a da ao P. Me de Diogo Soares o Alferes José Peixoto da Silva Braga, do que passou na Primeira Bandeira, que entrou ao descobrimento das Minas do Guayases até sair na Cidade do Belém do Grão-Pará - 1737. Coleção Notícias Práticas: I. Biblioteca Virtual / Laboratório de Pesquisa em História Social / IFCS / UFRJ. Biblio Virt-LIPHIS, 2001.

NP2 Notícia - $2^{a}$ Prática - Dada ao P. M. Diogo Soares sobre a abertura do novo caminho pelo Piloto José Inácio, que foi e acompanhou em todo ele ao mesmo Sargento-mor Francisco de Souza e Faria. 1727. Coleção Notícias Práticas: III. Biblioteca Virtual / Laboratório de Pesquisa em História Social / IFCS / UFRJ. Biblio

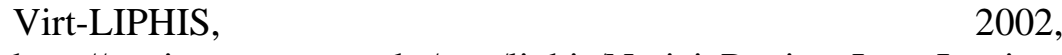
http://paginas.terra.com.br/arte/liphis/NoticiaPratica_Jose_Inacio. pdf, acesso em 09.12.2006.

Nam PENA, Martins (1968). "O namorador ou a noite de São João". In: PENA, Martins (1968). Comédias de Martins Pena. Rio de Janeiro : Edições de Ouro, 1968. p. 275-299 (Antologia).

Per RASI, Mauro. (1995). Pérola. Rio de Janeiro, RJ : Editora Record.

PRO Reminiscências de Santos (1930) - João Luís Promessa. Edição filológica de SILVEIRA, Claudia / KEWITZ (s/d), digitado.

GAM SILVA, Antônio José (19--). A vida de Esopo e guerras do alecrim e da manjerona. [s.1.]: Ediouro, p. 92-169. (Prestígio). 
SOUZA, Flávio de. (1983/1993) "Fica comigo esta noite”. Em Shell Brasil I Xenon Editora (Org.), Cinco textos do teatro contemporâneo brasileiro. Rio de Janeiro: Shell Brasil / Xenon Editora, p. 8-19.

RL TAUNAY, Alfredo D'Escragnolle Taunay, Visconde de (s/d). A retirada da Laguna - episódio da Guerra do Paraguai. São Paulo: Ediouro. (Prestígio). Biblioteca Virtual do Estudante de Língua Portuguesa 'http://Www.bibvirt.futuro.usp.bon, acesso em 25.01.2007.

Zeq ZEQUINI, Anicleide (2004). "A fundação de São Paulo e os primeiros paulistas: indígenas, europeus e mamelucos". Centro de Estudos e Pesquisas em Educação, Cultura e Ação Comunitária. Terra paulista : história, arte e costumes / coordenação de Maria Alice Setubal ... [et al.]. São Paulo : CENPEC: Imprensa Oficial, 2004, p. 29-42.

JHR RODRIGUES, Lêda Boechat (2004, org.). Nova correspondência de José Honório Rodrigues. Rio de Janeiro: Academia Brasileira de Letras. (Coleção Austregésilo de Athayde, 19).

\section{Corpus Diferencial}

CL BARBOSA, Afranio \& LOPES, Célia Regina (2004, orgs.). Críticas, queixumes e bajulações na Imprensa Brasileira do séc. XIX: cartas de leitores e cartas de redatores. Rio de Janeiro: Faculdade de Letras/UFRJ/Labor-Histórico, 2004. (versão eletrônica) $-[\mathrm{CL}=$ cartas de leitores; $\mathrm{CR}=$ cartas de redatores]

D2 CASTILHO, Ataliba T. de \& PRETI, Dino (1987, orgs.). A linguagem falada culta na cidade de São Paulo: materiais para seu estudo. Vol. II - Diálogos entre dois informantes. São Paulo: T. A. Queiroz/FAPESP.

EF CASTILHO, Ataliba T. de \& PRETI, Dino (orgs.) A linguagem falada culta na cidade de São Paulo: materiais para seu estudo Vol. I Elocuções formais. São Paulo: T. A. Queiroz, 1986.

A GUEDES, Marymarcia \& BERLINCK, Rosane Andrade (Orgs. 2000). E os preços eram commodos...Anúncios de jornais brasileiros do século XIX. São Paulo: Humanitas. (Série Diachronica, vol. 2).

DID PRETI, Dino e URBANO, Hudinilson (Orgs. 1989). A Linguagem Falada Culta na Cidade de São Paulo. Materiais para seu estudo. São Paulo: TAQ/Fapesp, vol. III, Diálogos entre o Informante e o Documentador. 


\section{INTRODUÇÃO}

Este trabalho tem por objetivo demonstrar os estágios de gramaticalização das orações de gerúndio no português brasileiro e tem como base a análise quantitativa e qualitativa de ocorrências coletadas em um conjunto de textos reunidos em corpora dos séculos XVIII, XIX e XX. Grande parte destes textos foi especialmente coletada e filologicamente transcrita para este trabalho e sua escolha está condicionada a critérios metodológicos advindos do modelo de Tradições Discursivas (TD) da escola da Romanística de Tübingen.O trabalho insere-se no Projeto Para a História do Português Brasileiro (PHPB), juntando-se aos recentes estudos diacrônicos desenvolvidos pelas várias equipes brasileiras envolvidas.

A hipótese de trabalho inicial parte da intuição de que ao longo da história do português brasileiro houve um decréscimo na utilização de construções adverbiais gerundiais em função da opção dos falantes da língua por outros recursos de junção de enunciados. Através deste trabalho também procuro analisar se esta intuição se verifica e se ela estaria orientada por alguns condicionamentos de ordem sintática, semântica ou discursiva. Para uma melhor compreensão do fenômeno a ser estudado, optei pelo procedimento de descrever a forma nominal gerúndio no português brasileiro em todas as suas possibilidades, também com a finalidade de verificar se em outros contextos sintáticos o gerúndio também sofreu algum tipo de mudança ao longo do período estudado. Dessa forma, foram consideradas variáveis lingüísticas que possam atuar sobre o processo de mudança em questão, como o contexto sintático em que estas estruturas aparecem, o tipo de texto, a norma lingüística, a finalidade discursiva e valor semântico associado às orações adverbiais.

Na primeira parte deste trabalho (capítulo I) traço um perfil histórico do gerúndio desde o latim, passando pela sua gramaticalização nas línguas românicas até chegar às descrições do gerúndio no português brasileiro. Primeiramente, faço uma descrição das formas nominais dos verbos no latim, partindo das possibilidades de uso do gerúndio, e estabelecendo um paralelo entre este e as demais formas, a fim de observar em que contextos sintáticos o gerúndio exibia funções similares àquelas exercidas pelas outras formas nominais dos verbos. A idéia é oferecer um panorama 
sobre os condicionamentos semânticos que influenciaram os planos morfológico e sintático dos usos do gerúndio nas línguas românicas, em especial, o português, que é o foco deste trabalho. Na revisão da literatura sobre o gerúndio nas línguas românicos, procuro destacar achados importantes nas descrições feitas para o francês e o espanhol e que possam ser incorporadas à análise.

Em seguida, no capítulo II, faço uma breve revisão da literatura sobre o fenômeno da gramaticalização, mais especialmente sobre a Proposta Funcionalista de Mudança Língüística defendida por Ataliba T. de Castilho (2003, 2004, 2006) e sobre os modelos de Tradições Discursivas. Defende-se aqui a adoção do modelo sociocognitivista de Análise Multissistêmica da Língua (Castilho, 2006), que prevê que os itens da língua atuam de maneira multilinear e dinâmica nos subsistemas do Discurso, do Léxico, da Semântica e da Gramática, sendo suas propriedades ativadas, reativadas e desativadas nos quatro subsistemas concomitantemente. Os itens envolvidos no processo de mudança são estudados sem que se estabeleça uma relação de precedência e hierarquia entre um e outro subsistemas. Para o estudo das orações de gerúndio, privilegia-se a descrição dos processos de sintaticização, semanticização e discursivização.

A apresentação dos corpora analisados nesta tese (capítulo IIII) virá acompanhada de uma descrição dos critérios envolvidos para a montagem dos conjuntos e é parte primordial deste estudo, que defende que as descrições de processos de mudança lingüística devem levar em conta os contextos discursivos em que determinados fenômenos lingüísticos aparecem.

No capítulo IV, sobre a sintaticização do gerúndio, inicio a análise das ocorrências do séc. XVIII, XIX e XX pela descrição das propriedades sintáticas das orações de gerúndio, e a partir delas proponho uma classificação dos gerúndios apenas pelas suas especificidades sintáticas. A partir da descrição dos tipos de gerúndios encontrados, farei uma análise quantitativa dos dados, procurando estabelecer relações entre os eventuais aumentos ou decréscimos nos índices encontrados para cada século.

A discursivização do gerúndio será analisada no capítulo V, no qual apresento as funções que o gerúndio desempenha por motivações sociocognitivas associadas ao subsistema do Discurso. Ainda neste capítulo apresento os resultados quantitativos e a distribuição das orações de gerúndio na tipologia textual analisada, procurando 
estabelecer relações a respeito do caráter formal/informal, oral/escrito em que aparecem.

No capítulo final da tese (capítulo VI), procuro demonstrar como os diferentes tipos de orações de gerúndio servem para estabelecer relações proposicionais entre enunciados, demarcar o emolduramento de cenas descritas (figura/fundo), com o objetivo de evidenciar como cada um dos tipos de orações de gerúndio da classificação adotada ganha sentido diferenciado em função da sua ocorrência em contextos específicos e por conta da finalidade discursiva específica. Verifico, portanto, o processo de semanticização do gerúndio, e analiso que propriedades semânticas são ativadas, reativadas ou desativadas em cada tipo de construção gerundial. 


\title{
- CAPÍTULO I -
}

\section{A dicronia do gerúndio do latim às línguas românicas}

\begin{abstract}
Antes que m'o digam, vou logo dizendo que não sou nem pretendo ser latinista. Fui forçado a entrar nesta seara por ser ella caminho da que me toca. É apenas um degrau para o santuario do portuguez; mas se o santuario é resplendente, que monta emfim que o degrau seja tosco e defeituoso?
\end{abstract}

Othoniel Motta (1934:40)

Neste capítulo traço um panorama da diacronia do gerúndio no latim e nas línguas românicas com o objetivo principal de verificar como se deu a evolução dessa forma nominal nessas línguas. Inicio pelo latim e, em seguida, resenho os autores que se preocuparam em estudá-lo no francês, no espanhol e no português. ${ }^{2}$

\section{I.1 O gerúndio na diacronia do latim}

Ao longo desta seção, faço primeiramente uma descrição das formas nominais dos verbos no latim, partindo das possibilidades de uso do gerúndio, e estabelecendo um paralelo entre este e as demais formas, a fim de observar em que contextos sintáticos o gerúndio exibia funções similares àquelas exercidas pelos particípios (presente e futuro), pelo gerundivo, e pelo supino. O objetivo desta descrição é o de oferecer um panorama sobre os condicionamentos semânticos que influenciaram os planos morfológico e sintático dos usos do gerúndio nas línguas românicas, em especial, o português, que é o foco deste trabalho.

O latim clássico exibia cinco formas nominais do verbo: infinitivo, gerúndio, gerundivo, particípio e supino. Essas formas podiam funcionar como verbos, desempenhar a função de nomes e adjetivos e ainda serem usadas em construções

\footnotetext{
${ }^{2}$ Não analiso neste capítulo a diacronia do gerúndio no romeno, no italiano e nas demais língua de Espanha.
} 
com valor de advérbios. Em sua função adverbial, essas formas nominais podiam compor dois tipos de estruturas: as orações adverbiais e as construções absolutas ${ }^{3}$.

\section{I.1.1 O gerúndio no latim}

Nas descrições gramaticais do gerúndio no latim, esta forma finita é considerada um substantivo verbal. Assim, por ser um nome, o gerúndio no latim é flexionado como um neutro singular da $2^{\mathrm{a}}$. declinação, nos quatro casos oblíquos (genitivo, dativo, acusativo e ablativo). No nominativo e no acusativo, o infinitivo é a forma selecionada nas construções que requerem esse complemento em uma forma infinita: $^{4}$

$\begin{array}{llll}\text { Nom. } & \text { Studere est utile } & = & \text { o estudar é útil } \\ \text { Gen. } \quad \text { Tempus studendi } & = & \text { o tempo de estudar } \\ \text { Cupidus studendi } & = & \text { desejoso de estudar } \\ \text { Dat. } \quad \begin{array}{l}\text { Do operam studendo } \\ \text { Aptus studendo }\end{array} & = & \text { atendo } \text { a estudar } \\ \text { acto para estudar } \\ \text { Ac. } \quad \text { Cupio studere } & = & \text { desejo estudar } \\ \text { Eo ad studendum } & = & \text { vou estudar } \\ \text { Abl. Discitur studendo } & = & \text { aprende-se estudando } \\ & \text { Exercetur in venando } & = & \text { ele exercita-se caçando, em caçar. }\end{array}$

É de interesse essencial para esta tese estudar qual a origem dos usos atuais de gerúndio no português. Verifica-se, portanto, que principalmente o ablativo do gerúndio do latim é que forneceu grande parte das possibilidades de uso do gerúndio no português.

\section{I.1.1.1 O ablativo do gerúndio no latim}

O ablativo é um caso do latim onde estão fundidos três casos primitivos: a) o ablativo propriamente dito, que indica afastamento, separação e origem; b) o caso instrumental e c) o caso locativo. Destas três relações de conteúdo básico desenvolveram-se no latim os complementos no ablativo que indicavam várias outras circunstâncias: causa, meio, instrumento, companhia, modo, qualidade, apreciação,

\footnotetext{
${ }^{3}$ Entende-se aqui a priori como uma construção absoluta, qualquer elemento nominal ou frasal que se adjunge a uma oração matriz, sem estabelecer uma relação de dependência sintática direta, por não compartilhar com esta nenhum complemento e por possuir seu próprio sujeito, o que lhe confere o status de uma oração parcialmente independente, não fosse o seu caráter nominal e sua interdependência semântica com o predicado da oração matriz. Portanto, em termos sintáticos, o que distingue as construções absolutas das orações adverbiais é o fato de que estas compartilham o sujeito da oração matriz, enquanto aquelas possuem um sujeito distinto daquele da oração à qual está adjungida.

${ }^{4}$ Quadro retirado de Ravizza (1958:289).
} 
limitação, inclusão e exclusão, lugar (origem e destino), tempo, movimento, matéria, etc. ${ }^{5}$ Mas este processo se deu de forma gradual como ensina Odette Campos (1972) ao observar que no período clássico o ablativo do gerúndio indica, normalmente, o meio ou o instrumento com que se realiza uma ação, sendo este talvez o seu sentido original de base. Nesse período o ablativo do gerúndio ocasionalmente exprime causa, tempo ou modo, mas mesmo nesse último caso ainda predominava a idéia de instrumento. No período tardio do latim, o ablativo do gerúndio amplia suas possibilidades, adquire "maior flexibilidade, exprimindo também outors valores semânticos". (Campos, 1972:9)

A autora lembra ainda que "o gerúndio com objeto era raro no período clássico, porque, neste caso, se usava o gerundivo. Esse fato impediu que o gerúndio desenvolvesse plenamente seu valor verbal. Ao contrário, encontramo-lo frequentemente coordenado com substantivos no ablativo, como um nome verbal" (Campos, 1972:9):

(1) Aut consolando aut consilio aut re iuuero. ${ }^{6}$

Ou consolando ou através de conselhos ou de minha fortuna, ajudarei.

Como já se falou acima, já em latim era possível identificar-se dois tipos de estruturas com o ablativo do gerúndio: a) o gerúndio com sujeito as orações adverbiais e b) as construções absolutas que passo a descrever a seguir.

\section{I.1.1.2 As orações adverbiais com gerúndio no latim}

Muitas das relações semânticas entre a oração matriz e a hipotática apontadas acima podem ser observadas com o uso do gerúndio como mostram os exemplos abaixo:

(2) tempo:

EST CRUOR VOCATUS AB EO QUOD EFFUSUS DECURRIT, VEL AB EO QUOD CURRENDO CORRUAT. ${ }^{7}$

Também é chamado de cruor porque quando é derramado, ele corre, ou porque quando ele (3) $\operatorname{modo}$ : corre ele escorre para o chão.

AGENDO ET AUDENDO RES ROMANA CREVIT. ${ }^{8}$

Agindo e ousando, Roma cresceu.

\footnotetext{
${ }^{5}$ Cf. Ravizza (1958:238-239).

${ }^{6}$ Campos (1972:11): Ter., He., 86.

${ }^{7}$ Schulte (2004:42): The Aberdeen Bestiary, Folio 89r, 1.13-14 (provavelmente do séc XII).

${ }^{8}$ Schulte (2004:42): Livius, Tius: HISTORIAE ROMANAE DECADES, ed: Electronic Text Center, University of Virginia Library, Vol.III (hhttp://etext.lib.virginia.edu/etcbin/toccer-new).
} 
(4) causa:

MORBO LABORANDO CAESAR GEMUIT. ${ }^{9}$

Estando doente, César gemia.

(5) finalidade:

PRAECLARA LAUDATIO, CUM DUABUS IN REBUS LEGATORUM UNA OPERA CONSUMITUR, IN LAUDANDO ATQUE REPETENDO. ${ }^{10}$

Um nobre panegírico, quando um dos negócios dos embaixadores é descartado por duas

(6) matéria: operações, louvando o homem e requerendo de volta o que foi roupado por ele.

(7) exclusão:

multa de bene beateque vivendo a Platone disputata sunt. ${ }^{11}$

muitos argumentos sobre o bom e feliz viver foram discutidos por Platão.

id deterruit me a scribendo. ${ }^{12}$

isto me dissuadiu de escrever.

O dativo do gerúndio é outro caso que nos interessa bastante para o estudo da diacronia dessa forma do latim ao português. No dativo, o gerúndio confere à oração subordinada o valor de finalidade:

(8) COQUENDO CULINAM INTRAVIT. ${ }^{13}$

Entrou na cozinha para cozinhar.

A noção de finalidade também podia ser expressa pelo gerúndio precedido da preposição $a d$, que the conferia o caso acusativo, embora este recurso fosse considerado uma construção marginal no latim:

(9) APPARET NOS $A D$ INTELLEGENDUM acusativo $_{\text {ET } A D \text { AGENDUM }}$ acusativo ESSE NATOS. $^{14}$

Parece que nascemos para compreender e para agir.

(10) canis est factus $a d$ venandum ${ }^{15}$

O cão foi feito para caçar.

Os exemplos com as preposições in e ad são provas de que mudanças estavam em curso, ou seja, o uso de preposições ao mesmo tempo servia para especificar a relação de dependência sintática entre a oração dependente e a oração matriz como também para indicar a relação semântica específica da oração dependente. $^{16}$

\footnotetext{
${ }^{9}$ Idem.

${ }^{10}$ Idem: Cicero, ACTIONIS IN C. UERREM SECUNDAE, LIBER SECUNDUS, cit.'L'ttp:-_//patriot.neth

$\sim$ lillard/cp/cic.verres.2.2.html.

${ }^{11}$ In Ravizza (1958:290).

${ }^{12}$ Idem.

${ }^{13}$ In Schulte (2004:41).

${ }^{14}$ Schulte (2004:42): Cicero, DE FINIBUS, XXI.58.

${ }^{15}$ In Ravizza (1958:290).

${ }^{16}$ Cf. Schulte (2004:42).
} 


\section{I.1.1.3 As construções absolutas no latim}

Nas construções absolutas, o gerúndio começa a aparecer no período clássico, já concorrendo com o particípio presente ativo, o gerundivo e o particípio futuro ativo, como mostram, respectivamente os quatro exemplos a seguir, que, adaptados ao português, podem muito bem ser expressos por formas no gerúndio:

(11) Quin illi remittendo de summa quisque iuris mediis consiliis copularent concordiam, patres patiendo abl..ger. tribunos militum pro consulibus fieri, tribuni plebi non intercedendo abl.ger. $_{\text {quo }}$ minus quattuor quaestores promisce de plebe ac patribus libero suffargio populi fierent? ${ }^{17}-\ldots$ aceitando os senadores... não intercedendo os tribunos contra o povo

(12) tibi ero praesente part.pres. reddam. $^{18}$ - quero dar-te [erg. o dinheiro], estando presente o teu senhor.

(13) cum [erg. populus] ... plausum meo nomine recitando gerv. dedisset, habui contionem. ${ }^{19}$ - Depois de o povo, tendo sido pronunciado meu nome, haver aplaudido, fiz um discurso.

(14) Carthaginienses, prima luce oppugnaturis part.fut.at. hostibus, saxis undique congestis augent vallum. $^{20}$ - Os cartagineses, querendo os inimigos atacar ao amanhecer, aumentaram a muralha com pedras que eles haviam trazido de todas as partes.

\section{I.1.1.4 O gerúndio adjetivo no latim}

Descrever um determinado uso do gerúndio em latim, é ao mesmo tempo analisar com que outra forma o mesmo conteúdo poderia ser expresso. Acima já falamos sobre a competição entre o particípio presente e o gerúndio no latim. Retomamos a questão, visando acentuar aqui o papel sintático que foi incorporado pelo gerúndio para expressar a idéia de adjetivação.

O particípio presente também podia indicar instrumento e modo, circunstâncias que foram incorporadas também pelo gerúndio no ablativo. O exemplo de Tito Livio abaixo mostra a convivência das duas formas no latim:

(15) Brevi deinde ceteros tutores summovet Adranodorus, iuvenem iam esse dictans Hieronymum ac regni potentem; deponendoque tutelam ipse, quae cum pluribus communis erat, in se unum omnium vires converit. ${ }^{21}$

Brandão (1933:26) comenta sabiamente este exemplo e discorre sobre o valor adjetival que o gerúndio passou a assumir:

\footnotetext{
${ }^{17}$ In Müller-Lancé (1994:42): Livius, 4, 43, 12.

${ }^{18}$ Idem, p. 40: Plauto, Asinaria V. 455.

${ }^{19}$ Ibidem, p. 42: Cicero Att. 4, 1, 6.

${ }^{20}$ Ibid., p. 41: Livius, 28, 15, 13.

${ }^{21}$ Brandão (1933:25-26): Tito Livio, XXIV, 4.
} 
Esta construção, pertence ao uso vulgar, desenvolveu-se sobremaneira no latim eclesiastico, reflexo assaz fiel da linguagem multidudinaria. Com o girar dos tempos, o ablativo do gerundio foi suplantando o participio presente pela sua analogia sintatica com êle, que lhe foi como transfundindo o seu caráter adjetival. Talvez haja concorrido para isso a já assinalada semelhança de natureza entre o gerundio e o gerundivo. Este, como vimos, sôbre possuir índole adjetival, tinha, por outro lado, certa fôrça de particípio presente passivo, como o provam ainda, por exemplo, textos do francês arcaico, v.gr.: 'Eüst grant peor de la teste PERDANT (eut grand, peur de as tête devant être perdue) Jérus; 143

Em latim, a mudança pode ser visualizada através de exemplos de gerúndios no ablativo que exibem um objeto direto, ao contrário do que prescrevia a gramática do latim clássico que dizia que o objeto do ablativo do gerúndio deveria sempre concordar com este no caso ablativo, o que não acontece nos exemplos abaixo, onde os objetos estão marcados no caso acusativo:

(16) Omnis populus vociferabatur clamore magno in laudando dominum. ${ }^{22}$

(17) Laudando promptos et castigando segnes. ${ }^{23}$

\section{I.1.1.5 O gerúndio em perífrases no latim}

No período mais tardio do latim ressurgem algumas perífrases constituídas com o gerúndio ablativo para exprimir o aspecto durativo ou progressivo:

(18) stat spargendo medelas. ${ }^{24}$

(19) stellas ire trahendo comas. ${ }^{25}$

(20) errando vadit quase caecus. ${ }^{26}$

\section{I.1.2 O gerúndio e suas formas concorrentes no latim}

Ainda cabe estudar o papel do gerúndio no latim em face das formas nominais constantes do exemplo acima, que concorriam com o mesmo para a expressão de determinadas funções tanto sintáticas como semânticas.

Diante de um quadro tão amplo de possibilidades ${ }^{27}$, não é de se estranhar que aos poucos uma das formas fosse se especializando cada vez mais na gramática do

${ }^{22}$ Idem, p. 24: Esdras, I, 3, 11.

${ }^{23}$ Idem, ibidem: Agric., 21.

${ }^{24}$ Id., p. 27: Carm. 5, 17, 5.

${ }^{25} I d ., i b .: 5,5,118$.

${ }^{26} I d$., ib.: Form. Sem. add. 4, 38.

27 Este raciocínio está baseado em dois dos cinco princípios de gramaticalização discutidos por Hopper (1991). Neste caso, teríamos um exemplo de estratificação (layering) em função da coexistência de formas com função similar, em que camadas mais antigas podem ou não ser 
latim e dos primóridos das línguas românicas para a expressão dos conteúdos semânticos que indicavam meio, modo, causa, condição, tempo, etc.

Para descrever as funções do gerúndio na sincronia atual do português, procuramos observar de que maneira essa forma nominal foi incorporada à gramática da língua. Como veremos mais adiante, na passagem do latim ao português arcaico, confundem-se os usos do particípio presente, do ablativo do gerúndio e do gerundivo. Em parte, isso se deve a uma similaridade na morfologia desses itens verbais e na concorrência dos mesmos para a expressão de alguma informação semântica específica ao serem adjungidos a algum nome ou a outro verbo.

A descrição que segue abaixo procura identificar as propriedades de similitude entre estas formas, principalmente no que se refere ao valor semântico desses itens.

\section{I.1.2.1 O particípio presente no latim}

A morfologia flexional dos particípios no latim exibia marcas de tempo e voz. Enquanto o particípio presente expressava a força ativa e simultaneidade de referência temporal, o particípio passado tinha força passiva e referência de tempo anterior, o particípio futuro marcava a referência temporal de posterioridade e força ativa. $^{28}$

O particípio presente ativo do latim exibia o morfema $-n t$, advindo do indoeuropeu: "amans < *amants, legens < *legents. ( cf. o sânscrito, bharán, nom. pl. bhara - NT - ah, o grego $\varphi \varepsilon \rho o-v \tau-o \varsigma)$ " (Brandão, 1933:11). Do indo-europeu, a forma do particípio presente herda a "índole" aposicional de que fala Brandão (op. cit. p. 12), cujo uso ampliou-se bastante em muitas línguas, especialmente no grego. Em latim isso se deu de maneira mais tímida, e seu uso aumentou a partir de autores como Salustiano e César (Brandão, 1933:13).

descartadas, mas que podem coexistir e interagir com novas formas. O outro princípio aventado por Hopper é o de especialização, que se refere ao fato de que um item pode passar a se tornar obrigatório em determinados contextos. Assim, ao mesmo tempo que o gerúndio coexistia com outras formas que exibiam as mesmas funções, aos poucos foi se especializando na expressão de determinadas funções sintáticas e semânticas.

${ }^{28}$ Cf. Schulte (2004:43). 
Em latim, o particípio presente podia referir-se a um substantivo ou a um pronome, flexionando-se de acordo com estes, daí a sua natureza adjetiva. No entanto, admitia a declinação de caso, principalmente exercendo a função de acusativo. Ele também exprimia voz, aspecto [Aktionsart], tempo e até mesmo um “certo matiz modal, assumindo então o caráter de verbo” (Brandão, 1933:12). Da mesma forma que o ablativo do gerúndio, o particípio presente exibia ainda uma relação tanto de simultaneidade como de anterioridade com o verbo da oração principal. Dessa relação básica "vão-se derivando, através de tenues cambiantes semanticos, outras relações: causa, modo, fim, meio, condição, concessão, hipótese, consequencia” (Brandão, 1933:13).

O estudo de Brandão (op. cit, p. 13) dá pistas bastante claras a respeito do escopo de predicação do particípio presente no latim. Ele observa que a "união semantica" do particípio ao verbo ou ao nome aos quais se liga é tão estreita que pode tornar o verbo da principal num verdadeiro verbo auxiliar, principalmente se os verbos da matriz expressarem alguma idéia de aspecto como ir, vir, continuar, acabar, estar, etc como em erat baptizans (estava batizando). Por outro lado, o particípio presente, ao predicar um nome, introduzia construções relativas que concorriam com o gerúndio na formação de construções infinitas como em Marcus subito adveniens me ibi invenit - Marcos, chegando de repente, ali me encontrou (Brandão, 1933:14). Interessante observar que neste caso, assim como alerta Brandão, o particípio presente "sem perder o caracter de adjetivo, adquire valor de adverbio, e, trasladado em português, poderá representar-se por um gerúndio, por um adverbio puro, por uma locução ou clausula adverbial ou por um adjetivo aposto" (Brandão, 1933:16) ${ }^{29}$.

Carlos Bennett (1921 apud Brandão, 1933:17) divide os usos do particípio presente em três tipos:

i. o uso atributivo, quando o adjetivo limita o substantivo: aqua fervens (agua fervente);

${ }^{29}$ Essa observação valida a nossa decisão por reconhecer uma categoria intermediária de predicação (v. Cap. sobre sintaticização do gerúndio) exercida pelo gerúndio em português, ou seja, um verbo no gerúndio que predica tanto o sujeito como o verbo da oração matriz. 
ii. o uso apositivo, quando o particípio estabelece uma relação de aposição com o substantivo a que se refere: talia tum memorat lucrumans e

iii. o uso predicativo, quando "a predicação principal se concentra no particípio: flens abiit, partiu CHORANDO”. ${ }^{30}$

Brandão (1933:17-18) adota esta descrição também para subdividir os usos dos gerúndios no português. Apesar de errônea, ela revela uma descrição acertadamente orientada pelo escopo de predicação destas formas.

Para este autor, a função atributiva do particípio presente pode ser reconhecida quando este elemento for utilizado como um adjetivo atributivo do substantivo. Os exemplos citados pelo autor revelam que estes particípios estão ligados aos nomes que exercem a função de sujeito, predicativo ou absolutivo:

(21) suavis homo, facundus... secunda loquens in tempore... multa tenens antiqua sepulta. ${ }^{31}$

(22) est lex... recta ratio imperans honesta, prohibens contraria. ${ }^{32}$

(23) Ordo est recta quaedam collocatio prioribus sequentia annectens. ${ }^{33}$

(24) Fuerunt et tomacula super craticulam argenteam ferventia posita. ${ }^{34}$

(25) Ante ipsamecclesiam hortus est gratissimus habens aquam optimam. ${ }^{35}$

Para o uso que chama de predicativo, ele observa o seguinte:

De modo geral, entende-se por predicativo o adjetivo, a perífrase adjetival, o particípio, o infinitivo referidos, mais ou menos intimamente, ao sujeito ou ao objeto de um verbo para denotarem o estado, a condição, o modo de ser, a atividade dêstes ao realizar-se ou no curso da ação expressa pelo verbo principal. Póde, pois, o predicativo prender-se ao sujeito, como em 'os soldados chegaram cansados,' ou ao objeto, como em 'vimos os soldados alegres'. Consideramos ainda predicativos o particípio e o infinitivo nestas frases: 'Os meninos foram vistos brincar ou brincando' e 'Vimos os meninos brincando' (Brandão, 1933:17)

Assim, vemos que já no latim o particípio presente competia com o gerúndio na adjunção a um nome em função de sujeito ou objeto, o que nos dá o pano de fundo para o surgimento das construções relativas que daí se desenvolveram nas línguas românicas. Assim como para o gerúndio ligado ao objeto de um verbo, o particípio presente pode referir-se ao objeto de um verbo de percepção (video, aspicio, audio, invenio, facio, fingo, induco):

${ }^{30}$ Cf. Brandão (1933:14-15), os grifos em negrito são meus.

${ }^{31}$ Os exemplos retirados de Brandão (1933) serão identificados assim como o autor o fez em seu livro, uma vez que muitas vezes tornou-se difícil recuperar a referência exata dos mesmos. Mantenho sempre a informação da página de seu estudo onde o exemplo aparece. Aqui: Ennio, An., 194,3 apud Bennett in Brandão (1933:15).

${ }^{32}$ Brandão (1933:15): Cic., Phil., 11, 12, in Zumpf.

${ }^{33}$ Idem, ibidem: Quint., 7, 1, in Madwig.

${ }^{34}$ Id., ib.: Petronio, Cena Trim., edição Heraeus 1923.

${ }^{35}$ Id., ib.: Peregrin. ad loca sancta, edição Heraeus, 1921, p. 5. 
(26) Polyphenum Homerus... cum ariete... colloquentem facit. $^{36}$

(27) observabo servolos venients aut abeuntis. ${ }^{37}$

(28) uxorem tuam neque gementem neque plorantem audivimus. ${ }^{38}$

Nestes exemplos, Brandão (1933:18) reconhece que o particípio presente “denota uma ação ou um estado atuais e 'cursivos', atribuidos ao sujeito ou objeto do verbo principal”.

Esta descrição de Brandão merece uma revisão do ponto de vista do papel sintático que os particípios e os gerúndios desempenham em relação aos nomes ou verbos que predicam. Se de um lado estes elementos estabelecem uma relação de dependência sintática com o nome que fornece o item sujeito às orações que integram, pois a própria morfologia $(-n t$ ou $-n d)$ neutraliza a necessidade de marcação do sujeito, por outro lado encerram uma oração plena,. Mais recentemente esta duplicidade de função sintática tem sido interpretada pelo conceito da minioração (small clause) ${ }^{39}$, fenômeno ao qual voltaremos quando da descrição dos usos do gerúndio em português.

Por último, resta retomar a descrição da função apositiva do particípio presente que é muito semelhante àquela exercida também pelo gerúndio. Neste uso, o particípio presente exprime diversas circunstâncias: tempo, modo, meio, fim, causa, condição, concessão. Em todas estas construções concorre ao lado desses valores semânticos a noção temporal, uma certa relação de tempo simultâneo vinculada ao verbo da oração matriz.

(29) tempo simultâneo: ille titi moriens nos comendavit. ${ }^{40}$

(30) tempo anterior: Quadratus cognoscens proditum Mithridatem... vocat consilium. ${ }^{41}$

(31) modo: talia tum memorat lucrumans. ${ }^{42}$

(32) meio: tu obiurgans me a peccatis rapis deteriorem in viam. ${ }^{43}$

(33) fim: Legati a Saguntinis Romam missi auxilium ad belum... orantes ${ }^{44}$

(34) causa: nunc tibi amplectimur genua egentes opum. ${ }^{45}$

(35) condição: Quis potest, mortem metuens, esse non miser? ${ }^{46}$

(36) concessão: Risus interdum ita repente erumpit, ut eum cupientes tenere nequeamus. ${ }^{47}$

${ }^{36}$ Id., ib.: Cic., Tusc.,5, 115.

${ }^{37}$ Id., p. 18: Andra., 84.

${ }^{38}$ Id., ib.: Amph., 1098, in Bennett.

${ }^{39}$ Cf. Stowell (1995: 272 apud Moraes de Castilho, 2004 e 2005).

${ }^{40}$ Brandão (1933:16): Adelp. 457 in Bennett.

${ }^{41} I d .$, ib.: Trin., 680.

${ }^{42}$ Id., ib.: En., An. 28, 2 in Bennett.

${ }^{43} I d$., ib.: Trin., 680.

${ }^{44}$ Id., ib.: Livio, 21, 62, in Isnardi.

${ }^{45}$ Id., ib.: Rud., 274, in Bennett.

${ }^{46}$ Id., ib.: Cic., Tusc. 5, 6, 15 in Buck e Hale. 
A ambigüidade semântica, promovida pela redução dos vários casos do indoeuropeu, que marcavam as circunstâncias específicas, gerou o fato de que, ao final do período clássico e do período imperial, as construções apositivas com particípio presente no latim viessem paulatinamente sendo realizadas com o suporte de partículas que lhes atribuíam o sentido específico, tais como vixdum, simul, extemplo, quippe, utpote, quase, sicut, tanquam, etsi, quanquam, nisi, etc. Em português, os advérbios como, quase, ainda, mesmo, meio e as preposições em e sem são os recursos mais usados para desambiguar as construções gerundivas.

\section{I.1.2.2 A natureza adverbial dos particípios: o particípio conjunto e o particípio ablativo absoluto}

Assim como vimos anteriormente para o ablativo absoluto do gerúndio, os particípios também podiam ser expressos de duas maneiras estruturais distintas: a) o particípio conjunto correspondia a um uso correferencial da oração adjungida, a qual compartilhava o sujeito da oração matriz e b) o particípio ablativo absoluto tinha um sujeito distinto daquele da oração matriz e tanto o verbo no particípio como o seu sujeito se apresentam no mesmo caso - o ablativo, enquanto que o particípio conjunto recebe seu caso, assim como o gênero e o número, concordando com o sujeito que compartilha da oração matriz:

(37) particípio conjunto:

HIS REBUS COMMOTUS, CAESAR PROFECTUS EST. ${ }^{48}$

Persuadido disto, Caesar partiu.

(38) particípio ablativo absoluto:

TRIBUNIS INTERCEDENTIBUS SENATUS LEGEM PERFERRE NEQUIVIT. ${ }^{49}$

Tendo os tribunos objetado, o senado não pôde aprovar a lei]

Schulte (2004:43) reconhece em ambos os casos que a função semântica associada a esses particípios é tanto temporal como condicional, no entanto, uma leitura mais cuidadosa permite a interpretação como causal. $\mathrm{Na}$ verdade, esta multiplicidade de interpretações pode ser entendida de uma perspectiva cognitiva. A noção de tempo tem sido interpretada nos estudos de gramaticalização como sendo

${ }^{47}$ Id., p. 17: Cic., De Or., 2, 28 in Zumpf.

${ }^{48}$ In Schulte (2004:43).

${ }^{49}$ Cf. Bayer \& Lindauer (1974:187 apud Schulte, 2004:44). 
uma categoria cognitiva de base. ${ }^{50} \mathrm{O}$ próprio autor argumenta que a natureza ambígua dessas formas corresponde a um uso que mais se aproxima da justaposição de orações, sendo assim a combinatória do termos de ambas as orações a responsável última pela atribuição da relação semântica específica:

In the case of absolute constructions, the absence of an overt or implied specification of the relationship between participial and main clause is an iconic way of rendering the notion of backgrounding: a structure that is underspecified in this way reflects the speaker's attitude to the content of the backgrounded clause. (Schulte, 2004:44).

Do ponto de vista estrutural, o licenciamento do ablativo absoluto depende de fatores sintáticos específicos, como alerta Ravizza (1958:239) quando alerta que "quando o particípio com o elemento que o acompanha faz parte da proposição principal, quer como sujeito, quer como complemento, não se pode usar o ablativo absoluto", como em:

(39) Alesandri mortui corpus in Graeciam delatum est. ${ }^{51}$

Morto Alexandre, o seu corpo foi levado para a Grécia.

(40) lupus agnum correptum laceravit. ${ }^{52}$

$\mathrm{O}$ lobo, tendo agarrado $o$ cordeiro, $o$ dilacerou.

$\mathrm{Na}$ verdade, vistos estes exemplos sob o prisma de norma culta do latim clássico, o que se discute aqui é o fato de que se a oração dependente exibia um termo que exercia a função de complemento da oração matriz (Alesandri e agnum, respectivamente), então a construção adjungida não poderia ser considerada como ablativo absoluto. Porém, uma mudança estava em curso e algumas ocorrências deixavam entrever tal fato, como o exemplo seguinte, no qual a construção absoluta exibe uma correferência com o sujeito da oração matriz:

(41) Caesar, principibus Trevirorum convocatis, hos singillatim Cingetorigi conciliavit. ${ }^{53}$

César, tendo reunido os chefes dos Tréviros, os reconciliou um por um com Cingetórige.

Basta rever a versão portuguesa destes exemplos para verificar que também estas formas competiam com o gerúndio, principalmente no que se refere à relação de tempo expressa nestas ocorrências.

${ }^{50}$ Cf. Claudi, Heine e Hühnemeier (1991:55), o eixo cognitivo pode ser assim interpretado Pessoa > Objeto > Processo > Espaço > Tempo > Qualidade. Tanto o valor condicional como o causal são decorrentes da composição semântica de natureza metafórica que une Tempo ao eixo da categoria Qualidade.

${ }^{51}$ In Ravizza (1958:239).

${ }^{5}$ Idem, ibidem.

${ }^{53} I d$., ib., p. 240. 


\section{I.1.2.3 A competição entre o particípio presente e o gerúndio no latim}

Stanko Skerlj (1926:70) observa que ainda mesmo no latim o particípio presente e o gerúndio estavam em competição, ambas formas exprimiam a) a concomitância temporal entre dois termos, b) a idéia adjetiva (relativa) e exibiam ainda c) a expressão adverbial através de proposições circunstanciais de modo, simultaneidade, tempo, causa, condição e concessão:

La concurrence de l'ablatif du gérondif, forme adverbiale, et du participe présent, forme adnominale, est possible en tant que les deux formes ont un même rôle: celui de déterminer une action par une autre action; en d'autres termes: en tant qu'ils remplacent, l'un et l'autre, des propositions circonstancielles de manière, de cause, de temps, de condicion, et peut-être de concession. En dehors de cela il y a des domaines dans lesquels leur rivalité ne se transporte que par exception: ainsi il arrive très rarement que le participe présent supplante l'ablatif du gérondif au sens purement instrumental (cf. ci-dessus $§ 44 \mathrm{~s}$.); et, d'autre côté, le gérondif ne remplace jamais une proposition purement relative, adjective, - ce qui est le rôle primitif du participe présent (cf. ci-dessus $\$ 201$ ).

Dans le lutte pour l'expression de propositions circonstancielles, le gérondif avait beaucoup de chance contre le participe présent (Skerlj, 1926:70)

Mais adiante, Skerlj (1926:73) explica a razão de o partícipio presente ter sido suplantado pelo gerúndio em latim:

La plus forte raison du succès du gérondif fut cependant le fait que le participe présent perdait de plus sa force verbale, la faculté d'exprimir des actions verbales. A juger de son sort dans le anciennes langues romanes, il était en train de passer tout à la catégorie des adjectifs. Au lieu d'attribuer à un sujet donné le rôle de porteur d'une action à l'aspect imperfectif, il le caractérisait par une qualité habituelle.

A mesma idéia tinha sido evidenciada no estudo de Samuel Garner (1887b:275) ao lembrar que os gramáticos de Port-Royal reconheciam que o particípio presente do francês medieval não era nada mais nada menos que o gérondif, pois, assim como este, aquele não recebia desinências de pessoa e número e nem mesmo podia ser declinado.

Odette Campos (1972) apresenta o seguinte quadro comparativo entre o ablativo do gerúndio e do particípio presente no latim clássico: 


\begin{tabular}{|l|l|}
\hline \multicolumn{1}{|c|}{ Ablativo do gerúndio } & \multicolumn{1}{|c|}{ Particípio presente } \\
\hline 1. Era um nome verbal, no caso ablativo. & $\begin{array}{l}\text { 1. Era um adjetivo verbal, que tinha flexão de } \\
\text { gênero, número e caso. }\end{array}$ \\
\hline $\begin{array}{l}\text { 2. Como tal, possuia função adverbial, } \\
\text { referindo-se ao verbo da oração; não tinha a } \\
\text { possibilidade de formar oraçôes absolutas com } \\
\text { sujeito próprio. }\end{array}$ & $\begin{array}{l}\text { 2. Como tal, referia-se a um nome da oração, } \\
\text { independentemente da função que este pudesse } \\
\text { desempenhar, concordando com ele, como um } \\
\text { simples adjetivo, ou formava orações } \\
\text { absolutas,com sujeito próprio, indo ambos para o } \\
\text { ablativo. }\end{array}$ \\
\hline $\begin{array}{l}\text { 3. Ligado ao sentido primitivo do ablativo, } \\
\text { indicava o meio ou o instrumento através do } \\
\text { qual se faz uma ação, podendo exprimir, no } \\
\text { período tardio, as circunstâncias de modo, } \\
\text { causa, tempo, etc... }\end{array}$ & $\begin{array}{l}\text { 3. Indicava as várias circunstâncias que } \\
\text { acompanham a oração principal. }\end{array}$ \\
\hline $\begin{array}{l}\text { 4. Exprimia exclusivamente uma ação } \\
\text { simultânea à principal. }\end{array}$ & $\begin{array}{l}\text { 4. Exprimia normalmente uma ação simultânea à } \\
\text { principal, podendo, ocasionalmente, exprimir a } \\
\text { anterioridade. }\end{array}$ \\
\hline $\begin{array}{l}\text { 5. Não formava perífrases, nem construções } \\
\text { que seriam o início de perífrases verbais. }\end{array}$ & $\begin{array}{l}\text { 5. Com alguns verbos, como esse e ire formava } \\
\text { algumas construções, que já teriam algumas } \\
\text { características das perífrases verbais, embora } \\
\text { ainda em forma embrionária. }\end{array}$ \\
\hline
\end{tabular}

Quadro 1. As funções do ablativo do gerúndio e do particípio presente no período clássico do latim (Campos, 1972:19).

A autora observa ainda que no período tardio do latim, as duas formas apareciam lado a lado, com o mesmo sentido:

(42) Impetu peruagatum incedium plena primum, deinde in edita adsurgens et rursus inferiora populando antiit remedia uelocitate mali... ${ }^{54}$

$\mathrm{O}$ incêndio, tendo-se alastrado com violência primeio nas partes planas, subindo em seguida para as partes altas e devastando de novo as partes baixas, antecipou com sua velocidade os remédios do mal...

Se os textos escritos nos mostram que era possível usar-se o gerúndio com as funções e valores do particípio presente, provavelmente esse emprego já era comum na língua falada desde época bem antiga. Acrescentando-se a isso o fato de que praticamente só o gerúndio permaneceu nas línguas românicas, podemos acreditar que apenas ele tenha existido na língua do povo, pelo menos na fase imediatamente anterior à cisão do Império. Conseqüentemente, o gerúndio já teria começado a exprimir os valores e funções do particípio presente, desde o latim vulgar do Império. Resta saber até que ponto o gerúndio incorporou as funções do particípio presente já no latim vulgar. Só o estudo das línguas românicas vai poder responder a esta pergunta (Campos, 1972:23)

\footnotetext{
${ }^{54}$ Campos (1972:21): Tac., Ann., XV, XXXVIII, 4.
} 
Quem pode ter respondido a esta pergunta de Odette Campos é Müller-Lancé que, em parte, evidenciou o caráter popular do ablativo do gerúndio. Ao analisar o uso das construções absolutas no latim vulgar através da tipologia textual, observou que a freqüência de ablativos do gerúndio era muito grande no texto Itinerarium Egeriae, considerado menos formal que outros textos dessa época utilizados em seu corpus: "Da es aber gerade in diesen Texten von Ablativi Absoluti nur so wimmelt, müßte dann der Umkehrschluß erlaubt sein, daß der Abl.Abs. deutlich volksprachlicheren Charakter habe als der Acc.Abs. "55 (Müller-Lancé, 1994:177).

\section{I.1.3 O gerundivo}

O gerundivo é uma forma nominal que expressa um sentido passivo ou modal. Além de seu uso atributivo, por estar ligado a um nome e como um item que compõe expressões impessoais, ele também pode ser uma forma dependente de outro verbo ou de uma sentença, embora morfossintaticamente se comporte como um adjetivo. Em oposição ao gerúndio, que segundo a norma do latim clássico não podia vir acompanhado de um objeto direto, o verbo expresso no gerundivo permitia a presença de um complemento objeto direto.

A interpretação semântica das construções com gerundivo sem preposição podia ser obtida em função do caso que lhe era atribuído: ${ }^{56}$

(43) nominativo (finalidade):

ALEXANDER A PATRE ARISTOTELI EDUCANDUS TRADITUS EST

Alexandre foi entregue a Aristóteles por seu pai para ser educado.

(44) acusativo (objeto):

CAESAR PONTEM IN FLUMINE FACIEDUM CURAT

César encomenda uma ponte para ser construída sobre o rio.

(45) ablativo (modo):

POMPEIUS PIRATIS PERSEQUENDIS MARE TUTUM REDDIDIT

55 Tradução minha: “Justamente porque nestes textos pululam ablativos absolutos, a conclusão reversa [ao que Anne Hettula afirma em seu texto de 1987, p.51-52] a que se deve chegar é de que o ablativo do gerúndio tinha um caráter popular muito maior do que o acusativo absoluto."

${ }^{56}$ Exemplos de Bayer \& Lindauer (1974:183 apud Schulte, 2004:45). 
Pompéia fez o mar novamente seguro perseguindo os piratas.

O uso de preposições também era um suporte sintático que permitia a interpretação semântica dos verbos no gerundivo em diferentes casos sintáticos:

(46) gerundivo no ablativo com a preposição $I N$ :

IN AMICIS ELIGENDIS HOMINES SAEPE NEGLIGENTES SUNT ${ }^{57}$

Ao escolher seus amigos, as pessoas freqüentemente são negligentes

(47) gerundivo no acusativo com a preposição $A D$ :

NON TANTUM EGO IMPENDERE VIDEO QUANTUM TU AUT VIDES AUT AD ME CONSOLANDUM ADFERS ${ }^{58}$

Eu vejo tantas coisas ameaçadoras como vês ou pões para incitar-me.

\section{A competição entre o gerundivo e o gerúndio no latim}

Estudiosos da diacronia do latim sempre discutiram a formação do gerúndio em -nd em oposição ao gerundivo em -ndus, entendido como particípio de obrigação. Adelaide Hahn (1943:280) estudou a questão da marcação de voz nas formas verbais não-finitas do latim e do inglês, partindo do estudo de línguas indoeuropéias como o hitita e o sânscrito. Nesse trabalho, ela defende que o gerundivo no latim desenvolveu-se a partir do gerúndio (Hahn, 1943:280), e não o contrário, como é afirmado por muitos outros autores ${ }^{59}$. O mesmo raciocínio foi defendido por W. H. Kirk em dois estudos publicados sobre a sintaxe do gerúndio e do gerundivo em latim (Kirk, 1942 e 1943). Outros (Meillet-Vendryes, 1924 apud Kirk, 1942) discutiram ainda que ambas as formas são de origem independente.

Diz Brandão (1933:22) que o gerundivo tem a mesma origem do gerúndio e que também pode ser chamado de particípio futuro ativo. Segundo este autor, em certos casos o gerundivo pode confundir-se sintaticamente com o gerúndio, assumindo suas funções e operando a mudança de caso no complemento deste verbo:

(48) studium videndi urbem ou studium videndae urbis. ${ }^{60}$

${ }^{57}$ Idem, ibidem.

${ }^{58}$ Idem, p. 46: Cicero: M. TULLI CICERONIS EPISTULARUM AD ATTICUM LIBER TERTIUS: [VIII] Scr. Thessalonicae in K. Iun. a. 696 (58), cit.hinttp://patriot.net/ lillard/cp/cic.att3.html.

${ }^{59}$ O estudo de Brandão (1933:12) e trabalhos recentes a respeito da questão da sintaxe do gerúndio e do gerundivo no latim defendem a precedência do gerúndio tal como o estudo Gerund and gerundive in Latin de D. G. Miller (2000): "The oldest documents in Italic and Latin support the hypothesis that the _erundive _ is older than the gerund + acc object." 'http://www.ingentaconnect.com/content/jbp/dia/2000/,

$00000017 / 00000002 / a r 00002$, abstracts acessado em 12.10.2006.

${ }^{60}$ Cf. Brandão (1933:22). 
Neste caso, o adjetivo em -ndus perde a idéia de obrigatoriedade e passa a expressar também a idéia de finalidade (studium videndae urbis = cidade para ser vista $;$ vir honorandus $=$ homem honorável/que deve ser honrado).

O que transcende de toda essa discussão é que também o gerundivo era uma forma que competia com o particípio presente e com o ablativo do gerúndio para expressar as mesmas circunstâncias proposicionais. Além disso, é importante ressaltar que o gerundivo permitia a leitura de obrigatoriedade (deliberandum censeo $=$ creio que é necessário deliberar , mi currendumst $=$ tenho que correr $)^{61}$. Tanto o gerundivo como o gerúndio exprimiam essa noção, como em studium evertendi republicam e studium evertendae reipublicae ${ }^{62}$. Segundo Hahn, há exemplos (p.ex. $a b$ urbe condenda) em que se pode ver que a idéia de obrigatoriedade "spread from the gerundive used predicatively in periphrasis with the copula, to the same form used as simple adjetive in attributive relation with a noun" (Hahn, 1943:290). À idéia de obrigatoriedade pode somar-se também o sentido de finalidade. A maioria das línguas românicas utiliza a forma nominal do infinitivo para expressar a idéia de finalidade e de obrigatoriedade (vou viajar, preciso ler), enquanto que línguas como o inglês ainda utilizam não só o infinitivo (he wants to go), como também uma forma gerundiva para a expressão de alguma nuance específica que se quer conferir ao verbo da oração adjungida (she didn't stop smoking).

\section{I.1.4 O supino}

O supino exibia no latim duas formas: o supino ativo (em -um) e o supino passivo $(\mathrm{em}-u)$.

O supino ativo em -um era utilizado com o caso acusativo e indicava a idéia de finalidade (relação, tendência e escopo) ${ }^{63}$ :

(49) Hannibal revocatus est patriam defensum. ${ }^{64}$

Acompanhado de verbos de movimento próprio ou figurado, reforçava-se o valor de finalidade e intenção (tendência) ${ }^{65}$

\footnotetext{
${ }^{61}$ Exemplos de Hahn (1943:288).

${ }^{62}$ Exemplos de Meillet-Vendryes (1924 apud Brandão, 1933:12):

${ }^{63}$ Cf. Ravizza (1958:292).

${ }^{64}$ Idem, pp. 292-293.
} 
(50) Legati venerunt postulatum auxilium.

Os embaixadores vieram para pedir auxílio.

(51) Venio spectatum ludos.

Venho para ver os jogos.

(52) Tibi supplicatum venio.

Venho para suplicar-te.

(53) Venerunt questum injurias.

Vieram para queixar-se das injúrias.

O supino passivo em $-u$ está condicionado ao uso com adjetivos de determinada categoria como facilis, dificilis, visu, incridibilis, mirabilis, jucundus, utilis, honestus, turpis, fas e nefas em construções do tipo facilis est no. Expresso no caso ablativo, indica relação ou limitação: ${ }^{66}$

(54) res jucunda auditu.

coisa agradável de se ouvir.

(55) visu mirabilis.

admirável de se ver.

(56) res facilis factu.

coisa fácil de se fazer.

(57) nefas dictu.

coisa ilícita de se dizer.

\section{I.1.5 Considerações finais a respeito dos estudos sobre gerúndio no latim}

A lição dos autores citados neste capítulo permitirá compreender as tentativas - ora acertadas, ora menos corretas - de descrição do gerúndio empreendidas pelos gramáticos do português. Vê-se pelo exposto que no latim tardio outras formas concorriam com o gerúndio para a expressão de várias circunstâncias adverbiais além de assumir algumas propriedades que cabiam ao particípio presente, como é o caso da função relativa. Foi possível observar que essa forma nominal, embora relativamente estável em termos sintáticos, passou por estágios de mudança ainda no latim. Vamos observar nas subseções seguintes como as construções gerundiais se comportaram na passagem do latim vulgar para as línguas românicas.

${ }^{65} I d ., i b$.

${ }^{66} I d$., ib. 


\section{I.2 O gerúndio nas línguas românicas}

Na passagem do latim vulgar para as línguas românicas, abandonaram-se algumas formas nominais do verbo que eram utilizadas em latim funcionando como verbos, nomes, adjetivos ou advérbios. O italiano, o espanhol, o português e o francês perderam o particípio futuro ativo e o gerundivo. As três primeiras reanalizaram gradativamente o uso do particípio presente, mantendo apenas o seu valor de adjetivo e, aos poucos, substituindo o seu uso adverbial pelas formas do ablativo do gerúndio. $\mathrm{O}$ francês manteve o particípio presente tanto para a expressão adjetiva como adverbial e descartou o ablativo do gerúndio. Além disso, novas possibilidades incorporam-se às línguas românicas como o uso de advérbios e outras construções participiais. ${ }^{67}$

Gerúndios sempre povoaram textos de norma culta, tanto de tradição religiosa como textos jurídicos medievais, como é o caso dos forais e dos documentos notariais da Idade Média. Da mesma forma como se deu com vários outros fenômenos lingüísticos incorporados às línguas românicas, inicialmente as construções absolutas com gerúndio eram abundantes e concorreram com construções de particípio presente e gerundivo. No entanto, durante esse período de sedimentação das mesmas línguas como índices de identidade de grupo - o que deve ter avançado até meados do século XV -, as mesmas línguas foram se afastando de sua base latina. Embora a aplicação do direito canônico romano e o produto de certas traduções de outras línguas românicas para o português ${ }^{68}$ tenham contribuído para a perpetuação de certos usos lingüísticos originários do latim clássico, a língua portuguesa, como qualquer outra língua românica, evoluiu como inovação à base latina. Da mesma forma, as outras línguas românicas aos poucos acomodavam-se segundo as influências e contatos lingüísticos ocorridos nas diversas comunidades da România. Assim, determinados usos decorrentes do latim eram abandonados e outros eram selecionados e reanalisados. É nesse período arcaico da língua portuguesa que se criam os artigos definidos, os pronomes de 3.a pessoa, surgem perífrases verbais, aumenta o número de conjunções e preposições em decorrência da perda de

${ }^{67}$ Cf. Müller-Lancé (1994:36-71).

${ }^{68}$ Um exemplo interessante de interferência promovida por tradições discursivas de uma língua para outra é o caso do Fuero Real de Afonso X que tem uma tradução para o português a partir do original em espanhol. 
morfologia de caso, entre outros itens que não cabe aqui citar, até que a língua possa culminar no que se tem chamado de português médio. Recentemente, Esperança Cardeira (2005), estudiosa da diacronia do português europeu, publicou um valioso estudo acerca dos fenômenos que permitem entrever a existência de um português médio entre o período arcaico e o clássico. Entre estes fenômenos, encontram-se o crescente abandono dos particípios terminados em - udo e a perda da ortografia etimológica dos substantivos terminados em -anu e -one, dando lugar às terminações -am e - ão. Tem-se defendido que a carta quinhentista de Pero Vaz de Caminha é um testemunho dessa base medieval intermediária do português europeu, embora também nela abundem as formas do gerúndio introduzindo hipotáticas temporais com valor de progressão narrativa. Isso pode servir de argumento para ilustrar a idéia de que nem tudo são inovações durante esse período intermediário e que havia sim permanências no português médio. Em meu trabalho, defendo que a permanência de construções absolutas tanto atende a exigências de tradição discursiva, uma vez que as mesmas são típicas de documentos jurídicos e religiosos, como também servem como variante sintática para as construções com conjunções e observo que também no plano discursivo seu uso está orientado pela possibilidade de acumulação de sentidos ou de ambigüidade como forma de preservar a face dos interlocutores.

A partir do final do século $\mathrm{XV}$, ocorre o fenômeno de relatinização das línguas românicas, fato que se observa nas artes e nas letras nas sociedades européias. Era o período do Renascimento. Nesse momento, formas anteriormente abandonadas foram sendo reincorporadas ao quadro das línguas românicas, outras tiveram seu uso mais ampliado, e é isso que podemos ver com relação às construções absolutas de gerúndio e de particípio presente, cuja alta freqüência podemos ver na obra de Gil Vicente e de Luis de Camões.

Como vimos na seção anterior, após o período clássico em que os textos em língua latina apresentavam uma alta ocorrência de construções sintaticamente mais elaboradas, no latim vulgar o gerúndio, embora com menor freqüência, ainda fazia parte de um amplo leque de possibilidades de uso. Nesta seção procuramos primeiramente demonstrar como se deu a incorporação do gerúndio na constituição do francês, do espanhol, do italiano e do português arcaicos, para, em seguida, descrever de forma resumida o seu uso atual nessas línguas. A idéia de comparar a 
descrição dos usos do gerúndio no português com as outras três línguas tem por objetivo verificar de que forma tais usos foram ou não incorporados nessas línguas, visualizar os motivos que levaram a uma normatização dos usos do gerúndio e, finalmente, observar como vêm sendo descritos recentemente nessas línguas.

\section{I.2.1 O gerúndio no francês}

Interessantemente, em francês deu-se que a forma gerundiva mantivesse o morfema $-n t$ do particípio presente ativo. O espanhol, o italiano e o português privilegiaram o morfema $-n d$, advindo do ablativo do gerúndio latino.

Existem duas teorias que respondem à pergunta se a forma -ant em francês corresponderia ao particípio presente ou ao ablativo do gerúndio latino. A maioria dos pesquisadores tende a aceitar o ablativo do gerúndio latino como a forma que deu origem ao gérondif arcaico, outros defendem que seria o particípio presente o item que lhe corresponderia em francês. Outros ainda defendem a idéia de que a forma arcaica do francês pode ser entendida como um particípio presente que perde a flexão de gênero e número, passando por um processo de contaminação do ablativo do gerúndio. ${ }^{69}$

Outra pergunta que se faz é se no francês arcaico essa forma deveria ser reconhecida como particípio ou como gerúndio. Samuel Garner (1887b) lembra que os gramáticos de Port-Royal declararam em 1660 que o particípio presente do francês medieval não era nada mais nada menos que o gérondif, ou seja, o ablativo do gerúndio, pois, assim como este, aquele não era suscetível de receber desinências de pessoa e número ou mesmo de ser declinado:

Je dis que nos deux participes aimant et aimé, em tant qu'ils ont le même régime que le verbe, sont plutôt des gérondifs que des participes; car M. Vaugelas a déjà remarqué que le participe em ant, lorsqu'il e le régime du verbe, n'a point de féminin et qu'on ne dit point par exemple: 'j'ai vu une femme lisante l'Ecriture, mais lisant l'Ecriture.' Que si on le met quelquesfois au pluriel: 'j'ai vu des hommes lisants l'Ecriture,' je crois que cela estvenu d'une faute dont on ne s'est pa aperçu à cause que le son de lisant et de lisants est presque toujours le même, le t ni le s ne se prononçant poit d'ordinaire. (Arnauld \& Lancelot, 1660 apud Garner, 1887b:275).

Ao contrário do que se lê acima, e embora se mantenha a idéia de que se devem considerar dois usos distintos dessas duas formas, em 1679 a Académie

${ }^{69}$ Cf. Müller-Lancé, 1994:53. 
Française assim normatiza essa diferenciação: o gerúndio é a forma verbal flexionada que deve ser vista como um adjetivo verbal, enquanto que a forma não flexionada deve ser reconhecida como um particípio presente:

Il faut dire, je les ay trouvez ayant, et non pas ayans le verre à la main. Je les ay trouvez mangeant des confitures, beuvant de la limonade, et non pas mangeans des confitures, beuvans de la limonade. Il faut parler de la mesme sorte si le relatif les se rapporte à des femmes. Je les trouvay mangeant des confitures, et non pas mangeantes des confitures; quoy qu'on puisse dire en parlant des femmes, Je les ay trouvées bien mangeantes et bien beuvantes. La raison est qu'aucun verbe actif n'a de participe qui regisse l'accusatif. (Nyrop, 1899/1930)

A tradição gramatical do francês, no entanto, adotou o particípio presente como a forma flexionada e o gerúndio como a forma não flexionada, assim como se observa na descrição das outras línguas românicas. Como se vê, a discussão gira em torno do fator flexão. Porém, Müller-Lancé (1994:54) verifica que, em muitos casos, tal critério não parece ser o suficiente para distinguir as duas formas, uma vez que muitas vezes elas aparecem de forma idêntica. Ele diz em seu estudo que no francês arcaico não havia a marca de feminino para o particípio presente. Esse autor verifica que até mesmo em descrições atuais do francês essa discussão parece ser tratada de maneira equivocada, quando, por exemplo, considera como gérondif unicamente as construções com a partícula en + a forma invariável do verbo em -ant (en lisant). Assim, para seu estudo das construções absolutas do latim ao francês moderno ele adota o termo particípio presente ativo para ambas as formas:

Auf diese Weise möchte ich dem Widerspruch aus dem Wege gehen, daß in Handbüchern zum Altfranzösischen von einem 'gérondif absolu', in Grammatiken des Neufranzösischen aber ganz selbstverständlich von einem 'participe absolu' gesprochen wird, obwohl sich die Konstruktionen funktional entsprechen und außerdem noch verwandt sind. (Müller-Lancé, 1994:54). ${ }^{70}$

\section{I.2.1.1 As construções absolutas no francês}

O estudo de Müller-Lancé (1994) sobre as construções absolutas pode lançar uma perspectiva de análise para o estudo do gerúndio em construções adverbiais do português. Neste trabalho ele analisa o uso de diversas formas que concorriam com o

\footnotetext{
${ }^{70}$ Tradução minha: "Dessa forma, gostaria de evitar a contradição que se instaura quando se fala em 'gérondif absolut' nos manuais do francês arcaico, enquanto que se fala efetivamente de um 'participe absolu' nas gramáticas do francês moderno, embora as construções funcionalmente se correspondam e além do mais ainda sejam aparentadas."
} 
particípio presente/gerúndio ${ }^{71}$ na configuração das construções absolutas. Passo a descrever de forma resumida essas possibilidades e agrego as considerações atinentes à questão das relações proposicionais que as construções com particípio presente / gerúndio podem indicar e de como se deu a evolução dessa forma no francês.

\section{I.2.1.1.1 As CAs no francês arcaico}

No período arcaico do francês as construções absolutas podiam compor-se de particípio presente/gerúndio, como em

(58) Et li rois a fait molt que prous, | Flore a le main prist voint tous ${ }^{72}$;

- e o rei agiu inteligentemente, ele tirou a mão de Florus [com] todos olhando.

mas outras variantes também eram possíveis. Seus predicados poderiam compor-se de um particípio perfeito passivo e outros itens não participiais como adjetivos, complementos preposicionados, advérbios e substantivos:

(59) particípio perfeito passivo:

ses gens vers Lymors conduisoit, | hiaumes laciez, haubers vestuz, | et les escuz as cos panduz; ${ }^{73}$

- ele guiou sua gente para Lymors, os elmos presos, as malhas postas e os escudos pendurados à volta do pescoço.

(60) adjetivo: L'espee nue na la loge entre. ${ }^{74}$ - ele adentra a cabana [com] a espada nua.

(61) complemento preposicionado:

..., quant il virent um chevailier | venir armé sor um destrier, | l'escu au col, lance el poing. ${ }^{75}$

- quando eles viram um cavaleiro, que vinha armado sobre um cavalo de batalha, o escudo à volta do pescoço e a lança em punho.

(62) advérbio: Des hostiex issent les escuz très avant ${ }^{76}$ - eles saíram da casa, os escudos avante.

(63) substantivo:

Che fu fait la MCCIIIIXX et XVI, le nuit saint Remy, Wille de Poutrohart, Jehan Vretet fil Allart, Andriu le borgne et leur compaignons eschevins adont. ${ }^{77}$

- Isto passou-se no ano de 1296 na noite de São Remínio, atuando Wille von Poutrohart, Jehan Vretet, o filho de Allart, o caolho Andriu e suas esposas atuando como jurados.

Em francês arcaico o uso do particípio presente ativo, com valor gerundivo, em construções absolutas é significativamente menor do que as construções com particípio passado passivo (29 ocorrências de particípio presente contra 49 de particípio passado num total de 87 ocorrências). Müller-Lancé observa que a imensa gama de possibilidades de expressão de relações proposicionais do latim diminui

\footnotetext{
${ }^{71}$ A partir daqui utilizo para o francês a notação particípio presente / gerúndio, de acordo com as considerações de Müller-Lancé a respeito da diferenciação dessas duas formas no francês.

${ }^{72}$ Floire et Blancheflor, V. 3110 in Müller-Lancé, 1994:49.

${ }^{73}$ Chrétien de Troyes, Erec et Enid V. 4929/4930 (ed. Roques), cf. Müller-Lancé, 1994:49.

${ }^{74}$ Béroul, Tristan V. 1987 in Müller-Lancé, 1994:50

${ }^{75}$ Chrétien de Troyes, Erec et Enide V. 141 in Müller-Lancé, 1994:50.

${ }^{76}$ Charr. Nym. 1396 citado em Nehry 1882:52 cf. Müller-Lancé, 1994:50.

77 Tailliar, E., citado em Nehry 1882:68 cf. Müller-Lancé, 1994:51.
} 
muito no período arcaico do francês. A relação de conteúdo que mais se verifica nesta época é a de modo (22/29 ocorrências).

Oriunda da linguagem jurídica lexicalizou-se a forma ce pendent (entretanto) que migrou de um contexto mais sentencial (enquanto isto durava) para um contexto mais adverbial. Outra forma que abandonou o domínio das construções absolutas para dar lugar a um advérbio é a antiga fórmula latina me sciente (com meu conhecimento) que em francês arcaico desenvolveu-se com o pronome possessivo mien/mon, gerando a fórmula mien escient que podia ser acompanhada de preposições (par le mien escïent, a esscïent).

Em seu corpus de análise do francês arcaico, Müller-Lancé (1994:230-231) não observa a repetição de fórmulas que já haviam sido gramaticalizadas ainda no latim como praesente ou absente. Estas só seriam retomadas no período clássico por conta do fenômeno da relatinização do francês e das outras línguas românicas. Por outro lado, ele afere uma alta ocorrência de fórmulas composas por veiant e oiant, cujas lexicalizações ele não atribui a nenhum antecedente latino, tendo sido, portanto, segundo este autor, gramaticalizadas dentro do próprio sistema do francês arcaico. Müller-Lancé observou também que o processo de gramaticalização de fórmulas originadas em construções absolutas estava relacionado ao domínio de conteúdo das lexias de sujeito das mesmas. Ele verificou três grandes grupos de sujeitos que deram margem a lexicalizações no francês arcaico: 1) o grupo dos sujeitos relacionados à descrição do vestuário da cavalaria, com verbos no particípio passado passivo (helmes laciez, espee çainte, halbercs vestuz); 2) o grupo dos sujeitos relacionados às pessoas presentes na ação descrita (voiant le pueple, se despollent; si parla oiant le barnage) e 3) o grupo dos sujeitos como complementos de tempo (entrant octobre).

\section{I.2.1.1.2 As CAs no francês clássico}

Muitos autores defendem a idéia de que somente no período clássico do francês as formas do ablativo do gerúndio foram reconstituídas em função da influência do humanismo na escola e na chancelaria. Alguns afirmam ainda que o estatuto sintático de oração subordinada temporal exercido pelas construções 
absolutas é advindo dessa influência e não do valor modal que poderia ter sido adquirido dessas construções do francês arcaico (Müller-Lancé, 1994:55).

No corpus do francês clássico de Müller-Lancé, assim como no período arcaico, a freqüência de uso do particípio presente ativo / gerúndio (10/58 ocorrências) para expressar alguma relação proposicional ainda é bastante tímida em construções absolutas em comparação às outras possibilidades sintáticas (particípio presente passivo e adjetivos). Ao contrário do francês arcaico, neste período reacende-se a amplitude semântica do particípio presente, assim como isso se dava no latim. Majoritariamente elas distribuem-se entre o valor modal e o temporal, com alguns casos que indicam condição e causa.

Nos exemplos que seguem, verificam-se construções absolutas com o particípio presente/gerúndio:

(64) Eulx disans ces parolles, voicy arriver Loup Garou, avecques tous se Géans, ${ }^{78}$ - dizendo eles estas palavras, também já veio Loup Garou com todos os seus gigantes.

No francês clássico também desenvolvem-se algumas construções de particípio composto com ayant, estant, ayant été + particípio passado passivo:

(65) Charlemaine de France estant premier couchié que nul des autres ne povoit dormir pour ce que trop s'estoient tost couchiés les barons; ${ }^{79}$

- tendo-se deitado ali Carlos Magno da França, não pôde dormir ali nenhum dos outros, uma vez que esses nobres tivessem se deitado muito cedo.

(66) Ayant donc Amulius été ainsi occis,... Rémus et Romulus ne voulerant point demeurer em la ville d'Albe $^{80}$ - Tendo sido assassinado Amulius desta forma, não queriam Rômulo e Remo permanecer na cidade de Alba.

A par do particípio presente / gerúndio concorriam outras formas ${ }^{81}$ :

(67) particípio passado passivo: Ces lettres receues et veues - recebidas e lidas estas cartas.

(68) adjetivo: la gueulle baye - [com] a boca aberta.

(69) complemento preposicionado:

le cueur, l'estomach et le pot au vin - o coração, o estômago e o traseiro com vinho.

(70) advérbio: jambe de sà, jambe de là - uma perna cá, uma perna lá.

Nyrop (1899) também observa algumas lexicalizações de particípios presentes variáveis e invariáveis em fórmulas de natureza jurídica como les ayants droit, les ayants cause, les ayants compte, cour séante à Paris, etc.

\footnotetext{
${ }^{78}$ Idem, p. 55.

${ }^{79}$ Recolhido das epopéias francesas (B.L.F. 226) in Eduard Koschwitz 1867:265-269, cf. MüllerLancé, 1994:56.

${ }^{80}$ Amyot, Romulus, citado em Benoit (1877:169) cf. Müller-Lancé, 1994:56.

${ }^{81}$ Exemplos de Müller-Lancé (1994: 55-57). Para o período clássico e moderno do francês cito apenas o trecho que contém a construção absoluta.
} 
Müller-Lancé (1994:254-255) verifica para este período a lexicalização de algumas fórmulas com o particípio passado passivo como ce faict, ce dict, cela faict que marcam o encerramento de uma ação anterior. Seguindo esta mesma linha, observou ainda o caso de passé + uma expressão de tempo delimitado. Do particípio presente ativo derivam as lexicalizações nonobstant (não obstante), moyennant (por meio de, através) e excepté (exceto), novas preposições incorporadas ao francês clássico assim como aquelas advindas do particípio perfeito passivo veu (visto, em vistas de) e saulve (salvo, exceto). Destas estruturas desenvolveram-se algumas conjunções no francês como veu que (visto que), pourveu que ([pres]supondo-se que), obstant que (obstando que) e non obstant que (não obstante que). É importante notar, porém, que o autor testou o grau de sentencialidade das expressões compostas por estes itens e chegou à conclusão de que as mesmas ainda deveriam ser reconhecidas como construções absolutas por exibirem ainda algum valor sentencial. O processo de gramaticalização dessas estruturas como preposições ou conjunções só dá, segundo ele, no período moderno da língua. O autor observa que no período clássico do francês a reincorporação de determinadas construções absolutas vindas do latim colaborou intensamente para o desenvolvimento principalmente de preposições e conjunções para expressar as relações proposicionais mais complexas, nota ainda que a partir do século XVII essa mesma produtividade, por conta de sua redundância, foi refreada através de normatizações.

\section{I.2.1.1.3 As CAs no francês moderno}

O particípio presente / gerúndio continuou sendo bastante produtivo a partir do francês moderno, em parte por conta da decisão da Académie de refrear a sua flexão, em parte pela ampliação de novas perífrases nas quais ele aparece aliado a outras formas participiais (ayant atteint, ayant été amenée, étant représenté), fenômeno que havia se iniciado já no francês clássico. Müller-Lancé atribui o aumento destas composições à deficiência do sistema de particípios do francês.

Assim, a par de construções absolutas formadas por um simples particípio presente / gerúndio como em 
(71) Les hommes vivant em moyenne moins longtemps que les femmes (huit ans de différence), ces situations sont très nombreuses. ${ }^{82}$

- Os homens vivendo menos do que as mulheres (oito anos de diferença), estas situações são muito freqüentes.

havia outras possibilidades de expressão com esta mesma forma participial: ${ }^{83}$

(72) particípio passado passivo com valor passivo: sa mission accomplie - sua missão cumprida.

(73) particípio passado passivo com valor ativo: le mois de juillet venu - vindo o mês de julho.

(74) perífrases de particípio perfeito ativo com avoir:

Le commandant Lassard ayant atteint l'âge de la retraite

- o comandante Lassard tendo atingido a idade de aposentadoria.

(75) com être: Mathieu étant parti pour une semaine en voyage d'études

- Mathieu sendo partido por uma semana em viagem de estudos.

(76) perífrases de particípio passivo: La 'Kawa' ayant été amenée au but par Rymer-Fogarty-Simul

- A 'Kawa' tendo sido trazida ao objetivo pelos motoristas Rymer, Fogarty, Simul.

(77) perífrases de presente passivo: ce dernier étant représenté par l'aileron

- esta última sendo representada pelo aerofólio.

Mantiveram-se no francês moderno as construções absolutas cujos predicados

eram formados por outros itens sintáticos:

(78) adjetivo: l'arme prête - a arma engatilhada.

(79) complemento preposicionado: les pieds dans les sandales - os pés nas sandálias.

(80) advérbio: L'ennemi dehors - o inimigo [lá] fora.

(81) expressões impessoais: $\underline{\text { S'agissant de la nation - Tratando-se da nação. }}$

Em comparação ao período clássico, no corpus do francês moderno analisado por Müller-Lancé, aumenta significativamente o uso do particípio presente ativo / gerúndio em competição com outras formas sintáticas (105/252 ocorrências). Aumenta a utilização de gerúndios para a expressão da causalidade. Müller-Lancé (1994:297) atribui tal fato a uma possível herança de sentido de base que se verificava nas perífrases participiais (ayant, estant, ayant été + particípio passado ativo) que se formaram durante o período clássico. Além disso, mantém-se igualmente alto o uso do gerúndio para a expressão de modo.

Esse autor encontrou novas fórmulas em processo de gramaticalização como cela dit, ceci dit e cela fait, todas elas compostas de um particípio passado. Ele lembra que o fato de considerá-las ainda em processo de gramaticalização se deve ao fato de que estas fórmulas ainda exibem grande força proposicional, ao contrário de expressões já usuais desde o francês clássico com ouvert + parte do corpo (les yeux ouverts, la bouche ouvert e sem o artigo bouche ouvert). Müller-Lancé reconhece em le cas échéant (eventualmente, sendo o caso) uma lexicalização cristalizada que não

\footnotetext{
${ }^{82}$ Le Monde, 22.4.1992, p. 16 in Müller-Lancé, 1994:60.

${ }^{83}$ Exemplos de Müller-Lancé (1994:59-62).
} 
poderia ser mais reconhecida como uma construção absoluta, por estar mais próxima de um advérbio do que de uma oração subordinada.

Müller-Lancé testou o grau de sentencialidade das várias expressões coletadas em seu corpus e verificou que no francês moderno há vários produtos de construções absolutas que podem ser considerados como elementos já gramaticalizados como preposições (excepté) e conjunções (excepté que, attendu que, à part), tendo perdido, assim, o seu valor sentencial e funcionando agora como concectores (juntores, na acepção de Raible). Por outro lado, o autor ainda visualiza um alto valor sentencial em determinadas expressões do francês moderno, embora estejam em estágio avançado de gramaticalização, desenvolvendo-se como conjunções (eu égard à, y compris, étant donné (que), exception faite de, compte tenu de). Ele reconhece que muitas vezes o critério de distinção entre uma construção absoluta e uma forma gramaticalizada possa parecer aleatório, mas ele diz que levou em conta a sua complexidade e a sua composicionalidade com vários termos (sujeito + forma verbal + complementos), procurando sempre conferir tal suspeita junto a falantes nativos que o ajudaram a reconhecer se tais construções se apresentavam como mais ou menos verbais. É o caso, por exemplo, de $v u+$ substantivo, em que $v u$ é reconhecido pelos falantes mais como uma preposição do que como um verbo, ao contrário dos particípios enumerados nas expressões acima descritas (p. ex. étant donné + substantivo). ${ }^{84}$

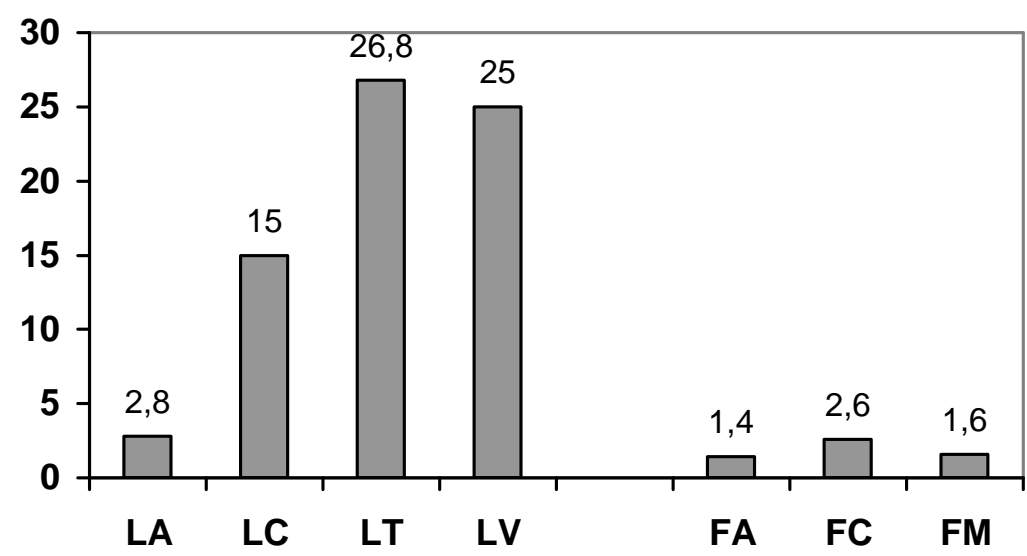

Gráfico 1. Frequiência de construções absolutas na diacronia do latim ao francês moderno (Cf. MüllerLancé,1994:308)

${ }^{84}$ Müller-Lancé, 1994:301-302. 
O gráfico 1 demonstra que há uma diferença significativa da frequiência de uso de construções absolutas nos três períodos do francês em comparação ao alto uso dessas formas no latim. O quadro indica ainda que é nos períodos do latim tardio (LT) e do latim vulgar (LV) que essas construções ganham maior visibilidade, ao contrário do que era espereado para o período arcaico (LA) e clássico (LC) do latim. Comparados os três períodos do francês, observa-se um descrésmo significativo no período arcaico (FA), com um leve aumento na utilização dessas construções no período clásscico (FC) e renovado declínio no seu uso já no período moderno (FM). Porém, o autor alerta que se para o período moderno do francês fossem considerados apenas os mesmos tipos textuais do francês clássico (textos literários e outras narrativas), a freqüência de uso de construções absolutas seria maior do que no período do francês clássico, o que prova que a tipologia textual desempenha um papel preponderante na análise de determinados fenômenos sintáticos, assim como defendo nesta tese.

\section{I.2.1.1.4 Considerações finais a respeito dos estudos sobre o gerúndio no francês}

Resumidamente, verificamos que o estudo de Müller-Lancé serve de orientação para nossa pesquisa por demonstrar através da diacronia do francês:

a) que o gerúndio é uma forma verbal muito utilizada na composição de orações adverbiais com valor absoluto;

b) que muitas destas construções com equivalentes do gerúndio (PPA) sempre estiveram em processo de gramaticalização, passando por estágios de lexicalização, até tornarem-se novas preposições, conjunções ou novos advérbios do francês;

c) que a utilização do gerúndio (PPA) em francês aumentou ou diminuiu em face do surgimento de novas formas sintáticas que podem compor o predicado das construções absolutas (outros particípios, adjetivos, substantivos, complementos preposicionados, advérbios) e, finalmente,

d) que para uma melhor interpretação de fenômenos de gramaticalização ligados aos gerúndios é preciso levar em conta a distinção entre dois tipos de orações 
adverbiais: i. aquelas cujo sujeito é um item compartilhado com a oração matriz e ii. aquelas que apresentam um sujeito com item não recuperável na oração matriz, como é o caso das construções absolutas. Pelo esse caráter de maior independência sintática, essas construções disfrutam do princípio de especialização (Cf. Hopper, 1991), pois dentro de um âmbito funcional, essas estruturas tendem a especializar-se como elementos obrigatórios em determinados contextos, assumindo significados semânticos mais gerais. Por conta disso, em seu estágio mais avançado de gramaticalização estas construções exibem também o princípio de descategorização (Hopper, 1991) que estipula que as formas em processo de gramaticalização tendem a perder ou neutralizar marcadores morfológicos e os privilégios característicos das categorias plenas (nome e verbo) e a adquirr as características das categorias mais secundárias (adjetivo, particípio, preposição, conjunção, etc.) ${ }^{85}$.

\section{I.2.2 O gerúndio no espanhol}

A exemplo do que se pode verificar nas várias descrições da passagem do latim para as línguas românicas, a tradição gramatical do espanhol também discute o estatuto sintático do gerúndio, alguns atribuem-lhe o status de derivado verbal, de valor unicamente adverbial Bello (1847 apud Reese, 1991) ${ }^{86}$, outros reconhecem nele a continuação do particípio presente latino, podendo assim assumir tanto a função adverbial como adjetiva Caro (1870 apud Reese, 1991) ${ }^{87}$. Outros há que recusam tanto uma como outra acepção e defendem que as construções com gerúndio, assim como as de infinitivo e particípio, não formam uma proposição separável da oração matriz, por não terem um sujeito autônomo, estas formas foram chamadas por Lenz (1920 apud Reese, 1991) ${ }^{88}$ de verboides. A discussão continuou até Gilli y Gaya (1948 apud Reese, 1991) ${ }^{89}$, que reconhece o gerúndio como uma verdadeira forma verbal que, juntamente com o infinitivo e o particípio, define como formas no personales del verbo.

\footnotetext{
${ }^{85}$ Omena \& Braga, 1995:81 apud Lopes, 2001.

${ }^{86}$ Bello, Andrés / Cuervo, R. J. (1847/1977): Gramática de la lengua castellana, Buenos Aires: Ed. Sopena Argentina.

${ }^{87}$ Caro, Miguel Antonio (1870/1976). Tratado del particípio. Yerbabuena, Colombia: Instituto Caro y Cuervo.

${ }^{88}$ Lenz, Rodolfo (1920). La oración y sus partes. Madrid: Centro de Estudios Históricos.

89 Gilli y Gaya, Samuel (1948/1960). Curso superior de sintaxis española, séptima edición. Barcelona: Publicaciones y Ediciones Spes, S.A.
} 
Nesta seção, seguindo o estudo de Reese (1991), primeiramente apresento resumidamente estas abordagens sobre o gerúndio no espanhol. Delas pode-se depreender uma discussão que se deu em torno do gerúndio adverbial com valor de posterioridade e do gerúndio adjetivo, cujos usos total ou parcialmente não foram aceitos por gramáticos a partir do séc. XIX como Bello (1847/1977), Caro (1870/1976), Gilli y Gaya (1948/1960) e ainda vêm sendo discutidos pela Real Academia Española ${ }^{90}$ (1979 apud Reese, 1991, a partir daqui, Academia). Em seguida, apresento o gerúndio nos diferentes contextos sintáticos, de um lado, tomando como referência o gerúndio ligado a algum nome expresso na oração principal, ligado portanto ao sujeito, ao objeto direto ou a algum nome que integra um sintagma preposicionado da oração matriz, por outro lado, ainda seguindo Reese (1991), apresento o uso do gerúndio em perífrases aspectuais. Em cada uma dessas seções, discuto algumas abordagens mais recentes estudadas por Reese (1991) sobre os usos do gerúndio, tais como Lajmanovich $(1968)^{91}$, Zdenek (1972) ${ }^{92}$, Bobes Naves $(1975)^{93}$ e o próprio estudo de Susanne Reese (1991), que propôs um interessante modelo de análise pragmática do gerúndio segundo propriedades sintático-discursivas.

\section{I.2.2.1 O estatuto sintático do gerúndio no espanhol}

Passo agora às descrições do gerúndio no espanhol e inicio com Bello (1847/1977), que foi um dos primeiros a preocupar-se com uma descrição mais cuidadosa do gerúndio nessa língua. Esse autor chama de derivados verbales as formas do infinitivo, particípio e do gerúndio e as considera como

medios de que se sirve la lengua para desnudar al verbo de los accidentes de número, persona, tiempo y modo, y darle en la oración el oficio de sustantivo, adjetivo o adverbio.Pero al mismo tiempo que de esta manera lo transforma, le conserve [sic] sus construcciones; es decir, le da complementos acusativos, le agrega afijos o enclíticos, lo modifica con adverbios y hasta puede ponerle sujeto (Bello/Cuervo, 1847/1977:169 apud Reese, 1991:7)

\footnotetext{
${ }^{90}$ Real Academia Española (1979). Esbozo de una nueva gramática de la lengua española, Madrid: Espasa Calpe, S.A. p. 448

${ }^{91}$ Lajmanovich, Josué David (1968). Sintaxis del gerundio español, Ph. D. Dissertation, Georgetown University 1967, Ann Arbor/Michigan: University Microfilms International.

92 Zdenek, Joseph (1972). Another look at the progressive, in Hispania 55 (1972), 498-99.

${ }^{93}$ Bobes Naves, María del Carmen (1975). Sistema, norma y uso del gerundio castellano, in Revista Española de Lingüística 5 (1975), 1-34.
} 
O gerúndio como derivado verbal desempenha o papel de um advérbio e representa a ação do verbo de maneira abstrata, porque modifica o verbo da mesma maneira que o fazem os advérbios e os complementos, significando um modo, uma condição, uma causa e outras circunstâncias que não podem ser atribuídas exclusivamente ao morfema -ndo e sim à combinação da raiz do verbo + o sufixo ndo (Bello/Cuervo,1847/1977:161-2 apud Reese, 1991:8).

Bello reconhece apenas duas possibilidades de expressão de tempo através do uso do gerúndio ${ }^{94}$ :

(82) Andando los caballeros lo más de su vida por florestas y despoblados, su más ordinária comida sería de viandas rústicas.

(83) Los cabreros, tendiendo por el suelo unas pieles de ovejas, aderezaron su rústica cena.

Em (82) o gerúndio expressaria simultaneidade com o verbo da oração matriz e exibe um matiz causal e em (83) haveria uma relação de anterioridade com o enunciado da oração principal. Bello não reconhece o gerúndio como forma verbal plena, mas sim como um derivado verbal que desempenha uma função sintática equivalente aos advérbios e complementos. Isso se daria em função do fato de que os gerúndios - diferentemente das formas verbais finitas - não podem constituir-se em predicados, ao contrário, são sempre partes de predicados, primordialmente de caráter adverbial. Segundo ele, o gerúndio ainda é dependente do verbo da oração matriz, mesmo quando a ele se agrega um sujeito. Reese entende que para Bello o morfema -ndo desempenha uma função adverbial igual àquela desempenhada pelo sufixo -mente de alguns advérbios (nuevamente, suelamente).

A primeira polêmica suscitada em torno do gerúndio no espanhol envolve o seu uso adverbial com valor de posterioridade e vem sendo discutida desde a segunda metade do séc. XIX (Bello, 1847) e ainda recentemente pela própria Academia (1979) que critica o uso de gerúndio que indica posterioridade em relação ao verbo a que está ligado, pois, para a Real Academia "denota el gerundio simple coincidencia de tiempo o tiempo inmediatamente anterior, nunca posterior" (Academia, 1973:443 apud Torrego, 2005:62-63). Algumas páginas adiante, a própria Academia afirma que o valor temporal de posterioridade do gerúndio seria correto apenas quando este for de posterioridade imediata: "Salió de la estancia

\footnotetext{
${ }^{94}$ Exemplos de Bello / Cuervo (1847/1977) apud Reese (1991:8).
} 
dando um fuerto portazo" (Academia, 1973:488). A mesma idéia foi defendida por M. Seco (1998) em seu Diccionário de dudas:

Cuando el gerundio [...] expresa tiempo, puede enunciar acción simultánea a la del verbo principal [...]; o inmediatamente anterior [...]; o inmediatamente posterior [...]. Este gerundio de posterioridad no es considerado correcto por los gramáticos, pero lo es cuando la posterioridad es inmediata a la acción principal (Seco, 1998:227 apud Torrego, 2005:62) ${ }^{95}$.

Leonardo Torrego (2005) discute essa posição e julga difícil medir o grau de imediatez expresso nas sentenças com o gerúndio adverbial. Ele usa como argumento o fato de que são comuns os textos com gerúndio de posterioridade em todas as épocas do espanhol, encontrado em textos como o Quijote, Santa Teresa, Gracián, Poema de Mío Cid, na Partida II e em Campoamor e que esta postura está muito mais voltada a uma normatização por um valor estilístico do que pela natureza gramatical do gerúndio, que em si permitiria todo e qualquer uso adverbial: "no hay nada en el gerundio que impida su empleo con valor de posterioridad inmediata o mediata. La norma, pues, es arbitraria, aunque debamos acatarla tan solo sea por el prurito de elegancia estilística." (Torrego, 2005:62-63)

O segundo tópico que gerou discussão na teoria de Bello (1847/1977) foi o uso adjetivo do gerúndio. $\mathrm{O}$ autor recusa todo e qualquer uso de gerúndios em função relativa e atribui isto a uma influência do francês ${ }^{96}$. Ele se apóia em Salvá (1831, § 15.2.1.10 apud Medina, 1994:289) que critica o uso do gerúndio acompanhando o substantivo: "El dar al gerundio español la fuerza del participio activo, como los que dicen 'Remito a Vd. cuatro cajas conteniendo mil fusiles', es copiar malamente la pobreza de la lengua francesa, que emplea una misma forma para ambos giros".

É importante observar que a argumentação que Bello (1847/1977) utiliza para criticar o primeiro exemplo da citação abaixo remete-nos à inovação que o gerúndio passou a desempenhar nas línguas românicas: a de funcionar ao mesmo tempo como advérbio e também como adjetivo, ficando difícil distinguir uma relação da outra, principalmente quando ele se refere ao sujeito da oração principal:

A veces parece el gerundio construirse com el sujeto de la proposición, modificándolo; y pudiera dudarse si conserva o no el carácter de adverbio: 'El ama, imaginando que de aquella consulta había de salir la resolución de la tercer salida, toda llena de congoja y pesadumbre

\footnotetext{
95 Seco, Manuel (1998).Diccionario de dudas y dificultades de la lengua española. Madrid: Espasa Calpe, $10^{\mathrm{a}} \mathrm{ed}$.

${ }^{96}$ Em português gerou-se a mesma polêmica a partir do estudo de Julio Moreira (1907) que cita este trabalho de Bello (1847) para recusar o gerúndio adjetivo no português. Comento isso, quando falo da diacronia do gerúndio no português (I.2.3.2.2).
} 
se fue a buscar al bachiller Sanson Carrascos', (Cervantes). Yo creo, com todo, que la cláusula de gerundio es, aun en casos como este, una frase adverbial que modifica al atributo; como lo haría un complemento de causa: 'El ama, por imaginar', o una proposición introducida por un adverbio relativo: 'El ama, como imaginaba'. Si el gerundio pudiera emplearse como adjetivo, no habría motivo de censurar aquella frase de mostrador, tan justamente reprobada por Salvá: 'Envío cuatro fardos, conteniendo veinte piezas de paño'; este modo de hablar es uno de los más repugnantes galicismos que se cometen hoy día. (Bello/Cuervo, 1847/1977:360 apud Reese, 1991:9)

E com isso fica patenteada a recusa de Bello em relação ao gerúndio em função adjetiva seja ela qual for. Alguns anos depois, o assunto é retomado novamente por Miguel Antonio Caro (1870/1976) que se opõe veementemente à posição de Bello (1847/1977), de que se considere o gerúndio apenas como um advérbio verbal, embora como este também não aceita como correto o último exemplo citado por ele (cuatro fardos conteniendo veinte piezas de paño). Caro (1870/1976) acredita que o gerúndio pode expressar tanto uma relação adverbial como adjetiva em relação à oração principal. Em seu modelo, ele refuta a idéia de que o verbo em -ndo em espanhol seja chamado de gerúndio por sugerir uma similaridade com o ablativo do gerúndio latino que, apesar da etimologia das formas, não existiria mais no espanhol moderno (Caro,1870/1976:145-7 apud Reese, 1991:9). Em contrapartida, adota a idéia de que a forma -ndo deva ser chamada em espanhol de particípio presente uma vez que funciona como modificador do substantivo e que por isso se assemelha mais a adjetivos ou advérbios. Caro ressalva, no entanto, que o substantivo que é modificado pelo gerúndio é ao mesmo tempo o sujeito do verbo com a forma $-n d o$.

Em sua resenha a respeito do estudo de Caro (1870/1976), Susanne Reese (1991:10) observa que um sentido "ativo" não pode ser atribuído ao sufixo -ndo, e sim à semântica do verbo a que este se agrega.

Esta autora observa que os pontos de vista contraditórios a respeito da forma -ndo como complemento sentencial foram incorporados às descrições que se seguiram de maneira a reconhecer para o gerúndio várias funções sintáticas. Cuervo (Bello/Cuervo, 1847/1977:459 apud Reese, 1991:10), em seu comentário sobre a gramática de Bello (1847), lembra que o gerúndio se encontra em um complicado processo de metamorfose entre particípio, advérbio, verbo e adjetivo. Reese observa que a partir de então as descrições tradicionais tentaram unir as duas propostas contraditórias de Bello (1847) e Caro (1870), muitas delas apenas com o intuito de definir uma única função semântico-sintática de base para o gerúndio. 
Lenz (1920 apud Reese, 1991), como Bello (1847), reconhece na forma -ndo a função de advérbio, mas também compreende nessa definição as construções perifrásicas com estar e ser. Normalmente as gramáticas tradicionais tratam das perífrases com gerúndio em capítulos à parte ${ }^{97}$ :

El gerundio castellano es un adverbio verbal que expressa la acción, ya momentánea, ya duradera, presentándola como circunstancia secundaria que precede o acompaña a otra acción.

Com verbos lógicamente auxilizares (gramaticalmente dominates) indica la acción duradera del verbo (Lenz, 1920:382 apud Reese, 1991:11)

Reese questiona se os sentidos acción momentánea e acción duradera, que em Lenz (1920) considera contraditórios, não seriam na verdade características depreensíveis dos verbos aos quais a forma -ndo se agrega. Diferentemente de Bello, Lenz não considera a forma -ndo como um derivado verbal, e sim como um verboid.

Verboides son aquellas formas verbales que no encierran en sí la expresión de la persona del sujeto y que, si se agregan a un nominativo sujeto, no forman con él una proposición separable aunque contengan todos los elementos de un juicio completo. Los verboides castellanos son: el infinitivo (sustantivo verbal), el participio (adjetivo verbal) y el gerundio (adverbio verbal) (Lenz, 1920: 371 apud Reese, 1991:11)

Gili y Gaya (1948/1960 apud Reese, 1991) ${ }^{98}$ recusa os termos verboid de Lenz e o derivado verbal de Bello. De sua parte, considera o gerúndio uma forma verbal: "El gerundio em su significiación adverbial no deja de ser verbo. Viene a ser uma acción secundaria que se suma a la del verbo principal modificándola o describiéndola." (Gili y Gaya, 1948/1960: 173 apud Reese, 1991:12). Além do mais, esses autores notam que a forma simples do gerúndio (cantando) expressa um valor imperfectivo e que a forma composta (habiendo cantado) tem valor perfectivo e indica anterioridade. Tal raciocínio trata ao mesmo tempo de dois domínios ligados aos verbos: o tempo e o aspecto. Reese, recusa essa proposta de Gili y Gaya, quando afirmam que o gerúndio expressa simultaneidade temporal ou anterioridade. Segundo seus dados, ela afirma que o gerúndio é uma forma verbal "atemporal" que sozinha não expressa relações de tempo, o que não quer dizer que o gerúndio não possa expressar fatos que estejam em uma relação de tempo, mas que isso só pode ser depreendido pelo contexto em que os gerúndios aparecem, através de elementos que coocorrem nos enunciados, como advérbios, expressões de tempo e a própria ordenação das orações.

${ }_{97}^{97}$ V. Gili y Gaya (1960 [1948]) e Real Academia (1979), cf. Reese, 1991:11.

98 Gilli y Gaya, Samuel (1960 [1948]). Curso superior de sintaxis española, séptima edición. Barcelona: Publicaciones y Ediciones Spes, S.A. 
Em seu trabalho, Reese procura demonstrar que a confusão que envolve a problemática das propriedades sintáticas dos verbos no gerúndio merece maior atenção, principalmente no que se refere à questão do aspecto: "Es spricht in der Tat einiges dafür, das Gerundium generell - sowohl in der periphrastischen als auch in der nicht-periphrastischen Konstruktion - als eine (nur) aspektuelle Verbform zu definieren." 99 (Reese, 1991:15). Partindo desse raciocínio, a estudiosa discute a idéia de que se possa postular que o sufixo -ndo seria um morfema de aspecto em línguas como o espanhol, uma vez que várias línguas dispõem de morfologia específica para marcar o aspecto.

\section{I.2.2.2 Gerúndio adjetivo}

As gramáticas tradicionais do espanhol procuraram normatizar o uso do gerúndio que apresenta uma co-referência com nomes expressos na oração matriz, aceitando apenas algumas construções com gerúndios ligados ao núcleo do sujeito (84), do objeto direto (85) e recusando toda e qualquer construção de gerúndios referidos a complementos preposicionados (86):

(84) Los alumnos, viviendo lejos, llegaban tarde a la escuela. ${ }^{100}$

(85) Veo a unos niños jugando pelota. ${ }^{101}$

(86) Desde la abadía, Mosén Millán, leyendo su brevario, oía el ruído de las birlas chocando entre sí.... ${ }^{102}$

Nas seções seguintes, apresento como os gramáticos do espanhol interpretam essas construções.

\section{I.2.2.3 Gerúndio referido ao sujeito da oração matriz}

Principalmente no que se refere ao gerúndio ligado ao sujeito e ao complemento preposicionado, as descrições tradicionais condenavam o seu uso com o valor de relativa restritiva, aceitando apenas as construções que pudessem ser lidas

\footnotetext{
99 Tradução minha: "Na verdade, tudo indica que o gerúndio - tanto nas construções perifrásticas como também nas construções não-perifrásticas - deve ser geralmente definido (somente) como uma forma verbal aspectual.

${ }^{100}$ Exemplo de Gilli y Gaya (1960) apud Reese (1991:22).

${ }^{101}$ Exemplo de Reese (1991:24).

102 Exemplo de Reese (1991:27).
} 
como relativas explicativas. Tal posição baseava-se na idéia de que é errôneo pensar que na passagem do latim para as línguas românicas o uso adjetivo do particípio presente pudesse ser expresso pelo gerúndio. O equívoco ainda apresentava como argumento o fato de que estes usos eram fruto da influência do francês. No entanto, como vimos acima, quando apresentei como se gramaticalizaram os usos dos particípios no francês, notamos que, tanto para a expressão tanto dos usos adjetivos como dos usos adverbiais das formas participiais originárias do latim, o particípio presente foi o único item sintático incorporado a essa língua. Veremos, a seguir, que a mesma argumentação foi utilizada para condenar esses usos no português.

Exemplos dessa discussão no espanhol são os comentários apresentados por Gili y Gaya (1948/1960) em relação às construções gerundivas explicativas e restritivas abaixo ${ }^{103}$ :

(87) Los alumnos, viviendo lejos, llegaban tarde a la escuela.

(88) ? Los alumnos viviendo lejos llegaban tarde a la escuela.

Enquanto o primeiro exemplo poderia ser aceito pelo fato de representar uma explicativa, o segundo enunciado, sem as vírgulas, indica um uso restritivo, especificativo em relação ao nome alumnos, e por isso não deveria ser expresso com o gerúndio e sim através de uma oração relativa iniciada pelo pronome que. $\mathrm{O}$ argumento de Gili y Gaya (1948/1960:174 apud Reese, 1991:22) baseia-se na idéia de que o gerúndio enuncia uma ação secundária do sujeito "com la cual desenvuelve, explica la acción principal”. Segundo esses autores, ao particularizar ou especificar o sujeito o gerúndio perderia a sua qualidade verbal e se tornaria um adjetivo, o que tornaria seu uso incorreto.

Essa argumentação parece ser generalizada entre os gramáticos tradicionais do espanhol que rejeitam inclusive as nominalizações do tipo decreto nombrando gobernador, ley reformando las tarifas aduaneras. Curiosamente, as indicações de cena em peças teatrais como Napoleón pasando los Alpes ou Don Antonio, escribiendo não eram vistas como agramaticais.

Caro (1870/1976) considera estas sentenças enfáticas, enquanto a Academia reforça que o ato é reforçado com a ajuda do gerúndio. O gramático considera

${ }^{103}$ Exemplos de Gilli y Gaya citados em Reese (1991:22). 
incorretas as expressões nas quais o sujeito do gerúndio exerce a função de predicativo na oração matriz:

(89) La Religión es Dios mismo hablando y moviéndose em la humanidad.

Reese (1991) refuta a agramaticalidade destas construções, dizendo que há muitas ocorrências de orações adjetivas acompanhadas de verbo ser em exemplos de seu próprio corpus:

(90) Somos - recalcó el portavoz popular - políticos haciendo uma función técnica. ${ }^{104}$

O critério das explicativas "corretas" e das restritivas "incorretas" também foi aplicado às construções com o verbo haber. Para Caro (1870/1976:39 apud Reese, 1991:23), quando o verbo haber assume um valor existencial não seria possível construir-se com alguma oração gerundiva como em

(91) Hay hombres creyendo en brujas.

$\mathrm{O}$ autor defende que neste caso haber tem um sentido existencial, e creyendo não expressa, portanto, ação concomintante ao verbo da oração principal, ao contrário, especifica hombres, por isso deveria ser considerado agramatical. No entanto, para Caro, quando haber assume um valor locativo, é possível anexar ao complemento uma oração gerundiva como em

(92) Hay allí unos hombres pescando.

Aqui, haber introduz uma idéia locativa, e pescando assume um valor explicativo, que expressa a ação de pescar como coexistente com o de haber.

Percebe-se que a discussão da aceitação ou não do gerúndio adjetivo em espanhol gira em torno das construções gerundivas que exibem a estrutura sintática $[\mathrm{SN}+\mathrm{G}]$ nas quais o gerúndio segue imediatamente o $\mathrm{SN}$ sujeito da oração matriz, ou do absolutivo, no caso das sentenças existenciais, como é o caso de (91) e (92), e ergativas. Nestes casos, a tradição gramatical do espanhol aceita estas ocorrências, argumentando que nelas o gerúndio assume um valor explicativo, e não restritivo como em (89) e (90). A discussão termina, quando o gerúndio aparece distanciado do sujeito da oração matriz como em (93) e (96), ou mesmo na anteposição do verbo em (95). Em todos os casos abaixo, no entanto, atribuem-se valores adverbiais ao

\footnotetext{
${ }^{104}$ Exemplo de Reese (1991:23).
} 
gerúndio, o que, a meu ver, confirma o acúmulo das funções adjetiva e adverbial que

o gerúndio passou a exercer nas línguas românicas: ${ }^{105}$

(93) Pasamos la vida disputando. (modal)

(94) El jaramago, flotando al viento como el penacho de una cimera, y las campanillas blancas y azules, balanceándose como en un columpio sobre sus largos y flexibles tallos, pregonaba la victoria de la destrucción y la ruina. (temporal)

(95) Aceptando una invitación de la Universidad de Río, partió para el Brasil. (temporal)

(96) Cuéntase que um compilador de las obras de Aristóteles, no sabiendo qué título poner a varios escritos no pertenecientes a la lógica, a la moral ni a la física, los llamó metafísicas. (causal)

(97) DIANA. - Buen gusto tenéis por cierto

CARLOS. - En siendo gusto señora, no importa que sea bueno. (condicional)

(98) De este insecto refieren una cosa:

Que, comiendo cualquiera porquería,

Nunca pica las hojas de la rosa. (concessiva)

\section{I.2.2.4 Gerúndio referido ao objeito direto da oração matriz}

A discussão em torno do gerúndio adjetivo atinge também as construções em que o gerúndio se refere ao objeto direto da oração matriz, como em

(99) Vi a una muchacha cogiendo manzanas,

considerada correta por Caro (1870/1976:71 apud Reese, 1991:25), em oposição a

(100) Envío una caja conteniendo libros,

que o autor afirma ser incorreta. Sua argumentação baseia-se no escopo de predicação do verbo da oração matriz. Segundo ele, no primeiro caso, coger manzanas recebe a "acción del verbo", é coisa vista pela muchacha, enquanto contener libros não é coisa enviada.

Por este raciocínio, só poderiam ser consideradas corretas as construções com gerúndio em sentenças que exibem um verbo de percepção sensorial ou cognitiva, os chamados verbos perceptivos, do tipo sentir, ver, oír, observar, distinguir, hallar ou com verbos de representação como describir, pintar, grabar, etc.

Outro argumento utilizado pelos gramáticos para recusar as construções do segundo tipo (caja conteniendo libros) refere-se à questão da paralelismo temporal que deve ocorrer entre os verbos da oração matriz e da oração gerundiva. No primeiro caso, pode-se depreender uma concomitância entre as ações de ver e coger manzanas, o que não acontece no segundo caso, pois contener libros reflete um

105 O exemplo (93) foi retirado de Spaulding (1931:100), (94)-(95) são da Academia (1979:493), (96)(98) de Caro (1976:57ss.) apud Reese (1991:23-24). 
estado de coisas temporalmente independente do ato de enviar. Gilli y Gaia (1948/1960:175 apud Reese, 1991:25-26) notam ainda que esse paralelismo temporal entre os verbos revela uma determinada dinamicidade do estado de coisas expresso pelo gerúndio, "es necesario que el gerundio exprese una acción, transformación o cambio en transcurso perceptible, y no cualidad, estado o acción tan lenta que se asemeja a una cualidad por no ser perceptible el cambio que se produce”.

Nestes argumentos estão envolvidos dois raciocínios de base que complicam a descrição adequada do gerúndio em orações reduzidas: 1) as reduzidas de gerúndio só podem exercer uma função adverbial e quando se confundem com o valor adjetivo, o que conta é o valor temporal de concomitância que exibem; 2) a outra idéia, também associada à não aceitação do gerúndio adjetivo, está relacionada à natureza do sujeito que o gerúndio toma emprestado da oração matriz, ou seja, segundo estes autores, o gerúndio só pode projetar um sujeito humano ou [+animado] e o verbo no gerúndio deve expressar a dinamicidade desse sujeito. No entanto, esses raciocínio caem por terra quando esses autores atestam como corretas as construções com verbos de natureza [-dinânica] como siendo, estando, teniendo, habiendo, etc. Se construções como Teniendo yo doce años ingresé en el Instituto Vizcaíno e ¿Qué miraría, no habiendo nada en la pared? são gramaticais, por que não o seriam outras como Observé a un hombre llevando un saco al sombrero ou Te envío una caja conteniendo libros?

Outros autores como Bobes Naves ${ }^{106}$ (1975 apud Reese, 1991:57-67) defendem que as construções com o gerúndio são ambíguas e seu estatuto sintático muitas vezes não pode ser definido claramente. Essa autora exemplifica tal fato nas orações gerundivas ligadas ao OD da oração matriz, como o exemplo anteriormente citado:

(101) Veo una muchacha [encuanto está] cogiendo manzanas (adverbial)

(20a) Veo una muchacha que coge manzanas (relativa)

(20b) Veo que una muchacha que coge manzanas (completiva)

Além disso, a autora lembra determinados exemplos de orações gerundivas adjetivas, nas quais o verbo no gerúndio pode representar uma predicação

\footnotetext{
${ }^{106}$ Bobes Naves, María del Carmen (1975). "Sistema, norma y uso del gerundio castellano", Revista Española de Lingüística 5 (1975), p. 1-34.
} 
secundária, sendo possível interpretá-lo como diretamente dependente do verbo da oração matriz, como nestes exemplos, típicos de anúncios e textos publicitários ${ }^{107}$ :

(102) Necesito señorita para un niño ayudando casa.

(103) Servientas zamoranas, trabajando por primera vez en Madrid, buscan casa

(104) Matrimonio com niño necesita señora mayor para la casa, viviendo en Fuenterrabía.

O mesmo se aplicaria a construções que podem ter diferentes interpretações, quando se modifica a posição da oração gerundiva:

(105)El capitán, viendo que el barco se hundía, mandó preparar las lanchas.

(105a) Viendo que el barco se hundía, el capitán mandó preparar las lanchas.

Enquanto (105) pode ser interpretada como adjetiva, (105a) pode ser interpretada como adverbial com valor causal. Bobes Naves defende através de exemplos como (105) e (105a) a hipótese de que os gerúndios muitas vezes são utilizados, quando o falante quer se expressar de maneira vaga ou ambígua:

"Creemos que muchas veces el uso del gerundio puede responder a razones pragmáticas, es decir a las relaciones del emisor o del receptor con el mensaje: el hablante puede desconocer las verdaderas relaciones entre dos acciones simultáneas o consecutivas en el tiempo, su conocimiento no va más allá de la existencia de una relación de subordinación y el uso del gerundio es obligado. Puede ser también que, aun conociendo el tipo de subordinación que se da entre las dos acciones, intencionalmente no quiera expresarlo, bien porque esto suponga una toma de postura o un juicio de valor, bien porque no quiera que los oyentes lleguen a ese juicio orientados por su expresión”. (Bobes Naves, 1975:14 apud Reese, 1991:67)

Reese (1991) não concorda com esta perspectiva e argumenta que é possível sim desambiguar estas construções, se se levar em conta o contexto em que os gerúndios estão inseridos. No entanto, creio que Bobes Naves tem razão quando afirma que o gerúndio, por razões pragmáticas, pode intencionalmente ser utilizado de forma ambígua, quando não se quer expressar claramente a relação sintática específica, ou mesmo quando não se pode fazê-lo devido às condições de produção do texto, o que envolve questões de planejamento, formulação e reformulação dos enunciados. $^{108}$

\section{I.2.2.5 Gerúndio referido a outros sintagmas nominais da oração matriz}

Também são consideradas incorretas na gramática tradicional as construções gerundiais que acompanham um nome em função de objeto indireto ou que faça parte de um complemento preposicionado.

\footnotetext{
${ }^{107}$ Exemplos de Bobes Naves apud Reese, 1991:60.

108 Tratarei desta questão no capítulo V, quando analiso a discursivização do gerúndio.
} 
(106) Oirá a la voz del héroe admirándonos con su fortaleza, del sabio predicando la verdad, y la del siervo de Dios acusando nuestra tibieza.

Caro (1870/1976) diz que nesses casos o uso do gerúndio como uma espécie de "particípio presente ativo" é fruto de um galicismo indevido na língua espanhola. $\mathrm{O}$ argumento utilizado para refutar esse uso está na própria designação de "particípio ativo”, que Caro não reconhece para o gerúndio, uma vez que nestes casos os gerúndios não assumem a função ativa que lhes seria própria. A exemplo do que se falou acima para os gerúndios referidos ao sujeito e ao objeto direto da oração matriz, ao acompanhar os complementos preposicionados os gerúndios assumiriam uma função meramente adjetiva que, segundo esse autor, não deve ser aceita.

\section{I.2.2.6 Gerúndio adverbial}

As reduzidas de gerúndio com valor adverbial têm sido as construções melhor descritas nas línguas românicas e não poderia ser diferente para o espanhol.

Como se pôde ver acima, a preocupação principal dos gramáticos era a de atribuir algum outro valor circunstancial ao valor de concomitância temporal que o gerúndio agrega às orações subordinadas por ele inciadas, tais como as relações de modo, causa, conseqüiência, condição, concessão, finalidade, exclusão, assim como estas orações são descritas nas outras línguas românicas.

Ao analisar as construções gerundiais do espanhol sob uma perspectiva sintático-pragmática, Susanne Reese (1991) fala das possibilidades de uso das orações gerúndivas condicionadas pelos contextos em que aparecem. A autora leva em consideração as questões pragmáticas que surgem com a Nova Retórica a partir dos anos 90 .

A estudiosa apresenta questões referentes ao domínio semântico das construções gerundiais no espanhol. Parte de um problema inicial que envolve o uso das orações gerundiais: as construções gerundiais permitem ser parafraseadas por construções conjuncionais (cuando, porque, si, aunque etc.), mas o morfema -ndo não deixa clara a relação proposicional expressa. O verdadeiro sentido precisaria ser recuperado através do contexto (Reese, 1991:1). 
Susanne Reese observa que as gramáticas do espanhol em geral não explicam a amplitude semântica que as orações gerundiais podem permitir e diz que tanto na tradição descritiva estruturalista como nos estudos gerativo-transformacionais o gerúndio tem sido pouco tratado. Aponta que ainda deve ser cumprida a tarefa de estabelecer uma relação entre a paráfrase as construções gerundivas e se na verdade essa reversibilidade seria possível (op. cit., p. 2).

Após traçar um perfil genérico do gerúndio e de como ele é explicado nas tradição gramatical, na segunda parte de seu trabalho a autora confronta-se com a uma análise ampla e detalhada das construções gerundiais em textos, levando em conta questionamentos teóricos de ordem textual e pragmática. Reese propõe-se a descrever as várias relações proposicionais que podem ser expressas por construções gerundiais e, por outro lado, tenta definir tanto fatores sintático-semânticos como também pragmáticos, que possam colaboram para definir o significado específico da construção gerundial no texto. O resultado deste trabalho é também a proposta de uma nova tipologia de construções gerundiais do espanhol e de seus usos.

Em sua metodologia, a autora estabelece três critérios definitórios que aplica às sentenças compostas de orações gerundivas:

I) o critério do conteúdo/referência entre a oração gerundiva e a oração matriz: os conteúdos das duas orações são confrotados e verifica-se se o conteúdo proposicional (estados, processos, acontecimentos, ações) da oração gerundiva constitui um estado de coisas independente da oração matriz ou se estabelece uma referência imediata com a oração matriz, particularizando algum aspecto da mesma.

II) o critério da pressuposição pragmática: nesse nível, analisa-se o contexto em que a construção gerundiva está inserida, para verificar a pressuposição pragmática envolvida nos enunciados. Dessa forma, segundo Reese, seria possível depreender o significado de acordo com o contexto em que a oração gerundiva se encontra. Aqui, analisam-se as orações gerundivas sob o ponto de vista da argumentação.

III) o critério do estatuto discursivo da oração gerundiva: assume-se que os enunciados têm uma função discursiva específica e que uma vez identificada 
a finalidade comunicativa, fica mais fácil interpretar o sentido da oração gerundiva. Nesse nível analisam-se as construções gerundivas sob a perspectiva dos atos de fala.

A título de exemplificação, apresento como a autor aplica essa metodologia a gerúndio condicional e ao gerúndio causal, uma vez que discuto mais detalhadamente os valores semânticos do gerúndio no capítulo sobre a semanticizição do gerúndio.

A autora observa que o gerúndio condicional pode aparecer em contextos ligados a atos de fala do tipo conselho, recomendação e advertência nos quais o falante confere ao interlocutor a decisão a respeito da efetiva realização de um determinado ato e de suas possíveis conseqüências:

(107) REGALE UNA VIDA

Apadrinando a un niño del Tercer Mundo Vd. puede operar un cambio inimaginable para él/ella y su familia. ${ }^{109}$

Outra possibilidade de interpretar atos de fala como condicionais refere-se ao uso do gerúndio em construções nas quais o falante/escritor comenta as possíveis ações executadas por terceiros:

(108) Sin duda, Leguina habrá de pagar el precio subjetivo de su error político al verse desautorizado de este modo por el jefe de su partido y del Gobierno, pero este país es benévole con los errores ajenos y Leguina puede consolidar nuevamente su estatudo personal reconociendo el error y persuadiendo, con toda llaneza, a la Cámara autonómica para que atienda la demanda del presidente. $^{110}$

Nas narrativas, é comum que determinadas construções com o gerúndio ilustrem uma espécie de ponderação do falante/escritor a respeito das conseqüências de um ato a ser executado:

(109) Salí del correo con un ánimo de mil diablos y hasta pensé si, volviendo a la ventanilla, podría incendiar de alguna manera el cesto de cartas. ¿Pero cómo? Arrojando un fósforo? Era fácil que se apagara en el camino. Echando previamente un chorrito de nafta, el efecto sería seguro; pero eso complicaba las cosas. ${ }^{111}$

Segundo a autora, o gerúndio também pode ser interpretado como condicional quando estabelece uma relação de generalização em um contexto que deve ser entendido como saber adquirido e experienciado:

\footnotetext{
${ }^{109}$ Reese (1991:139).

${ }^{110}$ Idem, p. 143.

111 ibidem, p. 145.
} 
(110) Calculando para estos algoritimos los valores promedios de decisiones binarias se obtiene:... ${ }^{112}$

Diferentemente das condicionais, nas orações causais tanto o conteúdo da apódose como da prótase são aceitos como existentes, tanto no mundo real como num plano fictício. Segundo Reese, gerúndios causais são típicos de narrativas e relatórios, mesmo quando determinados relatórios funcionem como prognósticos, como é o caso das previsões de tempo.

A autora reconhece dois tipos de gerúndios causais: a) gerúndios que explicam a causa (ursächlich-erklärende Gerundialphrasen) e gerúndios causais epistêmicos (epistemisch-begründende Gerundialphrasen). O primeiro deles seria o caso de sentenças nas quais as construções com o gerúndio servem para explicar determinadas atitudes em função de um contexto dado, como quando se explica o motivo que levou alguém a agir de uma determinada maneiro ou dizer determinada coisa:

(111) Una mozuela decía, viendo pasar la boda, con un cántaro al anca:

- ¡Todas se casan, y yo, mira! ${ }^{113}$

Outra possibilidade de a) seriam as construções gerundivas que servem para explicar a motivação e o objetivo a ser alcançado:

(112)Desde que supo eso, la noche era para Paco misteriosa y temible, y cuando se acostaba aguzaba el oído queriendo oír los ruidos de fuera. ${ }^{114}$

As construções gerundivas do tipo a) também podem ser interpretado como causais quando indicam a explicação de percepções a respeito de determinada situação:

(113) Mosén Millán se interesaba por Paco pensando que sua padres eran poco religiosos. ${ }^{115}$

Por fim, Reese aponta um segundo tipo de construções gerundivas causais, que seriam os gerúndios epistêmicos. Segundo Reese (1991:168), nestes casos o conteúdo expresso na prótase exibe um explicação epistêmica (acho que X, porque $Y$ ) e cita um exemplo que encontrou:

(114)El arroz es una planta anual de la familia de las gramineas originaria de las índias orientales (...) Es el cereal más importante que cultiva el hombre, siendo el elemento básico y casi único en la dieta de más de la mitad de la población mundial. ${ }^{116}$

\footnotetext{
112 ibidem, p. 148.

113 ibidem, p. 156.

114 ibidem, p. 162.

115 ibidem, p. 164.

${ }^{116}$ Reese (1991:168).
} 
A literatura sobre as relações de causa e conseqüência discutiu vastamente a questão que envolve construções do tipo:

(115) Os canos da calefação estouraram, porque houve geada.

(116) Houve geada, porque os canos da calefação estouraram. ${ }^{117}$

A tradição gramatical tem tentando descrever casos como (32) como explicativas, o que de um ponto de vista tanto sintático como semântico não se sustenta.

Vê-se que sua perpectiva de análise leva em conta não só o contexto imediato em que os gerúndios ocorrem, mas também o tipo de texto em que ele é encontrado e também as estratégias comunicativas envolvidas na produção dos enunciados. Segundo ela, a somatória desses elementos permite desambiguar as construções gerundivas e estabelecer a interpretação mais adequada da circunstância adverbial envolvida.

O trabalho é exaustivo e a autora teve o cuidado de interpretar cada um de seus exemplos pelos critérios acima estabelecidos. No entanto, justamente por conta da minúcia, sua metodologia ultrapassa os limites de uma classificação clara e consistente. Seu trabalho orienta-se mais para uma descrição da discursivazação do gerúndio, mas está atrelado a critérios de outra natureza, que precisariam ser descritos separadamente, quando tenta definir os valores semânticos das orações gerundivas (semanticização) e a estruturação sintática que exibem (sintaticização).

\section{I.2.2.7 O gerúndio em construções perifrásticas e semi-perifrásticas}

Em seu estudo sobre os gerúndios no espanhol, Reese (1991) discute o grau de aderência dos auxiliares aos verbos na forma $-n d o$. Parecem-me considerações importantes a respeito da semanticização dos verbos auxiliares em paralelo ao grau de gramaticalização dos gerúndios. A autora observa que, principalmente no que se refere à perda de autonomia semântica dos verbos auxiliares nas perífrases com o gerúndio, pode-se dizer que nem sempre isso acontece, como nos casos seguintes: ${ }^{118}$

(117) El pequẽ̃o Paco iba haciendo sus descubrimientos en la vida.

${ }_{117}^{117}$ Exemplos traduzidos de Wunderlich (1980 apud Reese, 1991:167).

118 Os exemplos que seguem a respeito das construções semi-perifrásticas são retirados de Reese, 1991:38-39. 
Neste caso o valor a expressão hacer descubrimientos confere ao auxiliar ir um caráter autônomo no sentido de verbo de movimento. São expressões "semiperifrásticas" como diz Fente ${ }^{119}$ (1976:32 apud Reese, 1991:38) na qual o valor original do verbo ir se mantém:

(118)Me gusta ir andando por todas partes.

Entre outros exemplos, Reese resgata em seu corpus estas outras ocorrências de construções que não devem ser entendidas como perifrásticas:

(119) La Jerónima había vuelto a salir, e iba al carasol, ella sola, hablando para sí.

(120) Estuvo allí haciendo penitencia.

(121)Antes era distinto, cuando podía estar una tarde entera viendo pasar un tren cargado de banano; ciednto cuerenta vagos cargadso de frutas, pasando sin pasar...

(122) Estaba don Gumersindo siempre hablando de su propia bondad... y de la gente desgradecida que le devolvía mal por bien.

Nos casos acima a co-ocorrência com locativos e outras expressões temporais intercaladas entre as perífrases permite a interpretação de autonomia dos verbos ir e estar.

Reese (1991:40-49) também faz um apanhado geral das possibilidades de expressão do aspecto nas construções perifrásticas com o gerúndio: ${ }^{120}$

a. $\mathrm{O}$ aspecto continuativo / durativo pode ser expresso em espanhol com os verbos ir, venir, andar, seguir, quedar. Reese (1991:40) afirma que mesmo dentro da perífrase o sentido de base dos auxiliares não se perde, e isso é o que caracteriza o aspecto envolvido na construção:

- ir $+-n d o$ : indica progressão ou desenvolvimento gradual de uma atividade.

- venir $+-n d o$ : descreve desenvolvimento que se inicia no passado e que se desdobra em direção ao ponto de referência temporal (majoritariamente o momento de fala).

- andar $+-n d o:$ representa atividades repetidas não contínuas sem um objetivo específico.

\footnotetext{
${ }^{119}$ Fente, R. / Fernandes, J. / Feijo, L. G. (1976). Perífrases verbales, 2a. ed., Colección "Problemas básicos del español”, Madrid: Sociedad General Española de Librería, S.A.

${ }^{120}$ A respeito dos limites da definição da categoria perífrase e da gramaticalização de perífrases ver Montserrat (2003) in Pusch-Wesch (Org), p. 147-160, e sobre a aspectualização e focalização em perífrases progressivas, ver Pusch (2003) in Pusch-Wesch (Org), p.179-192.
} 
Gili y Gaya (1948/1960) entendem estar -ndo com aspecto durativo, embora em composição com verbos imperfectivos a impressão de duração seja reforçada, em composição com verbos momentâneos (pontuais) resultem em um aspecto iterativo $^{121}$. Keniston $^{122}$ (1936:171 apud Reese, 1991:41) defende a idéia de que não se trata do aspecto durativo e sim do aspecto progressivo: "It serves to expand our consideration of a particular action or state into the periods immediately preceding and following the moment of observation”. Esta idéia leva em conta, portanto, o momento de fala como ponto de referência para a costrução. Isso corresponde ao entendimento de imperfectividade de Gili y Gaya (1960:132 apud Reese, 1991:41). Com o termo progressive aspect, Keniston quer apontar para uma forma de interpretação basicamente dinâmica dos fatos descritos:

(123) Estoy esperando tus explicaciones. ${ }^{123}$

No caso acima, o que se reforça, no entanto, não é o sentido dinâmico e sim o valor de estática do ato de esperar. Um valor progressivo pode ser depreendido quando a perífrase se compõe com verbos dinâmicos:

(124)Estaba ya oscureciendo, y en el cuarto primero no había luz. ${ }^{124}$

Portanto, a interpretação de aspecto progressivo depende do contexto e não é um traço básico da perífrase.

Há exemplos que não permitem uma leitura nem de duração nem de progressão, mas sim de marcação de um momento objetivo:

(125)Aquí falta una línea, estoy notando, no? De „propósito“ hacia abajo. ${ }^{125}$

No exemplo acima o acontecimento notar apesar de sua curta duração é visto como dinâmico e no decorrer, mas não pode ser alongado no tempo. O exemplo é aspectualmente imperfectivo (ou progressivo), mas não durativo. $\mathrm{O}$ ponto de referência temporal para a interpretação imperfectiva é nesse caso o momento de fala, o que é demonstrado pelo presente como tempo de estar. O esquema da perífrase estar -ndo para as línguas românicas seria o seguinte:

\footnotetext{
${ }^{121}$ também cf. Roca Pons, 1958:66 apud Reese, 1991:41.

${ }^{122}$ Keniston, H. (1937). Spanish Syntax List, New York: Holt, Rinehart \& Winston Inc.

${ }^{123}$ Exemplo de Keniston, 1936 apud Reese, 1991:41.

${ }^{124}$ Exemplo de Reese (1991:41).

125 idem.
} 


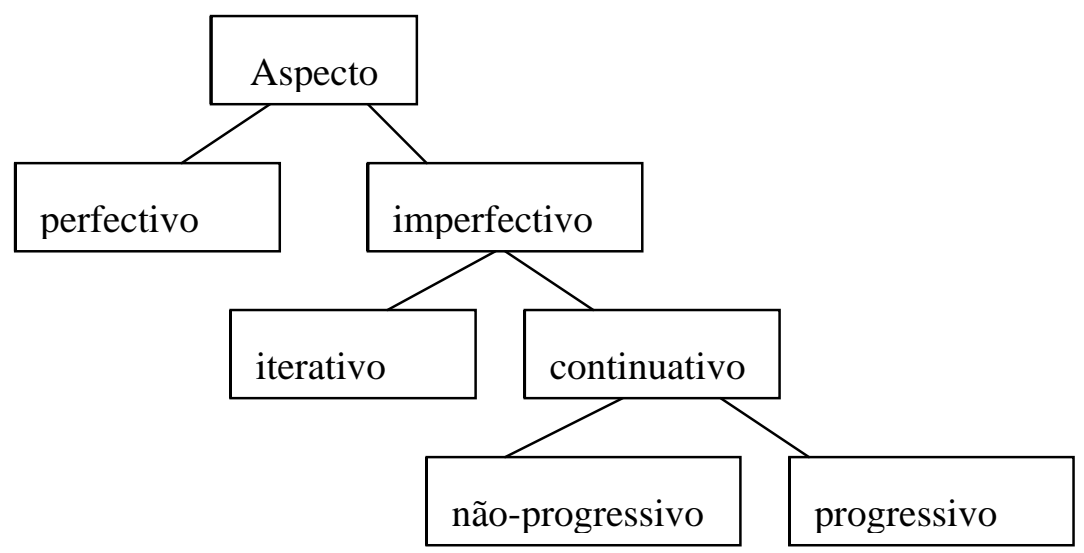

Quadro 1. O aspecto imperfectivo (cf. Comrie ${ }^{126}$, 1976:25 apud Reese, 1991:42)

Reese discute em seguida a questão sobre o valor imperfectivo específico que acompanha as construções perifrásticas estar -ndo. O espanhol, assim como outras línguas românicas, tem uma forma específica para o aspecto imperfectivo que é o pretérito imperfeito (cantaba, escribía). Além disso, é possível afirmar ainda que o presente também é um modo temporal que pode apresentar nuances imperfectivas.

Comparando com o inglês, em cuja língua, segundo Reese, não há a categoria de aspecto $^{127}$ o uso da progressive form (I am writting a letter) expressa a idéia de uma ação atual em andamento, enquanto que a forma simples expressa uma ação habitual ou constatações genéricas (I write about ten letters every day). Em espanhol, no entanto, a construção escribo cartas pode tanto ser interpretada como expressando aspecto habitual como também uma ação repetitiva e corriqueira. Segundo a autora, tanto o espanhol, como o italiano, e por conseguinte, também o português, a progressive form é usada para para representar ações ,in dynamic process of happening“.

Outro estudioso, Rallides ${ }^{128}$ (1966 apud Reese, 1991:45) afirma que as formas perifrásticas no presente e no imperfeito como estoy cantando / estaba cantando representam a ação como ,non-repetition (continuous)“, enquanto das formas simples canto / cantaba designam „repetition“. Reese considera errada essa

126 Comrie, Bernard (1976). Aspect. An introduction to the Study of Verbal Aspect and Related Problems, Cambridge: Cambridge University Press.

${ }^{127}$ Se considerarmos a aplicação do conceito de aspecto como uma categoria cognitiva de base da linguagem humana, esta afirmação de Reese pode ser discutida.

${ }^{128}$ Rallides, Charles (1966). "Differences in aspect between the gerundive forms and the nongerundive forms of the Spanish Verb", Hispania 49 (1966), 107-44. 
abordagem, pois, segundo ela, depedendo da semântica específica de cada verbo pleno expresso no gerúndio, a perífrase pode implicar uma repetição.

Ao estudar as diferenças entre as formas simples e as formas perifrásticas em todos os tempos do espanhol Douglass ${ }^{129}$ (1967) propõe essa discutível generalização:

(1) corresponding gerundive and non-gerundive forms are usually identical in aspect, (2) use of the gerundive form, by its redundant indication of imperfectiveness, usually signals emphasis or restriction around the point of orientation (...) (Douglass, 1967: 103 apud Reese, 1991: 45)

Acertadamente, Reese discorda de (1), pois não se pode confundir o uso distinto de duas estruturas como escolha estilística e não gramatical, já que na verdade a escolha específica depende de outros elementos que concorrem com elas e compõem com elas novos significados. E lembra a distinção que Comrie (1976) faz entre perfectivo e imperfectivo:

Perfectivity indicates the view of a situation as a single whole, without distinction of the various separate phases tha make up that situation; while the imperfective pays essential attention to the internal structure of the situation. (Comrie, 1976: 16 apud Reese, 1991: 46)

Reese concorda com Comrie (1976) quando ele diz que perfectividade pode ser combinada com imperfectividade, pois ,perfectivity involves lack of explicit reference to the internal temporal constituency of a situation, rather than explicitly implying the lack of such internal temporal constituency" (Comrie, 1976: 21 ff. apud Reese, 1991: 46), como no exemplo no qual a situação descrita durou ao longo de um determinado tempo, exibindo, no entanto, fases distintas, sendo assim progressivo, enquanto o complexo todo é igualmente apresentado com um simples conjunto total, o passado simples:

(126) Todas las tardes estuvieron entrando visitas. ${ }^{130}$

Reese concorda com a idéia de Douglass (1967) de que a construção perifrástica circunscreve um determinado hiato de tempo [Zeitweiligkeit] que envolve o ato descrito. Tal idéia é que exemplicaria a inaceitabilidade do seguinte enunciado:

(127)??Estoy sabendo nadar.

Poder nadar é uma capacidade que, uma vez aprendida, não se esquece. Uma limitação temporal explícita poderia causar a seguinte impressão no ouvinte:

\footnotetext{
129 Douglass, A. Thomas (1967). "Gerundive and Non-Gerundive Forms”, Hispania 50 (1967). 99103.

${ }^{130}$ Exemplo de Comrie, 1976: 23 apud Reese, 1991:46.
} 
(128)?? Sé nadar estos dias (este año, por dos oras).

A autora discute a questão da Zeitweiligkeit como componente semântico da perífrase com $-n d o$ :

(129) Juan habla inglés.

(130) Juan está hablando inglés.

Em (34) pode ser entendido que há uma capacidade ilimitada temporal de Juan, em contrapartida em (35) trata-se de uma ação atual e momentânea.

(131) Juan hablaba inglés

(132) Juan estaba hablando inglés.

Reese diz que num contexto narrativo (36), poderia ser entendido como expressão de uma capacidade, enquanto isso não seria possível para (37).

Reese tem razão quando diz que para interpretar o aspecto específico da perífrase com -ndo é preciso levar em conta a polissemia lexical de determinados verbos e de suas combinações com alguns objetos:

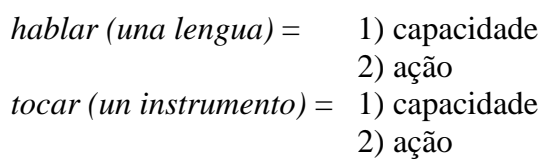

Outra observação importante de Reese, lembrando Zdenek (1972:498 apud Reese, 1991:48) e a Academia (1979:498 apud Reese, 1991:48) refere-se à possibilidade de a perífrase com -ndo permitir uma interpretação de ênfase (133) ou emotividade (136, 138 e 140) que o presente $\left(133,135,137\right.$ e 139) não oferece: ${ }^{131}$

(133) Desea que se case

(134)Está deseando que se case = He really wishes she'd get married.

(135) Cuánto nos divertimos anoche! Bailamos hasta las tres.

(136) Cuánto nos divertimos anoche! Estuvimos bailando hast las tres.

(137) Esperaba hablar con él y no apareció.

(138)Estaba esperando hablar con él y no apareció.

(139) Vas a jugar toda la tarde?

(140) Vas a estar jugando toda la tarde?

O valor enfático da perífrase pode ser explicado pela indicação formal do aspecto imperfectivo através de estar -ndo como um sinal do falante (escritor) para o ouvinte (leitor), para que ele possa colocar-se no lugar dele. Dessa forma o falante pode permitir que o ouvinte também perceba a emoção a que ele está submetido. ${ }^{132}$

\footnotetext{
${ }^{131}$ Exemplos de Zdenek, 1972:498 apud Reese, 1991:48.

132 Travaglia (2006:191) observou para o português que o aspecto imperfectivo é utilizado como mecanismo de focalização de partes do enunciado. Retomo isto no capítulo V quando falo sobre a discursivização do gerúndio em português.
} 


\section{I.2.2.8 Gerúndio independente}

Em seu estudo sobre o gerúndio, Lajmanovich ${ }^{133}$ (1968 apud Reese, 1991:5157) é da opinião de que as orações gerundivas no espanhol são basicamente ambíguas. Baseando-se numa pesquisa feita em um corpus de 1000 ocorrências de construções gerundiais e um corpus de comparação de 500 ocorrências recolhidas em textos de jornais, fez um catálogo com 16 tipos de paráfrases para tentar identificar o potencial de ambigüidade da construção gerundiva no espanhol. A partir das ocorrências, propôs uma classificação que compreende a seguinte divisão: gerl: o gerúndio faz parte de uma perífrase verbal; ger2: o gerúndio é um modificador do núcleo de sintagma nominal, como oração relativa; ger3: o gerúndio, juntamente com seus complemente, constitui uma estrutura periférica do sintagma verbal, como oração adverbial; ger4: o gerúndio é o único elemento da proposição, como oração coordenada independente.

Nesse trabalho, o autor evidencia a necessidade de se observar outros usos do gerúndio, além daquelas já descritas anteriormente. As construções coordenativas ger4 compreendem principalmente as orações com valor imperativo (141) e ou lenguaje codificado (142) como em

(141)Escuchando... Escuchando.

(142) Cocina llamando... Cocina llamando..

Outra possibilidade de interpretação de ger4 como orações coordenadas pode ser visualizada no exemplo abaixo:

(143) Su asunto será pasado a la Oficina Judicial, quedando usted automáticamente borrado de la lista.

Tradicionalmente esta oração seria interpretada com valor de posterioridade expresso pela forma em -ndo. No entanto, há outros exemplos nos quais a relação temporal de posterioridade não aparece:

(144)De presentarse así la reacción laboral, se entendía también que la respuesta gubernamental estaría em consonancia, no faltando quienes insisten en la perspectiva de la movilización de los gremios del transporte.

(145)Aumentaron mucho las entradas el martes, totalizando 9000 cabezas.

A categorização proposta por Lajmanovich para os exempos de ger4 pode ser ramificada em dois grupos, se observarmos que (141) e (142) são exemplos de maior independência sintática do que as ocorrências (144) a (145). Nestas orações, as

${ }^{133}$ Lajmanovich, Josué David (1968). Sintaxis del gerundio español, Ph.D. Dissertation, Georgetown University 1967, Ann Arbor/Michigan: University Microfilms International. 
construções com o gerúndio estabelecem uma relação do primeiro nível de junção (coordenação assindética) proposto por Raible (1992), ou seja, embora sejam sintaticamente independentes da oração principal, as orações gerundivas nestes últimos casos exibem uma dependência semântica em relação às principais.

\subsubsection{Considerações finais a respeito dos estudos sobre o gerúndio no espanhol}

A revisão da literatura a respeito das descrições do gerúndio no espanhol indicam questões que também são importantes para o português. Principalmente no que se refere à problemática que envolve os gerúndios adjetivos. O estudo de Susanne Reese traz contribuições interessantes a respeito das propriedades semânticas e discursivas do gerúndio e serão levadas em consideração nos capítulos que se referem a esses subsistemas da língua.

Terminado esse primeiro balanço sobre o gerúndio a partir do latim e como se deu sua passagem para as línguas românicas, passo às descrições que já foram feitas sobre o gerúndio no português.

\section{I.2.3 O gerúndio no português}

A incorporação do gerúndio ao quadro de conjugações do português a partir do latim tem explicações na obras dos gramáticos a partir do século XIX ${ }^{134}$. Alguns dedicaram-se a estudos descritivos sobre a diacronia do gerúndio no português. ${ }^{135}$

Há consenso entre os sintaticistas de que o gerúndio passou ao português, como às outras línguas românicas, oriundo do ablativo do gerúndio latino e de determinados usos do particípio presente, como o atesta, por exemplo, Epiphanio

\footnotetext{
${ }^{134}$ Sobre a diacronia do gerúndio, ver Jerônimo Soares Barbosa (1822), Julio Moreira (1907), MeyerLübke (1916), Epiphanio da Silva Dias (1918), Silveira Bueno (1958) e Said Ali (1964 e 1975).

${ }^{135}$ V. Othoniel Motta (1914, 1915 e 1937), Claudio Brandão (1933) e Odette Campos (1972 e 1980).
} 
$\operatorname{Dias}^{136}$ (1918). Júlio Moreira (1907:92-101) também explica em seus Estudos de língua portuguesa a origem do gerúndio:

"O gerundio latino que tinha tres fórmas (v. g.: amandum, amandi, amando) conservou-se em português com o seu emprego verbal mas com uma só fórma, em virtude do desapparecimento dos outros casos, cujas relações passaram a exprimir-se com o infinitivo precedido de preposições."

Em sua Grammatica Philosophica da Lingua Portugueza, Barbosa (1822:284-5) argumenta a favor da mudança que levou o gerúndio a assumir o papel anteriormente exercido pelo particípio presente:

\begin{abstract}
"A terminação em ndo semelhante á dos Gerundios Latinos impoz a nossos Grammaticos para os terem por taes. Mas he mais provavel, que estes participios activos em ndo tivessem sua origem dos adjectivos verbaes em nte, a alguns dos quaes davão nossos antigos Escriptores o mesmo regime do verbo, donde se derivavão, como Amante a Deos, Temente a Deos, Intemente a Deos, Annibal passante os montes Alpes; do que ainda temos restos em alguns nomes compostos, como Lugartenente, Malfazente, Maldizente, Missacantante, \&c."

O fato de terem reconhecido a dupla etimologia do gerúndio português não significou inicialmente que para ele fossem aceitos todos os "empregos sintáticos" originários do particípio presente latino. Essa discussão dividiu-se em três correntes que defendiam teses diferentes: ${ }^{137}$
\end{abstract}

1. Julio Moreira, Epiphanio Dias e Leite de Vasconcellos recusavam-se a aceitar o emprego do gerúndio em função adjetiva qualquer que fosse ela. Estes autores consideravam tais usos fruto de galicismos importados por jornalistas e escritores influenciados pela língua francesa tão em voga no século XIX;

2. Outro grupo de autores, como Souza Lima, Gladstone Chaves de Mello, Luis Carlos Lessa e outros, embora condenassem o uso do gerúndio como adjetivo quando indicava qualidades permanentes, admitiam-no quando este exprimia qualidades transitórias. Também no espanhol se observou tal teoria em Bello, Gilli y Gaya e Criado del Val, como apontamos anteriormente ${ }^{138}$;

3. A todos estes, opuseram-se veementemente Othoniel Motta, Carlos Brandão, Said Ali e Silvio Elia, por acreditarem que o gerúndio assumiu todas as

\footnotetext{
136 "A forma verbal em -ndo representa etymologicamente o ablativo do gerundio latino; herdou, porém, em parte, os empregos syntacticos não só do ablat. do gerundio, senão tambem, $e$ principalmente, do participio presente latino.” in Epiphanio Dias (1918:247).

${ }^{137}$ Cf. Campos, 1972:44-45.

${ }^{138}$ Cf. Campos (1972) e Reese (1991).
} 
possibilidades que eram expressas através do particípio presente no latim, tanto as que indicam ações transitórias, como as que referem-se a qualidades permanentes.

A fim de entender melhor essa problemática, traço um perfil histórico dessa discussão nas próximas seções. Para isso, acho importante rever como e em que funções o particípio presente entrou no português até ter sido substituído pelo gerúndio.

\section{I.2.3.1 O particípio presente no português}

Em sua Gramática normativa da língua portuguesa, Silveira Bueno (1958:388-390) apresenta o particípio presente como uma forma concorrente do gerúndio no português arcaico "em sua função de verbo, regendo, portanto, complementos próprios” (Bueno, 1958:388):

(146) Rei e senhor natural, não reconhecente superior em o temporal. ${ }^{139}$ (147) Ilhéus de Ires e Meitarana, circunstante a Ternate. ${ }^{140}$

(148) Perlas ricas e imitantes a côr da Aurora. ${ }^{141}$

$\mathrm{O}$ autor lembra que este "emprêgo do particípio presente, com função verbal, desapareceu da nossa língua, substituído pelo gerúndio ou pela oração relativa, adjetiva: 'Pérolas que imitam a côr da aurora' - 'Pérolas imitando a côr da aurora." (Bueno, op. cit., idem).

Na mesma seção, o gramático fala da gramaticalização do particípio em -nte "como adjetivo simples, qualificativo: contente, sapiente, ouvinte, pedinte, poente (...). Tendo sido adjetivos, em muitos casos, passaram a substantivos, como em: estudante, assistente, crente, constituinte, lente. Em casos menos numerosos passaram tais particípios a palavras invariáveis, tais como: não obstante, tirante, não embargante, passante de, etc.” (Bueno, op. cit., ib.).

Segundo Odette Campos (1972), o particípio presente teve pouca vitalidade no período arcaico e seu uso estava condiciconado a textos eclesiásticos como a Regra de São Bento, no qual abundam as formas de particípio presente e são raras as

\footnotetext{
${ }^{139}$ Barros, Déc., 4-7, i apud Bueno, 1958:388.

${ }^{140}$ Idem, ibidem, 4, 7, 9 apud Bueno, 1958:388.

${ }^{141}$ Camões, Lus., X, 102, apud Said Ali, Léx. do Port. Histór., 125, cf. Bueno, 1958:388. Camões não deve ser considerado como um autor do período arcaico do português, e sim do período clássico.
} 
ocorrências de gerúndio (Campos, 1972:65). Para esta época, a autora elenca os seguintes usos do particípio presente:

a) Em orações circunstanciais, regendo complementos:

(149)En'o nome de Deus. Eu rei don Afonso pela gracia de Deus rei de Portugal, seendo sano e saluo, teme)te o dia de mia morte, a saude de mia alma e a proe de mia molier raina dona Orraca e de me(us) filios e de me(us) uassalos e de todo meu reino ... ${ }^{142}$

b) Em orações adjetivas, regendo complementos:

(150) O terceiro, que sempre se ponham pallavras que sejam dereita lynguagem, respondentes ao latym... ${ }^{143}$

c) Como adjetivo:

(151)Certamente não somos abastamtes pera elo, pola multidão dos nossos peccados. ${ }^{144}$

d) Como nome:

(152)...ensina aos homẽes a serem bõos caualgantes. ${ }^{145}$

e) E em expressões estereotipadas, como novas conjunções e preposições, produtos de lexicalizações, do tipo nom embargante que, não obstante, por cõnseguinte, salvante, tirante.

(153)E nom embargante que dos seus direytos possa dar aaquelle que for mais amado... pero os ofiçios e dignydades e rrendas da terra... nom seram outorgadas, senom a quem as mais mereçer. ${ }^{146}$

O gramático Júlio Moreira (1907:92-101) aponta também para o fato de que no português moderno o particípio ativo do presente é representado por adjetivos e substantivos, mas que no período arcaico da língua ainda tinha o valor de forma verbal e cita exemplos de Adolpho Coelho ${ }^{147}$ como: os quaes tementes nostro señor, palavras ociosas e riso moventes e de Leite de Vasconcellos que "menciona tambem exemplos archaicos e vestígios de participio do presente no português moderno, como na frase "tirante isso", a que podemos accrescentar "não obstante isso",

\footnotetext{
${ }^{142}$ Exemplo da edição de Avelino de Jesus da Costa (1975): Os mais antigos documentos escritos em português: revisão de um problema histórico-lingüístico. Separata da Revista Portuguesa de História, XVII:263-340. Coimbra.

${ }^{143}$ D. Duarte, Leal Conselheiro, 373 apud Campos, 1972:66.

${ }^{144}$ Lopes, F., Crônica de D. João I, in TPM, 711, apud Campos, 1972:68.

${ }^{145}$ D. João I, Livro da Montaria, in TPM, 531-532, apud Campos, 1972:68.

${ }^{146}$ D. Pedro, Livro da Virtuosa Benfeitoria, in TPM, 554, apud Campos, 1972:68.

${ }^{147}$ Adolpho Coelho (1870): Theoria da conjugação em latim e português, apud Moreira, 1907:92101.
} 
"passante de" (...) Com valor semelhante ha mais algumas palavras, como “dependente de”, “adherente a”, “mal soante”, "bem fallante”, etc.” 148

Concluindo, a exemplo do que aconteceu nas outras línguas româncias, o particípio presente reduziu-se em português a lexicalizações em nomes, adjetivos, preposições e conjunções. Em conseqüência disso, abriu-se o caminho para que o gerúndio ocupasse o domínio em construções circunstanciais e em orações adjetivas, que é o que veremos a seguir.

\title{
I.2.3.2 O gerúndio no português
}

Como se disse acima, há entre os gramáticos um consenso de que o gerúndio, em comparação à forma do particípio presente, tornou-se uma forma vitoriosa. Para alguns, esse embate já teria ocorrido no latim como observa Meyer-Lübke (1916:306-307):

\begin{abstract}
"Êste fenómeno pode tomar-se por uma substituição do termo predicativo ou apositivo por um termo adverbial; e, posto que já ocorra em Tito Lívio e Vergílio, o seu uso não se estende até os escritores dos séculos IV e V; então adquire tal desenvolvimento, que tem de supor-se que existia na língua vulgar: anumus qui esta in corpore medius contemnendo bona non complet reluctatque bonis in lecione sua, Fungêncio, 105, 19; unus bene parcendo erigitur, alius male parcendo deicitur, 157, 1.

A igualdade completa do gerúndio e do particípio do presente aparece nesta frase: Transeuntia erant elementa ad maiorem gloriam inque ea permenenda, Filástrico, 80,7." in Meyer-Lübke (1916: 306-307).
\end{abstract}

Esse autor atesta que o uso do gerúndio no português é resultado de perdas e ganhos de terreno. Se de um lado ele atesta a vitória dessa forma em alguns contextos, em outros ele observa a restrição de seu uso:

\begin{abstract}
“Ao estudarem-se os derivados verbais, nota-se que o uso do gerúndio sofreu uma transformação profunda. O gerúndio teve no seu emprêgo uma grande limitação; em primeiro lugar, por ser possível construir o infinitivo com toda a espécie de preposições, pelo que, pouco a pouco, é quase completamente substituído pelo infinitivo; em segundo lugar, porque o ablativo do gerúndio ocupou cada vez mais o lugar do particípio do presente, que, por sua vez, passava a ser um mero adjectivo verbal.” Meyer-Lübke (1916:306-307)
\end{abstract}

Meyer-Lübke vê no infinitivo uma outra forma concorrente do gerúndio. Tanto no que tange as perífrases aspectuais como as orações reduzidas, o uso do infinitivo, em concorrência com o gerúndio, já vinha sendo apontado desde MeyerLübke (1916:306-307) que, no início do século passado, denunciava: "A ampliação do uso do infinitivo é antiga; e um pouco mais moderna a união com preposições,

${ }^{148}$ Leite de Vasconcellos, Estudos de philologia mirandesa, t. 1, p. 367, nota, apud Moreira, idem, ibidem. 
como dare ad manducare, que aparece na Vulgata, e se torna depois cada vez mais freqüente”.

Said Ali acrescenta mais um argumento em favor da gramaticalização do gerúndio no português, observando que, diferentemente do que aconteceu nas últimas fases do latim e no período arcaico do português, na passagem para o português clássico aumentou a sua freqüência de uso:

"o retraimento, observável em latim, seria todavia cousa insignificante em comparação do que se passou nas línguas românicas, sobretudo no idioma português a partir do século XVI, em que largamente se começou a usar o gerúndio para dar forma concisa e elegante a toda a sorte de orações subordinadas. ${ }^{149, " ~(S a i d ~ A l i, ~ 1920 / 1975: 50) ~}$

Essa observação também foi feita a respeito do francês por Müller-Lancé (1994) e está associada à questão da relatinização das línguas românicas a partir do século XVI.

Said Ali arremata seu texto, agregando um argumento que favorece a leitura dos gerúndios sob o prisma da semanticização dessa forma no português:

"Quem identifica a forma invariável em -ando, -endo, -indo, -ondo do verbo português com o ablativo do gerúndio latino anda muito bem se considera a cousa do ponto de vista morfológico; mas desacerta, e muito, se, no tocante à significação, tem em mente apenas as noções de instrumento e meio do gerúndio primitivo, ignorando as demais funções tomadas ao particípio do presente, ou dele herdadas.” (Said Ali, 1920/1975:51)

Textos mais antigos reforçam a argumentação de Said Ali. É o caso dos documentos notariais dos século XIII e XIV oriundos do Mosteiro de S. Miguel de Vilarinho e reunidos por Ana Maria Martins (2001) nos Documentos Portugueses do Noroeste e da Região de Lisboa. Os exemplos abaixo, retirados das primeiras páginas desse volume, são algumas provas que indicam a abundância de construções absolutas com gerúndio numa fase primitiva do português:

(154)... porque uos forades reuees nõ querẽdo purgar a reuelhia. nẽ star a dereyto. (S. Miguel de Vilarinho, 1293:8)

(155)Polha qual cousa mãdaua a todolhos Meyrios e iustiças do Reyno de Portugal. chamãdo os como braço segral. (S. Miguel de Vilarinho, 1293:9)

(156)Perante ffernã anes de sendj Juíz da dicta villa Pareçeu Dom Lourenço estevez Priol do Momsteiro de villarinho da hu parte e da outra Domigos martjnz de paradella dizẽdo o dito priol que o dito Domigos martjnz. Auja de dar ẽ cada huu Ãno. (S. Miguel de Vilarinho, 1357:6)

(157) da hua partte e lourẽçe stevez Priol desse Monsteiro da outra. dizẽdo os dictos cõõigos em seu nome e do dicto Cõuẽto que de custume antigo custumarõ dauer e ouuerom no dicto Monsteiro bõa raçom e mãtijmẽto. (S. Miguel de Vilarinho, 1364:6)

$\mathrm{O}$ entendimento inadequado de perpetuações, abandonos e avanços sobre outros contextos decorrente desse embate entre o gerúndio e outras formas nominais

\footnotetext{
${ }^{149}$ Segue um comentário de Said Ali sobre a relação psicológica que existe entre a oração adjetiva e a oração adverbial, impedindo muitas vezes que se possa distinguir a relação circunstancial da adjetiva nas cláusulas iniciadas por expressões gerundivas.
} 
gerou interpretações equivocadas a respeito desse processo de mudança lingüística. A discussão não pára por aqui, mas é hora de falarmos de estudos descritivos mais detalhados do gerúndio em português e de como ele tem sido tratado nas gramáticas mais atuais. É o que veremos na seção seguinte.

\section{I.2.3.2.1 Estudos descritivos do gerúndio em português}

Ao longo dos últimos dois séculos, a preocupação em descrever o gerúndio em português moveu-se entre os dois pólos acima apresentados. À perspectiva "expansionista" do gerúndio agregaram-se duas descrições cuidadosas feitas por Carlos Brandão (1933) e Odette Campos (1972). Ambos procuraram enumerar e esclarecer os argumentos que suportam a tese de que o gerúndio tornou-se em português uma forma muito produtiva em termos sintáticos. Carlos Brandão procurou fazê-lo de maneira a organizar os gerúndios segundo classes sintáticas como adjuntos e complementos de nomes ou de sentenças, além de descrever brevemente como se organizam dentro das perífrases aspectuais. Odette Campos fez um estudo histórico-descritivo do gerúndio, procurando demonstrar de que maneira determinados usos evoluíram em três períodos do português (arcaico, clássico e moderno) e concontrou-se na descrição mais ampla do gerúndio no século XX.

\section{I.2.3.2.1.1 O gerúndio no português - A descrição de Brandão (1933)}

Claudio Brandão foi um dos pesquisadores que estudou de maneira detalhada o gerúndio no português. Em sua tese de doutorado " $O$ particípio presente e $o$ gerundio em português" (1933), o autor fez um levantamento exaustivo das ocorrências de gerúndio em um corpus oriundo da literatura portuguesa e brasileira, e também de sermões e de traduções de textos bíblicos. Para os exemplos retirados destes últimos, Brandão procurou sempre recuperar a versão latina da Vulgata, de modo a esclarecer as distinções entre o uso do particípio presente latino e sua adaptação ao português através do uso de construções com gerúndio. Até então, as descrições gramaticais das orações relativas tinham se concentrado unicamente no estudo das orações introduzidas por algum tipo de pronome relativo e poucos foram 
o que se preocuparam em oferecer uma descrição clara dos relativas introduzidas pelo gerúndio.

Em seu estudo descritivo, Brandão adota quatro critérios que englobam propriedades tanto sintáticas como semânticas do uso do gerúndio: primeiramente, repetindo a lição que já havia aplicado à descrição dos particípios latinos, ele descreve o gerúndio que compõe orações subordinadas: o gerúndio apositivo, o gerúndio predicativo e o gerúndio atributivo. Por fim, apresenta as perífrases de gerúndio compostas de verbos aos quais o morfema -ndo se associa para a expressão do aspecto.

Apesar de alguns equívocos, principalmente no que se refere à confusão dos planos sintático e semântico para a distribuição dos usos do gerúndio, o trabalho de Brandão é uma contribuição valiosa a respeito das propriedades que essa forma nominal assumiu no português.

\section{I.2.3.2.1.2 O estudo histórico-descritivo de Odette Campos (1972)}

O estudo sobre a diacronia do gerúndio a partir do latim ao português moderno de Odette Campos (1972) é outro trabalho de significativa importância. A autora também parte de uma brevedescrição do gerúndio no latim e analisa a sua evolução em um corpus diferenciado do português arcaico ao português contemporâneo. Seu estudo retoma propõe uma reclassificação dos usos do gerúndio no português e reconhece o amplo leque de possibilidades que ele oferece, como se pode ver no quadro abaixo (Quadro XX). O trabalho retoma as discussões acerca da normatização do gerúndio e, assim como já o tinha feito Brandão (1933), prova que ampliaram-se os contextos de uso do gerúndio em português. 


\begin{tabular}{|l|c|c|c|}
\hline & $\begin{array}{c}\text { Português } \\
\text { arcaico }\end{array}$ & $\begin{array}{c}\text { Português séc. XVI ao } \\
\text { XIX }\end{array}$ & $\begin{array}{c}\text { Português } \\
\text { contemporâneo }\end{array}$ \\
\hline Gerúndio adverbial & $\mathrm{X}$ & $\mathrm{X}$ & $\mathrm{X}$ \\
\hline $\begin{array}{l}\text { Gerúndio } \\
\text { circunstancial }\end{array}$ & $\mathrm{X}$ & $\mathrm{X}$ & $\mathrm{X}$ \\
\hline Gerúndio adjetivo & $\mathrm{X}$ & $\mathrm{X}$ & $\mathrm{X}$ \\
\hline Gerúndio coordenado & $\mathrm{X}$ & $\mathrm{X}$ & $\mathrm{X}$ \\
\hline Perífrases de gerúndio & $\mathrm{X}$ & $\mathrm{X}$ & $\mathrm{X}$ \\
\hline Gerúndio exclamativo & & $\mathrm{X}$ & $\mathrm{X}$ \\
\hline Gerúndio interrogativo & & & $\mathrm{X}$ \\
\hline Gerúndio narrativo & & & \\
\hline
\end{tabular}

Quadro 2. Evolução dos usos do gerúndio na diacronia do português, baseado em Campos (1972)

A descrição que se segue procura incorporar as contribuições de Brandão (1933) e Campos (1972), além de retomar a discussão desencadeada no século XIX em torno do uso do gerúndio adjetivo e das perífrases com o gerúndio.

\section{I.2.3.2.2 Gerúndio adjetivo: uma discussão de longa data}

A gramaticalização do gerúndio adjetivo a partir do português clássico não foi muito bem compreendida por alguns gramáticos, o que gerou alguma discordância entre os estudiosos, a exemplo do que se pôde observar a respeito da diacronia do gerúndio no espanhol.

Ao descrever a etimologia do gerúndio no português, autores como Júlio Moreira (1907), Leite de Vasconcellos ${ }^{150}$ (1911 apud Said Ali, 1920/1975) e Epiphanio Dias (1918) afirmam que muitos escritores, ao usar o gerúndio, tentaram adaptar erroneamente ao português alguns usos que em latim eram exercidos pela forma verbal do particípio presente em -ant, como é o caso a) das perífrases aspectuais (erat dormiens) e b) das orações adjetivas (aqua fervens) e c) em construções que em português apresentavam a possibilidade de ser expressas com o a preposição $a+$ infinitivo (a correr). Eles argumentaram em seus trabalhos que principalmente em relação às orações adjetivas esse uso como gerúndio teria contaminado a língua portuguêsa por influência galicista, em decorrência de traduções feitas a partir dessa língua.

${ }^{150}$ Vasconcelos, J. Leite de (1911). Lições de filologia portuguesa. Lisboa: A. M. Teixeira \& Cta Porto: Imprensa Portuguesa. 
Júlio Moreira (1907), em seus Estudos de Língua Portuguesa, denuncia o que chamamos aqui de uma hipótese galicista para o uso do gerúndio em construções relativas. Segundo o autor, no português teria havido uma contaminação sintática dos usos do gerúndio, tomados por empréstimo dos usos do particípio presente nos textos franceses publicados em jornais. Aponta que o francês conservou a forma invariável do particípio presente do latim em ant, diferentemente do português, que teria apenas conservado a forma variável do particípio presente, reconhecidamente adjetivos (passante, falante, dependente, aderente, soante, temente, tirante, obstante).

\begin{abstract}
Moreira (1907:92-101) argumenta:
"Em francês deu-se a confusão da fórma do particípio do presente, que ao princípio só variava em numero, com a do gerundio, de modo que, por exemplo, aimant significa "amando", do latim amando, e "que ama" do latim amante. D'esta confusão nasceu a necessidade de estabelecer regras para os casos em que, segundo o sentido, esta fórma deveria ter flexões, variar em genero e numero, vindo por fim a prevalecer a que formulou a Academia em 1679, e que determinava que a fórma em ant deveria ser invariável quando designa acção e variável quando exprime estado.

De se haver conservado o participio presente em francês, resultou ser muito mais extenso naquelle idioma o uso das fórmas verbaes em ant do que no nosso o dos fórmas do gerundio, pois que na boca do povo, pelo menos, o participio do presente, como acima se disse, desappareceu de todo, se exceptuarmos as fórmas, mais ou menos estratificadas, de que se fez menção. Mas em virtude da leitura de nossos jornaes, que em grande parte reproduzem notícias e assuntos tratados em jornaes franceses, cuja traducção, ou pela escassez de tempo ou descuido das redacções, é muitas vezes atabalhoadamente escrita, e ainda pela leitura de livros traduzidos pouco esmeradamente do francês, ou de obras originaes portuguesas cujos autores se deixam arrastar pelos usos d'daquella lingua, succede que modernamente se manifesta grande tendencia para largo emprego abusivo das fórmas do gerundio."
\end{abstract}

Moreira (1907) assim postula a gramaticalização das orações adjetivas em português:

"O que todavia é verdade, é que a funcção dos particípios do presente latinos é actualmente expressa, na syntaxe do português popular, por uma oração relativa e ainda por outros modos, como veremos adeante, mas não por meio de um particípio.” (Moreira, 1907:93-94)

Mais tarde, Said Ali (1920/1975) irá criticar posições como esta de Julio Moreira, argumentando que o gerúndio português abarca tanto o valor adjetivo expresso pelo particípio presente como o seu valor verbal. Da competição dessas duas formas no português arcaico, teria vencido a forma do gerúndio no português, tendo sido largamente utilizado inclusive por autores do século XVI, tais como Camões.

Como já enumeramos acima, a crítica de Júlio Moreira estende-se também ao gerúndio nas construções perifrásticas:

151 grifo meu. 
“Ainda as expressões da chamada conjugação periphrastica, formada com o gerundio, são muito menos empregadas na linguagem popular do que na lingua culta. O gerundio é na maior parte dos casos substituido pelo infinitivo precedido da preposição $a$. Assim entre o povo dir-se-á antes 'está a estudar' do que 'está estudando” (Moreira, 1907:98).

O terceiro tópico de discussão na teoria de Júlio Moreira refere-se às construções que em português moderno já podiam ser expressas através do uso da preposição $a+$ infinitivo. Sua crítica não poupa os escritores que usam o gerúndio em lugar do infinitivo em orações como essa:

(158)É realmente difficil considerar Roma como um ninho balouçando-se no ramo de um ulmeiro, ou ver apenas no movimento social da Allemanha um fraco regato que vae cantando por entre as relvas altas. ${ }^{152}$

e argumenta que os falantes do português tinham à disposição outros recursos sintáticos para exprimir a ulterior função do gerúndio de expressar a finalidade, sem a necessidade de fazer uso das formas gerundivas:

"Vimos acima que em certos casos a fórma do gerundio é substituida na linguagem do povo por uma oração relativa ou por uma determinação precedida da preposição com; mas em outros, como no exemplo precedente, póde ser representada pelo verbo no modo infinitivo regido da preposição $a$. Em vez de "um ninho balouçando-se num ulmeiro" dir-se-ha "um ninho a balouçar-se num ulmeiro". A lingua popular tem pois estes tres processos para exprimir a função do gerundio nos casos de que falámos, e nunca emprega nesses casos a fórma do gerundio.” (Moreira, 1907:97).

A evitação do gerúndio pela "linguagem do povo" a que Julio Moreira se refere, parece indicar aqui uma forma de inovação que se deu no português europeu, que, a partir do português clássico, desenvolveu a forma $a+$ infinitivo em construções que no português arcaico podiam ser expressas com o gerúndio, como é o caso das construções perifrásticas e de casos em que o gerúndio ainda trazia do latim a função nominativa.

Um dos primeiros opositores da tese de Julio Moreira foi o professor brasileiro Othoniel Motta (1914). Em seu artigo Um ensaio de syntaxe histórica $-a$ evolução do gerúndio, ele apresenta cinco pontos de discordância em relação ao gramático português:

1. O gerúndio é popularmente utilizado no Brasil em perífrases e, ao contrário do que diz Julio Moreira, trata-se de um uso clássico registrado em muitos autores portugueses;

${ }^{152}$ Exemplo recolhido em Moreira, 1907:97. 
2. O gerúndio assume em português uma função que já não exercia no latim, a função nominativa em construções do tipo "E o modo com que Deus toma este tempo é não lh'o dando" (Vieira apud Motta, 1914:39);

3. Além das preposições em e sem, em português já se registrou a utilização da preposição com: "Os epigramas vos mando | Que tresladei de Marcial, | Se vos parecem mal, | Desculpae-me “com” calando” (Sá Miranda, Ed. Mich., p. 418 apud Motta, 1914:39);

4. A utilização da preposição $a+$ infinitivo em português é moderna em relação ao uso com o gerúndio: “O nosso caboclo não diria: Eu vi um home a cantá; mas sim: Eu vi um home cantando". Observe-se que antes do gerúndio, essa estrutura era expressa com o particípio presente no latim, Vidi hominem canentem.

5. O gerúndio português não descende apenas do ablativo do gerúndio latino, que não exprimia as circunstâncias de modo e tempo, mas tão somente a idéia de instrumento. A multiplicidade de circunstâncias que veio a ter em português é originária do particípio presente latino.

Se em português o gerúndio perdeu terreno para o infinito em alguns contextos, como o provam alguns exemplos da tradução da Vulgata feita pelo padre Pereira de Figueiredo citados por Motta (1914), em outros o gerúndio veio a assumir as funções do particípio presente. Esse processo se deu de maneira gradual. Ainda no latim o particípio presente começa a migrar para a categoria de meros adjetivos e em seguida para os substantivos. No português arcaico, ainda podemos perceber a vivacidade do particípio presente em algumas construções que posterioremente só poderiam ser expressas pelo gerúndio, como em "Nem hûa causa desfallece 'aos tementes' el'. Othoniel Motta (op. cit, p. 42) lembra em seu texto que o particípio presente "combina todas as funcções de um adjetivo com algumas das funcções de um verbo" e procura mostrar como o gerúndio avançou sobre estas funções:

a) O gerúndio em português passa a assumir a dupla função (adjetiva e adverbial) do particípio presente latino. O próprio padre Pereira de Figueiredo traduz expressões de particípio presente por construções gerundivas: 
(159) “Igitur Josue nocte consurgens movit castra” - “Josué, pois, levantando-se de noite descampou o exercito". 153

(160) “Igitur Josue de nocte consurgente, tulerunt sacerdotes arcam Domini." - "Levantando-se Josué antes do amanhecer...". 154

b) O particípio presente ligava-se como atributo ao verbo ser e a outros "verbos de ligação", é dessa função que o gerúndio herda a capacidade de formar perífrases no português: "veio correndo, appareceu chorando, anda dizendo, ficou cantando, vive sorrindo, etc".

c) O particípio presente expressava circunstâncias e, segundo Othoniel Motta, "esta é a natureza essencial do particípio latino":

"Por meio dos participios junta-se a uma palavra substantiva da clausula principal, em fórma de apposição, a designação de uma acção temporal, passada ou futura, que se refere á acção principal, de sorte que pelos particípios não somente se determina a relação do tempo, mas ainda a especie, a maneira e certas circunstancias da acção principal.

Os participios são por consequencia mui proprios a dar ao discurso brevidade e maleabilidade, sobre tudo porque podem juntar-se não sómente ao sujeito da proposição principal, o que succede mais frequentemente, mas ainda ao regimen directo ou indirecto, ou a outros membros da phrase." (observação de Madwig apensa in Freund traduzida por Theil apud MOTTA, 1914:43) ${ }^{155}$.

Essa pequena lista resume algumas das pistas oferecidas por Motta para explicar como o gerúndio foi tomando o lugar do particípio presente: "Essas primeiras escaramuças feitas pelo gerundio no campo do seu vizinho consaguineo, nem elle proprio suspeitava que fossem o inicio de uma acabada guerra de conquista.” (MOTTA, 1914:41).

A principal crítica de Othoniel Motta a Julio Ribeiro e a Leite de Vasconcellos refere-se ao fato de estes não aceitarem o uso do gerúndio em cláusulas adjetivas, função essa exercida em latim pelo particípio presente. Segundo ele, isso se deu porque "foi esse o ultimo reducto a ser tomado definitivamente pelo gerundio, foi nesse cantinho que o participio presente, embora em constante refrega, ainda conseguiu viver por algum tempo ao lado do gerundio" (Motta, 1914:44). Para fundamentar sua tese, Motta apresenta uma vasta lista de exemplos de gerúndios em cláusulas adjetivas não só entre os autores portugueses do séc. XIX, como Garrett, Camilo e Herculano, como também em textos mais antigos de Camões, Fernão Lopes e Vieira e também em trechos da tradução da Vulgata. E ao final, provoca os mesmos autores:

153 Jos. III, 1 apud Motta (1914:42).

154 Jos. III, 1 apud MOTTA (1914:42).

${ }^{155}$ Provavelmente FREUND, G. (1866). Grand dictionnaire de la langue latine (trad. N. Theil) Paris: Firmin Didot. 
"E se alguma duvida ainda resta aos doutos auctores portuguzes de que essa syntaxe é nossa, muito nossa e muito bella, convido-os a virem ao Brasil.

Lá nos aponta um caboclo, um gaucho de chiripá, espingarda pica-pau, trazendo á cinta um pato sarvage a gotezar sangue.

- Então, seu Jeremias, foi bonito o panazio?

- Foi sim sinhô, seu moço. Eu atirei o pato avuando.

E deixal-o contente com o seu pato; porque enfim, lá diz a sabedoria popular com o seu Jeremias, que 'mais vale um passaro morto doque cem...'

Completem Julio Moreira e Vasconcellos.” (Motta, 1914:47)

Silveira Bueno (1958) é outro gramático que defende o emprego do gerúndio pelo particípio presente: "Por nossa parte somos do entender que há exagero nos rigoristas: podemos encontrar exemplos de tal emprêgo desde os arcaicos, desde os clássicos até os melhores escritores de nossos dias, ajuntando a tudo isto que tal sintaxe já se encontrava no latim” (Bueno, 1958:386). Ao reconhecer a possibilidade de substituição do particípio presente pelo gerúndio, o autor propõe alguns testes para identificar uma e outra função.

O autor considera o gerúndio como forma de particípio presente:

a) O gerúndio na oração adjetiva

(161)Deixa assim de ser um espírito falando (que fala) a espíritos, passa a ser apenas um manipanso terrorizando (que terroriza) supersticiosos. ${ }^{156}$

b) O gerúndio como adjetivo, atributo do sujeito

(162) Saiu como um leão bramindo = que bramia $^{157}$

c) O gerúndio substituível pela forma arcaica

(163) Pérolas imitando $=$ imitantes a côr da aurora ${ }^{158}$

(164) Queimou-se com água fervendo $=$ fervente

E considera como gerúndio:

d) o complemento circunstancial, oração reduzida

(165) Cantando espalharei por tôda parte... ${ }^{159}$

e) quando for substituível pelo infinitivo ${ }^{160}$

(166) Estávamos estudando $=$ a estudar

(167) $\mathrm{O}$ dia amanheceu chovendo $=$ a chover

$\mathrm{Na}$ verdade, Silveira Bueno confunde-se ao conferir ao morfema -ndo rótulos diferentes por conta de seus usos. Ele mistura ao mesmo tempo a forma e a função.

\footnotetext{
${ }^{156}$ Eça de Queiroz, Cartas de Inglaterra, 18 apud Bueno (1958:389).

${ }^{157}$ Exemplo de Bueno (1958:389).

${ }^{158}$ Ibidem, p. 389.

${ }^{159}$ Camões, Lusíadas, I, 2 apud Bueno (1958:389).

${ }^{160}$ Exemplos de Bueno (1958:389).
} 
Bastaria dizer, no entanto, que o gerúndio português, em razão de suas funções sintáticas, não é o mesmo que o gerúndio latino.

Said Ali (1920/1975) foi outro autor que defendeu a tese de que a sintaxe do gerúndio ampliou-se no português. Ele atenta para a "largueza com que no século XIX se usou, como hoje, o gerúndio equivalendo a uma oração adjetiva”. Ele usa como contra-argumento à tese de Júlio Moreira o fato de que também no século XVIII as mesmas formas podiam ser encontradas, tal como nos exemplos retirados da Boêmia do Espírito: ${ }^{161}$

(168)Carta de Lei dando o Régio Beneplácito à Bula Dominus ao Redemptor da extinção dos Jesuítas.

O autor confirma o uso do gerúndio como forma de linguagem recebida dos seiscentistas com base nos exemplos retirados de uma carta de D. Francisco Manuel de Melo, constante da Boêmia do Espírito:

(169) Achar-se-ão na secretaria de V. M. papéis, cartas, e lembranças minhas, prevenindo, lembrando e pedindo a V. M. aquilo que, a meu fraco juízo, parecia mais conveniente às presentes ocorrências.

Para o século XVI, Said Ali apresenta exemplos de gerúndios desdobráveis na sua forma finita com pronomes relativos, provenientes do volume Vida do Arcebispo de Fr. Luís de Sousa:

(170) Acudiam cartas do nosso arcebispo a miúde, escritas com muito calor, e pedindo a Sua Santidade.

(171) Não faltam ali os raios, os trêmulos cometas imitando (2,90); em vão assopra o vento, a vela inchando $(2,22)$.

Tal como os demais autores citados, Said Ali denuncia o emprego do particípio presente com o mesmo valor sintático do gerúndio, no exemplo de Camões:

(172) Atenta a ilha Barem, que o fundo ornado tem das suas perlas ricas, e imitantes a cor da Aurora.

Ainda contra-argumentando com Leite de Vasconcelos, Said Ali (1920/1975:48) diz que "o confronto entre o nosso gerúndio e a forma francesa em ant" não é procedente, referindo-se ao fato de que o gerúndio nas línguas românicas em geral freqüentemente cede o lugar ao particípio presente. O autor lembra que o gérondif francês não se originou unicamente do particípio presente latino. Para Said Ali, Chantant procede tanto de cantantem como de cantando, ou seja, o particípio presente em francês confunde-se com o gerúndio, e lembra que enquanto no período

${ }^{161}$ Exemplos retirados de Said Ali (1975:45-52). 
arcaico o francês exibia a flexão de número, essa distinção podia ser feita, mas quando passou a ser invariável, já no período clássico, a diferença não podia mais ser detectada, "cumprindo então pedir esclarecimentos à sintaxe”. A respeito disso diz Brunot:

"De la sorte, la notion de variabilité du participe commence à s'obscurcir, et on le trouve souvent complètement invariable: si lours et si peu entendant à leurs affaires (Comm.,I, 97, 11). Dès lors, quand le sens n'indique pas impérieusement comme ici qu'on a affaire à un participe, il devient impossible de le distiguer et de remarquer le changement dont nous parlons." (Brunot apud Said Ali, 1920/1975:48-49)

Partindo desses pressupostos, o autor reconhece uma "adaptabilidade" que promovia uma confusão entre o particípio presente com o gerúndio do ablativo, fazendo com que uma das duas formas tendesse a desaparecer, "absorvidas as suas funções pela outra". O autor baseou-se em informações da gramática latina de Schmalz e Stolz (apud Said Ali,1975), na qual se lê que o gerúndio "ocorre freqüentemente, como que em competência ${ }^{162}$ com o particípio do presente e o infinitivo, sendo que em face do gerúndio do ablativo, o qual se acrescenta (a outro termo) como vocábulo invariável, por assim dizer, à guisa de fórmula, muito se retrai o particípio e também o infinitivo" ${ }^{\prime 163}$ (Schmalz e Stolz apud Said Ali, 1920/1975:50).

\section{I.2.3.2.2.1 Gerúndio predicativo}

Duas outras possibilidades de usos do gerúndio descritas por Brandão (1993) correspondem à função adjetiva que essa forma nominal pode exercer em relação a algum nome expresso na oração matriz: o gerúndio predicativo e o gerúndio atributivo. Porém, o próprio autor vê alguma dificuldade em separar a função predicativa da função atributiva em seu critério.

Em sua definição a respeito do gerúndio predicativo, Brandão diz:

"O gerúndio com valor de participio presente póde referir-se ao sujeito ou ao objeto de certos verbos como predicativo dêles, tal qual já se observava em latim (n.os 14, C. 17 e 18). Quando predicativo do sujeito, o gerundio ora se confunde com um adjunto adverbial de modo, ora com uma oração relativa de que, o qual, a qual, os quais, as quais; quando converter-se ou num infinitivo precedido de a (vi um menino CORRENDO ou A CORRER),

\footnotetext{
162 Observar que o termo competência está bem próximo da noção de "formas de gramáticas em competição" de gramaticalização.

163 Provavelmete Said Ali consultou a seguinte obra: Stolz, Friedrich \& Schmalz, Herman (1900). Lateinische Grammatik: Laut- und Formenlehre, Syntax und Stilistik. München: Beck.
} 
ou numa clausula adjetiva (vi uma mulher DANSANDO ou QUE DANSAVA)." (Brandão, 1933:51, grifo meu)

Mais adiante, ele também atribui aos gerúndios uma função atributiva. No entanto, em alguns casos o autor reconhece a dificuldade de interpretá-los como predicativos ou atributivos:

“ás vezes, a função predicativa do gerundio mal se distingue da sua função atributiva. No citado exemplo de Fr. Luis de Sousa: 'Soarão altas vozes pelo refeitorio repetindo apressadamente Credo, Credo,' o gerundio adjetivo repetindo deve-se interpretar antes como atributivo que como predicativo, pois a propria significação do verbo dominante - soaram - e o conjunto da frase impoem esta interpretação como a única natural e conforme á índole da lingua [...] Vimos também que com estar, andar, ir, vir, tomados no sentido pleno, sobretudo $\underline{\text { si os acompanham determinantes adverbiais que frisam e evidenciam tal sentido, o gerundio }}$ predicativo referente ao sujeito dêles á primeira vista se confunde com o gerundio atributivo." (Brandão, 1933:61, grifos meus)

Meus grifos demonstram a mesma confusão que já tinha sido observada acima, quando Brandão faz uma distinção entre relativas explicativas e orações adverbiais sem levar em conta a multiplicidade de interpretações (sintática e semântica) que se pode identificar em algumas construções com gerúndio. Vejamos primeiramente os casos que Brandão considera exclusivamente predicativos, como é o caso do gerúndio predicativo do sujeito e do gerúndio predicativo do objeto direto.

\section{I.2.3.2.2.2 Gerúndio predicativo do sujeito}

Os gerúndios com valor relativo ligados ao sujeito da oração matriz muitas vezes completam o sentido de determinados tipos de verbos expressos na apódose. $\mathrm{Na}$ tradição gramatical, estes verbos foram denominados "transobjetivos", pois além de projetarem um complemento de objeto, projetariam também um complemento de qualidade atribuída a esse objeto - o predicativo, enfim. ${ }^{164}$ Ao preocupar-se com a tipologia dos "verbos dominantes" (ir, vir, entrar, sair, nascer, morrer, viver, estar, seguir, acompanhar, aparecer, ser - arcaico, no sentido de estar sentado, soar, voar etc.), Brandão (1933:51-55) estabelece um critério bastante interessante que pode dar pistas para entender de que forma se dá o escopo da predicação dos gerúndios. Interessante é observar que muitos desses verbos (estar, viver, acompanhar, etc.) atribuem alguma noção de aspecto específica e poderiam formar verdadeiras perífrases, se aparecessem em posição imediatamente anterior ao verbo no gerúndio:

164 Trato destas construções no capítulo no item em que falo sobre o gerúndio em miniorações no capítulo sobre a gramaticalização do gerúndio. 
entre eles e o gerúndio aparecem, no entanto, elementos interpolados, tais como o sujeito compartilhado e locativos:

(173) eis que parece em cima da agoa Sebastião Dias bracejando com huma rodela... e sustentando na outra mão o arcabuz. ${ }^{165}$

(174) Appareceram um homem e uma mulher, conduzindo dois grandes pestes de bronze. ${ }^{166}$

(175) Soarão altas vezes [sic] pelo refeitorio, repetindo apressadamente Credo, Credo... ${ }^{167}$

(176)E á frente destes iam os dois irmãos, levando entre si um mancebo guapamente vestido. ${ }^{168}$

(177) e diante do toiro vinha muita gente, fugindo com grande grita. ${ }^{169}$

(178) Entrará Branca fallando / Com Inez ambas a par / Cantando de quando em quando, / E ás vezes suspirando... ${ }^{170}$

(179) Passando Jesus d'aquelle logar, o seguiram dois cegos, gritando e dizendo. ${ }^{171}$

(180) Alli forom dizer a elrey que a rrainha sija chorando. ${ }^{172}$

(181) em derredor do leito estavam moços pequenos mui fortemente chorando. ${ }^{173}$

(182) elle a acompanhou chorando até o logar onde se havia de entregar. ${ }^{174}$

(183) Nosso divino Mestre Jesus... nasce nu... estalejando com frio, sem abrigo nem bastante agasalhado. ${ }^{175}$

(184) têe o nome de Castello Giraldo, em ho qual elle viuia com hos seus, guardando pazes \& treguas a hos mouros. ${ }^{176}$

(185) voam e revoam por fóra de todas as janellas e frestas coriscos, allumiando aquella noite medonha e repentina. ${ }^{177}$

Podemos observar através dos exemplos acima que o fato de o gerúndio compartilhar o sujeito da oração matriz não pode ser um critério válido para tê-lo como predicativo (predicando um nome da oração matriz). Vários dos exemplos discutidos anteriormente e que são apresentados pelo autor como gerúndios apositivos poderiam ser interpretados também como predicativos do sujeito como defende Brandão. Isso se deve ao fato de que em ambos os casos o gerúndio aparece imediatamente após o nome que é compartilhado com a oração matriz. Assim, a posição sintática em que a construção gerundial ocorre parece ser decisiva para entender o escopo de predicação dos gerúndios nessas sentenças. Parece que a) quanto mais próximo o gerúndio está do sujeito da oração matriz, mais fácil é entendê-lo como predicativo do sujeito e b) quanto mais distante ele está do nome compartilhado com a oração matriz, mais difícil fica essa interpretação, pois nesses

\footnotetext{
${ }^{165}$ Brandão (1933:53-54): Fr. Luis de Souza, Hist. de S. Domingos, III, c. 26.

${ }^{166}$ Ibid., p. 54: Camilo, Martires, I. p. 43.

${ }^{167}$ Ibid., p. 54: Fr. Luis de Souza, His. S. Dom., I, 14.

${ }^{168}$ Ibid., p. 52: Garret, Arco de Sant'Ana, XXV.

${ }^{169}$ Ibid., p. 52: G. Resende, D. João II, LXXVII.

${ }^{170}$ Ibid., p. 52: Gil Vicente, Auto Pastoril Português.

${ }^{171}$ Ibid., p. 53: Pe. Pereira de Figueiredo, S. Mat. IX, 27 Cf. o texto da Vulgata: secuti sunt eum duo caeci, clamantes et dicentes.

172 Ibid., p. 53: Crest. Arc. 28.

173 Ibid., p. 53: Crest. Arc., p. 149.

${ }^{174}$ Ibid., p. 53: Vieira, Sermões, IV, 288. Cf. o texto latino: sequebaturque eam vir suus, plorans usque Bahurin. Reis, L.o II, III, 15 e 16.

${ }^{175}$ Ibid., p. 53: Fr. Tomé de Jesus, Trabalhos, VI.

${ }^{176}$ Ibid., p. 53: André de Resende, Hist. de Evora.

${ }^{177}$ Ibid., p. 54: Castilho, Q. Hist. II, 17.
} 
casos ele parece ressaltar o valor adverbial inerente à tal duplicidade de funções (adjetiva e adverbial ao mesmo tempo). Sendo assim, para os gerúndios ligados ao sujeito da oração matriz, poderíamos pensar em uma categoria realmente ambígua (fuzzy) em que o gerúndio simultaneamente tanto pode "apontar" para o verbo da oração matriz como para o sujeito da mesma, ora ressaltando-se mais o seu caráter adjetivo, quando mais próximo do nome, ora o seu caráter adverbial, quando mais distante do nome que empresta como sujeito. ${ }^{178}$

Talvez esse raciocínio possa ser discutido, pois quem sabe ele não se aplique quando o tipo do verbo exigir uma reordenação dos complementos, como é o caso dos verbos ergativos em (173) e (174), em que o sujeito naturalmente aparece posposto ao verbo em português, ou mesmo os exemplos de (176) a (179) que também podem ser considerados ergativos. Mas isso não impede que mesmo nesses casos se defenda a idéia de que o gerúndio tanto predica o verbo como o sujeito da oração matriz.

Além dos verbos acima enumerados, Brandão reconhece outros empregos exemplos de gerúndios ligados ao SN sujeito, como é o caso das construções que acompanham a sentença matriz que contém verbos na voz passiva (pronominal e perifrástica) e verbos reflexivos:

(186) Se aqui se suppõe o pobre pedindo esmola, como se trata do rico pagando-lhe a divida. ${ }^{179}$

(187) nos quaes lugares são achadas (as eguas marinhas) pelos cafres muitas vezes parindo. ${ }^{180}$

(188) sobre aquelle ramo... se véo pôr um roussinol, docemente cantando. ${ }^{181}$

Para Brandão, o gerúndio predicativo também pode estar ligado a um SN que encabeça uma construção nominalizada, que ocorre tipicamente nas indicações de cena, tanto em romances como em peças teatrais:

(189) Fausto, entrando pela porta do fundo, que deixa aberta, seguido de um grande cão d'água preto... (voltando-se para o cão)... ${ }^{182}$

Enfim, até aqui o que se pode dizer da contribuição de Brandão é que a natureza dos verbos da oração matriz deve ser levada em conta na descrição das orações gerundivas. É preciso, no entanto, levar outros elementos em consideração,

\footnotetext{
${ }^{178}$ Retomo esta questão na proposta de reorganização dos gerúndios no português.

${ }^{179}$ Brandão (1933:54): Bern., N. Fl. VI, 387.

${ }^{180}$ Ibid., p. 54: Fr. João dos Santos, Ethiopia Oriental, II, 3.

${ }^{181}$ Ibid., p. 54: Bernardim, Men. e Moça, II.

${ }^{182}$ Ibid., p. 55: Castilho, Fausto, Quatro IV, cena I.
} 
tal como a posição da gerundiva em relação ao nome que toma como sujeito e, eventualmente, a relação de tempo que estabelece entre uma e outra orações.

\section{I.2.3.2.2.3 Gerúndio predicativo do objeto direto}

Brandão (1933) também enumera em seu trabalho vários exemplos de orações gerundiais acompanhando verbos perceptivos. São recorrentes as construções gerundiais que acompanham os verbos ver, contemplar, olhar, ouvir, pintar, representar, introduzir, cantar, figurar, por, supor, imaginar, lembrar, dar, ter e considerar.

Vejamos alguns exemplos da exaustiva coleta empreendida por Brandão:

(190) viio em sonhos Jesus Christo... chamando todos a Juizo. ${ }^{183}$

(191) contemplava creanças lividas de fome, andrajosas, tremulas de frio, vergastadas pela chuva e pelo norte expiando sem culpa a vida crapulosa dos pais, ou compartilhando a miseria delles. ${ }^{184}$

(192) Olhem o covarde lançando-se a fugir antes de começar a batalha. ${ }^{185}$

(193) Ouvi, no poema de Job, a voz do Senhor, perguntando a seu servo onde estava quando o louvavam as estrellas da manhã. ${ }^{186}$

(194) e acham aos sobreditos senhores fazendo listas para a côrte, escrevendo cartas, arrumando negocios de mil pretendentes. ${ }^{187}$

(195) Silio Italico pinta a um famoso capitão, deleitando-se com um presente de armas que lhe offereceram. ${ }^{188}$

(196) fechando a caixa, cuja tampa representava uma Venus saindo nua das aguas. ${ }^{189}$

(197) O artifice... representa os hellenos derivando de Creta. ${ }^{190}$

(198) cantou ... o velho Laertes, mondando o seu jardim e chorando. ${ }^{191}$

(199) já se imaginam dando alcance á graça que tão alto alto lhes vôou sempre. ${ }^{192}$

(200) lembrei-lhe o justo, o filho de Deus, coberto de alfrontas, perdoando na cruz aos seus perseguidores. ${ }^{193}$

(201) O erudito e mais moderno biographo e editor do insigne epico... dá-o concluindo os seus estudos em 1542 e regressando á capital nesse mesmo anno ou no seguinte. ${ }^{194}$

(202) Duas vezes dei por mim mordendo os dentes. ${ }^{195}$

(203) Para andar no favor e na memoria dos potentados é preciso ter sempre fumegando o thuribulo da cortezã lisonjaria. ${ }^{196}$

(204) Consideremos tres Sacerdotes celebrando Missa. ${ }^{197}$

${ }^{183}$ Ibid., p. 55: Cron. dos Frades Menores, I, 40.

${ }^{184}$ Ibid., p. 56: Camilo, Vulcões de lama, VI, p. 127.

${ }^{185}$ Ibid., p. 56: Bern., N. Flor. II, 88.

${ }^{186}$ Ibid., p. 56: Ruy Barbosa, Oração aos Moços.

${ }^{187}$ Ibid., p. 56: Arte de furtar, XXXVII.

${ }^{188}$ Ibid., p. 57: Bern., N. Flor., I, 394.

${ }^{189}$ Ibid., p. 57: Rabello da Silva, Mocidade de D. João V, I, p. 74.

${ }^{190}$ Ibid., p. 57: L. Coelho, A Oração da Corôa, p. L.

${ }^{191}$ Ibid., p. 57: Camilo, Os Martires, I. 51.

${ }^{192}$ Ibid., p. 58: Arte de Furtar, XXXVII.

${ }^{193}$ Ibid., p. 58: Herc., Monge de Cister, c. II p. 31.

${ }^{194}$ Ibid., p. 58: L. Coelho, Luis de Camões, c. III.

195 Ibid., p. 58: Machado de Assis, D. Casmurro, LXXV.

${ }^{196}$ Ibid., p. 58: L. Coelho, L de Camões, c. XV. 
A par destas ocorrências, Brandão também enumera alguns verbos que mereceriam uma interpretação mais cuidadosa como é o caso de trazer, deixar, achar e encontrar:

(205) vierão dar com elles tres Cavalheiros, que trazião outro mal ferido gemendo em hum palafrem. ${ }^{198}$

(206) D. Jorge deixa-a dando aos hombros e murmurando. ${ }^{199}$

(207) Encontrei o homem chorando. ${ }^{200}$

\section{I.2.3.2.2.4 Gerúndio atributivo}

Para Brandão (1933:66), deve-se considerar o gerúndio como atributivo quando ele exibe as seguintes propriedades:

- modifica "nome ou pronome que sejam complementos preposicionados" - p. ex. (94?) e (95?);

- refere-se a nomes ou pronomes sujeitos ou predicativos dos verbos ser e parecer, ex. (96?) e (97?);

- relaciona-se com nomes ou pronomes precedidos de como, qual, que ou do que nas orações comparativas, ex. (98?);

- refere-se aos complementos ligados aos verbos haver, existir e faltar e seus sinônimos, ex. (99?) e (100?);

- limita a significação de um substantivo ou pronome, "acrescentando-lhe uma qualidade, um modo de ser, uma atividades transeuntes”, ex. (101?);

- indica "uma propriedade ou uma atividade ainda mesmo duradouras ou permanentes que pertençam a certo ser", ex. (102?);

- modifica “nomes tomados em sentido indefinido ou geral”, ex. (103?);

- $\quad$ aparece depois de alguns pronomes indefinidos como um... outro, ex. (104?).

${ }^{197}$ Ibid., p. 58: Bernardes, Luz e Calor, V parte, doutr. I.

${ }^{198}$ Ibid., p. 57: Barros, Clarim., I, 26.

${ }^{199}$ Ibid., p. 57: Camilo, O Senhor do Paço de Ninães, p. 89.

${ }^{200}$ Exemplo criado por Brandão (1933:59). 
Segundo Brandão (1933:62), o gerúndio atributivo expressa a idéia de tempo transitório e atribui a um nome ou pronome um modo de ser, uma qualidade, uma atividade, "mas apenas dentro de certo periodo e em determinada situação". Essa definição não permite uma distinção clara em relação ao gerúndio predicativo acima descrito. Por isso, é hora de examinar alguns dos exemplos recolhidos da farta lista de 16 páginas oferecida por Brandão, nos quais os gerúndios são reconhecidos por ele como atributivos:

(208) Combremse os baluartes de fumosas / Espessas, negras nuvens, atroando / Os ares, e altos Ceos com trovões falsos. ${ }^{201}$

(209) aquella arma irresistivel deixava, ao passar, uma larga cauda de cadaveres entretecida de moribundos debatendo-se em terra. ${ }^{202}$

(210) Porém o Santo Profeta, cuja língua era uma facha ardendo, lhe respondeu. ${ }^{203}$

(211) Não era a jerarchia constituindo uma especie de familias militares, de clans... Em vez disto, era o individualismo rebellando-se contra esse poder. ${ }^{204}$

(212) como a cruz de uma divindade sepultada, annunciando aos deicidas o castigo e a resurreição. ${ }^{205}$

(213) Não faltam ali os rayos de artificio, / Os tremulos Cometas imitando. ${ }^{206}$

(214)Devia haver dentro em casa preparadas grandes cadeiras ao fogo, muitos ministros rolando o material, e batendo-o com desmedidos molinilhos. ${ }^{207}$

(215) A terra abrazada e ardendo abrirá mil boccas. ${ }^{208}$

(216)Acudião cartas do nosso Arcebispo a miude escritas com muito calor, e pedindo a Sua Santidade declarasse a preminencia conhecida da Igreja de Braga. ${ }^{209}$

(217)á sua Corte chegou huma Dona cuberta de luto, pedindo-lhe que lhe desse hum Cavaleiro pera se combater com outro. ${ }^{210}$

(218)Avia juntas mais de cem molheres todas occupadas em officios mais proprios a sua natureza, hûas lavrando em suas almofadas, outras cozendo, outras fiando, outras tecendo panos, fitas, passamanes, outras fazendo botões, \& cousas a este modo. ${ }^{211}$

Em princípio, são detectáveis duas diferenças em relação aos exemplos dos predicativos descritos anteriormente: a) os verbos da orações "dominantes" são de natureza distinta e b) os gerúndios a que Brandão chama de atributivos em sua totalidade aparecem imediatamente após o substantivo que é compartilhado com a oração matriz. Mas este último também não parece ser um critério suficiente para estabelecer a distinção proposta por esse autor, já que mesmo entre os que chama de predicativos do sujeito ele apresenta exemplos de gerúndios pospostos imediatamente a um nome da oração matriz. Cabe lembrar que cada uma das orações acima é parafraseável por uma oração relativa restritiva (sem a dita pausa que as

\footnotetext{
${ }^{201}$ Brandão (1933: 66): Côrte Real, Segundo Cêrco de Diu, e. IV.

${ }^{202}$ Ibid., p. 69: Herc., Eurico, p. 104.

${ }^{203}$ Ibid., p. 72-73: Luz e Calor, I parte, doutr. IV.

${ }^{204}$ Ibid., p. 73: Herculano, O Bobo, p. 8.

205 Ibid., p. 75: Ruy Barbosa, Discurso no Instituto dos Advogados Brasileiros, em 18-maio-1911.

${ }^{206}$ Ibid., p. 75: Lus., II, 90.

${ }^{207}$ Ibid., p. 75: Bernardes, N. Flor., I, 18.

${ }^{208}$ Ibid., p. 76: Vieira, Sermões, VIII, p. 18.

${ }^{209}$ Ibid., p. 78: Fr. Luiz de Souza, Arceb.; L. V. C. 13, p. 221 do 2.0 vol.

${ }^{210}$ Ibid., p. 81: João de Barros, Clarimundo, L. I, c. 26.

${ }^{211}$ Ibid., p. 81-82: Frei Luis de Sousa, Arcebispo, L. II. c.6.
} 
distingue das explicativas). Vou procurar enumerar agora algumas pistas para tentar entender o motivo de Brandão ter dissociado os gerúndios predicativos dos gerúndios atributivos.

Ao contrário do que fez para os primeiros e para os gerúndios apositivos, nesta seção, ao longo de seis páginas de seu estudo, o autor apresenta alguns argumentos de caráter tanto sintático, como semântico e até mesmo pragmático dos gerúndios que exercem a função "atributiva".

O autor contrapõe alguns casos em que o gerúndio, ligado a um nome, pode ser interpretado como uma sorte de anacoluto. Em "O frio está cortando", "O sol está escaldando" ou "O homem ficou tremendo", segundo ele, os gerúndios não compõem perífrases, ao contrário, "são verdadeiras predicações de frio, sol $e$ homem" (Brandão, 1933:61), daí ser possível considerar gramaticalmente corretas as construções como "Um sol escaldando como esse não póde fazer bem” - vale lembrar que gerúndios em construções como essa sempre foram condenados pela tradição gramatical -, e então, ele observa:

"Construções dêste feitio ouvimo-las a cada passo no linguajar do povo, e assim é de inferir não repugna a português usar, em certos casos, o gerundio com fôrça de verdadeiro adjetivo. Nem se alegue ser tal uso uma infiltração do francês, pois êle vive no seio da multidão indouta,m circula na conversação familiar, brota espontaneo da bôca dos meninos ainda sem letras e aparece até no dialéto caipira, nos rincões sertanejos, tão apartads dos meios cultos, e portanto, quase nada sujeitos a influências alienigenas. E fosse embora um modismo importado do francês, não descubro razões para rejeitá-lo, uma vez que êle se arraigou, com vitalidade, no falar comum, tornando-se um recurso valioso de comunicação ideologica. É fenomeno necessario e incoibivel, em todos os terrenos lingüísticos, a interpenetração de idiomas falados por povos em contacto, fenomeno observavel em todas as fases da historia e em todos os territorios geográficos abertos ao caldeamento glótico. Tenho por demasia de zêlo purista condenarem alguns dos nossos filólogos de maior vulto o uso do gerundio atributivo. É verdade ser êle raro na lingua clássica, mórmente antes do século XVII, mas não é alheio dela. Fato emelhante [sic] já se nota no latim com o participio presente." (Brandão, 1993:61-62)

As considerações acima revelam um espírito investigativo digno de nota, ao apresentar argumentos de ordem sociolingüística que, àquela altura, ainda não haviam sido desenvolvidos. Ao fazer isso, critica a posição tradicionalista de Julio Moreira, Leite de Vasconcelos, Epiphanio Dias e Mário Barreto ${ }^{212}$. A estes comentários relacionados com as questões da norma lingüística ele agrega outras observações que julgo bem importantes:

212 Suponho que sejam estes os estudos citados por Brandão, verificando sua bibliografia: Julio Moreira (1913 e 1922), Leite de Vasconcelos (1911 e 1926), Epifanio Dias (1918) e Mário Barreto (1916 e 1921). 


\begin{abstract}
"Não vejo em que tachar frases como as seguintes: 'Recebi uma carta de F. comunicando-me tal cousa', 'O governo baixou um decreto regulando tal assunto'. São construções trilhadas na loquela do vulgo e já sancionadas pelos mais respeitaveis escritores modernos. Tambem aqui tem cabal aplicação o 'si volet usus' de Horácio: o uso, sabemo-lo á farta, é soberano, e quando impõe um modismo ou um vocábulo expressivos e vitais, é fragilissima contra êle a resistencia dos gramáticos e dos doutos, que são a minoria. A atuação dêstes é, sem dúvida, necessária como agente de depuração e de conservação dos idiomas cultos; mas tornar-se-á inoperante, sinão ridicula, quando pretender impôr á lingua canones inflexiveis e fórmas petrificadas, desconhecendo-lhe, assim, o característico mais frisante: a sua mobilidade contínua e incoercivel. Esta observação tem todo o cabimento no caso do gerundio atributivo. O povo o adotou, e os literatos, sentindo-lhes o poder significante, capaz de traduzir estados, aspectos, atividades para as quais não há, muitas vezes, adjetivos proprios, não o quiseram banir do discurso terso só por parecer uma bastardia gramatical.” (Brandão, 1993:62-63)
\end{abstract}

Neste trecho, novamente o autor reconhece o caráter inovador que se dá nas línguas, e como que antevê alguns princípios de uma teoria da mudança lingüística, quando fala da "mobilidade contínua e incoercivel" da língua e ao perceber que esse uso que chama de atributivo "muito ao revés de uma degenerecencia, é antes um progresso e uma conquista do português moderno.” (op. cit., p. 63-64). Brandão apóia-se nas observações de outros gramáticos que admitiam "explicita ou implicitamente, a vernaculidade do gerundio atributivo” (op. cit., p. 64), tais como Othoniel Motta, Eduardo Carlos Pereira, Said Ali, A. A. Cortesão, Antonio Garcia R. de Vasconcelos, Antenor Nascentes, Carlos Gois e Augusto Magne ${ }^{213}$. E compara com as observações feitas também para o espanhol por Lenz (1920), o qual reconhece que o gerúndio em lugar de um particípio presente, expressa a ação verbal referida a um substantivo sujeito, "sin tener em cuenta la función que éste tiene dentro de la proposición, y sin distinguir entre la acciôn transitória y la duradera" (Cf. Lenz, 1920:392 apud Brandão, 1933:64). Além disso, ele observa no gerúndio atributivo um valor de epiteto ou qualificativo (Cf. João Ribeiro apud Brandão, op. cit., p. 64).

Através da coletânea de exemplos apresentada, aliada aos argumentos de ordem pragmática e ao elenco de propriedades apontadas no início desta seção, podese deduzir que Brandão defende que se deve reconhecer a gramaticalidade de gerúndios ligados a algum nome da oração matriz, não só quando este exercer a função de sujeito ou objeto direto, e sim, também quando este nome desempenhar outras funções sintáticas além destas, sejam elas a de exercer o papel de complementos preposicionados (objeto indireto, objeto oblíquo ou adjuntos),

213 A exemplo do que fez Brandão, cito apenas os nomes, sem precisar o estudo específico a que recorreu. Cotejando a bibliografia do autor podemos identificar as datas: Othoniel Motta (1929), Eduardo Carlos Pereira (1907, 1909 e 1926), Said Ali (1920), A. A. Cortesão (1907), Antonio Garcia R. de Vasconcelos (1899), Antenor Nascentes (1928), Carlos Gois (1918) e Augusto Magne (1931). 
complementos de verbos ergativos e existenciais ou como complementos equativos em sentenças apresentacionais.

Para os exemplos de gerúndios apositivos que Brandão apresenta ligados a verbos ergativos (aparecer, nascer, morrer, etc.) e para os casos em que o gerúndio aparece ligado a verbos existenciais (haver, existir, faltar), que ele abriga entre os gerúndios atributivos, talvez o traço normativo tenha sido economizado justamente porque a tradição gramatical reconhecia como objeto direto os complementos que hoje são tratados como absolutivo. Por este raciocínio, se era objeto direto, podia então receber um gerúndio como predicativo.

\section{I.2.3.2.2.5 Considerações finais sobre o gerúndio adjetivo}

A discussão a respeito do gerúndio adjetivo já foi apresentada exaustivamente nas seções anteriores. Basta dizer aqui que Odette Campos remete-se a ela e, exatamente por apresentar um estudo descritivo, aceita todas as possibilidades do gerúndio adjetivo ligado a um nome da oração principal em qualquer função, quer seja ela a de sujeito, objeto direto ou outros complementos regidos de preposição. Nesses casos, segundo a autora, o gerúndio indica sempre qualidade transitória. Porém, acrescenta ainda alguns dados a respeito de usos que não teriam sido discutidos anteriormente, como é o caso dos gerúndios adjetivos que exprimem uma qualidade permanente, típico de nominalizações seguindo títulos ou leis e corriqueiro também na linguagem administrativa, como o mostram os exemplos:

(219) Dedé - "ABC da Mulata Esmeralda", romance completo contendo tôda a vida de Esmeralda desde o nascimento... ${ }^{214}$

(220) A 15 de maio foi publicado o decreto n.o 217 do Marechal Deodoro da Fonseca então presidente da República, autorizando a companhia a funcionar nos termos de seu estatudo... ${ }^{215}$

Em oposição ao período arcaico, quando são raros os gerúndios adjetivos no corpus de Odette Campos, no período que se estende do séc. XVI ao final do séc. XIX, a autora observa um emprego mais rico dos gerúndios adjetivos referindo-se ao sujeito, ao objeto direto ou a outros complementos precedidos de preposições. Nota ainda que aumenta o uso de gerúndios com verbos perceptivos e a partir do século XIX é que ampliam-se os usos do gerúndio adjetivo aliado a verbos de natureza

${ }^{214}$ Campos (1972:48): DG, PP, ato II, cena II, 89.

${ }^{215}$ Ibidem, p. 48: JB, 1.o, 2. 
distinta, anteriormente muito pouco registrado, e aumentando principalmente o uso do gerúndio adjetivo que exprime qualidades permanentes. Campos atribui a essa diversidade a razão para o surgimento de tanta discussão em torno do gerúndio em função relativa.

Campos oferece alguns exemplos para cada uma dessas novas modalidades que se desenvolveram no período mais recente do português e que à exceção dos que acompanha verbos perceptivos, podem indicar, dependendo do contexto, tanto uma ação transitória como uma qualidade permanente:

1) referindo-se ao sujeito da oração principal

(221) A água fria, batendo no estômago limpo, deu-lhe pancada dolorosa. ${ }^{216}$

2) referindo-se ao objeto direto da oração principal

a) com verbos de percepção, indicando somente uma ação transitória (222) Sentiu a cara ardendo e um engasgo angustioso na garganta. ${ }^{217}$

b) com verbos que significam pensar (= imaginar), imaginar, conceber $\mathrm{e}$ lembrar-se

(223) Geraldo imagina urubus farejando carniça. ${ }^{218}$

c) com o verbo ter possessivo

(224)E doía-lhe a cabeça tôda, parecia-lhe que tinha fogo por dentro, parecia-lhe que tinha nos miolos uma panela fervendo. ${ }^{219}$

d) com ter e haver existenciais

(225) Ah, sim... agora percebo... É uma cruz de madeira... e parece que há um homem dormindo junto dela. $^{220}$

e) com outros verbos de natureza distinta

(226)... há cerca de dois dias recebeu uma carta denunciando que... DA, 10, apud Campos, 1972:149.

(227) $\mathrm{O}$ governador do Estado promulgou leis legislativas concedendo as seguintes pensões especiais... $^{221}$

${ }^{216}$ Ibid. p. 145:RQ, Q, IX, 37.

${ }^{217}$ Ibid., p. 147: RQ, Q, IX, 38.

${ }^{218}$ Ibid., p. 147: VM, RIR, III, 42.

${ }^{219}$ Ibid., p. 148: GR, VS, 41.

${ }^{220}$ Ibid., p. 148: DG, PP, ato I, cena II, 36.

${ }^{221}$ Ibid., p. 149: CP, 6. 
Entre os verbos aos quais Campos prefere não atribuir nenhuma categoria, destacamos o verbo deixar já apontado por Brandão (1933) o qual mereceria, talvez, um estudo mais cuidadoso:

(228) Vai, vai dormir em paz, seu Tico Reunião. Deixa essa pobre gente curtindo a camueca dêles sossegados. ${ }^{222}$

3) Referindo-se a outros complementos da oração

a) ligado ao objeto indireto ou a outro complemento preposicionado

(229) O João Marreca olhou para o animal que todo se pontilhava de verrugas pretas, escaroçando-lhe o úbere, as pernas, o corpo inteiro... ${ }^{223}$

(230) Por falar neste: havia uma tradução portuguesa naquela coleção romântica com uma moça na capa, lendo um livro à luz do lampião, lembra-se? ? $^{224}$

b) ligado ao predicativo do sujeito

(231) “A integração da Amazonia" foi a principal tese, constituindo-se praticamente na tônica do Sétimo Congresso Nacional de Municípios. ${ }^{225}$

c) em casos especiais de construções absolutas nos quais o gerúndio vem junto a um nome precedido pela preposição com ou de, indicando na maioria das vezes um valor modal e eventualmente causal, como mostram respectivamente os seguintes exemplos

(232) Correu à botica uma negrinha, que voltou de mãos abanando. ${ }^{226}$

(233) Meu caro, com o custo de vida aumentando dia a dia, a gente tem que se virar. ${ }^{227}$

Assim como mostrou Müller-Lancé a respeito da estrutura sintática das construções absolutas do francês, Campos exemplica casos em que a preposição com pode ser depreendida do contexto:

(234)Ela disse, interrogando, a voz caindo... ${ }^{228}$

Ao final dessa exemplificação, Campos lembra que o gerúndio adjetivo no português moderno pode indicar tanto ações transitórias como qualidades permanentes. Apesar disso, esta última possibilidade é pouco atestada em termos numéricos, sendo os gerúndios que expressam ações transitórias mais freqüente (62/80) em comparação àqueles que designam qualidades permanentes (18/80).

\footnotetext{
${ }^{222}$ Ibid., p. 149: AC, FEC, ato I, 69.

${ }^{223}$ Ibid., p. 150: RQ, Q, II, 6.

${ }^{224}$ Ibid., p. 150: ML, GG, vol. I, 245.

${ }^{225}$ Ibid., p. 150: CP, 20.

${ }^{226}$ Ibid., p. 152: ML, CM, 245.

${ }^{227}$ Ibid., p. 151: DG, PP, ato I, cena I, 28.

${ }^{228}$ Ibid., p. 152: AF, AC in CR, I, 16.
} 


\section{I.2.3.2.3 Gerúndio apositivo}

Brandão assim define o gerúndio apositivo:

"Nêste emprego, o gerundio, referindo-se ao sujeito do verbo regente, faz o papel de uma clausula adjetiva explicativa, de uma clausula adverbial, de um adjetivo aposto, de um adverbio ou locução adverbial. O aposto, como bem o caracterizam Hale e Buck (Lat. Gr., § 317), é uma palavra frouxamente ligada a outra para mostrar esta sob aspecto especial." (Brandão,1993:36)

Pelo que se vê através dessa definição, Brandão defende um duplo escopo de predicação dos verbos no gerúndio. Por um lado, quando o autor diz que as orações com o verbo no gerúndio em aposição adverbial podem encerrar "uma clausula adverbial”, "um adverbio ou locução adverbial”, ele se refere ao gerúndio predicando o verbo ou o escopo da oração matriz. Por outro lado, quando reconhece no gerúndio em aposição relativa "o papel de uma clausula adjetiva explicativa" ou de "um adjetivo aposto", ele se refere ao gerúndio que pode predicar um nome, exercendo portanto a função de um adjetivo:

(235) Contão que certa raposa, | Andando (=, que andava) muito esfaimada, | Viu roxos, maduros cachos | Pendentes de alta latada. ${ }^{22}$

(236) e enxergava o vulto negro das águas balouçando-se (=, que se balouçavam) no abysmo que o Senhor lhes deu por morada. ${ }^{230}$

Parece que o critério adotado por Brandão para reconhecer os exemplos acima como relativas é o fato de os gerúndios estarem presos imediatamente aos nomes raposa e águas. A razão para ter entendido estas orações como relativas com gerúndio apositivo deve estar associada à idéia de que nelas "el gerundio enuncia uma acción secundaria del sujeto, com la cual desenvuelve, explica la acción principal” (Cf. Gilli y Gaya, 1960:174 apud Reese, 1991:22). Se "desenvolve" a ação principal, então aí está expressa uma sequiência de atos, o que permite estabelecer a circunstância de tempo para esse tipo de relativas. Nessas sentenças complexas, portanto, pode haver uma relação de simultaneidade, de anterioridade ou de posterioridade entre a oração matriz e a sua dependente. Além do mais, os dois exemplos acima podem ser concomitamente lidos como relativas e adverbiais, prova disso é o fato de podermos adotar para ambas a paráfrase sugerida por Brandão também com a conjunção quando. Conseqüentemente, muitos dos exemplos de orações com gerúndio apositivo indicando tempo apresentados por Brandão também podem ser lidos como casos de orações relativas explicativas:

\footnotetext{
${ }^{229}$ Brandão (1933:37): Bocage, I, 11.

${ }^{230}$ Ibidem, p. 37: Herc., Eur. 28.
} 
(237) tempo simultâneo: Quando na Cruz o Filho de Maria, | Amostrando-se a Affonso o animaua; | Elle adorando quem lhe aparecia, | Na Fê todo inflamado assi gritaua. ${ }^{231}$

(238) tempo anterior: O sacerdote tendo tomado no seu dedo do sangue, tocará com elle os cornos do altar. $^{232}$

(239) tempo posterior: Não levantou mão o Arcebispo da visitação correndo (= e assim correu) todas as Igrejas da cidade, \& visitando todo genero \& estado de gente... ${ }^{233}$

A sua minuciosa exemplificação faz saltar aos olhos o fato de que a relação de tempo parece ser uma circunstância de base que se associa aos gerúndios, pois, mesmo verificando a valor de simultaneidade, anterioridade ou posterioridade apontados por ele como categorias à parte das acima descritas, alguma outra relação proposicional pode ser agregada a estas orações. ${ }^{234}$ Evanildo Bechara (2002) aponta o seguinte:

"A oração adjetiva não assume apenas sentido qualificativo, mas pode ainda exprimir uma relação de fim, condição, causa, consequiência, concessão ou adversativa (...). Às vezes não se traçam limites rigorosos para mais de uma intepretação" Bechara (2002:129)

Tal possibilidade no português é, como ensina Othoniel Motta (1914:41), herança do particípio presente:

"Se o gerundio matou no portuguez o participio presente, não foi pelo simples gosto de o matar: nem tão sanguinario era elle. Matou para viver; matou para lhe tomar as attribuições. Ou melhor: - visto que o gerundio lhe usurpou as funcções, o participio foi morrendo de inanição aos bocadinhos.

E o gerundio, herdeiro de um rico despojo que eram as 'circunstancias' expressas pelo participio (...), apresentou-se em scena bizarro, ricamente arreado e magnificamente "viavel"

Brandão parece ter notado essa multiplicidade de sentidos, mas como ficou exposto acima, ele distingue na categoria de aposição a relação adjetiva da adverbial, sem levar em conta a concomitância dessas funções e para os casos de gerúndio em aposição adverbial, Brandão verifica as mesmas possibilidades já apontadas para as outras línguas românicas, tais como tempo (simultâneo, anterior e posterior), meio, modo, fim, causa, condição, conseqüência, concessão, extensão e exclusão (com a preposição sem, até o séc. XV):

(240) tempo simultâneo: E sorrindo [= enquanto sorria] com bondade por entre as lagrimas mal enxutas, D. Catharina deu-lhe um beijo. ${ }^{235}$

(241) tempo anterior: Logo que cada hum dos Deoses se partio, / Fazendo [= depois que fez] seus reaes acatamentos. ${ }^{236}$

${ }^{231}$ Ibid., p. 37: Lus., I, 19.

${ }^{232}$ Ibid., p. 39: Padre Pereira Figueiredo, Bíblia, Levítico, IV, 30.

${ }^{233}$ Ibid., p. 40: Fr. Luis de Souza, Arc. III, 4.o.

${ }^{234}$ Em seu trabalho sobre as orações reduzidas de gerúndio do português brasileiro, Maria Luiza Braga (2002) também reconheceu a dificuldade de se estabelecer critérios claros para a definição das relações proposicionais e optou por reconhecer em construções desse tipo o matiz modo-temporal.

${ }^{235}$ Ibid., p. 37: Rebelo da Silva, Mocidade de D. João V, I, 45.

${ }^{236}$ Ibid., p. 38: Lus. I, 41. 
(242) tempo posterior (com valor coordenativo): Entonce lhe beijou a mão, dizendo ( $=e$ disse $)$ que lhe tinha em mercê aquela espada. ${ }^{237}$

(243) meio: é de saber como lhe (á rainha D. Felipe) Nosso Senhor quis dar conhecimento do verdadeiro amor, mostrando-lhe (= com mostrar-lhe) a escuridade da presente vida. ${ }^{238}$

(244) fim: logo alguns senhores do conselho escreveram a el-rei D. Fernando, fazendo-lhe (= para fazer-lhe) saber todo o feito. ${ }^{239}$

(245) causa: alvoroçaram-se as gentes da cidade, sabendo (= porque souberam) que el-rei de Castella se vinha chegando. ${ }^{240}$

(246) condição: Da pouca gente o fraco peito humano / Não teve resistencia, \& se a tiuera / Mais dãno resistindo (= si resistisse) recebera. ${ }^{241}$

(247) conseqüência: os affectos da alma, se são extremamente intensos, atam-se pela vizinhança ao corpo, chegando o corpo (= de modo que chega o corpo) a padecer por enfermidade o que a alma padece por sentimento. ${ }^{242}$

(248) concessão: Mas inda que prazeres semelhantes ] Na morte acabão começando em vida (= conquanto comecem em vida). ${ }^{243}$

(249) extensão: Quanta cegueira a perversidade do coração humano, que assim se deixa enredar e seduzir pelo demonio, entrando (= a ponto de entrar) de parceria com seu inimigo declarado! $!^{244}$

(250) exclusão: Essemelhante he em filharem sandia delleitaçom em algûas cousas com pecado sem sperando boa nem uirtuosa fim. ${ }^{245}$

Assim como no exemplo de causa, há várias outras ocorrências citadas por Brandão que podem ser lidas tanto como relativas bem como adverbiais, dado o fato de que nelas os gerúndios aparecem imediatamente pospostos ao nome expresso na oração matriz que tomam por sujeito. Aqui vale retomar a lição de Otoniel Motta a respeito da dupla função que o gerúndio pode exercer, herdada do particípio presente latino, que “combina 'todas' as funcções de um adjetivo com 'algumas' das funcções de um verbo" (Allen e Greenough, 1903 apud Motta, 1914:42) ${ }^{246}$.

Além disso, a relação de modo também tem criado bastantes dificuldades para aqueles que procuram identificar a circunstância específica que se possa atribuir a determinas construções com gerúndio. As duas ocorrências apontadas por Brandão como exemplos de orações de modo revelam essa problemática:

(251) modo: O capitão, olhando de revez, resmungou uma satisfação ao abade. ${ }^{247}$

(252) modo: o ceu se abria fuzilando sobre a terra de uma parte e d'outra. ${ }^{248}$

É certo que nas duas ocorrências o verbo no gerúndio compartilha o mesmo sujeito com a oração matriz. No entanto, essa propriedade se apresenta de maneira

${ }^{237}$ Ibid., p. 40: Zurara, D. João I, XLI.

${ }^{238}$ Ibid., p. 41: Zurara, D. João I, 39.

${ }^{239}$ Ibid., p. 42: Zurara, D. João I, XXXII.

${ }^{240}$ Ibid., p. 44: Fernão Lopes, D. João I, XXVII.

${ }^{241}$ Ibid., p. 44: Lus., II, 69.

${ }^{242}$ Ibid., p. 44: Viera, Serm. VIII, 38.

${ }^{243}$ Ibid., p. 44-45: Quebedo, Aff. Afr. IV, 74.

${ }^{244}$ Ibid., p. 45: N. Flor., III, 76.

${ }^{245}$ Ibid., p. 51: L. Conselheiro, c. 57.

${ }^{246}$ Allen, J. H. \& Greenough J. B. (1903). New Latin Grammar. Boston : Ginn.

${ }^{247}$ Brandão (1933: 42): R. da Silva, Mocidade, 1.o 150.

${ }^{248}$ Ibid., p. 42: Godinho, Relação, 77. 
distinta nas duas sentenças. Em (251) o verbo no gerúndio aparece imediatamente após o sujeito da oração matriz, enquanto em (252) o verbo da subordinada está distanciado do sujeito compartilhado. A relação de modo como o capitão resmungou e como o céu se abria não se dá, portanto, de maneira equivalente. Em (251) a subordinada pode ser parafraseada ao mesmo tempo tanto por uma relativa (que olhava de revez) como por uma adverbial de tempo (enquanto olhava de revez) e ainda responder à pergunta Como olhava o capitão?, o que evidencia a multipla interpretação que sentenças assim podem oferecer. O próprio Brandão (1933:42) adverte sobre as orações de modo: "Nesta circunstância o gerundio assume papel assaz indecizo, confundindo-se ora com o gerundio predicativo, ora com o gerundio atributivo".

Dada a multiplicidade de sentidos que as orações gerundivas exibem, muitas vezes algum valor semântico pode ser ressaltado através de estratégias específicas para cada circunstância em especial: a ordem da oração dependente em relação à matriz (p.ex. a anteposição nas condicionais), as marcas de tempo numa e noutra oração (p.ex. para distinguir a relação de anterioridade e posterioridade) ou a coocorrência de alguns itens lexicais com os gerúndios, como é o caso das seguintes ocorrências de gerúndios modificados pelos advérbios como, ainda e quase apontados por Brandão:

(253) O homem bom... foi tão ledo... e assim como chorando com prazer, se afastou d'elle. ${ }^{249}$ (254) serão condemnados sem misericordia, ainda submettendo-se elles ás decisões da igreja. ${ }^{250}$ (255)Ferido emfim do mal, ja quase agonizando se foi á cama do p. Ignacio Pomponio. ${ }^{25}$

\section{I.2.3.2.3.1 Gerúndio em construções absolutas}

A exemplo do que se discutiu a respeito do latim e das outras línguas românicas, Brandão também reconhece um estatuto sintático diferenciado para as construções com gerúndio que não têm como sujeito um item sintático da oração matriz, sendo assim mais independentes do que as outras orações adverbiais acima descritas, sendo tradicionalmente chamadas de construções absolutas:

"Ocorre o gerúndio absoluto, quando êle, tendo sujeito próprio, não se vincula diretamente ao sujeito ou a outro termo da oração principal. O gerundio absoluto póde ser puro ou precedido

\footnotetext{
${ }^{249}$ Ibid., p. 48: Fernão Lopes, D. João I, VII.

${ }^{250}$ Ibid., p. 49: Herc., Hist. da Inquis., L. I, p. 52.

${ }^{251}$ Ibid., p. 49: Bern., N. Flor. III, 63.
} 
da preposição em, e, como o ablativo absoluto latino formado com o participio presente (n.os 21 a 23), exprime várias circunstâncias" (Brandão, 1993:46).

Nestes exemplos, a noção de tempo parece exibir uma maior autonomia semântica do que nas orações adverbiais acima comentadas:

(256) tempo simultâneo: atraz dessa (primeira palavra) sahirão as mais de tropel, como levada de moinho, em se lhe afastando a porta. ${ }^{252}$

(257) tempo anterior: Vinda a noite, repousando (=e depois que todos já repousavam) já todos, Belisa se começou agastar levemente. ${ }^{253}$

(258) tempo posterior: E a terra abrindo a sua bocca devorou a Coré, morrendo muitissimos. ${ }^{254}$

Curiosamente, Brandão não elenca na categoria das construções absolutas a relação de modo, reconhecendo apenas as circunstâncias de causa, condição, concessão e conseqüência:

(259) causa: Na cidade de Napoles estava sentenciado á morte um pobre homem, a que não valeram arrazoados, nem embargos, nem a propria innocencia, prevalencendo contra tudo a prova das testemunhas. $^{255}$

(260) condição: Em me cheirando a filhós, em me dando o vento da empada, ou em vendo reluzir o prato de ovos, não havia doze horas na minha taboada de sabbado para domingo. ${ }^{256}$

(261) concessão: Tal foi a caridade de S. Roque, não chegando (=conquanto não chegasse, ou ainda, mas não chegou) a ser tal a caridade de S. Paulo. ${ }^{257}$

(262) consequiência: A ilha Egina ardeu antigamente me tal peste que a varreu de toda a especie humana, escapando (= de modo que escapou) unicamente el-rei Caco. ${ }^{258}$

Brandão também considera apositivas as orações gerundiais nas quais ocorrem um gerúndio impessoal, um gerúndio com sentido passivo ou um gerúndio com sujeito oracional:

(263) gerúndio impessoal: Pelo sertão dentro deste reino indo para o Ponente está situada a provincia de Conche. ${ }^{259}$

(264) gerúndio com sentido passivo: Esto em geeral he pecado de êueja, tirando (= sendo tirados) certos casos speciaaes que aos leterados pertencem declarar. ${ }^{260}$

(265) gerúndio com sujeito oracional: E nom embargando que cada huma destas uirtudes per sy he suficiente pera endereçar naquella real carreira per poucos seguida... ${ }^{261}$

\section{I.2.3.2.3.2 Gerúndio circunstancial (Campos, 1972)}

O gerúndio circunstancial "exprime uma ação acessória que acompanha a principal, equivalendo a uma oração circunstancial modal, temporal, causal,

\footnotetext{
${ }^{252}$ Ibid., p. 46: Bern; Luz e Calor I parte, Doutr. VI, § VIII.

253 Ibid., p. 47: Bernardim, Men. e Moça, VIII.

${ }^{254}$ Ibid., p. 47: Pe. Pereira de Figueiredo, Numeros, XXVI, 10.

${ }^{255}$ Ibid., p. 47: Vieira, Serm. 7.o, 197.

${ }^{256}$ Ibid., p. 47: D. Francisco Manoel de Mello, Apologos dos Relogios Falantes.

${ }^{257}$ Ibid., p. 48: Vieira, Serm. VIII, 38.

${ }^{258}$ Ibid., p. 48: N. Flor., III, 62.

${ }^{259}$ Ibid., p. 49: Fr. João dos Santos, Ethiopia, IV, 1.o.

${ }^{260}$ Ibid., p. 50: Leal Conselheiro, c. XV.

${ }^{261}$ Ibid., p. 50: Leal Conselheiro, c. V.
} 
concessiva, etc..." (Campos, 1972:36). Nesse caso, o gerúndio equivale aos usos circunstanciais herdados do particípio presente. Em relação ao sujeito, essas orações podem construir-se com o mesmo sujeito da oração principal, com sujeito próprio ou ainda sem sujeito nas construções impessoais, como é o caso das construções absolutas.

Segundo a autora, a distinção que se pode fazer do gerúndio adverbial do circunstancial seria pela presença ou ausência de pausa entre o gerúndio e a oração principal: se há pausa, temos um gerúndio circunstancial, caso contrário, sem pausa, há o gerúndio adverbial. Esse argumento parece indicar que o gerúndio adverbial está muito mais integrado à oração principal do que o gerúndio circunstancial, que sintaticamente seria mais independente. Outro argumento a favor desta idéia seria o fato de que os gerúndios adverbiais são uma espécie de perífrases em formação como chegou trazendo, exclamou soltando uma risada, passeia navegando, saiu correndo, passouvoando, amanheceu vomitando.

A freqüência na distribuição dos gerúndios circunstanciais se dá de maneira equivalente em todas as épocas do português analisadas por Campos (1972), o que leva a autora a afirmar que "trata-se, portanto, de um fato geral a toda a România, o que revela a sua antiguidade dentro do contexto neo-latino e sua existência já no latim vulgar.'(Campos, 1972:113).

Tabela 1. Distribuição dos sujeitos dos gerúndios circunstanciais, conforme Campos, 1972.

\begin{tabular}{|l|c|c|c|}
\hline & $\begin{array}{c}\text { Português } \\
\text { arcaico }\end{array}$ & $\begin{array}{c}\text { Português do séc. XVI ao } \\
\text { XIX }\end{array}$ & Português contemporâneo \\
\hline $\begin{array}{l}\text { Sujeito idêntico } \\
\text { ao }\end{array}$ & $35 / 42$ & $6 / 42$ & $1 / 42$ \\
Da OP & $61 / 73$ & $11 / 73$ & $1 / 73$ \\
\hline Sujeito próprio & $134 / 141$ & $7 / 141$ & 0 \\
\hline $\begin{array}{l}\text { Oração sem } \\
\text { sujeito }\end{array}$ & & \\
\hline
\end{tabular}

Quanto à posição dos gerúndios circunstanciais, Campos (1972:115) lembra ainda que eles podem aparecer em três posições: antepostos ou pospostos à oração principal e ainda vir intercalado entre os elementos dessa mesma oração.

A autora verificou ainda que as orações com gerúndio circunstancial pode construir-se com verbos de diversa natureza: intransitivos, transitivos ou de ligação. 
Quando transitivos, acompanham-lhes os respectivos complementos objeto direto, indireto e quando de ligação apresentam o seu predicativo. Um exemplo para este último caso:

(266) Mas sendo ou não sendo península, o Pôsto Seis é uma porção de terra, edifícios, gente e ar cercados de botequins por todos os lados. ${ }^{262}$

Por ter esse caráter verbal, os gerúndios circunstanciais podem exprimir a noção de tempo indicando simultaneidade, anterioridade e posterioridade em relação à oração principal:

(267) Vós, diz Cristo, Senhor nosso, falando com os pregadores, sois o sal da terra... ${ }^{263}$

(268) Faustino - ... (Isto dizendo, tira do bôlso um pente, com o qual penteia-se enquanto fala.

$(269)^{264} \ldots$ e deu na pobre menina alguns encontrões, embaraçado por não saber se lhe daria a esquerda ou a direita; finalmente acertou, e deu-lhe a esquerda, ficando êle do lado da parede. ${ }^{265}$

Observamos que os exemplos arrolados por Campos (1972:97-98) indicam que muitas vezes a posição desses gerúndios em relação à principal é um fator determinante na interpretação semântica tanto do tempo como da circunstâncias expressa por essas orações. A anteposição parece favorecer a leitura de anterioridade e o valor de causa e condição. A posposição indicando valor de posterioridade no tempo permite a interpretação da oração como conseqüencial. A intercalação dos gerúndios parece indicar a noção de tempo simultâneo e o valor de modo.

Ainda sobre o tempo, Campos (1972:118) lembra que o gerúndio desde o latim, assim como o partícipio presente, exprimiam simplesmente uma ação simultânea à principal e que nas línguas românicas, por não ter uma morfologia específica para a expressão de tempo, liga-se à temporalidade do verbo de que depende, acompanhando os valores de tempo deste. A exemplo do que ocorreu no francês e no espanhol clássicos, o português desenvolveu perífrases com ter e haver + gerúndio para exprimir a anterioridade (havendo lido, tendo conquistado, etc.).

Em relação ao aspecto, Campos (1972:121) adota a lição de Castilho (1966:§ 58c) de que o gerúndio é uma forma verbal que indica o aspecto imperfectivo cursivo:

\footnotetext{
${ }^{262}$ Campos (1972:116): CC, P6, 15.

${ }^{263}$ Ibid., p. 97: Vieira, Pe. A., Sermão de Sto. Antônio, § 1, vol. XI, 157.

${ }^{264}$ Ibid., p. 97: Martins Pena, L.C., O Judas em Sábado de Aleluia, cena IV, 46-47.

${ }^{265}$ Ibid., p. 98: Almeida, M.A. de. Memórias de um sargento de milícias, XX, 95-96.
} 
"Essa imperfectividade se dá de forma independente, quando o gerúndio está em orações narrativas, onde se desconhecem os limites de início e término da ação. Mas, nas orações subordinadas, o valor aspectual do gerúndio depende do verbo da oração principal. Se este também for imperfectivo, a ação será imperfectiva propriamente dita; se for perfectivo, a ação do gerúndio dar-se-á dentro dos limites de duração daquele verbo.

Além disso, dependendo do valor semântico do verbo que está no gerúndio, a ação imperfectiva pode adquirir valor progressivo ou inceptivo-progressivo." (Campos, 1972:121122)

A autora elenca ainda algumas partículas que acompanham o gerúndio e que lhe dão suporte para a interpretação semântica específica: em, sem, como, como que, embora, mesmo, só e nem. As mais antigas são as preposições em e sem, sendo a primeira de uso extremamente especializados no português moderno e tendo a última desaparecido a partir do português clássico. Como e como que ocorrem para dar suporte à expressão modal do gerúndio. Para o valor concessivo, ocorrem algumas vezes as partículas embora e mesmo. Já o advérbio só permite várias nuances quando agregado ao gerúndio, conferindo-lhe o valor de condição (só mesmo entrando na faca) e juntamente com a conjunção que indica consequiência (cada surra que só você vendo). $\mathrm{O}$ advérbio nem forma orações concessivas negativas (nem brincando você é capaz de se matar).

Quanto ao valor semântico das orações com gerúndio circunstancial, Campos arrola as seguintes possibilidades idênticas para todos os períodos do português: modal, temporal, causal, condicional, concessivo, final e consecutivo.

\section{I.2.3.2.3.3 Gerúndio adverbial (Odette Campos) ou gerúndio coordenativo} (Brandão):

Normalmente, o gerúndio adverbial equivale a um advérbio de modo, de meio ou de instrumento. Segundo Campos (1972:35) "existe um tipo de gerúndio, que apresentamais características de advérbio do que de oração circunstancial proprieamente dita". Conforme a autora, esse gerúndio mantém-se mais próximo do latino por apresentar-se mais próximo do verbo da oração principal, e eventualmente por indicar o meio ou o instrumento com que se realiza a ação do verbo da oração matriz, "a expressão de modo, com que o encontramos, já é um alargamento do seu sentido latino primitivo" (Campos, op. cit., p. 35). Vejamos alguns exemplos oferecidos pela pesquisadora: 
(270) Reparava nessas coisas, mas não ria nem pensando, de mêdo dos poderes da baiana, multa de fôrça com o povo da linha do chão. ${ }^{266}$

(271) ...em cujo golfo, como em praça, passeiam navegando as embarcações sem mais roteiro... ${ }^{267}$

(272) ... - Ah! ah! ah! - como é isso, Margarida; mula-sem-cabeça?... exclamou o rapaz soltando uma risada. $^{268}$

(273) Jogou a fantasia no chão e foi para outra sala soluçando. ${ }^{269}$

(274) Um dia amanheceu vomitando preto e com febre. ${ }^{270}$

(275)Quando o pai chegou trazendo consigo uma negra velha rezadeira, Josias, inconsciente... sibilava... ${ }^{271}$

Odette Campos afirma que certos gerúndios adverbiais passaram um processo de desgaste semântico a ponto de se transformarem em verdadeiros advérbios como em sair voando, sair ventando, passar correndo, passar voando e passar raspando. O termo gerúndio adverbial que consta de sua tese (Campos, 1972) foi retirado da publicação que lhe seguiu (Campos, 1980), e a autora incorporou casos como os dos exemplos acima ao grupo dos gerúndios circunstanciais. Na verdade, a autora tinha razão quando verificou que em casos como passar correndo havia algo distinto do que meramente a agregação de uma circunstância, uma vez que o verbo finito que o acompanha perde perde algumas de suas propriedades semânticas, aproximando-se de uma sorte de verbo auxiliar. Cometo exemplos desse tipo no capítulo IV sobre a sintaticização do gerúndio.

\section{I.2.3.2.4 Perífrases verbais}

Brandão (1933:84) considera que ainda no latim o particípio presente ligado a determinados verbos chegou a "chamar a si a predicação principal, assumindo os ditos verbos, em muitos casos, um papel secundario, quase de auxiliares, em consequencia do seu esvasiamento semantico”. Segundo esse autor, seria esse fato o germe de algumas das perífrases verbais das línguas românicas com a finalidade de expressar o aspecto.

Para o português, Brandão aponta os verbos estar, andar, ficar, ir, vir, começar, continuar, acabar e seus sinônimos como sendo aqueles se combinam ao morfema $-n d o$ formando perífrases aspectuais.

\footnotetext{
${ }^{266}$ Ibid., p. 34: CP, M in CR, 127.

${ }^{267}$ Ibid., p. 94: Marques Pereira, N., Compêncio Narrativo do Peregrino da América, vol. I, I, 19.

${ }^{268}$ Ibid., p. 94: Guimarães, B., O Seminarista, IX, 175.

${ }^{269}$ Ibid., p. 112: AM, LCh, 149.

${ }^{270}$ Ibid., p. 112: LR, ME, VIII, 16.

${ }^{271}$ Ibid., p. 112: RQ, Q, X, 42.
} 
Um fenômeno que a priori tem sido interpretado como anglicismo e que é recorrente em contextos de comunicações telefônicas de caráter comercial, o assim chamado gerundismo, indica um uso do gerúndio com interpretação de futuro remoto (vou estar mandando, poderei estar mandando). No entanto, os exemplos (282-284), apresentam ocorrências de uma forma germinal do hoje chamado gerundismo, o que confirma parcialmente a hipótese feita por Verena Kewitz (comunicação pessoal) de que essa estrutura já deveria estar disponível em PB em períodos anteriores ${ }^{272}$ :

(276)É preciso, Senhor Redactor, que o Corre- | io va prestando estes serviços ao interes-| se publico. || Eu me proponho á ir fazendo estes e | outros lembretes, em quanto elles forem | recebidos gratis, pois não escrevo por | gloria, e sim por ser. (CJ-SP- 446-CP-12jul1854)

(277) mas isso eu estou falando a nível de elocubração porque também não me preocupa... inclusive sabe... eu não vou mais estar vivendo... o que me interessa é o espaço da minha vida sabe?...(D2-SP-343-séc.XX)

(278)então... em vez de estar trabalhando:.... sei lá.... digamos... numa enxada eu vou estar apertando um botão de computador... qualquer coisa desse tipo (D2-SP-343-séc.XX)

\section{I.2.3.2.5 Gerúndio coordenado (Campos, 1972)}

A exemplo do que já tinha sido apontado por Brandão (1933:40) e que veio a ser considerado mais tarde também por Braga (2002), as orações reduzidas de gerúndio também podem ser interpretadas como um tipo de coordenação, com sujeito expresso ou subentendido. Nesses casos, ao invés de subordinar-se ao verbo da oração matriz, ele compõe uma estrutura justaposta a ela. Podem indicar um valor tanto aditivo como adversativo, ou até mesmo conclusivo em relação à proposição inicial, como se vê respectivamente nos exemplos abaixo:

(279) A velha correu logo para a Tia Maria, ajoelhando-se a seus pés... LR, ME, XVIII, apud Campos, 1972:154.

(280) Agora, posso afirmar que os dirigentes do serviço voltaram atrás, apresentando, porém, uma série de dificuldades.

(281)... submetidos à Assembléia, receberam aprovação unânime, sendo, portanto, eleitos ... EM, 1.o, 2, apud Campos, 1972:156.

Observa-se que nestes casos o gerúndio muitas vezes vem acompanhado de conjunções que dão suporte à interpretação específica, como é caso de mas, porém, portanto, etc.

Em termos de ordenação sintática, estas construções aparecem sempre depois da oração a que se coordenam, podem ter o mesmo sujeito da oração principal ou ter sujeito próprio.

\footnotetext{
${ }^{272}$ Exemplos retirados de Simões (2006).
} 


\section{I.2.3.2.6 Gerúndio narrativo (Campos, 1972)}

Em alguns casos, o gerúndio pode exibir alta independência sintática, chegando a ser equivalente a um verbo finito, mesmo sem aparecer coordenado a outro verbo finito. Campos (1972:50) atribui o seu uso em razão de um condicionamento pragmático, "em descrições dotadas de grande vivacidade onde a afetividade justifica a ausência da forma verbal pessoal”:

(282)... tem feira, pensou - tudo se agitando e se desencontrando, abrindo-se em leque e se reagrupando, convergindo e espadanando, gente muita, pirâmide de frutas, barraquinhas de livros e revistas berrando pela bôca de mil cores, chamados e gritos e adeuses e pregões - tudo fúlgido, barulhento e confuso como numa febre. ${ }^{273}$

Campos afirma que esse é um uso que se desenvolveu no português no período contemporâneo e que praticamente não existiria nas fases anteriores da nossa língua. A autora acentua o "conteúdo afetivo" destas construções e diz que são comuns as "descrições vivas" em orações desse tipo, "onde uma seqüência de gerúndios enfatiza o que se pretende reproduzir" (Campos, 1972:158). Quando essas construções têm um valor afetivo mais acentuado, a autora define-os como sendo da categoria dos gerúndios exclamativos.

Nesse tipo de orações, em lugar do verbo finito, encontra-se um substantivo, um adjetivo, uma forma nominal (infinitivo preposicionado, particípio ou gerúndio), ou ainda qualquer nome precedido de preposição:

(283)Lívia de braços fechados no peito. Lívia silenciosa. O frio entrava pelo seu corpo. ${ }^{274}$

O mesmo fenômeno foi apontado por Müller-Lancé (1994:76) para o francês (les mains vides, la tête baissée, les mains dans le poches) e indica uma dessentencialização das construções absolutas. ${ }^{275}$

\section{I.2.3.2.7 Gerúndios exclamativos, interrogativos e imperativos}

Campos prefere dissociar o gerúndio exclamativo e interrogativo dos narrativos posto que estes não aparecem em sequiências como no último caso. Este uso teria sido primeiramente detectado por Maurer (1968 apud Campos, 1972:160):

\footnotetext{
${ }^{273}$ Campos (1972:51): CS, D in CR, 37.

${ }^{274}$ Campos (1972:158): JA, MM, 260.

${ }^{275}$ Sobre a dessentencialização, ver Lehmann (1988).
} 
(284)-- Ô diacho! E a gente precisando tanto de cobre, hein, Marcolino! $!^{276}$

(285)Christo e o Vigario de Christo ambos dormindo? Christo dormindo no meio da tempestade, e Pedro dormindo no meio das guardas, e das cadêas, e ambos com a morte à vista, sem nenhum cuidado? 277

A autora argumenta que o uso exclamativo é mais freqüente que o interrogativo e entre estes ela distingue os interrogativos propriamente ditos e as orações interrogativas carregadas de valor afetivo:

(286)Leleco - Que é isso, Zé Gato? Dando pulo de costas por causa de uma violinha?... ${ }^{278}$

Cunha \& Cintra (1985:481) reconhecem ainda o uso imperativo do gerúndio (Andando! [= Vá andando! Ande!].

\section{2.3.2.8 Orações reduzidas: coordenação, subordinação ou fórmulas com um estatuto sintático distinto?}

Braga (2002:242) estudou o caso das orações reduzidas de gerúndio no português e concentrou-se nas orações de tempo-condição com o objetivo de verificar em que medida as propriedades sintáticas da subordinação e da coordenação afetam essas construções.

Para Braga (2002), a relação subordinação versus coordenação deve ser discutida primordialmente para as orações de tempo, tradicionalmente identificadas como casos de subordinação. A autora observa que estas estruturas introduzem a idéia de continuidade no eixo da adição, e que por este motivos poderiam facilmente ser consideradas como formas de coordenação.

Tradicionalmente usa-se considerar as orações reduzidas como estruturas de subordinação. Entre os argumentos usados para defender esta idéia estão propriedades que podem ser apontadas para o grupo das subordinadas adverbiais (Mateus et alii: 2003):

a) as adverbiais podem ser destacadas por clivagem como qualquer outro constituinte;

\footnotetext{
${ }^{276}$ Campos (1972:161): DA, CA, 81.

${ }^{277}$ Ibid., p. 160-1: Sim. Vieira, Pe. A., Sermão das Cadêas de S. Pedro, § 2, vol. VIII, 7.

${ }^{278}$ Ibid., p. 162: AC, FEC, ato I, 40.
} 
b) orações subordinadas apresentam mobilidade sintática, ao contrário das coordenadas;

c) as adverbiais não são argumentos do predicado principal.

Tal propriedade pode ser verificada a partir de testes de substituição das adverbiais por itens não argumentais, como os ADVs, os SADVs e SPs, e também "há a possibilidade de interpretação co-referencial do sujeito nulo da OS relativamente ao SN sujeito da outra oração".

Alguns dados revelam as marcas tênues que impedem a adoção do termo subordinação para todas as reduzidas de gerúndio. O exemplo abaixo denota a idéia de adição a que se refere Braga (2002:241):

(1) Loc: Isto é para vocês verem o que seja a ginecologia que se emprega ao termo... ao sexo masculino $e$, além do mais, ela podendo ser primitiva,e como é primitiva, é secundária também. (EF-SSA)

A autora analisa seus dados levando em conta um grupo de fatores que julga relevante para a análise, como a posição da oração gerundiva em relação à oração matriz, a explicitude do sujeito, a identidade do sujeito e o nível sintático do constituinte ao qual a oração se articula. A partir dos resultados da análise, Braga sugere que essas reduzidas apresentam tanto propriedades das subordinadas como das coordenadas, o que evidenciaria um estatuto distinto para estas estruturas.

\section{I.2.3.2.9 Gerúndios flexionados no português}

Maria Lobo (2000 e 2001) estudou o caso particular do gerúndio flexionado com morfologia de pessoa/número (GF) no português dialetal encontrados em Porches e Alte (Algarve) e no Alto Alentejo. Nestes trabalhos a autora nota que esse uso não está circunscrito somente a essas zonas, e que também pode ser encontrado nos dialetos galegos, além de referências à sua existência na ilha da Madeira, no Algarve, na Beira Baixa, na Beira Alta e, na Espanha, nos dialetos fronteiriços de Cedilho (Cáceres) e de Olivença (Badajoz). Nesses dialetos, além da forma não flexionada do gerúndio (GNF), o gerúndio aparece flexionado com as marcas de pessoa e número, segundo o paradigma: (eu) vindo $+\emptyset$, (tu) vindo $+s$, (ele) vindo + $\emptyset$, (nós) vindo + mos, (vós) vind $(o)+$ eis, (eles) vind $(o)+e m$. 
Segundo a autora, o GF pode ocorrer em contextos que tradicionalmente estão reservados às formas finitas dos verbos, principalmente em orações introduzidas por complementador. Assim, o GF pode aparecer

(i) em orações adjuntas modificadoras da frase sem conector (287 e 288);

(287)Enfim, os homens lá vão ainda porque não têm tractores e, então, hoje a coisa, estarem a pagar, eles tendem as coisas em casa, fazem a toda a hora, quando querem, vão fazendo o serviço com um macho, com mais pausa. (Cordial, AAL36)

(288) Não sei como tanto devâmos, ganhândomos tanto dinheiro! (Ervedosa do Douro, in Azevedo $(1928-9))$

(ii) em orações adjuntas introduzidas por preposição em (ou ende) (289);

(289) Em vendem a pessoa assim $\{\mathrm{pp}\}$ ou com uma idade $\{\mathrm{pp}\}[\mathrm{AB} \mid \mathrm{ou}, \mathrm{ou}]$ ou mal ou qualquer coisa, \{pp\} uns têm consciência, outros não têm. (Cordial, PAL7)

(iii) em orações adjuntas introduzidas por advérbios (290);

(290) Onde é que eles mesmo /trabalhandem/ /trabalhando/, em ganhando o dinheiro, podiam semear alguma coisinha para eles. (Cordial, PAL11)

(iv) em orações adjuntas modificadoras do predicado (291);

(291)E, às vezes, anda aquele rebanho junto, $[\mathrm{AB} \mid \mathrm{e}] \mathrm{e}$, depois, às vezes, $\{\mathrm{fp}\}$ vão dormir pensandem [AB|que é] que são todas fêmeas e há [AB|algum] algum macho ali no meio! (Cordial, PAL 13)

(v) em orações relativas livres introduzidas por onde e quando (292 e 293);

(292)Quando sentindim outros animais, espantam-se (Odeleite, in Cruz (1969))

(293) Onde estando a menina está alegria (Nisa, in Carreiro (1948))

(vi) em orações comparativas (294);

(294)Isto os arrendamentos, já se sabe, que não há como as coisas estandem nas mãos dos donos, está a compreender. (Cordial, AAL29)

(vii) em orações independentes com valor exclamativo (295);

(295)Deixa que o teu pai logo te diz! Molhandes aí a cabeça toda, moço dum raio! (Colos, in Guerreiro (1968))

(viii) com função predicativa (296) em também em orações condicionais introduzidas por se (297) e em orações causais introduzidas por como (298). Nestes últimos dois casos a flexão não é visível: ${ }^{279}$

(296)E então, nessa altura, vieram dois rapazes $\{\mathrm{pp}\}$ fazendem parte, rapazes novos, e eu e mais um outro é que éramos os velhos [...] (Cordial, PAL 17)

(297)...aquilo, se o homem não arrebentando... (Olhão, in Palma (1967))

(298)E depois, nós éramos quatro irmãos e\{fp\} ficámos só com minha mãe e eu, como sendo o mais velho, [AB|é q-] é que fui sempre o mais escravo. (Cordial, AAL35)

Maria Lobo (2000) verificou o maior número de GFs em orações adjuntas, do que em orações comparativas e como predicativo. Também observou, que

\footnotetext{
${ }^{279}$ Exemplos de Lobo (2000:4-5).
} 
diferentemente da norma padrão, a ordem $\mathrm{Su}-\mathrm{V}$ é mais freqüente em orações em que ocorre um conector e a ordem V-Su é mais usual em orações sem conector:

(299) ...aquilo, se o homem não arrebentando... (Olhão, in Palma (1967))

(300)E chamava-lhe ele $\{\mathrm{pp}\}$ tomateiras! Sendo ele criado aqui, $\{\mathrm{pp}\}$ talvez aí, $\{\mathrm{pp}\}[\mathrm{AB} \mid$ vá lá] vá lá, /a/ uns quinhentos metros da distância [AB|da ca-, d-] da casa do tio. (Cordial, PAL5)

Além disso, o GF aparece tanto nas orações em que o sujeito é co-referente com o da oração matriz como quando é disjunto, como é o caso das construções absolutas. A exemplo do que acontece nas orações finitas, o antecedente do sujeito nulo nessas costruções pode ser tanto o sujeito (292) como o objeto da oração matriz (301), ou pode ser um tópico (302), estar na frase anterior (303), ser determinado pragmaticamente (304), ter uma interpretação arbitrária (305) ou ser um expletivo (306) :

(301)Em sendem crescidos, levo-os a Lisboa. (Baixo Alentejo, in Delgado (1951))

(302) O pão quando estando lêvedo, $[\mathrm{AB} \mid e s t a ́$ a farinha, a $\{\mathrm{fp}\}]$ a massa é mais leve. (PAL30)

(303)Eles têm duas instalações. [AB|ag-\{fp\}] Agora, em fazendem o resto das outras é que fica tudo ali junto, já. Fica já ali a garagem, fica casa para tudo, não é. (AAL24)

(304)Em querendos ir, vamos. (Cedillo, in Vilhena (1965))

(305) Mesmo pagando o dinheiro, $\{\mathrm{pp}\}$ não há quem queira ir fazer. (PAL11)

(306) Porque $[\mathrm{AB} \mid \mathrm{o}\{\mathrm{fp}\}]$ a azeitona é uma das coisas que, chove agora, e, em estando bom, [AB|já se] já se trabalha. (AAL30)

A autora conclui ainda que deve haver uma diferença semântica entre dois grupos distintos de orações com GF:

(307) Morrendo a mãe, o João foi viver com os avós. <aspecto perfectivo>

(308)Eles adormeceram pensando que já era noite./a pensar que já era noite. <aspecto progressivo>

(1) nas gerundivas adjuntas de frase (307) e as gerundivas ditas de "posterioridade" a leitura semântica é mais do aspecto perfectivo e nelas nem sempre está presente a leitura cursiva/progressiva que se verifica obrigatoriamente nas (2) gerundivas adjuntas internas, gerundivas predicativas, gerundivas independentes, gerundivas complemento de verbos perceptivos e gerúndio em complexos verbais (308), as quais parecem exibir uma estrutura funcional diferente, que impossibilita a ocorrência do gerúndio composto (tendo feito) que obrigaria a leitura perfectiva, mas possibilita a paráfrase com a preposição $a+$ infinitivo. 


\section{I.2.3.2.10 Considerações finais a respeito dos estudos sobre o gerúndio no português: questões em aberto}

A partir do que se leu acima sobre as descrições do gerúndio no português percebe-se que essas classificações levam em conta propriedades sintáticas, semânticas e discursivas dessa forma nominal do verbo. Muitas vezes, trata-se de descrições imbricadas que ora estão orientadas pelas propriedades sintáticas, ora pelos traços semânticos, e outras vezes pelas funções discursivas que o gerúndio pode apresentar. Embora sejam contribuições de muita valia para o entendimento do gerúndio no português, seria necessário separar estes argumentos conforme as propriedades específicas que são ativas, reativadas e desativadas em cada um dos sistemas da língua, a fim de verificar como se organizam os vários usos do gerúndio. É, portanto, tarefa deste estudo sobre o gerúndio observar como estes dispositivos sociocognitivos são gerenciados no português brasileiro. Mais especificamente, é de interesse desta tese verificar qual o estatudo sintático, semântico e discursivo do gerúndio na composição de sentenças simples e complexas.

A revisão da literatura sobre o gerúndio no latim e seus desdobramentos nas línguas românicas serve como orientação para a classificação dos tipos de gerúndio de acordo com suas propriedades cognitivas de base. A descrição feita para as outras línguas românicas deve servir de suporte a essa classificação. 


\title{
- CAPÍTULO II -
}

\section{Revisão da literatura sobre os modelos teóricos adotados}

\begin{abstract}
Partindo do principio fundamental de que as linguas são por natureza mutaveis e perfectiveis, cumpre-lhes fixar regras verdadeiras, conciliando o falar do povo, reflexo da sua psicologia, com a lingua dos letrados, produto da sua cultura, de sorte que, por um periodo tão longo quanto possivel, se estabeleça o equilibrio entre as duas correntes, a popular e a erudita, tornando-se o idioma um instrumento de comunicação ideologica, ductil, prestadio.
\end{abstract}

Claudio Brandão (1933:65)

Através do presente capítulo faço uma revisão da literatura sobre os modelos teóricos adotados como base para esta tese. Inicio com a apresentação da modelo de Análise Multissistêmica da Língua proposto por Castilho (2006), no qual o autor defende a adoção do conceito de língua como um conjunto de sistemas que são ativados concomitantes: o Léxico, a Semântica, o Discurso e a Gramática. Nesta tese, considero ainda o modelo de Tradições Discursivas que teve sua origem nos estudos desenvolvidos pela Romanística alemã, mais especificamente da Universidade de Tübingen.

\section{II.1 A teoria da gramaticalização revista}

Em estudos subseqüentes em torno de sua Proposta Funcionalista de Mudança Lingüística Castilho (2006a e 2006b) ${ }^{280}$ apresenta um histórico do que se tem proposto, a partir de Humboldt $(1822)^{281}$, para o fenômeno que por ora convencionou-se chamar de gramaticalização. $\mathrm{O}$ autor faz um leitura exegética das proposições feitas por diversos autores a respeito do assunto, procurando organizar

\footnotetext{
${ }^{280}$ Para uma visão mais ampla do desenvolvimento desse modelo, v. Castilho (1997, 2003, 2004, 2004a, 2004b, 2004c e 2005).

${ }^{281}$ Humboldt, Wilhelm von (1822/1822). Über das Entstehen der grammatischen Formen und ihren Einfluß auf die Ideenentwicklung. Tradução espanhola de C. Artal, Sobre el origen de las formasgramaticales, Barcelona: editorial Anagram.
} 
os argumentos que com o passar dos anos foram se somando, para, a partir daí, propor uma reordenação do conceito de gramaticalização.

Castilho (2003, 2006a e 2006b) observa que os pesquisadores assumem a língua como uma entidade estática, que pode ser representada através de camadas linearmente dispostas umas às outras, estabelecendo-se derivações entre essas mesmas categorias que são de campos diversos como o léxico, a semântica, o discurso e a gramática. O autor nota que essas perspectivas ainda não foram claramente formuladas, mas observa que nelas reunem-se as seguintes percepções sobre a língua: (1) as línguas naturais são conjuntos de signos lineares, ocorrendo suas modificações em passos unidirecionais (Hopper/Traugott, 1993/2003:100 apud Castilho, 2006a). Essa perspectiva tem um apelo neogramatical e entende a gramaticalização como um enumerado de mudanças pelas quais passa um item lexical. Segundo esta perspectiva, a gramaticalização consiste na atribuição de um caráter gramatical a um item cada vez mais autônomo (Meillet, 1912) ${ }^{282}$, desenvolvendo-se de um forma derivada para uma forma flexional (Kurylowicz, $1965)^{283}$, mudando através da língua-linha de uma categoria sintática para outra. (2) Os produtos lingüísticos avançam do léxico para a gramática, sendo portanto, derivacionais (Heine/Claudi/Hünnemeyer, 1991). (3) Os domínios lingüísticos da fonética, da sintaxe, da semântica e do discurso conectam-se por derivação.

Mais adiante, Castilho (2006a) visualiza três fases nos estudos sobre a gramaticalização. Neles observa-se que os pesquisadores postulam que as expressões exibiam um percurso (1) do Léxico para a Gramática, ou (2) do Discurso para a Gramática, ou (3) da Semântica para a Gramática.

$\mathrm{Na}$ perspectiva que analisa o percurso (1) do Léxico para a Gramática, entende-se a mudança sob uma trajetória empreendida pelos itens lexicais que segue o seguinte esquema: Léxico > Sintaxe > Morfologia > Morfofonêmica > zero. Sob este prisma pôde-se estudar a gramaticalização de substantivos, pronomes e expressões de tratamento, verbos, advérbios, conjunções e preposições.

\footnotetext{
${ }^{282}$ Meillet, A. (1948) L'évolution des formes grammaticales. In: A. MeilleT. Linguistique historique et linguistique générale. Paris: Champion, p. 130-148, [1912].

${ }^{283}$ Kurylowicz, J. (1975) The Evolution of Grammatical Categories. In: Esquisses linguistiques II, p. 38-54 [1965].
} 
Posteriormente, a partir do estudo de Givón (1979: 208-209 apud Castilho, 2006a) agregou-se o Discurso a esta escala: Discurso > Sintaxe > Morfologia > Morfofonêmica > zero. Por esta perspectiva estudaram-se os operadores discursivos e argumentativios na estruturação dos textos falados e escritos.

Na perspectiva (3) da Semântica para a Gramática procurou-se evidenciar que tipos de mudanças de significado ocorrem simultaneamente à gramaticalização de determinados itens (Traugott 1989, Traugott/König, 1991 e Heine/Claudi/Hünnemeyer, 1991b apud Castilho 2006a). Nela estão envolvidas as noções de mudança de um sentido concreto para um sentido abstrato como é o caso do surgimento das preposições nas línguas africanas a partir de itens lexicais que indicam partes do corpo humano através de estratégias de base cognitiva como a metáfora e a metonímia.

Para Castilho (2003, 2004, 2006a e 2006b) estas perspectivas assumem a língua como umo "uma combinação estática e linear de itens separáveis", servem bem para analisar a língua como um produto (érgon), mas não como um processo (enérgeia). Em suas mais recentes publicações, Castilho (2006a) defende que se deve analisar a língua como um conjunto complexo e dinâmico de sistemas. Sua proposta tem base nos achados dos pesquisadores ligados ao Projeto NURC e ao Projeto da Gramática do Português Falado, e mais recentemente houve aplicação destas idéias em estudos desenvolvidos dentro do Projeto Para a História do Português Brasileiro, no qual se insere esta tese.

A proposta de mudança funcionalista de Castilho tem como postulados as seguintes premissas: (1) É possível analisar as línguas naturais tanto do ângulo de sua produção como do ângulo de seus produtos. (2) Vista sob o ângulo de sua produção, as línguas devem ser definidas como um conjunto de processos mentais, pré-verbais, que atuam (i) simultaneamente, de maneira não seqüencial, (ii) dinamicamente, não sendo, portanto, estáticas, (iii) multidirecionalmente, não sendo, assim, entidades unilineares. (3) Da perspectiva de seus produtos, a língua pode ser vista como um multissistema do qual fazem parte quatro subsistemas: (i) o Léxico, (ii) o Discurso, (iii) a Semântica e (iv) a Gramática. (4) Esses subsistemas devem ser considerados autônomos uns em relação aos outros. Assim sendo, postula-se que um subsistema não deriva do outro, nem se propõe uma hierarquia entre eles. Em função disso, 
exclui-se a idéia de que possa haver subsistemas centrais ou periféricos, uma vez que todos atuam simultaneamente. (5) Assume-se que princípios sociocognitivos de ativação, desativação e reativação, provindos dos estudos da conversação, gerenciam estes subsistemas, orientados pela finalidade de uso a que determinados itens estão disposto na enunciação.

As idéias de Castilho (2006a) chocam-se com o modelo da chamada "ciência clássica que postula (a) que a tarefa da ciência é encontrar as regularidades ocultas na aparente desorganização dos fenômenos encontrados na natureza, (b) que para isso é preciso analisar os dados em seu plano estático, ou seja, a partir dos produtos, a fim de (c) elaborar sistemas analíticos lineares em que o todo é igual à parte.

Ao criticar tal postura, Castilho não considera errada a abordagem da ciência clássica, mas alerta para o fato de que muitas vezes não é possível estabelecer critérios claros e lineares que permitam integrar itens de varia natureza a sistemas estáticos. Para isso é preciso considerar uma ciência dos sistemas complexos (teoria do caos segundo Gleick, 1988:43 apud Castilho, 2006a), que deve estar interessada em (i) uma determinada ordem que não exibe necessariamente uma periodicidade, preocupada em analisar (ii) o comportamento irregular e imprevisível de sistemas não lineares, dinâmicos nos quais itens transitam de uma categoria a outra em combinações infindas (Waldrop, 1993:335 apud Castilho, 2006a). Segundo esta perpectiva, os sistemas complexos jamais chegam a uma estabilidade, pois thes é característico o deslocar-se de uma lado para o outro como um pêndulo. Além disso, seria preciso desenvolver uma método descritivo para aquilo que é vago, aproximativo, impreciso (Talmy, 2001:vol.1 p. 31 apud Castilho, 2006a). Uma conseqüência dessa postura é o fato de não mais entender como aberrações aquilo que não se enquadra dentro de categorias definidas e sim como sintomas de mudanças e acomodações, que "combinam a estabilidade e o caos" (Gleick, 1988:68,79 apud Castilho, 2006a). No domínio da Lingüística, isso se aplica aos fenômenos de variação e mudança que tradicionalmente têm sido execrados pelas gramáticas normativas de cunho prescritivo. Os pesquisadores que trabalham nessa linha entendem que num sistema complexo existem agentes que interagem com outros de variadas maneiras, são caóticos e imprezíveis porque atuam simultanemamente e não de maneira seqüencial, não se pode verificar se um agente determina ou atua sobre outros agentes. Por conta disso não se pode analisar os 
sistemas complexos através de seus componentes, mas sim através da interação entre eles. Sob este prisma, verifica-se que os agentes de um determinado sistema complexo "aprendem" novas formas de interagir, ganhando experiência e revendo a todo momento a sua atuação. Essa abordagem permite assim observar que os significados são determinados pelas relações dinâmicas entre os agentes do sistema.

\section{II.1.1 A análise multissistêmica da língua}

Seguindo estes passos "multidirecionais", segundo a proposta de Castilho (2006a) a Lingüística multissistêmica deveria, então, preocupar-se em analisar as categorias como entidades não-lineares e não-estáticas, sendo multilineares e dinâmicas. Por este raciocínio, não seria possível "derivar categorias semânticas, gramaticais e discursivas umas de outras, pois elas convivem, e atuam em subsistemas dotados de dinâmica própria”. Esse procedimento tem um complicador que afeta a estratégia de análise: a análise pode começar por qualquer sistema, mas não deve deter-se num deles, ao contrário, deve-se evidenciar de que maneira Léxico, Discurso, Semântica e Gramática atuam um sobre os outros. Isso tem consequiências quanto ao procedimento metodológico de análise, pois torna-se assim multidisciplinar. Assim, a tarefa de descrever a mudança lingüística multissistêmica tma como base os processos constitutivos da lexicalização, da semanticização, da discursivização e da gramaticalização. Dessa forma, em termos práticos, os fenômenos lingüísticos que na abordagem tradicional da gramaticalização eram descritos em bloco, passam a ser estudados segundo esses quatro processos, sem estabelecer uma relação de precedência e hierarquia entre um e outro sistemas, de forma que muitas vezes é necessária a análise da interface entre um sistema e o outro, o que decorre do caráter multidirecional dos processos de mudança lingüística, nos quais pode haver ou não a saliência de um desses sistemas.

O sistema lingüístico exibe, portanto, os seguintes subsistemas: o Léxico, a Semântica, o Discurso e a Gramática. Nesta proposta, todos esses subsistemas são vistos como não interdependentes e compartilham processos sociocognitivos, organizados por estratégias conversacionais que merecem ser descritos na seção seguinte. 


\section{II.1.1.1 Os princípios sociocognitivos}

O dispositivo sociocognitivo é o princípio reitor que assegura a eficácia dos atos de fala. Ele é social porque está baseado na análise das situações que ocorrem num ato de fala e é cognitivo porque é prévio à execução lingüística. De acordo com ele, o falante ativa, reativa e desativa propriedades lexicais, semânticas, discursivas e gramaticais no momento da criação de seus enunciados de que resultam as expressões que são realizadas no ato da conversação. Esses três mecanimos foram identificados pelos pesquisadores do PGPF e foram incorporados por Castilho (2003, 2004 e 2006a e 2006b) em sua proposta de mudança lingüística e readaptados além dos limites do subsistema do Discurso, mostrando que essas estratégias são comuns aos demais sistemas do Léxico, da Semântica e da Gramática.

O princípio da ativação é o movimento mental de escolha das propriedades lexicais, gramaticais, semânticas e discursivas que se agruparão nos enunciados. Durante a interação o falante usa de um amplo leque de possibilidades de agrupamento das categorias e dos traços composicionais para construir a dimensão lexical, semântica, discursiva e gramatical dos enunciados. O produto dessa atividade resulta da escolha de propriedades que são tidas como inerentes aos itens lingüísticos ou que são construídas no momento da interação.

O princípio da reativação consiste no movimento mental por meio do qual o falante faz um rearranjo das propriedades lexicais, semânticas, discursivas e gramaticais. Este recurso é utilizado basicamente nas estratégias de correção e reformulação como a repetição e a paráfrase, de forma a eliminar os erros de planejamento durante o processo da conversação. Na Gramática o princípio de reativação promove a reanálise de sintagmas e de sentenças, acarretado mudanças da fronteira sintática.

O princípio da desativação é o movimento que resulta no abandono das propriedades lexicais, gramaticais, semânticas e discursivas dos itens (palavras ou enunciados) que estavam sendo ativados. Nesta perspectiva, o silêncio ganha um 
significado especial, assim como a estratégias de despreferência que consiste em verbalizar o que não é esperado, violando-se, assim, o princípio de projeção pragmática $^{284}$. Isso se verifica nos apagamentos, nas elipses, nos vazios pragmáticos gerados por conta de estratégias como responder uma pergunta com outra pergunta, recusar um convite, inserir pausas, reformular enunciados abandonando recursos sintáticos, semânticos, lexicais anteriormente utilizados.

Segundo o autor, estes princípios agem simultaneamente, de maneira nãoseqüencial, o que contraria o princípio da unidirecionalidade, reforçando a idéia de que a língua é um processo (enérgeia) e não um produto (érgon). Eles atuam, portanto, ao mesmo tempo nos diferentes subsistemas, através de processos como a lexicalização, a semanticização, a discursivização e a gramaticalização que geram os distintos produtos do Léxico, da Semântica, do Discurso e da Gramática. É o que veremos a seguir.

\section{II.1.1.2 Os processos e os produtos da língua como um multissistema}

Para Castilho (2006a), a Lexicalização é o processo de criação de itens lexicais a partir de "um conjunto de categorias e subcategorias cognitivas prévias à enunciação com base nas quais construímos os traços semânticos inerentes". A combinação desses traços gera a criação dos itens lexicais, que serão realizados na língua como um Nome, um Verbo, um Adjetivo, etc. As subcategorias desses elementos referem-se aos traços inerentes ou às propriedades intensionais dos itens lexicais.

O Léxico é considerado um conjunto de categorias cognitivas prévias à enunciação como PESSOA, OBJETO, ESPAÇO, TEMPO, VISÃO, MOVIMENTO, EVENTO, etc. Esta definição tem como pressuposto a idéia de que adquirimos o Léxico através de desses traços e da possibilidade de combiná-los em diferentes padrões. Castilho propõe que o Léxico é fruto de "um continuum que vai da cognição pré-verbal para a expressão verbal, da língua-enérgeia para a língua-érgon”. No

${ }^{284}$ Cf. Marcuschi (1983) apud Castilho (2006a). 
momento da interação o falante e seu interlocutor decidem como administrar o Léxico, ativando, desativado ou reativando as propriedades dos itens.

No processo da lexicalização a ativação se dá pelo movimento mental de escolha das categorias cognitivas e seus traços semânticos que serão agrupadas nas palavras. Através da relexicalização (reativação) rearranjamos as propriedades lexicais e as palavras que as representam. Quando palavras deixam de ser utilizadas ocorre a sua deslexicalização (desativação) e, normalmente, antes de a troca lexical ser definitiva ocorre a variação entre o item lexical que é abandonado e o item que passa a ser utilizado.

A Semanticização é o processo de criação, alteração e categorização dos sentidos. Esse processo inclui a semanticização léxica, a semanticização composicional e a semanticização pragmática. Nele estão envolvidas as estratégias cognitivas de emolduramento da cena com seus participantes e sua hierarquização, estabelecendo-se relações de Figura e Fundo na demarcação do objeto de referêcia, entre outras estratégias. Os mecanismos como a metáfora, a metonímia, a generalização atuam na alteração dos sentidos.

A Semântica é o subsistema em que se criam, alteram-se e categorizam-se os significados. Os estudos de Semântica tiveram desdobramentos em várias escolas: (1) a Semântica Cognitiva, que se preocupa com a alteração de significado, procurando verificar como (a) enquadramos os participantes através de frames, scripts e cenários, (b) como estebelecemos relevos e hierarquizamos os participantes da cena ao propor perspectivas, evidenciar escopos, e distribuir os eventos através de estratégias de figura / fundo, (c) como "estabelecemos e combinamos espaços mentais", (d) como incluímos, excluímos ou facalizamos os participantes da cena, (e) como movimentamos os participantes de maneira real ou fictícia, e (f) como mudamos nossa visão sobre os participantes através da metáfora, da metonímia, da especialização e da generalização ${ }^{285}$; (2) a Semântica Composicional, que se ocupa das alterações de significado a partir de processos metonímicos do intercâmbio de propriedades de itens, também chamado de Semântica Sintática; (3) a Semântica Lexical, que investiga a dêixis e a foricidade, a referenciação, a predicação e a conexão, e (4) a Semântica Pragmática, que estuda a criação de significados em

${ }^{285}$ Cf. também Talmy, 2001. 
função da interação entre os locutores e sua relação com os itens lingüísticos e lida com a inferência, a pressuposição, os atos performativos e a implicatura conversacional.

A semanticização (ativação) consiste na criação dos significados de que resultam as categorias da dêixis/foricidade, da referenciação, da predicação, da verificação e da conexidade. A ressemantização (reativação) representa a readequação dos significados à representação dos objetos e eventos. A dessemantização (desativação) é decorrente das alterações de sentido provocadas pela metáfora, pela metonímia, pela generalização e pela especificação, pelas quais "silenciamos" o sentido anterior e simultaneamente ativamos novos sentidos.

A Discursivização consite no processo de criação do texto, resultado de um conjunto de atividades de negociação conversacional no qual estão envolvidos o locutor e o interlocutor e através das quais “(i) se instanciam as pessoas do discurso e se constroem suas imagens, (ii) se organiza a interação através da elaboração do tópico conversacional (...), (iii) se organiza essa interação através dos procedimentos de correção sociopragmática, (iv) se abandona o ritmo em curso através de digressões e parânteses (...), e (v) se estabelece a coesão textual por meio de expedientes vários". $\quad \mathrm{O}$ Discurso é aqui entendido como uma estrutura acabada na qual se podem identificar unidades ${ }^{286}$ e também é conversação, ou interação lingüística presencial que inclui o locutor, o interlocutor e o tema ${ }^{287}$. O produto da Discursivação é o texto e também sua ordenação em gêneros discursivos. Ele é resultado da organização das unidades discursivas, dos processos de reformulação do quadro tópico, da descontinuação tópica e da estratégias de conexão textual. Nele estão presentes as pessoas do discurso e a imagem que se constrói de ambos, elabora-se o quadro tópico do evento conversacional, que é organizado por processos de correção sociopragmática ou através de estratégias como o abandono e a reativação de tópicos através de digressões e parênteses, gerando novos tópicos discursivos e quando se estabelece coesão textual por meio de estratégias diferenciadas. A Teoria do Discurso teve seus desdobramentos através das

\footnotetext{
${ }^{286}$ Cf. Propp e Labov-Waletzki apud Castilho (2006 $)$ : Labov, W., \& Waletzky, J. (1967). Narrative analysis: Oral versions of personal experience. Pp. 12-44 in J. Helm (Ed.), Essays on the verbal and visual arts. Seattle, WA: University of Washington Press. Classic work focused on the importance of evaluative statements in first-person narratives.

${ }^{287}$ Cf. Sacks-Schegloff-Jefferson (1972) apud Castilho, 2006a.
} 
disciplinas como a Retórica, a Análise do Discurso, a Análise da Conversação e a Lingüística de Texto.

A discursivizaçãa (desativação) promove a seleção de palavras necessárias à hierarquização dos tópicos e à construção das unidades discursivas, enquanto a rediscursivização (reativação) abre caminho à repetição, correção e paráfrase dos anunciados que asseguram a coesão do texto. A desdiscursivização (desativação) é o abandono da hierarquia tópica com estratégias como parênteses e digressão.

A Gramaticalização é o conjunto de alterações fonológicas (fonologização), morfológicas (morfologização) e sintáticas e funcionais (sintaticização).

A Gramática é entendida como o subsistema onde se analisam "as estruturas em processo de cristalização" organizadas em três subsistemas: a Fonologia, que estuda os itens fônicos, a Morfologia, que se ocupa da estrutura da palavra, e a Sintaxe que lida com as estruturas sintagmática e funcional da sentença. Os produtos da Gramática são as categorias gramaticais como o fonema, a sílaba, o morfema, a palavra, o sintagma, e a sentença.

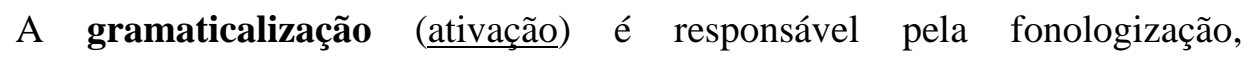
morfologização, sintaticização, ordenação dos constituintes, concordância e organização da estrutura argumental. A regramaticalização (reativação) é a reformulação das construções através de reanálise, como a mudança das fronteiras entre constituintes, o redobramento sintático, entre outros. $\mathrm{O}$ processo da desgramaticalização (desativação) é responsável pelo surgimento da categoria vazia na gramática das línguas.

Resumidamente, essa proposta adota como estratégia o recurso da análise de cada subsistema separadamente de modo a observar os fenômenos lingüísticos a partir da saliência de um ou de outro subsistema, evitando, desta forma, regras de determinação e dependência entre os mesmos. 


\section{II.1.1.3 Contribuições da abordagem multissistêmica à análise do gerúndio}

Para esta tese, importam os subsistemas do Discurso, da Semântica e da Gramática, e aqui mais especificamente o da Sintaxe do gerúndio. Pela análise do processo de discursivização do gerúndio pretende-se ressaltar os mecanismos de textualização do gerúndio, ou seja, de sua incorporação ao quadro dos gêneros discursivos, bem como as estratégias de ativação e rediscursivização inerentes à utilização do gerúndio como item que participa da organização dos quadros tópicos.

No subsistema da Semântica, a semanticização do gerúndio será estudada como um processo que envolve o emolduramento dos participantes e dos eventos de um determinado cenário, atuando aí como elemento que serve para demarcar o relevo (Travaglia, 2006) e a tematização (Koch, 2006). Além disso, será tópico desse capítulo o estudo das relações proposicionais envolvidas nas construções adverbiais, relativas e coordenadas, mostrando a ambigüidade semântica que é inerente às construções gerundivas.

No módulo da Gramática, será estudado o processo de sintaticização do gerúndio na constituição de orações adverbiais e relativas, além de outros recursos como sua utilização em perífrases e construções imperativas. Em especial, estuda-se nesse capítulo a flutuação categorial que as construções gerundivas exibem em determinadas orações que sintaticamente apresentam-se como ambíguas, entre oração adverbial e adjetiva. 


\section{II.2 O modelo das Tradições Discursivas}

"La lengua misma no es una obra (ergon) sino una actividad (energeia). Por eso su verdadera definición no puede ser sino genética. Pues ella es el siempre reiniciado trabajo del espíritu de volver el sonido articulado capaz de expresar la idea." Humboldt (1990 [1836]:65) ${ }^{288}$

\section{II.2.2.1 O conceito de linguagem segundo Coseriu}

O conceito de que a linguagem é fruto de uma capacidade adquirida geneticamente pelo homem para expressar-se foi adotado por Coseriu em seu livro Sprachkompetenz (Coseriu, 1988) e está baseado nas observações feitas por Humboldt (1990 [1836]) e Gabelentz (1972 [1891] apud Loureda, 2006:1). Coseriu define a linguagem como

una actividad humana universal que es realizada individualmente en situaciones determinadas por hablantes individuales como representantes de comunidades lingüísticas con tradiciones comunitarias del saber hablar (Coseriu, 1992:80ff apud Loureda, 2006:1).

Assim, o ato de falar é uma atividade universal, comum a todos os homens; também é histórica, pois quem fala emprega, pelo menos uma língua; e é individual porque quem fala é um indivíduo e porque tem lugar em um entorno determinado (Loureda, 2006:1).

Nesse mesmo estudo a respeito da competência lingüística, Coseriu procura acomodar as descobertas do cours de Saussure ao seu modelo de análise, e propôs algumas representações gráficas (quadros 3, 4 e 5) de forma a ilustrar como a asserção inicial de Humboldt pode ser incrementada com as de Saussure:

\begin{tabular}{|l|c|c|c|c|}
\hline & \multicolumn{2}{|c|}{ Atividade } & Conhecimento & Produto \\
\cline { 3 - 5 } Falar em geral & pa & & & \\
\hline Língua particular & & & langue & \\
\hline Discurso/Texto & & role & & \\
\cline { 2 - 4 } & & &
\end{tabular}

Quadro 3. O níveis da língua segundo Coseriu (1988:73)

\footnotetext{
288 Tradução do original em alemão: "Man muss die Sprache nicht sowohl wie ein todtes Erzeugtes, sondern weit mehr wie eine Erzeugung ansehen (...). Sie selbst ist kein Werk (Ergon), sondern eine Thätigkeit (Energia). Ihre wahre Definition kann nur daher eine genetische sein. Sie ist nämlich die sich ewig wiederholende Arbeit des Geistes, den articulirten Laut zum Ausdruck des Gedanken fähig zu machen.” (Humboldt, 1963 [1836]:416-418)
} 
O quadro 4 revela que a cada nível da língua cabe uma atividade específica. Ao nível universal se atribui a atividade do falar em geral; ao histórico, a língua em particular, o registro específico de que faz uso o falante, e no plano individual é onde se concretizam os textos ou o discurso.

\begin{tabular}{|c|c|c|c|}
\hline & Atividade & Conhecimeno & Produto \\
\hline Falar em geral & \multirow{3}{*}{ Performance } & & \\
\hline Língua particular & & Competence & \\
\hline Discurso/Texto & & & \\
\hline
\end{tabular}

Quadro 4. Os níveis da língua segundo Coseriu (1988:74)

Por outro lado, o quadro 5 revela que cada uma dessas atividades baseia-se em saberes ou compentências distintas: o saber falar em geralé um saber elocucional; o saber expressar-se em uma língua específica é um saber idiomático e o saber elaborar textos adequados às situações específicas, de acordo com os temas e os interlocutores é o saber expressivo:

\begin{tabular}{|l|c|c|c|}
\hline Nível & \multicolumn{3}{|c|}{ Ponto de vista } \\
\hline & $\begin{array}{c}\text { Atividade } \\
\text { (energeia) }\end{array}$ & $\begin{array}{c}\text { Conhecimento } \\
\text { (dinamis) }\end{array}$ & $\begin{array}{c}\text { Produto } \\
\text { (ergon) })\end{array}$ \\
\hline nível universal & falar em geral & competência elocucional & totalidade dos enunciados \\
\hline nível histórico & $\begin{array}{c}\text { língua particular } \\
\text { concreta }\end{array}$ & competência idiomática & (língua particular abstrata) \\
\hline nível individual & discurso & competência expressiva & texto \\
\hline
\end{tabular}

Quadro 5. Os níveis universal, histórico e individual da língua segundo Coseriu (1988:75)

Estas considerações de Coseriu são o pano de fundo para o que veio chamarse de tradições discursivas. A partir destes raciocínios Eugenio Coseriu (1992: 103 apud Loureda, 2006) afirma que os textos podem decorrer de suas próprias tradições, sendo, portanto, independentes dos idiomas em particular, como é o caso dos provérbios e de determinadas fórmulas fixas como cumprimentar, fórmulas religiosas ou específicas de determinada tipologia textual, como é o caso da tradição jurídica (Loureda, 2006:5).

A Linguística Textual deu origem a diferentes correntes de análise da textualidade: 1) a textualidade a partir dos elementos lingüísticos que aparecem em cada texto; 2) a textualidade a partir dos elementos do conteúdo temático e de sua macroestrutura (textos descritivos, técnicos, argumentativos, etc); 3) a análise do 
texto segundo a sua inserção situacional e, por último, 4) a análise do texto segundo a sua funão ou finalidade comunicativa, decorrente de sua ilocução dominante (Kabatek, 2004:2).

A esses campos de estudo aliaram-se durante a década de 80 os estudos que combinavam diferentes aspectos da lingüística variacional e da pragmática. Em Tübingen, com o trabalho de Brigitte Schlieben-Lange (1983 e 1993 apud Kabatek 2004), uma das alunas de Coseriu, iniciou-se a proposta de uma "pragmática histórica" através de um estudo que "relacionava a discussão sobre a oralidade e 'escrituralização' com uma visão histórica e ofereceu assim o fundamento para o que mais tarde se chamaria o estudo de TD" (Kabatek, 2004:3). Desde então, o conceito veio sendo ampliado e reformulado por pesquisadores como Peter Koch (1997) e Wulf Oesterreicher (1997).

\section{II.2.2.2 A ampliação da noção de tradições discursivas segundo Peter Koch}

No modelo de interpretação da linguagem humana em três níveis proposto por Coseriu, Peter Koch reconhece uma nova subdivisão que afetaria o nível histórico. Segundo Koch, esse nível precisaria ser subdividido em dois: o nível histórico das línguas em particular (alemão, francês, inglês, português) e o nível histórico das tradições discursivas - estas compreendem os gêneros textuais, estilos, gêneros retóricos, atos de fala, etc.:

"Dito de outra maneira, pode-se dizer que a atividade do falar, com uma finalidade comunicativa concreta, atravessaria dois filtros concomitantes até chegar ao produto do ato comunicativo ou enunciado: um primeiro filtro correspondente à língua e um segundo, correspondente às tradições discursivas" (Kabatek, 2004:3)

\begin{tabular}{|l|l|l|l|}
\hline \multicolumn{1}{|c|}{ Nível } & \multicolumn{1}{|c|}{ Domínio } & \multicolumn{1}{c|}{ Tipo de Norma } & \multicolumn{1}{c|}{ Tipo de Regra } \\
\hline universal & $\begin{array}{l}\text { competência } \\
\text { lingüística }\end{array}$ & & regras da linguagem \\
\hline histórico & língua particular & normas lingüísticas & regras da língua \\
\hline histórico & tradição discursiva & normas discursivas & regras discursivas \\
\hline individual/atual & discurso & & \\
\hline
\end{tabular}

Quadro 6. O redobramento do nível histórico da língua segundo Koch (1997

Segundo esse paradigma, ao analisarmos a tradição do soneto em várias línguas, por exemplo, podemos observar no nível histórico algumas convergências 
do ponto de vista formal (o número de estrofes, a ocorrência de rimas) e do ponto de vista do conteúdo (o tema do amor segundo a concepção dos trovadores). No nível histórico das línguas em que foram escritos, podemos verificar uma adaptação desses complexos formais e de conteúdo de acordo com as regras das normas lingüísticas específicas de cada língua. Embora também o léxico denotre evocações de uma língua para outra, também este domínio é afetado, pois está submetido às regras da morfologia da língua em particular, assim como os fenômenos sintáticos e fonológicos.

Kabatek (2006) propõe o seguinte esquema para compreender essa reduplicação do nível histórico:

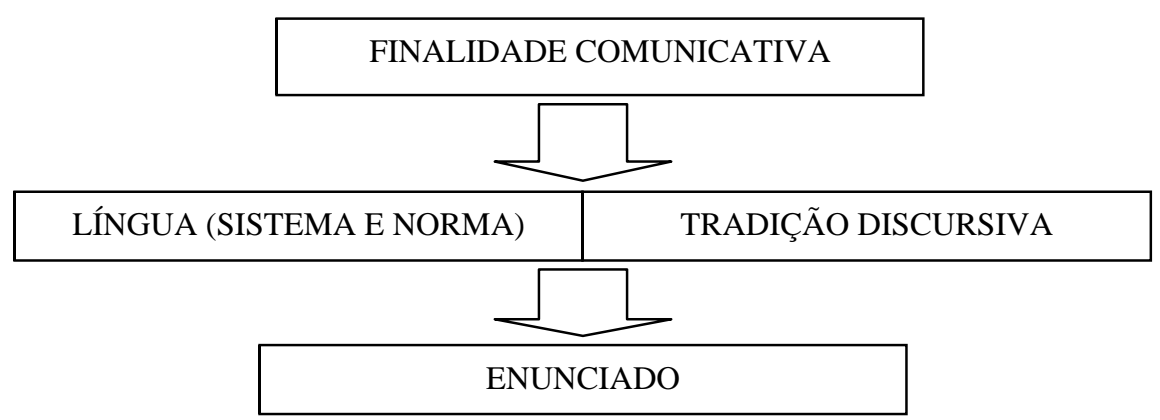

Figura 1. A reduplicação do nível histórico (Kabatek, 2004)

Para Koch (1997), é preciso diferenciar o domínio das tradições discursivas dos outros complexos da língua pelos seguintes motivos:

\section{(i) Tradição discursiva vs. Língua Particular}

Quando se analisa a realização de um gênero textual X dentro de uma língua específica, se é que se entende um gênero textual como uma forma de tradição discursiva, é preciso levar em conta que mesmo que esse gênero $\mathrm{X}$ só ocorra em francês, ainda assim haverá microestruturas que serão evocações de outras tradições discursivas que não são necessariamente exclusivas da comunidade lingüística que fala francês. Nesse sentido é preciso também diferenciar as assim chamadas 
variedades diastráticas, pois nem sempre os falantes se comunicam na sua variedade lingüística específica, principalmente quando grupos de estratos distintos interagem, como é o caso dos falantes de língua dos jovens e os falantes de alguma línguagem técnica.

\section{(ii) Tradição discursiva vs. Competência Lingüística}

Se de um lado as regras discursivas, juntamente como as regras de uma língua particular, representam grandezas históricas, por outro lado, as regras da linguagem têm um caráter mais universal. As regras discursivas definem a escolha dos atos de fala e de recursos textuais que darão forma aos gêneros textuais. As regras da linguagem abarcam grandezas universais do ato de falar. Nesse nível os falantes se submetem a condicionamentos do tipo oral vs. escrito, dialógico vs. monológico, hierarquia vs. horizontalidade entre os falantes, interlocutores conhecidos vs. interlocutores estranhos, ou caráter comunicativo vs. caráter apelativo vs. caráter expressivo, ou exposição descritiva vs. narrativa vs. dissertativa etc. Essas regras são constantes universais, enquanto que a definição de um conjunto de enunciados sob a etiqueta de gêneros textuais como notícia, palestra, soneto, canção, talkshow, sermão, carta remete a uma classificação que abarca o nível histórico em que foram sendo constituídos. Assim, podemos verificar que escolha de um gênero textual especifico é dependente das regras dos outros níveis da linguagem aqui definidos.

\section{(iii) Tradição discursiva vs. Discurso}

A explanação acima deve dar conta da diferenciação. Resta acrescentar que a “ligação a uma tradição discursiva ('Interdiscursividade') é orientada por regras (do discurso), o que não acontece com a alusão a discursos particulares ('Intertextualidade').” (Koch, 1997:54)

Koch define a importância da grandeza tradição discursiva no concerto dos quatro domínios da linguagem e sua importância para a) a literatura e a lingüística, b) para o estudo da oralidade e da escrituralização e, por fim, c) para a história da língua e o início do processo de escrituralização. 


\section{(iv) Literatura e lingüística}

Para a literatura é de suma importância diferenciar o discurso individual, a obra literária dentro do conceito das tradições discursivas, principalmente no que se refere à definição de correntes literárias, além disso importam para a análise literária as instâncias da comunicação e os modelos comunicativos básicos do homem (a épica, a lírica, o drama, a narração), etc. Segundo ele, o domínio da língua particular cada vez mais representa um material importante para a análise literária, mas não é um objeto de estudo per se.

Em contrapartida, para a lingüística, a língua particular são o objeto de análise mais importante. Nos últimos 200 anos desenvolveram-se métodos de análise que diferenciam o estudo das línguas de outras disciplinas filológicas e humanistas.

Saussure dividiu conseqüentemente o complexo da langage em dois domínios claros: a langue e a parole. A lingüística tomou para si como objeto de estudo a langue. A partir dos anos 70, com a abertura nos estudos da linguagem, desenvolveram-se disciplinas como a Lingüística de Texto e a Pragmática, as quais se podem ser consideradas uma lingüística da parole. No entanto, Koch discute o que poderia ser a parole dentro desse esquema.

Segundo Saussure a parole deveria ser equiparada ao domínio do discurso proposto por Koch, ou seja, ao nível individual de atualização dos textos. No entanto, “a lingüística é uma ciência cujo objeto de estudo não são os produtos isolados da atividade humana (obras), e sim conhecimento de regras às quais essa atividade está submetida"(Cf. Humboldt apud Koch, 1997:55). Assim, a lingüística deve interessarse pelo material que dá pistas sobre como o conhecimento de regras atua sobre os outros níveis da linguagem (o conhecimento das regras da linguagem, o conhecimento das regras das línguas, o conhecimento das regras do discurso). Nesse sentido, não pode haver uma linguiística somente do discurso.

Para Koch, o que se vê no curso de Saussure como linguistique de la parole se reduz a uma linguiística da competência lingüística ou das tradições discursivas e reconhece que tanto a Lingǘstica de Texto como a Pragmática se apresentaram 
como disciplinas da lingüística que tentaram fazer esta descrição, mas sem fazer uma distinção clara entre os domínios da competência linguiística e das tradições discursivas (Koch, 1997:56). Ele lembra ainda que ao fazer isto, estas disciplinas se referem às linguas particulares, mas não seus fenômenos não são puramente lingüísticos no sentido de lidarem com os fenômenos lingüísticos específicos de uma língua em particular. Em função disso, essas disciplinas apresentam uma disponibilidade clara para associar-se aos estudos realizados por disciplinas afins. $\mathrm{O}$ domínio da competência lingüística apresenta interlocução com disciplinas como a psicologia, a sociologia, a semiótica, a lingüística cognitiva, a antropologia, a filosofia, a fonética etc. O domínio das tradicões discursivas, por outro lado, necessita da cooperação de disciplinas como a análise literária, a musicologia, a retórica, a história da cultura, a diplomática, a história da economia, do direito, da igreja, etc., uma espécie de interdisciplina.

Assim, o que antes era específico de um domínio específico do conhecimento passa a ser admitido como objeto de estudo de outras disciplinas. Por esta perspectiva, afirma-se que o estudo das tradições discursivas pode influenciar o estudo da literatura, e exemplifica isso citando o fato de que os estudiosos da literatura trovadoresca de tradição romanística não podem deixar de lado os textos medievais alemães que lhes correspondem. Por este raciocínio, para a análise literária o estudo das tradições discursivas vai além do conhecimento a respeito da língua em particular.

Da mesma forma para a lingüística é essencial que o romanista que trabalha com diacronia deva compreender que o seu campo de trabalho está delimitado pelo critério das línguas particulares. A língua particular, portanto, está acima da tradição discursiva.

\section{II.2.2.2.5 Oralidade e escrita}

Para Koch (1997), no domínio do discurso podem ser reconhecidas duas variáveis independentes: o mediático e o conceitual. Toda tradição discursiva tem um "perfil” mediático, p. ex., small talk (fônico), um rol de leis (gráfico), uma palestra científica (graficamente fixada, mas realizada fonicamente através da leitura) 
e assim por diante. Ao mesmo tempo, toda tradição discursiva é basicamente conceitual, ou seja, podemos ordená-la a um contínuo de distância e proximidade que independe do seu perfil mediático, seja ele fônico ou gráfico.

$\mathrm{O}$ autor defende que os dois conceitos podem ser claramente divididos e exemplifica: quando se lê em voz alta um artigo jornalístico o seu valor mediático não muda, ou seja, ele permanece um artigo jornalístico. No entanto, uma entrevista gravada e diferente de uma entrevista reproduzida num jornal, ou seja, são duas tradições discursivas diferentes, que não só se diferenciam pelo seu caráter mediático como pelo seu valor de conceitual.

\section{II.2.2.2.6 A história da língua e o início da escrituralização}

A história da língua é a história de uma língua particular. Porém, desde Gabelenz (1891 apud Koch 1997) sabe-se que é preciso reconhecer a história interna e a história externa da língua. Enquanto uma refere-se às mudanças de fatos de uma língua particular (mudanças fonéticas, sintáticas e lexicais), a história externa das línguas leva em conta eventos extra-lingüísticos relevantes para a história de uma língua em particular, tais como eventos histórico-políticos, econômicos, culturais, religiosos. No Brasil, a mudança da corte para o Rio de Janeiro, a busca pelo ouro, a fundação da faculdade de Direito em Olinda e São Paulo definem marcos importantes da história externa do português brasileiro.

A afirmação de Peter Koch quando diz que não há uma ligação clara entre as mudanças que se processam no interior das línguas e a história externa das mesmas $^{289}$, parece-me no mínimo discutível e contraditória com as afirmações anteriores. No entanto, parece adequado quando ele diz que mudanças no campo político, econômico, cultural e religioso podem despertar novas necessidades comunicativas. Quando isto acontece, aparecem novas tradições discursivas. Segundo Koch, o material lingüístico de uma língua específica que aí aparece pode sofrer algumas modificações, modificando assim, de alguma forma, o nível histórico da língua em particular e a história interna dessa mesma língua. Por isso, entende-se

\footnotetext{
289 "nun besteht zwischen dem internen Wandel und den externen Ereignissen eigentlich gar keine unmittelbare Verbindung (außer in Fällen gezielter Sprachpolitik)“ (Koch, 1997:57)
} 
as tradições discursivas como o verdadeiro elo de ligação entre a história interna e a história externa de uma língua.

No que se refere ao processo de escrituralização das línguas românicas, Koch lembra os trabalhos da romanística de Freiburg que analisaram os princípios da escrita nas línguas românicas. Esses especialistas identificaram que nos estágios primevos da escrita a preocupação desses que escreviam não era primordialmente a de se preocupar com um registro segundo as normas de uma língua em particular. Mais do que isso, eles procuravam adaptar o seu domínio de conhecimento seguindo esquemas, tradições discursivas que foram sendo adquiridas de outras comunidades. Imagino que ele se refira, por exemplo, ao caráter híbrido desses documentos, como é o caso dos forais da Península Ibérica. As traduções do espanhol para o português dos textos de Afonso X, como o Foro Real, por exemplo, se preocupavam mais com a eficiência por razões comunicativas e de tradição discursiva do que com a pureza do registro na língua em particular. Imagino que isso possa se aplicar ao grupo do PHPB quando analisamos textos de diferentes estágios de aquisição do português no Brasil. Por analogia, entendo que é preciso ter consciência do processo de escrituralização do português brasileiro nas diferentes fases de sua história externa, tal como é o caso do processo da relatinização das línguas românicas que certamente afeta o PB e mais especificamente por conta das várias ondas de imigração portuguesa que desencadearam processos de relusitanização do $\mathrm{PB}$, sem falar é claro nos outros contatos lingüísticos decorrentes da escravatura, do aprisionamento de índios, da imigração de novos conquistadores ao longo dos últimos cinco séculos. No que tange às tradições discursivas, é preciso levar em conta que contornos de tradição foram trazidos para cá nas várias épocas e em que medida podemos reconhecer isso na documentação histórica depositadas nos arquivos do país, quer seja ela constituída de cartas mais ou menos oficiais, memórias históricas, sermões religiosos impressos ou manuscritos.

Para retomar Koch (1997:58), que vou seguindo ao longo de toda esta seção, da mesma forma que é possível visualizar a constituição das línguas românicas como entidades autóctones através de seu processo de escrituralização. Seria possível resgatar aspectos da mudança interna do português brasileiro tanto em oposição a si mesmo como em oposição ao português europeu, se levarmos em conta os elementos que afetam o nivel histórico das tradições discursivas. Em resumo e a título de 
exemplo, seria perguntar-se em que medida a ocorrência de traços de uma linguagem jurídica em documentação epistolar oficial transmutou-se de um entorno meramente oficial para o um contexto mais próximo da oralidade, mesmo que ainda em estágios iniciais do processo de mudança esses mesmos índices ainda dessem conta de uma certa distância comunicativa?

Koch reconhece assim o domínio das tradições discursivas como uma grandeza que, juntamente com os outros três níveis, integra o contínuo pelo qual se pode fazer uma análise adequada da língua.

\section{II.2.2.3 A historicidade das tradições discursivas}

Koch (1997) alerta ainda que na literatura procura-se definir as correntes literárias através da ocorrência de um conjunto de características constantes e tendencialmente conservadoras, o que faz crer que há uma estabilidade relativamente alta dessas constantes através do tempo. No entanto, do ponto de vista das tradições discursivas, pode-se perceber que estas convenções nem sempre se dão de maneira tão linear e fixa. Aqui poderíamos aludir o conceito de familiaridade de Wittgenstein (1953, §§ 66-71 apud Koch, 1997) e ao conceito de prototipicidade que foi posteriormente postulado pela psicologia cognitiva. O modelo abaixo, proposto por Koch, é a tentativa de representar esse idéia:

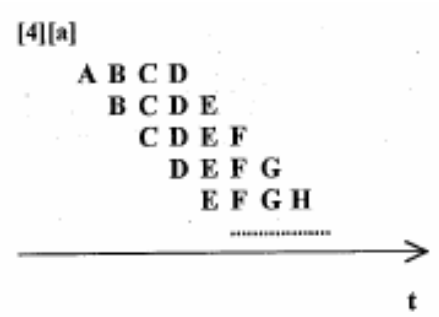

Figura 2. O contínuo de filiação das tradições discursivas (Cf. Koch, 1997:60)

Nessa representação vê-se o contínuo da filiação de uma tradição discursiva, sendo que em um estágio mais avançado da evolução de uma TD [EFGH] ela já não corresponda ao conteúdo da TD $[\mathrm{ABCD}]$ que lhe serviu de modelo. 
Os modelos, no entanto, parecem não dar conta da complexidade da dinâmica das tradições discursivas, seja por processos de extensão ou restrição, quer seja por transposições metonímicas ou metafóricas. Assim, para simbolizar essa dinâmica de transformação, Koch (1997:61-69) apresenta outras possibilidades de representação que passo a descrever.

\section{II.2.2.4 As tradições discursivas como tradições culturais entre conservadorismo e dinamismo}

A prática da linguagem no nível das tradições discursivas oscila entre a convenção e a inovação. Koch compreende que, para que se compreenda a problemática envolvida, é preciso levar em conta que as TDs na verdade são um tipo específico entre as mais distintas tradições culturais da humanidade e que apresentam semelhanças com a tradição das artes plásticas, da música, da gastronomia, do esporte, da religião etc. Ou seja, da mesma forma que qualquer uma das tradições culturais pode mudar de acordo com os condicionamentos impostos por necessidades práticas, o mesmo pode acontecer com as TDs da linguagem. Ao final de seu texto, Koch afirma que seria preciso adotar uma teoria dos universais das TDs que se inclua em uma ampla teoria das tradições culturais.

Para entender-se a dinâmica de transformação das TDs Koch formula alguns postulados e condicionamentos que operam sobre a evolução dos bens culturais:

(a) Tradições culturais nunca emergem ex nihilo;

(b) Quando surge uma nova tradição cultural ou uma nova TD é preciso sempre contar com um certo conservadorismo;

(c) Características conservadoras de uma tradição cultural podem perder sua função e em alguns casos podem ser estetizadas, ou melhor, serem reelaboradas como recursos estéticos;

(d) A inovação ocorre através da diferenciação de tradições culturais;

(e) A inovação ocorre através da mistura de tradição culturais;

(f) A inovação ocorre através da convergência de tradições culturais;

(g) Tradições culturais podem extinguir-se. 
Vamos ver o que continua a nos dizer Peter Koch (1997) neste seu texto tão importante para o estudo das tradições discursivas.

\section{(a) Tradições culturais nunca emergem ex nihilo}

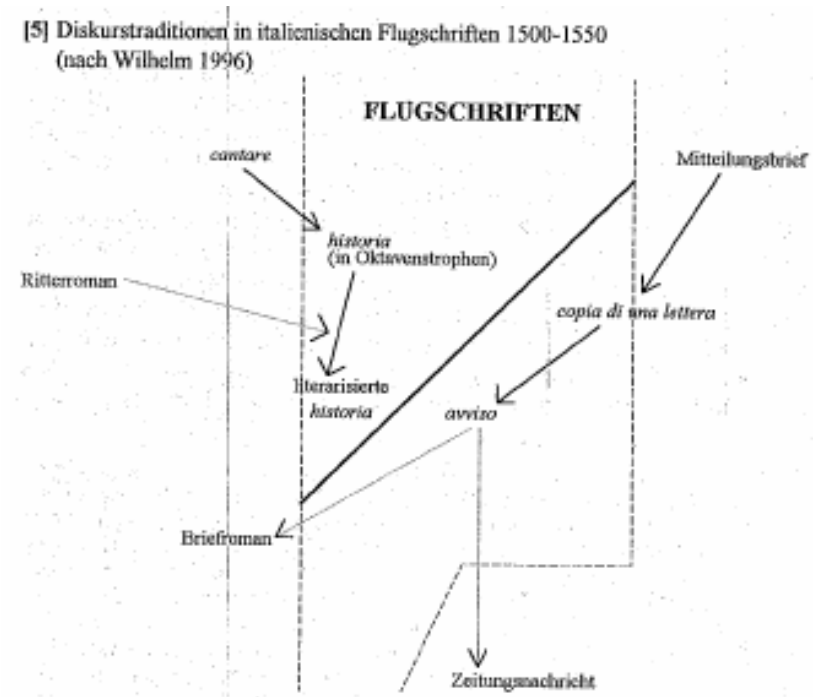

Figura 3. Tradições discursivas nos panfletos [Flugschriften] italianos de 1500-1500 (Wilhelm, 1996 apud Koch, 1997:63)

Os estágios de mudança nem sempre são tão nítidos. Para exemplificar através de uma analogia com o campo da estética técnica, Koch mostra que ao longo da história dos carros, o seu design veio sendo tão modificado que hoje não reconhecemos em um carros esportivo a sua origem como carruagem.

Para ilustrar como isso se dá na linguagem, Koch exemplifica com o trabalho de Raymund Wilhelm (1996 apud Koch, 1997) sobre os panfletos italianos. Com o advento da imprensa ao final do século XV, na Itália os panfletos tornaram-se muito comuns. Apesar de sua moderna medialidade e recepção os primeiros panfletos refletiam tradições discursivas já definidas. Na primeira metade do século XVI surgem a historia (escrita em oitavas) e o avviso (escrito em prosa). Se de um lado a historia nada mais era do que uma reformulação do cantare, gênero musical que tradicionalmente era memorizado e que através de sua versão escrita, a historia, representava uma nova possibilidade de ganhar dinheiro; o avviso surgiu da cópia de uma carta informativa (copia de uma lettera). Pelo esquema acima pode-se verificar como a partir de distintas tradições discursivas geram novas formas discursivas que 
culminaram em dois outros gêneros textuais: o romance epistolográfico e a notícia jornalística.

\section{(b) $\mathbf{O}$ conservadorismo de tradições culturais}

Para Koch, quando surge uma nova tradição cultural ou uma nova TD é preciso sempre contar com um certo conservadorismo, ou seja, nas novas tradições permanecem durante algum tempo determinados elementos constitutivos das tradições de base, mesmo que em termos de objetivos comunicativos estes itens sejam disfuncionais.

Para exemplificar com um exemplo estético, Koch lembra que o desenho circular do relógio surge para comportar o movimento dos ponteiros. Com o advento dos relógios digitais, apesar de poder ser adpatado para um modelo mais retilíneo, durante algum tempo a estética dos relógios arredondados permaneceu, somente recentemente o design destes relógios se modificou e ampliou. A mesma coisa pode ser observada com uma tradição discursiva do tipo notícia de jornal. O que no princípio era simplesmente a cópia de uma carta ou de relatórios, ao longo do tempo veio a transformar-se num gênero jornalístico. Assim, pode-se dizer que o avviso dos panfletos e pasquins italianos do século XVI poderia ser considerado um gérmen da tradição discursiva dos artigos jornalísticos. Em seu texto, Peter Koch faz considerações relevantes para aqueles que estudam a diacrônia dos gêneros jornalísticos, observando como ainda hoje é possível reconhecer em notícias impressas o caráter

Encontrei na Biblioteca Nacional de Lisboa (BNL) um documento interessante que confirma essa hipótese. Trata-se de um pasquim do século XVII, escrito no Maranhão pelo padre jesuíta Luis Figueira, que traz alguns elementos interessantes, os quais dão pistas sobre o surgimento dos textos jornalísticos portugueses e brasileiros. Essa carta notícia apresenta o seguinte título: 


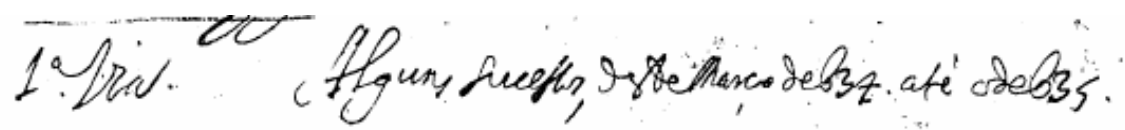

Figura 4. 1.a Via - Alguns sucessos, desde Março de [1]634 até ode[1]635.(BNL, PBA 475 F $7075)^{290}$

O texto disposto em colunas mantém à esquerda os subtítulos do itens abordados na notícia:

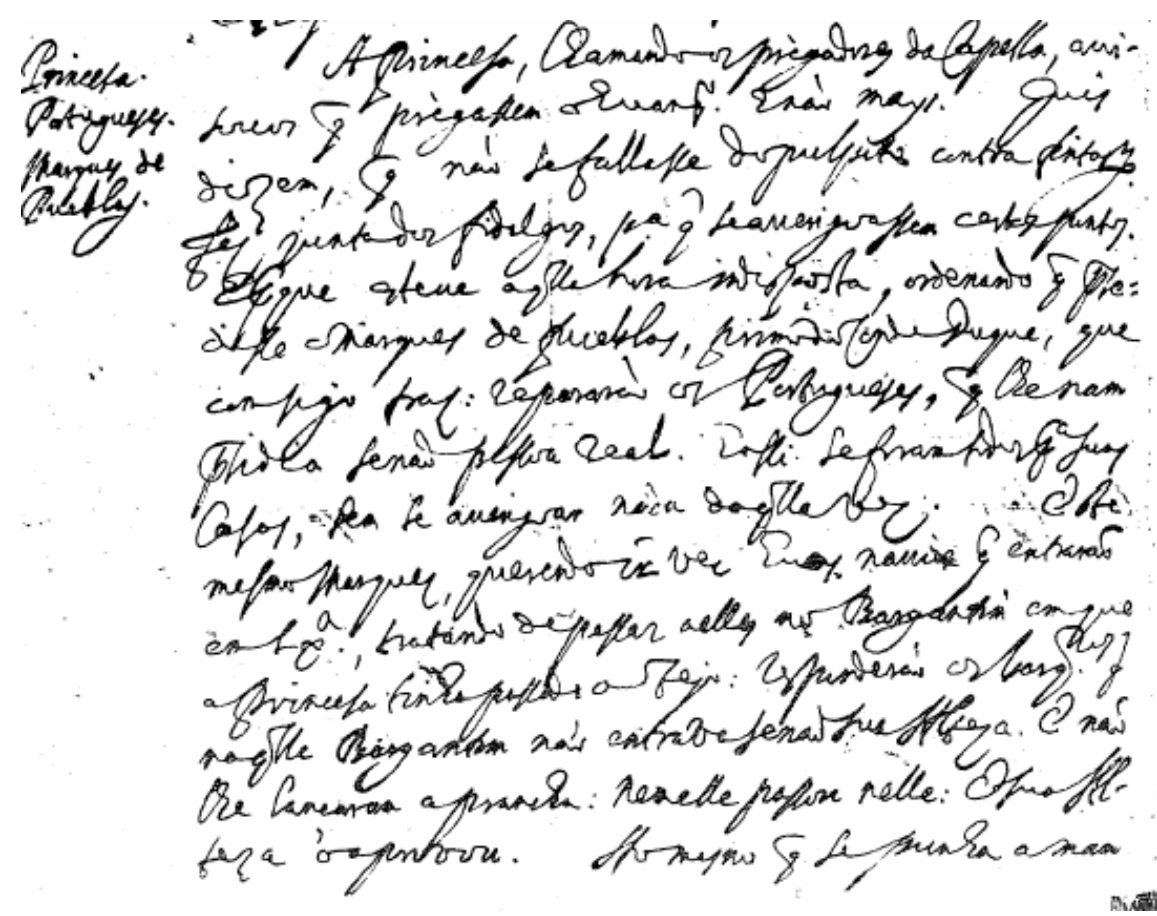

\begin{tabular}{|l|l|}
\hline Princesa & A princesa, chamando os pregadores daCapella, avi- \\
Portugueses & souos que pregassen [?] enão mays. Quis \\
Marques de & dizem, que naõ sefallasse dopulpito [?] \\
Quellus & fes junta dosfidalgos, para que seaveriguassem certos pontos.
\end{tabular}

Figura 5. Alguns sucessos, desde Março de [1]634 até ode[1]635.(BNL, PBA 475 F 7075)

O trecho seguinte exibe uma outra disposição das informações. As novas do reino aparecem como um lead de notícias jornalísticas. Peter Koch atribui este a textos dessa natureza a fonte do recurso posteriormente utilizado nos jornais.

${ }^{290}$ Manuscrito da Biblioteca Nacional de Lisboa: BNL, PBA 475 F 7075, Maranhão [?], Padre Luis Figueira [?], Relação de algumas cousas tocantes ao Maranhão e Grão-Pará, escrita pelo Padre Luis Figueira da Companhia de Jesus. 


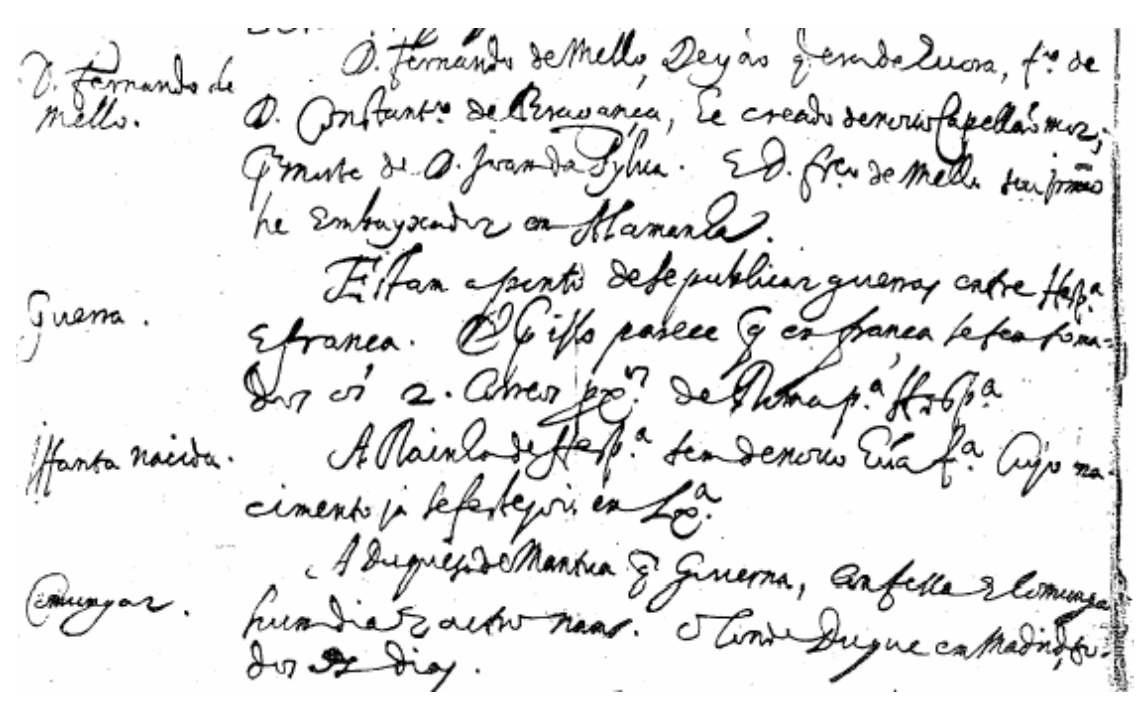

\begin{tabular}{|l|l|}
\hline Guerra. & $\begin{array}{l}\text { Estam aponto desepublicar guerras entre Hespanha } \\
\text { Efrança. \& [?] isto parece que enfrança sefes }\end{array}$ \\
\hline Infanta nacida & $\begin{array}{l}\text { A Rainha deHespanha teve denovo hûa filha cujo na- } \\
\text { cimento já sefestejou enLixboa. }\end{array}$ \\
\hline
\end{tabular}

Figura 6. Alguns sucessos, desde Março de [1]634 até ode[1]635.(BNL, PBA 475 F 7075)

\section{(c) A esteticização de recursos sem função em tradições culturais}

Características conservadoras de uma tradição cultural podem perder sua função e em alguns casos podem ser estetizadas, ou melhor, serem reelaboradas como recursos estéticos.

A música tem exemplos bem claros desse processo reformulação da tradição. Mas concentremo-nos em um exemplo literário. Nas sociedades em que a oralidade era o meio pelo qual se perpetuavam as tradições textuais os cantos e as epopéias eram marcados por elementos como assonâncias, rimas, ritmo e outros recursos ligados à musicalidade que ajudavam na memorização dos textos poéticos. Com a expansão da escrita em várias sociedades, essa característica vocal evoluiu de um recurso técnico para um recurso estético que perpetuou na produção poética.

\section{(d) A inovação ocorre através da diferenciação de tradições culturais}

No domínio das tradições discursivas podemos retomar o exemplo do avviso italiano que acabou se dividindo como gênero em duas novas correntes textuais: a notícia e o romance epistolar. Esse tipo de inovação fez surgir gêneros como as memórias históricas, os diários de viagem ou de navegação que atendem uma função 
político-administrativa do colonizador. Essa inovação foi reinaugurada no Brasil por obras como a própria Carta de Pero Vaz de Caminha e mais tarde o diário de viagem de Pero Lopes (1530), ao descrever a viagem que fez com seu irmão, o donatário Martim Afonso.

\section{(e) A inovação ocorre através da mistura de tradição culturais}

O mundo da música tem exemplos inumeráveis deste tipo de inovação na mixagem de variados estilos e escolas musicais.

No século XIII aumentam no norte e no centro da Itália as comuni, grupos sociais mais elitizados que impõe uma demanda de discursos políticos. Durante a Idade Média, havia portanto uma hierarquização dos grupos sociais e a tradição dos discursos públicos generalizantes já não era mais vigente. Isso deu margem a que retóricos da alta Idade Média cultivassem a assim chamada ars dictandi que produziam discursos modelo. Tais textos estavam por um lado baseados na tradição das cartas e outros documentos da diplomática, o que lhes dava um caráter de distanciamento comunicativo muito grande, apesar de sua realização fônica através da leitura. Para suprir esta deficiência de interlocução com seus ouvintes, incorporaram-se a estes discursos elementos presentes em cartas oficiais do tipo dictamen tais como a exortação e a estrutura textual. Porém, este esquema constitutivo do texto baseado em salutatio - exordium - narratio - petitio conclusio era considerado muito rígido e, assim, uma nova tradição discursiva foi incorporada à nova tradição de discursos políticos: a tradição do sermão. Outras características substituíram os elementos mais rígidos: o salutatio foi substituído pelo pedido de atenção, por exemplo, e outros foram incorporados, tal como o elogio ao ouvinte (commendatio).

Estas considerações são de vital importância para o trabalho que apresenta nesta tese e serão retomadas mais adiante, uma vez que analiso de que forma houve interferência de tradições discursivas distintas na constituição dos diferentes gêneros, como é o caso das cartas brasileiras incorporadas ao corpus de análise desta tese. Retomo esta questão quando falo mais adiante a respeito da constituição de corpora diacrônicos do português brasileiro. 


\section{(f) A inovação ocorre através da convergência de tradições culturais}

Recentemente vivenciamos a inflação dos meios de comunicação de massa. A demanda pela atenção do público e a conseqüente guerra pela audiência obrigou às emissoras de televisão a readaptar a sua grade de programas. Daí o surgimento daquilo que Peter Koch chama de Info-tainement, uma evolução que converge duas tradições distintas de comunicação: a informação e o entretenimento. Assim, não é raro encontrar hoje em dia programas televisivos que incorporam características de uma e de outra tradição. No Brasil, imagino que seria interessante pesquisar do ponto de vista da tradição discursiva o surgimento dessa nova modalidade de programa jornalístico que insiste na divulgação do topos da violência urbana através de um modelo discursivo baseado em elementos dos gêneros textuais da tradição do entretenimento.

\section{(g) Tradições culturais podem extinguir-se}

O gênero historia dos panfletos italianos de que fala Raymund Wilhelm (1996) é um exemplo do desaparecimento de uma tradição discursiva. Escrito em estrofes de oito versos, esse gênero textual foi abandonado como instrumento de divulgação da notícia, uma vez que essa característica vocal perdeu sua função mnemônica em razão da ampla divulgação das notícias através de textos manuscritos e impressos.

Em suas conclusões, Peter Koch afirma que é necessário que se faça uma distinção entre o domínio das tradições discursivas dos outros domínios da linguagem, principalmente no que se refere ao domínio das línguas em particular. Ele insiste que é preciso ter em mente que as tradições discursivas se relacionam com o lingüístico, mas que este domínio não é exclusivamente lingüístico, pois incorpora o elemento cultural que transcende o escopo de uma língua particular.

\section{II.2.2.5 A definição do conceito de tradições discursivas}

Muitas têm sido as tentativas de definir o conceito de TD. Alguns autores concentram-se no domínio histórico dos quatro níveis da linguagem constante da proposta de Coseriu (1987 [1980]), tal como o fazem Peter Koch (1997) e 
Oesterreicher (1997). Kabatek (2006) propõe em seus textos que se entenda o conceito de tradições discursivas como um modelo de análise lingüística que transcende o próprio domínio proposto por Coseriu, pois crê que esse nível estabelece um elo de ligação entre os demais domínios. As setas do esquema citado denunciam essa proposta. Para definir o que são as TDs parte do material composicional desses elementos, recusando a crítica de que quando se fala em TD está-se falando exclusivamente de gêneros discursivos:

"Uma primeira abordagem poderia entender então as TD como modos tradicionais de dizer as coisas, modos que podem ir desde uma fórmula simples até um gênero ou uma forma literária complexa. Agora, precisamente por essa relação entre as TD e os gêneros, tem-se entendido em alguns trabalhos como sinônima a noção de TD com a de gênero. Mas se fosse assim, o próprio termo TD não seria mais do que um substituto para algo já estudado à exaustão pela lingüística de texto.” (Kabatek, 2004:4)

Kabatek (2004:5) explica o conceito de TD enumerando alguns traços definidores:

- Um desses traços seria a relação que um texto estabelece em um determinado momento da história com outro texto ou textos anteriores. Nessa relação temporal surge então o fator repetição como um desses traços. Alerta que a repetição pode referir-se a um ou mais elementos da TD de base.

- Outro elemento que a define como tal é a condição de que uma TD deve ser sempre discursiva, embora haja outros tipos de tradições culturais, tal como descreve Peter Koch (1997) em seu texto.

- A segunda condição refere-se ao fato de que nem toda repetição forma uma TD. Os elementos constitutivos do nível histórico de uma língua particular como a repetição de "o", "a", "é" e "que", as quais não podem formar sozinhas uma TD. No entanto, determinadas escolhas feitas no nível histórico de uma língua podem compor um TD, como é o caso da escolha pelas construções passivas em receitas, o uso do futuro do subjuntivo nas orações condicionais presentes em textos jurídicos etc. Mas de que repetição fala-se aqui? A repetição pode dar-se na escolha por determinadas estruturas sintáticas: Weinrich (Cf. Castilho, comunicação pessoal) já tinha reconhecido que a relação de tempos distingue o esquema textual "comentário" do esquema "narração". 
- A terceira condição está ligada ao conceito de evocação e refere-se ao conteúdo dos textos, ou seja, a evocação é a repetição dos conteúdos temáticos que são tratados nos textos, isto é, a hierarquia temática da línguagem específica de um texto, como é o caso dos sermões que sempre evocam textos bíblicos e outros textos religiosos, tais como as crônicas de vidas de santos etc.

Satisfeitas estas condições, nota-se assim que a TD evidencia a concomitância de dois fatores definidores da TD: a evocação e a repetição, ou seja, uma situação B evoca uma situação A que permite a realização de um texto 2 como repetição de um texto 1:

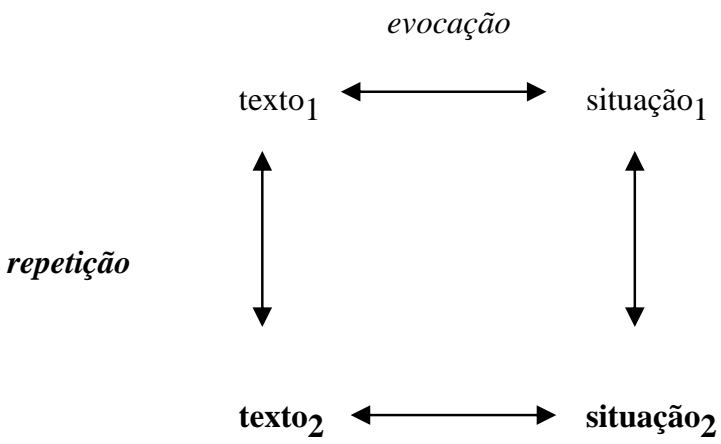

Esquema 1: Evocação (Kabatek, 2004)

Em resumo e a fim de distinguir tradições discursivas do conceito de gênero textual, vale observar a leitura de Oscar Loureda (2006) a respeito desta questão:

Entre las tradiciones discursivas se encuentran los tipos de texto (géneros o clases de discurso). Se definen por tres propiedades: a) son funcionales, pues aportan ciertos elementos que contribuyen a dotar de sentido a lo que se dice; b) son proyección (= concreción) de los rasgos universales del hablar; y c) forman parte siempre de los actos de habla, o sea que no hay palabras dichas que no pertenezcan a un género (Loureda, 2006:8).

Essas premissas servem de pano de fundo para a definição do conceito

de TD:

Entendemos por Tradição Discursiva (TD) a repetição de um texto ou de uma forma textual ou de uma maneira particular de escrever ou falar que adquire valor de signo próprio (portanto é significável). Pode-se formar em relação a qualquer finalidade de expressão ou qualquer elemento de conteúdo, cuja repetição estabelece uma relação de união entre atualização e tradição; qualquer relação que se pode estabelecer semioticamente entre dois elementos de tradição (atos de enunciação ou elementos referenciais) que evocam uma determinada forma textual ou determinados elementos lingüísticos empregados (Kabatek, 2004:7, grifos meus).

A definição proposta por Kabatek responde em parte a crítica que se tem feito a respeito do que seriam verdadeiramente as TDs. Comumente se tem dito que falar 
de uma TD é a mesma coisa que se referir a um gênero textual. No entanto, a preocupação quando se fala em conceitos como repetição, evocação, atualização e tradição é a de, por um lado, 1) não só analisar a composicionalidade dos textos, a exemplo do que se tem feito comumente nas várias correntes da Lingüística Textual, sejam eles processos de construção do texto, ou seja, suas propriedades formais e funcionais, tais como os recursos de referenciação ou até mesmo, como se fez na Gramática do Português Culto Falado, analisando o processamento de recursos mais voltados para a oralidade tais como repetições, correções, paráfrases e parênteses (Jubran \& Koch, 2006). Por outro lado, o que se propõe ali é também 2) observar em que medida a norma de uma língua particular é afetada em decorrência das transposições, atualizações ou permanências de tradições discursivas, promovendo assim a mudança lingüística strictu sensu.

Alguns críticos do modelo podem até afirmar que a adoção do termo TD seria equivalente a atribuir uma perspectiva diacrônica aos modelos de Lingüística Textual. Muitas destas críticas referem-se ao fato de que o modelo de TD ainda não desenvolveu uma metodologia clara, dotada de instrumentos e conceitos claramente definidos e que tomou da empréstimo a terminologia específica de outras correntes de análise, como os modelos teóricos da Gramaticalização, da Análise do Discurso, ou até mesmo da Análise da Conversação. Talvez a crítica seja procedente e resta aos defensores do modelo explicitar os seus instrumentos de análise, dispondo-os com a terminologia adequada.

No que se refere à questão dos instrumentos de análise, Kabatek reconhece a fluidez da proposta quando discute a questão da relação entre tradição discursiva e referência, quando reconhece a dificuldade de se associar as tradições discursivas e as variedades lingüísticas, ou seja, percebe que a questão da norma lingüística na diacronia pode ser um empecilho no desenvolvimento do trabalho, se o pesquisador não tiver instrumentos claros para distinguir uma norma da outra. Esse fato me parece uma questão central que afeta os estudos da constituição do português brasileiro. Vale a pena pergunta, de que norma estamos falando quando analisamos a documentação de diacronias passadas? Em que medida os textos estão constituídos de elementos de duas normas distintas? As cartas de administração privada e até mesmo determinadas cartas oficiais estão povoadas de fórmulas da tradição culta, mas o corpo de seus textos (narratio) resvala para a informalidade. Ao mesmo tempo 
que essas características são elementos preciosos de análise, o pesquisador deve estar atento para a diferenciação entre essas duas normas, pois aquilo que é importante para aquele que estuda traços de oralidade na escrita pode se tornar para o sintaticista, por exemplo, um fator desviante que leva a conclusões enviesadas, ou seja, não basta separar o corpus por gêneros, mas é preciso agregar a isto um novo eixo que inclui as variadas normas lingüísticas de um mesmo sistema. Creio que a proposta de análise pelas TDs pode trazer contribuições importantes para o estudo da diacronia das línguas. É preciso, no entanto, afinar estes instrumentos e estabelecer os limites e possibilidades que o modelo pode oferecer.

Ao modelo teórico de TDs Kabatek agrega outros conceitos, tais como a composicionalidade paradigmática, a composicionalidade sintagmática, a transformação, a interferência positiva e a interferência negativa, a convergência e a divergência.

A composicionalidade paradigmática refere-se aos elementos constitutivos de uma TD que a definem como "soneto" ou "poema de amor", tais como forma, disposição em 14 versos, esquema de rimas, conteúdo lexical associado ao campo semântico do amor etc. Da composicionalidde paradigmática surgem então possibilidades de transformação. Algumas TD podem ser "fortemente fixadas", como é o casos textos associados às instituições jurídicas e religiosas, enquanto outras, em função de alguma necessidade de expressão, são modificadas ao longo do tempo, e daí a inovação que se pode perceber na criatividade que se estabelece nos bate-papos na internet, nos SMSs ou nas mensagens de correio eletrônico (v. Koch, 1997). Kabatek lembra que a transformação pode afetar um só ou vários aspectos concomitantes da composicionalidade de uma TD. Ao observermos esse conceito, percebemos o quanto é importante verificar a mudança ocorrida a partir de um gênero $X$, tal como o tipo textual carta que subdivide em vários outros gêneros textuais ao longo da diacronia das línguas. Essas considerações são importantes para a constituição de um corpus linguisticamente representativo: uma carta do século XVIII tem elementos constitutivos que não se repetem numa carta do século XX, que por sua vez pode ter incorporado TDs de outros gêneros. Resta saber em que medida isso afeta o trabalho de pesquisa de quem trabalha com o léxico, com a semântica, com a sintaxe e até mesmo com a fonologia. Essa ainda é uma questão aberta a contribuições. 
A bibliografia associada à Lingüística de Texto denomina esses processos constitutivos adotando a seguinte terminologia:

regularidades textuales, esquemas tradicionales, propiedades social e históricamente consolidadas, rasgos socialmente reconocibles, estructuras relativamente estables, formas discursivas arquetípicas, esquemas fijados socioculturalmente, estructuras globales o propiedades convencionalizadas (Loureda, 2006:7).

Ao falarmos de transformação dos aspectos constitutivos de determinadas TDs, precisamos entender o conceito de interferência lingüística, ou seja, a interferência que se estabelece entre duas TD: "por definição, sempre que houver transformação de uma TD, haverá interferência" (Kabatek, 2004:10).

Há dois tipos de interferência: a interferência positiva e a interferência negativa. A interferência positiva é geralmente entendida como a ocorrência de elementos de uma língua A em um texto da língua B. Por outro lado, a interferência negativa é entendida como a "ausência de determinados elementos em um texto da língua B por causa da presença da língua A” (Kabatek, idem). A interferência negativa divide-se em interferência negativa de convergência (preferência por formas comuns às duas línguas, evitando formas diferentes) e interferência negativa de divergência (preferência por formas diferentes, evitando formas comuns) como é o que acontece por exemplo na tradução de algumas obras do espanhol para o português e vice-versa. Outro exemplo seria o fato de um autor de crôncias, sabendo da diferença das características textuais entre um texto épico e uma crônica, evita utilizar as expressões que remetam à forma do outro texto.

Para o conceito de interferência vale lembrar que Kabatek adota a idéia de Coseriu quando fala da equivalência. Textos fixos podem exteriorizar a tradicionalidade, na sua imobilização ou na sua repetição

y sus límites suelen coincidir con los de una comunidad lingüística dada: puede haber equivalencia (por ejemplo, refranes de distintas comunidades que expresan el mismo contenido, fórmulas de saludo para las mismas situaciones; o frases famosas traducidas que también son célebres en otras comunidades (Loureda, 2006:6).

A composicionalidade sintagmática vê-se na "sucessão de elementos (ou de subtextos) ao longo de um texto" (Kabatek, 2004:9). É o caso por exemplo do romance Ulisses que é composto de uma gama de diferentes tipos de TD, embora seu conteúdo temático seja uniforme. 
Kabatek (2004:11-19) apresenta o seu projeto de análise de juntores nos textos medievais do espanhol a partir do esquema proposto por Wolfgang Raible (1992) e observa que "a análise dos esquemas de junção para ter um critério de determinação das TD não é evidentemente a única possível' (Kabatek, 2004:19). Ao final de seu texto, o autor reconhece que

o estudo da história da língua desde as TD não oferece um paradigma diferente para substituir outras perspectivas, ao contrário, parece perfeitamente compatível com elas. O que oferece é uma perspectiva mais diferenciada, e talvez em alguns casos vai possibilitar a solução de alguma questão concreta ainda aberta (Kabatek, 2004:20).

\section{II.2.2.6 Como aplicar o modelo das tradições discursivas à análise da mudança lingüística?}

Uma nova teoria que se constrói precisa de fundamentos e seus instrumentos precisam ser testados à luz de fenômenos lingüísticos específicos. Pelo que se viu acima, segundo o modelo das tradições discursivas, o foco de análise pode recair tanto sobre a macroestrutura dos textos e das tradições a que pertencem, como também pode incidir sobre fenômenos lingüísticos específicos que façam destas estruturas textuais, ou seja, o cenário é o mesmo, mas a iluminação pode revelar o todo ou a parte. A partir daqui, apresento algumas abordagens que tentaram privilegiar o foco sobre fenômenos lingüísticos específicos, sem perder a noção do cenário em que os mesmos atuam, ora como protagonistas, ora como co-adjuvantes. Passo, portanto, a ilustrar esse tipo de análise através dos trabalhos de Company e Company (2005) e Pons Rodríguez (2005).

\section{II.2.2.6.1 As variáveis da difusão da mudança lingüística segundo Company Company (2005)}

Concepción Company Company (2005), a exemplo de Castilho (2006), fez em seu estudo uma revisão dos estudos sobre a mudança lingüística e também percebe que há uma noção generalizante da noção de gramaticalização como um processo histórico pelo qual se criam novas formas de expressão na gramática, mas observa que o tratamento usual dado à atualização ou difusão da mudança sintática tem tido uma explicação de natureza interna, em termos sintáticos, semânticos e até 
pragmáticos, abstraída de qualquer motivação exógena. Estes estudos parecem entender o processo como sendo social- e discursivamente homogêneos e que à primeira vista não parece ser afetado pela estrutura social e cultural do grupo de falantes, nem pelas características das tradições discursivas e dos corpora textuais empregados, nem mesmo pelos registros situacionais e sociais refletidos nesses corpora. Partindo desses pressupostos que configuram os estudos sobre gramaticalização, a autora retoma os postulados desses modelos e propõe novas variáveis que devem ser consideradas para verificar-se a mudança lingüística também como um fenômeno ligado à constituição dos textos e suas tradições discursivas. Em suma, o texto fala da importância de cruzar estes fatores determinantes, a seu modo de ver, para a manifestação da mudança lingüística. Em meu projeto de pesquisa eu já apontava para esses postulados já a partir do modelo da língua como um multissistema proposto por Ataliba Teixeira de Castilho (2004 e 2006).

O objetivo principal do estudo é verificar quais são os fatores que podem acelerar ou retardar a difusão da mudança sintático-semântica, ou seja, os fatores que incidem na velocidade da mudança na progressão da forma inovadora ao longo do canal de gramaticalização. A autora procura identificar o conjunto de causas, internas e externas, que influenciam a velocidade da mudança de uma forma conservadora por outra inovadora. A idéia é mostrar que os processos de gramaticalização podem estar fortemente condicionados por variáveis não estritamente gramaticais.

sabemos bastante de las causas internas de la generación de un cambio sintático-semántico y de la interacción de los distintos niveles de lengua en su producción, pero carecemos en gran medida de información sobre las causas que motivan o inhiben la difusión o actualización del cambio, esto es, la velocidad de su avance en el canal de gramaticalización. El análisis de la difusión es precisamente el motivo de este trabajo (Company Company, 2005:5).

Company Company (2005:6) adota como modelo de trabalho os estudos ligados à linha de pesquisa sobre variação, diacrônica e sincrônica, na dependência de registros textuais (Biber 1995: caps.7-8; e os trabalhos reunidos em Biber y Finegan 1994 apud Company Company, 2005), variação em dependência de gêneros discursivos e tradições discursivas como os diversos estudos de Oesterreicher et al. 1998 e de Jacob y Kabatek 2001 (apud Company Company, 2005), de sociolingüística tradicional (Labov 1972: cap. 8 apud Company Company, 2005); e 
em trabalhos recentes que integram a sociolingüística e a gramaticalização como Torres Cacoullos (2001 apud Company Company, 2005) que

han mostrado que el cambio gramatical depende en gran medida y está condicionado por la situación comunicativa, por el género textual y registro situacional en que se escribe y emplea ese texto, por las tradiciones culturales en que se producen los textos y, desde luego, por la conformación social y actitud lingüística del grupo de usuarios de la lengua (Company Company 2006:6).

Neste texto, a pesquisadora mexicana propõe um modelo de análise baseado em em seis variáveis:

1. profundidade histórica ou antigüidade da mudança lingüística em questão;

2. forma fônica, ou aspecto formal, da forma ou construção inovadora;

3. freqüência de emprego das formas ou construções conservadora e inovadora;

4. tipo de categoria que experimenta a mudança;

5. tipo de sociedade usuária da língua e

6. gênero textual ou tradição discursiva de manifestação da mudança.

A autora observa que os fatores 1, 2, 3 e 4 podem ser qualificados como internos ao sistema lingüístico enquanto que o fator 5 é exclusivamente externo e o 6 é ao mesmo tempo interno e externo.

\section{Variável 1. Profundidade histórica ou antigüidade da mudança lingüística}

A mayor tiempo, mayores posibilidades de reemplazo total de la forma conservadora

A autora exibe como evidência para o esclarecimente desta variável o caso da marcação prepositiva dos objetos indireto e direto no espanhol. Parte do canal diacrônico semântico-cognitivo que gerou a mudança (meta locativa > meta ou destino da ação verbal: OI > meta imediata da transitividade ou entidade afetada pela ação verbal com OD que pelo seu traço de humanidade se assemelha a um OI > meta imediata de transitividade com OD inanimados).

(2) Para que no nos peleemos, puse a la silla en medio

Después de conocer mucho a la vida, ya no me interesa tanto el teatro (apud Company 2002).

- $\quad$ tibi Jordanni presbítero vel ad filios tuos... conponituro (Pensado 1984:126). 
Company Company observa que ouve uma mudança total da forma etimológica e que esse é um processo de mudança muito antigo: o ibero-romance e talvez já o próprio latim vulgar já exibiam este processo de mudança em que o acusativo podia competir com o dativo flexionado em função de objeto indireto (Meyer-Lübke 1890-1906:III,58, 384; Lapesa 1964/2000:88; latim arcaico: Bassols 1956:I.98 apud Company Company, 2005).

\section{Variavel 2. Aspecto fônico da forma ou construção inovadora}

A mayor parecido formal de la forma innovadora con otra ya existente, más posibilidades de que el avance en el canal de gramaticalización se produzca de manera rápida y el reemplazo se realice en un periodo diacrónico breve

Para esta variável, a autora apresenta a pronominalização anômala de pronomes objeto em orações bitransitivas do espanhol americano e das Ilhas Canárias, do tipo eso se los dije a ustedes-a ellos nos quais a pronominalização etimológica, compré una bicicleta a los niños > se la compré, pedí el libro a los alumnos > se lo pedí, está quase desaparecida. A causa disto seria o fato de que a forma inovadora resultante se los - se las é formalmente idêntica ao pronome acusativo etimologicamente plural los - las: a inovação assim, passaria desapercebida dos falantes. Outra evidência seria a concordância de número anômala do verbo haber em seu emprego existencial (En todos los mundiales han habido errores que han modificado en muchos sentidos el curso de los partidos - México, apud Company 2004a:320 apud Company Company, 2005).

\section{Variable 3. Frequência de emprego das formas ou construções inovadoras}

A mayor frecuencia de empleo de la forma conservadora, mayor dificultad de la innovadora para avanzar en el canal de gramaticalización

Segundo Company Company, os estudos de gramaticalização coincidem na observação de que as gramáticas codificam melhor aquilo que os falantes usam mais. Assim, quanto maior a frequência do emprego da forma inovadora, mais possibilidade haverá de que "se libere de sus restricciones distribucionales, semánticas y contextuales originarias y se generalice; la baja frecuencia suele 
inhibir la extensión o generalización de los cambios" (Company Company, 2005:18). A alta frequência possibilita a gramaticalização da nova forma, a pouca frequência impede a difusão da mudança. Isto parece um racicínio circular, pois a cada aumento pressupõe-se um novo aumento e assim sucessivamente o que tornaria as línguas infladas de inovações e poucas tradições, o que efetivamente não acontece.

Certamente há evidências de que o aumento de freqüência pode levar auma mudança, mas nem sempre é assim que acontece. Como evidência de seu raciocínio, a autora cita o fato de que a mudança entre haber e tener em estruturas de posse tardou mais de 1000 anos para cumprir-se no espanhol. Ela crê que a lentidão na velocidade da mudança deve ter sido motivada pelo fato de que haber era um verbo mais freqüente (auxiliar em tempos compostos, em perífrases modais de obrigação, como verbo existencial) embora tivesse já desde cedo um adversário semântico e sintático no verbo tener.

\section{Variável 4: Tipo de categoria que experimenta a mudança}

La difusión de un cambio puede ser altamente dependiente del significado básico de una categoría y de su función comunicativa básica

Segundo a autora, categorias dêiticas mudam mais rapidamente na história de uma língua e ela acredita que a difusão da mudança se realiza de maneira mais lenta, porque o significado dêitico não está dado a priori, mas se atualiza no ato de fala, na interação comunicativa entre falante e ouvinte. O verbo e o substantivo demonstram mais flexibilidade para gramaticalizar-se em marcadores discursivos no espanhol: vale, ¡vaya!, ¡y dale!, ¡venga!, ¡vamos!, jándale!, por outro lado, o substantivo, como categoría dêitica, gerou somente alguns marcadores discursivos: jlástima!, ¡ojo!, ¡híjole! Outra evidência seriam as categorias de conteúdo modal, que mudam rapidamente. Por meio delas o falante aporta sua valoração sobre um evento e pode codificar matizes subjetivos dos que carecem as categorias não modais ou não modalizadas. De acordo com a autora, caberia pensar que as categorias sintáticas básicas de uma língua podem apresentar uma velocidade mais lenta de mudança, que, por exemplo, os marcadores de discurso, pois estes estão submetidos a um constante desgaste e erosão expressiva. 


\section{Variável 5. Tipo de sociedade usuária da língua}

A mayor carácter innovador de una sociedad, mayor será la aceptación de innovaciones lingüísticas y mayor el avance de la forma innovadora en el canal de gramaticalización; a menor establecimiento de centros de difusión de cultura o más alejada de un foco cultural esté una sociedad, mayor será también el avance de la forma innovadora en el canal de gramaticalización

Analisar como se constitui uma sociedade tendo em vista a amplitude e o grau de escolarização que perpassa a mesma em uma determinada época tem sido tarefa daqueles que lidam com a história social das línguas. Trata-se de um projeto pouco fácil e, como diz Concepción Company Company, de difícil apreensão, pois contém vários ângulos distintos. Se de um lado compreende-se que a linguagem é "una forma de conducta social y la lengua existe en tanto que vehículo para comunicar situaciones sociales, ideas y sentimientos de individuos insertos en sociedad" (Company, 2005:22, Cf. Labov 1972:183), por outro lado é difícil reconhecer claramente o caráter conservador ou inovador de uma sociedade. Para isso importaria estudar cuidadosamente em que medida esta comunidade está distanciada dos centros importantes de difusão de cultura, e em que medida a sua heterogeneidade étnica afeta a produção lingüística e cultural. Com esta variável, Company Company quer testar em que medida esses fatores podem acelerar ou retardar a adoção de uma forma inovadora e acrescenta que esse acumulado de causas "puede incidir en los procesos de normativización lingüística". Mas a autora reconhece que é problemático tentar medir o caráter inovador de uma determinada sociedade, da mesma forma como é difícil estabelecer qual é o seu centro difusor de cultura ${ }^{291}$.

Uma evidência para este fator seria a distinção entre o espanhol da Argentina e do Uruguay em relação às outras variantes americanas do espanhol. Uma das causas para as mudanças ocorridas naqueles dois países seria o fato de o vice-reinado de La Plata só foi constituído tardiamente ao final do século XVII, caracterizando-se como sociedades muito pobres enquanto à sua atividade e produção culturais no período colonial.

\footnotetext{
${ }^{291}$ Para isto a autora recomenda a leitura de Rickford (1986:248-249), Ferguson (1994), Biber (1995) e Tannen/Hamilton (2001).
} 


\section{Variável 6. Gênero textual ou tradição discursiva onde se manifesta a mudança}

El avance de una innovación puede ser altamente dependiente del género discursivo que favorece la innovación; las diferencias entre géneros para la difusión de una innovación son en términos de frecuencias relativas de uso, no de presencia-ausencia

O questionamento a respeito da relação entre evolução lingüística e tradição textual parece ser um problema importante para a língüística diacrônica (Kabatek (2001:97 apud Company Company, 2005). Para ilustrar esta variável, Company Company toma como exemplo a gramaticalização da palavra hombre no espanhol. Em espanhol medieval e também em outras línguas românicas, existia uma forma de significado indefinido tal como hombre e todas as suas variantes omne, onbre, ombre, etc:-, que era derivada do substantivo latino homine, próxima a um pronome, que expresava a ausência de um ser humano referencial concreto. A mudança iniciou já no latim em orações negativas; homo, con valor genérico, entrava em correlação com nemo e reforçava o significado indefinido deste pronome. Assim, o uso de homo foi ampliando-se até se tornar independente de nemo e dos contextos oracionais negativos originários e chegou a constituir, em espanhol, numa forma nominal genérica, a partir da qual se originou um uso pronominal de significado indefinido não referencial com o qual se expresssava a impessoalidade nominal. Assim, uma forma léxica com significado referencial adquiriu empregos e significado de pronome na seqüência [forma léxica: substantivo > forma gramatical: pronome] que é um típico canal de gramaticalização: nome referencial > nome genérico > ambiguo entre nome genérico e pronome indefinido > pronome indefinido.

A partir de um estudo de Julia Pozas (2004 apud Company Company, 2005) observa que o avanço de hombre no canal de gramaticalização ao seu valor de pronome indefinido se realizou em dependência de certos gêneros discursivos, os textos sapicienciais, o que justifica que esta gramaticalização nunca se difundiu na língua medieval em geral e sim estava condicionada a um gênero discursivo específico. Da mesma forma, ela observa a partir do trabalho de Gabriela Colinas (2003 apud Company Company, 2005) sobre a gramaticalização dos advérbios em mente que o substantivo latino no ablativo mente adquire caráter gramatical ao longo do tempo, passando a constituir um elemento formativo de outras palavras, tornandose o sufixo -mente. A mudança se dá mediada pelo gênero discursivo, pois o 
fenômeno ocorre muito mais em textos sapienciais, ao contrário dos textos históricos e poéticos. O gênero sapiencial tem como elementos composicinais as tradições discursivas que indicam verdades generalizadas e normas morais que favorecem o emprego de formas diversas de modalização.

Ao final de seu texto, Company Company enumera algumas conclusões a respeito da proposta que faz. Primeiramente nota que a) ao longo da Idade Média, o gênero sapiencial constituiu uma tradição discursiva e cultural que motivou e condicionou boa parte das mudanças experimentadas pelo espanhol desse período. Cogita-se, inclusive, que algumas inovações registradas nesse gênero jamais chegaram à oralidade; b) é necessário perguntar-se como uma inovação emerge a partir de um gênero discursivo à oralidade e como se convencionaliza (Fergunson, 1994 apud Company Company, 2005); c) talvez seja relevante levar em consideração tais variáveis para enriquecer o nosso entendimento de mudança lingüística: uma perspectiva do ponto de vista interno e externo da língua pode permitir aclarar fenômenos ainda pouco conhecidos; d) a freqüência de uso é uma variável fundamental que incide sobre o comportamento de todas as outras variáveis e condiciona a maneira geral os processos de gramaticalização e sua atualização.

O texto apresentado por Concepción Company Company no colóquio de Tübingen em dezembro de 2005 procura incorporar o estudo das tradições discursivas aos postulados defendidos pelos pesquisadores de gramaticalização. Johannes Kabatek considera que a idéia de agregar o modelo de TD como uma parte independente da análise de mudança lingüística pode representar uma perspectiva equivocada do que se entende por TD. Segundo ele, a idéia principal é que o modelo de TD deve ser entendido como o pano de fundo para a compreensão da linguagem como um todo, e por isso não poderia ser reduzido a um dos fatores de análise per se, sendo assim considerado como um conceito marginal de uma teoria maior. No entanto, creio que Company Company procura justamente verificar a concomitância destes fatores, não estabelecendo uma relação hierárquica entre os mesmos. Um argumento final de seu texto denota que a amplitude de avanço de uma mudança lingüística em um canal de gramaticalização é um fato multidimensional (v. também Castilho 2004 e 2006) no qual a estrutura lingüística está em dependência de fatores sociais, culturais e textuais. 


\section{II.2.2.6.2 A interface Análise do Discurso vs. Tradições Discursivas e sua importância para a constituição da Língüística de Texto}

A proposta de Company Company (2005) ilustra uma abordagem dos fenômenos de mudança lingüística, levando-se em conta os fatores tanto internos como externos da língua esponhala. É uma perspectiva de fora para dentro, procurando explicar os fenômenos inseridos em seus contextos específicos. Outra perspectiva de análise pode ter como ponto de partida os próprios fatores internos, para a partir deles, identificar a constituição de uma realidade (textual, social) mais exterior. Uma abordagem assim foi apresentada no mesmo colóquio de Tübingen por Lola Pons Rodríguez (2005), ao analisar um dos muitos processos de textualização a que esteve submetida a língua espanhola.

Antes, é importante entender alguns aspectos do que se entende por texto. Até aqui tentou-se diferenciar o conceito de TD da usual definição que se dá aos textos e seus gêneros, mas ainda não se falou da distinção que Coseriu fazia entre as suas duas concepções do se que se define por um texto. Para isso, retomo Loureda (2006). $\mathrm{O}$ autor observa que de um ponto de vista de seus traços essenciais, os falantes fazem uso dos gêneros como "modelos ideales intuitivos aglutinadores paradigmáticos" das características necessárias de todos os textos e uma mesma natureza. Assume-se, portanto, que os textos são construções ideais (types), ou modelos de textos, mas não são textos concretos (tokens).

7.2.4.2. Son intuitivos. En cuanto instrumentos de los hablantes, son fruto de la inmediatez de su conocimiento de la realidad. No dependen, por lo tanto, de la reflexión u organización objetivamente justificada, sino de la percepción accidental de clases de cosas distintas; de ahí que cada comunidad de habla intuya, o pueda intuir, diferentes tipos de texto. En otras palabras, la distinción de géneros no se basa en rasgos objetivos impuestos imperativamente por rasgos físicos de los discursos, pues de lo contrario las distinciones de todas las comunidades de habla coincidirían.

7.2.4.3. Son aglutinadores paradigmáticos. Cada tipo incorpora una serie de propiedades que lo distinguen de otros. Son modelos entre los que los hablantes podemos (y debemos) elegir. Por ello, aprender sus rasgos esenciales supone aprender a identificar los tipos de texto, aprender a asignarles unidad y aprender a usarlos para generar expectativas (Loureda, 2006:9-10).

Vê-se, assim, que os textos são intuitivos porque decorrem de um conhecimento comum da realidade por parte dos falantes e são aglutinadores paradigmáticos porque atualizam propriedades inerentes aos modelos de origem. 
A pesquisadora Lola Pons Rodríguez da Universidade de Sevilla, em seu texto El peso de la tradición discursiva en un proceso de textualización (2006), trata primordialmente da discussão em torno dos elementos constitutivos dos gêneros discursivos, tanto de ponto de vista formal como funcional. Em seu texto, a autora primeiramente investiga a diferenciação entre os conceitos de intertextualidade constitutiva (relação entre textos de mesma corrente de gênero textual) e de intertextualidade intratextual (relação entre os conteúdos de textos que podem ou não ser de uma mesma tipologia).

Partindo de elementos como a repetição e a interferência, termos incorporados ao modelo teórico das Tradições Discursivas, Lola Pons analisa em seu trabalho um corpus baseado em relatos de hagiografia (episódios de vida de santos) do tipo flos sanctorum (séc. XIII), derivados da Legenda Aurea (c. 1264) e manuscritos medievais que traduzem para o castelhano este material. A autora analisa de que maneira a forma discursiva tratado evolui em termos de constituição lingüístico-textual em textos que tratam do mesmo conteúdo, ou seja, sobre a vida de santos e mulheres virtuosas. Sua análise descortina uma perspectiva ao mesmo tempo horizontal e vertical sobre a constituição dos textos. Da mesma maneira que analisa o conteúdo temático desses textos, a autora compara a sintaxe dos textos confrontados, o que permite identificar uma mudança na constituição desse gênero discursivo.

Aplicando o modelo de junção proposto por Raible (1992) ao trecho de um texto do século XIII, Lola Pons verificou que nele se revela um uso majoritário de técnicas de junção do pólo da agregação como o uso de justaposições simples de frases, junção mediante referência anafórica e elevado uso de coordenação (principalmente utilizando o conector „e“). Em contraposição, uma amostra do século XV de um texto do tipo tratado com conteúdo hagiográfico evidenciou que a dimensão de junção desse texto deslizava em direção ao pólo da integração, apresentando maior número de subordinadas, uso de construções absolutas com gerúndio e particípio passado, uso de nominalizações introduzidas por preposições ou grupos preposicionais.

Através da análise conjunta destes e de outros textos escritos em um período de 200 anos, a autora procura mostrar que determinados usos sintáticos estão condicionados à tarefa comunicativa que estes textos desempenhavam. Seu texto 
traça um desenho histórico cuidadoso da tradição cultural de divulgação das vidas de santos através de distintos gêneros textuais. Se de um lado os processos de repetição de uma tradição advinda ainda de escritos traduzidos do latim conservavam determinadas práticas lingüísticas, a interferência efetuada em outras TDs, cuja finalidade maior era a argumentação em torno do discurso moral, promovia mudanças internas dentro das próprias TDs e favoreciam a mudança lingüística dos elementos constitutivos do espanhol como língua particular, como é caso do surgimento do pronome relativo el cual. Estavam em jogo os pólos da distância e da proximidade de que falam Peter Koch e Wulf Oesterreicher (1999) recentemente traduzido por Lópes Serena (Koch/Oesterreicher, 2006).

\section{II.3 Considerações finais a respeito dos modelos adotados}

A proposta de trabalho apresentada na introdução desta tese procura levar em conta os instrumentos de análise oferecidos por estes dois modelos. Ao seguir os passos do modelo de TDs, procuro enumerar os condicionamentos que possam atuar para o uso do gerúndio no português brasileiro, por acreditar que os usos estão marcados pelos contextos. A opção pelo modelo de análise multissistêmica da língua é decorrente da crença de que apesar de serem ativados concomitantemente todos os subsistemas da língua, uma descrição mais particularizada de como funcionam as estratégias de cada um deles ajuda a compreender fenômenos de mudança lingüística. O capítulo seguinte deve ser entendido como uma continuação da discussão apresentada aqui. Nelo traço um panorama do contexto socio-histórico que envolve a documentação escolhida como corpus de análise, levando em conta suas características textuais e procurando dispor estes textos em categorias nítidas que possam, desse modo, validar a quantificação que dá suporte ao estudo. 


\title{
- CAPÍTULO III -
}

\section{A constituição de um corpus diacrônico do português brasileiro dos séculos XVIII, XIX e XX e seus traços lingüístico-discursivos}

\begin{abstract}
Já que no theatro do Mundo Sabio certamente hey de apparecer ignorante, quero tambem apparecer desculpado. He precizo, Leitor,que saibas [se acaso es benigno] o motivo, que tive para intentar esta obra, que confesso pedia huma pena, nã̃ menos elegante, e erudita, que pratica, e authorisada. O motivo, foy o zelo; e amor da Patria, virtude engrandecida por muitos, e praticada por poucos (...). Esta negligencia da mocidade Portugueza claramente se dá a conhecer na falta de muitos estudos; sendo huma das mais notaveis nã̃ saber organizar com sufficiencia qualquer especie das Cartas, e muitos mais sendo em annos, em que ou cultivaõ as Universidades, ou poem espada à cinta."
\end{abstract}

Cândido Lusitano (1745)

Este capítulo dialoga diretamente com aquele que o antecede e também com o capítulo V, em que trato da discursivização do gerúndio. Nele aplico os instrumentos de análise propostos pelo modelo das TDs, de modo a caracterizar as três classes de textos utilizadas nos corpora de análise reunidos para esta tese: cartas, anúncios, memórias históricas e peças teatrais. Esta análise não tem a pretensão de esgotar as características textuais destes tipos de textos, mas sim, evidenciar quais destas características podem ser de vital importância para a análise do fenômeno gramatical aqui estudado: o gerúndio. A escolha dos corpora está orientada, portanto, pelos seguintes pressupostos teóricos:

1. Um dos objetivos básicos do Projeto Para a História do Português Brasileiro (PHPB), ao reconstituir a história do português brasileiro, é fazê-lo analisando documentos escritos que ofereçam uma maior proximidade com o vernáculo ou com os falares cotidianos. Acredita-se que as análises lingüísticas podem ser tanto baseadas em textos oficiais, e, portanto, mais formulaicos, como também em textos mais particulares, menos formulaicos e mais próximos da oralidade. Porém, cremos 
que quanto maior for o "recheio de informalidade" de um texto, muito mais profícua e menos enviesada será a análise lingüística.

2. Os estudos diacrônicos no Brasil tiveram um grande impulso no âmbito da Teoria Lingüística, principalmente a partir da década de 80. Em 1997, iniciou-se o Projeto Para a História do Português Brasileiro (PHPB) que corresponde, segundo Castilho (1998, p. 7 e p. 63), a um "NURC diacrônico" e tem como objetivo "investigar a contraparte diacrônica das inúmeras análises sincrônicas já publicadas" pelos Projetos NURC (Projeto da Norma Urbana Culta) e Gramática do Português Falado. Dentre os tópicos da agenda do projeto está a coleta e edição de documentos para a formação de um corpus do Português Brasileiro.

3. A tarefa de seleção e edição de documentos tem seguido uma agenda e já conta com anúncios de jornais do séc. XIX e cartas de leitores e de redatores de jornais do séc. XIX. Além desses documentos, as equipes têm selecionado e editado cartas oficiais e não-oficiais dos séculos XVIII e XIX. Inicialmente, os critérios de seleção não eram muito claros. No decorrer das discussões dos seis seminários já realizados, tais critérios foram sendo reavaliados e reformulados, de acordo com os estudos de mudança lingüística e da disponibilidade de fontes de cada equipe regional.

Recentemente, para o corpus da equipe paulista do PHPB, Simões \& Kewitz (2005 e 2006) procuraram estabelecer um controle maior da seleção dos documentos, levando em conta vários critérios não apenas gramaticais, mas também de caráter tanto de história social e espaços comunicativos onde foram produzidos os textos, como também de fatores discursivos como a finalidade comunicativa que fez gerar o documento e a própria constituição do gênero carta e seus subgêneros.

Na medida em que observamos (Simões/Kewitz, 2005 e 2006) que a constituição dos gêneros textuais era de vital importância para análise de fenômenos lingüísticos, percebemos que não era adequado verificar em apenas um gênero textual se houve mudança gramatical. Os romanistas alemães chamaram a atenção para a questão das Tradições Discursivas (TDs), agregando-se, assim, um novo tópico à agenda do PHPB.

Outro fator preponderante na análise de fenômenos lingüísticos é a necessidade de se levar em conta outras tipologias textuais que podem elucidar os 
processos de mudança de fenômenos específicos. No caso do gerúndio, uma melhor distinção entre os subgêneros das cartas e uma compreensão de que índices discursivos estão presentes nas memórias históricas pode ajudar a entender a abundância ou escassez de ocorrência desse item tanto nestes dois gêneros como nos registros de uma língua oral concepcional de séculos anteriores, registrada nos entremezes e nas peças teatrais.

De acordo com estudos já realizados, como os de Pessoa (2002), que fala de textos retirados da imprensa do Recife do século XIX, ou as reflexões de Mattos e Silva (2002), acerca da constituição de corpora para o Projeto Para a história do português brasileiro, é possível perceber uma preocupação por editar documentos que mantenham um caráter mais próximo da oralidade. Na UFRJ, o grupo de trabalho do PHPB-RJ tem editado documentos da administração pública, documentos da administração privada, tais como cartas de comércio, cartas particulares, textos literários e outros textos com traços mais próximos da oralidade como as cartas de leitor e de editor publicadas em jornais do século XIX.

Algumas restrições impõem-se, no entanto, à adoção de textos dessa natureza. Naturalmente contextos discursivos distintos podem enviesar a interpretação de fenômenos lingüísticos submetidos a filtros que vão desde o caráter público/particular, simetria/assimetria entre autor/leitor, gêneros textuais construídos através de tradições discursivas do português (carta particular, carta de comércio, carta de leitor, carta de editor, texto literário, petição, requerimento, inventário, devassa, autos criminais, diálogos entre dois interlocutores, aula expositiva, etc.). Uma leitura prévia em um corpus de amostragem selecionado para este estudo denuncia essas irregularidades, definindo e restringindo o uso das orações reduzidas de gerúndio ao sabor da necessidade discursiva de cada autor ou falante.

Kabatek (2003) aponta para o risco de se enviesar a análise de mudança lingüística, quando não se levam em conta as diferentes tipologias textuais:

A este problema se puede responder eligiendo textos de la misma tradición discursiva, pero entonces lo que se investigará no será la história de la lengua sino la história de un género concreto, con el peligro de que este género contenga elementos prácticamente ausentes en otras tradiciones (pensemos, por ejemplo, en el la historia del futuro de subjuntivo y el género jurídico castellano). Si por el contrario elegimos textos de géneros diversos, siempre existirá el peligro de que la cantidad de elementos varíe mucho por las características del texto en cuestión. Si se quiere investigar la gramaticalización de perífrases verbales temporales, por ejemplo, los resultados obtenidos en las crónicas serán, frente a los textos 
jurídicos, muy variados. Consecuencia de estas observaciones podría ser el rechazo completo de toda investigación del cambio lingüístico más allá de la investigación de la evolución de los enunciados o textos. La lengua y su evolución diacrónica serian ficciones construidas por los lingüistas, y en realidad no habría más que textos con sus respectivas tradiciones, con gramáticas emergentes casualmente sin história propia alguna (Kabatek, 2003:15).

Mais adiante, o autor (Kabatek, 2003:16) enumera as questões que considera centrais na análise dos fenômenos lingüísticos na perspectiva da diacronia, se se levar em conta os condicionamentos impostos pelas tradições discursivas:

i) O que varia segundo as tradições discursivas em questão e o que não varia, já que além de toda diversidade textual há elementos no sistema de uma língua que se mantêm bastante estáveis através das tradições discursivas?

ii) Que elementos variam através das tradições discursivas?

iii) Qual é a possível relação (sincrônica e diacrônica) entre aquilo que é próprio das tradições discursivas e o que é próprio do sistema lingüístico?

Penso que (i) está atinente à minha preocupação em relação à opção por determinadas construções com orações gerundivas, no que se refere, por exemplo, às fórmulas mais ou menos estratificadas das cartas oficiais, petições, despachos, etc. $\mathrm{O}$ estudo empírico dos textos permite entrever que há usos de orações gerundivas em diferentes tradições discursivas, o que de certa maneira responde (ii). Para isso foi preciso estabelecer critérios bastante claros, ou seja, destacar fatores lingüísticos bastante evidentes que pudessem permitir essa leitura clara, tal como a identificação de índices de simetria ou assimetria entre os interlocutores, grau de publicidade, etc. Já a questão (iii) parece indicar uma limitação a que o meu próprio estudo está submetida, se eu não procedesse a uma escolha variada dos corpora de análise. Assim, penso que ao identificar claramente os fatores apontados em relação à questão (ii), terei subsídios adequados para responder (iii).

Uma vez que este trabalho fala da diacronia de uma forma verbal, é preciso ter em conta a historicidade dos textos. Kabatek retoma Coseriu (1979 apud Kabatek, s/d:1, digitado) que, assim como vimos anteriormente (Cap. II.1.2), diferencia a historicidade em três níveis:

- a historicidade lingüística no sentido próprio (historicidade da língua em particular), 
- a historicidade da tradição (repetição) de determinados textos ou de determinadas formas de textos,

- a historicidade genérica no sentido de uma "Zur-Geschichte-Gehörens" (pertença à história).

Quando fala da historicidade da língua em particular, o autor reflete a respeito do caráter individual que define a alteridade, a transferência de um para o outro do bem comum que é a língua. Isso se daria num nível primário da historicidade. $\mathrm{O}$ segundo tipo de historicidade refere-se a todas as demonstrações culturais, inclusive as lingüísticas. A repetição de objetos culturais, ao mesmo tempo que matém esquemas predeterminados, força as mudanças:

Die Wiederholbarkeit von Textformen umfasst eine kontinuierliche Skala von minimalen Traditionsmarkierungen - etwa einer bestimmten Textbezeichnung oder einer bestimmten Formel in einem ansonsten nicht fixierten Text - über die durchgehende formale Organisation bis hin zur kompletten Fixierung des Textes (Kabatek, s/d:2). ${ }^{292}$

Entendo isso como uma forma de interpretar as mudanças lingüísticas não só em função de usos individuais e necessidade pragmáticas imediatas, mas sim como uma mudança dependente também dos contextos em que os fenômenos lingüísticos estão inseridos.

Diskurstraditionen sind, wie schon betont (1.1.); eine einzelsprachunabhängige Ausprägung sprachlicher Historizität. Sie sind an kulturelle Gruppen gebunden, die sich nach künstlerischen, wirtschaftlichen u. a. Kriterien definieren und sich allenfalls zufällig mit Sprachgemeinschaften decken (Koch, 1988:343). ${ }^{293}$

É preciso tomar cuidado, no entanto, com a confusão que correntemente se faz ao se tentar definir o que seriam as tradições discursivas. Muitos incorrem no erro de defini-las simplesmente no plano da escrita como sendo os próprios gêneros textuais ou suas tipologias internas. Peter Koch (1997) foi mal interpretado quando em uma nota de rodapé de seu texto afirma:

Die Konsequenz einer Unterscheidung zwischen individuell/aktuellem Diskurs und historischer Diskurstradition wird jedoch noch nicht gezogen. Nicht akzeptabel ercheint es mir, wenn das Verhältnis von Sprachtyp und Einzelsprache mit dem Verhältnis von Textsorte und Text (Diskurs) parallelisiert wird (117) [Cf. Coseriu 1981]: die ,Textsorte' (von mir im

\footnotetext{
${ }^{292}$ Tradução minha: "A repetição de formas textuais compreende uma escala contínua de marcas de tradição mínimas - quase como de uma determinada marca textual ou de uma determinada fórmula em um texto ainda não fixado - através de uma contínua organização formal até uma completa fixidez. do texto"

${ }^{293}$ Tradução minha: "Tradições discursivas são, como já pontuamos (1.1.), uma representação de historicidade lingüística que é independente das línguas em particular. Elas estão ligadas a grupos culturais, que se definem por critérios artísticos, econômicos, entre outros e que, quando muito, coincidem com as comunidades lingüísticas (cf. Coseriu 1981,40; Schlieben-Lange 1982, 108s.; Koch 1989)".
} 
folgenden als ,Diskurstradition' bezeichnet) steht ja gerade auf derselben (historischen) Ebene wie die Einzelsprache (Koch, 1997:45, grifo meu). ${ }^{294}$

O conceito de tradição discursiva perpassa a noção de gênero, mas não se reduz apenas a este rótulo, assim como vimos anteriormente (Cap. II.1.2). O procedimento metodológico descrito nas seções seguintes é, portanto, a tentativa de agregar as contribuições da Romanística de Tübingen para o estudo das tradições discursivas. A seguir, descrevo os critérios de seleção dos corpora tendo em conta (i) a historicidade lingüística no sentido próprio (historicidade da língua em particular), (ii) a historicidade da tradição (repetição) dos gêneros carta, anúncios, memórias históricas, entremezes e peças teatrais e (iii) a historicidade genérica dos elementos discursivos constantes desses textos. É, portanto, uma descrição teórica da seleção do corpus, pelos critérios expostos aqui expostos.

\section{III.1 O gênero Carta e a tradição bolonhesa da Ars dictandi}

A arte da epistolografia foi cultivada pelas comuni do norte e do centro da Itália a partir do século XI e irradiou-se pela Europa, sendo seguida até o advento do Renascimento. Nesse período difundiram-se as artes dictandi em decorrência de uma demanda provocada pelo desenvolvimento político e econômico. Aumentou assim a quantidade e a variedade de documentos oficiais requeridos pelo clero, pela nobreza e pelos cidadãos como explica Martin Camargo: “A estabilização dos domínios feudais depois de séculos de tumultos e a emergência dos primeiros estados centralizados modernos conduziam a um volume de correspondência diplomática sem precedentes, registros oficiais e outros." (Camargo, 1991:31 apud Tin, 2005:31). Segundo esse autor, ao final do século XI, com a Controvérsia das Investiduras, houve um estímulo para o estudo da retórica como modelo para a escrita e para a propaganda. O clima intelectual dessa época gerou a criação de novas disciplinas e isso levou a que "modos tradicionais de classificar o conhecimento, como as sete artes liberais" começassem a ser modificados, da mesma forma como as instituições que os haviam perpetuado. Um dos centros mais importantes da ars dictaminis foi o convento beneditino de Montecassino.

\footnotetext{
${ }^{294}$ Tradução minha: "a conseqüência de uma diferenciação entre discurso individual/atual e tradição discursiva histórica ainda não será feita. Não me parece aceitável que se paralelize a relação de gênero discursivo e texto (Discurso) (117) [Cf. Coseriu 1981]: o 'gênero' (definido por mim a partir daqui como 'tradição discursiva') localiza-se no mesmo nível (histórico) que a língua em particular" (Koch, 1997:45, grifo meu).
} 
Johannes Kabatek (2005:74), ao estudar o processo de escrituralização (textualização) das línguas românicas através da tradição de difusão de textos jurísticos do direito romano, também identificou em Bolonha o centro irradiador de uma Renascença cultural. Além disso, observou que, à parte da grande riqueza e da importância econômica da cidade livre, a escola de artistas local deve ter criado condições propícias a isso.

A ars dictandi, que norteava a produção dos documentos da diplomática, prescrevia um rígido código de regras na constituição dos textos que era baseado no modelo da Retórica. Essas regras eram o salutatio, o exordium, o narratio, o petitio, e o conclusio. O salutatio é o lugar em que são apresentadas as pessoas, o propósito e o tema. Nele deveria estar especificado ao mesmo tempo o autor da carta e seu destinatário e se estavam no mesmo grau de hierarquia, e se eram amigos ou inimigos. O exordium é o espaço em que se pontuam os tropos e as figuras que servem para adornar o discurso e "mover" a audiência (Tin, 2005:32). Aos poucos esse esquema rígido foi sendo adaptado às necessidades discursivas a que os textos deviam atender. O produto dessa inovação resulta no surgimento de tradições discursivas mistas, como o sermão, o aviso, a memória, o diário e as cartas de toda a sorte (Koch, 1997).

A partir do início do século XII até o final do século XIV, Bologna é o centro da Ars dictaminis. O professor secular de Bologna, Adalberto Samaritano, foi o autor da obra de ars dictandi mais antiga que se conhece. Seus Praecepta dictaminium devem ter sido escritos entre 1111 e 1118 . Nesse tratado, Samaritano descreve os vários tipos de saudação, ao lado de uma seleção de modelos de cartas. Esse é o molde da tradição do qual serão retirados os secretários de cartas que se publicaram nos séculos seguintes, modificados ao longo da história, de acordo com a demanda específica de cada comunidade.

\section{III.1.1 A arte de escrever cartas e sua popularização na França}

A arte de escrever cartas saiu das muralhas dos palácios e dos palacetes e popularizou-se entre aqueles que viam na carta uma maneira de estabelecer elos com os parentes e os amigos distantes. É nesse contexto que surgem os secretários de 
cartas, compêndios com modelos de fórmulas de saudação e despedida, coletâneas de cartas, e não raro, reunem inclusive regras de bons $\operatorname{modos}^{295}$ :

Roger Chartier (1995), ao discutir sobre a introdução das práticas de escrita na Europa entre os séculos XVI e XVIII, menciona um fenômeno ocorrido na época. La Secretaire a la mode (O Secretário da Moda) de Jean Puget de La Serre, publicado em 1640, é o best-seller de um gênero muito apreciado: as coletâneas de modelos de cartas. Destinado inicialmente aos epistológrafos nobres ou burgueses, esses secretários logo são incluídos no catálogo de editoras, que publicam livros de ampla circulação, como a Bibliothèque Bleue. Segundo o historiador, "é duvidoso que tais modelos eruditos tenham realmente servido aos leitores populares" (p.116), porém a própria posse do livro já aponta para uma popularização do gênero Cunha (2005).

O ciclo da tradição continuou, e à parte das inovações naturais do gênero, os esquemas rígidos de produção das cartas perpetuou-se através da transmissão desse modelo de um país europeu ao outro. Um fato que ilustra bem essa idéia é a ampla difusão de uma obra do francês Jean Puget de La Serre (1595-1665), que raramente é citada nos trabalhos que analisam a importância de sua atuação como renomado historiador. O manual epistolar Le Secrétaire à la Mode já contava em 1634 com sua nona edição ampliada e revisada e sua obra foi revisada, ampliada e reeditada durante em seu próprio nome em dezenas de reimpressões que alcançam o século XIX. $^{296}$

Se a tradição bolonhesa da ars dictandi foi a inspiração do Secrétaire francês de Puget de la Serre, sua obra faz o caminho inverso e devolve à Itália a sua versão de escrever cartas através das traduções feitas dessa obra para o italiano em 1673 por Livio Alessandri e em 1675 por Girolamo Brusoni.

Nesse vai-e-vem dos tratados de cartas, muito se copiou e se adaptou, nem sempre se fazendo a devida referência ao próprio la Serre, numa prova de que esse tipo de tradição discursiva ultrapassava os limites das línguas francesa e italiana e de que determinadas TDs perdem sua "autoria" à medida que são incorporadas a comunidades linguísticas que as adotam e atualizam - lembrando Coseriu: as normas discursivas que regimentam o nível histórico da tradição de um texto podem afetar as normas lingüísticas de uma língua particular.

\footnotetext{
${ }^{295}$ Uma das obras de epistolografia que traz regras de bons modos é o Il Secretario di Corte de Jean Puget De La Serre, traduzido para o italiano por Girolamo Brusoni em 1675.

296 Christian Leroy (2002:250) aponta reedições do Secrétaire de Puget de la Serre em 1633, 1640, 1641, 1644, 1650, 1651, 1655, 1659, 1666, 1680 e 1695. Encontrei na Biblioteca Pública de Viseu (Portugal) e na Unibibliothek de Tübingen (Alemanha) outras edições datadas de 1634, 1654, 1671, 1739 e 1747.
} 


\section{III.1.2 A tradição epistolar em Portugal e seus ecos no Brasil: os secretários de cartas}

A tradição de escrever cartas em português começou a ser regulada a partir do século XVII com a publicação do livro Corte na Aldeia (1619) de Francisco Rodrigues Lobo (1573-1621), um dos primeiros teóricos da epistolografia em Portugal. A partir do século XVIII surgem vários secretários de cartas, manuais com cartas compiladas por autores como Francisco José Freire, cuja obra O Secretario Portuguez (1745) foi publicada ao longo do século XVIII e XIX em várias edições revisadas e

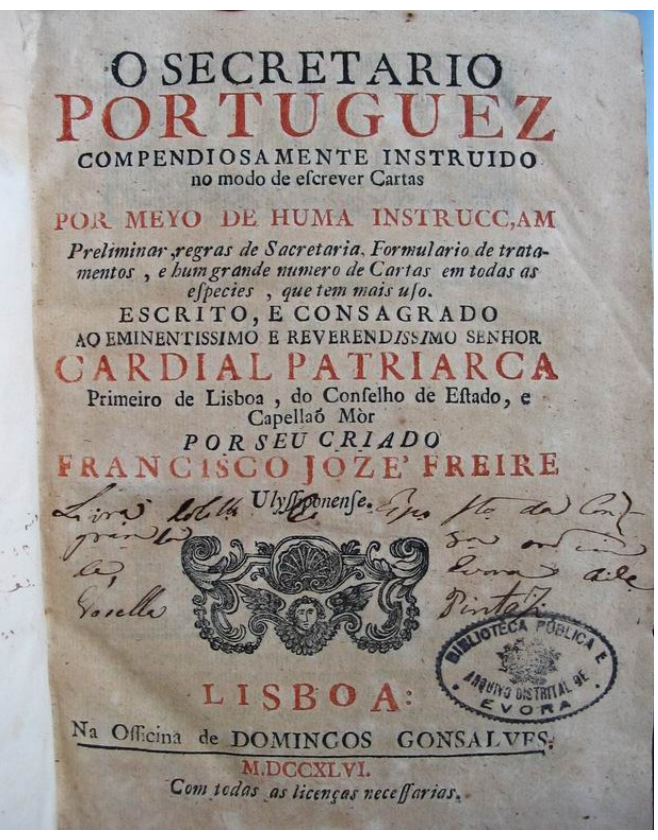
ampliadas. Naturalmente, a arte de escrever cartas da tradição latina também passa ao português via outras línguas. Francisco José Freire, por exemplo, toma o autor italiano $^{297}$ Isidoro Nardi como modelo para seu secretário de cartas e não deve lhe ter passada desapercebida a edição espanhola do secretario espanhol-francês de Sobrino.

Como o próprio autor recomenda na introdução de sua obra, o modelo de produção das cartas toma como base a tradição das línguas latinas, o que já aí prova que a constituição desse gênero era um conhecimento compartilhado pelos autores das língas românicas e que seguia o canal da tradição epistolar desde os primeiros teóricos do gênero ainda no Latim:

Porèm muy pouco confio nas minhas instrucçoens, se o novo Secretario naõ for dotado de hum vivo engenho, e naõ tiver hum inteiro conhecimento das linguas Latinas, e Materna, e huma larga liçaõ dos melhores, que escreveraõ Cartas, e etrataraõ [sic] do modo como sedevem formar. (Cândido Lusitano / Freire, Franciso José, 1746:introdução)

297 "Hum dos melhores Authores; e dos mais modernos he o Academico Arcade Isidoro Nardi, a quem sigo nesta Instrucçaõ Preliminar” Freire (1746, introdução). 
$\mathrm{Na}$ introdução de seu epistolário, Freire simplesmente traduz e adapta as instruções constantes do Segretario de Isidoro Nardi, que por sua vez também copiou e adaptou ao italiano aquilo que já fazia parte do Secretaire de Puget (v. Quadro 7):

Per essere adunque tale, si richiedono necessariamente, oltre la pratica, una intiera congnizione della lingua Latina, una frequente lettura de' migliori Autori accreditati in essa,una foda intelligenza delle Scienze, ed una piena erudizione, che possederono i Cardinali Salodetto, Bembo, ed altri non pochi, i quali da questa decorasa professione, e riceveron a loro estimazione, e ritrattero premj, e posti di dignità eminenti. (Nardi, Isidoro, 1730? [1710]: introdução)

Em sua introdução, Freire trata da constituição do gênero de maneira simples:

Todas as cartas (reservando as de narraçaõ, e discripçaõ) se dividem em quatro periodos. No primeiro se narra o facto; no segundo se roga a que se agradeça, ou respectivamente se daõ os agradecimentos; no terceiro se offerece o prestimo; e no quarto se desejaõ felicidades (Cândido Lusitano / Francisco José Freire, 1746:introdução).

Vê-se que também esta lição foi retirada de Isidoro Nardi, como mostra o seguinte trecho:

Tutte le lettere (alla riserva delle Narrative, e Descritive) si dividono in quatro periodi, anchorchè il quarto periodo soglia terminarsi alla Francese concisamente. Nel primo periodo si dice el fatto. Nel secondo si prega a gradire, o respettivamente si ringrazia. Nel terzo si fa litanza de' comandi scambievoli. Nel quarto si saluta (Nardi, Isidoro, 1730? [1710]: introdução). 


\begin{tabular}{|c|c|}
\hline 1654 & $\begin{array}{l}\text { "Il n'y a rien de si commun que d'escrire des Lettres. Mais ce n'est pas vne chose commune } \\
\text { de les bien desser. Le necessité de la vie fait que chacun s'em mesle. Car lesignorans aussi } \\
\text { bien que les doctes ont souuent besoin de communiquer par lettres auec leurs amis absens. } \\
\text { Mais ordinairement il n'y a que les gens d'estude qui le sçachent fair auec grace. Pour } \\
\text { Papprendre il faut auoir de beaux [A ij] que traitent le choses qui importent, \& y em a de } \\
\text { plusieur fortes, comme lettres d'aduis, de conseil, de remonstrance, de commandement,de } \\
\text { prieres,de recommendation, d'offre de secours, de plainte, de reproches, d'excuse, \& } \\
\text { semblables" (La Serre, 1654. Le Secretaire a la Mode Sieur de la Serre, p. 3-4) }\end{array}$ \\
\hline 1673 & $\begin{array}{l}\text { "Non v'hà cosa nel Mondo più communale di quella dello scrivere lettere; mà non è già } \\
\text { cosa communale lo scriuere di buon'aria. La necessità, che porta seco la vita ciuile di } \\
\text { communicare insieme, cagiona, che ciascuno prattichi questa professione, facendo } \\
\text { egualmente mestiere a'Sauij, e à gl'Itnoranti il trattare per lettere co i [A loro] loro amici } \\
\text { lontani. E pure non v'há chi sappia pratticare coueneuolmente così ordinaria facenda, } \\
\text { trattone gli huomini letterati,mentre per esercitarla con grazia ne fà bisogno di belli esempli } \\
\text { per imitarli, e di buoni precetti per pratticarli." (La Serre, 1673. Secretario alla Moda De } \\
\text { La Serre \& Livio Alessandri, p. 1-2) }\end{array}$ \\
\hline 1705 & $\begin{array}{l}\text { "AU LECTEUR. Ayant appris que mon Sécrétaire la Cour, rempli de diverses lettres que } \\
\text { j'avois faites par divertissement en ma jeunesse, courroit le monde sous mon nom, avec } \\
\text { quelque sorte d'approbation, dans les pays étrangers, s'étant imprimé plus de trente sois, } \\
\text { sans qu'il soit tombé entre mes mains pour le corriger depuis vingt ans qu'il en est partti. } \\
\text { J'ai voulu faire présent de ce nouveu comme d'un ouvrage digéré où vous trouverez plus de } \\
\text { satisfaction \& moins de fautes. Il porte le nom de Sécrétair à la mode, asin qu'en tout tems } \\
\text { il soit de saison, puisque les manieres d'écrire se changent; recevez-le d'aussi bon coeur } \\
\text { que je vous le donne. Que s'il ne vou est pas agréable apprenez à vous taire charitablement, } \\
\text { ou à médire de bonne grace: c'est le meilleur conseil que je vous puis donner pour à } \\
\text { présent." (La Serre, 1747. Le Secretaire à la Mode par le Sieur De La Serre, p. 5). }\end{array}$ \\
\hline 1739 & $\begin{array}{l}\text { "Il n'y a rien de si commun que d'écrire des Lettres; mais ce n'est pas une chose commune } \\
\text { que de les bien dresser. Pour apprendre à la faire, il faut avoir de beaux exemples qu'on } \\
\text { puisse imiter, \& de bons préceptes qui fervent de conduire." (1739. Le Nouveu Secretaire } \\
\text { du } \text { Cabinet }^{298} \text { ) }\end{array}$ \\
\hline $\begin{array}{c}173 ? \\
{[1710]}\end{array}$ & $\begin{array}{l}\text { "Non vi ha cosa più comune che lo scriver letter: e pure non è cosa cosi commune il saper } \\
\text { comporle.La necessità della Vitta fa, che ognuno s'insegni a farle; mentre tanto } \\
\text { gl'ignoranti, quanto i Savj hanno bene spesso bisogno di comunicar per lettere co'loro } \\
\text { Amici assenti: ma per l'ordinario è mestiere solo di Uomini intendenti il saper comporle } \\
\text { con grazia, e con buena forma." (Nardi, 1730? [1710]. Il Segretario principiante ed } \\
\text { instruito, p. 7-8) }\end{array}$ \\
\hline 1746 & $\begin{array}{l}\text { "Nam ha cousa mais commua que o escrever Cartas ; e } \mid \text { com tudo naõ he cousa commua o } \\
\text { sabellas compor. A ne- } \mid \text { cessidade da vida faz, com que cada hum entre a fazellas; | porque } \\
\text { tanto aos ignorantes, como aos sabios frequente- | mente he precizo o communicarem-se por } \\
\text { meyo de Cartas com os | auzentes : Porèm pelo ordinario sò he proprio de pessoas } \\
\text { intelligen- | tens o compollas com methodo, e boa fórma. Para isto valem se de | preceitos, e } \\
\text { de exemplos, os quaes por serem muitos (pois saõ | muitas as diversidades de Cartas) mais } \\
\text { servem a alguns par [sic] lhes con- | fundir, que para lhe illustrar o entendimento. Eu alguns } \\
\text { dou pelo | discurso desta Obra em advertencias, que faço no princípio de qual- | quer } \\
\text { especie de Cartas, procurando facilitar o caminho aos que se | applicarem a taõ nobre, como } \\
\text { precizo emprego." (Cândido Lusitano / Francisco José Freire, 1746. O Secretário } \\
\text { Portuguez compendiosamente instruido na arte de escrever cartas, introdução) }\end{array}$ \\
\hline
\end{tabular}

Quadro 7. A tradição dos secretários de cartas e suas evocações.

298 Talvez também de La Serre. 
Ao longo da primeira parte do secretário de cartas de Francisco José Freire, encontramos a transcrição de modelos de cartas que ele compilou de autores da nobreza portuguesa. Freire tinha submetido estas mesmas cartas à aprecicação de especialistas e, na segunda parte do seu livro, ele reproduz as respostas que recebeu dessas pessoas como um gênero também a ser seguido, rotulando-as de cartas discursivas. Vale a pena determo-nos na primeira destas cartas, que representa uma análise metalingüística dos seus subgêneros. $O$ trecho sublinhado evidencia uma consciência lingüística que, à primeira vista, nos parece precoce e digna de ser enquadrada nos estudos contemporâneos da Pragmática, não fosse a data pregressa a essa abordagem da língua, que está claramente fundamentada nas já antigas e conhecidas lições da Retórica:

Carta I.

Meu amigo. Eu não tenho juízo para fazer juizo, tenho-o | para em tudo o sujeitar ao juizo de v. m. Deste modo | he que sou capaz de dar o meu parecer sobre as cartas de N., | que v.m. me remette, como cousa que muito estima. Sou igu- | almente de opiniaõ que dellas sahe aquelle suavíssimo cheiro, | que devem exhalar as cartas familiares; o que pouco percebe |a ignorancia de huns, e despreza muito a inveja de outros. | A linguagem he taõ pura, como de Author, que par escre- | ver molha a penna nas fontes mais puras da eloquencia Por- | tugueza; quero dizer, que segue os Escritores, que só deviaõ | authorizar o Diccionario da nossa lingua. As expressoens saõ | propriissimas do estylo epistolar familiar; e estou certo que | muitos, a quem incha a presumpçaõ, faraõ hum conceito | [p. 153] muy diverso deste meu; porque seguem hum estylo tal, que | se os Oraculos fallassem assim, seria inutil consultà-los pela | impossibilidade de entendè-los. Eu naõ sey como chame a | semilhante estylo; mas lembro-me que o grande Vieira lhe | dà o nome de boçal, em lugar do de culto, com que perten- $\mid$ dem distingui-lo os que delle usaõ. Està, meu amigo, taõ in- $\mid$ troduzido nas cartas familiares este estylo, que a outro qual- | quer chamaõ fallar plebeo. Concedeo-lhe que assim seja em | muitas partes. Por veutura [sic] o povo tambem naõ he mestre ? I Naõ dizia Cicero que elle era quem o ensinava: Magister | meus populus? De forte que o pay da eloquencia queria ter $\mid$ o povo por mestre, e hoje ha quem se injuria de o ter por $\mid$ companheiro. Eu naõ quero ser popular em tudo, mas nem | tambem singular sobre todos; $\mathrm{e}$ se me censuraõ os meus es- / critos, eu gosto de seguir a plebe dos Escritores, ainda que | me contem nella. Sey que as Cartas tem, ou devem ter as | suas frazes proprias, e as suas vozes familiares, como queria | Cicero, e ensinava Seneca entre os Romanos, e entre nòs | practíca o Marquez.... que se imprimisse as suas Cartas, | naõ allegaria eu agora com Seneca, e Cicero. Os gregos naõ | affectavaõ tanto o estylo Attico; o Jonico, o Borico, e o Eo- | lico, que tambem naõ usassem muitas vezes do commum. Ora | este commum he que eu desejara na nossa lingua, e louvara | na composiçaõ familiar; e se tivera authoridade, pegara na | penna para o persuadir. Este meu desejo; que naõ he mais | que balbuciar, por ser ainda menino em hum tal estudo; quer | dizer mais do que soa: quer dizer que deve v. m. por utili- | dade da Patria, e credito do seu nome, compor sobre este | assumpto, e introduzir o bom gosto de escrever Cartas, a | quem o tiver estragado, jà que na sua primeira idade conhe- $\mid$ cem todos em v. m. aquellas luzes, que muitas vezes se naõ | vem rayar em annos provectos. Eu jà de[esta?] aqui me offere- | ço por discipulo, assim como ha muito tempo que me tenho | offerecido por seu Criado; e teria huma grande ventura, se | [p. 154] me resultara tanto aproveitamento da primeira offerta, como $\mid$ me resulta gloria da segunda. Deos guarde a v. m. $\& c$.

(Cândido Lusitano / Freire, Francisco José, 1746:152-154, grifo meu) 
Magister meus populus. O povo como mestre. O "sociolingüista" do séc. XVIII tinha uma concepção clara da adaptação do texto ao público e a despeito de referendar a preocupação com a tradição, orienta o "mestre das cartas", José Francisco Freire, "que as Cartas tem, ou devem ter as | suas frazes proprias, e as suas vozes familiares, como queria | Cicero, e ensinava Seneca entre os Romanos". Ou seja, fazer próprio o que é de outros, incorporar a tradição e adaptá-la assim como “entre nòs | practíca o Marquez....".

Estas considerações remetem à questão da inovação que ocorre através da mistura e da convergência de tradições culturais de que fala Peter Koch (1997), ou seja, as cartas, ao mesmo tempo que representam produtos de caráter de alto distanciamento comunicativo, realizam-se também com elementos menos rígidos, provindos da oralidade. É o que mostra por exemplo, outro autor das cartas discursivas que Freire (1745) oferece como modelo de cartas argumentativas:

Carta 7

Meu amigo. Naõ posso acabar comigo de seguir a opi- | niaõ de N..... desejando eu seguilo em tudo o mais, | para fazer justiça aos seus grandes estudos. Em mim naõ ho | obstinaçaõ, podera ser ignorancia; porèm desejo seguir | os vestigios daquelles primeiros Authores, que prescreveraõ $\mid$ os preceitos ao estylo epistolar, e felizmente os praticaraõ. | Que he huma carta, mais que huma mensageira, que como $\mid$ tal deve correr? Logo tambem naõ so de profissaõ, mas de | estylo, deve ser corrente; e muito mais corraõ as minhas car- $\mid$ tas, que sò foraõ escritas para correr. Assentem-se (se se de- $\mid$ vem assentar) na cadeira como mestras aquellas, que escre- | veraõ os Varoens grandes, de que Portugal naõ he esteril : e | versehia a sua fertilidade, se gozassem do beneficio da im- | pressaõ, que as minhas nem merecem, nem aspiraõ a este lu- | gar; porque confesso que naõ pude conseguir o escreve-las | [p. 161] mais à luz do Sol, que à do candieiro: entendo por esta luz | a do meu talento, e aquella pela da arte. V. m. que de mim | deve fazer este mesmo conceito, naõ deixe igualmente de me | seguir na opiniaõ, de que o estylo epistolar deve ser corren- $\mid$ te; porque saiba que eu nesta parte sou \begin{tabular}{l|l|l} 
como os Juristas, que & se envergonhaõ de fallar sem ley nas materias legaes, Cice- $\mid$ ro, que \\
\hline
\end{tabular} he o Bartholo dos Secretarios, dizia a Attico que / conversava com elle, quando escrevia: e em outro lugar nos | deixou hum grande exemplo, quando affirmou que escrevera $\mid$ a sua carta com palavras quotidianas; isto he, com as usuaes, / de que usaõ na conversaçaõ os homens polidos, e civilizados, / e deste modo deo a entender que guardava os termos subli- / mes para o Senado, quando nelle se revestisse do caracter do $/$ Orador. Plinio, que occupa o lugar immediato a Tulio (ain- | da escrevendo em seculo infeliz) amava o estylo singelo, de | que nos dà em muitas cartas diversos exemplos, e se naõ he $\mid$ em todas, nisso mesmo imitou a Cicero; porque (como eu | ja disse a v. m. em outra occasiaõ) he muy diverso o estylo, | de que se usa, quando se escreve a pessoa de alto caracter, ou $\mid$ se trataõ materias de grande peso. Seneca nas suas cartas fa- $\mid$ miliares observa com tanto escrupulo o mesmo estylo, que | declama contra outro qualquer, como improprio ao assum- | pto; o que serà facil de ver lendose as suas cartas a Lucillio. | Verdadeiros imitadores destes grandes homens foraõ entre | nòs o P. Antonio Vieira, D. Francisco Manoel, e mais al- | gum. Nelles admiramos a nobreza, com que se explicaõ nas $\mid$ suas cartas, mas por meyo daquellas expressoens, de que el- | les mesmos usariaõ, se conversassem com o mesmo sujeito, | a quem escreviaõ. Pelo contrario, quando a carta he para | pessoa de alta esfera, ensinaõ-nos que o estylo deve ser gra- | ve sem escuridade, e artificioso sem affectaçaõ, de que saõ | exemplos as cartas, que escreveraõ a Principes. Isto, meu | amigo, he o que sinto, e sinto que outros naõ sigaõ o mesmo; | porque nesta materia gostariamos fructos mais maduros da | [p. 162] mocidade 
Portugueza, se bebesse nas fontes puras. V. m. no $\mid$ seu serviço me mande como deve, que eu obedecery como posso \&c.

(Cândido Lusitano / Freire, Francisco José, 1746:160-162, grifos meus)

Os trechos sublinhados revelam características que iremos verificar nas cartas brasileiras coletadas por nós para o período que vai do séc. XVIII ao séc. XX. Ressalto alguns elementos que julgo importantes para entender o raciocínio que vou seguindo aqui:

(i) as cartas pertencem a uma tradição que ultrapassa o domínio epistolar (cf. Koch, 1997),

(ii) as cartas dividem-se em subgêneros, de acordo com o grau de intimidade entre os escribas,

(iii) quanto mais distante o grau de intimidade, tanto maior será a preocupação com a seleção de estruturas lingüísticas, o que definirá, assim, o estilo particular de cada uma e

(iv) cartas são uma interface entre a escrita e a oralidade, pois pendulam entre um pólo e outro, dependendo do grau de intimidade entre aqueles que se escrevem. Discusto isso mais cuidadosamente nas seções que seguem.

\section{III.2 Estratégias de constituição de um corpus de análise}

Nas seções que se seguem, procuro demonstrar o raciocínio adotado para a constituição do corpus submetido à análise nesta tese. Como já foi dito antes, preocupei-me em tornar os conjuntos de documentos homogêneos por suas características gramaticais e discursivas, separando-os por tipologias e controlando a quantidade de palavras. Grande parte dos documentos foram editados exclusivamente para este trabalho e com a preocupação de oferecê-los à análise dos pesquisadores do Projeto PHPB, tendo sido publicada já uma parte dessa documentação em Simões/Kewitz (2006).

A apresentação que segue tem por objetivo desvendar as características discursivas desses documentos. Essa análise concentra-se primeiramente no conjunto de cartas dos séculos XVIII e XIX por razões óbvias: por serem de autoria diversa, era preciso controlar o objetivo de escrita, o grau de hierarquia entre os missivistas e 
buscar pistas sobre a norma lingüística de que faziam uso esses escribas. Os documentos foram coletados no Arquivo Histórico do Estado de São Paulo, no Museu Republicano de Itu, na Biblioteca Nacional do Rio de Janeiro, na Biblioteca Nacional de Lisboa e na Biblioteca Pública de Évora ${ }^{299}$. Além disso, houve uma preocupação em identificar a nacionalidade dos autores como brasileiros através de pesquisa genealógica incansável em obras de nobiliarquia brasileira (Paes Leme, 1777/1980 e Silva Leme, 1903-1905).

\section{III.2.1 Cartas brasileiras do séc. XVIII ao séc. XX}

Ao longo dos seminários de pesquisa do grupo PHPB-SP, realizadas em maio e junho de 2005, Verena Kewitz e eu apresentamos alguns critérios para a seleção de cartas do século XVIII e XIX ligados ao que se pôde aprender dos estudos de Análise do Discurso e da Análise da Conversação, mais especificamente da Lingüística Textual.

Naquela ocasião, mostramos ao grupo de São Paulo que, durante a coleta de manuscritos nos arquivos históricos de São Paulo e nas bibliotecas, fizémos algumas constatações a respeito das características da epistolografia luso-brasileira. Observamos que, principalmente em relação às cartas, encontrávamos documentos oficiais com características textuais diversas, que apresentavam índices híbridos de uma norma considerada culta para a época e ao mesmo tempo alguns traços de norma popular. Se de um lado podíamos entrever elementos de norma mais controlada, associados tanto à própria tradição espistolar oficial e jurídica, como é o caso das fórmulas de início e de fim, o corpo destas cartas deixava entrever alguns elementos de uma norma considerada mais informal. Com o objetivo de proceder a uma definição mais detalhada das categorias comunicativo-pragmáticas dos textos, a exemplo do que se tem feito em Análise da Conversação em relação à língua falada, elaboramos um quadro de categorias comunicativas baseado nos trabalhos de Henne \& Rehbock (1982) ${ }^{300}$ e de Allwood (1976).

\footnotetext{
${ }^{299}$ Agradeço à Prof. Maria Filomena Gonçalves da Universidade de Évora pela viabilização do acesso à documentação da Biblioteca Pública de Évora.

${ }^{300}$ Henne \& Rehbock (1982:32-33) observaram as seguintes categorias em seu trabalho: (a) tipologia da conversação; (b) relação de tempo-espaço; (c) constelação dos falantes entre si; (d) grau de
} 
A combinatória das categorias discursivas (i) grau de publicidade e (ii) grau de simetria entre os escritores e, eventualmente, (iv) grau de planejamento do texto (registro/níveis de fala) e (v) dimensões da ação comunicativa (tipologia dos atos de fala) resulta numa melhor definição do documento analisado de forma a assumi-lo como sendo oficial ou não-oficial. A fixidez temática pode parecer à primeira vista indiferente para a constituição do subgênero, mas aliado ao registro de fala, perceptíviel através do do grau de planejamento do texto e à tarefa comunicativa, ou objetivo comunicativo na acepção de Kabatek (2006), ou dimensões da ação comunicativa segundo Allwood (1976), podem evidenciar uma maior ou menor formalidade na produção dos textos escritos.

A proposta ali feita procurava aliar o que se conhece do estudo da língua falada ao domínio da escrita. Koch \& Oesterreicher (1990), em seu trabalho de análise sobre o processo de escrituralização das línguas românicas, também falam das condições comunicativas de produção dos enunciados escritos e falados e estratégias comunicativas utilizadas pelos falantes/escribas durante o ato de elocução. Ali, os autores observavam que a produção tanto escrita quanto falada se apóia em dois eixos: o eixo gráfico vs. fônico e o eixo da proximidade vs. distância. E chamavam a atenção que determinadas tipologias textuais da oralidade apresentavam características de maior distância entre os interlocutores, como é caso do discurso científico, enquanto textos escritos podem, por seu lado, apresentar maior proximidade comunicativa, se observarmos as cartas pessoais. Assim, a tensão proximidade vs. distância se dá não só por condições comunicativas, mas também por elementos ligados ao objetivo ou à tarefa a ser executada.

Apoiando-nos nestas propostas, iniciamos a coleta dos manuscritos e procuramos identificar os pontos em comum aos mesmos, de forma a verificar a composicionalidade daqueles gêneros textuais.

Ao longo da coleta, pudemos encontrar alguns exemplares interessantes que descortinavam algumas pistas sobre o registro de fala do seus escritos.

publicidade; (e) relação social dos falantes; (f) dimensões da ação comunicativa; (g) grau de conhecimento entre os falantes; (h) grau de planejamento temático dos falantes; (i) fixidez temática da conversação. 
A idéia com este trabalho inicial de escolha de documentos para a constituição dos corpora do PHPB-SP era visualizar em que medida as questões ligadas às TDs importam para a análise de mudança lingüística e perguntar: de que forma a escolha de um determinado gênero textual condiciona a seleção de fenômenos linguiísticos específicos? Ou seja, se num determinado conjunto de dados se verifica alta frequiência de relativas cortadoras, será que isso não estaria condicionado à opção do autor / falante por um determinado gênero textual, por exemplo, a carta particular, gênero no qual há simetria entre os interlocutores e que permite um maior relaxamento no planejamento dos textos? Sobretudo, defendíamos que é necessário atentar para a variedade de gêneros textuais e equilibrar os seus subconjuntos de forma a evitar conclusões enviesadas sobre mudança lingüística.

\section{III.2.2 As categorias discursivas das cartas brasileiras e os traços definidores de seus subgêneros}

Levando em consideração que muito do que se registra na escrituralidade é decorrente da oralidade, é possível proceder a uma definição mais detalhada das categorias comunicativo-pragmáticas dos textos a exemplo do que se tem feito em Análise da Conversação em relação à língua falada.

Henne \& Rehbock (1982) elaboraram um quadro para as categorias da fala, a saber: (a) tipologia da conversação; (b) relação de tempo-espaço; (c) constelação dos falantes entre si; (d) grau de publicidade; (e) relação social dos falantes; (f) dimensões da ação comunicativa; (g) grau de conhecimento entre os falantes; (h) grau de planejamento temático dos falantes; (i) fixidez temática da conversação. Esse elenco de categorias pode servir de norte para a construção de um quadro de categorias comunicativo-pragmáticas adaptado para a escrita. As categorias (a) e (b) ali descritas importam tão somente para os textos escritos, se puderem ser identificadas claramente as demais categorias apontadas.

A combinatória das categorias discursivas (i) e (ii) e eventualmente (iv) e (v) resulta numa melhor definição do documento analisado de forma a assumi-lo como sendo oficial ou não-oficial. A fixidez temática (iii) pode parecer à primeira vista indiferente para a constituição do subgênero, mas aliado ao registro de fala (v) e às 
tarefas comunicativas (iv) - objetivo comunicativo na acepção de Kabatek, ou dimensões da ação comunicativa segundo Allwood (1976) - podem evidenciar uma maior ou menor formalidade na produção dos textos escritos.

\begin{tabular}{|l|l|}
\hline \multirow{2}{*}{ CATEGORIAS COMUNICATIVO-PRAGMÁTICAS DA ESCRITA } \\
\hline \multirow{4}{*}{ (i) Grau de publicidade } & particular \\
\cline { 2 - 2 } & semi-particular \\
\cline { 2 - 2 } (ii) Grau de simetria entre os escritores & pública \\
\cline { 2 - 2 } & ascendente \\
\cline { 2 - 2 } (iii) Fixidez temática & horizontal \\
\hline \multirow{3}{*}{$\begin{array}{l}\text { (iv) Grau de planejamento do texto } \\
\text { (registro / níveis de fala) }\end{array}$} & sem fixidez \\
\hline \multirow{5}{*}{ núcleo temático fixo } \\
\cline { 2 - 2 } & tema altamente fixo \\
\hline \multirow{5}{*}{ (v) Dimensões da ação comunicativa } & livre (popular-comum) \\
\cline { 2 - 2 } & semi-controlado (comum) \\
\cline { 2 - 2 } & altamente controlado (formal) \\
\hline & comandar, ordenar, forçar \\
\cline { 2 - 2 } & acusar, repreender, recriminar \\
\cline { 2 - 2 } & atacar, desafiar \\
\cline { 2 - 2 } & requerer, pedir, implorar, solicitar \\
\cline { 2 - 2 } & narrar, informar, relatar, reportar \\
\cline { 2 - 2 } & obedecer, confirmar, aceitar, concordar, ceder \\
\cline { 2 - 2 } & $\begin{array}{l}\text { protestar, refutar, negar, objetar, repudiar, } \\
\text { recusar, opor-se }\end{array}$ \\
\hline & aceitar, concordar, admitir, reconhecer \\
\cline { 2 - 2 } & agradecer \\
\hline
\end{tabular}

Quadro 8. Categorias comunicativo-pragmáticas da escrita adaptadas de Henne \& Rehbock (1982) e Allwood (1976)

A combinatória das categorias discursivas (i) e (ii) e eventualmente (iv) e (v) resulta numa melhor definição do documento analisado de forma a assumi-lo como sendo oficial ou não-oficial. A fixidez temática (iii) pode parecer à primeira vista indiferente para a constituição do subgênero, mas aliado ao registro de fala (v) e às tarefas comunicativas (iv) - objetivo comunicativo na acepção de Kabatek, ou dimensões da ação comunicativa segundo Allwood (1976) - podem evidenciar uma maior ou menor formalidade na produção dos textos escritos.

Uma leitura semelhante das mesmas categorias discursivas que compõem os textos, sejam eles escritos ou falados, foi proposta por Koch \& Oesterreicher $(1990)^{301}$ :

\footnotetext{
${ }^{301}$ Uma versão revista e ampliada foi traduzida para o espanhol por Araceli López Serena e publicada pela Gredos (2006).
} 


Proximidade
Condições comunicativas
-privado
-confiança
-emoção
-referência situacional
-proximidade física
-diálogo
-espontaneidade
etc.
Estratégias comunicativas:
-preferência por contextos
extralingüísticos, gestos etc.
-baixo grau de planejamento
-valor provisório
-agregação
etc.

\section{Proximidade}

Condições comunicativas

-privado

-confiança

-emoção

-referência situacional

- proximidade física

-diálogo

ntaneidade

etc.

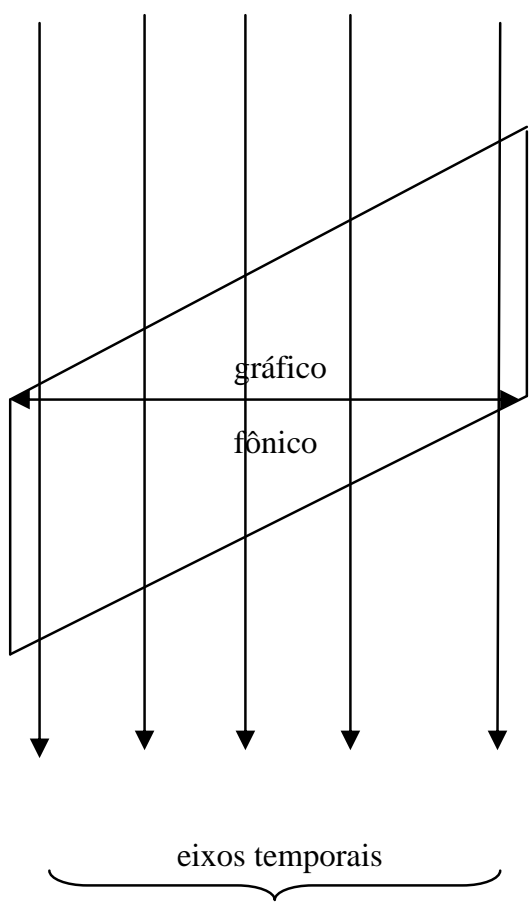

\section{Distância}

Condições comunicativas -público -menor confiança -falta de emoção -falta de referência situacional -distância física -monólogo -reflexão etc. Estratégias comunicativas -preferência por contextos lingüísticos -alto grau de planejamento -valor definitivo -integração etc.

Quadro 9. A tensão proximidade/distância segundo Koch \& Oesterreicher (1985)

Uma leitura entrecruzada dos dois quadros apresentados anteriormente permitenos identificar pontos em comum no que se refere à constituição dos gêneros textuais escritos ou falados - e à sua caracterização como textos de maior ou menor formalidade.

Os exemplos a seguir, coletados em cartas incorporadas aos corpora do projeto PHPB, ilustram a aplicação desse entrecruzamento das categorias discursivas apresentadas nos quadros 8 e 9:

(1) [C 182 Ald 22] $]^{302}$ Antonio de Camargo, antes Sim esteindio ouCu- | rtou. Ronpeu Com Vozes ativa epitulante. contra $\mid$ os meus portadores queforão bus car asditas Rapari | gas. que sieles não vortasem. efosem prudentes | sertamente nodia $\underline{20}$ deste Prizente més fugirão 3 in- | dios hú capatas dos animais - por nome dumingos | dias. eoutro JuaquimdeSouza. eoutro Bonifasio | Dias. (grifo

302 A notação que antecede cada um dos exemplos segue o seguinte critério: $\mathrm{C}=$ carta, $18=$ séc. XVIII, $2-2^{\mathrm{a}}$. metade desse século, $\mathrm{AI}=$ fundo do Arquivo Histórico do Estado de São Paulo (AEHSP) intitulado C00228 - Aldeamento de Índios, $\mathrm{CM}=$ fundo do AHESP intitulado C00262 Militares Comandantes Cap. Mór de Bragança, Atibaia e Nazaré, 1723-1822, WL = Correspondência passiva de Washington Luiz (AHESP). O último número indica o número da carta de nossa classificação $[22=$ carta número 22]. 
meu $)^{303}$

O exemplo (1) demonstra, ao mesmo tempo, que o autor é falante de uma variante [+/- culta e +/- popular]. $\mathrm{O}$ documento insere-se no conjunto de cartas oficiais pela fixidez temática e pela tarefa comunicativa a que se propôs o autor. O caráter de documento oficial dá a entender que o autor selecionaria o registro culto da língua. Contudo, fatores discursivos no exemplo (1), tais como o alçamento da vogal e a rotacização no item "ouCurtou", ausência de concordância no sintagma "Com Vozes ativa epitulante" e a permuta de vogais "prizente"/"dumingos", autorizam-nos a afirmar que este autor, apesar da tentativa de produzir um texto em norma culta - mesmo levando-se em conta a escolha lexical especializada - conferiu ao seu texto um registro de norma popular.

Vejamos outro exemplo de uma carta particular, escrita em grau ascendente:

(2) [C 19 1 BAN 9] Senhor AlfereS Joaõ deoliveira Leme / Por eSte vou aoS peS de vossamerce va Lerme doSeo patroSinio por que aConte / Se Manoel filh[o] dadefunta getruSdeS daCoSta eSte temeSta | do eminha Caza portenSiozamentes Com maõ pro Se dimento egover | nar Como for por mever Ser humaviuva pobre edezempa | rada e Cauzado deSta Criatura eCa eStou Com minha filha mal | faLada eSte Suplicante BemmoStra Ser davida Era da por | que CoSta naõ Seter CofeSado a Coatro ou SinCo[a?]noS | e So Balentias epor tanto Rogo a vm.ce pelo amor deDe | os qûeirame fazer eSta eSmoLa fazer Como Senhor Capitam Mor | porque eSte Seie prezo e diSpuLSado Nazare novede8[outu]bro1813 | De vossamerce veneradora E Criada | Margarida Leite (grifo meu)

O exemplo (2) revela a necessidade de separar exemplares do gênero cânone “carta particular" em conjuntos diferentes, segundo características discursivas distintas: registro de fala [norma culta/norma popular], relação entre os falantes [hierarquia ascendente, horizontal ou descendente], dimensões da ação comunicativa [pedido, ordem, informação, queixa], etc. Os trechos grifados trazem exemplos do plano sintático que conferem ao texto um baixo grau de planejamento, pelo abandono de construções, um processo bastante parecido com os contextos de correção, de reformulação ou de paráfrases próprios da fala [por que aConte|Se Manoel filh[o] dadefunta getruSdeS daCoSta eSte temeSta | do eminha Caza]. Também no plano morfossintático, denotando pistas do plano fônico, podemos entrever usos de uma norma menos culta [porque eSte Seie prezo e diSpuLSado], embora as fórmulas de endereçamento, aliadas às condições comunicativas de alta emotividade, evidenciem o caráter ascendente da missiva como em [Por eSte vou aoS peS de vm.ce va Lerme

303 Para este texto, optamos por marcar em negrito os trechos que julgamos relevantes para as análises. 
doSeo patroSinio] e [epor tanto Rogo a vm.ce pelo amor deDe | os qûeirame fazer eSta eSmoLa fazer Como Senhor Capitam Mor].

Julgamos, portanto, necessário estabelecer critérios claros para identificar os traços discursivos mais nítidos das variadas tradições discursivas que habitam os vários gêneros textuais. E a partir destas categorias, imaginamos que será possível pensar-se numa forma de indexar as fontes manuscritas, a fim de facilitar tanto a coleta de cartas, como a organização dos conjuntos de documentos, o que poderia evitar que a análise de dados linguiísticos se torne enviesada. Um exemplo disso seria apor documentos que $a$ priori parecem da mesma categoria de gênero [carta particular de administração privada], mas com marcas de registros distintos [norma culta x norma popular], que é o que se tem verificado em textos dos séculos XVIII e XIX.

Não podemos nos comprometer a fazer uma descrição exaustiva da constituição do gênero textual [carta] em sua dimensão histórica ou mesmo sincrônica. Essa é uma tarefa reservada aos pesquisadores que estudam os gêneros textuais. Nossa preocupação deve limitar-se a visualizar em que medida as questões ligadas às TDs importam para a análise de mudança lingüística. Em relação a isso, poderíamos lançar a seguinte questão: de que forma a escolha de um determinado gênero textual condiciona a seleção de fenômenos lingüísticos específicos? Ou seja, se num determinado conjunto de dados se verifica alta frequiência de relativas cortadoras, será que isso não estaria condicionado à opção do autor / falante por um determinado gênero textual, por exemplo, a carta particular, com simetria entre os interlocutores? É preciso levar em conta que é necessário atentar para a variedade de gêneros textuais e equilíbrio dos subconjuntos de forma a evitar conclusões enviesadas sobre mudança lingüística.

\section{III.2.3 Cartas da Administração Pública e da Administração Privada}

Entre os pesquisadores brasileiros do PHPB, Afrânio G. Barbosa tem pensado nessa linha, quando diz que se deve "buscar o confronto entre diferentes corpora de materiais escritos de uma mesma época por meio da instrumentalização de um dado fenômeno lingüístico, que funcionaria como fio de prumo da comparação." (Barbosa 2002:425). Referindo-se a um trabalho quantitativo de Douglas Biber (1991) que cruzava diferentes corpora da língua inglesa com determinadas formas lingüísticas, 
Barbosa verificou que esse autor "demonstrou não haver marcas lingüísticas específicas da fala ou da escrita, mas sim dimensões ou conjuntos de formas lingüísticas que, combinadas diferentemente, identificam os tipos de texto, seja ele a escrita acadêmica, seja ele a entrevista radiofônica." (op.cit).

A constituição do gênero carta tem sido alvo de estudos de pesquisadores ligados ao PHPB. A tradição filológica (Spina, 1994 apud Barbosa, 2005) segmenta os documentos escritos em dois grandes grupos: documentos privados e documentos públicos. Essa segmentação pareceu-nos insuficente assim como a Barbosa (1999 e 2005), que propôs uma categoria intermediária que "aproximava diversos manuscritos ora da macrocategoria dos oficiais, ora da dos privados" (Barbosa, 2005). O autor observa que há documentos que ocupam "um espaço intermediário entre a Administração Pública e os Documentos Privados" e propõe que as duas categorias tradicionais sejam desmembradas em três: Administração Pública, Administração Privada e Documentos Pessoais. Os documentos da Administração Pública foram assumidos por Barbosa (1999) a partir da proposta da equipe do Projeto Resgate Barão do Rio Branco (1997), enquanto que os documentos pessoais têm sido assim tipificados pela tradição filológica (Spina, 1994 apud Barbosa 2005).

A seleção dos documentos aqui apresentados segue esse mesmo raciocínio e baseia-se em critérios de coleta de caráter histórico-discursivos. Esse conjunto de cartas é fruto de uma ars interpretandi que se desenvolveu paralelamente à coleta, pois, ao mesmo tempo em que efetuamos uma pesquisa filológica, o fizemos com o olhar de lingüistas, não em busca de fenômenos específicos - gramaticais ou não -, mas procurando agregar a essa coleta uma ampla pesquisa histórica dos espaços sociais, a fim de deixar entrever claramente os contextos de produção dessas cartas: o contexto sócio-histórico, o contexto discursivo do gênero, de suas fórmulas e da quebra de protocolo em relação às formulas previstas, para, assim, identificar o contexto de produção dentro do conjunto de textos ao qual pertencem as cartas.

Durante o período colonial, o gênero carta cumpria determinadas funções comunicativas e acumulava a possibilidade de transmitir informações que hoje se reservam a outros gêneros da escrita, ou seja, com o passar dos séculos houve uma especilização do grande gênero carta que se subdividiu em subgêneros. A equipe do 
Projeto Resgate ${ }^{304}$ propõe uma subdivisão dos documentos coloniais brasileiros e portugueses que compreende uma gama de tipos textuais mais ou menos formatados, mas que se observados à lupa, deixarão entrever traços discursivos de textos ora mais ou menos particulares, ora mais ou menos emotivos, mais ou menos preservadores de uma norma dita culta. Somente a partir da segunda metade do século XIX (na época da República) o gênero carta pessoal apresentava um formato mais definido em relação ao que se conhece hoje como carta particular.

Para um estudo de fenômenos lingüísticos dos documentos anteriores ao século XX, interessa observar que apesar da permanência de um alto grau de fixidez de fórmulas é possível entrever usos inovadores que surgem em função da necessidade pragmática do missivista, e, nesse momento, ele abandona as fórmulas, dando margem à presença de itens do vernáculo. O compromisso com o papel era mais controlado no séc. XVIII por questões ligadas ao próprio trânsito das cartas e à dificuldade de se encontrar o material de suporte: o papel e a tinta. Por outro lado, o baixo grau de publicidade desses documentos permitia uma certa informalidade entre os missivistas que se escreviam em grau de hierarquia horizontal, algo impensável nos dias atuais, talvez agora reservado aos bilhetes que acompanham a documentação oficial.

$\mathrm{Na}$ seção seguinte, apresento três conjuntos de documentos selecionados e editados por Simões/Kewitz (2006) para a formação de corpora do PHPB: Aldeamento de Índios (século XVIII), Cartas Paulistas da BNRJ (século XIX) e Correspondência Passiva de Washington Luiz (século XIX).

\section{III.2.3.1 Cartas da Administração privada do século XVIII}

No espaço intermediário descrito por Barbosa (1999, 2002 e 2005) como Administração Privada localizam-se as cartas por nós coletadas no fundo Aldeamento de Índios do Arquivo Histórico do Estado de São Paulo (AHESP).

Esses documentos foram produzidos em sua grande maioria por religiosos de várias ordens - carmelitas, beneditinos, franciscanos e padres jesuítas - incumbidos de

304 O Projeto Resgate "BARÃO DO RIO BRANCO" tem como objetivo divulgar documentos coloniais referentes ao Brasil depositados no Arquivo Histórico Ultramarino de Lisboa. As imagens encontram-se disponíveis em CD-ROMs e já foram publicados vários catálogos com verbetesresumos de cada um dos documentos e Códices microfilmados. 
administrar as aldeias de índios do entorno da vila de São Paulo, tais como Embu, Itapecerica, Guarulhos, São José, Barueri, Escada, Laranjeiras, algumas mais distantes como Peruíbe e Queluz. As cartas apresentam como tema comum a informação sobre o cotidiano das aldeias e sobre listas de índios, e boa parte delas são cartas ascendentes, geradas a partir de solicitações ou ordens, muitas delas gerando novas cartas na instância superior. Esse dado evoca um outro tema ligado aos estudos das TDs e à Análise do Discurso que trata da intertextualidade desses documentos, ou seja, tarefas comunicativas distintas geram a produção de gêneros discursivos distintos a partir dos episódios envolvendo os autores das cartas.

Se por um lado observamos nessas cartas do séc. XVIII um alto grau de fixidez das fórmulas e a relação dos textos analisados com TDs distintas, por outro lado verificamos aquele acúmulo de funções comunicativas a que nos referimos anteriormente e não é raro encontrar desabafos e destemperos ao lado de meras prestações de conta a respeito do cotidiano das aldeias.

Estas cartas apresentam grau semiparticular de publicidade e normalmente revelam uma assimetria de grau ascendente entre os escritores:

(3) [C 181 Ald 3] Meu Senhor Remeto aVossaExcelencia a Lista dos Indios que | memandou fizeSse

(4) [C 18 1 Ald 5] do mais humilde Servo devossaexÇelenÇia | Frei Sebastiam dosAnjos | ExcelentiSSimo SSenhor

A fixidez temática em torno do cotidiano dos aldeamentos é um dos aspectos que torna homogêneo o conjunto destas cartas. Aliam-se a essa uniformidade na produção o grau de ascendência observado anteriormente e a gama de tarefas comunicativas desempenhadas pelos religiosos por meio delas. Por vezes, os missivistas agregam informações específicas do aldeamento à prestação de contas acerca do número de índios aldeados e seus respectivos nomes.

(5) [C 181 Ald 8] Fui entregue das Cartas que VossaExcelenCa mefes onRa | esCrever huâ pelos indios que foram aSua pre | Zensa onde meordena que vindo oSargento maior| Manoel gonçalvez de Aguiar daSua viagem os Remeta para Sua | aldea. aSim o farei etudo omais que VossaExcelenCa me- | ordenar emeordena

A função comunicativa dos textos está aliada ao papel social desempenhado pelos religiosos junto aos indígenas aldeados. Muitos destes documentos são relatos recriminatórios por ora do comportamento dos índios, por vezes da precária situação em que se encontram as aldeias e de como são tratados pelos aldeados. Em consequiência disso, além da crítica, dos protestos e do relato dos acontecimentos, as mesmas cartas 
trazem em seu bojo o pedido de intervenção das autoridades superiores. As dimensões da ação comunicativa que envolvem estes textos, permitem aos estudiosos, entre outras coisas, avaliar questões referentes à escolha lexical específica empreendida em um determinado estágio do português utilizado em solo brasileiro. Além disso, é possível também entrever recursos de modalização do discurso.

acusar, repreender, recriminar

(6) [C 181 Ald 6] tendo notiÇia de que hua jndia CaZada $\mid$ que tem omarido emoCaminho doCu[y]aba por | ordem de vossa excelencia, andava empeCadoCom | outro jndio CaZado, Com jndiCios de que | tinhaõ tenÇaõ defugirem; equerendo eu | por Remedio ahisto, SemeauZentou odi | to jndio. etendo eu feito exaltas d[ili] | genCias por ela [p]or todas estas partes, Sem | fruto algum, prendi aos parentes para efei | to deComfeÇarem averdade; osquais Com | feÇaõ Ser hido para aspartes davila de | JaCarehy, em Companhia dehum homem, ehua $\mid$ molher exComungados desta quaresma | dobairro deSaõ Joaõ. Cujos nomes Saõ | Francisco Rodriguez, e Maria Thomas; eComo naõ | Seja Sso ojndio Cujo nome he Se[bastiam] | Como taõ bem hum Rapas que ConCigo levo[u] | por nome Francisco ejunta mente ojndio Se | guira ospaSSos deSSua dama, eSe alonga | raõ para mais Lonje; fiCando Caminho | amplio para osque quiZerem Seguir omesmo | norte

$\underline{\text { requerer, pedir, implorar, solicitar }}$

(7) [C 18 1 Ald 6] mando aLguns jndios emais hum | Cabo em [Segui]mento deLa, para oque peSSo avossa | excelencia: RepaÇe Carta para os Cabos, ou ofi | Ciais dejustiCa deSSas viLas prinCipal | adeJaCarehy para faZerem apriZão eintre | gaLa aos jindios; por que eLes perSsi onaõ | podem faZer.

narrar, informar, relatar, reportar

(8) [C 18 1 Ald 11] Por mevir dizer oSargento<mor> da Aldea deNossa Senhora | daescada que oadmninistrador della tin | ha feito fugir a 3 Indios porque os queria | violentos alevar Comçigo para as minas de | paranapanema, Como juntamentes deixara | mais levar ahuã India por hu' homem | de goratingueta, esCrevy ao Religiozo doCa $\_$margo que aSiste nadita Aldea, tive por | Respposta aque vay incluza

obedecer, confirmar, aceitar, concordar, ceder

(9) [C 182 AI 24] Emcumprimento da Ordem de Vossa Excelencia arespeito do estado / das tres Aldeas informo, que os Indios de Crapocouva vi | vem , muita parte deles, e seconserva aSsua Ireja nosen | tro de hum grande quintal, que este he attacado - | com valos noqual notempo dos extintos Jezuitas

protestar, refutar, negar, objetar, repudiar, recusar, opor-se

(10) [C 181 Ald 16] Senhor Coronel SeVossamerce tivece posto ocobro, que lhepedi ostempos paSsados nes | tes deZaforos, naõ meSocedera agora huma perturbaçam Comoindio | Joaõ Irmaõ

Os manuscritos reunidos no fundo Aldeamento de Índios estão claramente submetidos a uma tradição epistolar que remonta a outras sincronias e são reminiscências de adaptações feitas através da adoção de tradições discursivas específicas. Dessa forma, é possível notar-se, através (xxx a xxx) dos enunciados de abertura e desfecho das cartas, o caráter formulaico a que estavam submetidas. No entanto, o alto controle destas fórmulas só se apresenta no contorno das epístolas, o seu 
interior revela por vezes um certo despreparo do missivista quanto à organização textual de seus textos com denotam os exemplos em (b). As fórmulas de abertura e desfecho já eram amplamente convencionalizadas, e, portanto, propícias a menores riscos de ferir a norma estabelecida para esse tipo de texto. Para o analista da sincronia da língua naquele século, talvez essas formas sejam menos interessantes que o uso considerado inapropriado tão visível nos desabafos empreendidos por estes religiosos.

(11) [C 182 AI 23] Illustrissimo Excelentissimo Senhor | Com amais reverente Submissam, erespeito, reprezenta aVossa Excelencia |Francisco daCunha Lobo, Director daAldea deBoú

(12) [C 181 Ald 7] Deos guarde por - | muitos annos a VossaExcelenCa para emparo dos pobres Aldeya de | Sa ̃̃ joa[õ] 10 demarÇo de1722 annos | de VossaExcelenCa Seu humilde vaSsallo | Frei Constantino deSanta Maria

O trecho abaixo ${ }^{305}$ revela uma escrita do pensamento através das repetições, abandonos de enunciados, retomadas de tópicos apresentados em enunciados anteriores e também nos itens de dêixis mal encadeados, dando margem à confusão de referências [porém, assi, e assim só, e como, cujo, os que, os quais, que, este, esta]. O exemplo (13) revela traços da oralidade, se observamos a descontinuidade na organização tópica [topicalização à direita].

(13) [C 181 Ald 4] Vai aLista que pude faZer dosIndios desta / aldea que estaõ pelas aldeas dos padres daCompanhia | naõ vay ameu gosto Como deZejava por quanto nesta | Aldea naõ tenho quem ConheSsa atodos quantos por elas | estaõ. eaSsim Sso vaõ em aLista osque tem pa - | rentes nesta aldea, epor parentes osConheÇem. | einda Si pela poCa ComuniCaÇaõ que tem huns. | Com outros; naõ tem verdadeiro ConheÇimento | dos filhos que vaõ havendo. eaSi So vaõ aÇen $\mid$ tados osque tive deles notiÇia serta desenden | tes por parte materna. epara Com mayor Serte | Za querendo faZer esta Lista dosque Senaõ tem | deles ConheÇimento mandava chamar hua india | AÇistente em hua deSSas aldeas, obrigada aesta, | por Ser ela demayor familia, emais parentella; | Cuja memandou por Resposta que oReligioZo que ago | verna por nem hum modo adeichava vir, eque | bem ConheÇia ela Ser desta aldea, eosmais que ne | la estavaõ, Cuja he o de Bohy [[por SeCom por des | ta amayor parte dagente]]. mas oReligioZo | que lá aCiste diZia denem hua Sorte ashavia | deixar vir por quanto em taõs naõ fiCaria quem lhes | trabalhaÇe, atemoriZandos Com promeSSas | deCastigos. esta he aResposta que memandou | esta india. fiCando Sempre esperando muitas | aCazioins deSeus. mayores Gostos.

Todos os índices discursivos observados nos exemplos acima revelam uma uniformidade dessas cartas como pertencentes a um gênero textual específico, que foram escritos ora num registro mais formal, seguindo as normas prescritas para uma determinada tradição discursiva (a) ora num registro mais informal, menos culto (b). Os exemplos em (b) oferecem pistas para identificar uma norma menos rígida, tais como:

- Ausência de pontuação [esperada], tornando a sintaxe mais truncada, denotando um possível abandono de estruturas sintáticas.

305. Destacamos em negrito os elementos que indicam o grau semicontrolado do planejamento do texto. 
- Ruptura de tópico discursivo e início de novo tópico sem os nexos esperados, como elementos adverbiais, conjunções, ou mesmo pontuação adequada.

- Ordem inesperada de constituintes nas sentenças, tais como topicalizações, recursos de cliticização inesperados, etc.

- rotacizações (ex. vortei) e assimilações de fonemas

- Repetições e paráfrases

\section{III.2.3.2 Cartas Paulistas da BNRJ}

As Cartas Paulistas depositadas na Biblioteca Nacional do Rio de Janeiro (BNRJ) foram coletadas para esta tese e também para constituir o corpus paulista do Projeto PHPB. ${ }^{306}$ Estas cartas giram em torno da pessoa de José Bonifácio de Andrada e Silva e foram escritas entre 1801 e 1822, período que marca grandes transformações na história do país. Não é por acaso que estas cartas tratam da temática sobre a tensão política que imperava na época. Tanto as cartas para José Bonifácio como aquelas trocadas entre João Ferreira de Oliveira Bueno e outros destinatários falam do momento político que envolvia principalmente as regiões de Santos, São Paulo e Rio de Janeiro. Além do interesse que possam despertar aos pesquisadores da língua, elas possuem um valor histórico inestimável que podem de alguma forma ajudar a entender o distanciamento que o Brasil demarcava em relação a Portugal naquele momento.

Um dos critérios de escolha destes documentos anterior à própria coleta foi tentar reconhecer a nacionalidade brasileira dos missivistas. Além da nacionalidade, outro fator de seleção era a origem do documento. A busca no Catálogo de Fontes Manuscritas do Brasil Colônia do prof. Afranio Barbosa (UFRJ) revelou poucas cartas originárias exclusivamente da cidade de São Paulo. Tomamos uma decisão que hoje cremos acertada de incluir documentos oriundos de outras cidades da então vigente Capitania de São Paulo, cidades que mantinham laços políticos e sociais firmes naquele intervalo histórico (1800-1822). A própria ocorrência destas cartas destinadas a moradores da cidade de São Paulo evidencia esse vínculo. Entre elas estão Itú, Sorocaba e Santos, cidade natal dos irmãos Andrada e centro nervoso do

\footnotetext{
${ }^{306}$ Este conjunto foi coletado com a colaboração do Prof. Dr. Afranio Gonçalves Barbosa da UFRJ em julho de 2004 e encontra-se publicado em Simões/Kewitz (2006).
} 
período da independência. Apoiamo-nos nas considerações de Groppi (2001a e 2001b), quando fala sobre a extensão do território paulista e Salles (1998 e 2001), quando fala sobre a constituição dos corpora paulistas.

Outro critério importante eram as características discursivas destas cartas. Mattos e Silva (2001 e 2002) alerta para a necessidade de constituir corpora homogêneos a fim de possibilitar análises mais fidedignas. A exemplo do recorte teórico que permeou a seleção dos outros dois conjuntos de cartas publicados por Simões/Kewitz, procurou-se aqui selecionar textos que, mesmo sendo oficiais, pudessem ser enquadrados dentro da categoria informal de interlocução autor/leitor. Outros fatores discursivos importantes referem-se a i) simetria/assimetria entre missivista e destinatário, ii) registro oficial formulaico/oficial "popular", feitos ora por um "autor seguro" por um "autor inseguro", ou por "mãos hábeis”, "mãos pouco hábeis" e "mãos inábeis" segundo Rita Marquilhas (1996 apud Barbosa, 2002).

\section{III.2.3.3 Cartas Particulares da Correspondência Passiva de Washington Luiz}

Uma boa parcela da correspondência passiva do fundo Washington Luiz (Arquivo Histórico do Estado de São Paulo - AHESP) insere-se na classificação de documentos privados proposta por Barbora (1999) e conta com diversas caixas de documentos do fim do século XIX e da primeira metade do XX. Trata-se de cartas escritas por parentes de Washington Luiz, nascidos nos Estado do Rio de Janeiro, cunhados e amigos. Os documentos selecionados para o corpus são cartas escritas no século XIX, quando da fase de estudante e início da carreira de advogado de Washington Luiz e da primeira metade do século XX, quando o destinatário das cartas já se encontrava em alta ascensão na vida política, período em que foi presidente da república.

Por serem particulares, as cartas recebidas por Washington Luiz tinham um baixo grau de publicidade, especialmente as da segunda metade do século XIX, como mostra o exemplo retirada de uma carta do irmão Lafaiete:

(14) [C 192 WL 70] ${ }^{307}$ Junto a esta a primeira carta do Chico, que como verás já escreve de modo bem

307. A notação que antecede cada um dos exemplos indica a sua origem [WL = fundo intitulado Correspondência passiva de Washington Luiz], o autor [L = Lafayette Luiz Pereira de Souza, F= Francisco Joaquim da Costa, $\mathrm{C}=$ Francisco Luiz Pereira de Sousa (Chico), $\mathrm{R}=$ Raphael Tobias de Barros e N = Luiz Pereira Nunes] e o ano em que foi escrita [1895]. 
legivel. - Recebi hontem a importancia do cheque que me mandaste, tudo hontem mesmo entregue ao Doutor Joaquim Celidonio (...).

Em sua maioria, as cartas apresentam um grau de simetria horizontal entre destinatário e remetente. Em algumas cartas, percebe-se, de forma indireta, um grau de simetria ascendente (destinatário). Isso talvez se deva à idade e ao respeito para com o destinatário por sua progressiva ascenção na carreira política, quando Washington Luiz advogava em Batatais e já participava da vida política local. Observe-se o exemplo a seguir:

(15) [C 192 WL 24] Rio 3 de Outubro de 1896 | Meu caro Washington | Ha muito que não tenho noticias tuas, senão muito vagas. Estimarei muito que esta vos encontre de perfeita saude, cheio de felicidades, e que na advocacia tenha feito progresso inauditos como dezejo. Sabes que fui amigo de teu finado Pae, e por conseguinte tenho por obrigação de ser dos filhos tambem, mormente quando elles tem como você, qualidades, e mere-cimentos que muito aprecio. (...) Escreve -me para a Rua d'Assembleia $\mathrm{n}^{\circ} 1191^{\circ}$ andar. Esta carta vae Registrada. Acceita saudades e um apertado | abraço do Velho amigo sincero | Francisco Joaquim da Costa

As cartas apresentam temas livres ou com núcleo temático fixo. Uma carta particular dificilmente apresentará um tema altamente fixo, visto que o remetente relata diversos fatos, informa sobre a família, agradece, e assim por diante. A carta pode ser vista como um diálogo escrito, que oferece retomadas de tópicos anteriormente tratados e propondo novos temas:

(16) [C 192 WL 69] O Chico continua com pequenas melhoras. Hontem foi ouvido de novo. Doutor Ascendino Reis, que julgou de alguma conveniencia applicação da electrecidade de correntes continuas, opinião esta que foi modificada pelo Doutor Coronel Xavier, que entende de ser conveniencia agora, d'essa especie de electrecidade nas pernas (...).

(17) [C 192 WL 11] Washington. Vencendo-se as apolices das casas á Rua Direita, em principios de Novembro, desejava saber si você quer que reforme a sua nas mesmas companhias e pelo mesmo preço.

(18) [C 192 WL 11] Washington. Procurando hoje as apolices de seguro de fogo de nossas casas, verifiquei, ao contrario do que pensava, que só uma dellas é commum a nós dois, e está por ella a sua casa segura só em trinta contos. Terá você uma outra apolice ?

As dimensões da ação comunicativa nessas cartas apresentam-se na forma de relatos ou narrativas de fatos particulares, prestação de contas, justificativas, pedidos de favores, agradecimentos e, mais raramente, reclamações. O exemplo abaixo ilustra um desabafo do irmão Lafayette em relação ao advogado que tratava do inventário do pai de Washington Luiz. Nota-se que o remetente faz uso de determinados termos indicando sua insatisfação e ira.

(19) [C 192 WL 33] O Doutor Lousada entregou-me a semana passada cópia das contas do Procurador, incumbido de levantar as apolices e receber os juros; é escandalosa a tal conta como verás pela cópia junta. $\mathbf{O}$ tal procurador cobra a modesta quantia de 300\#000, e além d'isso a modestiscima porcentagem de $10 \%$ por receber os juros vencidos ! A imbecilidade do Senhor Lousada chegou a tal ponto que depois de recebidas as apolices, escreveu-me perguntando se queria que as mesmas me fossem lançadas, ficando eu com a responsa=bilidade das dividas, por ser isso, dizia elle, mais simples; quando nada é mais simples do que vendel- as e pagar aos credores. Reclamei a elle contra a exorbitante porcentagem, não sei em que dará. - Sem mais para aqui e abraça-te o irmão 
e amigo Lafayette

Pelas marcas lingüísticas (morfossintáticas e discursivas), pode-se analisar o grau de planejamento dessas cartas e observar as três categorias: livre (popularcomum), semi-controlado (comum) e altamente controlado (formal). Observe o exemplo a seguir para um registro mais livre:

(20) [C 192 WL 23] Meu caro Washington Recebi a tua carta de 26 de Janeiro proximo passado no dia 4 de Fevereiro. Tive imenso praser por ter noticias tuas e dos teus que a muito não tinha; e creio que para mim era uma tristesa; dirás se não tinha $[\emptyset]^{308}$ é porque não devias-me $[\emptyset]$ po[r] que eu responderia, não, escrevite não tive resposta julguei que já tivesses de [sic] mudado, por isso não escrivi mais esperei que algum dia tivesse noticias tuas para escrever-te. Ainda maior praser tive pela noticia que me dás do teu casamento em uma familia distinta de nome conheço a muito tempo, quando recebi a tua carta estava presente o Senhor Eduardo Corrêa, socio do primo Belisario disse-me que conhecia a familia que era tão distinta que dava me o parabens, por tanto te en vio um saudoso abraço de felicitações e faço votos ao Altissimo para que la[deteriorado] a sua benção e sejão muito felises e por muitos annos, e outro tanto fasem a Sinhá, Am[erica] e Nhonho. E' muito provavel que eu não possa ir porque sou gerente aqui na Salina e agora é que se está fasendo callxitas, por isso talves nao possa ir o que sinto bastante, e espero me desculparás Nós aqui temos gosado saude, a Sinhá é que de ves enquando é atormentada pela mal dita enxaqueca, já tem experimentado muitos reme dios mas sem proveito mas está gorda e moça ninguem é capas de avaliar a idade pelo estado, ella lhe pede que logo que tenhas occa sião lhe mande um retrato da tua noiva que deseja conhecer assim como dos teus Irmãos, tua e de Lafaiete ja tenho. Manda-me noticias de teus Irmãos o Lafaiete a ultima ves que estive com elle no Rio ia eu almocar em um Hotel convidei o, disse -me que ia com pressa fallar com um individuo a hora certa; mas, que eu o esperasse um pouco no Hotel que elle lá ia ter esperereio [sic] um pouco não appareceo e nunca mais o vi. Hoje tambem recebi carta da minha mana Amelia que tambem levei muito tempo sem ter noticias d'ella, ultimamente estando no Rio tive noticias fui visita-la, está morando em São Domingos na Rua General Osorio n ${ }^{\circ} 27$ [e]m casa de um nosso parente filho do primo Antonio De n ovo te abraço assim como a Sinhá Amenea e Nhonho e a teus Irmões e te desejo saude e felicidades Seu tio e amigo certo Luiz Pereira Nunes [grifos nossos]

O grau semicontrolado de planejamento é sugerido por expressões como:

(21) [C 192 WL 1] por isso desculpe-me não ser mais extenso, assim como qualquer erro etc.

(22) [C 192 WL 1] Como em geral escrevo muito ligeiro desculpe alguns erros, e rasgue ou guarde bem minhas cartas

Alguns fenômenos lingüísticos observados nas cartas dão indícios de menor controle do registro, tais como:

- alternância entre o uso do pronome "você" e as formas de "tu". Tal fenômeno aparece em diversas cartas, as quais apresentam variação também do mesmo autor;

- senteças relativas: cortadora e pronome lembrete (v. exemplo 19 acima);

- $\quad$ sintaxe truncada

- repetição e/ou paráfrase de termos e sintagmas;

- falta de concordância

${ }^{308}[\emptyset]=$ objeto direto nulo. 
Para finalizar, vejamos os exemplos a seguir nos quais o remetente Lafayette se corrige, rasurando e substituindo termos:

(23) [C 192 WL 39] Junto encontrará[s $\uparrow$ ] vecê a ordem de 273\#000, que de accordo com o teu pedido te remetto"

A letra 's' em "encontrarás" foi nitidamente acrescentada após a rasura de "você", indicando correção de "você" para "tu”.

(24) [WL L 1890] Não disponho actual mente de muito tempo, <paro por isto aqui> continuando logo que possa...”

A expressão entre $<>$ representa o que foi esccrito por cima de "parando", substituída por "paro". Ao que parece, o remetente se corrigiu por ter escrito duas formas seguidas de gerúndio "parando" e "continuando".

\section{III.2.3.4 A textualização do gerúndio nas cartas}

Além das característica apontadas acima, é possível ver que o fenômeno sintático aqui estudado, desempenha um papel importante na constituição do gênero carta. Um olhar cuidadoso sobre os dados revela que o gerúndio não é apenas ativado como mecanismo da Sintaxe e sim do Discurso:

(25) [C 181 Seb 15 1] Movendoçe nesta villa em meu Juizo huã Contenda deCauza Sivel entre partes Agravou demim huã dellas para omeo ouvidor Geral ${ }^{309}$

(26) [C 181 Seb 2 1] Tendo avizado porvarias vezes aVossaExcelencia dachegada de tres navios olandezes noporto desta villa, inthe aopreZente naõ tenho tido Resposta, C2

(27) [C 182 BAN 6 1] ObedeSendo orespeitaveu despacho devossa enxelencia enformo Naforma Seguinte OS[oplicante] Padre Joaõ Barboza deSumCam Sendo Naturar Naferguezia deja vari PaSou Acazade Naoscal dacompanha torio verde onde Tem deSua Molher dois filhos

(28) [C 182 Gen 6 1] Obedecendo ovenerando despacho deVossaExcelencia fi[s] toda adeligencia poS = sivel para informar avossaExcelencia pella minha propria maõ, como do= mesmo informe Seve, mas naõ pude continuar pella debilidade Comque meacho doente emCama:

(29) [C 182 Seb 22 1] Sendome preSizo Saber donde adeser adeviZaõ domeu destrito, Com oCapitam Mor deSaõ Sebastiaõ, faSo= espedir por proprio esta avossa Excelencia para que me faSa merce = destinar destrito para eumesaberaver neste laburiozo trabalho emque ando Rompendo esteSertaõ Com aes= trada naforma que vossa Excelencia madetreminou;

(30) [C 191 Ald 26 1] Satisfazendo aCarta que por Ordem deVossa Excelenca escreveome o Sargento-mor ajudante de Ordens, Joaquim Joze Pinto de Morais Leme, respondo que nos suburbios desta Aldeia CirCunstanciado Com al gumas qualidades eactividade para Director dos Indios pareceme suficiente Salvador Pereira de Pontes, do destricto da Com CeiCam dos Guarulhos.

Não é mero acaso o fato de encontrarmos tantos gerúndios iniciando as cartas mais oficiais. Assim como já discutimos anteriormente, isso é reflexo de um processo de discursivização das construções de gerúndio por razões de tradições

\footnotetext{
${ }^{309}$ Para melhor compreensão do rótulo que endereça as ocorrências v. Tabela XXX.
} 
discursivas. Nos modelos de cartas mais oficiais do manual de Isidoro Nardi (1730?) encontramos fórmulas equivalentes para o italiano:

A Monsignor Martelli. Roma.

Essendo dalla Santità di Nostro Signore stato rimesso a V.S. Illustriss. un memoriale del Dottor N.N. perche ne parli: (Nardi, 1730?, p.64 )

PER LA CARICA DI FISCALE.

Giambatttista Altieri, \&c.

Dovendo noi provedere di persona idonea fedele, e diligete la Carica di Fiscale del Tribunale della nostra Badia de' Ss. Severo, e Martirio nella Città di Orvieto; Ed essendo informati, che le predette qualità concorrono in quella del Sig. Pompeo Febei, volentieri siam condescesi ad eleggerlo sicoome in virtù della presente lo eleggiamo Fiscale del nostro Tribunale, come sopra. (Nardi, 1730?, p. 176)

PER LA CARICA DI PROCURATOR.

Giambattista Altieri, \&c.

Desiderando noi che i Ministri, assittuarj Coloni, e Lavoradori de' nostri beni Abbatiali godano tutti que' Privilegj, esenzioni, ed immunità,che loro competono per disposizione de' Sacri Canoni, delle Costituzioni de' Sommi Pontefici, e della consuetudine de' Nottri indulti particolari (Nardi, 1730?, p. 177)

Um breve levantamento feito no "O Secretario Brazileiro, Contendo 306 Modelos de Cartas sobre Todos os Assuntos e um Formulário de Requerimentos e Memoriaes" (s/d) ${ }^{310}$, dos finais do séc. XIX, mostra que a lição foi seguida:

$\mathrm{Ill}^{\mathrm{mo}} \mathrm{Ex}^{\mathrm{mo}} \mathrm{Sr}$.

Tendo esta associação resolvido commemorar o seu $2^{\circ}$ aniversario,a 15 do corrente, com um grande concerto e baile, a directoria tem a honra de convidar a V. Ex a e sua Exma Familia para assistirem a elles, pelo que desde já se lhes confessa agradecida.

$\mathrm{Ill}^{\mathrm{mo}} \mathrm{Ex}^{\mathrm{mo}} \mathrm{Sr}$.

Havendo actualmente uma vaga de $2^{\circ}$ escripturario no Thesouro Nacional, julgo-me com direito a ella, por ser o $3^{\circ}$ mais antigo e desempenhar conscienciosamente os meus deveres.

$\mathrm{O}$ autor ressalta que embora haja muitos manuais de cartas baseados em modelos de autores nacionais e estrangeiros, eles "contém formulas desusadas $e$ modos de dizer archaicos, que não poderião ser hoje empregados nem mesmo por pessoas de grande leitura litteraria. Outros encerrão modelos taes que attrahirião o ridiculo sobre quem os seguisse entre nós" (O Secretário Brazilerio, s/d, p. 5). Ora, pelo que se vê, por esse crivo de inovação do autor do Secretário não passaram os gerúndios em cabeça de sentença que iniciam as cartas mais oficiais. Prova disso são os exemplos encontrados nas cartas oficiais mais recentes, iniciando e terminando as mesmas:

${ }^{310}$ Provavelmente do final do séc. XIX, ou dos primeiros anos do séc. XX. Em uma das cartas o missivista solicita uma certidão de nascimento, informando que nasceu em 1840. Em outros modelos de cartas registram-se as datas de 1882 e 1888. 
(36) [C 202 CLis 18 1] Tendo em projeto a reunião de uns quinze ou vinte contos brasileiros contemporâneos num volume, acabo de traduzir um conto seu, "Mistério em São Cristóvão", e muito apreciaria conhecer sua opinião sobre minha tradução, já que se trata de autor dos mais difíceis em matéria de transposição.

(37) [C 202 CLis 61 1] Ilustre Escritora: | Tencionando o Instituto Estadual do Livro dessa Diretoria de Letras lançar, ainda no corrente ano, na sua coleção de divulgação (Cadernos do Rio Grande), uma seção dedicada a textos de autores brasileiros modernos, vimos a sua presença solicitar o interesse no sentido de que a referida seção seja inaugurada por Vossa Senhoria.

(38) [C 202 JHR 51 1] Prezado Mestre José Honório, | Em regressando de uma excursão programada com os pós-graduados a Porto Seguro, tive de encontrar sua carta-bilhete de 3 de julho de 1981 .

(39) [C 202 JHR 51 4] Antecipando nossos agradecimentos e aguardando com a emoção de sempre a complementariedade de sua magnífica participação no "In Memoriam" subscrevome,cordialmente, | Maria Regina Simões de Paula.

\section{III.2.4 Conclusões prévias sobre a constituição do corpus}

Os elementos discursivos apontados são pressupostos primordiais para que se analisem, sincrônica e diacronicamente, questões como norma e inovação, e para que se identifique o percurso empreendido por determinados itens da fala para a escrita ou vice-versa. Dessa forma, poderemos entrever índices da oralidade em sincronias distintas e ampliar o leque de traços definidores de normas específicas. A identificação dessas normas era restrita à análise da escolha lexical empreendida e aos desvios da norma culta. Tradicionalmente os textos literários têm sido largamente utilizados pelos gramáticos normativos em seus exemplos para referendar a constituição de uma norma tida como culta. Nas palavras de Barbosa (2002:425):

Se à luz de seus procedimentos e conclusões, avaliarmos a distribuição de certas marcas lingüísticas em diferentes tipos de textos do passado colonial, estaremos seguindo na direção do paraíso da Lingüística Histórica, ou seja, ao invés de saber da linguagem de uma época por apenas um único tipo de texto, muitas vezes literário ou forense, saber das matizes lingüísticas de sincronias passadas para chegar a um Sociolingüística Histórica. Desse modo, na prática, é preciso selecionar e controlar entre os tipos de textos coloniais os fenômenos lingüísticos relevantes para as questões da história da língua portuguesa.

Através dessa análise, procuramos (Simões/Kewitz, 2005 e 2006) estabelecer alguns critérios que nos ajudassem a indentificar a homogeneidade dos conjuntos dessas cartas com o objetivo futuro de utilizar estes corpora para as análises lingüísticas específicas de cada domínio da língua, seja ele a morfologia, a sintaxe, a fonologia, o léxico ou o próprio discurso. Além disso, acredita-se que os critérios ali definidos podem ajudar a construir um quadro mais detalhado da história social da linguagem de cada período e região brasileira e, ao levar em conta todos esses aspectos, promover um estudo mais apurado da história do Português Brasileiro. 
Incorporei a esta tese os critérios que desenvolvi com Verena Kewitz para a seleção dos corpora reunidos por nós e já publicados (Simões/Kewitz, 2006a). Aplico estas estratégias ao corpus que constituí para este trabalho. A seguir, passo à descrição desses documentos.

\section{III.3 A Distribuição do corpus de análise}

As seções seguintes têm por função esclarecer o leitor deste trabalho quanto aos seguintes tópicos: (i) distribução dos documentos selecionados, (ii) características lingüístico-discursivas dos subgêneros incorporados (memórias, anúncios, entremezes e peças teatrais), (iii) critérios de notação adotados para rotular as ocorrências.

O corpus de análise desta tese está divido entre (a) um Corpus Básico, composto de memórias históricas, cartas, entremezes e peças teatrais, organizados diacronicamente em seis conjuntos (primera e segunda metade dos séculos XVIII, XIX e XX), e (b) um Corpus Diferencial, ampliado com subgêneros das cartas do século XIX, como as Cartas de Leitores e Redatores de Jornais Brasileiros, com os Anúncios de Jornais Brasileiros do séc. XIX, e com inquéritos de língua falada do séc. XX oriundos do Projeto da Norma Urbana Culta (NURC), do Projeto Filologia Bandeirante (Filoband) e do Projeto Português Brasileiro Popular (PBpop). ${ }^{311}$

Grande parte dos documentos manuscritos selecionados para o corpus de análise são provenientes de levantamento feito presencialmente no Arquivo Histórico do Estado de São Paulo (AHESP), na Biblioteca Nacional do Rio de Janeiro (BNRJ), no Museu Republicano de Itu (MRI), na Biblioteca Nacional de Lisboa (BNL), no Arquivo Nacional da Torre do Tombo de Lisboa (ANTT) e nos CDs-Rom com as imagens dos documentos do Arquivo Histórico Ultrarino de Lisboa (AHU). Os quadros com a descrição do corpus indicam (i) os conjuntos de documentos especialmente editados para este estudo, que estão publicados no segundo volume desta tese, ao lado dos outros documentos editados, descartados da análise, mas oferecidos à constituição do corpus paulista do Projeto PHPB, (ii) fazem parte

${ }^{311}$ Foi necessário dividir os corpora em dois conjuntos pelo fato de não ser possível encontrar os subgêneros textuais reunidos no Corpus Diferencial. Sempre que necessário alerto para o conjunto específico. Isso afeta principalmente a interpretação quantitativa das ocorrências. 
também do corpus de análise os manuscritos que já haviam sido transcritos para este trabalho e que foram publicados por Simões/Kewitz (2006) e, finalmente, os quadros apresentam ainda (iii) uma seleção de manuscritos e impressos editados por outros membros da equipe do Projeto PHPB, tais como as Cartas de Leitores e Redatores publicadas em jornais, organizadas por Barbosa/Lopes (2002) e os Anúncios de Jornais Brasileiros publicadas por Guedes/Berlinck (2000).

O corpus de língua falada compreende inquéritos do Projeto NURC (Castilho/Preti, 1986 e 1987; Preti/Urbano, 1989): um Diálogo entre dois informantes (D2), um Diálogo entre documentador e informante (DID) e duas Elocuções Formais (EF), além de um inquérito do Projeto Filoband e outro do Projeto PBpop, coordenado pela professora Ângela Cecília de Souza Rodrigues $(\text { FFLCH-USP) })^{312}$.

Para cada século foram recolhidas todas ocorrências de orações gerundivas, como também de orações adverbiais conjuncionais que apareceram num conjunto de 5000 palavras por cada uma das seis fases de $50 \operatorname{anos}^{313}$. A seguir, apresento individualmente cada conjunto de gênero textual analisado.

\section{III.3.1 Cartas}

As características lingüístico-discursivas das cartas Oficiais, cartas de administração privada e das cartas particulares descritas acima também amplicam-se às cartas de leitores e redatores de jornal incluídas aqui para o Corpus Diferencial do século $\mathrm{XIX}^{314}$. Vale notar, no entanto, que estas últimas estão condicionadas a fatores específicos que se aplicam mais particularmente a este subgênero:

(i) Tanto as cartas de leitores como as cartas de redatores estão submetidas a um controle de publicidade muito maior que as outras, o que promove maior foco por parte dos autores nas formulações, que são passíveis de revisão e reformulação antes de sua publicação, o que aproxima mais da norma culta;

\footnotetext{
${ }^{312}$ Os inquéritos do Projeto Filoband e do Projeto PBpop ainda não se encontram publicados.

${ }^{313}$ Os documentos analisados foram dispostos em fases de 50 anos, mas consiederou-se uma margem de alguns anos antecipando, ou avançando a fase em questão. Isso explica o fato de a memória de Capistrano de Abreu (1907) ter sido considerada como texto do séc. XIX, bem como os textos de Zequini (2004) e Érnica (2004) para o séc. XX.

314 Os itens assinalados com asterisco $(*)$ no quadro 4 foram editados especialmente para o corpus de análise e se encontram no vol. 2 desta tese.
} 
(ii) As cartas de leitores têm finalidade distinta, pondendo dividir-se em subgêneros: carta de reclamação endereçada ao redator, carta pessoal fictícia, possivelmente produzidas por algum jornalista com o objetivo de criticar algum evento ocorrido na cidade de São Paulo, entre outras possibilidades. O tom emocional perpassa todas estas cartas, o que afeta tanto a escolha do léxico, como as estratégias de argumentação;

(iii) As cartas de redatores são na maioria das vezes retratações a respeito de alguma reclamação feita por algum leitor ou representam algum tipo de crítica a algum evento ocorrido na cidade de São Paulo, o que as aproxima do gênero jornalístico editorial (v. Koch, 1997, a respeito da inovação a partir da tradição). 


\begin{tabular}{|c|c|c|}
\hline & Cartas & $\begin{array}{c}\text { Número de } \\
\text { palavras }\end{array}$ \\
\hline $\begin{array}{c}\text { 1.a séc XVIII } \\
1700-1749\end{array}$ & $\begin{array}{c}\text { Aldeamento de Índios - 1721-1810 (AHESP)* } \\
\text { (Simões/Kewitz, } 2006 \text { e Simões, 2006) } \\
\text { Militares e Capitão Mór de São Sebastião e Vila Bela - 1721-1819 (AHESP)* }\end{array}$ & 5000 \\
\hline $\begin{array}{c}\text { 2.a séc XVIII } \\
\text { 1750-1799 }\end{array}$ & $\begin{array}{l}\text { Aldeamento de Índios - 1721-1810 (AHESP)* } \\
\text { (Simões/Kewitz, 2006 e Simões, 2006) } \\
\text { Militares e Capitão Mór de São Sebastião e Vila Bela - 1721-1819 (AHESP)* } \\
\text { Militares Comandantes - Capitão Mór de Bragança, Atibaia e Nazaré - 1723- } \\
\text { 1822 (AHESP)* } \\
\text { Cartas Títulos de Sesmarias Capitães Generais 1646-1822 (AHESP)* }\end{array}$ & 5000 \\
\hline \multirow[t]{2}{*}{$\begin{array}{c}\text { 1.a séc XIX } \\
1800-1849\end{array}$} & $\begin{array}{c}\text { Aldeamento de Ìndios - 1721-1810 (AHESP)* } \\
\text { Militares e Capitão Mór de São Sebastião e Vila Bela - 1721-1819 (AHESP)* } \\
\text { Militares Comandantes - Capitão Mór de Bragança, Atibaia e Nazaré - 1723- } \\
1822(\text { AHESP)* } \\
\text { Cartas Títulos de Sesmarias Capitães Generais 1646-1822 (AHESP)* } \\
\text { Capitão Mór de Lorena e Areas - 1721-1822 (AHESP)* } \\
\text { Militares - General Arouche - Vale do Paraíba - 1816-1821 (AHESP)* } \\
\text { Cartas da Biblioteca Nacional do Rio de Janeiro (BNRJ)* } \\
\text { (Simões/Kewitz, 2006) }\end{array}$ & 5000 \\
\hline & $\begin{array}{c}\text { CORPUS DIFERENCIAL DO SÉX IX } \\
\text { Cartas de Leitores e Redatores } \\
\text { Críticas, Queixumes e bajulações na Imprensa Brasileira do séc. XIX } \\
\text { (Barbosa/Lopes, 2004) }\end{array}$ & $(5000)$ \\
\hline \multirow{2}{*}{$\begin{array}{c}\text { 2.a séc XIX } \\
1850-1899\end{array}$} & $\begin{array}{c}\text { Correspondência Passiva de Washington Luiz (AHESP) } \\
\text { (Simões/Kewitz, 2006) } \\
\text { Correspondência Passiva de Prudente de Moraes (MRI)* } \\
\text { Coleção Clube Republicano (MRI)* } \\
\text { Correspondência Passiva de Paulino Lima (MRI)* }\end{array}$ & 5000 \\
\hline & $\begin{array}{c}\text { CORPUS DIFERENCIAL DO SÉX IX } \\
\text { Cartas de Leitores e Redatores } \\
\text { Críticas, Queixumes e bajulações na Imprensa Brasileira do séc. XIX } \\
\text { (Barbosa/Lopes, 2004) }\end{array}$ & $(5000)$ \\
\hline $\begin{array}{l}\text { 1.a séc XX } \\
1900-1949\end{array}$ & $\begin{array}{l}\text { Correspondência Passiva de Washington Luiz (AHESP) } \\
\text { (Kewitz, 2005) } \\
\text { Correspondência entre Mário de Andrade, Mário Bandeira e Tarsila do Amaral } \\
\text { (Moraes, 2001 e Amaral, 2001) }\end{array}$ & \\
\hline $\begin{array}{l}\text { 2.a séc XX } \\
1950-2000\end{array}$ & $\begin{array}{c}\text { Correspondência Passiva da Família Simões* (Simões, 2006) } \\
\text { Correspondência Passiva de Clarice Lispector (Jacintho, 1997) } \\
\text { Nova correspondência de José Honório Rodrigues (Rodrigues, 2004) }\end{array}$ & 5000 \\
\hline Total & $\begin{array}{c}\text { Corpus básico } \\
\text { Corpus diferencial }\end{array}$ & $\begin{array}{c}30.000 \\
(10.000)\end{array}$ \\
\hline
\end{tabular}

Quadro 10. Corpus Básico e Corpus Diferencial de cartas. 


\section{III.3.2 Memórias}

No capítulo sobre a revisão da literatura sobre TDs mostrei que a constituição dos gêneros textuais é fruto de adaptações e inovações de outros gêneros. Vimos que o avviso da tradição epistolar italiana dividiu-se em notícia e romance epistolar. Destes surgiram os diários de navegação ao final do século XV e a partir do XVI, dando conta aos monarcas dos novos descobrimentos. Na tradição portuguesa, das cartas notícia e dos diários, como é o caso da Carta de Pero Vaz de Caminha (1500) e do Diário de Viagem de Pero Lopes (1530), chegamos às notícias práticas, relatos escritos por bandeirantes e outros desbravadores, que registravam a progressão de suas viagens e seus feitos, numa mescla entre carta e diário. Paralelamente, à medida que se constituia uma nova identidade luso-brasileira, foi preciso registrar a diacronia dos fatos históricos que demarcavam eventos e feitos significativos da história do Brasil. Nesse momento surgem as memórias históricas, algumas ufanistas, como a de Frei Gaspar da Madre de Deus (1797), outras mais críticas, como a Dissertação de Marcelino Pereira Cleto (1781).

A Memória para a História da Capitania de São Vicente de Frei Gaspar (1797) foi vilmente plagiada por Manuel Cardoso de Abreu, que ardilosamente registrou em seu manuscrito a data de 1796, anterior em um ano à data de publicação do livro de Frei Gaspar, para tentar atribuir o plágio ao verdadeiro autor: "Não fôra a iniciativa dos irmãos Arouche e a modéstia do velho monge teria permitido que se consumasse inaudito atentado, o mais indecorosos [sic] caso de sic vos non vobis" (Taunay, 1975 [1920]:19). Os irmãos Arouche fizeram com que fosse publicada em Lisboa. Isso se deu tardiamente, uma vez que o religioso fosse avesso ao alarde e não se preocupava em publicar suas obras, tendo-se perdido muito de seus escritos por esse motivo.

O plágio de Manuel Cardoso de Abreu, oferecido a Luz Pinto de Souza Coutinho, com o título adulterado para Memória Histórica da Capitania de São Paulo, envolve outra figura histórica do Brasil, Marcelino Pereira Cleto, o Juiz da Alfândega e Juiz de Fora da Vila de Santos, posteriormente ouvidor no Rio de Janeiro, ninguém menos que o escrivão da Devassa de Minas Gerais, responsável 
pelo processo movido contra o Tiradentes ${ }^{315}$ e membro da Relação da Bahia. Em correspondência à Rainha D. Maria I, Cleto dá conta da situação da Capitania de São Paulo, com base em informações de Manuel Cardoso de Abreu, ali chamado de Manoel de Abreu Fialho ${ }^{316}$ :

Esta no | ticia nos Comunicou, peSsoa de muita verdade | que tranzitando pella Provincia de Paraguay | desde o anno demil sete centos sincoenta esinco | Se Recolheu agora neste demil sete centos seten | ta eoito, a esta Cidade deSaõ Paulo Sua pa | tria, e este he Manoel deAbreu Fialho a quem conhecemos, ja detempo das escolas, edosprimei | ros Rudimentos da Gramatica Latina desde o anno de mil sete Centos evinte e seis. Saõ | Paulo nove de Setembro demil sete Centos se | tenta e oito annos. (Carta de Marcelino Pereira Cleto à Rainha D. Maria I, de 9 de setembro de 1778, ANTT, Papéis do Brasil, COD. 13, MF 1997)

Este trecho da carta prova ao mesmo tempo a nacionalidade brasileira de Manuel Cardoso de Abreu e a possível identidade brasileira também de Marcelino Pereira Cleto, uma vez que na carta cita a ligação de amizade entre os dois desde o período da alfabetização. O certo é que o próprio Marcelino Pereira Cleto escreveu sua Dissertação da Capitania de Saõ Paulo já em $1781^{317}$, publicada em 1977 na Coleção Paulística ${ }^{318}$ ao lado do Divertimento Admirável ${ }^{319}$ do próprio Manuel Cardoso de Abreu. Uma edição cuidadosa dos manuscritos de Marcelino Pereira Cleto, incluido o rascunho de 1781 depositado na Biblioteca Nacional de Lisboa talvez pudesse trazer luz ao percurso desse plágio e desvendar se a abundância de memórias histórias escritas por esses três autores envolve um plágio de Cleto do próprio plágio de Cardoso de Abreu. Para o estudo da Lingüística Brasileira, a

315 Ao que parece, sua reputação continua em baixa. Curiosamente, nos livros de tombo sobre a documentação da Devassa de Minas Gerais, que se encontra depositada na Torre do Tombo em Lisboa, há uma intervenção recente de um pesquisador ao lado do seu nome com a inscrição "Traidor!".

${ }^{316}$ Em um estudo sobre os autores coloniais publicado no V. II dos Anais do Museu Paulista (1925), A. Taunay reconhece Manoel de Abreu Fialho como sendo o Manoel Cardoso de Abreu. A troca do nome era comum nesse século, ora identificando-se o sobrenome do pai, ora o da mãe. Na Genealogia Paulista de Silva Leme (1903-1905, Vol III, p. 237) consta: “Joanna Maria casada em 1762 em Mogimirim com Ignacio Vieira de Abreu, natural de Santo Antonio do Jaraguá, Meia Ponte, Goiás, $f^{\circ}$ de Manoel de Abreu Fialho, de Santo Amaro, e de Theresa de Jesus, de S. Paulo, n. p. de José de Abreu Fialho, de Lisboa, e Izabel Vieira Antunes, de S. Paulo, n. m. de João Rodrigues Nogueira, de Mogi das Cruzes, e de Francisca Moraes Cavalcanti, da mesma vila.”

${ }^{317}$ (a) Dissertaçã̃ da Capitania de Saõ Paulo, Sua decadencia, e modo de restabelece-la (ANTT, COD. 12, fl. 2-23v), manuscrito autógrafo com rubrica em todas as páginas, datada de Santos a 25 de outubro de 1781 e (b) Dizertaçã̃ A respeito da Capitania de S. Paulo eSua decadencia esobre omodo de restabelecella, datada de Santos a 25 de outubro de 1781, provavelmente um rascunho de (a) (BNL, PBA 686, 546-575).

${ }^{318}$ CLETO, Marcelino Pereira (1977/1781). "Dissertação da Capitania de São Paulo, sua decadência e modo de restabelecê-la. 25 de outubro de 1782. In: Roteiros e notícias de São Paulo Colonial - 17511804, São Paulo: Governo do Est. de SP, Coleção : Paulística, 1977.

319 Manoel Cardoso de Abreu, "Divertimento Admirável para os historiadores observarem as máquinas do mundo reconhecidas nos sertões da navegação das minas de Cuiabá e Mato Grosso". In: Roteiros e Notícias de São Paulo Colonial. São Paulo: Governo do Est. de SP, Coleção : Paulística, 1977. 
contraposição desses documentos pode revelar interessantes recursos de paráfrase e reformulação para uma época de que temos tão pouco documentação dessa natureza. Os trechos da Memoria Historica da Capitania de São Paulo e de todos os seus memoraveis successos, desde o anno de 1531 de Cardoso de Abreu (1797?) ${ }^{320}$ e da Dizertaçã̃ A respeito da Capitania de S. Paulo eSua decadencia esobre omodo de restabelecella de Marcelino Pereira Cleto (1781) servem nesta tese como amostra dessa possível contraposição.

Além do (1) plágio de frei Gaspar e (2) da Dizertaçaõ de Marcelino Pereira Cleto, incluí ao corpus de memórias do século XVIII e XIX dois outros textos que também editei para este trabalho: (3) uma cópia a Memoria economica $e$ metallurgica sobre a fabrica de ferro de Ypanema Sorocaba 1820, escrita pelo mineralogista nascido em Santos (SP) José Bonifácio de Andrada e Silva, depositada na BNRJ (I-28,25,13) e (4) uma cópia do Plano, emque sepropoem omelhoramento daSorte dos Indios de 1802 concebido pelo paulista José Arouche de Toledo Rendon e depositado no AHU de Lisboa (AHU-73-4092), posteriormente publicado pelo RIHGB com o título de Memória sobre as aldeas de indios da província de S. Paulo. José Arouche de Toledo Rendon foi o primeiro diretor da Academia de Direito de São Paulo, atual Faculdade de Direito do Largo de São Francisco. ${ }^{321}$

\section{III.3.2.1 Alguns traços lingüísticos das memórias}

Como já disse anteriormente, não me preocupei em fazer um estudo detalhado das características textuais nem das memórias nem das peças teatrais do século XVIII e XIX. Isso seria tarefa de um estudo específico, feito segundo o aparato da Análise do Discurso. O critério de escolha dessa tipologia textual diversificada também já foi apresentado. Resta apenas fazer um apanhado geral das

\footnotetext{
${ }^{320}$ A pesquisadora Renata Ferreira Costa (FFLCH/USP) é responsável pela edição filológica da memória de Manuel Cardoso de Abreu para a sua tese de mestrado. Em 2005 encontramo-nos no Arquivo Histórico do Estado de São Paulo e, durante a seção de fotos que eu fazia do manuscrito, fiquei sabendo da pesquisadora que ela já estava fazendo a edição. O trecho de 5000 palavras que transcrevo nesta tese é de minha inteira responsabilidade.

${ }^{321}$ Os trechos de 5000 palavras das memórias históricas editadas por mim não constam do volume II desta tese, em função de não haverem sido transcritos na íntegra, à exceção da memória de José Bonifácio, que se encontra editada em sua totalidade naquele volume. Os documentos Dizertaçã̃ de Marcelino Pereira Cleto e o Plano de José Arouche de Toledo Rendon serão objeto de edição em trabalho futuro, posterior a esta tese.
} 
características discursivas desses textos para que se visualize o recorte de análise adotado.

Escolhi as memórias históricas por dois motivos:

1. Embora as memórias tenham se tornado públicas através de sua impressão, até o final do século XIX elas tinham em vista um leitor a quem a obra era oferecida. Porém, é natural supor que eram fruto de uma produção mais controlada e passível de revisões. Além disso, o fato de ser um produto lingüisticamente controlado aproxima o documento da norma culta padrão de cada sincronia aqui analisada.

2. As memórias escolhidas para este conjunto têm como fio condutor a história da Capitania de São Paulo, à exceção das duas notícias práticas da primeira metade do século XVIII que rezam uma sobre as bandeiras de Minas Gerais ao Grão Pará e a outra sobre a Colonia de Sacramento. A idéia de manter o foco sobre a história do território de São Paulo tem por objetivo a uniformidade na centração tópica a fim de poder controlar melhor o uso do gerúndio narrativo nesse tipo de texto. 


\begin{tabular}{|c|c|c|}
\hline & Memórias & $\begin{array}{l}\text { Número } \\
\text { de } \\
\text { palavras }\end{array}$ \\
\hline \multirow{2}{*}{$\begin{array}{l}\text { 1.a séc XVIII } \\
\text { 1700-1749 }\end{array}$} & $\begin{array}{l}\text { Notícia - la Prática }(1734) \\
\text { José Peixoto da Silva Braga }\end{array}$ & \multirow{2}{*}{2500} \\
\hline & $\begin{array}{l}\text { Notícia- } 2^{a} \text { Prática }(1727) \\
\text { José Inácio }\end{array}$ & \\
\hline \multirow{2}{*}{$\begin{array}{l}\text { 2.a séc XVIII } \\
1750-1799\end{array}$} & $\begin{array}{c}\text { Dizertaçaõ a respeito da Capitania de S. Paulo (BNL)* } \\
\text { Marcelino Pereira Cleto (1781) }\end{array}$ & \multirow{2}{*}{2500} \\
\hline & $\begin{array}{c}\text { Memoria Historica da Capitania de São Paulo (AHESP)* } \\
\text { Manuel Cardoso de Abreu (1797?) }\end{array}$ & \\
\hline \multirow{2}{*}{$\begin{array}{l}\text { 1.a séc XIX } \\
1800-1849\end{array}$} & $\begin{array}{c}\text { Memoria Economica e Metallurgica sobre a Fabrica de Ferro de Ypanema } \\
\text { Sorocaba }(1820)^{*} \\
\text { José Bonifácio de Andrada e Silva }\end{array}$ & \multirow{2}{*}{2500} \\
\hline & $\begin{array}{c}\text { Plano, emque sepropoem omelhoramento daSorte dos Indios }(1802)^{*} \\
\text { (Memória sobre as aldeas de indios da província de S. Paulo) } \\
\text { José Arouche de Toledo Rendon }\end{array}$ & \\
\hline \multirow{2}{*}{$\begin{array}{l}\text { 2.a séc XIX } \\
1850-1899\end{array}$} & $\begin{array}{l}\text { A retirada da Laguna }(1871) \\
\text { Alfredo D'Escragnolle Taunay, o Visconde de Taunay }\end{array}$ & \multirow{2}{*}{2500} \\
\hline & $\begin{array}{c}\text { Capítulos da História Colonial (1907) } \\
\text { Capistrano de Abreu }\end{array}$ & \\
\hline \multirow{2}{*}{$\begin{array}{l}\text { 1.a séc XX } \\
1900-1949\end{array}$} & $\begin{array}{l}\text { Reminiscências de Santos (1930) } \\
\text { João Luís Promessa }\end{array}$ & \multirow{2}{*}{2500} \\
\hline & $\begin{array}{l}\text { (Kewitz/Silveira, 2004, ed.) } \\
\text { Na capitania de S. Vicente (1918) } \\
\text { Washington Luiz }\end{array}$ & \\
\hline \multirow{2}{*}{$\begin{array}{l}\text { 2.a séc XX } \\
1950-2000\end{array}$} & $\begin{array}{c}\text { A fundação de São Paulo e os primeiros paulistas: indígenas, europeus e } \\
\text { mamelucos (2004) }\end{array}$ & \multirow{2}{*}{2500} \\
\hline & $\begin{array}{l}\text { Anicleide Zequini } \\
\text { Uma metrópole multicultural na terra paulista (2004) } \\
\text { Maurício Érnica }\end{array}$ & \\
\hline Total & Corpus Básico de Memórias & 30.000 \\
\hline
\end{tabular}

Quadro 11. Corpus de memórias históricas

A análise que se faz nos capítulos sobre a sintaticização e a discursivização do gerúndio leva em conta também as orações conjuncionais e mostrará qual é a freqüência dessas estratégias de junção não só nas memórias, como nas cartas e nas peças teatrais. Espera-se, com esta análise, demonstrar como uma determinada tipologia textual se constrói em função também dos recursos sintático-discursivos de que fazem uso os seus autores/locutores.

\section{III.3.3 Anúncios de jornais do séc. XIX}

Os anúncios de jornais do séc. XIX reunidos ${ }^{322}$ por Guedes/Berlinck (2000) têm características que merecem ser ressaltadas:

${ }^{322}$ Os anúncios foram publicados nos seguintes jornais, nas datas indicadas, e foram coletados pelos pesquisadores indicados entre parênteses: O Farol Paulistano - 1828/1829 (Marilza de Oliveira), Diário Popular - 1879-1884 (Ataliba Teixeira de Castilho), Correio Paulistano - 1879 (Soraia 
(i) Quanto ao seu conteúdo: neles anunciavam-se os produtos e serviços disponíveis nas cidades em questão, além de servirem como denúncia de fuga de escravos ou anúncios indicando a perda de algum bem pessoal;

(ii) Quanto a sua linguagem: os anúncios caracterizam-se por textos de composição heterogênea quanto à norma, mas é comum a todos um alto grau de nominalização das sentenças, típico do texto propagandístico. Apesar de não dispormos de informações sobre as condições de produção destes textos, nota-se que eles foram registrados à base do texto ditado pelo anunciante. ${ }^{323}$

As breves observações feitas acima apontam para especificidades desse gênero textual que interessam para a análise das orações gerundivas. Veremos no Cap. V que os anúncios são depositários de construções de gerúndio bastante interessantes.

\begin{tabular}{|c|c|c|}
\hline & $\begin{array}{c}\text { CORPUS DIFERENCIAL DO SÉC XIX: } \\
\text { Anúncios de Jornal }\end{array}$ & $\begin{array}{c}\text { Número de } \\
\text { palavras }\end{array}$ \\
\hline $\begin{array}{c}\text { 1.a séc XIX } \\
1800-1849\end{array}$ & $\begin{array}{c}\text { Anúncios de Jornais Paulistas do séc. XIX } \\
\text { E os Preços Eram Commodos... } \\
\text { (Guedes/Berlinck, 2000) }\end{array}$ & 5000 \\
\hline $\begin{array}{c}\text { 2.a séc XIX } \\
1850-1899\end{array}$ & $\begin{array}{c}\text { Anúncios de Jornais Paulistas do séc. XIX } \\
\text { E os Preços Eram Commodos... } \\
\text { (Guedes/Berlinck, 2000) }\end{array}$ & 5000 \\
\hline Total & & 10.000 \\
\hline
\end{tabular}

Quadro 12. Corpus de anúncios de jornal do séc. XIX

Floriano Machado), Município de Araraquara - 1884 (Taísa Kawakami e Chimena Meloni Silva de Barros), A Notícia 1896-1899 (Taísa Kawakami e Franciane Maria de Godoy Eufrade), Gazeta de Campinas - 1870-1872 (Maria Aparecida C. R. Torres Morais), Correio de Jahu - 1897 (Clotilde de Almeida Azevedo Murakawa), A Constituinte - 1879-1880 (Helena Micheletti) e A Mocidade - 18741875 (Marymarcia Guedes).

${ }^{323}$ Para a linguagem dos anúncios de jornais do séc. XIX, v. Brandão, Helena Nagamine (2004). O cotidiano em anúncios de jornais do séc. XIX. VI Seminário Para a História do Português Brasileiro. Itaparica/BA. 


\section{III.3.4 Entremezes, peças teatrais, elocuções formais e diálogos entre informantes}

O quadro de Koch/Oesterreicher (1985) ${ }^{324}$ apresentado anteriormente dá conta de como os diferentes enunciados, tidos como atos de fala ou textos propriamente ditos, se movimentam entre o pólo do formal para o informal, do planejado para o menos planejado, da norma padrão para a norma popular. A idéia de incorporar entremezes e peças teatrais ao corpus de análise adota o procedimento já conhecido de analisar uma oralidade concepcional, uma vez que não dispomos de registros da língua falada em sincronias passadas.

\section{III.3.4.1 Os Entremezes do século XVIII}

O entremez nasceu como forma de entretenimento popular sem grandes pretensões, era uma peça de caráter burlesco, geralmente apresentada nos entreatos de peças maiores e que geralmente incorporavam um número musical ao final. $\mathrm{O}$ objetivo era aliviar a tensão emocional provocada pelas tragédias passionais. Os primeiros entremezes datam do século XII, mas foi a partir de Cervantes, no século XVI, que o entremez se consolidou como gênero ${ }^{325}$. Muitos entremezes foram traduzidos do espanhol para o português. Seu conteúdo era preponderantemente popular e tinha como característica principal o fato de trocar o verso pela prosa nos diálogos. Por estes traços constitutivos e por serem retrato de uma norma mais popular, penso que os entremezes servem como subsídio para analisar a fala concepcional de uma norma aproximada àquela que se falava no Brasil naquele período em que a influência político-cultural de Portugal no Brasil era mais marcada.

Para o corpus, foi selecionada a peça Guerras do Alecrim e da Manjerona do autor brasileiro Antônio José da Silva (1737), que viveu grande parte de sua vida em Portugal, onde foi perseguido e executado pela Inquisição. Também agreguei os seguintes entremezes de autores desconhecidos editados por Célia Lopes ${ }^{326}$ : As

\footnotetext{
${ }^{324} \mathrm{~V}$. quadro 3 deste capítulo.

325 Encyclopaedia Britannica do Brasil Publicações Ltda: ihttp://orbita.starmedia.com/ stargate $2 /$ entremez. htm, acesso em 10.12.2006.

326 Na impossibilidade de identificar textos teatrais do século XVIII que fossem genuinamente brasileiros, agreguei ao corpus quatro entremezes portuguezes coletados na Biblioteca Nacional de
} 
Filhozes do Entrudo Feitas em Casa de Pantufo Rombo Sapateiro e sua Mulher Mona Xorina... de autor desconhecido (1785) e o Novo Entremez Intitulado Dezengano para os Homens nam se Fiarem em Mulheres (1788), tendo sido os dois publicados em Lisboa.

\section{III.3.4.2 O Teatro Brasileiro dos séculos XIX e XX}

Para o século XIX foram escolhidas a peça Macário de Álvares de Azevedo (1855), autor paulista que viveu no Rio de Janeiro até voltar a São Paulo para estudar na Academia de Direito, e O Namorador ou a Noite de São João do dramaturgo carioca Martins Pena (1845). Para a segunda metade do século XIX, escolhi a peça Sangue Limpo do autor paulistano Paulo Eiró (1862), que nessa peça escrita em 1962 retrata o dia 7 de setembro de 1822. A peça traz nos seus personagens a caricatura dos paulistas: o negro, o índio, o agregado, o religioso, o militar. O autor preocupou-se em reproduzir na fala desses personagens o dialeto específico de cada comunidade que representa, bem como os registros de formalidade que imperavam à época, como o grau de hierarquia entre os falantes: a irmã utiliza o pronome você ao se dirigir ao irmão, que por sua vez chama a irmã por $t u$. Na codificação dos dados desta peça identifiquei a norma das ocorrências como culta ou popular de acordo com o personagem.Ainda para a segunda metade do século XIX selecionei da comédia Almanjarra de Artur Azevedo e Aluísio Azevedo (1888), que se passa no Rio de Janeiro do final desse século.

Lisboa e editados por Célia Lopes (UFRJ) para o Projeto Rearranjos no quadro pronominal do português: variação sincrônica e mudança diacrônica. 


\begin{tabular}{|c|c|c|}
\hline & Entremezes, peças teatrais e diálogos & $\begin{array}{l}\text { Número } \\
\text { de } \\
\text { palavras }\end{array}$ \\
\hline $\begin{array}{c}\text { 1.a séc XVIII } \\
1700-1749\end{array}$ & $\begin{array}{l}\text { Guerras do Alecrim e da Manjerona (1737) } \\
\text { Antonio José da Silva, o Judeu }\end{array}$ & 5000 \\
\hline $\begin{array}{c}\text { 2.a séc XVIII } \\
1750-1799\end{array}$ & $\begin{array}{c}\text { As Filhozes do entrudo (1785) } \\
\text { Dezengano para os homens (1788) }\end{array}$ & $\begin{array}{l}2500 \\
2500\end{array}$ \\
\hline $\begin{array}{l}\text { 1.a séc XIX } \\
1800-1849\end{array}$ & $\begin{array}{c}\text { Macário (1855) } \\
\text { Álvares de Azevedo } \\
\text { O Namorador ou a Noite de São João (1845) } \\
\text { Martins Pena }(1815+1848)\end{array}$ & $\begin{array}{l}2500 \\
2500\end{array}$ \\
\hline $\begin{array}{c}\text { 2.a séc XIX } \\
1850-1899\end{array}$ & $\begin{array}{c}\text { Sangue limpo (1862) } \\
\text { Paulo Eiró } \\
\text { Almanjarra (1888) } \\
\text { Artur Azevedo e Aluísio Azevedo } \\
\end{array}$ & $\begin{array}{l}2500 \\
2500\end{array}$ \\
\hline $\begin{array}{l}\text { 1.a séc XX } \\
1900-1949\end{array}$ & $\begin{array}{c}\text { O rei da vela }(1937) \\
\text { Oswald de Andrade } \\
\text { O Telescópio }(1951) \\
\text { Jorge Andrade }(1922-1984) \\
\end{array}$ & $\begin{array}{l}2500 \\
2500\end{array}$ \\
\hline $\begin{array}{l}\text { 2.a séc XX } \\
1950-2000\end{array}$ & $\begin{array}{c}\text { Fica Comigo Esta Noite (1983) } \\
\text { Flávio de Souza } \\
\text { Pérola (1994) } \\
\text { Mauro Rasi }\end{array}$ & $\begin{array}{l}2500 \\
2500\end{array}$ \\
\hline Total & Corpus básico & 30.000 \\
\hline
\end{tabular}

Quadro 13. Corpus Básico de Entremezes e Peças Teatrais

Para o século XX, procurei escolher autores paulistas, a fim de manter a uniformidade com o restante do corpus. São elas: $O$ Rei da Vela de Oswald de Andrade (1937), O Telescópio (1951) de Jorge Andrade, Fica Comigo Esta Noite de Flávio de Souza (1983) e a comédia Pérola de Mauro Rasi (1994).

\section{III.3.5 Diálogos de norma culta e popular do séc. XX}

O Corpus Diferencial composto de diálogos gravados de norma culta e popular foi agregado ao conjunto básico analisado, a fim de que pudéssemos explicitar de que maneira as orações de gerúndio neles se distribuem e comparar essa 
freqüência com os outros gêneros recolhidos para a $2^{\mathrm{a}}$. metade do séc. XX e aqui analisados.

\begin{tabular}{|c|c|c|}
\hline & $\begin{array}{c}\text { CORPUS DIFERENCIAL DO SÉC XX: } \\
\text { Diálogos de Norma Culta e Popular do séc. XX }\end{array}$ & $\begin{array}{c}\text { Número } \\
\text { de } \\
\text { palavras }\end{array}$ \\
\hline \multirow{3}{*}{1. a séc XVIII } & NURC SP D2 360 & $(5000)$ \\
$1700-1749$ & NURC SP DID 234 & $(5000)$ \\
& NURC SP EF 405 / POA 278 & $(5000)$ \\
& Filologia Bandeirante Inq. 2 & $(5000)$ \\
Total & (Terezinha Florêncio de Souza/Taubaté) & $(5000)$ \\
\hline
\end{tabular}

Quadro 14. Corpus Diferencial de Diálogos de Norma Culta e Popular do séc. XX

A quadro 15 traz uma visão geral do número de palavras coletados para os corpora selecionados:

\begin{tabular}{|c|c|c|c|}
\hline & Memórias & Cartas & $\begin{array}{c}\text { Entremezes, } \\
\text { peças teatrais } e \\
\text { diálogos }\end{array}$ \\
\hline & \multicolumn{3}{|c|}{ Número de palavras } \\
\hline $\begin{array}{c}\text { 1.a séc XVIII } \\
1700-1749\end{array}$ & 5000 & 5000 & 5000 \\
\hline $\begin{array}{c}\text { 2.a séc XVIII } \\
1750-1799\end{array}$ & 5000 & 5000 & 5000 \\
\hline $\begin{array}{l}\text { 1.a séc XIX } \\
\text { 1800-1849 }\end{array}$ & 5000 & $\frac{5000}{(10.000)^{327}}$ & 5000 \\
\hline $\begin{array}{l}\text { 2.a séc XIX } \\
\text { 1850-1899 }\end{array}$ & 5000 & $\frac{5000}{(10.000)^{328}}$ & 5000 \\
\hline $\begin{array}{l}\text { 1.a séc XX } \\
1900-1949\end{array}$ & 5000 & & 5000 \\
\hline \multirow{2}{*}{$\begin{array}{l}\text { 2.a séc XX } \\
\text { 1950-2000 }\end{array}$} & \multirow{2}{*}{5000} & \multirow{2}{*}{5000} & 5000 \\
\hline & & & $(25.000)$ \\
\hline $\begin{array}{c}\text { Total } \\
90.000 \\
(45.000)\end{array}$ & 30.000 & $\begin{array}{c}30.000 \\
(20.000)^{329}\end{array}$ & $\begin{array}{c}30.000 \\
(25.000)\end{array}$ \\
\hline
\end{tabular}

Quadro 15. Quadro geral de palavras dos Corpora Básico e Diferencial.

${ }^{327}$ Corpus Diferencial de anúncios e cartas de leitores e redatores de jornal do séc. XIX.

${ }^{328}$ Idem.

${ }^{329}$ Corpus Diferencial de diálogos de norma culta e popular do séc. XX. 


\section{III.3.6 Considerações finais sobre os corpora analisados}

Iniciei este capítulo expondo a preocupação técnica de organizar um corpus devidadamente equilibado pela distribuição de gêneros e seus subgêneros e pela quantidade de texto. Essa metodologia apoiou-se nos pressupostos teóricos do modelo de Tradições Discursivas, que alia o estudo das tipologias textuais à análise de fenômenos gramaticais específicos. Baseado nisto, analisei as características constitutivas dos gêneros e subgêneros escolhidos, procurando identificar o seu canal de tradição. O método privilegia também o modelo da Análise Multissistêmica da Língua proposto por Castilho (2004, 2005 e 2006), permitindo assim uma visualização um tanto mais nítida do uso do gerúndio no português brasileiro.

No capítulo seguinte, inicio a análise das ocorrências de gerúndio, começando pelo subsistema da Gramática. Nele apresento e discuto uma classificação que é fruto da revisão da literatura sobre o gerúndio empreendida no Cap. I e que também brotou do estudo das ocorrências encontradas nos corpora analisados. 


\section{- CAPÍ́tulo IV -}

\section{A sintaticização do gerúndio}

O gerúndio atacou de rijo. O pobre do particípio, afuroado por elle, foi pedir guarida no quarto dos adjetivos e dos substantivos; mas o cabrião lá mesmo o fariscou, de maneira que o participio, de uma feita, até foi parar na capoeira das preposições, todo a tremer, rebaixado, em excesso, da sua prístina dignidade

Othoniel Motta (1934:44)

\section{IV.0. Observações preliminares a respeito da sintaticização do gerúndio}

Independentemente do subsistema em que atua, quando se fala em construções com o gerúndio, é preciso pensar em dois elementos constitutivos dessa forma nominal:

$$
[\text { raiz do verbo }+ \text { morfema }-n d o]
$$

Para descrever os princípios de ativação, reativação e desativação é necessário separar os traços específicos de cada uma das duas partes do verbo expresso no gerúndio: (1) Da raiz do verbo é preciso depreender as propriedades semânticas desse item lexical, tais como a) a classe semântica do verbo e b) os graus de gramaticalização desse verbo (pleno, funcional ou auxiliar); além disso, é preciso ter em conta as propriedades sintáticas desse verbo: a) a possibilidade de projeção de sujeito e complementos, b) a sua natureza como núcleo de predicação (primária e secundária) ou c) a impossibilidade de ser o núcleo da predicação (verbos auxiliares). (2) Do sufixo -ndo é preciso depreender as propriedades semânticas: a) a possibilidade de expressão de aspecto imperfectivo, não só nas perífrases, mas também nas construções adverbiais, b) a possibilidade de marcar através dessa morfologia relações proposicionais específicas (causa, condição, tempo, modo, etc.); por outro lado, deve-se levar em conta as propriedades sintáticas desse morfema: introdução a) de elemento predicativo (orações adjetivas), b) de relação de adjunção 
sintática (orações adverbiais) e c) marcação de nominalização do núcleo da predicação nas perífrases. Esse procedimento será seguido ao longo dos três capítulos que descrevem a atuação do gerúndio nos três subsistemas analisados.

\section{IV.1 A questão do sujeito nas orações reduzidas de gerúndio}

Tanto as gramáticas normativas como as descritivas apontam determinadas propriedades sintáticas e semânticas que definem o sujeito como um complemento que é projetado pelo verbo. A tradição gramatical constuma denominá-lo como " $O$ ser sobre o qual se faz uma declaração (Cunha e Cintra, 1985:119), "ser de quem se diz alguma coisa (Luft:1978:128), "termo da oração que está em relação de concordância com o NdP” (Perini, 2001:77). Mira Mateus e outros (1989 e 2003) elencam ainda as seguintes propriedades do sujeito como argumento externo predicador:

1. ocupa a primeira posição argumental, é o argumento mais elevado na hierarquia temática (sujeito lógico);

2. é a expressão com a função de tópico (sujeito psicológico, assunto acerca do qual se afirma, nega ou questiona o predicado);

3. é o elemento controlador do acordo verbal (flexão);

4. é o controlador preferencial da anáfora frástica;

5. é o controlador exclusivo dos pronomes anafóricos;

6. pode ter realização nula com verbos impessoais (chover, nevar)

7. não exibe uma forma pronominal para o chamado sujeito indeterminado (Dizse que..., Dizem que...)

Ao discutir a definição da categoria sujeito, Perini (2001:78-79) alerta para certos casos duvidosos em que as propriedades acima não se aplicariam. Segundo o autor, o mais sério de todos talvez seja o caso do gerúndio, que não exibe as desinências de pessoa-número, mas que mesmo assim deve ser analisado como uma forma verbal que projeta sujeitos, porque a maioria desses traços definitórios está presente nos nomes que nessas construções funcionam como sujeito. Perini aponta os critérios a partir dos quais deve-se considerar que as orações com gerúndio têm um sujeito, comentando os exemplos abaixo ${ }^{330}$ :

(1) Marivânia chegando, a farra vai começar.

${ }^{330}$ Exemplos de Perini (2001:78-79). 
(2) Chegou um amigo meu de Cuiabá.

(3) Chegando um amigo meu, por favor receba-o bem.

(4) Eu chegando, a farra vai começar.

Perini observa que a) em (1) o nome Marivânia antecede o verbo, tal como é o caso de línguas SVO como o português; b) assim como em orações ergativas finitas (2), nas orações gerundiais o sujeito aparece posposto ao verbo (3); e, finalmente, c) o sujeito pode ser retomado por pronome do caso reto, como em (4). Tais critérios sugerem que o gerúndio pode ter sujeito. $\mathrm{O}$ autor nota que tais achados complicam a conceituação de sujeito que comumente é descrito como um "termo que está em relação de concordância com o verbo". Por outro lado, para Perini, se se puder considerar que o gerúndio tem sujeito, será mais fácil descrever as condições que governam a possibilidade de posposição de elementos, como um amigo meu em (3) e será mais fácil explicar, "de maneira mais simples e unificada", a ocorrência dos pronomes retos em orações gerundiais, como Eu chegando em (4).

Essas considerações remetem às observações que Maria Lobo (2000 e 2001) fez a respeito dos gerúndios flexionados nos dialetos portugueses e galegos, ao notar que, a exemplo das orações finitas, os GFs aparecem com maior freqüência em orações nas quais ocorre um conector e nelas o sujeito pode apresentar a ordem $\mathrm{Su}$ V. Em orações gerundiais com o sujeito nulo, o atencedente é recuperado nessas orações pela flexão de pessoa e número: ${ }^{331}$

(5) Em sendem crescidos, levo-os a Lisboa. (Baixo Alentejo, in Delgado (1951))

(6) O pão quando estando lêvedo, $[\mathrm{AB} \mid$ está a farinha, $\mathrm{a}\{\mathrm{fp}\}]$ a massa é mais leve. (PAL30)

(7) Eles têm duas instalações. $[\mathrm{AB} \mid \mathrm{ag}-\{\mathrm{fp}\}]$ Agora, em fazendem o resto das outras é que fica tudo ali junto, já. Fica já ali a garagem, fica casa para tudo, não é. (AAL24)

(8) Em querendos ir, vamos. (Cedillo, in Vilhena (1965))

O fenômeno dos GFs parece confirmar as suspeitas de Perini (2001) sobre o fato de o gerúndio poder projetar um sujeito. Esta inovação do português europeu e do galego demonstra que nestas construções esta propriedade foi reativada nos verbos em questão e prova disso é a morfologia de pessoa e número que aparece nestes verbos.

\section{IV.2 O gerúndio na minioração}

\footnotetext{
${ }^{331}$ Exemplos de Lobo (2000 e 2001).
} 
Em contrapartida ao que ficou dito acima, podemos testar essa hipótese pelo prisma da teoria da minioração (small clause) proposta por Stowell (1995:271 apud Moraes de Castilho, 2005:57) e assim formulada:

Small clause theory is based on the conviction that this semantic relation is reflected uniformly in constituent structure, in the sense that the subject/predicate relation is always enconded syntactally in terms of a pair of sister constituents, as in

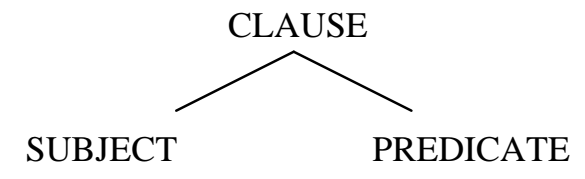

A definição acima indica que o predicado de uma minioração não é um verbo flexionado, como acontece numa sentença plena (full clause), mas sim um verbo em sua forma não-finita (infinitivo, gerúndio, particípio passado), ou mesmo um adjetivo, uma preposição ou um nome. Assim, as miniorações poderiam ser encontradas em dois grupos: $[+\mathrm{V}]$, miniorações verbal e adjetiva, e [-V], miniorações nominal e prepositiva.

Em termos estruturais, a minioração "não é a projeção de uma categoria funcional, mas a projeção lexical do predicado, sendo que o sujeito ocupa o lugar de especificador dessa projeção ou é adjungido a ele” (Moraes de Castilho, 2005:57). Kato (1998 apud Moraes de Castilho, 2005) observa que a minioração pode exercer a função gramatical de de complemento ( 9 e 11), de adjunto (12 e13) ou predicativa (14-16):

(9) Considero [os meninos inocentes]

(10) Maria acha [o João um gênio]

(11) Eu vi [as visitas saindo]

(12) Eu como as cenouras [PRO cruas]

(13) Encontrei o dinheiro [PRO escondido]

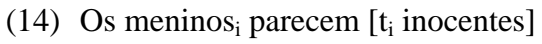

(15) Essa conversa $a_{i}$ soa [ $\mathrm{t}_{\mathrm{i}}$ falsa]

(16) Os soldados ${ }_{\mathrm{i}}$ continuam [ $\mathrm{t}_{\mathrm{i}}$ feridos]

Moraes de Castilho (2005) aplica essa teoria ao processo de gramaticalização dos verbos aver, teer, seer e estar como auxiliares no português arcaico, observando que aver, ao se especializar como verbo de posse inalienável, tornou-se residual em contextos de posse material, em conseqüência de ter exibido em outras eras um campo semântico bem mais amplo. O verbo seer e o estar também ocorriam em 
construções locativas e concorriam nessas estruturas no português arcaico, como mostram os exemplos recolhidos por essa autora: ${ }^{332}$

(17) Seendo o honrado padre en sa cela

(18) Alma que é no inferno

(19) O servo de Deus estando em sa cela

(20) Está em hua torre muito alta.

Segundo a autora, foi justamente a ocorrência seer e estar em contextos locativos o que permitiu a sua evolução para verbos auxiliares em perífrases com o gerúndio, e diz isso apoiando-se nas generalizações propostas por Clark (1978 apud Moraes de Castilho, 2005), que mostram que, "são os verbos das "construções locativas' que atuam como auxiliares nas construções perifrásticas" (Ribeiro, 1993:356 apud Moraes de Castilho, 2005:78). Em sua pesquisa sobre processos de redobramento sintático, a pesquisadora observou que o verbo estar passou por alterações sintáticas que o localizam nos seguintes pólos:

estar pleno > estar funcional > estar auxiliar

Além disso, a autora nota que estar passou também por grandes alterações semânticas a partir do português arcaico até o português moderno, passando a subcategorizar miniorações com gerúndio e infinitivo preposicionado, descaracterizando-se como um verbo funcional e movendo-se para a categoria de um verbo auxiliar:

estar em um lugar físico > estar num estado > estar numa situação > estar >

Alia-se ainda a isso o fato de estar como auxiliar ter se tornado um verbo definitivamente não-temático, pois nesses casos, ao contrário do que acontece ainda na ocorrências de gerúndio como miniorações, ele não projeta um sujeito e nem atribui papel theta ao seu complemento (Moraes de Castilho, 2005:199), tornando-se assim um suporte de flexão verbal e da noção de aspecto, tendo com isso o seu sentido de base esvaziado.

No português arcaico e médio, o gerúndio constituía uma minioração que estava sempre adjungida a um verbo e podia apresentar-se da seguinte forma:

(i) como núcleo dessa sentença (ablativo absoluto):

(21) Madre uelida, meu amigo ui; / nõ lhi faley e con el me perdi / moyr'ra agora, querendo-lhi ben [XIII CR 274:11] $]^{333}$;

${ }^{332}$ Exemplos de Moraes de Castilho (2005). 
(ii) como um predicativo do sujeito e aderir-se a um SV como um advérbio (não constituia um perífrase):

(22) Entrará Branca fallando / com Inês; ambas a par / cantando de quando em quando, / e às vezes suspirando entre cantar e cantar [XVI GV I:167]

(iii) como um item integrante de um enunciado de valor progressivo e fazer parte do VP (como verbo principal de uma perífrase):

(23) sempr'ando coidando em meu coraçõn / com'eu iria mia senhor veer [XIII CA 276:1]

Moraes de Castilho (2005:216-220) ilustrou bem o movimento do verbo estar de verbo pleno a verbo auxiliar, enumerando os seguintes estágios:

A) $\mathrm{O}$ verbo estar, um verbo funcional, aparece com um complemento locativo, e muitas vezes com um sujeito explícito. O gerúndio, uma minioração, está em adjunção a estar, mais precisamente à sua direita.

B) $\mathrm{O}$ verbo estar perde seu locativo e o sujeito, tornando-se um verbo inacusativo e auxiliar.

C) O complemento do gerúndio, quando clítico, pode se cliticizar a estar ou se antepor a ele.

D) O verbo estar, passa a ser um auxiliar, ou seja, passa a ser somente um suporte de tempo, e o gerúndio é reanalisado como verbo principal.

Os exemplos abaixos dão conta desses quatro estágios:

(24) [XIV CGE2 408:16] ẽvioulhes dizer que lhe nõ entrassen ẽ sua terra e que lhe nõ fezessem hi dampno nem huu. Mas os das naves nõ leixaron entõ d' estar hy, atendendo outras naves que lhes avyam de viir ẽ o mais gẽtes e mayor ajuda

(25) [XV VPA1 61:21] E nós ambos irmãos estevemos em Arimatia atendendo aquesta hora que nos disse Nostro Senhor Jesu Cristo

O exemplo (24) da fase (A) ainda exibe o locativo hy. Este deu lugar a seu redobro, que se tornou complemento de estar como em (25). Num estágio seguinte (B), o verbo estar perde seu locativo, tornando-se um verbo inacusativo:

(26) E pois steve gram peça fazendo sa oraçom

O passo seguinte (C) demonstra que o complemento e o sujeito do gerúndio, quando clíticos, podem se cliticizar a estar ou se antepor a ele:

(27) [XIII SG 371:27] e foi-se asi a rei Artur e este[ve-o] catando

${ }^{333}$ Exemplos de Moraes de Castilho (209-210) 
O verbo estar passa definitivamente a auxiliar nos contextos em que ele somente desempenha a função de suporte de tempo, "e o gerúndio é reanalisado como verbo principal":

(28) [XIV LLCP 120:23] O conde com Froiaz Vermuiz chegou-se acerca do arraial e ordenou suas azes e esteve atendendo se iria el rei dom Afonso a lidar com ele.

Os passos acima descritos servem para provar como o gerúndio saiu de um contexto de minioração, funcionando assim como predicador secundário, e ocupou a posição de verbo pleno que agora já não era mais exercida pelo verbo estar. No entanto, vale lembrar que o gerúndio como minioração permaneceu no português, como é o caso das orações adverbiais nas quais o sujeito é idêntico ao da oração matriz, nas orações relativas e nas orações sintaticamente ambíguas.

Moraes de Castilho (2005:206) defende em seu trabalho que "o radical do gerúndio e do infinitivo asseguram sua função verbal, enquanto as terminações $\{$ ndo $\}$ e $\{r\}$ asseguram sua função nominal'. Assim, quando o radical do gerúndio seleciona os argumentos internos e externo, ele licencia seu uso na função de "predicadores primários", como é o caso do gerúndio como ablativo absoluto (aqui construções absolutas, CAs). Por outro lado, "ao selecionarem os radicais verbais, $\{$ ndo\} e \{r\} licenciam o uso do gerúndio e do infinitivo na função de "predicadores secundários”, como miniorações” (op. cit., p. 207).

Para este trabalho, que se concentra nas vários usos do gerúndio, assumo o conceito de minioração para os casos em que o gerúndio é o núcleo de uma predicação secundária, em orações adverbiais com identidade de sujeito, em construções ambíguas e orações relativas, visto que seu sujeito é uma "projeção lexical do predicado" da OM. Mas, como este trabalho se concentra nos vários usos do gerúndio, amplio a classificação, ao analisar também as construções nas quais o gerúndio é núcleo de uma predicação primária, como é o caso das perífrases verbais do português moderno, das construções absolutas, das estruturas nominalizadas, dos gerúndios imperativos, exclamativos ou interrogativos, e, finalmente, quando atuam como articuladores do discurso. 


\section{IV.3 Proposta de classificação do gerúndio em português}

Como se viu na seção acima, elejo a relação do gerúndio com o seu sujeito para classificar os seus usos, separando-os em dois grupos: (i) gerúndios dependentes do sujeito em minioração (núcleo de predicação secundária) e (ii) gerúndios independentes do sujeito de uma oração matriz (núcleo de predicação primária). A exemplificação abaixo serve como panorama geral da classificação que proponho nesta tese e será discutida ao longo deste capítulo.

\section{(i) O gerúndio como núcleo de uma predicação secundária (dependente)}

\section{a. Gerúndio adverbial dependente}

Neste caso, o sujeito essas pessoas se repete nessa função na oração gerundial iniciada pelo gerúndio agindo e no pronome eles da oração que funciona como matriz dessa gerundial.

(29) [M 202 ZEQ 7] Essas pessoas conviviam com a população nativa, conheciam seus usos e costumes, sua língua, e casavam-se com filhas dos principais chefes indígenas. Foi o que ocorreu com o Bacharel de Cananéia e também com João Ramalho, do planalto acima de São Vicente. Agindo como intermediários das negociações entre nativos e portugueses, eles favoreceram a posterior ocupação e colonização do território.

\section{b. Gerúndio ambíguo}

O gerúndio ambíguo é identificado aqui também como categoria fuzzy, pois tanto pode ser interpretado como adjetivo ligado ao sujeito da OM, como também uma oração adverbial que estabelece alguma circunstância, que no exemplo abaixo é a de tempo posterior:

(30) [M 192 HC 16] À parte geográfica das expedições corresponde mais ou menos o seguinte esquema: Os bandeirantes deixando o Tietê alcançaram o Paraíba do Sul pela garganta de São Miguel, desceram-no até Guapacaré, atual Lorena, e dali passaram a Mantiqueira, aproximadamente por onde hoje transpõe a E. F. Rio e Minas.

\section{c. Gerúndio adjetivo}

O gerúndio adjetivo pode estar ligado ao $\mathrm{OD}$, ao OI, a OBL ou a qualquer SP da OM:

(31) [C 201 MA 323 20] Recebi ontem um anúncio do jornal indicando a venda do livro, dois dólares. 


\section{(ii) O gerúndio como núcleo de uma predicação primária (independente)}

\section{d. Gerúndio adverbial independente (construção absoluta ou ablativo absoluto)}

$\mathrm{Na}$ construção absoluta, o radical do gerúndio seleciona o seu próprio argumento interno (a respectiva posse), que conseqüentemente é distindo daquele da OM (a sesmaria de Pero de Goes):

(32) [M 201 WLC 27] É por isso que, em Piratininga, sem que se fizesse menção da qualidade de vila, como era de uso nesses documentos, foi concedida a sesmaria de Pero de Goes, sendo a respectiva posse dada alguns dias depois na ilha de S. Vicente.

\section{e. Gerúndio em nominalizações}

Os gerúndios em nominalizações aparecem ligados a um SN não-sentencial, ou seja, que não exerce a função sintática de argumento externo ou interno de uma sentença:

(33) [C 182 BAN 2 1] Vossamerce bem tem deplorado, emminha prezensa oindecente estado denoSa Igreja Matriz; quatro paredes nuas evermelhas, Sem portas, Sem janelas, reprezentando mais ûa olaria, que aCaza deDeos: onde Com bastante escrupulo ConServo oSantissimo Sacramento.

\section{f. Gerúndio imperativo}

(34) Andando! Andando! (exemplo criado)

\section{g. Gerúndio como articulador discursivo}

O gerúndio como articulador discursivo não exibe na superfície o seu sujeito, estando este subentendido no Discurso, ou seja, voltando tanto pode apontar para o falante/escritor como para o interlocutor/leitor. Além disso, nessas construções não é possível identificar nem uma OM e nem as propriedades que pudessem caracterizar esta sentença como uma oração adverbial:

(35) [C 202 SIM 4 6] Voltando ao nosso papo, são 23:04 de domingo | e chegamos a pouco da casa da mãe, e pra | variar tomamos chuva, só prá variar, mas | nesses últimos dois dias aqui tem chovido não | é brincadeira, mas mesmo assim esta uns 28 graus | e por ai cada vez mais frio. 


\section{h. Gerúndio em perífrase verbal}

(36) [C 182 BAN 2 10] Fico esperando resposta de Vossamerce para Com mais e[st]imo, eZelo Continuar aobra daCaza doSenhor, que felismente ConServarâ aestimavel PeSoa deVossamerce por dilatados años. Vila 2 de otubro de1794

Feita esta segmentação, segundo a propriedade de predicação que o gerúndio pode exercer, na seção seguinte, passo (a) a apresentação do quadro geral de distribuição das ocorrências e (b) à análise isolada dos tipos de gerúndio.

\section{IV.4 Apresentando o quadro geral de ocorrências}

Inicialmente, ofereço um quadro geral (tabelas 2 e 3) do Corpus Básico (memórias, cartas e teatro) com a distribuição das ocorrências nos três séculos estudados $^{334}$ :

Tabela 2. Total de ocorrências analisadas no Corpus Básico

\begin{tabular}{|c|c|c|c|}
\hline Tipo de construção & Adverbial & Não-adverbial & \\
\hline Oração gerundial & 522 & 257 & 779 \\
\hline Oração conjuncional & 667 & - & 667 \\
\hline Total & 1189 & 257 & 1446 \\
\hline
\end{tabular}

Pelo que se pode observar da tabela 2, neste trabalho lido com um Corpus Básico total de 1446 ocorrências, sendo 779 delas construções de gerúndio. Nota-se ainda que coletei do Corpus Básico um conjunto de orações adverbiais conjuncionais com a finalidade de contrapô-las aos gerúndios adverbiais (dependentes e independentes). Analiso esta questão mais detalhadamente no capítulo sobre a semanticização do gerúndio (cap. VI). Por ora, cabe apenas observar que na média dos três séculos as orações adverbiais conjuncionais $(61,9 \%)$ se mostram mais produtivas que as orações gerundiais $(38,1 \%)$.

O quadro que segue, demonstra a distribuição geral dos tipos de gerúndio nos três séculos analisados. Nele separei as orações adverbiais com gerúndios depedentes

\footnotetext{
${ }^{334}$ O Corpus Diferencial inclui outros tipos de texto que não eram comuns ao três períodos, será considerado apenas para os capítulos da discursivização (V) e da semanticização (VI). Dele fazem parte as cartas de leitores e redatores, os anúncios do séc. XIX, e as elocuções gravadas do séc. XX. Somam-se ao quadro da tabela 1 com 309 orações gerundiais e 330 orações conjuncionais, perfazendo juntamente com o Corpus Básico um total de 2065 ocorrências (1088 OGs e 977 orações conjuncionais).
} 
das independentes (construções absolutas). Incluí um gráfico de barras para promover uma melhor visualização dessa distribuição:

Tabela 3. Distribuição dos tipos de gerúndio por século no Corpus Básico

\begin{tabular}{|c|c|c|c|c|c|c|c|c|c|}
\hline \multirow{4}{*}{$\begin{array}{c}\text { Tipo de predicação } \\
\text { Predicação secundária } \\
\text { (dependente) }\end{array}$} & \multirow{2}{*}{$\begin{array}{l}\text { Tipo de gerúndio } \\
\text { (a) adverbial }\end{array}$} & \multicolumn{2}{|c|}{$\begin{array}{r}\text { Séc. XVIII } \\
\%\end{array}$} & \multicolumn{2}{|c|}{$\begin{array}{r}\text { Séc. XIX } \\
\%\end{array}$} & \multicolumn{2}{|c|}{$\begin{array}{r}\text { Séc. XX } \\
\%\end{array}$} & \multicolumn{2}{|c|}{ Total } \\
\hline & & 162 & 50,8 & 120 & 43,5 & 72 & 39,1 & 354 & 45,4 \\
\hline & (b) ambíguo & 18 & 5,6 & 15 & 5,4 & 8 & 4,3 & 41 & 5,3 \\
\hline & (c) adjetivo & 1 & 0,3 & 20 & 7,2 & 5 & 2,7 & 26 & 3,3 \\
\hline \multirow{6}{*}{$\begin{array}{l}\text { Predicação primária } \\
\text { (independente) }\end{array}$} & (d) construção absoluta & 88 & 27,6 & 57 & 20,7 & 23 & 12,5 & 168 & 21,6 \\
\hline & (e) em nominalizações & 1 & 0,3 & 1 & 0,4 & 3 & 1,6 & 5 & 0,6 \\
\hline & (f) imperativo & 10 & 3,1 & 3 & 1,1 & 1 & 0,5 & 14 & 1,8 \\
\hline & (g)articulador discursivo & 3 & 0,9 & 4 & 1,4 & 4 & 2,2 & 11 & 1,4 \\
\hline & (h) perífrase & 36 & 11,3 & 56 & 20,3 & 68 & 37,0 & 160 & 20,5 \\
\hline & Total & 319 & & 276 & & 184 & & 779 & \\
\hline
\end{tabular}

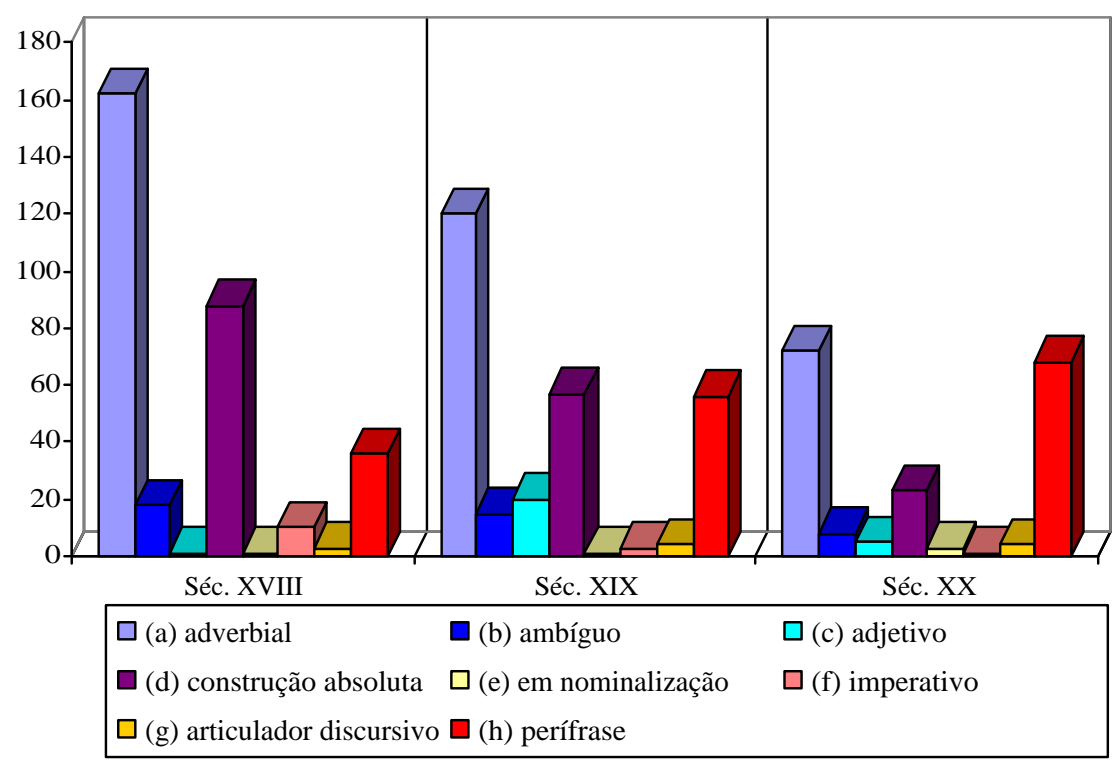

Gráfico 2. Distribuição dos tipos de gerúndio por século no Corpus Básico por número de ocorrências.

A tabela 3 e o gráfico 2 ilustram uma significativa e progressiva redução dos gerúndio adverbiais gerundiais (dependentes e independentes) no decorrer dos três séculos. Diminui tanto o número de ocorrências dessas orações, como também reduzse a freqüência de uso em relação aos outros usos do gerúndio em cada século. Este 
fenômeno não ocorre isoladamente para as orações adverbiais de gerúndio dependentes e independentes, mas afeta também as orações adverbiais conjuncionais, como prova mais adiante o gráfico 3.

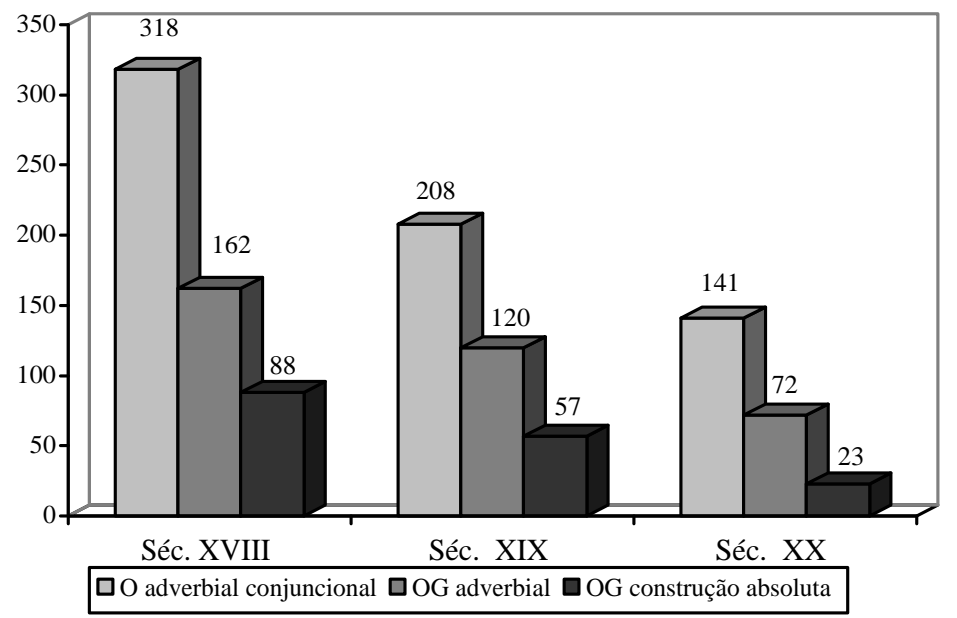

Gráfico 3. Distribuição geral das orações adverbiais no Corpus Básico por número de ocorrências

Nota-se ainda um aumento progressivo das perífrases com gerúndio ao longo dos três séculos, tanto em relação ao número de ocorrências gerais de perífrases como também percentualmente, ao levarmos em conta a sua frequiência em relação aos outros tipos de gerúndio $(36 / 11,3 \%>56 / 20,3 \%>68 / 37 \%)$.

Observa-se também um equilíbrio do gerúndio ambíguo (adjetivo do sujeito ou fuzzy) nos séc. XVIII (18/41) e XIX (15/41) com uma redução bem marcada de ocorrências no século XX (8/41).

Quanto ao gerúndio adjetivo, nota-se um alto índice de uso durante o século XIX (20/7,2\%) em comparação com os outros dois momentos (1/0,3\% no XVIII e $5 / 2,7 \%$ no $\mathrm{XX})$.

Em relação à distribuição geral de todos os demais tipos, vemos que, ao funcionar como articulador discursivo (falando nisso...), o gerúndio apresenta uma frequiência equilibrada nos três períodos $(3>4>4$ ocorrências $)$, mas percentualmente observa-se um aumento gradual $(0,9 \%>1,4 \%>2,2 \%)$. As nominalizações do tipo Jabuticabeira produzindo são igualmente pouco freqüentes nos três séculos. O resultado obtido para o gerúndio como articulador discursivo, em 
nominalizações e para o gerúndio imperativo parece estar relacionado à questão da tipologia textual, de que trato mais especificamente no capítulo V.

Feita esta primeira ilustração da frequiência de uso do gerúndio, segundo a classificação proposta nesta tese, passo a descrever isoladamente os tipos de gerúndio e os fatores sintáticos considerados na análise.

\section{IV.5 O gerúndio como núcleo de predicação secundária (dependente)}

\section{IV.5.1 O gerúndio em orações adverbiais dependentes}

Nesta seção, procuro inicialmente (5.1.1) estabelecer as propriedades e os limites entre dois tipos de adjunção sentencial:

(a) a adjunção de orações adverbiais infinitas com sujeito correferente ao da oração matriz (orações gerundiais adverbiais) e

(b) a adjunção de estruturas adverbiais infinitas com sujeito não-correfente ao da oração matriz (construções absolutas).

Em seguida, em (IV.5.1.2) e (IV.5.1.3) apresento qualitativa e quantitativamente os fatores sintáticos pertinentes à análise das orações adverbiais gerundiais dependentes e as construções absolutas, tais como (i) a natureza do sujeito da OG, (ii) a (não-) identidade com o sujeito da OM, (iii) a posição sintática das OGs em relação à sua OM (anteposição, interpolação, posposição), (iv) a distruição diacrônica das OGs adverbiais no português brasileiro. Quando relevante, estabeleço cruzamentos entre esses grupos de fatores.

\section{IV.5.1.1 As propriedades sintáticas das orações adverbiais}

Em seu estudo sobre as ligações sentenciais, Lehmann (1988:217) apresenta seis escalas de gramaticalização, nas quais se podem dispor as várias ligações sentenciais:

1. "degradação" hierárquica das orações subordinadas (parataxis : embedding); 
organizada verticalmente. ${ }^{335}$ No nível mais superior encontra-se o pólo da agregação [Aggregation], no nível mais inferior o pólo da integração [Integration]. Entre o pólo da agregação para a integração, Raible identifica oito segmentos distintos, que correspondem a determinadas técnicas de junção:

(I) simples justaposição de orações sem juntores (parataxe assindética);

(II) junção através de retomada correferencial de um item da oração anterior;

(III) ligação de orações principais através de juntores explícitos (parataxe sindética);

(IV) ligação de orações através de conjunções subordinativas;

(V) ligação de orações através de construções gerundiais e participiais;

(VI) junção de relações através de construções com grupos preposicionais (locuções prepositiva);

(VII) junção de relações através de preposições e/ou morfemas de caso, e finalmente (VIII) junção através de morfemas marcadores de caso ou papel temático.

335 Adaptei o quadro de Raible com exemplos dos corpora brasileiros (quadro 17). 


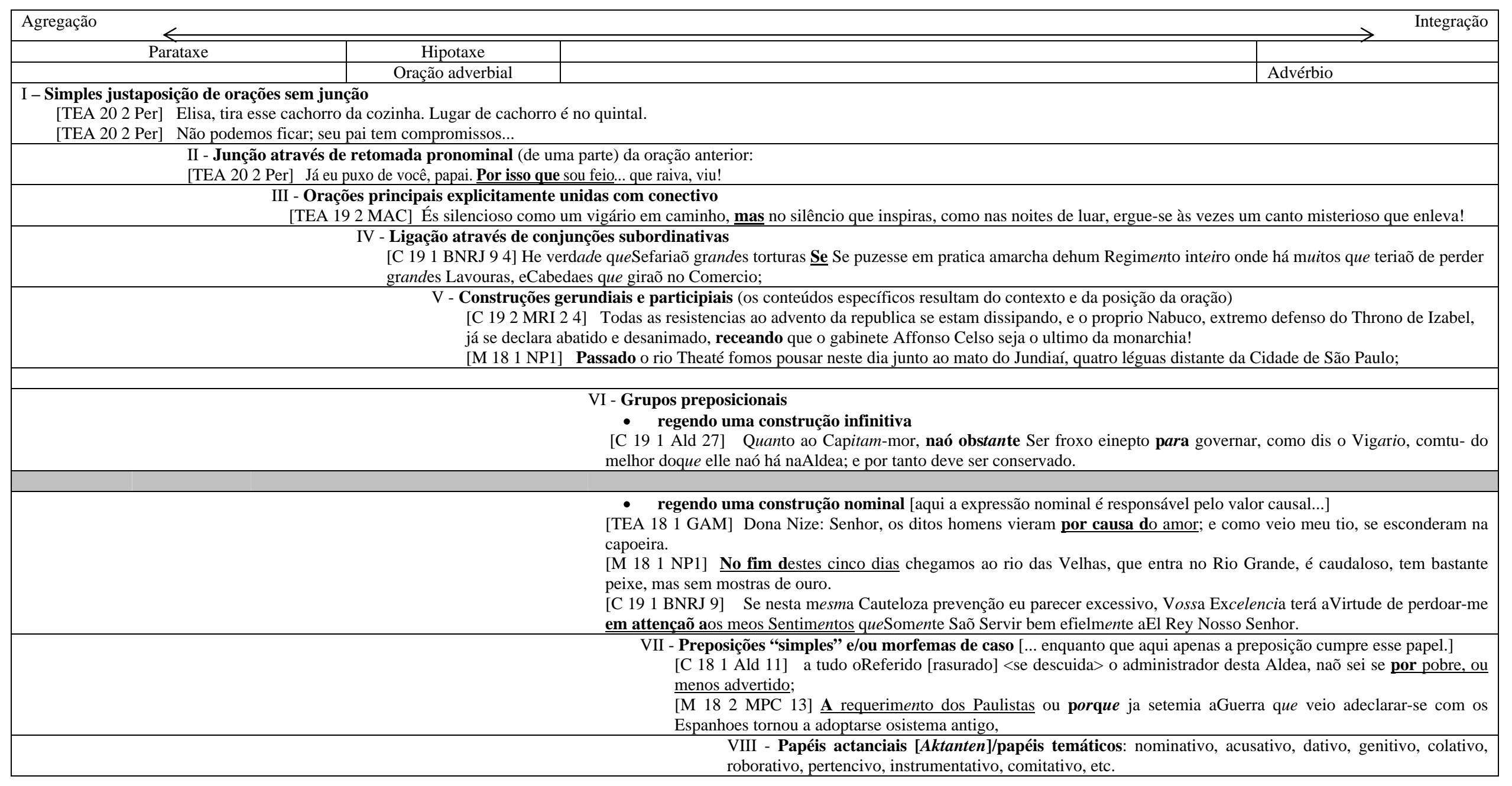

Quadro 17. A escala de de agregação e integração (adaptado de Raible, 1992) 
A partir da leitura dos trabalhos de Lehmann (1988) e Raible (1992), MüllerLance (1994:76) alarga em seu estudo o espectro de propriedades das construções absolutas e verifica o seu grau de sentencialidade, procurando identificar quais dos elementos enumerados abaixo aplicam-se às construções em análise:

1. O predicado é um verbo finito (pessoa e número expressos).

2. Introdução por uma conjunção.

3. Segundo a valência do predicado podem ser expressos dois ou três complementos.

4. O sujeito da oração subordinada pode estar expresso na oração principal como um sujeito pronominal.

5. Expressão de tempo, aspecto, modo e diátese.

6. A oração subordinada tem um sujeito próprio, que até pode coincidir com o da $\mathrm{OP}$, mas que pode aparecer de uma forma explícita na OP, mesmo que seja sob forma de um morfema de pessoa.

Segundo o autor, a posição de uma construção absoluta nesta escala depende do número de elementos de sentencialidade presentes. No quadro 18, Müller-Lancé (1994:76) ilustra a gradação de sentencialidade de termos em adjunção, tendo, de um lado, as orações adverbiais - equivalente às estratégias (IV) e (V) de Raible (1992) -, numa posição intermediária as construções absolutas e, de outro lado, os advérbios:

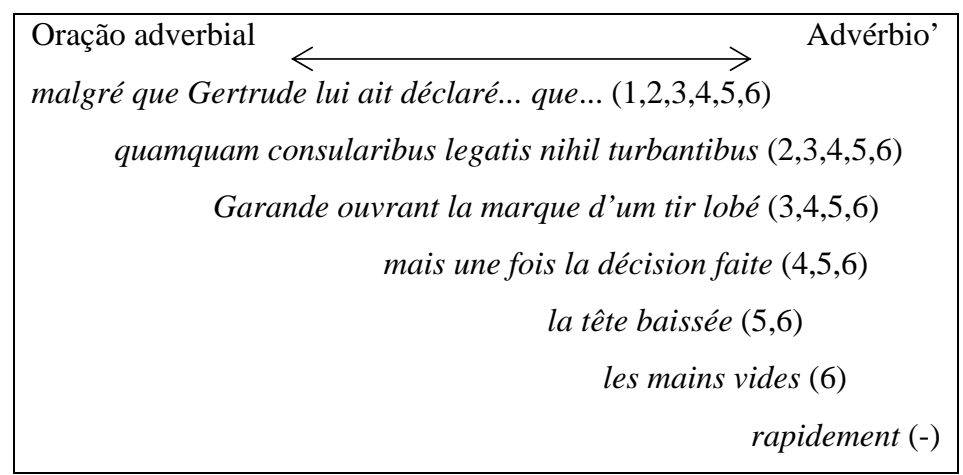

Quadro 18. Escala de sentencialidade segundo Müller-Lancé (1994:76) 
Aplicando-se estes critérios às OGs teríamos o seguinte quadro para as propriedades sintáticas das OGs:

\begin{tabular}{|c|}
\hline Propriedades sintáticas da orações gerundiais adverbiais \\
\hline O predicado é um v \\
\hline $\begin{array}{l}\text { Algumas palavras de suporte podem anteceder imediatamente a forma nominal do gerúndio, } \\
\text { como determinados advérbios: não, como, mesmo, meio, etc. e algumas preposições como sem, } \\
\text { em, com, de: } \\
\text { - } \underline{\text { Com os preços aumentando, não vamos viajar; }} \\
\text { - Chegou de mãos abanando. }\end{array}$ \\
\hline $\begin{array}{l}\text { Segundo a valência do predicado podem ser expressos dois ou três complementos: } \\
\text { - Ela entrou em casa }\left[\left(\mathrm{SUJ}_{\varnothing}\right) \text { trazendo um presente }(\mathrm{OD}) \text { para a filha }(\mathrm{OI})\right] \text {. }\end{array}$ \\
\hline $\begin{array}{l}\text { O sujeito (argumento interno) da oração gerundial adverbial está expresso na oração matriz, } \\
\text { através da realização de um sujeito lexical ou de morfologia de pessoa e número no radical do } \\
\text { verbo da oração matriz: } \\
\text { - Vendo que a filha não chegava, Mariana começou a preocupar-se. } \\
\text { - Vendo que a filha não chegava, preocupou-se }\end{array}$ \\
\hline $\begin{array}{l}\text { O sujeito da oração matriz pode estar implícito na oração subordinada, ou pode ser explícito, } \\
\text { pospondo-se ao gerúndio: } \\
\text { - Vendo que a filha não chegava, preocupou-se (presença do item filha > sujeito mãe ou pai } \\
\text { - Chegando o pai, começaram a jantar. }\end{array}$ \\
\hline
\end{tabular}

Quadro 19. Propriedades sintáticas das orações gerundiais adverbiais

\section{IV.5.1.2 A natureza do sujeito compartilhado nas orações gerundiais adverbiais gerundiais}

A tabela 4 dá conta da distribuição geral das orações gerundiais adverbiais (OGadvs) segundo a natureza do sujeito nelas realizado:

\begin{tabular}{|l|l|c|c|}
\hline \multicolumn{4}{|l|}{ Natureza do sujeito nas orações gerundiais adverbiais (OGadvs) } \\
\hline OGadvs com sujeito gramatical & nulo & 329 & $93,5 \%$ \\
\cline { 2 - 5 } & substantivo & 15 & $4,3 \%$ \\
\cline { 2 - 5 } & pronome & 9 & $2,6 \%$ \\
\hline OGadvs sem sujeito gramatical & & - & \\
\hline & Total & 353 & \\
\hline
\end{tabular}

Tabela 4. A natureza do sujeito nas orações gerundiais adverbiais (OGadvs). 
Observa-se ali que na grande maioria dos casos $(93,5,9 \%)$ nas OGadvs o sujeito não se realiza lexicalmente sob a forma de um SN substantivo. Devido à identidade com o argumento externo da OM, não há casos de sujeito oracional. Também por este motivo não ocorrem argumentos únicos do tipo absolutivo existencial ou ergativo, possíveis apenas nas $\mathrm{CAs}^{336}$.

\section{IV.5.1.2.1 Sujeito nulo}

As OGadvs com sujeito nulo aparecem preferencialmente na posposição ${ }^{337}$. OGadvs ocorrem na anteposição de maneira condicionada, ou seja, quando o sujeito já foi anunciado no contexto. É o caso do exemplo (37), que mostra uma linda topicalização de OD no séc. XVIII, na pessoa de oSugeito, que é o argumento interno da OG em anteposição ao verbo emtrou. Outro exemplo de um sujeito dado pelo contexto pode ser visto em (38), em que o sujeito é o próprio autor da memória, José Bonifácio.

(37) [C 182 BAN 4 5] oSugeito desta forma oConduziraõ aCadea da qual omandei Sol- tar na Seguinte manhã por ja estar Resti tuido aoSeu juizo prezumindo Ser mo rador deste destrito despois deSolto em trou afazer Requerimentos ao Juis para lhe mandar tomar fê das feridas Requeren do Contra aqueles por quem omandei prender [p. 2] Prender:

(38) [M 191 BON 1] Tendo vizitado a Real Fabrica de ferro de Saõ João do Ypane_ Ma e apanhado da boca doshomens, que ahi rezidiaraõ e trabalharaõ to- das as noticias mais importantes que pude recolher, passo agora a ex_ pôr oseu estado actual eos melhoramentso que deve ter.

(39) [C 202 SIM 13 3] eu tava num | sufoco tão grande pois quando está aqui mas sabe que | | [p. 2] aí tem alguém doente e que derepente pode acontecer | alguma coisa, você já fica esperando. Ge é nessas horas | que sentimos o quanto as pessoas são importantes, eu adoro | minha vó, sinto não poder ajudá-la, ficando sempre | perto dela, mas depois dessa chega a conclusão que não dá | para ficar muito tempo sem ir aí; é uma barra tão | grande que não dá nem para pensar.

\section{IV.5.1.2.2 Sujeito expresso por um substantivo}

Nas sentenças compostas de OGadvs com sujeito lexicalizado, o argumento interno da OM apresenta-se nulo, pois pode ser recuperado na oração subordinada. Nesses casos aparece predominantemente em anteposição, como o mostram os exemplos abaixo:

(40) [M 182 MCA 45] Obedeceo oMancebo, equerendo Gonçallo Fernandez agradecer oobzequio, offereceo-lhe no= fim dajornada hum Colar demuito preço; mas ogenerozo Mancebo cor=

\footnotetext{
${ }^{336}$ Trato da natureza do complemento absolutivo na seção em que discuto o gerúndio adjetivo (5.3).

${ }^{337}$ Comento mais detalhadamente a posição das OGadvs no tópico 6.1.4.
} 
tezmente seescuzou de oaceitar, dizendo, que para asua escravidaõ bastavaaCa= deya [p. 8] aCadeya Com que oprendera abenignidade doDoador.

(41) [M 191 RDN 35] (b) vendo oGovernador Geral que as Aldeas estavaõ despovoadas; [sendo] alia[s] os Indios taõ neceSsarios para todo oServiço, que [se empreendia] afavor daCoroa, determinou a 18de8[outu]bro dodito anno, que todos osque fossem aoSertaõ buscar Indios, paga[ss]em 05.o, pondo nas Aldeas deSua Magestade a5.a parte della[[e]]s, eque metade deste 5.o seRemetesse áBahia para lá fundar huma Aldea.

(42) [M 201 PRO 19] Tendo dúvida com ele os ditos Irmãos da Misericórdia sobre a Igreja, recorreram à Sua Majestade que resolveu que a dita Igreja servisse de Matriz e que os Irmãos da Misericórdia alargassem e fizessem outra Igreja da Misericórdia que com efeito assim o executaram e fazendo a Igreja da Misericórdia, trazendo para ela os ornamentos e alfaias que lhes pertenciam, e que mandaram fazer outra igreja e assim ficaram divididas uma da outra.

\section{IV.5.1.2.3 Sujeito expresso por um pronome}

Também para as OGadvs com pronome sujeito vale o raciocínio de correferência apontado acima. Em nosso corpus, encontramos uma ocorrência em que o sujeito é retomado anaforicamente através de outros pronomes (estes mesmos) como em $(44)^{338}$ :

(43) [C 181 Ald 63 ] etendo eu feito exaltas d[ili] genCias por ela [p]or todas estas partes, Sem fruto algum, prendi aos parentes para efei to deComfeÇarem averdade; osquais Com feÇaõ Ser hido para aspartes davila de JaCarehy, em Companhia dehum homem, ehua molher exComungados desta quaresma dobairro deSaõ Joaõ. Cujos nomes Saõ Francisco Rodriguez, e Maria Thomas;

(44) [M 191 RDN 40] §. 16. Mas como entaõ sedeo liberdade ahuma multidaão deIndios, que fazia oGrande Cabedal dos Paulistas, ecomque deneceSsidade emhumdia empobreceraõ as mais Ricas Cazas, povoaraõ-se prodigiozamente as Aldeas para onde eraõ mandados os Indios (c) Einda posteriormente foraõ [entran]do outros para [ellas], porque tendo muitos ficado nas mesmas Cazas, emque existiaõ, com officio deadministrados, [estes] mesmos quando [Sa]hiaõ eraõ Re[colhidos] as Aldeas.

(45) [M 201 WLC 7] Devendo eles ser homens feitos, dando-se ao mais moço a idade de 18 anos, teriam nascido antes de 1532, em tempo anterior à chegada de Martim Afonso, que aí teria encontrado o velho Diogo Braga, casado à moda da terra, e com família numerosa já cristã.

\section{IV.5.1.3 Gerúndio em estruturas de redobro sintático}

Os gerúndios em também aparecem em estruturas de redobro sintático, como podemos ver pelos exemplos $(46-49)^{339}$. Em alguns casos o redobro se dá apenas pela repetição do radical do verbo como em (46) e (47). Em outros casos, o próprio verbo no gerúndio é duplicado, (48 e 49). Estas estruturas apresentam a propriedade semântica da adição e serão retomadas também no capítulo sobre a semanticização do gerúndio (cap. VI):

\footnotetext{
${ }^{338}$ Para efeito prático, incluo entre os pronomes os quantificadores e os demonstrativos.

${ }^{339}$ A oração gerundial do exemplo (48) é uma construção absoluta (CA).
} 
(46) [C 191 BNRJ 6 20] Recebi ainformaçaõ do Capitam Mor de Porto feliz, etendo ja falado sobre esta materia, determino de novo naõ aprezentar ao Governo determinando fazelo em tempo mais oportuno, e proprio.

(47) [C 192 WL 18 4] Queira aceitar saudades, e transmittir as mesmas, de todos, a Sophia, um saudoso abraço da minha parte, acei- tando outro da Mãe estre- mosa que muito o considera

(48) [A 192 SP 32] Como se tenha dado este equi|voco até com os senhores empregados/do correio de São Paulo; acontecen|do por muitas vezes entregarem as/cartas que veem com destino ao|Hotel das Familias, o unico, como|já dissemos, situado em frente á|praça do Mercado, e essas cartas|teem hido parar no hotel da Esta|ção no Braz, acontecendo ás ve|zes ficarem as cartas detidas por|longo tempo - A Constituinte, 02 de outubro de 1879

(49) [M 181 NP1 76] destes negros nos mataram um, e um cavalo, o que visto pelo Cabo se fez um forte em um dos ranchos, que lhe pareceu melhor, mandando recolher todo o milho, que se achou, a um paiol, a que pôs guardas, como o fez também a sete índios, que cativamos, mandando-lhe lançar a todos suas correntes

\section{IV.5.2 Gerúndio em orações sintaticamente ambíguas}

Durante a coleta de dados, deparei-me com casos interessantes de subordinação sentencial, nos quais o gerúndio aparece imediatamente adjacente ao sujeito da OM. Às vezes o G estabelece uma predicação do tipo ambígua (fuzzy), podendo ao mesmo tempo ser interpretada a oração em que ocorre como adjetiva ou como adverbial. Em construções desse tipo, o sujeito da OG é o mesmo da OM, mas diferentemente das OGadvs e das CAs, nestas estruturas o sujeito aparece ligado imediatamente ao G, exibindo normalmente a seguinte estruturação sintática:

$$
[\mathrm{Su}+[\mathrm{OG}]+\mathrm{V}+(\mathrm{Co})+(\mathrm{C} 1)]
$$

(50) [C 191 CL 389 14] ]... ora o Estudante pobre, vendo que o rico pode campar assim; não se vexarà não podendo trazer se não uma calça de ganga, umas meias de lã ou de algodão?

O gráfico 4 ilustra a observação que fizemos a respeito do quadro geral de ocorrências do Corpus Básico, onde observamos a queda progressiva do gerúndio ambíguo do séc. XVIII para o séc.XX.

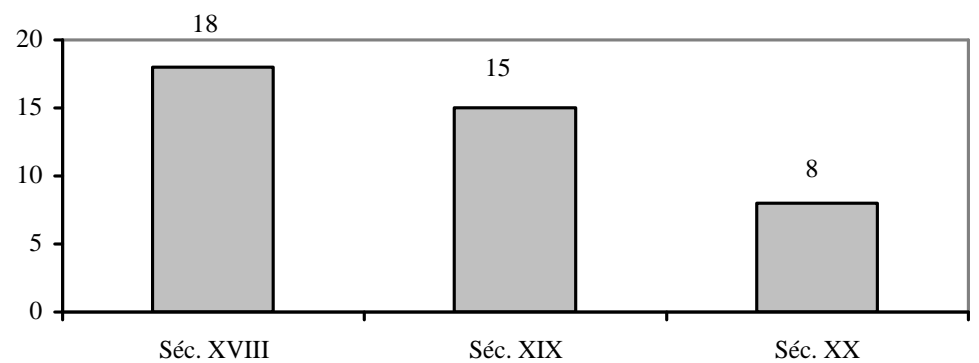

Gráfico 4.Orações ambíguas com gerúndio ligado ao sujeito. 


\section{IV.5.2.1 As propriedades sintáticas das OGs ligadas ao sujeito}

As gramáticas não têm tratado de maneira clara este tipo de construção e, em sua maioria, descreve uma estrutura assim como sendo um caso de oração adverbial. Alguns autores, porém, reconhecem nela uma espécie de oração relativa, pelo fato de o G exibir uma propriedade típica dos adjetivos, que é a de atribuir uma qualificação a algum SN. Brandão (1933) ora chama-a de oração com gerúndio predicativo do sujeito, ora de gerúndio atributivo, e Campos (1972) denomina as orações desse tipo como oração adjetiva com gerúndio ligado ao sujeito da oração principal. Estes dois autores argumentam com a idéia de que nestes casos a construção introduzida pelo gerúndio agrega ao SN uma qualidade permanente ou transitória. Nas subseções seguintes apresento algumas das propriedades sintáticas das OGs ambíguas.

\section{IV.5.2.1.1 A topicalização de sujeitos}

Por vezes é possível enxergar essas estruturas sob um outro ponto de vista, num nível em que o subsistema do Discurso parece estar mais saliente. Falo dos casos em que o sujeito projetado pelo radical do verbo no gerúndio parece ter sido extraído do interior da própria OG. Isso se dá principalmente nos casos em que esse sujeito inicia a sentença. Vejamos alguns exemplos:

(51) [TEA 182 FE 10] Pant. Estas mulheres em se achando juntas, já entraõ a contar o como vivem com os maridos, mas a minha naõ ha de dizer, que eu lhe gastase os dotes em vicios, se os gastei foi em me devirtir com ella em romarias, como ella mesmo diz, e por isso, porque gastei o dinheiro, estou agora de dia, e de noute a trabalhar, para passar a vida sem calotes.

(52) [TEA 182 FE 19] Pant. Eu sendo rapaz, n'uma occasiaõ fui pôr hum rabinho de trapo no capote de hum marujo, porém elle precentio-me, correo a traz de mim, e dezamcou-me o corpo com huma corda que trazia, de que estive sangrado, mas eu nunca mais uzei de similhantes brincos; porque inda hoje me lembra o tal castigo.

(53) [C 191 Gen 84 Este talves sabendo oque por cá sepassava, munio- se do privilegio da bulla, procurando sêr Thezoureiro del- las na Freguezia da Paraibuna, que hé no Destricto de Jacarehÿ, caminho de Sã̃ Sebastiaõ, e distante desta Villa déz legoas.

(54) [C 192 WL 6 2] e eu cumprindo um dever de Amigo tenho a participar-te que ha um mez tractei casamento com a Senhora Dona Candida Novaes filha do Coronel José Novaes de Aguiar residente em São Carlos. Aproveito tambem a occasião para offerecer-te quando para estes lados vierdes [p.2] um modesto rancho, nésta fazenda que já tem o nome da futura[1],

(55) [M 192 HC 16] À parte geográfica das expedições corresponde mais ou menos o seguinte esquema: Os bandeirantes deixando o Tietê alcançaram o Paraíba do Sul pela garganta de São Miguel, desceram-no até Guapacaré, atual Lorena, e dali passaram a Mantiqueira, aproximadamente por onde hoje transpõe a E. F. Rio e Minas.

(56) [C 201 MA 323 3] O caso do "obsecar" eu sabia perfeitamente mas é um desses casos que, tantos na vida! a gente resolve a trouxe-mouxe e vai de repente, alguém obriga a gente a raciocinar mais de espaço about. É um caso curioso de etimologia popular... semi-erudita. Os 
galiparlas dos jornais, querendo obséder, mais lembrando obcecar (cuja grafia naturalmente não lembravam), fizeram "obsecar", verbo novo com o sentido tão necessário de obséder.

Isso também pode acontecer quando a OG aparece interpolada dentro de outra oração dependente, tal como no exemplo abaixo:

(57) [M 182 MPC 17] nada milhorou com esta providencia aCapitania, antes notempo doprimeiro General se reduzio amaior extremo; porquanto este fazendo mais conta, com os descobrimentos que intentou do Tibaí, e Guatemí, naõ lhe cervindo de exemplo ainutilidade com que nos tempos antigos se tinhaõ feito semelhantes des- pezas pela Fazenda Real, fez ao Povo hum extraordi- nario reclame obrigando aque fosse nas expediçoens, que fes para osditos descobrimentos, doque Se seguio Morrerem nellas huma grande parte, dos que foraõ, dezertarem outros para Es- panha, o modarem outros daCapitania, antes que experimen- tacem igual vechaçaõ, eaqui seve Segundo golpe na Povo- açaõ daCapitania

\section{IV.5.2.1.2 A aposição de OGs a outros constituintes de valor adjetivo}

Nos casos abaixo, apesar da OG fuzzy aparecer distanciada do sujeito, antecede-lhe uma seqüência de particípios, advérbios, apostos nominais e outras orações relativas, promovendo assim uma identidade sintático-semântica entre estes itens, que acabam reforçando a hipótese de que esta categoria se enquadra entre os predicativos do sujeito que têm natureza sintática diversa e ambígua.

(58) [M 191 RDN 4] §. 1. Logo que sefundou a Vila deSa ̃̃ Paulo noanno de1560 (a) Os Guaianazes oriundos dePirati $=[\mathrm{p} .2]$ dePiratininga emais Indios [ali moradores], [v]endo que [hiaõ concorrendo Portugueses], eocupando suas terras, [mudaraõ]= [se] dos Su[burbios] daVila; fundando-se asduas Aldeas de Saõ Miguel edePinheiros.

(59) [A 192 SP 31] Attenção|Aos senhores viajantes do Norte e Sul, e dos senhores|empregados do correio.|O HOTEL DAS FAMÍLIAS, o unico|com este titulo na capital de São|Paulo, já muito conhecido por mi|lhares de familias honestas, comolo mais accomodado em preços,| offerecendo sempre todas as com/modidades desejaveis e necessa|rias para as Exelentíssimas familias que|viajam, é situado desde sua pri|mitiva abertura, á Rua Munici|pal número 6 - em frente á praça do|mercado.

\section{IV.5.2.1.3 O gerúndio ligado ao sujeito posposto na OM}

Encontrei também alguns exemplos em que uma OG ambígua acompanha um

sujeito que na OM aparece posposto, como mostram estes dois exemplos com o verbo deixar:

(60) [M 181 NP1 15] Aqui nos deixou o Anhangüera adiantando-se com parte da Tropa, ficando a mais expedindo-se para o seguir

(61) [M 181 NP1 76] Em todo esse tempo nos não deixou o gentio, perseguindo-nos os negros, que não se iriam conduzir algumas batatas de vinte e cinco batatais que tinham grandes, e excelentes no gosto: destes negros nos mataram um, e um cavalo, o que visto pelo Cabo se fez um forte em um dos ranchos, que the pareceu melhor, mandando recolher todo o milho, que se achou, a um paiol, a que pôs guardas, como o fez também a sete índios, que cativamos, mandando-lhe lançar a todos suas correntes, excetuando um índio do torto, também cativo, a que depois deu liberdade. 
As características observadas nos exemplos acima, permitem-nos reunir as propriedades das OGs ambíguas (fuzzy) da seguinte forma:

Quadro 20. Propriedades sintáticas das orações gerundiais ambíguas

- (i) localizam-se em posição imediatamente adjacente ao SN que tomam por sujeito $\rightarrow$ [+adjetivo] e [-advérbio]

- (ii) podem aparecer apostas a outros itens predicativos como adjetivos, particípios, advérbios, apostos nominais e outras orações relativas $\rightarrow$ [+adjetivo] e [+advérbio]

- (iii) denotam uma atividade passageira, transitória, atribuindo um modo de ser, uma qualidade que se atribui ao nome a que estão ligadas ${ }^{340} \rightarrow$ [+adjetivo] e [+advérbio]

- (vi) movimentam-se com grande facilidade pela sentença, embora tal estratégia acarrete mudança de sentido ou nuance $\rightarrow[\varnothing$ adjetivo] e [+advérbio]

Algumas propriedades são mais exclusivas ou mais restritas para um determinado tipo de oração subordinada. É o caso da propriedade de (i) posição de adjacência ao $S N$, que é opcional para as adverbiais, mas condiciona as adjetivas, que não obedecem ao critério da (vi) mobilidade na sentença, reservado apenas às adverbiais e a algumas OG ambíguas que aparecem em enumerações, mesmo assim, essas OGs aparecem sempre em último lugar na sequência com outros itens predicativos e imediatamente antes do verbo da OM.

\section{IV.5.2.2 Variações sobre o mesmo tema}

Aplica-se aqui a idéia defendida por Castilho (2006) de que nem sempre é possível estabelecer os limites claros entre uma categoria e outra como a ciência clássica queria fazer. Ao contrário, é preciso entender a gramática das línguas como um conjunto de sistemas complexos que exibem "um tipo de ordem sem periodicidade, mas em fluxo contínuo, em mudança" e que denotam um comportamento imprevisível e, também, que determinadas estruturas transitam por estes sistemas em combinações infinitas (Cf. Waldrop apud Castilho, 2006), estabelecendo "relacionamentos simultâneos, não construídos passo-a-passo, como

${ }^{340}$ Cf. Bechara, 2003:517. 
os genes de uma célula” (idem, op. cit.). Compreendo, portanto, que estruturas como aquelas estudadas aqui pendulam de lá para cá. Os pólos dessa oscilação também não são estáveis, pois essas estruturas, como categoria ambígua, ou fuzzy, apontam para os quatro subsistemas concomitantemente. Fotografar seu movimento seria uma tarefa difícil, que uma representação tridimensional não seria capaz de dar conta, pois mostram que o falante/escritor ativa, desativa e reativa propriedades de seus itens composicionais ao mesmo tempo. Brandão (1933) já havia percebido esta oscilação, e para os casos de gerúndio ligados ao $\mathrm{SN}$ sujeito da $\mathrm{OM}$, que classifica como "gerúndio predicativo do sujeito", ele observa o seguinte: "Vêe-se que, em muitos dos exemplos acima, o particípio vale exatamente como clausula adjetiva, na qual se poderá converter, sem ofensa da sintaxe, nem da semantica” (Brandão, 1933:54). Ora, o que não ofende à sintaxe e nem à semântica está entre esses dois pólos. Também sem saber exatamente como enquadrar estes casos, Brandão diz ainda que estes se confundem com o que chama de "gerúndio atributivo", forma que aliás era aquela execrada pelos gramáticos do séc. XIX. Para esta problemática, o autor nota o seguinte:

A atuação dêstes [os gramáticos que condenavam o gerúndio ligado ao sujeito] é, sem dúvida, necessária como agente de depuração e de conservação dos idiomas cultos; mas tornar-se-á inoperante, sinão ridicula, quando pretender impôr á lingua canones inflexiveis e fórmas petrificadas, desconhecendo-lhe, assim, o característico mais frisante: a sua mobilidade contínua e incoercivel. Esta observação tem todo o cabimento no caso do gerúndio atributivo. $\mathrm{O}$ povo o adotou , e os literatos, sentindo-lhe o poder significante, capaz de traduzir estados, aspectos, atividades para as quais não há, muitas vezes, adjetivos proprios, não o quiseram banir do discurso terso só por parecer uma bastardia gramatical (Brandão, 1933:63).

Dava-se assim, portanto, a sintaticização do gerúndio ligado ao sujeito, ou seja, a ressintaticização (reativação) do morfema gerúndio [-ndo], que no período arcaico andou de braços dados com o particípio presente na exercício da adjetivação. Agora ele aparece renovado em outros contextos, dotado de novas funções, tanto sintáticas, como semânticas ou discursivas. Brandão continua:

póde-se hoje considerar vernáculo o emprêgo do gerundio atributivo e, alêm disso, vantajoso para a lingua, pois alivía o periodo de muitas cláusulas relativas e conjuncionais, tantas vezes pesadas e malsoantes, acelera o adamento da frase, tornando-a mais plastica, mais colorida, mais exata (op. cit., p. 63)

e arremata

Muito ao revés de uma degenerecencia, é antes um progresso e uma conquista do português moderno (op. cit., p. 63-4). 
Falando em sintaticização, e já que estamos falando de Brandão, em suas perguntas retóricas a respeito da validade do uso atributivo do gerúndio, ele enuncia um termo que tem sido resgatado pelos teóricos da gramaticalização:

"Si, portanto, existem na lingua dois gerundios epítetos, genuinos, extremes, sem eiva de peregrinismo, por que constituirão um caso insulado, uma anormalidade inexplicavel? Por que deixarão êles [os gerúndios atributivos] de comunicar essa sua, propriedade tão util e tão fecunda, a outros gerundios em identicas condições sintáticas e semanticas? Por que há de falhar aqui a analogia , si o terreno é tão propício ao amplo desenvolvimento da sua atuação? (op. cit., p. 65, grifo meu)

Naturalmente, Brandão vê como uma ganho para a língua a adoção desse "giro frasal" que "brotou da multidão", ou mesmo que tenha vindo de "outras terras" mais francesas e menos lusas. O raciocínio se aplica a uma tendência atual de uso do gerúndio, talvez mais anglicista, que não "vou estar analisando" aqui, uma vez que não me preocupo nesta tese em descrever, em detalhe, a configuração das perífrases com gerúndio. Aos que torcemos o nariz para o gerundismo atual, um conselho vindo dos idos de 1933: "Si êles correspondem a uma necessidade expressional, se preenchem uma deficiência lingüística, hão de triunfar, a despeito da resistencia e clamor dos puristas exagerados e dos conservadores incondicionais” (op. cit., p. $65)$.

Guardemos estas lições também para os gerúndios adjetivos ligados ao predicativo, ao absolutivo existencial e ergativo, aos sintagmas preposicionados, que apresento a seguir ainda nesta seção sobre os gerúndios dependentes. Lembremos ainda deste conselho, quando falarmos sobre os gerúndios em nominalizações do tipo jabuticabeira produzindo, que descrevo na seção sobre os gerúndios independentes.

A fim de observar melhor este fenômeno, incluí no gráfico 5 as ocorrências de gerúndio ambíguo, ligados ao sujeito da OM: 
Distribuição do gerúndio ligado a um SN da OM

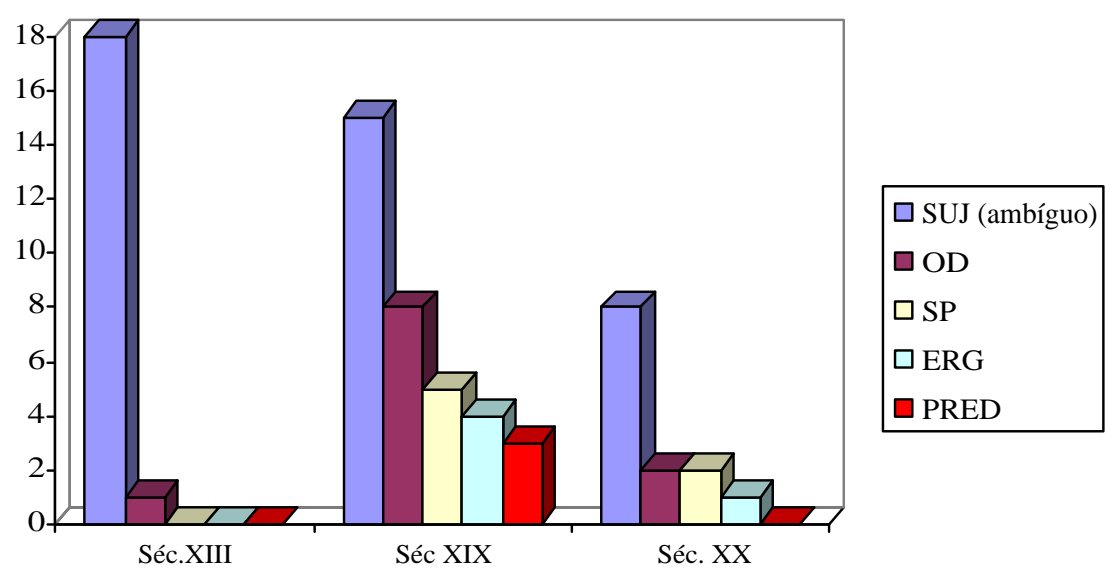

Gráfico 5. Distribuição do gerúndio ligado a um $\mathrm{SN}$ da $\mathrm{OM}$ (gerúndio ambíguo + gerúndios adjetivos)

Observamos aqui o gerúndio ambíguo segue, no século $\mathrm{XX}$, a tendência de decréscimo também observada para o gerúndio adjetivo, mas sua ocorrência é bastante alta no séc. XVIII em comparação com aos outros tipos de oração com gerúndio adjetivo. Esse dado é uma evidência a mais para a tese defendida aqui de que o gerúndio ligado ao sujeito tem um estatuto diferenciado dos outros tipos de gerúndio adjetivo. Alia-se a esta idéia o fato de que o gráfico 6 aponta um paralelismo de decréscimo das orações ambíguas com o decréscimo das orações adverbiais de gerúndio (dependentes e independentes) e conjuncionais no período analisado. Desse modo, temos aqui dois argumentos de ordem quantitativa que confirmam o caráter ambíguo ( [-adjetivo] e [+adverbial] ) dessas construções.

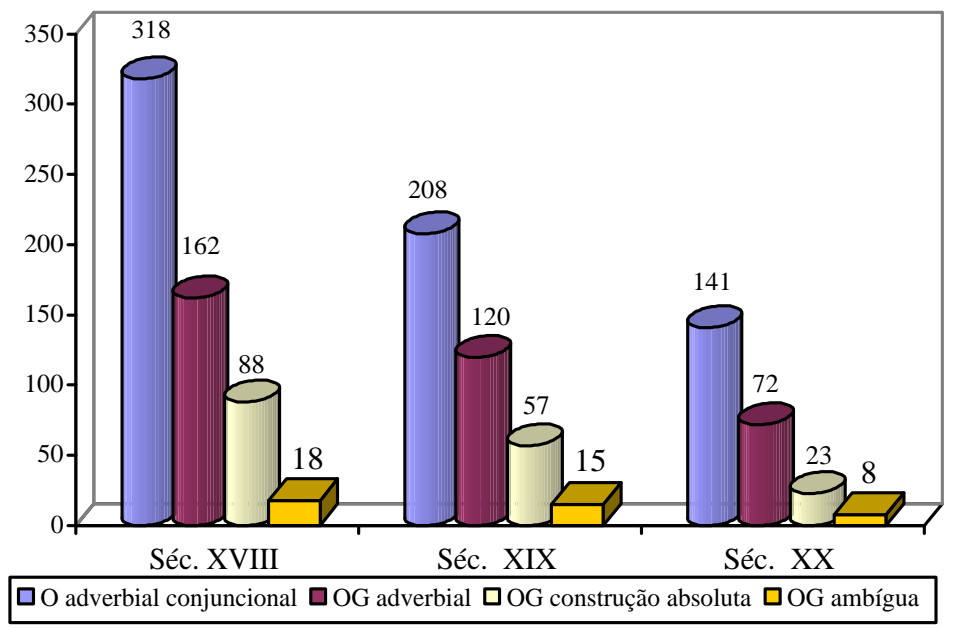

Gráfico 6. Comparação entre orações adverbiais e OG ambíguas 


\section{IV.5.3 Gerúndio em orações relativas}

Nestas construções o gerúndio liga-se unicamente a um SN da OM, predicando-o. O SN pode exercer distintas funções sintáticas na OM (OD, OI, OBL, SP). A estrutura sintática destas construções é a seguinte:

$$
[\mathrm{Su}+\mathrm{V}+[\mathrm{Co}(\mathrm{SN})+\mathrm{G}]]
$$

(62) [C 191 CL 392 4] E o Governo | o que faz? tambem não sei, mas é de querer, que | tenha $\underline{\text { mandado }}$ algum officio, ou Portaria (OD) á Camara, | ou ao Juiz Almotacel recommendando providencias.

(63) [M 202 ERN 13] A solução para o problema dos transportes foi a construção de uma rede ferroviária (SP) ligando toda a região da cafeicultura ao porto de Santos.

\section{IV.5.3.1 A diacronia das orações com gerúndio adjetivo}

O quadro geral de ocorrências (tabela 3) já havia apontado que o gerúndio adjetivo é pouco produtivo nos três séculos em comparação a outros tipos de orações com gerúndio (adverbiais, construções absolutas e perífrases). No entanto, se observado dentro do universo das orações ligadas a um SN da oração matriz, verificamos pela tabela 5 que o gerúndio adjetivo é significativamente alto no século XIX (77\%) em comparação com os outros dois séculos, havendo um decréscimo no século XX (19,2\%), embora ainda seja bastante representativo, se comparado com o séc. XVIII $(3,8 \%)$. Esse resultado confirma que a produtividade do gerúndio adjetivo no séc. XIX era mesmo tão alta que gerou a discussão sobre esse uso entre os gramáticos dessa época.

Tabela 5. Distribuição do gerúndio adjetivo nos três séculos analisados

\begin{tabular}{|l|c|c|c|c|c|c|c|c|}
\hline Gerúndio ligado a & \multicolumn{2}{|c|}{ Séc.XVIII } & \multicolumn{2}{|c|}{ Séc XIX } & \multicolumn{2}{|c|}{ Séc. XX } & Total & Total \\
\hline OD & 1 & $100 \%$ & 8 & $40 \%$ & 2 & $40 \%$ & 11 & $42,3 \%$ \\
\hline SP & 0 & - & 5 & $25 \%$ & 2 & $40 \%$ & 7 & $26,9 \%$ \\
\hline Absolutivo ergativo & 0 & - & 4 & $20 \%$ & 1 & $20 \%$ & 5 & $19,2 \%$ \\
\hline Predicativo & 0 & - & 3 & $15 \%$ & 0 & - & 3 & $11,5 \%$ \\
\hline Total & 1 & $3,8 \%$ & 20 & $77 \%$ & 5 & $19,2 \%$ & 26 & \\
\hline
\end{tabular}

A tabela 6 demonstra que na segunda metade do séc. XIX houve um aumento significativo do gerúndio adjetivo em relação à fase anterior $(6 / 30 \%>14 / 70 \%)$, denunciando o período em que esse fenômeno mais chamou a atenção dos gramáticos, estendendo-se a discussão até o início do século XX (Cf. Julio Moreira, 
1907; Leite de Vasconcellos, 1911 apud Said Ali, 1920/1975 e Epiphanio Dias, 1918):

Tabela 6. Frequiência de gerúndios adjetivos nas duas metades do séc. XIX

\begin{tabular}{|l|c|r|c|c|c|}
\hline Gerúnio ligado a & \multicolumn{5}{|c|}{ Séc. XIX } \\
\hline & \multicolumn{1}{|c|}{$1^{\text {a }}$ metade } & \multicolumn{2}{|c|}{$2^{\text {a }}$. metade } & Total \\
\hline OD & 3 & $50 \%$ & 5 & $35,7 \%$ & 8 \\
\hline SP & 1 & $16,7 \%$ & 4 & $28,6 \%$ & 5 \\
\hline Absolutivo ergativo & 1 & $16,7 \%$ & 3 & $21,4 \%$ & 4 \\
\hline Predicativo & 1 & $16,7 \%$ & 2 & $14,3 \%$ & 3 \\
\hline Total & 6 & & 14 & & 20 \\
\hline
\end{tabular}

A seguir, apresento alguns exemplos de orações relativas com gerúndio adjetivo.

\section{IV.5.3.2 Tipos de orações de gerúndio adjetivo}

\section{IV.5.3.2.1 Gerúndio ligado ao objeto direto da OM}

A tabela 5 demonstra que o gerúndio adjetivo ligado ao OD da OM é o tipo mais freqüente (11/26) no cômputo geral de todos os séculos, sendo sua ocorrência maior no século XIX, seguindo a tendência de aumento dos gerúndios adjetivos descrita na seção anteiror. Abaixo, alguns exemplos dos três séculos:

(64) [M 182 MPC 19] nada milhorou com esta providencia aCapitania, antes notempo doprimeiro General se reduzio amaior extremo; porquanto este fazendo mais conta, com os descobrimentos que intentou do Tibaí, e Guatemí, naõ lhe cervindo de exemplo ainutilidade com que nos tempos antigos se tinhaõ feito semelhantes des- pezas pela Fazenda Real, fez ao Povo hum extraordinario reclame obrigando aque fosse nas expediçoens, que fes para osditos descobrimentos

(65) [C 192 MRI 3 2] Não deixem de apresentar na occazião opportuna, emenda re=duzindo a lista civil do Imperador, e supprim[indo] a datação da Impe= ratirz eoutras pessoas da Famillia Imperial. [espaço] Notem, isto é essencial, sob pena de vossês ficarem [com lesoutres].

(66) [C 201 MA 323 9] Confesso com lealdade que jamais refleti seriamente sobre isso, isto é, seriamente refleti sim, mas não refleti longamente. Mas a seriedade está nisto: se emprego flexões pronominais iniciando a frase, coisa que literiamente é erro, Me parece etc., devo empregar também literariamente "O desespera" porque o caso é absolutamente o mesmo. Se trata duma ilação, é verdade, mas ilação absolutamente lógica sobre o ponto de vista filosófico, e tirado da índole brasileira de falar, o que a torna, além de filosoficamente certa, psicológicamente admissível.

Neste capítulo não tratarei da questão sobre a natureza dos verbos que selecionam o gerúndio adjetivo ligado ao OD. Esse é um condicionamento ligado ao subsistema da Semântica e será descrito no capítulo VI, quando trato da 
semanticização do gerúndio. No entanto, é interessante observar as duas construções que seguem, onde o verbo deixar seleciona um OD. Em (67) o verbo deixar projeta um item que poderia ser comutado por um OD nulo, deyxey [que os soldados continuassem com as muitas experiências]. O fato de o verbo no gerúndio estar expresso com um se apassivador torna a construção dúbia, podendo inclusive ser interpretada como uma CA. No exemplo seguinte, o OD é uma pessôa:

(67) [C 181 Seb 19 3] Por avizo que tive de minha consorte acharse muito mal para morrer sahy dos Matos Sem ter achado Ribeiro de ouro de ma yor conveniencia que o antigo, e deyxey [OD $\varnothing]$ continoando-se com as mesmas experiencias, para em ella melhorando logo tornar;

(68) [C 192 WL 9 5] Quando sahi de São Paulo, deixei uma pessôa copiando os estatutos da Santa Casa e incumbi a um amigo de remetter a copia para você.

\section{IV.5.3.2.2 Gerúndio ligado ao objeto indireto da OM}

Não foram encontradas ocorrências de gerúndio adjetivo ligado ao OI da OM nem no Corpus Básico nem no Corpus Diferencial.

A tradição gramatical considera qualquer argumento interno do verbo antecedido de preposição como objeto direto. Por este motivo é que o exemplos abaixo foi considerado por Campos (1972) como um caso de gerúndio ligado ao OI da OM:

(69) O João Marreca olhou para o animal que todo se pontilhava de verrugas pretas, escaroçando-lhe o úbere, as pernas, o corpo inteiro... ${ }^{341}$

Nesta tese considero como OI o elemento que exibe as seguintes propriedades sintáticas e semânticas apontadas por Mateus et alii (2003:289):

- o constituinte OI exibe o traço semântico [+ animado], pondendo ser [+ hum] (Deu um livro a Antonio) ou [- hum] (Deu uma pintura à estante);

- quando clítico, é comutável pelo pronome pessoal lhe;

Os demais casos foram incluídos na categoria de complemento oblíquo (OBL), de que tratamos abaixo.

${ }^{341}$ Ibid., p. 150: RQ, Q, II, 6. 


\section{IV.5.3.2.3 Gerúndio ligado ao complemento oblíquo da OM}

Apenas no Corpus Diferencial do séc. XX foi encontrada uma ocorrência de gerúndio adjetivo ligado a um complemento oblíquo:

(70) [EF SP 405 26] seria o fato que nos leva a pensar... na:: na arte nascendo ligada à magia... é o fato de que essas representaçoes eram feitas sempre na parte escura das cavernas...

Considera-se aqui como complemento oblíquo o argumento interno que exibe as seguintes propriedades (Cf. Mateus et alii, 2003:294; Castilho, em andamento):

- é um constituinte expresso por SN não comutável por $o$ ou por lhe, por um SP comutável por Prep + ele / isso / lá, ou por um SAdv comutável por SP.

- pode ser considerado obrigatório ou opcional segundo a argumentalidade do verbo a que está ligado.

No exemplo acima, a sentença o fato que nos leva a pensar na arte nascendo ligada à magia, o constituinte na arte é complemento obrigatório da rede argumental do verbo pensar (isso nos leva a pensar em alguma coisa).

Castilho (em andamento) lembra que esse argumento tem sido considerado como quase-obrigatório e que na gramática tradicional é visto como adjunto adverbial, como o exemplo citado por Mateus et alii (2003:294):

Há falta de leite por causa da seca.

Supondo-se que pudéssemos agregar uma oração de gerúndio a esse enunciado, teríamos o seguinte:

Há falta de leite por causa da seca assolando o país.

Neste caso, considerei o gerúndio como elemento ligado ao complemento de um SP (seca), uma vez que se refere somente ao segundo substantivo.

\section{IV.5.3.2.4 Gerúndio ligado ao complemento de um sintagma preposicionado}

Embora sejam apenas 7 as ocorrências encontradas no Corpus Básico, nota-se que o gerúndio ligado ao complemento de um SP segue a tendência de aumento observada para os demais casos de gerúndio adjetivo encontradas na segunda metade 
do séc. XIX, voltando a cair no século XX $(0>5>2)$, como se pode ver pelas tabelas 5 e 6 . Abaixo, alguns exemplos desse tipo de gerúndio:

(71) [M 191 RDN 48] Eportanto, nunca devia prezumir eSsa exactiSsima deligencia dehum homem extranho, governando Indios livres, sem ter huma proporcionada paga doseo trabalho.

(72) [M 192 RL 23. Aos pés do espectador, vasta campina a que embelezam magníficos acidentes; além, as grandes orlas da mata que acompanham as sinuosidades das belas águas do Aquidauana; ao longe a extensa serra de Maracaju, com os píncaros escalvados, refletindo os esplendores do sol, e coroando toda esta massa prodigiosa, azulada pela distância. Foi este ponto, com razão, chamado pelos Guaicurus Campo Belo (Lauiad).

(73) [M 202 ERN 13] A solução para o problema dos transportes foi a construção de uma rede ferroviária ligando toda a região da cafeicultura ao porto de Santos.

\section{IV.5.3.2.5 Gerúndio ligado ao absolutivo de verbos existenciais}

Antes de descrever o $\mathrm{G}$ ligado ao complemento único de verbos monoargumentais, apresento as propriedades sintáticas que os caracterizam como absolutivos em sentenças apresentacionais.

\section{IV.5.3.2.5.1 As propriedades sintáticas do absolutivo}

Nas sentenças existenciais o verbo não projeta um sujeito, tendo-se gramaticalizado como verbo funcional, ou seja, não atribui papel temático. Nestas construções o SN "é indefinido e não tem relação semântica de predicação com o $V$. É incerto seu estatuto funcional" (Castilho, Gramática funcional do português, digitado). A gramática tradicional considera o argumento único do verbo haver como objeto direto. Já para o argumento único do verbo existir, a tradição gramatical atribui a função de sujeito, devido a uma determinada identidade deste com um pronome nominativo. Lyons (1968:410 apud Castilho, op. cit.) considera as construções com os verbos existenciais como implicitamente locativas, uma vez que para serem adequadamente interpretadas, elas requerem a complementação através de uma expressão locativa ou temporal. Segundo este autor, é isto que explica o fato de muitas línguas exibirem algum tipo de advérbio locativo, como é o caso do inglês (there is/are), do francês "il y $a$ ", do italiano "ci sono", e mesmo do português arcaico (hai) ende > en > hy. No espanhol o locativo $y$ ainda permanece na morfologia de haver, em hay. Em tais casos, o verbo funciona como apresentador da cena, fronteando o elemento que toma como argumento único. A ocorrência abaixo é 
o exemplo único que encontramos desse tipo de gerúndio nos dois corpora analisados:

(74) [A 191 SP 9] Na Rua Direita número 2 ha para vender uma| negrinha nova, nação Benguella, meia ladina; sa-|bendo já o serviço da casa por d'entro, e sem de-|feito nem-um. Quem quizer comprar queira apare-|cer na mesma casa, e tractar com o Senhor d'ella. O Farol Paulistano, 18 de outubro de 1828

Tchekhoff (1978 apud Castilho, op. cit.), além de outros sintaticistas, notou que um determinado grupo de línguas "deixam de marcar gramaticalmente o paciente, deixando de codificar o agente, dando lugar a um grande número de Vs monoargumentais" (Castilho, op. cit.). Nestes casos, o argumento único dos verbos chamados ergativos carrega consigo propriedades típicas do OD dos verbos transitivos. Esses verbos são também chamados de inacusativos. Castilho nos ensina ainda que as sentenças ergativas caracterizam-se por (i) apresentar um sujeito que "é um argumento não controlador do estado de coisas descrito pelo $V$ ” e (ii) nelas não se pode identificar o causador da ação, e tão somente o evento causado. O verbo ergativo funciona nestas sentenças para apresentar o conteúdo do SV. Integram esta categoria verbos como chegar, partir, entrar, aparecer, surgir, sumir, desaparecer, acontecer, ocorrer, etc., associados a uma cena que se apresenta como dada, sem que se possa precisar a identidade de um agente causador, e ainda outros que indicam processos para os quais não se pode identificar a intervenção de um agente controlador do evento, como amanhecer, florescer, brotar, murchar, germinar, nascer, etc. (Cf. Ciríaco / Cançado, 2006). O exemplo que segue é um caso de de gerúndio ligado ao absolutivo ergativo:

(75) [M 192 RL 22]

(76) Era a estrada larga e corria ao longo de magníficos bosques, onde predominavam os umbus balsâmicos, espalhando ao longe o perfume das flores abertas, os piquis, carregados de frutos, e as inesgotáveis mangabeiras.

Por estas características, Castilho considera os dois argumentos descritos acima como absolutivos em sentenças apresentacionais.

\section{IV.5.3.2.6 Gerúndio ligado ao absolutivo de verbos ergativos}

O gerúndio adjetivo ligado ao absolutivo de verbos ergativos segue a tendência de aumento de freqüência na segunda metade do séc. XIX (cf. Tabela 4 e 5), como já foi apontado para as outras formas do gerúndio adjetivo. 
O estatuto sintático do complemento absolutivo de verbos ergativos já foi discutido no tópico anterior e resta-nos somente apresentar alguns exemplos em que o gerúndio aparece ligado a esse argumento:

(77) [M 192 HC 15] Por terra aproveitavam as trilhas dos índios; em falta delas seguiam córregos e riachos, passando de uma para outra banda conforme lhes convinha, e ainda hoje lembram as denominações de Passa-Dois, Passa-Dez, Passa-Vinte, Passa-Trinta; balizavam-se pelas alturas, em busca de gargantas, evitavam naturalmente as matas, e de preferência caminhavam pelos espigões.

(78) [C 191 BNRJ 6 10] aoque naõ quizeraõ anuir dizen= do que naõ Largariaõ as armas, emquanto naõ obtivessem, o que queriaõ, vindo ao mesmo tempo officio da Camara exigindo omesmo, bem que forçado pelo partido dos Rebeldes, entre os quais muito se distinguiraõ o Brigadeiro Pinto 1v. oCoronel Francisco Alvarez, os Majores Modesto Macedo

(79) [TEA 192 SL 13] VITORINO : Quem se deixa desprezar tendo uma espada à cinta?|RAFAEL : Que mal conheces o mundo! A honra é a geração; ninguém me tira disto. Em vão nasce um homem, à semelhança de Deus, possuindo inteligência, rico de vontade e esperanças.

De acordo com as propriedades apontadas para os verbos ergativos, consideram-se ergativos os verbos seguir, vir, nascer dos exemplos anteriores, por não serem os seus complementos (córregos e riachos, offício da Camara e um homem) os elementos controladores do estado de coisas descrito por estes verbos.

\section{IV.5.3.2.7 Gerúndio ligado ao predicativo da OM}

O gerúndio adjetivo ligado ao complemento predicativo da OM aparece no

Corpus Básico com o verbo ser, como mostram os exemplos a seguir:

(80) [TEA 192 SL 19] LUÍSA : Pareceu-me ouvir bulha fora. | RAFAEL : É engano teu: eu nada ouço. | VITORINO : Há de ser algum pateta que volta das luminárias, falando em Constituição, garantias, e nas visagens que nos estão fazendo os tais deputados do Retiro. É o que se trata, $\mathrm{n}[\mathrm{a}] \mathrm{s}$ [sic] praças, nas casas, nas boticas, em toda parte.

(81) [TEA 192 SL 26] LUÍSA (escondendo o rosto) : Deus meu, é certa a minha desonra! | VITORINO : Conheço, sim. Eu sei de tudo, e vou-lhe dizer para que se fie em mim; mas antes perdoe-me. Sim. D. Luísa, perdoe-me ter sido um espião, um vilão ruim, que tem seguido os seus passos, espreitando as suas ações: mas eu, talvez pela demasiada confiança que me davam, pensava que éramos todos da mesma família.

(82) [D2 SP 360 37a] L2 (....... se é o pai / [ L 1 sempre é () / L2 perguntando diz que quem quebrou foi a mae

No Corpus Básico não foram encontradas ocorrências desse tipo de gerúndio para os séculos XVIII e XX. Para o último século encontramos a seguinte ocorrência no Corpus Diferencial:

(83) [D2 SP 360 37a] L2 (...) ... se é o pai / [ L 1 sempre é () / L2 perguntando diz que quem quebrou foi a mãe 
Os exemplos abaixo ilustram casos de gerúndio predicativo em estruturas com o complemento predicativo da OM sendo seguido de uma construção comparativa introduzida por como:

(84) [TEA 191 Mac 9] MACÁRIO Por quê? O DESCONHECIDO Porque havia ser alegre como Arlequim assistindo a seu enterro...

(85) [C 192 CL 475 6] E a velocidade crescia ! e corria-se, voava-se, cor- | tava-se o espaço como um raio fendendo as nuvens!

\section{IV.5.3.3 As propriedades sintáticas das orações relativas}

As orações com gerúndio adjetivo exibem as propriedades descritas no quadro 21 .

Quadro 21. Propriedades sintáticas das orações relativas

- (i) localizam-se em posição imediatamente adjacente ao SN que tomam por sujeito

- (ii) O SN sujeito da oração relativa pode exercer distintas funções sintáticas na OM (OD, OI, OBL, SP) ${ }^{342}$. A estrutura sintática é a seguinte:

$$
[\mathrm{Su}+\mathrm{V}+[\mathrm{Co}(\mathrm{SN})+\mathrm{G}]]
$$

- (ii) podem aparecer apostas a outros itens predicativos como adjetivos, particípios, advérbios, apostos nominais e outras orações relativas

- (vi) não se movimentam com facilidade pela sentença, a não ser nas seqüências de orações relativas:

- [C 192 MRI 3 2] Não deixem de apresentar na occazião opportuna, emenda re=duzindo a lista civil do Imperador, e supprim[indo] a datação da Impe= ratirz eoutras pessoas da Famillia Imperial.

\section{IV.5.4 Conclusões parciais a respeito do gerúndio na minioração (dependente)}

$\mathrm{Na}$ seção 5 deste capítulo procurei demonstrar de que maneira estão distribuídos os verbos no gerúndio que são núcleo de uma predicação secundária, ou seja, que predicam um constituinte nominal da OM, seja através de uma construção adverbial, adjetiva ou como categoria ambígua entre estes dois pólos. Verifiquei que as orações adverbiais e as construções com gerúndio ambíguo apresentam um

342 O gerúndio ligado ao sujeito foi considerado nesta classificação como uma categoria ambígua, descrita na seção anterior (5.2). 
descréscimo de uso equivalente. Notei que esse paralelismo aproxima as orações fuzzy das adverbiais, embora tradicionalmente tenham sido consideradas orações relativas, por estarem localizadas em adjacência imediata ao SN sujeito da OM.

Observei ainda que a problemática em torno do gerúndio adjetivo discutida ao final do séc. XIX e início do séc. XX se vê refletida no aumento dessas construções na segunda metade do séc. XIX, embora o seu uso seja relativamente tímido, se comparado à alta produtividade dos outros tipos de gerúndio, como é o caso das OGadv, das CAs e das perífrases.

Na seção seguinte, apresento os casos de gerúndio em sentenças plenas, como é o caso das perífrases verbais, ou "relativamente" plenas, tais como as CAs, as nominalizações, o gerúndio imperativo, e o gerúndio funcionando como articulador discursivo.

\section{IV.6 O gerúndio como núcleo de predicação primária (independente)}

Diferentemente do que ocorre na minioração, o gerúndio independente não é o núcleo de uma predicação secundária. Neste caso, o gerúndio projeta o argumento externo de forma independente. O sujeito ao qual está ligado o gerúndio não exerce nenhuma função sintática na OM. No entanto, à falta de uma morfologia de tempo, modo e pessoa, típica dos verbos, o verbo no gerúndio apresenta-se numa relação de dependência sintático-semântica com um verbo finito que dá suporte à falta de dessa morfologia. No caso das construções absolutas, o gerúndio apóia-se no verbo da OM. Nas perífrases, é seu auxiliar que cumpre esta função e, nas demais formas mais nominais do gerúndio independente, em nominalizações, em orações exclamativas e interrogativas, nas formas imperativa, e como articulador discursivo, a relação tempo-modo é recuperada na instância da enunciação, que pode ser uma conversação em curso ou pode se dar pelo enquadramento (framing no sentido Talmyiano) promovido pela relação entre os eventos envolvidos nessa cena.

Nas subseções seguintes, descrevo como o gerúndio independente se distribui nas suas variadas formas de realização. 


\section{IV.6.1 Gerúndio em oração adverbial independente (construção absoluta)}

Como já observamos no capítulo I, entende-se por construção absoluta (CA) qualquer elemento nominal ou sentença que se adjunge a uma oração matriz, sem estabelecer uma relação de dependência sintática direta, por não compartilhar com esta nenhum complemento, porque projeta o seu próprio sujeito, o que lhe confere o status de uma oração parcialmente independente, não fosse o seu caráter nominal e sua interdependência semântica com o predicado da oração matriz. A dependência semântica se estabelece primordialmente pela relação de seqüenciação dos eventos envolvidos tanto na OM, como na OG. Assim, em termos sintáticos, o que diferencia as construções absolutas das orações adverbiais é o fato de que estas compartilham o sujeito da $\mathrm{OM}$, enquanto aquelas possuem um sujeito distinto daquele da oração à qual está adjungida.

\section{IV.6.1.1 As propriedades sintáticas das construções absolutas}

Além das propriedades apontadas por nós para as OGadvs, vale a pena enumerar também outras características inerentes às CAs observadas por MüllerLancé (1994:25-36):

1. Toda CA é uma predicação encaixada ${ }^{343}$, ou seja, a construção pode ter dois ou mais termos integrantes, mas, em determinadas circunstâncias, um dos dois pode ser completado pelo contexto e pelo menos um dos termos assume a função de sujeito enquanto o outro, a função de predicado.

2. A CA precisa ter um sujeito próprio e deve permitir uma distinção entre os sujeitos. (a) $\mathrm{Na}$ maioria das vezes o sujeito da CA é diferente do sujeito da oração principal, mas (b) as duas podem ter o mesmo sujeito, embora seja explicitado novamente através de dêixis apropriada.

3. O predicado da CA não pode ser uma forma verbal finita nem ser um infinitivo. Os predicados podem ser tanto uma forma verbal infinita como também substantivos e adjetivos de caráter deverbal

4. O predicado da CA não pode ser excluído (construção exocêntrica)

5. O todo da CA tem um estatuto de circunstante, portanto, adjunto, e por isso pode ser excluído.

6. A CA não pode depender de uma preposição.

${ }^{343} \mathrm{O}$ termo encaixada (embedding) tem origem no modelo transformacional de Chomsky e refere-se às orações que na estrutura superficial são dependentes, mas que, estando "encaixadas" na oração matriz, funcionam como orações independentes (Müller-Lancé, 1994:25, nota 32). 
Os critérios acima referem-se a todos os tipos de construções absolutas, sejam elas de particípio, gerúndio ou nominais:

(86) [M 181 NP2 2] Subida a Serra, e saindo no alto dela se dá logo, Rmo. Sr., com um campo admirável, que a nível da mesma Serra, e abunda de capões, pinheirais, e em partes de matos carrasquenhos, com muitos e vários córregos, de que a maior parte deságuam campo dentro, caminho de noroeste e poente.

(87) [M 181 NP2 45] Quase na saída desse mato fica outro ribeirão que chamam o de Cristo, com 4 palmos de fundo na passagem, e 7 braças de largo: passado este subimos uma ladeira, e continuando pelo mesmo mato, caminho de nornoroeste quase um quarto de légua chegamos à Desejada.

(88) Lívia de braços fechados no peito. Lívia silenciosa. O frio entrava pelo seu corpo. ${ }^{344}$

Como neste trabalho concentro-me no gerúndio, não importa aqui o critério (6), que afeta apenas as construções nominais. Campos (1972:158), porém, aceita como absoluta a construção de braços fechados, na qual reconhece a base verbal do particípio fechados.

Não vejo necessidade também em aplicar o critério (2b) para o português, pois na maioria das vezes o item anafórico pode ser apagado, sem prejuízo do sentido ali expresso, como mostra o exemplo abaixo:

(89) [M 191 RDN 40] §. 16. Mas como entaõ sedeo liberdade ahuma multidaão deIndios, que fazia oGrande Cabedal dos Paulistas, ecomque deneceSsidade emhumdia empobreceraõ as mais Ricas Cazas, povoaraõ-se prodigiozamente as Aldeas para onde erã̃ mandados os Indios (c) Einda posteriormente foraõ [entran]do outros para [ellas], porque tendo muitos ficado nas mesmas Cazas, emque existiaõ, com officio deadministrados, [estes] mesmos quando [Sa]hiaõ eraõ Re[colhidos] as Aldeas.

Vamos testar agora os critérios restantes com base no seguinte exemplo:

(90) [C 181 Ald 6 2. equerendo eu por Remedio ahisto, SemeauZentou odi to jndio.

1. Toda a CA é uma predicação encaixada: na construção acima, o constituinte a locução verbal querendo por projeta o pronome eu como sujeito e os argumentos internos remedio (OD) e ahisto (OBL).

2. A CA precisa ter um sujeito próprio e deve permitir uma distinção entre os sujeitos: o sujeito poderia ser elidido em função da presença do item me que aparece na oração matriz, mas permanece sendo distinto do sujeito da oração matriz ( $o$ dito jndio).

${ }^{344}$ Exemplo de Campos (1972:158): JA, MM, 260. 
3. O predicado da CA não pode ser uma forma verbal finita nem ser um infinitivo: em construções com verbos auxiliares, é ele quem assume o morfema [ndo].

4. O predicado da CA não pode ser excluído (construção exocêntrica): esta propriedade é a que distingue de maneira mais efetiva demonstra a independência desse tipo de orações adverbais. Se retirarmos o predicado querendo por Remedio ahisto, a construção não se sustenta.

5. O todo da CA tem um estatuto de circunstante, portanto, adjunto, e por isso pode ser excluído: este critério denota que a construção absoluta não tem estatuto de argumento, mas sim de adjunto, sendo portanto, facultativa. No entanto, o mesmo critério pode ser aplicado a boa parte das orações adverbiais dependentes. ${ }^{345}$

Assim como fiz para as OGadvs, analiso agora a natureza do sujeito nas CAs.

\section{IV.6.1.2 A natureza do sujeito nas orações adverbiais absolutas}

Como vemos na tabela 7, grande parte das CAs apresentam um sujeito lexicalizado:

Tabela 7. Natureza do sujeito na construção absoluta (CA)

\begin{tabular}{|l|l|c|c|}
\hline \multicolumn{4}{|c|}{ A natureza do sujeito nas construções absolutas (CAs) } \\
\hline CAs com sujeito gramatical & nulo & 24 & $24,7 \%$ \\
\cline { 2 - 5 } & SN substantivo & 52 & $53,6 \%$ \\
\cline { 2 - 5 } & pronominal & 18 & $18,6 \%$ \\
\cline { 2 - 5 } & oracional & 3 & $3,1 \%$ \\
\hline & Subtotal & 97 & $57,7 \%$ \\
\hline CAs sem sujeito gramatical & & 71 & $42,3 \%$ \\
\hline & \multicolumn{3}{|c|}{ Total } \\
\hline
\end{tabular}

\footnotetext{
${ }^{345}$ Nesta tese não me proponho a discutir se o estatuto sintático das orações adverbiais é de argumento ou de adjunto. Um estudo bastante interessante a respeito dessa questão foi feito sobre o gerúndio espanhol por Luis Paris (2003), que aplica a teoria da Semântica Cognitiva de Talmy (2000) às orações adverbiais gerundiais, estebelecendo critérios ligados à relação entre os eventos na construção da cena (framing).
} 
$\mathrm{Na}$ maioria das vezes as CAs projetam um sujeito lexical que pode ser expresso por um SN substantivo $(53,6 \%)$, por um pronome $(18,6 \%)$ ou por uma oração $(3,1 \%)$, podendo também ser nulo $(24,7 \%)$.

Por serem independentes em relação ao sujeito da OM, as CAs comportam os verbos que não projetam um argumento externo. Isso explica o alto índice dessas construções sem um sujeito gramatical $(42,3 \%)$. Nestes casos, encontramos os verbos que projetam apenas um argumento (monoargumentais), como os absolutivos existenciais e ergativos, e os verbos com o se indeterminador e apassivador.

Apresento a seguir alguns exemplos dessas construções segundo a natureza do sujeito.

\section{IV.6.1.2.1 Sujeito nulo}

Nos casos em que o argumento externo é nulo, o sujeito é recuperável através de algum item da OM que nela não desempenha a função de sujeito.

(91) [C 181 Seb 15 2] Movendoçe nesta villa em meu Juizo huã Contenda deCauza Sivel entre partes Agravou demim huã dellas para omeo ouvidor Geral etratando de Seus papeis para siguir Seo agravo Cuja parte estava preZa naCadea desta Villa, empenhandoçe neste negoçio oesCrivaõ daCamara Thome gomes mar Zagaõ Com noqu[_?rasurado]aSsj dores Breadores eproCurador ejun tos naCaza doComçelho meman daraõ xamar para prezidir nella [OM],

(92) [C 191 CR SP 396 1] Rogamos a todos os Cidadãos nos queirao illustrar com seus talentos e lembranças, que todos aceitaremos; e publicaremos, vindo na forma que a lei, a decencia, e moderaçao exigem.

(93) [C 202 CLis 43 1] Prezada Clarice: | em resposta à sua carta de 15 do corrente, informo que continuo disposto a editar o seu excelente, mas ill fated, A maçã no escuro. Sucede, todavia,que já estamos praticamente no meio do ano e, neste 1959 de angústias e incertezas financeiras, graças aos desvarios juscelínicos, seremos obrigados a diminuir grandemente o volume de nossa produção editorial. Assim sendo, não posso garantir a publicação do romance dentro de curto prazo.

Em (91), o sujeito de tratando pode ser recuperado na correferência com três elementos presentes neste trecho: os constituintes em теи Juizo e para о теи ouvidor Geral presentes na primeira CA que aparece logo no início dessa sentença complexa; outro item que colabora na recuperação do sujeito [eu] é o pronome me, presente no SV memandarã̃ xamar da OM. Observe-se que neste exemplo enumeram-se três CAs, que servem de contexto pressuposto para a ação que se desenrola em seguida e passa a ser narrada pelo autor da carta. 
Na carta de redator do corpus diferencial do séc. XIX (92), a CA condicional introduzida por vindo projeta um sujeito que na superfície seria o OD da OM. No entanto, esse item também é nulo na OM, porém, ambos, sujeito da CA e OD da OM, podem ser recuperados pela correferência com os itens talentos e lembranças da sentença que as antecede.

Na correspondência enviada a Clarice Lispector (93), o item assim resume as explicações dadas pelo editor nos enunciados anteriores. Vale observar que a construção assim sendo já pode ser considerada a lexicalização de um dêitico, neste caso composto por uma base verbal aliada a outro item dêitico. O estudo da diacronia das CA tem mostrado que elas são as construções adverbiais que estão mais dispostas a lexicalizar-se. Isso provavelmente se dá pelo fato de serem mais nominais que verbais, o que as torna, portanto, mais suscetíveis desse passo. Isso de alguma forma explica também o surgimento de uma nova locução conjuncional sendo que, como dão conta disso os exemplos abaixo. Observe-se que a primeira ocorrência, da primeira metade do século XVIII ainda carrega consigo um item sujeito Cauzo, que já não aparece nas ocorrências seguintes.

(94) [C 181 Seb 2 15] e[astanta] des ReZes emp[e]rtaraõ Sento eVinteesin co mil Reis que pertanto deicharaõ empenhadas as[tantas] Espingardas, Sendo CauZo que osditos, naõ mandem da Villa deSanctos odinheiro,

(95) [M 182 MPC 27] 10 Nas terras deSertaõ; ouSerra aSima, produzem bem o milho, feijaõ, esofrivelmente aCanna deAsucar, mandioca, Anil, Trigo, Sendo que nestes ultimos generos pouco Secuida; e os Pau Listas seaplicaõ mais à criaçaõ de Animais e com efeito dellas sai muito gado, eToucinho em Curitÿba que fica para La daSerra, que cobre Parnagoà erao algum dia famozas as suas fazendas de gado, hoje porem estaõ menos ren dozas, tanto pellos direitos que se inovaraõ sobre os animais dasua produçaõ, como por se ter adiantado, emtoda aCapitania esta Criaçaõ; taõbem nella seprodus exselente Trigo, emque mais alguma couza cuidaõ, que noResto da Capitania.

(96) [C 192 WL 4 6] creditei hoje em tua conta a quantia de 1:600\#000, sendo que tirei 100\# 000 para [p.3] pagar-me dos phono $=$ gramas que te $\operatorname{mand}=$ dei.

(97) [M 201 PRO 6] Sobre os conventos, igrejas e capelas, adiante, em resumo, procurarei historialos em base dos dados que consegui, alguns documentados e outros em uma publicação anônima em 1870, e também baseado na tradição, sendo que com referência ao Convento de Santo Antônio e Ordem Terceira da Penitência, serei mais prolixo em virtude de ter em mão o velho arquivo da Venerável Ordem Terceira da Penitência, reorganizado com muito trabalho em 1926.

(98) [M 202 ERN 2] Em 1820 havia poucas estradas no território paulista, sendo que as localizadas no interior foram construídas a partir dos antigos caminhos expansionistas traçados nos séculos anteriores.

Encontramos também outros casos de sujeito nulo nas CAs, nos quais fica difícil recuperar o sujeito. Nessa carta de um religioso que administrava a aldeia de Escada (hoje Guararema/SP) está contando o caso que se sucedeu entre ele e um índio aldeado que o agrediu. 
(99) [C 181 Ald 19 39] Ecomo detudo isto contando ao Tenente Coronel para o C[a]stigar, fes taó pouco Cazo, que imaginando Eu inquiriSse o Cazo, oque lhefez fo[y] [p. 2] Dizerme naó ser posivel; tendo experiencia delle ser taó dezatento que nesta Aldeia diante do vezitador da Companhia, eoSubprior da Aldeia de Sã̃ Joseph atirou a hu' homem, que por lhenaõ apegar fogo aespingarda, o naó matou;

No jogo narrativo em questão, o envolvimento emocional do frei é tão grande que confundem-se os participantes da cena: ele mesmo, o índio, o Tenente Coronel, o Subprior da Aldeia de Sã̃ Joseph e homem em quem o Tenente Coronel atirou, ou teria sido o índio quem atirou? O fato é que, quem reclama de tudo isso é o frei, e ele é, portanto, o sujeito de contando. Além disso, trata-se de uma CA interpolada de maneira curiosa em outra sentença complexa: Ecomo detudo isto fes taó pouco Cazo, que o que lhe fez foy Dizerme naó ser posivel. Note-se ainda que dentro dessa mesma sentença há nova intervenção do enraivecido frei, funcionando também como uma CA: imaginando Eu inquiriSse o Cazo.

Foi encontrado ainda uma caso especial que o aproxima dos gerúndios flexionados galego-portugueses:

(100) [M 181 NP1 67] Retiraram-se para o mato os Tapuias, mas sem nunca nos perderem de vista, e tanto, requerendo darmos sepultura ao Carvalho persuadidos, aqui estaria morto, procuraram em duas avançadas que nos deram, o tirá-lo e comê-lo, e vendose rebatidos nos pediram por acenos que lhes déssemos ao menos a metade para a comerem, por ser diversa a língua da geral.

A fim de desambiguar a construção, o autor dessa memória histórica da primeira metade do séc. XVIII optou por marcar o verbo principal da CA com a morfologia de pessoa e número [-mos].

\section{IV.6.1.2.2 Sujeito expresso por um substantivo}

O sujeito expresso por um substantivo e seus especificadores é a forma mais produtiva nas CAs que projetam um sujeito gramatical $(52 / 97=53,6 \%)$ :

(101) [C 182 BAN 7 5] efalecendo a may do mesmo Suplicante, por iSso Recahio nelle e em Sinco ir maons que tem pobriSsimos, edelles Sam[Duas?] mu das, ehuma aleijada o dominio[7] para proCura[r e?] Ser Restituidos deste Sitio

(102) [C 191 Seb 12 6] Saiba Vossa Excelenca que ouzo de hir as terras do Convento buscar augua hé muito antigo, einda quando as terras naõ estaõ muradas, senaõ hum pedaço, e este mesmo desmantelado pormuitas partes, apasa gem hé nesseSsaria para huma eoutras terras e[__?] e apasagem naõ Cauza esCandalo muito prinçipalmente naõ paSsando oPovo pellos muros [nem] por Portaõ, mas Sim [p. 2] Sim pellos fundos

(103) [C 202 CLis 61 1] Ilustre Escritora: | Tencionando o Instituto Estadual do Livro dessa Diretoria de Letras lançar, ainda no corrente ano, na sua coleção de divulgação (Cadernos do Rio Grande), uma seção dedicada a textos de autores brasileiros modernos, vimos a sua presença solicitar o interesse no sentido de que a referida seção seja inaugurada por Vossa Senhoria. 


\section{IV.6.1.2.3 Sujeito expresso por um pronome}

Quando o sujeito da CA é pronominal, ele aparece normalmente expresso pelo pronome pessoal, aqui, os pronomes eu e ella:

(104)[C 181 Seb 15 6] preguntandolhes eu, Sehera al guã ordem ouCervico deSua Magestade que Deos guarde Responderaõme, oque vossaExcelencia nessas Duas Certidoins verâ que asmandej paçar pellos ofiçiaes de Justiça que prezentemente Seaxaraõ

(105) [C 181 Seb 19 3] Por avizo que tive de minha consorte acharse muito mal para morrer sahy dos Matos Sem ter achado Ribeiro de ouro de ma yor conveniencia que o antigo, e deyxey continoando-se com as mesmas experiencias, para em ella melhorando logo tornar;

Eventualmente, o pronome pode aparecer extraído da CA. Na ocorrência abaixo, talvez o advérbio de negação tenha colaborado para a topicalização do pronome $e u$ :

(106) [C 192 WL 15 2] Ora, eu não podendo faser isso sem primeiro remetter toda a safra (para cuja venda aguardo melho- ra de preço) combi- námos aguardar essa opportunidade que será certamente em Janeiro.

Ocorrem também os pronomes indefinidos isolados:

(107) [C 182 BAN 4 3] epar= tindo estes Sobre elle este Sepos em= fuga onde para oSogei tarem lhe deraõ Alguas bordoadas das Coais edaqueda que [_? ?]eu no xaõ aConteSeu ficar com acara maxucada e Com hû leve feri= mento dopau feito por hû que oencon trou por diante

(108)[TEA 182 FE 37] Tram. Vamos, eu levo o resto do trem. Levaráõ tudo para dentro, despois tornando, vem pôr a meza para merendarem todos, e na meza poem os alguuidares do assado, e das filhozes, paõ, azeitonas, selada, rabos, copos, facas, e a burracha no chaõ ao lado de Sergio, e entrando todos a comer rusticamente dirá?

ou também acompanhados de outros especificadores:

(109)[M 182 MPC 46] e heSerto, que estando naCidade deSaõPaulo tudo isto, sepo- voa, aumenta, eemriquece aterra deSertaõ, eSedes- falca Amarinha qu[ando?]e sedeve cuidar mais naSua povoação?

(110) [M 191 RDN 12] §. 4. Oexcelentissimo Senhor Dom Luis Antonio deSo[i]za, conheceo bem aneceSsidade deerigir Freguezias emAldeas, que fossem tomando m[aior] [calor] por offeito das suas deligencias esperançava-se muito nasdeSa õ Miguel, Pinheiros, eSaõ Joze. (a) comtudo unicamente erigio em Villa esta ultima ficando as outras em Aldeas, como d'antes.

O uso de pronomes de tratamento são comuns da correspondência oficial:

(111)[C 182 Ald 23 1] Com amais reverente Submissam, erespeito, reprezenta aVossa Excelencia Francisco daCunha Lobo, Director daAldea deBoú, que permetindo lheSua Magestade peloSeuReal directorio, oter em SuaCaza hú Indio daSua respectivaAldea, para as dispoziçoens damesma, Avizos, [espaço] remeSsas deCartas e mais destribuiçoens das Ordens deVossa Excelencia, concervava o Suplicante para oreferido, hú rapas deNome Francisco,

(112) [C 191 CL 389 19a] E como talvez eu não | tenha occasião de ouvil-os, publicando | Vossa

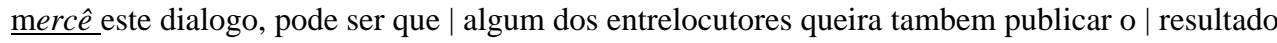
da meditação do Senhor Portuguez | velho. 


\section{IV.6.1.2.4 Sujeito oracional}

O sujeito oracional aparece apenas em duas CAs:

(113) [M 181 NP1 6] Neste pousos falhamos um dia, sendo a causa o requerer toda a Tropa a Anhangüera, e fizesse a resenha que lhe tinha prometido antes de fazer em Mogi, e a que tinha já faltado.

(114) [C 192 WL 4 4] Como quan= do me destes ordem para comprar as acções não me disseste que tinhas pressa, e sendo opinião geral que as acções de = viam baixar, deixei de comprar, mesmo tam $=$ bem quando quiz com $=$ prar não achei um lote de 17 acções pois que um lote pequeno e de numero impar nem sempre se obtem.

\section{IV.6.1.3 Construções Absolutas sem sujeito gramatical}

As CAs sem sujeito gramatical compõem-se de verbos monoargumentais no gerúndio, como os verbos existenciais haver e ter (114-116) e os verbos ergativos do tipo, acontecer, entrar, sair, chegar (117-118). Também fazem parte destas construções os verbos que projetam um complemento indeterminador ou apassivador se que, em alguns caso, também pode ser nulo.

Tabela 8. Distribuição das construções absolutas sem sujeito gramatical

\begin{tabular}{|c|l|c|c|}
\hline CAs sem sujeito gramatical & absolutivo (existencial) & 7 & $9,9 \%$ \\
\hline & absolutivo (ergativo) & 5 & $7,0 \%$ \\
\hline & indeterminado & 59 & $83,1 \%$ \\
\hline & Total & 71 & \\
\hline
\end{tabular}

\section{IV.6.1.3.1 Absolutivo existencial}

(115) [C 182 Ald 24 8] Havendo aprovidencia de serem obrigados os Indios, que sequizerem izentar dotrabalho aque unidos com osmais zelozos verifiquem os desman xos dos valos, eaque os vezinhos confinantes, que tiverem direito naqueles campos de fora por pro $=$ prios ou foreiros os naó queimem sem fazer sa bedor ao Director dodia para os Indios aserarem, ede fenderem oseo quintal noato dofogo, he sem duvida, que naó entraraó mais criaSsoens, nem deixaraó deplantar querendo trabalhar, para se remirem das suas necessidades

(116) [C 192 WL 13 5] Arrangei um emprego explendido: estou na repartição de Terras e Colonisação, como auxiliar de escripta; te- nho $150 \# 000$ reis mensa[e]s, mas havendo durante o o meu $1^{\circ}$ anno um imposto de $10 \# 000$ fico redusido a $140 \# 000$ o que já não é pouco;

(117) [C 201 WL 1 9] O facto é que o projecto de lei eleitoral, que elle elaborou com o João Cabral, despertou mediocre enttusiasmo. Poucos o terão lido na integra, dada a sua desmensurada extensão. Mas todo mundo o censura por este ou por aquelle motivo, havendo quasi sempre razão nas criticas exaradas. 


\section{IV.6.1.3.2 Absolutivo ergativo}

(118) [M 181 NP1 8] Escusou-se este com a promessa, de que em chegando o Capitão João Leite da Silva Ortiz, seu Genro, que nos tinha ficado atrás, e era o outro descobridor, a faria ele cabo no Rio Grande.

(119) [M 182 MPC 35] andaõ todos elles noprezente trienio arrendados em $41.500 \$ 000$ reis os contratadores tem largado adiferentes Arrendatarios os Dizimos da Marinha naforma que consta do Mapa junto doNumero 1.o em 15.804\$000 reis entrando o- Dizimo das Baleis [sic, por baleias $\rceil$ das duas armaçoens da Bertioga, eSaõ Sebastiaõ, oqual regularmente im porta no trienio 1.704\$000 reis oque elles recebem, enaõ arrendaõ, deminuidos estes dizimos daMarinha na emportancia de 41.500\$000 reis vece que nototal dellas toda as Povoaçoens deSerra aSi- ma 25:696\$000 reis e as da Marinha 15.804\$000reis

\section{IV.6.1.3.3 Construções com se indeterminador e se apassivador: sujeito indeterminado}

Já é antiga a discussão em torno do estatuto sintático do pronome se. Maurer Jr. (1951:50 apud Bittencourt, 2006:7) propõe que esta forma tem origem no indoeuropeu, ultrapassa o latim tardio e tem ecos no português falado no Brasil. Da voz média do indo-europeu surgem os depoentes no latim, com sentido ativo e forma passiva. A forma passiva pronominal irradiou-se pelas línguas românicas e com isso abriu caminho para a ampliação semântica do pronome se no português. Maurer Jr. (1951) sugere que essa forma tenha desenvolvido o sentido impessoal, quando usada com verbos intransitivos e verbos transitivos indiretos. Atualmente, podemos identificar nesse pronome a função indeterminadora, a função passiva, a função reflexiva e a função recíproca. Seu apagamento está associado ao rearranjo pronominal ocorrido na segunda metade do séc. XIX e que foi observado por Tarallo (1993 apud Bittencourt:6).

Para efeito prático, incluí neste grupo todas as construções de gerúndio em que o se se realiza lexicalmente ou como nulo, sem discutir as propriedades sintáticas que possam identificar esse item como indeterminador ou apassivador.

\section{IV.6.1.3.3.1 Construções com se apassivador ou se indeterminador explícito}

No exemplo (119) há uma seqüência de verbos que projetam o item apassivador se. Nota-se que todo o segmento está construído em torno da indeterminação, marcada em vários itens: no particípio posta, no SV da oração 
matriz podia restituir-se e na indeterminação do sujeito de medindo. No exemplo (120) a indeterminação vem marcada pelo item se e pela marcação de caso dativo em ao Instituto Estadual do Livro. Neste caso, se não houvesse a presença da preposição $a$, o Instituto poderia ser interpretado como o sujeito de um verbo reflexivo.

(120) [M 182 MPC 9] 3.o Posta nesta cituaçaõ aCapitania podia restituirse Logo, cuidadandose nasua Povoaçaõ, ou mandandoselhe nova gente, ourepartindosse com ella, daque sempre chegava dePortugal, com animo de seestabalecer nas Minas, emedindo asforças daCapitania emeios deestabalecimento que ofrece pro curar que se aplicasem aelle osseus povoadores em utilidade propria eaumento daReal fazenda:

(121) [C 202 CLis 61 4] Quanto à remuneração pelo trabalho, nossa orientação tem consistido em dar ao Autor $10 \%$ sobre o número de exemplares publicados, pagos em livros, não se reservando de resto ao Instituto Estadual do Livro senão o direito de distribuição dos volumes restantes.

(122) [M 201 WLC 20] As palavras do Roteiro de Pero Lopes de Souza - documento que mais deve valer para as coisas do mar que para os acontecimentos de terra - devem ser entendidas de modo consentâneo, dando-se-lhes o valor que elas devem ter.

\section{IV.6.1.3.3.2 Construções com se apassivador e indeterminador nulo}

Assim como foi observado por Duarte (2002) e Duarte/Lopes (2002), a indeterminação também pode ocorrer de forma nula, quando o pronome se é elidido da construção.

(123)[M 191 RND 63] §. 29. E porque nem sempre podia durar opatrocínio doOuvidor Campello, eera precizo que houvesse hum meio deconstranger os Indios aobServância doseo Termo, pondo__os no estado dehuma cega obediência aos seos Reverendissimos PPadres, lembrou entaõ aosCapuchos serem Legisladores, efazerem Leys penais contra os Leigos.

Pode ainda a construção indeterminada ser construída com algum verbo do tipo ergativo que não seleciona um argumento absolutivo nos moldes apresentados anteriormente. $\mathrm{Na}$ ocorrência abaixo o item assim funciona como um item dêitico que recupera o evento descrito anteriormente e poderia ser interpretado como um complemento oblíquo de succedendo:

(124)[C 192 WL 15 5a] Penso que os commissarios farão a reforma, visto a safra proxima ultra passar em muito a ex - pectativa orçada no contrato; de maneira que assim succedendo fica - rei sem o pesadelo da letra de 40.

Há outros casos de indeterminação, em que é possível recuperar o pronome indeterminado do tipo a gente pelo contexto, como mostra a ocorrência abaixo:

(125) [C 202 SIM 2 9] No dia seguinte de manhã, fomos à Lambari, | lá é super legal, tem um cassino, que está | sendo restaurado para ser novamente aberto, que é | simplesmente maravilhoso, nós não entramos pois | estava fechado mas só vendo por fora já da para | ficar encantado, ele fica bem no alto ao lado, em | baixo tem um lago enorme, não sei se é lago ou rio, | é um monte de la água, 
Finalmente, pelos resultados obtido na tabela 6, podemos afirmar que a indeterminação do sujeito nas CAs é bastante significativa. Ela ocorre em 42,3\% dessas construções, com verbos existenciais, ergativos e com aqueles que projetam um item indeterminador e apassivador. Tal fato está associado à natureza parentética das CAs e será analisado sob o ponto de vista da semântica no capítulo VI.

\section{IV.6.1.4 A posição das orações adverbiais}

O gráfico 7 mostra que tanto as orações adverbiais gerundiais (OGadvs e CAs) como as conjuncionais distribuem-se de maneira equivalente segundo sua posição, sendo a posposição o lugar preferido por estas estruturas, seguida da anteposição. Essas construções aparecem interpoladas de forma diversificada. A seguir, apresento algumas destas formas de interpolação.

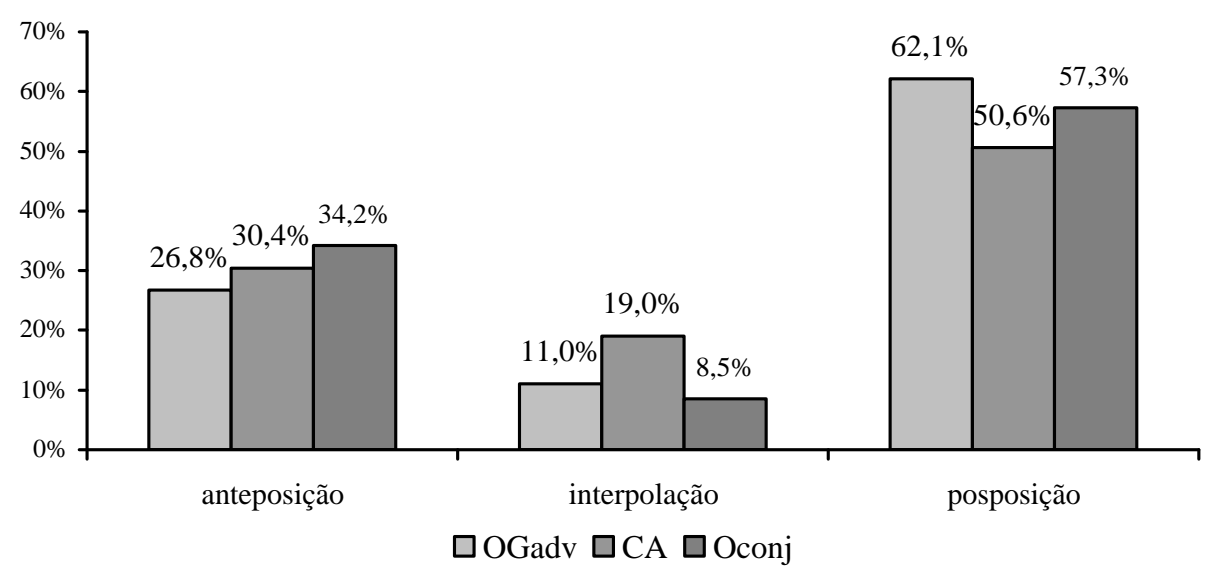

Gráfico 7. Posição das orações adverbiais gerundiais e conjuncionais

É bastante freqüente o uso de orações adverbiais de gerúndio (OGadvs e CAs) que aparecem encaixadas em uma outra oração, formando uma sorte de clause combining em que uma oração subordinada se insere dentro de outra subordinada, como é o caso de (125) e (126): 
(126) [C 191 Ald 28 1] Alem deque jâ pus na Prezença de Vossa Excelencia aRespeito da ComiSsão deque foi Vossa Excelença Servido encarregarme em Moji Guassu, tenho em beneficio pú- blico departicipar a Vossa Excelencia que tendo desertado muitas das Aldeas de- Guoyases de Gentios Comquistados na Capitania, grassaõ agora portodas aquelas Campanhas, epassando o Rio grande, vem Contaminar as fertis Campanhas desta Capitania entre omencionado Rio grande, e Rio Pardo

(127) [C 192 WL 14 5] Faço isso para minha tranquilidade, porque não merecendo fé minha palavra tenho satisfação em ver garantida [p. 2] em toda a plenitude a minha maior credora $\mathrm{e}$ mais ainda aos herdeiros da mesma.

O exemplo (127) mostra uma CA encaixada dentro entre uma OGadv e a a sua oração matriz:

(128)[M 191 RDN 36] §. 14. Apezar detodas asprohibiçoeñs, as violencias as violencias [sic] afugentaraõ os Indios dasAldeas: osque dellas seviaõ livres nem das molheres, efilhos selembravaõ (a) ASsim os Indios daCapitania deSã̃ Paulo foraõ augmentar asPovoaçoeñs deGoyás, Cuyabá, Geraes, eRio Grande: deSorte, que em1628[[3]] (b) vendo oGovernador Geral que as Aldeas estavaõ despovoadas; [sendo] alia[s] os Indios taõ neceSsarios para todo oServiço, que [se empreendia] afavor daCoroa, determinou a 18de8[outu]bro dodito anno, que todos osque fossem aoSertaõ buscar Indios, paga[ss]em o5.o, pondo nas Aldeas deSua Magestade a5.a parte della[[e]]s, eque metade deste 5.o seRemetesse áBahia para lá fundar huma Aldea.

A interpolação pode dar-se também logo após a um elemento que foi

topicalizado, como é o caso da oração abaixo em que o sujeito ellas foi extraído da própria CA:

(129) [TEA 192 Alm 5] RIBEIRO - Nada, que elas, em chegando a certa idade, é preciso arrumá-las; quando não, ficam para aí tias, e não acham quem as pretenda, a não ser algum troca-tintas, mais namorado do dote que de outra coisa.

A CA pode localizar-se interpolada após um complemento da OM como em

(129), no qual a CA interrompe o fluxo da sentença iniciada pelo adjunto para oque,

(130) [C 181 Ald 5 3] que tenho notiCia deque - deÇendia deindia desta aldea chegou ater Com migo para Saber daSerteZa. para oque ajun tando alguñs indios mais Antigos que o ConheÇeÇem [a]chei muitos que oConheÇiaõ aSSeus paSSados;

ou em (130), em que aparece depois do adjunto epara os quais ornamentos.

(131) [C 181 Ald 12 12] epara os quais ornamentos naõ Com Corendo os indios seti rari[a] esmola no destrito

No exemplo abaixo a CA aparece interpolada depois de um adjunto de tempo:

(132) [M 192 HC 29a] No dia de São Francisco Xavier (3 de dezembro de 637), estando celebrando a festa com missa e sermão, cento e quarenta paulistas com cento e cinqüenta tupis, todos muito bem armados de escopetas, vestido de escupis, que são ao modo de dalmáticas estofadas de algodão, com que vestido o soldado de pés à cabeça peleja seguro das setas, a som de caixa, bandeira tendida e ordem militar, entraram pelo povoado, e sem aguardar razões, acometendo a igreja, disparando seus mosquetes. 
A posição marcada de interpolação tem uma motivação icônica. Esta é a posição preferida para a agregação de informação secundária. Trato disso no capítulo sobre a semanticização do gerúndio (Cap. VI).

\section{IV.6.2 Gerúndio adjetivo ligado a um SN em sentença plena}

Brandão (1963) e Campos (1972) chamam de gerúndios narrativos a ocorrência de vários gerúndios em cascata, ligados a um SN independente. Segundo estes autores, podem ser vistos também como gerúndios aditivos:

(133) ... tem feira, pensou - tudo se agitando e se desencontrando, abrindo-se em leque e se reagrupando, convergindo e espadanando, gente muita, pirâmide de frutas, barraquinhas de livros e revistas berrando pela bôca de mil cores, chamados e gritos e adeuses e pregões - tudo fúlgido, barulhento e confuso como numa febre. ${ }^{346}$

(134) gente muita, pirâmide de frutas, barraquinhas de livros e [revistas] berrando pela bôca de mil cores, chamados e gritos e adeuses e pregões - tudo fúlgido, barulhento e confuso como numa febre. $^{347}$

Como adoto parâmetros sintáticos para classificar as orações de gerúndio, não assumo a terminologia proposta por esses autores, uma vez que está baseada em critérios textuais, do Discurso. O mesmo raciocínio se aplica aos gerúndios exclamativos e interrogativos, pois essa nomenclatura denota uma classificação semântica. Por este motivo, incluí todos estes casos na categoria dos gerúndios ligados a um $\mathrm{SN}$ em construções nominalizadas.

Nessa variável, o gerúndio é núcleo de uma predicação primária e projeta todos os seus argumentos, incluindo o seu próprio sujeito ao qual se une em uma relação adjetiva. Ele ocorre em construções nominalizadas, que podem ser convertidas na sua contrapartida finita, em sentenças afirmativas (134 e 135), exclamativas (136 e 137) ou interrogativas (138 e 139).

(135) [C 182 BAN 1] Vossamerce bem tem deplorado, emminha prezensa oindecente estado denoSa Igreja Matriz; quatro paredes nuas evermelhas, Sem portas, Sem janelas, reprezentando mais ûa olaria, que aCaza deDeos: onde Com bastante escrupulo ConServo oSantissimo Sacramento.

(136) [TEA 192 SL 16] Em vão nasce um homem, à semelhança de Deus, possuindo inteligência, rico de vontade e esperanças. (...) Mártir de seus deveres, dando a vida pela pátria, seu destino, sua recompensa é o esquecimento; não haverá cruz humilde para fazer menção de sua morte. Não, Vitorino, eu nada pedirei.

(137) [C 192 CL 474 6] Veja, pois, comadre, como não andará uma pobre | mãi! || Bem disse nho Frutuoso - que a causa de tudo que | estamos soffrendo é não se ter soldados, e que por isso | qualquer estrangeiro nos faz quanto desaforo quer, e | nós sempre aguentando com cara alegre....

${ }^{346}$ Campos (1972:51): CS, D in CR, 37.
${ }^{347}$ Idem, ibidem. 
(138) [TEA 202 Per 10] EMÍLIO Todos falando ao mesmo tempo... da esquina a gente já podia ouvir os gritos.

(139) Você chegando a essa hora? [exemplo criado]

(140) [Christo e o Vigario de Christo ambos] dormindo? Christo dormindo no meio da tempestade, e Pedro dormindo no meio das guardas, e das cadêas, e ambos com a morte à vista, sem nenhum cuidado $?^{348}$

\section{IV.6.3 Gerúndio imperativo}

O verbo no gerúndio pode compor uma espécie de perífrase verbal com valor imperativo, como mostram os exemplos abaixo. Por esse motivo, preferi não incluílos na categoria das nominalizações (IV.6.2), embora o rótulo gerúndio imperativo esteja mais associado à semântica que à sintaxe. Estas orações podem organizar-se da seguinte forma:

(i) compõem uma perífrase verbal

(141) [TEA 182 FE 22a] Tram. Tome Compadre, vá passando-as pelo assucar, e naõ coma nenhuma.

(ii) podem ocorrer com o verbo ir extraído da sentença gerundial

(142) [TEA 182 FE 16] Pant. Ora vamos Compadre trabalhando, que o verdadeiro entrudo, he comer bem, e beber-lhe melhor.

(iii) podem ocorrem sem um verbo que dê suporte à morfologia do modo imperativo:

(143) [exemplo criado] Circulando! Circulando!

No capítulo VI explico o processo de semanticização do gerúndio em forma imperativa.

\section{IV.6.4 Gerúndio como articulador discursivo: o lado sintático}

O gerúndio como articulador discursivo apresenta propriedades sintáticas que o diferenciam das demais categorias aqui descritas. Caracteriza-se por não projetar o sujeito gramatical, pondendo este ser recuperado na instância da enunciação, ou seja, o sujeito semântico desses verbos são os participantes envolvidos no ato ilocutório.

\footnotetext{
${ }^{348}$ Campos, 1972:160-161: Sim. Vieira, Pe. A., Sermão das Cadêas de S. Pedro, § 2, vol. VIII, 7.
} 
Podem ser encontrados tanto na fala como na escrita e é de supor-se que tenha sido este o percurso empreendido por estas estruturas no canal de sintaticização traçado por esta forma (oralidade > escrita).

Vejamos alguns exemplos da fala:

(144) [TEA 181 GAM 26] Dona Clóris: Advertindo que aquele que mais extremos fizer a nosso respeito, coroará de triunfos a Manjerona, ou Alecrim, para que se veja qual destas duas plantas tem mais poderosos influxos para vencer impossíveis.

(145) [DID SP 234 23] e tirando a parte do artista a senhora acha que devem haver outros cuidados para a peça ser bem::bem apresentada obter um bom sucesso?

(146) [DID SP 234 39] escuta Dona I. passando assim mais agora para o campo de filme...eu queria saber qual o tipo de::o que mais chama atenção da senhora no que diz respeito a cinema? não é? eu sei que a senhora já::a senhora já disse que não gosta de drama gosta de comédia

(147) [EF POA 278 28] então, talvez, dependendo do todo, uma situação de síntese a identificação, se tiver assim, um caráter já de uma pequena, um pequeno exame, então já está com um nível mais, mais complexo

Nas escrita, encontramos gerúndios articuladores discursivos organizando o

texto. Alguns exibem maior proximidade com a fala, como acontece nas cartas

particulares escritas entre parentes e amigos (149 a 151).:

(148) [C 182 Ald 25 1] A esta vai junta hua relaçaõ por mim feita, que a VossaExcelencia naõ desagradará Ler, tolerando-me a groSseria do papel e escrita, por que o Lu gar e occaziaõ naõ permittio outra couza.

(149) [M 191 BON 13] As choffarias de forjar eextender as massetas destes pequenos fornos estaõ agora sem uzo emYpanema, eem seu lugar há hum ou dous martinetes defazer pregos. [espaço] Passando agora á $\mathrm{Fa}_{-}$brica nova, construida por Hultgren debaixo da direção de_ Frederico Warnhagen (aquem já communiquei $\mathrm{m}\{\mathrm{u}\}$ itas das refle- xoes que aqui vou expôr) consta esta de dois fornos unidos hum aoutro, como em Figueiró dos Vinhos, cuja construção efigu_ ra do edificio, hé quaze amesma, porem mais elegante;

(150) [C 202 SIM 1 15] Falando um pouco do m [^nosso] apartamento, (meu e das meni- | nas) está ficando com uma carinha decente;

(151) [C 202 SIM 3 7] "se o Zé estivesse aqui, se encontraria no mes- | mo dilema em que me encontro: Comprar ou não comprar?”| Está bem, comprarei... || Falando em comprar, você poderia me fazer um favor!

(152) [C 202 SIM 4 6] Voltando ao nosso papo, são 23:04 de domingo | e chegamos a pouco da casa da mãe, e pra | variar tomamos chuva, só prá variar, mas | nesses últimos dois dias aqui tem chovido não | é brincadeira, mas mesmo assim esta uns 28 graus | e por ai cada vez mais frio.

O quadro geral (tabel 3) mostra que são poucos os gerúndios articuladores discursivos nos séculos XVIII e XIX por conta da restrição que os corpora dessas sincronias nos impõem.

Como se pode ver pelos exemplos, esse tipo de gerúndio exibe propriedades bastante salientes do subsistema do discurso. Discuto essas características no capítulo $\mathrm{V}$. 


\section{IV.6.5 O gerúndio em perífrases}

Nas construções perifrásticas ${ }^{349}$, o verbo auxiliar funciona como suporte da morfologia de tempo, modo e pessoa para o verbo no gerúndio, que funciona aqui como núcleo de uma predicação primária. O auxiliar também é responsável pela noção de aspecto (v. Cap. VI).

Assim como já observamos na tabela 3, aumenta o uso de perífrases ao longo dos três períodos analisados. A porcentagem apontada para cada século demonstra que aumenta gradativamente a freqüência de gerúndios em perífrases, avançando sobre outros tipos de gerúndio, que passam a ser menos utilizados. Podemos, por exemplo, comparar esse aumento com o decréscimo de uso das construções adverbiais (OGadvs e CAs). Não se pode afirmar que essa seria uma mudança encaixada, mas vale observar que o gerúndio também funciona como um advérbio do seu auxiliar nas perífrases. Por esse ponto de vista, poderíamos dizer que o uso adverbial do gerúndio muda de contexto sintático, movendo-se de uma predicação secundária (gerúndio dependente nas OGs) e de uma predicação encaixada (gerúndio independente nas CAs) para uma predicação primária que se realiza de forma plena, utilizando um verbo auxiliar como suporte de morfologia. O gráfico 7 dá uma idéia da freqüência das orações adverbiais de gerúndio e das perífrases de gerúndio: ${ }^{350}$

\footnotetext{
349 A preocupação com a classificação das orações de gerúndio do português brasileiro aqui desenvolvida não leva em conta o detalhamento necessário que envolve a questão das perífrases verbais com o gerúndio. O foco deste trabalho recai sobre a variação de usos do gerúndio nos três séculos analisados e como os mesmos estão distribuídos pela tipologia textual (Cap. V). A respeito da gramaticalização do gerúndio em perífrases, v.: BELINE, Ronald (2005). Ter + particípio e Estar + gerúndio: Aspecto verbal e variação no Português do Brasil. Campinas: UNICAMP. Tese de doutorado.

${ }^{350}$ As porcentagens referem-se apenas ao total das orações adverbiais de gerúndio e das perífrases, por isso não completam $100 \%$.
} 


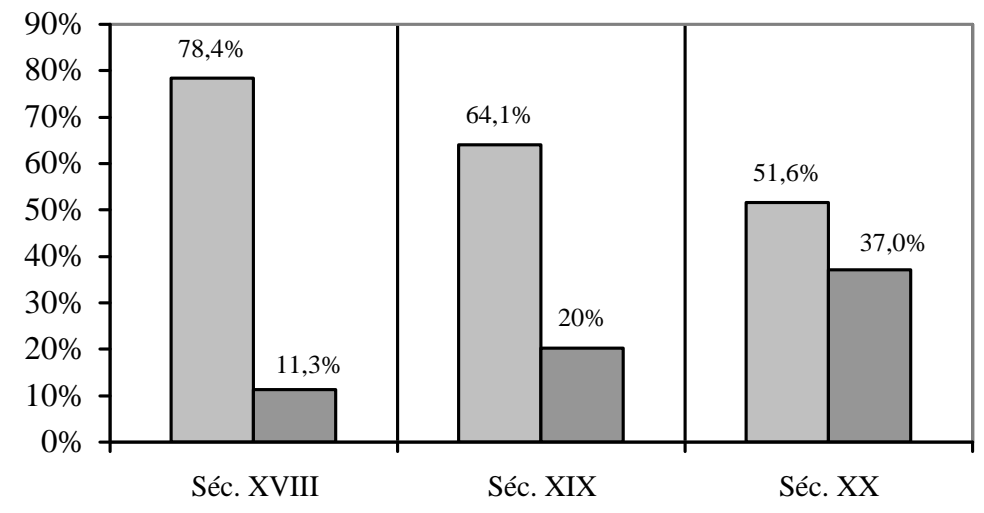

$\square$ Ogadvs e CAs $\square$ Perífrases de gerúndio

Gráfico 8. Frequiência de perífrases de gerúndio e das orações adverbiais gerundiais por século.

Estão representadas nos corpora as perífrases com os verbos estar, andar, ir, vir e ficar. Sua semântica será tratada no capítulo VI:

(153) [C 181 Seb 2 26] Óófisial olandes que veio aterra, prometeume desahir fora deste porto para odeSanctos aosvinte enove deste há, que Como estavaõ dando lados, onaõ podiaõ faZer mais breve

(154) [C $181 \mathrm{Seb} 8$ 1] Cheguei a esta Vila aos vinte etres de Dezembro com bastantes molestias das muitas agoas mais deSsaude Seja Deus Louvado bem on de fico esperando muitas oCazioiñs doa grado denoSsa [ei]celencia para aellas naõ fal tar como devo

(155) [C 182 Seb 20 8] Acarta emcluza emque eu da va parte vossamerce a vossamerce das Trinxeyras já fes duas [aRibadas?] epor mais que tenho falado não hâ emmenda eela vayce queimando.

(156) [C 182 Seb 22 3] Sendome preSizo Saber donde adeser adeviZaõ domeu destrito, Com oCapitam Mor deSaõ Sebastiaõ, faSo= espedir por proprio esta avossa Excelencia para que me faSa merce = destinar destrito para eumesaberaver neste laburiozo trabalho emque ando $\underline{\text { Rompendo }}$ esteSertaõ Com aes= trada naforma que vossa Excelencia madetreminou;

Não foram consideradas perífrases as estruturas menos gramaticalizadas com os verbos estar, andar, ficar encontradas nos corpora, nas quais esses verbos ainda podem ser considerados plenos:

(157)[C 181 Ald 19 19] Equal odo administrador, preguntese atodos, e ainda aos mesmos Indios. [espaço] Dia da Ascençaó de Chri[st]o [dilacerado] estando detarde na Igreja emcómendandome a Deos, que Sabe Deos quem Seemcómenda, vy ao Padre Companheiro comvozes alteradas naporta da Caza, aoque acodindo pregunteilhe oque tinha ou oque hera Socedido ?

(158) [C 182 BAN 4] Pellas 9 oras danoute 26 deste mes Semeveyo - dar parte que nesta villa andava hû Sugeito tomado dabebida movendo pendencia eda ndo porretadas pellas Ruas; pelo que omã dei ReColher aCadea athe ReCuperar oSeu Juizo: 
(159) [TEA 202 Per 16] Fico vagando pela casa, feito alma penada, esbarrando nos fantasmas do passado

\section{Conclusões sobre a sintaticização do gerúndio em português}

Neste capítulo estabeleci critérios para a classificação do gerúndio pelas suas propriedades sintáticas. Eleji a relação do gerúndio com o seu sujeito para classificar os seus usos, separando-os em dois grupos: (i) os gerúndios dependentes do sujeito em minioração, como núcleo de predicação secundária, entre eles o gerúndio adverbial (OGadv), o gerúndio ambíguo e o gerúndio adjetivo, e (ii) os gerúndios independentes do sujeito da oração matriz, como núcleo de predicação primária, entre os quais o gerúndio adverbial independente em construções absolutas (CAs), o gerúndio em nominalizações, o gerúndio imperativo, o gerúndio como articulador discursivo e o gerúndio em perífrases verbais. As ocorrências dos corpora foram analisadas quantitativamente e os resultados apontaram uma significativa e progressiva redução dos gerúndios adverbiais (OGadvs e CAs) no decorrer dos três séculos. A comparação com as orações adverbiais conjuncionais mostrou que também diminuiu a freqüência deste tipo de construção ao longo dos três séculos, acompanhando o ritmo de redução das orações adverbiais gerundiais. Em contrapartida, observou-se um aumento progressivo das perífrases com gerúndio ao longo dos três séculos analisados. Os índices obtidos para os gerúndios adjetivos indicam que houve um índice mais elevado desse tipo de gerúndio durante o século XIX em comparação com os outros dois séculos. Os demais tipos não se mostraram significativos em questões numéricas, sendo encontrados com poucas ocorrências nos três períodos.

A classificação proposta neste capítulo foi suficiente para atestar a distribuição dos gerúndios nos três séculos e será mantida para a análise do seu papel discursivo e semântico nos capítulos que seguem. 


\section{- CAPÍtulo v -}

\section{A discursivização do gerúndio}

\section{Observações preliminares sobre o papel discursivo do gerúndio}

A partir daqui, trato do gerúndio como elemento que funciona na organização interna dos textos falados e escritos. Para isso quero retomar alguns conceitos relacionados à constituição do texto falado para adaptá-los e incorporá-los à análise do gerúndio como marca discursiva que desempenha uma função específica na organicidade do texto.

Esta abordagem transcende o recorte frasal comumente proposto na descrição gramatical tradicional e, a exemplo do que se tem estudado para a língua falada, elege o texto como um conjunto de unidades pragmático-discursivas que também na sua versão escrita denota processos de elaboração, interação entre escritores e leitores, permitindo entrever também nessa variante o teor de organização do texto. $\mathrm{Na}$ língua falada, essas unidades discursivas são negociadas na interação face a face através de turnos conversacionais e encerra unidades maiores aos turnos, chamadas de tópicos discursivos que se caracterizam pela centração temática negociada no momento da interação. Nesse sentido, assumo também para o texto escrito a noção de tópico discursivo que se usa descrever para a língua falada e, ao longo das descrições a respeito da discursivização do gerúndio, procurarei evidenciar as propriedades de centração tópica e de organicidade, exemplificando como construções com o gerúndio podem servir como marcas lingüístico-discursivas de delimitação tópica e, além disso, exemplificar que as construções com gerúndio podem servir como estratégias de construção textual, introduzindo repetições, correções, paráfrases, parênteses, e colaborando nas estratégias de tematização/rematização e referenciação, funcionando assim como uma sorte de marcadores discursivos seqüenciadores. 
$\mathrm{Na}$ seção seguinte, quando falo das estratégias de discursivização do gerúndio, procuro evidenciar em qual dessas duas partes do verbo (raiz ou sufixo ndo) é que determinadas propriedades são ativadas, reativadas, desativadas. Isso tem conseqüências para a interpretação da discursivização, rediscursivização e desdiscursivização do gerúndio. Ao falar, por exemplo, da desdiscursivização do gerúndio interpretarei isso como uma desativação que aconteceu no processo de reformulação de enunciados e que resultou no apagamento da marca morfológica do gerúndio. Disso pode-se compreender, portanto, que no plano do discurso a desativação de uma marca sintática (morfema -ndo) pode estar ligada à reativação de um conteúdo informacional.

Como este estudo insere-se numa proposta maior que vê a língua como um conjunto de sistemas, quero retomar alguns argumentos utilizados por Castilho (1997) ao verificar que alguns fenômenos de desgramaticalização podem ser explicados sob um outro ponto de vista. Nesse estudo preliminar a respeito da proposta funcionalista de mudança multissistêmica, Castilho (1997) lembra que muitos têm explicado como casos de desgramaticalização a formação de itens discursivos delocutivos como falou ? e de marcadores conversacionais como tá ? sabe ? entende ? compreende? viu ? né ?:

"Nesses casos, um Verbo deixa de funcionar como núcleo da sentença, 'desgramaticalizandose'. O ponto tem sido sustentado por alguns lingüistas brasileiros. Eles argumentam que nos exemplos acima os itens passam a apresentar-se numa forma fixa (não podem ter alterações de tempo e de pessoa), ocupam lugares determinados nos enunciados falados (à direita das unidades discursivas) e não mais organizam sentenças, como núcleos predicadores. Um corolário desse argumento é que seriam postulados como categorias do discurso quaisquer itens privados de propriedades gramaticais - estratégia analítica que, no mínimo, seria muito estranha para a configuração de um campo científico.

Casos como estes, entretanto, podem ser interpretados como fenômenos de discursivização. Se postularmos a língua como uma atividade criativa, por que não avaliar os dados acima pelo ângulo do ganho de propriedades discursivas? Além do mais, se reconhecemos que delocutivos e marcadores conversacionais são categorias do discurso, por que procurar neles propriedades sintáticas, mais claramente identificáveis no limite da sentença ? E por que supor que propriedades discursivas excluem propriedades gramaticais? Não é verdade que os marcadores conversacionais têm uma distribuição regular nas unidades suprassentenciais ? Isso não é a gramática convivendo com o discurso?" (Castilho, 1997:567)

Ora, se a discursivização também afeta itens sintáticos tão distintos como os verbos, por que não aplicar o mesmo raciocínio a sentenças encabeçadas por gerúndios? Vamos testar essa idéia através dos seguintes exemplos:

(1) (DID 234:298-302) $)^{351}$

${ }^{351}$ Uma vez que contamos com apenas 16 ocorrências de gerúndios articuladores discursivos nos Corpora Básico e Diferencial, nos capítulos V e VI serão utilizados exemplos de outros inquéritos do 
Doc. $\quad$ escuta Dona I. passando assim mais agora para o campo de filme...eu queria saber qual o tipo de::o que mais chama atenção da senhora no que diz respeito a cinema? não é? eu sei que a senhora já::a senhora já disse que não gosta de drama gosta de comédia

(2) (DID SP 161, 402-5)

Doc. C. A. voltando a:: falar nas peças que você.: das peças que você participou... onde elas foram representa::das assim:: em que tea::tros... em que loca::is?... foi só em São Paulo ou:: vocês foram pro interior?

(3) (DID 235:163-9)

Doc. e em relação aos aos::produtos do mar você gosta de alguns?

Inf. de::falando em PEIxes assim ca/prefiro...camarão...e:: em questão de peixe...--aliás camarão não é peixe né? precisa explicar bem isso aí--ah::falando em peixes eu prefiro a pescada...pescadinha branca é é::é a uma das únicas...qualidades de peixe que eu prefiro...o resto não faço questão os::tra::maris::co...e esse negócio todo aí eu não gosto não...

Do que se leu acima no texto de Castilho (1997), aplicando este raciocíonio aos gerúndios destacados nestes três exemplos, podemos dizer que em construções do tipo "passando para o campo de filme", "voltando a falar nas peças" e "falando de peixe” houve a desgramaticalização do verbo no gerúndio. Neste tipo de construção o verbo perde algumas de suas propriedades sentenciais, deixa de funcionar como oração dependente, o que é depreensível de sua impessoalização (quem é que fala?), a construção em que está inserido se dessentencializa (onde está a oração principal?). Além disso, ainda se observa uma determinada dessemanticização dos verbos passar, voltar e falar, que funcionam aqui apenas como dêiticos textuais, ou seja, uma espécie de elo de ligação entre um tópico e outro, embora neles ainda se reativem determinados traços semânticos a preservação das categorias de EVENTO e ESPAÇO para os três verbos, desativando-se o traço semântico de movimento físico e ativando-se o sentido de "movimento do discurso" para os verbos passar e voltar, e para o verbo falar preserva-se o traço semântico transferência de informação sem o traço agentivo, uma vez que o verbo aparece impessoalizado. O resultado da reordenação dessas propriedades ratifica o seu uso como verbos prototípicos da articulação do texto tanto falado como escrito. Fazem parte desse grupo verbos de determinada classe, tais como os verbos que indicam atividades metalingüísticas (falar, dizer, conversar, contar, perguntar, responder), dentre estes, os verbos ligados a processos de referenciação (referir-se, retomar, comparar); os verbos de movimento do sujeito (ir, voltar, continuar, partir, mudar);

Projeto NURC para a análise qualitativa: os inquéritos DID SP 234, 137, 161, 235, 242; os inquéritos D2 SP 396, 255, 62, 396, 333, 343 e os inquéritos EF REC 337, EF RJ 379, EF SP 405. Segue-se aí a notação convencional entre parênteses que se adotou dentro do Projeto NURC, indicando também o número das linhas no inquérito. 
verbos de movimento do objeto (pegar, tirar, colocar); verbos de resultado de movimento (deixar, largar); verbos de percepção visual (mostrar); alguns volitivos (querer, mandar) e, finalmente, os verbos ligados à atividade mental (pensar, entender, observar, analisar, supor, crer, constatar, descobrir).

Nesse sentido, pode-se dizer que, no processo de construção do texto, desativam-se determinadas propriedades sintáticas de alguns verbos expressos no gerúndio e reativam-se outras dos planos morfossintático e semântico como, por exemplo, a reativação da propriedade de aspecto imperfectivo que confere ao segmento encabeçado pelo gerúndio o papel de FUNDO na relação de framing/windowing (Talmy, 2000). No DISCURSO, esses gerúndios atuam como elementos que demarcam o relevo no processamento da informação, estabelecendo uma relação de focalização sobre as partes do texto que se organiza durante o processamento da fala. Desse modo, assim como nos exemplos acima, determinadas classes de verbos, quando estes são expressos no gerúndio, exercem duas funções específicas: (i) primeiramente servem como itens que orientam a estruturação dos tópicos, através de estratégias de construção textual distintas como parênteses e repetições e; além disso, concomitantemente a essa função na organização tópica (ii) os gerúndios podem desempenhar funções de caráter mais argumentativo ligadas ao relevo no processamento do texto como enfatizar, intensificar, marcar sentido especial, marcar contraste, inserir um reforço argumentativo, marcar importância para a estrutura ideacional/informacional, ou marcar foco informacional sobre determinados domínios (Travaglia, 2006 in Jubran/Koch, org.), o que pode ser visto também através da parentetização (Jubran, 2006a in Jubran/Koch, org.) e mais especialmente no recurso da tematização de conteúdo informacional (Koch, 2006a in Jubran/Koch, org). ${ }^{352}$

Nesta capítulo concentro-me em (ii) e para entender como essa função articuladora pode ser exercida pelo gerúndio, seria importante verificar que

\footnotetext{
352 Apesar de ser um conceito que nasce no seio da Análise do Discurso, a noção de relevo será estudada no capítulo sobre a semanticização do gerúndio (Cap. VI), uma vez que estão envolvidas aí estratégias de tematização de conteúdos semânticos. Esta estratégia segue a motivação prática de descrever separadamente a atuação dos itens lingüísticos isoladamente segundo cada subsistema da língua. No entanto, está claro que há intersecções entre os subsistemas que são ativamos concomitantente, como vimos defendendo desde o início desta tese. Nesse sentido, cremos que a questão do relevo será melhor visualizada quando oposta aos outros itens analisados no subsistema da Semântica.
} 
princípios cognitivos estão envolvidos em cada uma dessas funções. Discuto isso na próxima seção.

\section{V.1. A ativação, reativação e desativação do gerúndio no subsistema do Discurso}

No capítulo II apresentamos o dispositivo sociocognitivo de caráter pré-verbal através do qual o falante ativa, reativa e desativa as propriedades composicionais dos itens lexicais. Ali, vimos que esse dispositivo representa um caráter "social" porque é negociado pelos falantes no momento da enunciação e é "cognitivo" porque nele estão envolvidas as categorias cognitivas e os traços semânticos inerentes aos itens lexicais. Agora verificaremos como esse dispositivo funciona no subsistema do Discurso. Para isso, vale a pena retomar os postulados de Castilho (2006) para o plano discursivo/textual.

\section{V.1.1 A ativação do gerúndio no discurso}

No sistema discursivo, o princípio de ativação (discursivização) produz a hierarquização dos tópicos, a construção das unidades discursivas e sua conexão, etc. Castilho (2006).

O exemplo abaixo é uma demonstração de como o gerúndio pode atuar como elemento que atua na organização do texto. Em (4), a ativação do gerúndio (discursivização) marca a retomada de um tópico abandonado anteriormente:

(4) (D2 SP 396:557-560)

Doc. bom ... voltando à ... à televisão ... eu acho que o professor ...

L1 C. ...

Doc. C. ... gostaria de falar ainda ... vamos dizer alguma coisa algum ... o lado crítico vamos dizer assim da televisão?

Doc. (agora)vocês Acham que os::tecidos --voltando ao...ao assunto--...éh::os tecidos se adaptavam eram adequados ao nosso clima...naquela época?

No exemplo que se segue, o gerúndio é ativado como estratégia de reformulação no início do tópico "Comércio nas cidades da Europa":

(5) (DID SP 137:523-33)

Doc. $\quad$ o senhor chegou a falar em... lojas shopping center e tal como é que é o comércio nessas cidades da Europa e no caso nas cidades dos Estados Unidos?

Inf.

[

bom para a gente gastar dinheiro... ((risos)) ( ) a gente já viaja (mesmo) com essa... ( ) ainda que você faça intenção de não gastar... acaba-se gastando muito né?... mas:: ((pigarro))... bom o comércio... é:.... falando assim sob um aspecto 
muito::: simples a respeito do comércio de de nós que vamos LÁ quem vamos ver vitrines coisa que eu deTESto fazer aqui... em São Paulo e que lá eu acompanhei minha mulher em... todas as::... a:: as vitrines ou todas as lojas onde ela quis ir né?...

\section{V.1.2 A reativação do gerúndio no discurso}

No Discurso, a rediscursivização [reativação] abre caminho à repetição dos enunciados para assegurar a coesão do texto, para alterar o eixo argumentativo, etc. Castilho (2006).

(6) (DID 235:277-86)

Doc. $\quad$ se você fosse vegetaria::na como é que você se alimentaria?

Inf. partindo de uma:...de uma:...--como é que a gente fala?--...de uma definição...vegetaria::na eu iria comer vegetais né?((riu))

Doc. $\quad$ mas é só vegetais que come não?...

Inf. bom... acho que sim né?...pensando em vegetais num termo abrangente::acho que tem que ser só vegetais não?...ou:: o vegetariano como também::éh peixe...e essas coisas? acho que não né?...((vozes incompreensíveis))uhn?...

No exemplo acima, depois que o gerúndio foi ativado na negociação entre documentador e informante no início do subtópico "Comida vegetariana" em partindo de uma definição vegetariana, e em função da pergunta com valor delimitador do documentador "Vegetais comestíveis", a informante reativa o gerúndio (rediscursivização) na retomada do turno em pensando em vegetais num termo abrangente.

\section{V.1.3 A desativação do gerúndio no discurso}

A desativação produz no sistema discursivo (desdiscursivização) a alteração da hierarquia tópica, levando os locutores a manobras tais como os parênteses e as digressões Castilho (2006).

Para ilustrar a desativação do gerúndio (desdiscursivização), retomo o exemplo (3). Nessa ocorrência, o gerúndio é inicialmente ativado na construção falando em peixes e logo em seguida desativado na reformulação em questão de peixe, , o gerúndio foi apagado, representando aqui o grau zero do gerúndio (radical e morfema -ndo). Logo após a interrupção corretora aliás camarão não é peixe né? o gerúndio é novamente reativado na repetição da construção falando em peixe, que renova a elaboração do tópico "Produtos do mar preferidos".

(3) (DID 235:163-9)

Doc. e em relação aos aos::produtos do mar você gosta de alguns?

Inf. de::falando em PEIxes assim ca/prefiro...camarão...e:: em questão de peixe...--aliás camarão não é peixe né? precisa explicar bem isso aí--ah::falando em peixes eu prefiro a pescada...pescadinha branca é é::é a uma das únicas...qualidades de peixe que eu prefiro...o resto não faço questão os::tra::maris::co...e esse negócio todo aí eu não gosto não... 
A partir dessas considerações preliminares a respeito dos princípios de ativação, reativação e desativação do gerúndio, passo a descrever como essa forma nominal participa da organização do texto

\section{V.2. O gerúndio na articulação do tópico discursivo}

A noção de tópico discursivo é tida como uma unidade de análise que se manifesta na conversação através dos "enunciados formulados pelos interlocutores a respeito de um conjunto de referentes explícitos ou inferíveis, concernentes entre si e em relevância num determinado ponto da mensagem” (Jubran, 1992:361). O tópico conversacional apresenta duas propriedades definitórias: a centração e a organicidade. A primeira envolve elementos que possibilitam o reconhecimento dos segmentos tópicos: a concernência, que denota a relação de interdependência semântica entre os enunciados, evidenciando o assunto de que se trata; a relevância, que se vê evidenciada através das relações tema-rema estabelecidas entre os itens de determinados segmentos (dêixis tópica) e, finalmente, a pontualização, que indica o lugar do segmento no evento conversacional. A organicidade refere-se à distribuição dos assuntos em quadros tópicos e pode ser observada e analisada em dois níveis: o plano hierárquico e o plano linear, no primeiro pode-se verificar o grau de dependência que se estabelece entre subtópicos em relação a um supertópico; os mesmos subtópicos podem distribuir-se em uma seqüência contínua ou de maneira descontínua no plano linear.

No plano linear a continuidade se dá quando há o esgotamento de um tópico e se instaura um novo tópico. A descontinuidade se verifica quando há a cisão de um tópico em partes, através de movimentos de inserção conversacional a) pela suspensão definitiva de um tópico quando se introduz um novo tópico antes de que tenha sido esgotado o precedente; b) pela cisão de um tópico quando se anuncia um tópico em determinado momento do texto e somente desenvolvendo-o em uma etapa posterior (inserção segundo o esquema A B A ou alternância do tipo A B A B) ou c) pela expansão posterior de um tópico quando outro já abordado anteriormente é reinserido em um momento posterior do texto, ficando seus segmentos coconstituintes distanciados na linha do discurso (Jubran, 2006a:99-100). No plano 
seqüencial da conversação as construções com gerúndio representam marcas

lingüísticas que servem para introduzir, manter, retomar ou anunciar o abanodono do tópico como nos exemplos abaixo:

(7) (DID 242:569-584)

Inf. aGOra... as missas estão todas com muita participação... eles estão até pedindo a pessoas que vão ajudar... não é? antigamente era o serviço feito só por aqueles meninos... que se chamavam coroinhas não é? e hoje não... as pessoas estão participando da missa as missas que eu tenho assistido todas tem havido muita participação... inclusive estão fazendo muita participação tamBÉM com o pessoal éh... entre todos que estão... assistindo... mostrando assim uma união... ((fala de terceiros ruídos))

Doc. então continuando com a participação da missa que nós estamos falando né? a senhora disse das... das freiras tal...

Inf. o que você queria ((riu)) que eu dissesse mais?... eu... eu estava... observando que... TOdos os que estão assistindo à missa... estão assistindo à missa... estão se cumprimentando... ao terminar a missa não é?

(8) (D2 255 SP:301-321)

L2 apenas eu gostaria de... de... de...de situar o seguinte...eu tenho impressão que o homem moderno hoje perdeu muito... assim o sabor ... de aproveitar uma viagem entende? eu acho que ... quando a gente pode pegar uma bicicleta por exemplo e sair andando de bicicleta ou um cavalo ... entende? ou mesmo a PÉ ... entende? tudo isso dá um sabor de paisagem ... um sabor assim humano MUIto maior do que esses transportes de alta velocidade ... mesmo com o trem numa certa situação quer dizer ...então ... eu tenho a impressão que o homem se desumaniza um pouco por perder assim esse tipo de de viagem mais lenta ... mais saborosa ... mais aproveitada entende?

Doc. agora mudando um pouquinho de assunto além das atividades profissionais no no no fim de semana ... vocês vão ao assim algum lugar para se distrair?

L1 bom eu tenho impressão que:: o sítio ... que eu possuo... e é muito mais sítio ... porque morando na cidade a gente costuma designar de sítio todo terreno um pouco maior do que as dimensões habituais daqueles em que se vive mas na realidade é uma chácara ...

(9) (D2 255 SP:511-2)

Doc. retornando um pouquinho ao ... aо cinema ... o senhor poderia falar um pouco sobre os ... tipos de filme ... a predileção por eles?

(10) (D2 255 SP:1412-5/1475-81)

Doc. $\quad$ professor C. ... professor R. poderiam nos mencionar vamos dizer na escala de:....-- não sei se seria certo - de valores ... os problemas de uma cidade:. ... de uma ciDAde comum ...

L1 (...) [longa resposta de L1]

L2 é eu não teria muito que acrescentar ... o C. de certa forma colocou muito bem o problema eu poderia só complementar me referindo por exemplo a alguns aspectos como a poluição ... que hoje em são Paulo se torna insuportável né? e a poluição é reflexo exatamente dessa atitude individualista né? do homem de um modo geral ... com seus condicionamentos a/ atuais né?

O exemplo (7) traz um gerúndio que indica a manutenção do tópico discursivo iniciado pelo informante. $\mathrm{O}$ exemplo (8) exibe a passagem de um subtópico a outro sendo orientada pelo documentador que vê na fala de L2 o estogamento do subtópico "Viagem com diferentes meios de transporte" e introduz um novo subtópico "Destinos de viagem no fim de semana". O esgotamento é verificável no ínicio do turno anterior de L2 apenas eu gostaria de situar o seguinte. 
A confirmação da passagem se dá pela presença do marcador discursivo de concordância bom que acumula aqui a função de articulador discursivo promovendo a continuidade do subtópico proposto pelo documentador. Em (9) o mesmo documentador promove uma interrupção baseada na descontinuidade tópica, convidando o interlocutor a retornar a um subtópico já anunciado em outro ponto da conversação. No exemplo (10) a lexia do verbo no gerúndio não é suficiente para indicar o esgotamento do tópico, ali ele vem antecedido da construção eu poderia só complementar que compõe com o gerúndio uma espécie de locução que denota o aspecto terminativo. Assim, nas construções de (7) a (10) temos exemplos de gerúndios funcionando como elementos que introduzem, retomam ou finalizam unidades tópicas. À exceção do exemplo (10) em que há uma sorte de locução verbal, nos outros dois verifica-se o baixo grau de integração sentencial que confere a essas construções um estatuto sintático diferenciado da hipotaxe tradicional assim como já tínhamos observado anteriormente nos exemplos de (1) a (3).

A passagem de um tópico a outro obedece a procedimentos distintos. A transição pode ser gradual, acontecer através de superposição de tópicos nas situações em que um dos interlocutores tenta introduzir um novo tópico, enquanto o outro locutor ainda desenvolve o anterior, fazendo com que dois tópicos diferentes convivam temporariamente num mesmo ponto da conversa (Jubran, 2006a:108). Pode ocorrer também um espécie de movimento tópico quando os interlocutores promovem um "deslizamento" de um para outro aspecto do mesmo tópico com a finalidade de "ocasionar um conjunto diferente de mencionáveis (referentes, entidades)" (Maynard, 1980:271 apud Jubran, 2006a:108). Esse “deslizamento" pode promover o surgimento de um novo quadro tópico. Essas interrupções representam variadas estratégias realizadas na conversação, sendo as mais comuns as digressões, os parênteses e as reformulações. Os interlocutores fazem uso destas estratégias para dar exemplos do que se fala, fazer sínteses ou análses do que se diz, fazer comparações entre dados ou fatos mencionados, ou usar reformular o que foi dito (Jubran, 2006a:109).

Cada um desses movimentos exibe marcas lingüístico-discursivas que atuam na delimitação tópica e representam uma estratégia auxiliar de segmentação do texto. Sua sistematização é difícil, pois estas marcas a) nem sempre são realizadas e são, portanto, facultativas; b) são multifuncionais, pois atuam em diferentes planos, 
podendo ao mesmo tempo funcionar como o marcador conversacional agora que inicia vários tópicos, mas pode atuar também como articulador do texto e da organização intratópica; c) são de natureza diversa, de diferentes níveis lingüísticos (prosódico, sintático, léxico-semântico) ou ainda representar estratégias de construção textual (paráfrases, repetições, tematizações), marcadores discursivos ou procedimentos intrínsecos da oralidade (hesitação e interrupção) (Jubran, 2006a:109-110).

Para este trabalho importa verificar que o gerúndio é uma marca lingüística do plano sintático que pode aparecer no momento de transição dos tópicos discursivos e que pode atuar na construção de paráfrases, repetições, tematizações, e também nos parênteses. Passamos agora a descrever como se comportam os gerúndios nessas estratégias no plano da organização linear e da organização hierárquica do texto falado.

\section{V.2.1 O gerúndio em parênteses}

Há duas modalidades de inserção: a) uma apresenta uma maior extensão textual e tem estatuto tópico, "porque instaura uma outra centração dentro do segmento tópico em que ocorre, provocando a divisão desse segmento em partes não-contínguas na linearidade do texto" (Jubran, 2006a:302), apresentando um esquema A B A, em que B é o tópico inserido; por outro lado, outra modalidade de inserção pode ser reconhecida em b) unidades de menor extensão textual que não têm estatuto tópico, porque não constituem uma nova centração; trata-se de uma breve suspensão do tópico no qual se encaixa. Para Jubran (2006a), de um ponto de vista conversacional poderiam ser reconhecidos como parênteses as inserções tanto do tipo (a) quanto do tipo (b), por representarem uma suspensão momenânea de um tópico.

Parênteses desempenham no discurso funções textual-interativas que integra quatro classes distintas de elementos focalizados através dessas estratégias: a classe 1) dos parênteses que focalizam ${ }^{353}$ a elaboração tópica (quer sejam o conteúdo

\footnotetext{
${ }^{353}$ A noção de focalização neste capítulo remete à nomenclatura utilizada pelo grupo Organização Textual-Interativa do Projeto Gramática do Português Falado e distingue-se do conceito de relevo, que será discutido no capítulo VI (Semanticização do gerúndio). No subsistema do Discurso, a focalização refere-se às estratégias de articulação dos tópicos, dos turnos e das unidades discursivas. No subsistema da Semântica, o relevo refere-se às estratégias de tematização e rematização empreendidas
} 
tópico, a formulação lingüística em si, ou a estrutura tópica do discurso) e as classes dos parênteses que focalizam 2) o locutor, 3) o interlocutor e 4) o próprio ato comunicativo. Em cada uma dessas classes os parênteses desempenham funções específicas.

Nas seções que seguem, procuro evidenciar de que forma o gerúndio atua nos processos de parentetização. Concentro-me aqui nas estratégias mais salientes observadas: a focalização da elaboração tópica e dos interlocutores.

\section{V.2.2 Gerúndio em parênteses focalizadores da elaboração tópica}

\section{V.2.2.1 Gerúndio em parênteses focalizadores do conteúdo tópico}

No exemplo (11), o gerúndio é ativado para introduzir um parêntese no qual o um evento vivenciado pelo falante funciona como exemplificação. Nessa função, atuam ao mesmo tempo o morfema [-ndo] e o radical do verbo selecionado, juntamente com outros intes que dão suporte a essa função, como o trecho que inicia a inserção eu até poderia dar um exemplo. O articulador então retoma o tópico despois desta inserção:

(11) (D2 255 SP:679-698)

L2 (...) se no na no determinado horário ... em que a televisão é mais procurada não existir o programa de violência ou de prêmio ... só existir outro nível de programação... a população irá aprendendo a a assistir esses programas ...eu até... poderia dar um exemplo curioso a vocês ... eu eu uma vez fiz uma viagem a Mato Grosso ... e lá em Mato Grosso eu conversando com ... um um administrador de uma fazenda que trabalhava por lá ... eu ... notei que o homem ... era assim profundo conhecedor de de do quem era os ministros e de atos do governo e eu ... fui descobrir que ele ouvia a Hora do Brasil diariamente quer dizer QUEM poderia imaginar que um cara lá fosse ouvir diariamente a Hora do Brasil? ele ouvia porque não tinha outra coisa para ouvir naquele horário ... então é a mesma coisa que eu digo quer dizer a televisão na casa e o sujeito com outro programa ele acaba assistindo ... e se forem educativos os programas ... se forem programas realmente de de acréscimo cultural ... ela está estará cumprindo um papel que hoje é até desconhecido não é?

\section{V.2.2.2 Gerúndio em parênteses focalizadores da estrutura tópica}

A estratégia de parentetização pode funcionar também para a organização das subdivisões de um quadro tópico. No exemplo (12), essa função está reservada tanto ao articulador discursivo agora como à sentença mudando um pouquinho de assunto,

pelo falante/escritor com a finalidade de orientar a atenção do interlocutor/leitor para o conteúdo semântico dos enunciados. 
na qual o verbor mudar é selecionado no gerúndio para demarcar a orientação que se dá ao tópico em curso. Na ocorrência (13) encontrada na memória de José Bonifácio, o verbo passando cumpre essa função. Na contrapartida escrita, o item agora moveuse da margem esquerda para o interior do enunciado, resultado do condicionamente planejado que é típico do texto escrito.

(12) (D2 255 SP:314-316)

Doc. $\quad$ agora mudando um pouquinho de assunto além das atividades profissionais no no no fim de semana ... vocês vão ao assim algum lugar para se distrair?

(13) [M 191 BON 13] As choffarias de forjar eextender as massetas destes pequenos fornos estaõ agora sem uzo emYpanema, eem seu lugar há hum ou dous martinetes defazer pregos. [espaço] Passando agora á $\mathrm{Fa}$ _ brica nova, construida por Hultgren debaixo da direção de_ Frederico Warnhagen (aquem já communiquei $\mathrm{m}\{\mathrm{u}\}$ itas das refle- xoes que aqui vou expôr) consta esta de dois fornos unidos hum aoutro, como em Figueiró dos Vinhos, cuja construção efigu_ ra do edificio, hé quaze amesma, porem mais elegante;

Assim como se muda o curso de um tópico, é possível voltar a ele através da marcação de retomada do mesmo. É o que acontece nos exemplos abaixo nos quais os verbos no gerúndio cumprem essa função:

(14) (D2 SP 396:708-711)

L1 tive eu fui tudo... na vida... eu tive negócio de fazenda... então voltando...

Doc.

[

deve entender... como é que (que) o senhor vendia?...

ah:: então o senhor

(15) (D2 SP 62:707-10)

L1 [superposição] é ... mas é é o fato ... dentro da própria da própria Medicina ... e voltando um pouco ao problema do clínico geral ... é realmente uma injustiça ele é o que mais trabalhou é o que mais conhece ...

Ao estudar os processos de parentetização, Jubran (2006a) observou que essa estratégia é bastante produtiva em textos falados, sendo de menor ocorrência em textos escritos:

Como o texto escrito prototípico é planejável com antecedência, ou seja, é pensado, projetado e lapidado antes de sua versão final, as descontinuidades que o parêntese provoca nos segmentos tópicos nem sempre têm as mesmas configurações das verificadas no texto falado. Pelo fato de que na escrita o modus sintático prevalece sobre o pragmático, nele não é de se esperar a ocorrência de parênteses que promovam cortes sintáticos, nem que se intercalem em determinadas fronteiras em que uma inserção poderia romper estruturas canônicas

(Jubran, 2006a:357).

A autora acredita ainda que devido à natureza planejada do texto escrito, muitas das funções de focalização da formulação lingüística do tópico discursivo estariam "bloqueadas" para a escrita, uma vez que elas se realizem preferencialmente no processamento face a face. No entanto, as mesmas estratégias de mudança e volta a um tópico em desenvolvimento podem ser encontradas nas cartas particulares, que são integrantes do contexto escrito mais informal, ambiente no qual a reprodução de 
itens da oralidade promove a aproximação entre os interlocutores, como mostram os exemplos da correspondência passiva da família Simões:

(16) [C 202 SIM 3 7] Você me encorajou para comprar "Nieztsche", peguei-o, olhei[o = corrigido em = -]o, lembrei de você por sinal, foi na banca da [p. 2] tia, pensei: "se o Zé estivesse aqui, se encontraria no mes- mo dilema em que me encontro: Comprar ou não comprar?" Está bem, comprarei... Falando em comprar, você poderia me fazer um favor! Houve um problema com, não, entre a distribuidora da Abril e as bancas de Assis, fiquei um bom tempo sem receber coisa alguma, e minha coleção "Literatura Comentada" esta totalmente parada,

(17) [C 202 SIM 1 15] Falando um pouco do m [ $\uparrow$ nosso] apartamento, (meu e das meni- nas) está ficando com uma carinha decente;

(18) [C 202 SIM 1 17] Aqui está um tempo horrível, um frio e uma / chuva que não para mais, o difícil é trabalhar à noite. Bom mudando de Magali para Gerônimo, e você como | está? Não conseguiu vender o bar ainda? mas calma | que tudo dá certo, tá?

(19) [C 202 SIM 4 6] Voltando ao nosso papo, são 23:04 de domingo | e chegamos a pouco da casa da mãe, e pra | variar tomamos chuva, só prá variar, mas | nesses últimos dois dias aqui tem chovido não | é brincadeira, mas mesmo assim esta uns 28 graus | e por ai cada vez mais frio.

Nem sempre o radical do verbo e o morfema gerúndio cumprem função articuladora concomitantemente, como nos casos acima, em que o radical dos verbos voltar e mudar já orientam o ouvinte/leitor para a retomada de um tópico. $\mathrm{Na}$ ausência de uma lexia verbal que dê conta dessa estratégia, o falante pode agregar outros itens que dão suporte a esse recurso, como é o caso de ainda mais uma vez que se associa a falando nela no exemplo abaixo:

(20) (D2 SP 62:846-852)

L2 então:: não dá:: o indivíduo fala "poxa eu vou perder um ano dois anos aí pesquisando vou levantar um problema defender uma tese aí" ... e às vezes não tem sorte na vida dele entende?

L1 uhn uhn ... é que hoje:: dentro da nossa profissão ainda mais uma vez falando nela ... até parece que sou emPOLGAdo por ela né? ((risos)) não acha? ...

O gerúndio também pode ser selecionado com a finalidade de marcar o estatuto discursivo de um fragmento do texto, hierarquizando as sequiências em fases.

Em (21) o gerúndio indica o esgotamento do tópico em curso:

(21) (EF REC 337: 702-9) $)^{354}$

Inf. - para ele: Dukheim ... primeiramente vem o direito... o direito... o até mesmo os mo:res... que vocês estudaram ... vem:... de maneira secundária ... o principal já no tempo né? de Dukheim era o direito ... como máximo ... num é? para impor normas ... e ... finalizando mesmo o direito reproduz ... todas as formas essenciais ... e é apenas ... estes que precisamos conhecer

\footnotetext{
${ }^{354}$ Exemplo coletado em Jubran (2006a:339).
} 


\section{V.2.3 Gerúndio em parênteses que focalizam o locutor/autor e o interlocutor/leitor}

\section{V.2.3.1 Marcador voltado para os participantes da relação diádica}

Quando o parêntese projeta um foco sobre o interlocutor, ele pode servir para chamar a atenção do interlocutor para um elemento do tópico:

(22) [DID SP 234 23] Doc e tirando a parte do artista a senhora acha que devem haver outros cuidados para a peça ser bem::bem apresentada obter um bom sucesso?

Jubran (2006a:357) observou que não se aplicariam ao texto escrito muitas das funções dos parênteses que focalizam os interlocutores e o ato comunicativo. No entanto, encontramos alguns exemplos também nas cartas e em anúncios nos quais o verbo no gerúndio desempenha a função de um marcador voltado para a relação entre os interlocutores, missivista ou leitor (23-26).

Nestes casos o verbo no gerúndio, tanto na fala como na escrita, denota um matiz imperativo que

(a) pode estar orientado mais para o destinatário que para o emissor (tolerando$m e=$ Tolere-me!), ou para ambos (reservando - Reservemos!):

(23) [C 182 Ald 25 1] A esta vai junta hua relaçaõ por mim feita, que a VossaExcelencia naõ desagradará Ler, tolerando-me a groSseria do papel e escrita, por que o Lu gar e occaziaõ naõ permittio outra couza.

(24) [C 191 BNRJ 8 3] Hé impraticavel omandar hum Regimento inteiro Sem muito pre-zuizo de particulares. emesmo publico. e quando Seja precizo inter-valo / Reservando os impedimentos / com outros Regimentos destaCidade teraõ demandar daqui athe Coritiba que saõ 100Legoas, pelo menos 300 homens. [imperativo orientado para os interlocutores]

(b) ou pode estar orientado para o ato de elocução do falante/autor. Neste caso o radical do verbo no gerúndio é sempre um verbo de elocução e afins, advertindo, notando, attendendo, que pode ser comutado pela forma finita do mesmo verbo (eu advirto, eu noto, eu atendo [= recordo])

(25) [C 18 2 2 Seb 20 3] Tenho dado o cum primento adita ordem paSsando mostra as ditas Companhias, don- de entraram Brancos, Mulatos, Pretos e uriundos; advirtindo que Cada hum estam emSuas Companhias, as dos Brancos Sam tres Companhias, aCompanhia doCapitam Manoel Gomes deAr.o aCompanhiadoCapitam Joas deAguiar [D]altara, eaCompanhia desta villa estâ Sem Capitam Nem Alferes, eoque a R[ê ou i ?]ge hê - oSargento deNumero [D]oSe [F]elis;

(26) [C 192 MRI 4 6] Eu não posso ser pe[_ ]do porque estou resol- vido afazer Carreira no 5.o, eportanto nunca mais a[rredo] um passo [p. 3] dáli: Portanto vosse pense no caso e me escreva, notando que me persuado que o Cezario deseja e quer ser deputado f[eder $][$ al $]$ pelo d[istrict $]$ o. [imperativo] 
(27) [TEA 181 GAM 26] Dona Clóris: Advertindo que aquele que mais extremos fizer a nosso respeito, coroará de triunfos a Manjerona, ou Alecrim, para que se veja qual destas duas plantas tem mais poderosos influxos para vencer impossíveis. [imperativo orientado para o ouvinte]

(28) [A 192 SP 35] A La Ville de Paris LARGO DO ROS[Á]RIOGRANDE REDUCÇÃO EM PREÇOSEm consequencia de termos de emprehender uma viagem á Europa, expressamente para fazer acquisição de um grande sortimento, resolvemos reduzir os preços já moderados das fazendas existentes, apesar de serem modernas e do mais apurado gosto. Convidamos porisso o respeitável publico a aproveitar esta diminuição de preços attendendo que o sortimento que actualmente existe e chegado de novo. Os abaixo assignados encarregam se de qualquer encommenda para Europa. Samuel Abraham \& A.C. Jullo A Mocidade, 10 de maio de 1874 [imperativo]

Alguns desses articuladores têm um matiz condicional, orientando o interlocutor/leitor a "ver" a cena do ponto de vista do falante/autor

(29) [C 192 WL 18 2] Estou certa na felicidade de Sophia que o destino lhe con- sedeu um homem de quali- dades, e caracter ellevado e que saiba compreender ou antes apreciar as qualidades [p.2] que Sophia possue, pondo de parte a modestia, e naô é por sêr Mãe reconheço que Sophia é uma menina muito boasinha, e saberá compreender todos os deveres de uma boa esposa,só peço a Deus que os abençoe e a felicidade de voces seja eterna, assim será tambem a minha. [imperativo orientado para os interlocutores]

(30) [EF POA 278 28] então, talvez, dependendo do todo, uma situação de síntese a identificação, se tiver assim, um caráter já de uma pequena, um pequeno exame, então já está com um nível mais, mais complexo supondo que eu tenha dito quais são, as características da, da, do processo da avaliação, que eu tenha dado aqui em aula expositiva, daqui a pouco eu pergunto identifique no texto, a, a seguir as características da avaliação;

As observações feitas nesta subseção sobre a função focalizadora dos interlocutores desempenhadas pelos verbos no gerúndio envolvem questões semânticas inerentes aos verbos selecionados pelo gerúndio, que serão retomadas no capítulo seguinte. Trata-se de uma intersecção entre os subsistemas do Discurso e da Semântica. Se de um lado os gerúndios funcionam na articulação dos tópicos e da relação diádica, estabelecendo foco sobre as unidades e os participantes do evento lingüístico (fala ou escrita), no subsistema da Semântica o conteúdo proposicional desses verbos serve para promover o relevo de informações secundárias.

Tabela 9. O gerúndio como articulador discursivo na tipologia textual

\begin{tabular}{|l|l|c|}
\hline [+ escrito] & Memórias & - \\
\cline { 2 - 3 } [+ formal] & Cartas oficiais & - \\
\hline \multirow{4}{*}{$\begin{array}{l}\text { [+ oral] } \\
\text { [- formal }]\end{array}$} & Cartas particulares & 4 \\
\cline { 2 - 3 } & Peças teatrais & - \\
\hline & EF & 2 \\
\cline { 2 - 3 } & D2 & - \\
\cline { 2 - 3 } & DID & - \\
\hline & PBiloband & - \\
\hline
\end{tabular}

A tabela 9 engloba apenas os dados da $2^{\text {a }}$. metade do séc. XX, já que não dispomos de inquéritos de língua falada para as outras fases analisadas. Ele mostra 
que o gerúndio como articulador discursivo é mais comum nos contextos menos formais tanto da fala como da escrita, como é o caso das cartas particulares (16-19). Nos contextos mais formais como as EFs, o gerúndio pode ser utilizado como organizador do tópico, como no exemplo (30) acima e no seguinte (31):

(31) [EF SP 405 1] Inf (...) então nós vamos começar pela Pré-História... hoje exatamente pelo período... do paleolítico... a arte... no período paleolítico... o paleolítico é período período... da pedra lascada... como vocês todos sabem... não é?... e... tem uma duração de aproximadamente de seiscentos mil anos... seria exatamente... pegando a (fase) da evolução do homem... enquanto homem `sapiens'... que já deixou de ser (macaco)... passou a usar a inteligência... a conseguir fazer coisas...

Até aqui apresentei as propriedades discursivas do tipo de gerúndio que exibe maior saliência do subsistema do Discurso: o gerúndio como articulador discursivo. Nas seções seguintes apresento a distribuição dos outros tipos de gerúndio na tipologia textual analisada, ressaltando-lhes, sempre que for possível, as suas propriedades discursivas. 
Tabela 10. Distribuição dos tipos de gerúndios nos três séculos por tipologia textual (Corpus Básico).

\begin{tabular}{|c|c|c|c|c|c|c|c|c|c|c|c|c|}
\hline $\begin{array}{l}\text { Geral } 3 \\
\text { séculos }\end{array}$ & 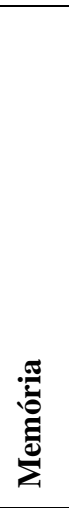 & $\%$ & 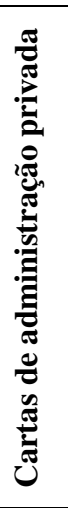 & $\%$ & 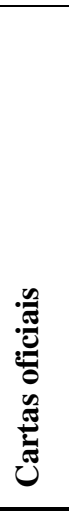 & $\%$ & 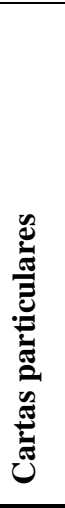 & $\%$ & 茪 & $\%$ & है & $\%$ \\
\hline $\begin{array}{l}\text { OAdv } \\
\text { gerundiais }\end{array}$ & 150 & 53,2 & 54 & 57,4 & 50 & 50,5 & 44 & 32,1 & 56 & 33,5 & 354 & 45,4 \\
\hline $\begin{array}{l}\text { construção } \\
\text { absoluta }\end{array}$ & 85 & 30,1 & 30 & 31,9 & 21 & 21,2 & 21 & 15,3 & 11 & 6,6 & 168 & 21,6 \\
\hline ambíguo & 14 & 5,0 & 0 & - & 12 & 12,1 & 9 & 6,6 & 6 & 3,6 & 41 & 5,3 \\
\hline adjetivo & 11 & 3,9 & 0 & - & 1 & 1,0 & 9 & 6,6 & 5 & 3,0 & 26 & 3,3 \\
\hline perífrase & 20 & 7,1 & 7 & 7,4 & 14 & 14,1 & 47 & 34,3 & 72 & 43,1 & 160 & 20,5 \\
\hline $\begin{array}{l}\text { articulador } \\
\text { discursivo }\end{array}$ & 1 & 0,4 & 2 & 2,1 & 0 & - & 7 & 5,1 & 1 & 0,6 & 11 & 1,4 \\
\hline nominalização & 1 & 0,4 & 1 & 1,1 & 1 & 1,0 & 0 & - & 2 & 1,2 & 5 & 0,6 \\
\hline imperativo & 0 & - & 0 & - & 0 & - & 0 & - & 14 & 8,4 & 14 & 1,8 \\
\hline $\begin{array}{l}\text { Total de } \\
\text { gerúndio }\end{array}$ & 282 & & 94 & & 99 & & 137 & & 167 & & 779 & \\
\hline $\begin{array}{l}\text { Total de OAdv } \\
\text { conjuncionais }\end{array}$ & 152 & & 79 & & 69 & & 113 & & 254 & & 667 & \\
\hline Total & 434 & & 173 & & 168 & & 250 & & 421 & & 1446 & \\
\hline
\end{tabular}

A tabela 10 contém os resultados gerais dos três séculos do Corpus Básico (memórias, cartas e peças teatrais). Ela permite uma visão global da distribuição dos tipos de gerúndio na tipologia textual analisada, mas como é apenas a somatória de seis sincronias, cada uma de 50 anos, esconde detalhes da evolução desses usos que precisam ser desvendados. Feito um comentário geral sobre a distribuição das ocorrências analisadas nesse corpus mais homogêneo, passo a uma descrição mais detalhada, que inclui a análise de outras tipologias que foram agregadas de acordo com a disponibilidade delas para cada período analisado, segundo os parâmetros de controle definidos no capítulo III. 
O quadro geral com a distribuição das orações de gerúndio de acordo com o tipo de texto exposto na tabela 10 revela detalhes bastante significativos para a análise a que me propus nesta tese. Essa tabela contém ainda a contagem de orações adverbiais conjuncionais, já que uma das propostas de análise era contrapor as orações adverbiais gerundiais (dependentes e independentes) e as conjuncionais a fim de verficar se houve alguma mudança nesse domínio. Os percentuais indicados ao lado do total de ocorrências indicam como estão distribuídos os tipos de gerúndio dentro de uma mesma tipologia textual. É importante salientar que o número absoluto das ocorrências refere-se a cada porção de 5000 palavras de cada tipo de texto em cada uma das seis fases analisadas. Dessa forma, será levada em conta aqui a frequiência percentual dos gerúndios.

\section{V.3 A discursivização do gerúndio adverbial}

\section{V.3.1 As orações gerundiais adverbiais (OGadvs) nos textos}

Assim como já havíamos observado no capítulo anterior, ao longo dos três séculos diminui o quadro geral de ocorrências de OGadvs. A tabela $11^{355}$ deste capítulo está acrescida dos textos dos Corpus Diferencial para os séculos XIX e XX, e mostra que essa tendência também se confirma nessas outras tipologias textuais. No séc. XVIII, as OGadvs representam 50,8\% do total de orações de gerúndio, e já no séc. XX essa freqüência baixa para $26,5 \%$.

No séc. XVIII, os contextos preferidos pelas OGadvs são as cartas oficiais (61\%), as cartas da administração privada $(56,9 \%)$ e as memórias $(55,1 \%)$, como mostram respectivamente os exemplos de (32) a (34). Embora numericamente também seja bastante freqüente nas peças teatrais (28/208), observa-se que as OGadvs são comuns em textos mais formais.

${ }^{355} \mathrm{~A}=$ Anúncios; $\mathrm{CL}=$ Cartas de leitores; $\mathrm{CR}=$ Cartas de redatores; $\mathrm{CAP}=\mathrm{Cartas}$ da administração privada $\mathrm{CO}=$ Cartas oficiais $; \mathrm{M}=$ Memória; $\mathrm{FB}=$ Filoband $\mathrm{PBP}=\mathrm{PBpop}$. 
Tabela 11. Quadro geral dos tipos de gerúndio por tipologia textual e por século.

\begin{tabular}{|c|c|c|c|c|c|c|c|c|c|c|c|c|c|c|c|c|c|c|c|c|c|c|c|c|c|c|c|c|c|}
\hline & . & \multicolumn{6}{|c|}{ Corpus Diferencial } & \multicolumn{10}{|c|}{ Corpus Básico } & \multicolumn{10}{|c|}{ Corpus Diferencial } & \multirow[b]{2}{*}{ Total } & \multirow[b]{2}{*}{$\%$} \\
\hline & & $\mathrm{A}$ & $\%$ & $\mathrm{CL}$ & $\%$ & $\overline{C R}$ & $\%$ & CAP & $\%$ & $\mathrm{CO}$ & $\%$ & $\mathrm{CP}$ & $\%$ & $\mathrm{M}$ & $\%$ & TEA & $\%$ & D2 & $\%$ & $\overline{\mathrm{DID}}$ & $\%$ & $\mathrm{EF}$ & $\%$ & FB & $\%$ & PBP & $\%$ & & \\
\hline \multirow{10}{*}{ 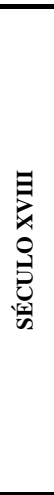 } & OAdv gerundial & & & & & & & 37 & 56,9 & 25 & 61,0 & 7 & 41,2 & 65 & 55,1 & 28 & 35,9 & & & & & & & & & & & 162 & 50,8 \\
\hline & construção absoluta & & & & & & & 22 & 33,8 & 8 & 19,5 & 8 & 47,1 & 41 & 34,7 & 9 & 11,5 & & & & & & & & & & & 88 & 27,6 \\
\hline & ambíguo & & & & & & & 0 & - & 5 & 12,2 & 1 & 5,9 & 6 & 5,1 & 6 & 7,7 & & & & & & & & & & & 18 & 5,6 \\
\hline & adjetivo & & & & & & & 0 & - & 0 & - & 0 & - & 1 & 0,8 & 0 & - & & & & & & & & & & & 1 & 0,3 \\
\hline & nominalização & & & & & & & 1 & 1,5 & 0 & - & 0 & - & 0 & - & 0 & - & & & & & & & & & & & 1 & 0,3 \\
\hline & imperativo & & & & & & & 0 & - & 0 & - & 0 & - & 0 & - & 10 & 12,8 & & & & & & & & & & & 10 & 3,1 \\
\hline & perífrase & & & & & & & 3 & 4,6 & 3 & 7,3 & 1 & 5,9 & 5 & 4,2 & 24 & 30,8 & & & & & & & & & & & 36 & 11,3 \\
\hline & Total de gerúndios & & & & & & & 65 & & 41 & & 17 & & 118 & & 78 & & & & & & & & & & & & 319 & \\
\hline & Total de OAdv conj. & & & & & & & 58 & & 39 & & 22 & & 69 & & 130 & & & & & & & & & & & & 318 & \\
\hline & Total & & & & & & & 123 & & 80 & & 39 & & 187 & & 208 & & & & & & & & & & & & 637 & \\
\hline \multirow{10}{*}{ 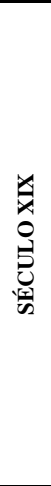 } & OAdv gerundial & 29 & 43,9 & 32 & 59,3 & 9 & 60 & 9 & 69,2 & 11 & 42,3 & 30 & 41,7 & 54 & 44,6 & 16 & 36,4 & & & & & & & & & & & 190 & 46,2 \\
\hline & construção absoluta & 19 & 28,8 & 10 & 18,5 & 4 & 26,7 & 3 & 23,1 & 5 & 19,2 & 11 & 15,3 & 37 & 30,6 & 1 & 2,3 & & & & & & & & & & & 90 & 21,9 \\
\hline & ambíguo & 10 & 15,2 & 1 & 1,9 & 0 & - & 0 & - & 7 & 26,9 & 2 & 2,8 & 6 & 5,0 & 0 & - & & & & & & & & & & & 26 & 6,3 \\
\hline & nominalização & 1 & 1,5 & 2 & 3,7 & 0 & - & 0 & - & 0 & - & 0 & - & 0 & - & 1 & 2,3 & & & & & & & & & & & 4 & 1,0 \\
\hline & imperativo & 0 & - & 0 & - & 0 & - & 0 & - & 0 & - & 0 & - & 0 & - & 3 & 6,8 & & & & & & & & & & & 3 & 0,7 \\
\hline & articulador discursivo & 1 & 1,5 & 0 & - & 0 & - & 0 & - & 0 & - & 3 & 4,2 & 1 & 0,8 & 0 & - & & & & & & & & & & & 5 & 1,2 \\
\hline & perífrase & 3 & 4,5 & 5 & 9,3 & 0 & - & 1 & 7,7 & 3 & 11,5 & 20 & 27,8 & 14 & 11,6 & 18 & 40,9 & & & & & & & & & & & 64 & 15,6 \\
\hline & Total de gerúndios & 66 & & 54 & & 15 & & 13 & & 26 & & 72 & & 121 & & 44 & & & & & & & & & & & & 411 & \\
\hline & Total de OAdv conj. & 7 & & 55 & & 19 & & 9 & & 14 & & 48 & & 65 & & 72 & & & & & & & & & & & & 289 & \\
\hline & Total & 73 & & 109 & & 34 & & 22 & & 40 & & 120 & & 186 & & 116 & & & & & & & & & & & & 700 & \\
\hline \multirow{9}{*}{ 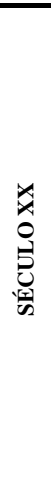 } & OAdv gerundial & & & & & & & 8 & 50,0 & 14 & 43,8 & 7 & 14,6 & 31 & 72,1 & 12 & 26,7 & 8 & 16,0 & 10 & 24,4 & 1 & 2,7 & 3 & 14,3 & 1 & 4,0 & 95 & 26,5 \\
\hline & construção absoluta & & & & & & & 5 & 31,3 & 8 & 25,0 & 2 & 4,2 & 7 & 16,3 & 1 & 2,2 & 0 & - & 0 & - & 4 & 10,8 & 2 & 9,5 & 1 & 4,0 & 30 & 8,4 \\
\hline & ambíguo & & & & & & & 0 & - & 0 & - & 6 & 12,5 & 2 & 4,7 & 0 & - & 2 & 4,0 & 0 & - & 0 & - & 0 & - & 0 & - & 10 & 2,8 \\
\hline & \begin{tabular}{|l|} 
adjetivo \\
\end{tabular} & & & & & & & 0 & - & 1 & 3,1 & 3 & 6,3 & 1 & 2,3 & 0 & - & 1 & 2,0 & 4 & 9,8 & 4 & 10,8 & 0 & - & 0 & - & 14 & 3,9 \\
\hline & nominalização & & & & & & & 0 & - & 1 & 3,1 & 0 & - & 1 & 2,3 & 1 & 2,2 & 1 & 2,0 & 0 & - & 0 & - & 0 & - & 1 & 4,0 & 5 & 1,4 \\
\hline & imperativo & & & & & & & 0 & - & 0 & - & 0 & - & 0 & - & 1 & 2,2 & 0 & - & 0 & - & 0 & - & 0 & - & 0 & - & 1 & 0,3 \\
\hline & articulador discursivo & & & & & & & 0 & - & 0 & - & 4 & 8,3 & 0 & - & 0 & - & 0 & - & 2 & 4,9 & 2 & 5,4 & 0 & - & 0 & - & 8 & 2,2 \\
\hline & perífrase & & & & & & & 3 & 18,8 & 8 & 25,0 & 26 & 54,2 & 1 & 2,3 & 30 & 66,7 & 38 & 76,0 & 25 & 61,0 & 26 & 70,3 & 16 & 76,2 & 22 & 88,0 & 195 & 54,5 \\
\hline & Total & & & & & & & 28 & & 48 & & 91 & & 61 & & 97 & & 104 & & 71 & & 102 & & 50 & & 76 & & 728 & \\
\hline
\end{tabular}


(32) [C 181 Ald 5 2] Como odeZejo devossa exÇelenÇia, eomeu he a- juntar aesta aldea os indios que dela andaõ exparÇidos portantas partes, chamandoos - aoforo deCativos, pela ContinuaÇaõ dosan nos paSSa dos, Como este que agora mando - apreZenSSa devossa exÇelenÇia Como quem lhe pode por oRemedio.

(33) [C 182 Seb 20 2] Tenho dado o cum primento adita ordem paSsando mostra as ditas Companhias, don- de entraram Brancos, Mulatos, Pretos e uriundos; advirtindo que Cada hum estam emSuas Companhias, as dos Brancos Sam tres Companhias, aCompanhia doCapitam Manoel Gomes deAr.o aCompanhiadoCapitam Joas deAguiar [D]altara, eaCompanhia desta villa estâ Sem Capitam Nem Alferes, eoque a R[ê ou i ?]ge hê - oSargento deNumero [D]oSe [F]elis;

(34) [M 182 MCA 3] aSsim como seequivocarão todos elles em ordem aPovoa $=\left[\rightarrow\right.$ (a) vide n. $\left.^{\circ} 120\right]$ çaõ deSaõ vicente, dando-lhe principio mais antigo, doque o anno de 1530, noqual seu Fundador ogrande Martim Afonso deSouza, sem controver= sia alguma, ainda seachava emLisboa, dispondo-se para aviagem daAme $=$ rica.

No séc. XIX, observamos que essa tendência se mantém para as cartas da administração privada $(69,2 \%)$ e sua freqüência diminui nas cartas oficiais $(42,3 \%)$ e nas memórias (44,6\%). Nos documentos do Corpus Diferencial desse século, as OGadvs aparecem bastante nas cartas de redatores (60\%) e de leitores (59,3\%). Podemos associar esse fenômeno ao caráter planejado dessas cartas, em oposição às cartas particulares $(41,7 \%)$.

(35) [C 191 CR SP 398 1] Muitos paes que, tendo filhos em circustancias de adquirirem instrucção, e não o podendo fazer por sua limitada fortuna, nenhuma duvida terão de concorrer para esta sociedade, que lhes pode prestar meios, que alias não poderião obter.

(36) [C 191 CL SP 389 6] De | volta sentei-me a descançar na ponte franca | e ai estavão talvez ao mesmo fim dois su- | geitos, um dos quaes era um Portuguez | velho, e Brasileiro novo, digo Portuguez | velho, porque nasceu nas marges do Doiro, | e ja é avançado em annos, e Brasileiro no- | vo, porque vivendo entre nós, e adherin- | do á nossa causa tem tantos annos de Bra- | sileiro quanto o Brasil de Nação Indepen- | dente; o outro era um rapaz Paulista, e | segundo me persuado, estudante de Latim.

Nas peças teatrais as OGadvs representam 36,4\% das ocorrências de gerúndio, mantendo-se assim uma freqüência equivalente à do séc. XVIII $(35,9 \%)$.

(37) [TEA 191 Mac 17] O DESCONHECIDO Tens razão: a virgindade é uma ilusão! Qual é mais virgem, aquela que é deflorada dormindo, ou a freira que ardente de lágrimas e desejos se revolve no seu catre, rompendo com as mãos sua roupa de morte, lendo algum romance impuro?

Considerada alta em relação aos outros tipos de gerúndio encontrados nas peças teatrais do séc. XIX, também nesse século é o contexto menos favorecido para a realização das OGadvs, o que confirma que esse tipo de gerúndio não era tão freqüente na fala como o era na escrita.

Os resultados obtidos para o século XX deixam bem clara a idéia aqui defendida de que esse tipo de gerúndio é mais freqüente em contextos formais do que na escrita mais relaxada e nos enunciados de língua oral. Observamos uma gradação que vai do maior para o menor grau de formalidade do texto (Gráfico 9). 


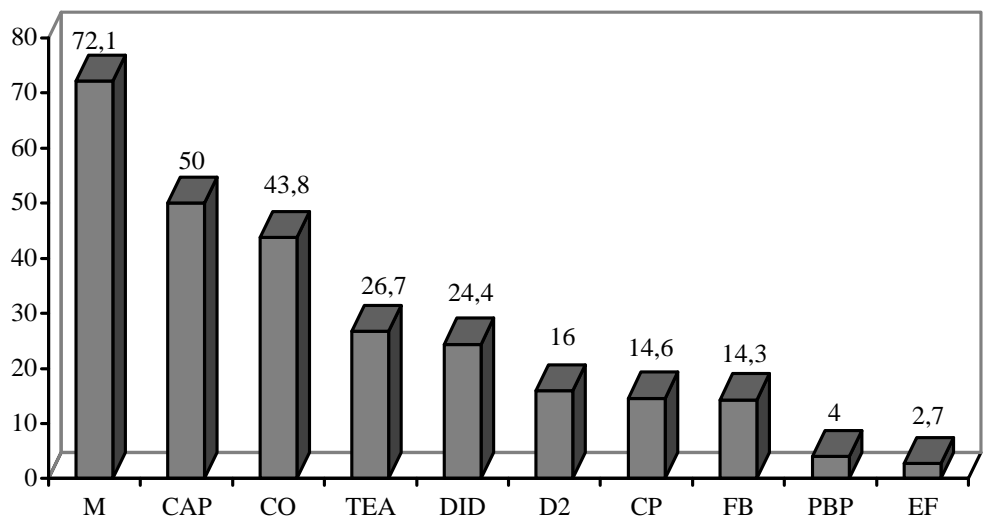

Gráfico 9. Freqüência de OGadvs por tipo de texto no séc. XX.

Curiosamente, era de se esperar que a $\mathrm{EF}$ como texto mais formal exibisse uma maior ocorrência de OGadvs, mas aqui ele representa apenas $2,7 \%$, sendo o tipo de texto com a menor representatividade desse tipo de gerúndio. No entanto, é possível esclarecer este contra-senso. Se somarmos as ocorrências adverbiais das orações de gerúndio (OGadvs e CAs), obtemos 13,5\% de freqüência para as EFs, o que restitui o inquérito de PBpop ao pólo mais extremo do traço [-formal]. Nas EFs o professor se preocupa com a clareza, e o gerúndio, por conta de sua ambiguidade, não atende essa necessidade. Os exemplos de (38) a (40) deixam clara a relação de condição entre os enunciados:

(38) [EF SP 405 27] então não havendo a luz... não pode haver a refração diferente aí dos raios luminosos e portanto não existe a cor...

(39) [EF POA 278 30] se tiver assim, um caráter já de uma pequena, um pequeno exame, então já está com um nível mais, mais complexo supondo que eu tenha dito quais são, as características da, da, do processo da avaliação, que eu tenha dado aqui em aula expositiva, daqui a pouco eu pergunto identifique no texto, a, a seguir as características da avaliação;

(40) [EF POA 278 35] então, uma mesma questão, muitas vezes, pode exigir, ah, diferentes processos mentais, dependendo da maneira como ela é apresentada

(41) [EF POA 278 45] aqui, ele recebeu uma comunicação, e a, e a utiliza da mesma maneira, sem modificar, ele repete, memorização pura e simples, mas aqui, ele vai atuar sobre uma comunicação podendo ser essa sua atuação de três diferentes maneiras, tu fez (fizeste) alguma pergunta, André?

Além disso, o único exemplo de OGAdv encontrado no PBpop poderia muito bem ser inserido dentro da categoria perífrase, não fosse o fato de o verbo ficar nesta construção ser mais pleno:

(42) [PBpop 220 59] Inf. é depois d'eu... vários... já... já:: teve uma ocasião que ficô cinco aqui morando mais eu... aí depois um voltô pra/pro norte otro procurô suas casa né ... casô né cada (um) foi se virano mais ainda tem otro mais eu ainda o esposo dessa menina... e é assim 
O mesmo fato é observável para os verbos ficar e estar nas peças teatrais da $2^{\mathrm{a}}$. metade do séc. XX:

(43) [TEA 202 Per 2] EMÍLIO A única vez que ele não fazia o café era no dia do seu aniversário. Nesse dia quem fazia era ela. Ele então ficava na cama fingindo que dormia. Ela descia, fazia o café, subia e passava pelo nosso quarto.

(44) [TEA 202 Per 13] PÉROLA Em vez de namorar, sair com as moças, fica enfurnado dentro casa, me provocando...

(45) [TEA 202 Per 17] EMÍLIO Cinco minutos depois já se acostumaram e nem prestam mais atenção. Fico vagando pela casa, feito alma penada, esbarrando nos fantasmas do passado que estão por toda parte.

(46) [TEA 202 Per 18] EMÍlIO Papai se aposentou; quer dizer, fica em casa, de pijama, matando formiga.

(47) [TEA 202 Per 24] VADO Sua mãe pegou num sono! Tá aqui do meu lado, dormindo tão gostoso...Tá tudo bem aí, filho?

(48) [TEA 201 Tel 8] LEILA - Vamos. Bié! E o Sebastião? Não fica na fazenda ajudando papai?

(49) [TEA $201 \mathrm{Tel}$ 14] ADA - Estou aqui para defender o que é meu, pensando em coisas sérias.

(50) [TEA 202 FCN 16] O caixão está no corredor, meio enlatado. Atravancando a circulação. Como eu morri na cama, ele falou: "Ninguém mexe nele. Foi aí que ele morreu, é aí que ele vai ficar".

O gráfico 9 revela ainda que o texto teatral (escrito), exemplar de uma língua falada concepcional, está orientado para o pólo de maior formalidade em relação aos outros textos de língua falada.

\section{V.3.2 As construções absolutas de gerúndio (CAs) nos textos}

O ritmo de decréscimo no uso de OGadvs é acompanhado pelas CAs ao longo dos três séculos $(27,6 \%>21,9 \%>8,4 \%)$, como se pode depreender da tabela 10 , provando que estes dois tipos de orações de gerúndio mantêm uma unidade quanto ao seu uso.

No séc. XVIII, os contextos preferidos pelas CAs são as cartas particulares $(47,1 \%)$, as cartas da administração privada $(33,8 \%)$ e as memórias $(34,7 \%)$, sendo pouco produtivas nos entremezes analisados (11,5\%). $\mathrm{O}$ alto índice verificado nas cartas particulares deve-se ao grau semi-público dessas cartas nesse século, que poderiam ser consideradas também como cartas da administração privada. À falta de cartas com grau de privacidade maior para este século, procuramos dividi-las segundo o grau de relaxamento expresso nos textos, detectável através da frequência de interrupções e paráfrases, como ilustra o exemplo abaixo, no qual podemos observar um menor planejamento do texto, de que são pistas os problemas de dêixis instaurados ora pela ausência do referente, marcado por um OD nulo (venha logo buscar $\left.\left[\mathrm{OD}_{\varnothing}\right]\right)$, ora pela confusão em relação à pessoa referida (porlhedizer): 
(51) [C 181 Ald 14 12] eobom he crialo depequeno Comadoutrina emque hade ficar. eordenando odito Senhor que oReColha, venha logo buscar que nenhu aduvida hâ emSeentregar, e devame vossamerce eSte trabalho, porlhedizer que atal crianSa naõ hia, para oCuyava, fico paraServir avossamerce aquem Deos guarde

No séc XIX, as memórias continuam sendo o ambiente preferido pelas CAs $(30,6 \%)$, mas contamos também com uma boa representatividade desse tipo de orações de gerúndio nos anúncios (28,8\%):

(52) [A 19 2 2 SP 2] Propagadora da Instrucção|Popular|Estão abertas as matriculas e escolas desta|associação, havendo mais este anno um curso|de arithmetica e outro de geometria, dirigidos pelos distinctos academicos senhores. Bandeira|e Cardoso de Mello Junior, que expontanea e|obsequiosamente se offereceram.|As aulas funccionam das cinco e meia da|tarde até ás nove horas da noite de todos os|dias uteis, com excepção dos sabbados, e gra-|tuitamente. Correio Paulistano, 05 de janeiro de 1879

(53) [A 192 SP 5] DE|F.M. RIESEMBERGER/Taubaté, em frente a estação da estrada de ferro|Os mosaicos para terreiro são de reconhe-|cida vantagem para o aperfeiçoamento do|café; sua collocação é igual a do tijolo,e|dando-se -lhe o nivellamento necessario para|o esgoto das aguas, meia hora depois de uma grande chuva, ficará o terreiro completamente enxuto para receber o café. Estes mosaicos são de igual solidez á pedra de granito, e re-|sistem inalteraveis a acção do sol e da chuva.|Esta fabrica tendo em vista a grande acei-|tação que tem merecido dos senhores fazendeiros do norte da provincia,|os mosaicos para terreiros,|reduzio seos preços consideravelmente, ven-|dendo estes ao milheiro para mais facilidade.| Correio Paulistano, 22 de janeiro de 1879

Tanto nas memórias como nos anúncios, a função das CAs é de disponibilizar ao leitor um quadro mais nítido do evento ou da cena descrita ${ }^{356}$ :

(54) [M 191 RDN 33a] §. 13. Parecia zelo egrande cuidado, com que seimpedia por todos osmeios, sem exceptuar odaExcomunhaõ (a) que osparticulares naõ tiveSsem os Indios nas suas Cazas, eSitios: mas naõ erasenaõ ambiçaõ impedindo-se por $\|$ [p. 5] poreste meio, que os Indios secivilizavam, eganhavam algum jornal, procurando-se [unicamente] que existiSsem nas Aldeas para servirem forsados nas occazioens, emque eraõ chamados.

No século XX (gráfico 10), repete-se para as CAs a tendência também observada para as OGadvs (v. gráfico 9). As CAs aparecem mais nos textos escritos de maior formalidade e de maior planejamento como as cartas de administração privada, oficiais e as memórias.

\footnotetext{
${ }^{356}$ Este argumento interessa para o esclarecimento da semanticização do gerúndio e será retomado no capítulo VI.
} 


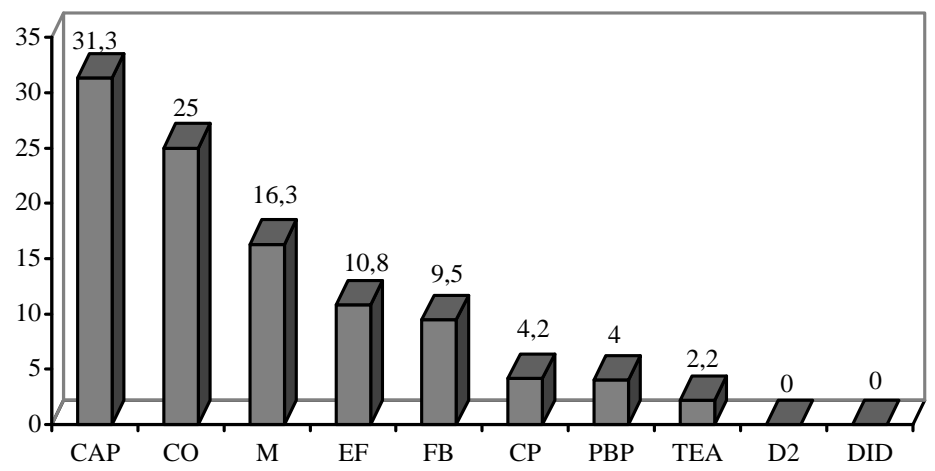

Gráfico 10. Freqüência de CAs por tipo de texto no séc. XX

Por outro lado, contamos com poucas ocorrências na língua falada, mas nesses contextos, são comuns a CAs de caráter mais idiomático (formulaico), como ocorre nos seguintes exemplos, que representam três tipologias de distintos graus de oralidade (55 e 56), incluindo aí o exemplo recolhido em uma carta particular (57):

(55) [PBpop 220 11] Inf. não/ ficô depois que eu fiquei duente eu num pude trabaiá mais né então e depois chegando a idade... pronto ((ri))

(56) [TEA 201 RV 22] ABELARDO II Não são não. Descanse. Eu entendo de socialismo. Olhe. A lei de férias só deu um resultado. Não há mais salário de semana ou de mês. É por dia de trabalho, ou por contrato. Somando bem, os domingos, feriados e dias de doença eram mais que as férias de hoje.

(57) [C 202 SIM 2 9] No dia seguinte de manhã, fomos à Lambari, | lá é super legal, tem um cassino, que está | sendo restaurado para ser novamente aberto, que é | simplesmente maravilhoso, nós não entramos pois | estava fechado mas só vendo por fora já da para | ficar encantado, ele fica bem no alto ao lado, em | baixo tem um lago enorme, não sei se é lago ou rio, | é um monte de ła água,

\section{V.3.3 A dessintaticização das orações adverbiais gerundiais}

No capítulo IV apresentamos um gráfico (Cap. II, gráfico 2) com os resultados obtidos no Corpus Básico. Ele continha a freqüência de orações adverbiais gerundiais, separadas em dependentes e independentes, e de orações adverbiais conjuncionais por século. Já tínhamos observado que diminui tanto o número de orações gerundiais como de orações conjuncionais. O gráfico 11 ilustra esse fato e reune as num grupo só as orações de gerúndio ( $\mathrm{OGadv}$ e $\mathrm{CA})$ : 


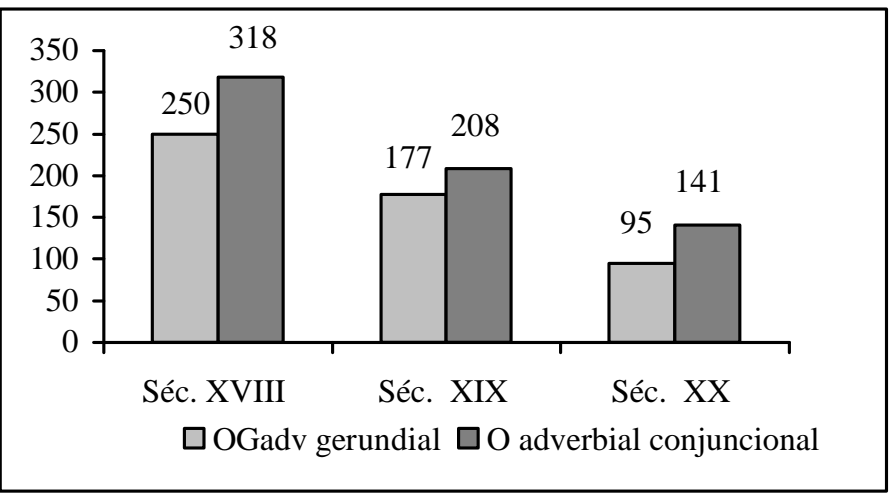

Gráfico 11. Orações adverbiais gerundiais e conjuncionais no Corpus Básico.

A média ponderada de uso de orações adverbiais no Corpus Básico (gráfico 12) mostra que nos três séculos mantém-se um padrão, ou seja, embora o número absoluto de ocorrências diminua (v. gráfico 11 acima), há sempre uma maior frequiência de orações conjuncionais, sendo o resultado do séc. $\mathrm{XX}$ aquele que mostra um maior distanciamento entre estas duas variantes: 40,3\% para as gerundiais e 59,7\% para as conjuncionais. Este gráfico denota uma tênue mudança favorecendo o uso de conjunções na expressão das relações proposicionais entre os eventos.

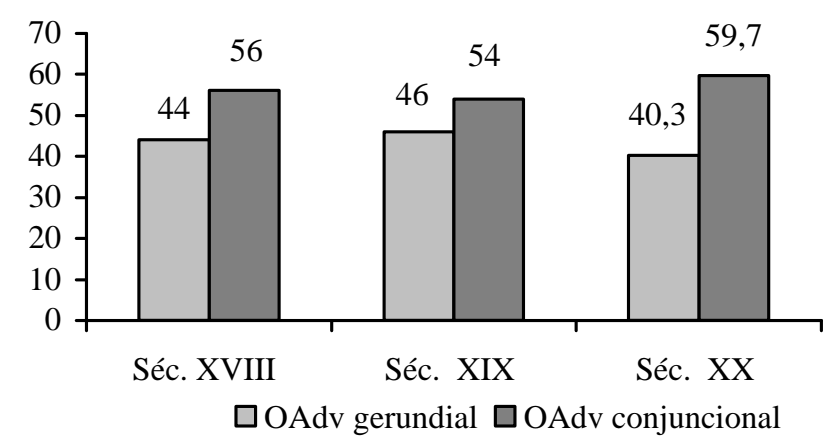

Gráfico 12. Média ponderada de orações adverbiais gerundiais e conjuncionais no Corpus Básico.

O gráfico 13, abaixo, incorpora o Corpus Diferencial dos séculos XIX e XX e mostra que mantém-se de forma equivalente a média ponderada na distribuição desses dois tipos de construções adverbiais, ou seja, mais conjuncionais que gerundiais. No entanto, o conjunto do século XX aponta uma diferença em relação aos resultados para o mesmo período no Corpus Básico: é muito mais baixo o número de orações gerundiais e, em conseqüência, bem mais alto o índice de orações 
conjuncionais. Isso se deve ao fato de que para a $2^{\mathrm{a}}$. metade do século $\mathrm{XX}$ foi possível controlar melhor o Corpus Diferencial, agregando a ele uma gama diferenciada de inquéritos de língua falada (D2, DID, EF, PBpop, Filoband). Certamente isto influenciou o resultado, que já tinha sido apontado pelos cálculos feitos para o Corpus Básico, do qual fazem parte peças teatrais mais populares.

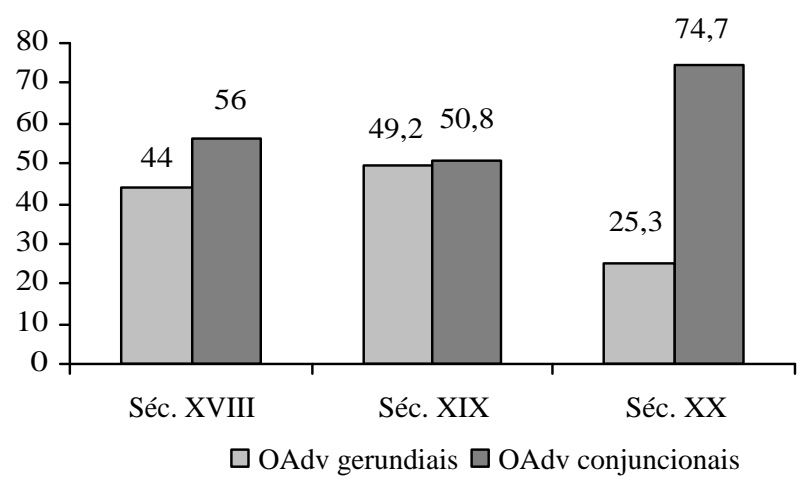

Gráfico 13. Orações adverbiais gerundiais e conjuncionais nos Corpora (Básico e Diferencial)

Em resumo, a aposição destes dois resultados, levando-se em conta, portanto, tanto o Corpus Básico como o Corpus Diferencial, é altamente relevante para esta tese. Se de um lado, os gráficos 12 e 13 evidenciam que houve um decréscimo tanto no uso de gerúndios como de conjunções para a expressão de alguma relação adverbial no período estudado, por outro lado, os gráfico 9 e 10 demonstram que, nas fases mais recentes do português brasileiro, contextos mais informais e de língua falada privilegiam a realização de orações adverbiais conjuncionais. Os argumentos aqui apresentados procuram comprovar a suspeita inicial de que o canal de mudança sintática pode envolver questões de tradições discursivas, ou seja, um determinado contexto discursivo específico, que pode ser encontrado em tipologia textual diferenciada, pode ser o ambiente que acolhe a mudança sintática, porque nele se ativam, reativam ou desativam determinadas propriedades que podem ser sintáticas ou semânticas. Nesse sentido, a dessintaticização tanto do gerúndio como das conjunções está associada aos contextos discursivos em que eles aparecem. Quanto maior a informalidade, menor a freqüência desse tipo de junção. Uma rápida olhada no corpus de língua falada e das peças teatrais mostra que as relações proposicionais 
que se estabelecem entre enunciados podem realizar-se na gramática da língua de maneira diferenciada. Através da ordenação adequada na justaposição de enunciados, que pode estar ainda aliada a recursos fônicos, como o aumento na tessitura de voz, pode dar proeminência a determinado conteúdo semântico de certos enunciados, enquanto o tom baixo pode obscurecer e "despreferenciar" o conteúdo de outros.

\section{V.4 A discursivização das perífrases verbais}

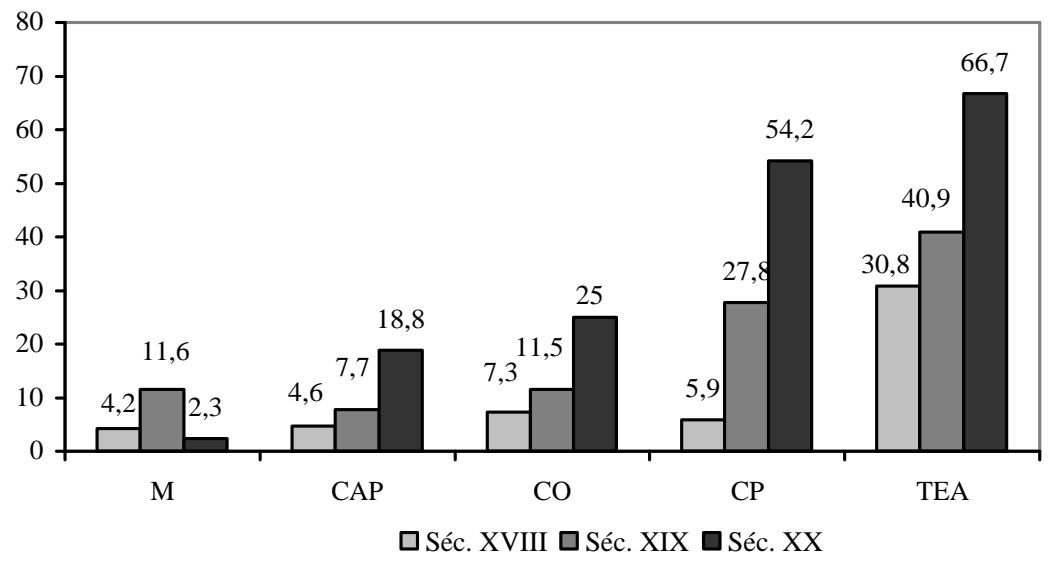

Gráfico 14. A evolução das perífrases de gerúndio no Corpus Básico

No capítulo IV, já havíamos observado que os resultados obtidos na quantificação das ocorrências do Corpus Básico apontavam um aumento progressivo das perífrases ao longo dos três séculos $(11,3 \%>20,3 \%>37 \%)$. O gráfico 14 demonstra como estão distribuídas essas perífrases de gerúndio segundo a tipologia textual específica. Nota-se aí que os menores índices de perífrases foram encontrados nas memórias históricas e nas cartas da administração privada e oficiais, enquanto os índices mais altos estão nas cartas particulares e nas peças teatrais.

As memórias apontam um aumento no século XIX e uma sensível redução no século XX, sendo o índice deste século menor do que o dos outros séculos. Esse aumento pode explicar-se talvez pela opção dos autores do século XIX em descrever o cotidiano das pessoas envolvidas nos fatos históricos narrados:

(58) [M 191 RDN 12a] §. 4. Oexcelentissimo Senhor Dom Luis Antonio deSo[i]za, conheceo bem aneceSsidade deerigir Freguezias emAldeas, que fossem tomando m[aior] [calor] por offeito das suas deligencias esperançava-se muito nasdeSa õ Miguel, Pinheiros, eSaõ Joze. (a) comtudo unicamente erigio em Villa esta ultima ficando as outras em Aldeas, como d'antes. 
(59) [M 191 RDN 22] Estes Homeñs / fallo dos Indios aldeados / que sendo tirados núz dos [dos sertões] Brazilicos mais porforça doque por vontade, que tantos tempos seConservaraõ pouco vestidos debaixo deescravidaõ, (a) que naõ obstante oSoberano osdeclarar livres, ficarã̃ contudo vivendo segeitos asAldeas, sofrendo inSolencias contrarias á liber= dade doHomem, (b) eque huma Serie defactos ostem feito viver sempre na ultima baixeza, emizeria, como mais adian- te mostrarei;

(60) [M 192 HC 8] Costumavam partir de madrugada, pousavam antes de entardecer, o resto do dia passavam caçando, pescando, procurando mel silvestre, extraindo palmito, colhendo frutos; as pobres roças dos índios forneciam-lhes os suplementos necessários, e destruí-las era um dos meios mais próprios para sujeitar os donos.

(61) [M 192 HC 19] As bandeiras no século XVI devastaram sobretudo o Tietê, cujos numerosos Tupiniquins depressa desapareceram, e o alto Paraíba, chamado rio dos Surubis em Piratininga, segundo informa Glimmer; com o tempo foram-se alongando os raios do despovoamento e depredação, característico essencial e inseparável das bandeiras.

Nas memórias do século XX, o foco concentra-se na decrição dos lugares e de sua ocupação:

A fundação da vila de São Paulo esteve orientada para a colonização do planalto. Por cerca de 300 anos, não passou de um núcleo urbano acanhado, cuja área construída praticamente se reduzia à colina onde fora instalado, em 1554, o colégio dos jesuítas. Como o solo não era especialmente fértil nem havia em seu entorno metais preciosos em quantidade expressiva, o movimento de colonização dos sertóes acabou por desenvolver para além de suas redondezas os núcleos de povoamento ligados às atividades econômicas mais promissoras. Com isso, houve, sobretudo a partir dos surtos econômicos da segunda metade do século XVIII, a tendência à concentração da riqueza longe de São Paulo, nas localidades em que as elites agrárias habitavam (Érnica, 2004:157).

Talvez um corpus maior de memórias, com exemplares de vários autores, pudesse evidenciar se houve mesmo uma desdiscursivização das perífrases de gerúndio nesse tipo de texto. Além disso, é bom lembrar que o gênero memória histórica passou por transformações ao longo do período analisado. Em pleno século iluminista, elas cumpriam uma função política específica, caracterizando-se como gênero intermediário entre a carta e a narrativa histórica. Os artigos de historiadores do século XX, principalmente da $2^{\mathrm{a}}$. metade do século, têm maior caráter de divulgação científica, e procuram apagar as marcas de envolvimento emocional que as memórias da $1^{\mathrm{a}}$. metade do séc. XIX ainda traziam, ao narrar como os índios continuavam vivendo sogeitos asAldeas, sofrendo inSolencias contrarias á liberdade doHomem. O que se quer dizer aqui, é que não é somente a grandeza gênero textual que define o uso e sim a suas especificidades inerentes, uma vez que os gêneros textuais podem ser portadores de diversas tradições discursivas. A escolha de delimitar a coleta de dados por gêneros textuais representa apenas um procedimento metodológico que se aproxima do ideal. Daí a opção por selecionar textos que contivessem o mesmo conteúdo narrativo: a história da capitania de São Paulo. 
À exceção das memórias, observa-se uma tendência de aumento em todos os tipos de textos, de século para século. No entanto, é nas cartas particulares e nas peças teatrais que a mudança se faz sentir com maior vigor. Nas cartas particulares o índice salta de $5,9 \%$, no séc. XVIII, para $27,8 \%$ no século XIX - lembrando que estes índices envolvem o desprestígio de algum outro tipo de oração gerundial, no caso em questão, a redução das orações adverbiais gerundiais. Já no séc. XX, praticamente dobra o índice de perífrases nas cartas particulares. As peças teatrais são o solo mais fértil das perífrases nesse conjunto de textos, ocupando o lugar de destaque no século XX, com $66,7 \%$.

A análise do gráfico 6 demonstra que a discursivização do gerúndio se deu de maneira equilibrada nos domínios de cada um dos tipos de texto, ou seja, embora sua ocorrência seja mais tímida nas cartas mais formais, na evolução do quadro de distribuição dos tipos de gerúndio em cada tipo de texto, a perífrase também foi ganhando espaços no interior desses contextos, ou seja, uma mudança que não só afeta a história do português falado no Brasil, como também a língua escrita.

Pelos resultados obtidos para o Corpus Diferencial do séc. XIX (v. tabela 11), é possível verificar que os anúncios são o ambiente menos propício à presença de perífrases(4,5\%). Isso também se deve à natureza desse texto, que exibe outras características sintáticas, as quais, por sua vez, atendem a sua função discursiva específica. Abaixo, os únicos exemplos de perífrases encontradas nos anúncios:

(62) [A 191 SP 19] José Maria Avellar Brotero participal ao respeitavel Público; que parte do Compendio de| Direito Natural ja se acha a venda na loja do Senhor| Dom Thomaz de Molina. Os Senhores Assignantes serão| entregues dos seus exemplares logo que o mesmo| Compendio esteja completo, aquelles Senhores porém| que quizerem ir recebendo segundo vem chegando| do Rio de Janeiro, podem mandar buscar a Casal do A. O Farol Paulistano, 21 de março de 1829

(63) [A 192 SP 1] J. M. Villaronga|Faz ciente ás pessoas que tiverem|negocios a tratar comsigo, que élencontrado na sala de pintura|do theatro São José, onde está deco|rando os pannos dos theatros do|Norte da província.|Póde ser procurado das 7 da|manhã ás 6 da tarde. Correio Paulistano, 05 de janeiro de 1879

Já as cartas de leitores $(9,3 \%)$ contam com um índice intermediário entre as cartas de administração privada e as cartas oficiais. Note-se que não foram encontradas perífrases de gerúndio nas cartas de redatores. 


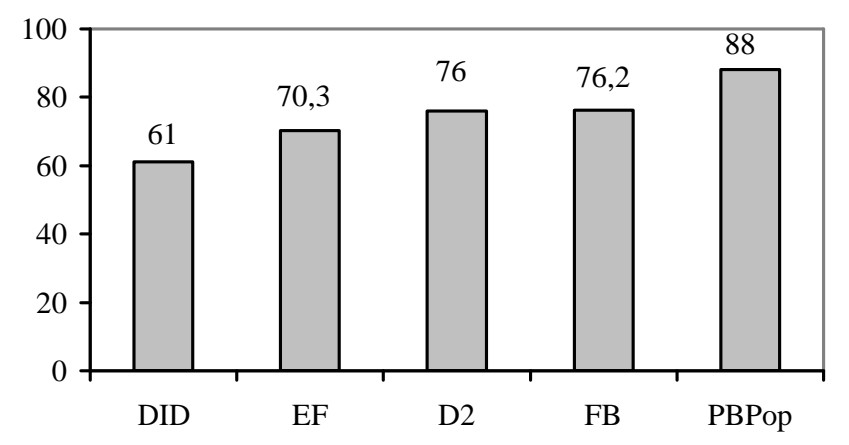

Gráfico 15. Perífrases de gerúndio na língua falada da $2^{\mathrm{a}}$. metade do séc. XX.

Se os resultados obtidos para as peças teatrais do séc. XX já indicava uma supremacia das perífrases na língua falada, é o quadro de sua distribuição nos inquéritos de lingua falada do Corpus Diferencial do séc. XX que ratifica essa idéia (gráfico 15), além de contribuir com alguns dados a respeito de como essa mesma forma é selecionada de acordo com o tipo de texto falado e de acordo com a norma.

O contexto de língua falada mais propício à realização de perífrases é o de fala popular, com 88\% (PBpop). Empatam com um índice também alto os diálogos entre dois informantes $(76, \%)$ e o depoimento do Projeto Filoband (76,2\%), mostrando que contextos mais informais permitem um uso mais freqüente desse tipo de gerúndio em oposição a outros tipos. Os inquéritos DID exibem a particularidade de que neles o diálogo se dá entre o documentador e o informante e nessa circunstância, o falante pode sentir-se mais intimidado, ao contrário dos diálogos D2, nos quais o documentador participa apenas como organizador dos tópicos.

Curiosamente aquele que é contexto mais formal da fala, o das elocuções didáticas (EF), conta com um índice também alto (70,3\%). Vale a pena discutir um pouco isso. Além das funções semânticas gerais que o aspecto desempenha no estabelecimento de um ponto de vista em relação a um fato narrado, dispondo seu movimento numa cadeia temporal (início, duração e fim de um processo), as perífrases de gerúndio cumprem também um papel importante na descrição das cenas: através do aspecto imperfectivo são projetados espaços, pessoas e conteúdos abstratos - vejam que aqui já avanço na descrição do subsistema da Semântica e 
retomarei esta questão no capítulo seguinte. A primeira função é mais genérica e é por isso que as perífrases são tão produtivas no português brasileiro.

(64) [FB2 220 19] Inf. nu (vendo) nói vendia muito ovo agora nu: :: nu tamo lidando mais com galinha botadera ( )

(65) [PBpop 22024$]$ Inf. eu ficava pensando "meu deus tanta família... tantos irmão que eu tenho" porque eu tenho vinte e dois irmão então... é:: é assim porque... bom da minha mãe só são vinte... vinte mais tem mais dois particulá entendeu?...

Já a segunda função atua mais em contextos formais, porque requer maior abstração. Isso explica o alto índice de perífrases nas EFs. Vejamos alguns exemplos:

(66) [EF SP 405 23] as coisas para eles ainda estão muito confusas quer dizer... criar uma pessoa... ou criar uma imagem é mais ou menos a mesma coisa... no sentido de que nós estamos criando uma coisa nova... do nada...

(67) [EF SP 405 56] eu acho que sim eu acho que a arte do retrato é MUIto difícil porque aí você exige a semelhança... enquanto se você está criando você não precisa colocar nenhum padrão... a não ser o padrão da própria obra... certo?

(68) [EF POA 278 21] o que é uma taxionomia, por que um professor deve conhecer uma taxionomia e utilizá-la, não que necessariamente ele precise saber que neste momento o aluno está desenvolvendo um processo de análise, mas ele precisa, ao planejar, ao prever as suas atividades no seu trabalho docente,

(69) [EF POA 278 39] então, nós temos a compreensão...é a segunda categoria então, o homem faz, está utilizando um processo mental, já de compreensão, quando ele utiliza a informação através de uma interpretação, através de uma tradução, sobre isso, aqui, até os autores que (ininteligível) eram Bloom, ainda fez (fizeram) uma subidivisão, ela não é de maior importância mas vale a pena apenas para, a título de, de esclarecimento, de maior compreensão

As ocorrências acima mostram que os professores instauram um "presente" (neste momento) em seus discursos e prova disso são os verbos no presente do indicativo (estão, exige, precisa, faz, temos, etc.), e juntamente projetam personagens e outros participantes imagéticos (as coisas, você, o aluno, o homem).

\section{V.5 A discursivização do gerúndio ambíguo}

O gráfico 16 mostra que a discursivização do gerúndio ambíguo se deu de maneira diferenciada nos corpora analisados. No geral, dispomos de poucos exemplos no Corpus Básico, são apenas 41 casos de gerúndio ligado ao sujeito da OM e, no cômputo geral, percebe-se um decréscimo progressivo do séc. XVIII para o séc. XX $(18>15>8)$. Não encontramos ocorrências dele nas cartas oficiais do séc. XX, e nas peças teatrais não ocorre a partir do séc. XIX. Nas cartas da administração privada ele simplesmente não ocorre. Distribui-se de maneira irregular nas cartas particulares, baixando no século XVIII e voltando a aumentar na $1^{a}$. metade do século XX. Essa oscilação, no entanto, combina com o seu caráter 
fuzzy, entre oração adverbial e oração adjetiva. Aliás, em termos relativos, no Corpus

Básico é mais freqüente do que o conjunto dos outros tipos de gerúndio adjetivos.

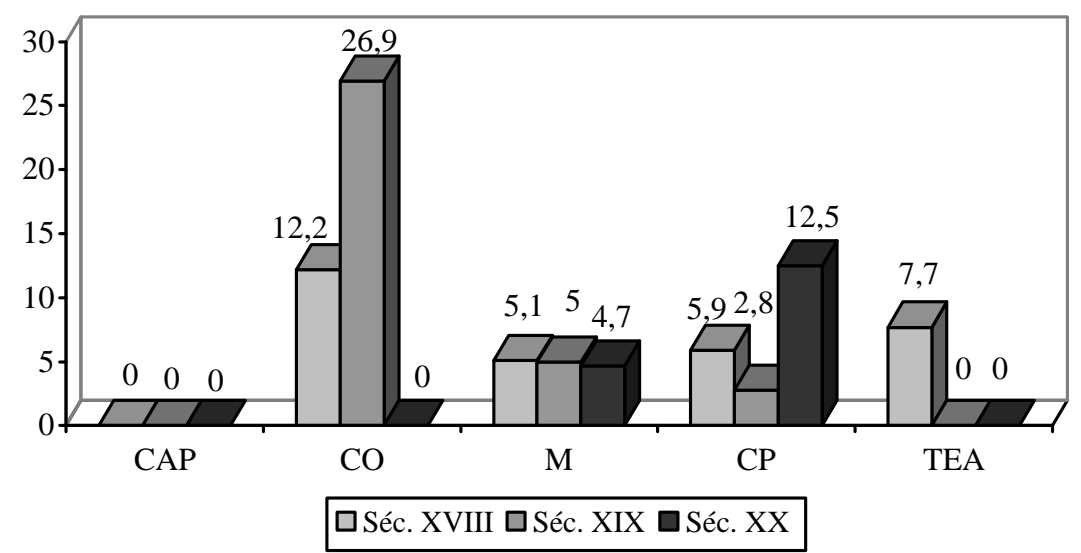

Gráfico 16. O gerúndio ambíguo no Corpus Básico

Embora de maneira tímida, se compararmos com as cartas $(5,1 \%>5 \%>$ 4,7\%), as memórias são o ambiente em que o gerúndio ambíguo se manifesta de maneira mais estável nos três séculos:

(70) [M 181 NP1 82] Nesse tempo se tinha humanizado já mais o gentio, buscando-nos, e servindonos sem arco e flecha, e admirando muito as nossas armas.

(71) [M 192 HC 16] À parte geográfica das expedições corresponde mais ou menos o seguinte esquema: Os bandeirantes deixando o Tietê alcançaram o Paraíba do Sul pela garganta de São Miguel, desceram-no até Guapacaré, atual Lorena, e dali passaram a Mantiqueira, aproximadamente por onde hoje transpõe a E. F. Rio e Minas.

(72) [M 202 ERN 4] Uma dessas estradas corria em direção ao vale do rio Paraíba do Sul até a atual cidade de Bananal, no trajeto para o Rio de Janeiro. Outra, avançando pela serra da Cantareira, alcançava Bragança, de onde era possível chegar ao sul de Minas.

O quadro geral de ocorrências (v. tabela 11) aponta que o gerúndio ligado ao sujeito é o terceiro tipo de gerúndio utilizado nos anúncios de jornais do séc. XIX (15,2\%, com 10 ocorrências):

(73) [A 192 SP 44] Confeitaria||CAMPINEIRA||Mudou-se da rua do Imperador para a rua Direita número 54. Participa ao respeitavel publico que recebe qualquer encommenda de doces de qualquer qualidade, para casamento, baile e baptisados, bebidas de todas as qualidades, como sejam vinhos Italianos e francezes, Bordeaux, Borgogne, Souterne e Porto; licores de qualquer qual[i]dade.| Fornece para meza: Champagne de diversas qualidade.| Este estabelecimento estando com proporções para bem servir aos seus freguezes espera d'elles topda [toda] a coadjuvação.| Encontra-se todos os dias café da manhã e pão com manteiga. A Mocidade, 28 de junho de 1874

(74) [A 192 SP 45] O abaixo assignado tendo-se associado na garantia do premio integral com o senhor Joaquim Vieira de Moura, faz publico d'ora em diante a assignatura dos bilhetes garantidos, poderá ser feita por qualquer dos dois e da maneira seguinte: Ornellas \& Moura.| Pedro C. Ornellas A Mocidade, 02 de agosto de 1874

(75) [A 192 SP 46] ATTENÇAO||Eduardo Pons e sua senhora Dona Elettra S. Pons, resolvendo habitar n'esta cidade, offerecem-se para leccionar, canto piano e flauta. No hotel do Commercio, aonde residem, se recebem os avisos. A Mocidade, 09 de agosto de 1874

No século XX, encontramos esta ocorrência no inquérito D2: 
(76) [D2 SP 360 112] L1 tinha-se esperanças...em que dona Ana Cândida tendo assumido a procuradoria geral do Estado...em ela sendo mulher...que ela defendesse um pouco mais a:: a classe não?

A distribuição do gerúndio ambíguo parece estar condicionada tanto pela sua propriedade sintática de ordem, como pelo seu caráter discursivo. Os gerúndios ligados ao sujeito interpolam-se na oração matriz e sabe-se que a inserção é o ambiente preferido para a agregação de informação secundária à qual se quer dar destaque. Assim, para os exemplos acima, recolhidos nas memórias, nos anúncios e o exemplo do D2 também vale o raciocínio apresentado anteriormente explicando o alto índice de perífrases de gerúndio nas EFs. Também aqui vemos que o gerúndio atende às necessidades do contexto discursivo, porque nele são reativadas essas propriedades semânticas. Não se trata aqui, portanto, de discutir se é uma forma privilegiada nos textos de norma mais culta ou popular, formais ou informais. Se fosse assim, eles não apareceriam nas cartas particulares escritas por Mario de Andrade, tão conhecidas pela sua irreverência:

(77) [C 201 MA 340 1] outro dia lhe escrevi uma carta sem conversa, pela sua que obrigava a resposta pronta. Mas sua carta anterior, comentando o "Grifo da morte" me devia uns considerandos. Vão aqui.

(78) [C 201 MA 340 6] Não sei se lhe contei, uma circunstância curiosa que me preocupou muito foi que depois de exames, diagnóstico de médico e tudo, tendo que escrever o estudo de introdução pro livro do Gallet, li toda a correspondência dele e topei inesperadamente com uma carta dele, duns cinco anos atrás, em que uma grafóloga aí do Rio, amiga dele, topando com uma carta minha na secretária dele, não sabendo de quem era nem me conhecendo pessoalmente, disse a ele que o indivíduo da carta iria em poucos anos sofrer dos rins e se tratasse muito porque o caso podia se tornar muito grave.

\section{V.6 A discursivização do gerúndio adjetivo}

As orações de gerúndio adjetivo também são pouco representativas nos corpora, contando com 26 casos nos três séculos do Corpus Básico, chegando a 44 ocorrências, se considerarmos o Corpus Diferencial do séc. XIX e do séc. XX. Concentro-me inicialmente no conjunto mais uniforme de dados, para tentar detectar em que ambiente textual ele pode ter se desenvolvido a partir do séc. XVIII. Dos 26 exemplos encontrados no Corpus Básico, 20 ocorrem no século XIX. O gráfico 17 aponta que ele ocorre mais freqüentemente nas memórias, embora que também timidamente $(1>9>1)$. Neste tipo de texto, ocorrem os gerúndios ligados ao objeto direto (79), ao absolutivo ergativo (80) e ao SN complemento de preposição de (81):

(79) [M 182 MPC 19] naõ lhe cervindo de exemplo ainutilidade com que nos tempos antigos se tinhaõ feito semelhantes des- pezas pela Fazenda Real, fez ao Povo hum extraordi- nario reclame obrigando aque fosse nas expediçoens, 
(80) [M 192 RL 22] Era a estrada larga e corria ao longo de magníficos bosques, onde predominavam os umbus balsâmicos, espalhando ao longe o perfume das flores abertas, os piquis, carregados de frutos, e as inesgotáveis mangabeiras.

(81) [M 202 ERN 13] A solução para o problema dos transportes foi a construção de uma rede ferroviária ligando toda a região da cafeicultura ao porto de Santos.

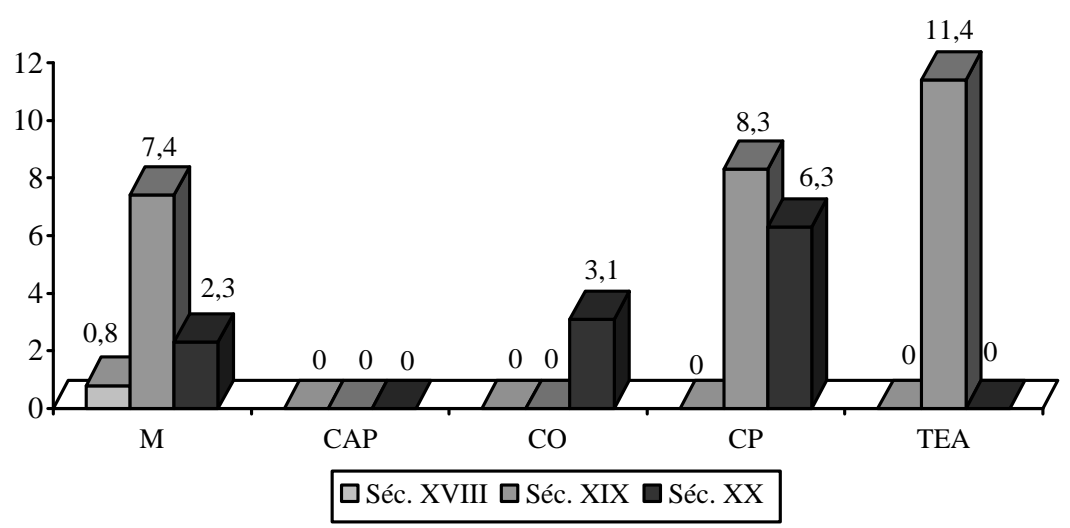

Gráfico 17. Freqüência de orações de gerúndio adjetivo por século no Corpus Básico.

Levando-se também em conta o Corpus Diferencial nota-se que, como já havíamos apontado no capítulo IV, é na $2^{\mathrm{a}}$. metade do séc. XIX que o gerúndio adjetivo ganha mais vigor, contando com 21 ocorrências das 29 que ocorrem neste século. Neste período, o gerúndio adjetivo aparece em quase todas as possibilidades sintáticas, à exceção do gerúndio ligado ao complemento absolutivo de verbo existencial. Essas ocorrências aparecem bem distribuídas na tipologia textual representada no corpus, e comparando-se as duas fases desse século, nota-se ainda que há um aumento quantitativo do gerúndio adjetivo em todos os gêneros textuais, mantendo-se igual nas cartas de redatores. O pequeno número de ocorrências não permite uma afirmação muito segura a respeito do processo de discursivização do gerúndio adjetivo (v. gráfico 18). No entanto, como esse era um fenômeno que não estava isolado a um determinado tipo de texto, de que é prova a distribuição equilibrada nos vários gêneros textuais, há uma evidência que o gerúndio adjetivo era bastante produtivo nesse século. 


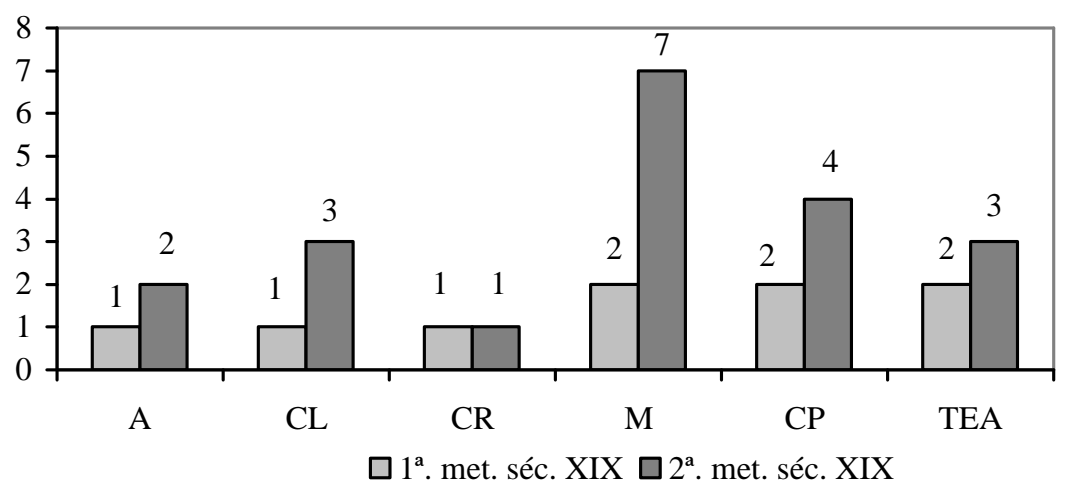

Gráfico 18. Gerúndios adjetivos no século XIX.

Embora diminua bastante, no séc. XX esta é uma forma ainda bem representada nas cartas particulares e nos inquéritos DID, sendo na maioria dos casos construções de gerúndio ligado ao OD da oração matriz:

(82) [C 201 MA 323 20] Recebi ontem um anúncio do jornal indicando a venda do livro, dois dólares.

(83) [DID SP 234 89] ontem eu assisti...Carvalho Pinto falando com DOnas de casa...a filha dele...e o::a Sônia Ribeiro Alik Kostakis então eu assisti...mas falava-se muito sobre o o o alto custo de vida...era isso que se falava...mas é::meio cansativo pro/ o programa político né?...depois de assistir a novela a gente (não) vai assistir...programa político ((risos)) vão até tarde atrapalha um bocado ((ri))

\section{V.7 A discursivização do gerúndio em nominalizações}

As orações de gerúndio independente em construções nominalizadas são pouco freqüentes, distribuindo-se pelos corpora de maneira distinta tanto em textos de língua escrita como de língua falada, de forma que não podemos dizer que este tipo de construção esteja condicionada a algum tipo de texto específico, embora determinados tipos de nominalizações sejam mais específicos da interação face a face, como é o caso das sentenças exclamativas e interrogativas:

(84) [TEA 202 Per 10] EMÍLIO Todos falando ao mesmo tempo... da esquina a gente já podia ouvir os gritos.

(85) [PPop 220 78] Inf. aquele monte de criança tudo pequeno né... tudo dependendo do meu esposo ele tinha que... trabalhá né? sei que o médico "ó cê tem que operá... cê tem que escolhê o a vida" ((ri)) aí que eu falei "não peraí" eu falei "não peraí né quero vivê mais" ((ri))

(86) [D2 SP 360 60] L2 ah sim sete sete e meia que seis e meia da manhã...quer dizer é o horário normal que eles acordam inclusive em fé::rias a gente está viajan::do...todo mundo querendo dormir mais tar::de seis e meia quinze para as sete está todo mundo acordado...

O mesmo recurso pode ser visualizado nas cartas de leitores do séc. XIX que envolvem um maior grau de emocionalidade, como se reproduzissem a fala. No 
exemplo (87), o autor da carta dialoga com uma comadre fictícia e faz um desabafo em tom de ironia. Já o leitor de jornal, no exemplo (88), reclama de um professor que não cumpre o seu trabalho a contento:

(87) [C 192 CL 474 6] Veja, pois, comadre, como não andará uma pobre | mãi! || Bem disse nho Frutuoso - que a causa de tudo que | estamos soffrendo é não se ter soldados, e que por isso | qualquer estrangeiro nos faz quanto desaforo quer, e | nós sempre aguentando com cara alegre....

(88) [C 191 CL SP 393 4] (...) de | maneira que o pequeno estudo (que ao | meu ver, não é nem-um) dos meninos | com umas tão longas, e continuadas ferias, | ficão no mesmo estado como que nunca es- | tudassem, e no entanto a soffredora Na- $\mid$ ção concorrendo com os 150:000 réis annuaes | sem que d'elles provenha-lhe o menor bem.

São comuns também nos finais das cartas, resultado de um longo processo de discursivização do gerúndio nesse gênero textual.

(89) C 202 CL 42 5] Com um abraço, esperando que a senhora compreenda a minha posição diante de fato tão desagradável, | cordialmente, |Anna Maria | assistente social

\section{V.8 A discursivização do gerúndio imperativo}

Os resultados obtidos na tabela 11 para o gerúndio imperativo indica que este tipo de construção tem um representação pouco significativa que pudesse permitir alguma afirmação quanto ao seu caráter de mudança. O maior índice foi encontrado no século XVIII, mas este fato está condicionado ao contexto comunicativo de um dos entremezes analisados.

\section{Conclusões sobre a discursivização do gerúndio no português brasileiro}

Iniciei este capítulo com a análise do papel discursivo exercido pelo gerúndio nos textos orais e escritos como elemento utilizado para a articulação dos tópicos discursivos, na elaboração de paráfrases e como focalizador da elaboração tópica. Os resultados quantitativos mostraram que as orações adverbiais (OGadvs e CAs) são pouco freqüentes em textos de pouca formalidade como as cartas particulares, os diálogos de teatro e os inquéritos de língua falada da $2^{\mathrm{a}}$. metade do século $\mathrm{XX}$, permanecendo bastante produtivas em textos de maior planejamento como as memórias, as cartas da administração privada e as cartas oficiais. Comparando-se as orações adverbiais gerundiais com as conjuncionais notou-se uma maior preferência por orações conjuncionais no século $\mathrm{XX}(74,7 \%)$. Em relação às perífrases com gerúndio, foram encontrados os menores índices nas memórias 
históricas, nas cartas de administração privada e nas cartas oficiais, contextos de maior formalidade e planejamento de texto. As memórias são o contexto mais resistente às perífrases nos três séculos. À exceção das memórias, notou-se uma tendência de aumento em todos os tipos de textos, de um século para o outro. Os índices mais altos de perífrases aparecem nas cartas particulares e nas peças teatrais. $\mathrm{O}$ corpus de língua falada do séc. XX mostrou que o contexto mais propício à realização de perífrases é o de fala popular. O uso de perífrases em elocuções formais mostrou-se condicionado à semântica envolvida no uso das perífrases como recurso de relevo. O gerúndio adjetivo aparece de forma bem distribuída no séc. XIX na tipologia textual analisada. Embora diminua bastante, no séc.XX o gerúndio adjetivo ligado ao OD da OM ainda está bem representado nas cartas particulares e na língua falada. Os gerúndios em nominalizações do tipo afirmações, exclamações e perguntas são produtivos na língua falada, bem como o gerúndio imperativo.

A opção por analisar o comportamento do gerúndio segundo a tipologia textual, as condições de produção e a norma envolvida mostrou-se bastante pertinente, pois através dela pode-se perceber em que contextos se deu a diminuição de alguns tipos de gerúndio (OGadvs e CAs) e o aumento de outros (perífrases).

No capítulo seguinte, analiso o comportamento dos tipos de gerúndio segundo a semântica envolvida nestas construções. 


\section{- CAPÍtULO VI -}

\section{A semanticização do gerúndio}

Quero acrescentar, à guisa de informações sobre a jovem e sobre mim, que vivemos exclusivamente no presente pois sempre e eternamente é o dia de hoje e o dia de amanhã será um hoje, a eternidade é o estado das coisas neste momento.

Clarice Lispector. A hora da estrela, 1977.

Até o momento já evidenciamos as propriedades sintáticas das orações de gerúndio, dispondo-as assim em classes, e o papel discursivo que desempenham no português brasileiro, observando também em que contextos determinadas classes mais aparecem. Neste capítulo analiso que funções semânticas o gerúndio desempenha, como estabelecer o relevo e projetar alguma relação proposicional com o evento expresso na $\mathrm{OM}$ e verifico como as orações de gerúndio se comportam ao longo dos três séculos analisados, de acordo com o seus valores semânticos, relacionando-os com a sua atuação na tipologia textual estudada.

\section{VI.1. O gerúndio como item sintático que evidencia o relevo no processamento da informação}

Ao longo do trabalho mostramos que as construções de gerúndio muitas vezes são utilizadas como recurso estilístico que serve para estabelecer o relevo nos enunciados. O falante/leitor escolhe esta estratégia para destacar informações que julga importantes ou que servem de ponto de partida para a compreensão de seus enunciados por parte do ouvinte/leitor. Aplica-se aqui o conceito de relevo assim como foi estudado na descrição do processamento dos tópicos discursivos (Travaglia, 1999 e 2006) e amplia-se esse conceito também à construção do texto escrito. Por estar associado ao conteúdo proposicional dos enunciados, julgamos mais coerente proceder a uma descrição dessa estratégia neste capítulo, uma vez que ela afete as propriedades semânticas do gerúndio. Essa dupla função do relevo, ou seja, discursiva e semântica, já havia sido detetectada:

Parece que o falante dá relevo a elementos dentro do desenvolvimento do tópico discursivo por razões diversas, sobretudo por razões ideacionais/cognitivas, argumentativas e 
emocionais, com diferentes funções. $\mathrm{O}$ relevo, assim, estaria ligado à estrutura ideacional e interacional do texto (Travaglia, 1999:78).

O conceito de relevo está associado ao grau de saliência que certos itens ganham em um texto durante o processamento da fala. Ao produzir seus enunciados, o falante a) pode manter todos os elementos envolvidos nos eventos descritos em um mesmo plano, sendo que aí não há caso de relevo, exemplo disso são os enunciados que obedem a uma ordem canônica em uma determinada língua; b) pode fazer elevar determinados elementos do texto a um plano superior, dando-lhes ênfase em relação aos outros - neste caso temos o chamado relevo positivo, ou proeminência -, seguindo o exemplo anterior, o falante pode ferir a ordem de adjacência e mover determinados constituintes projetando o foco de atenção sobre o elemento deslocado, ou c) pode rebaixar a um plano inferior determinados elementos do texto, uma espécie de 'ocultamento' de elementos que, do ponto de vista do falante, não têm interesse para a conversação ou para o texto, quase sempre isso ocorre como estratégia de argumentação - tal procedimento é chamado de relevo negativo ou rebaixamento (Travaglia, 2006:167). Os exemplos abaixo ilustram respectivamente um caso de proeminência e outro de rebaixamento elaborados através de construções com gerúndio:

(1) (D2 255 SP:644-651) 357

L2 é eu gostaria de acrescentar C. o seguinte ... que:: eu tenho a impressão que:: tendo em vista o potencial que representa a televisão ... potencial assim ... de ligação entre o ... países de ligação entre pessoas entende? comunicação ... dando até mesmo unidade nacional você falou ... nesse momento que:.... retirava a riqueza dos regionalismos ... mas ... o mesmo veículo que pode ter ... causar este mal poderá causar um bem ...

(2) (DID 234:172-4)

Doc. e tirando a parte do artista a senhora acha que devem haver outros cuidados para a peça ser bem::bem apresentada obter um bom sucesso?

Em (1), o falante interrompe a formulação após o que e projeta o relevo sobre o potencial da televisão, argumento que toma como base para fazer a afirmação que é concluída após o articulador que marca a retomada do enunciado interrompido. NO exemplo (2) o documentador promove uma "debreagem" no tema, ou seja, tira a parte do tópico que para ele no momento não é relevante.

O relevo pode ser expresso por estratégias de diferente natureza: a) um contraste entre figura e fundo; b) hierarquização de informações essenciais e

\footnotetext{
${ }^{357}$ A notação entre parênteses indica que esses inquéritos de língua falada não fazem parte dos corpora utilizados para a análise quantitativa.
} 
secundárias; c) indicação de relevância pragmática de algum elementos da situação presente da enunciação e d) fatos de focalização em determinados itens que ocorrem nas unidades tipológicas do texto (narrativa, descrição, dissertação, injunção).

Entre os recursos utilizados para marcação do relevo no texto, destacam-se elementos ligados mais especificamente ao plano da língua como a entonação, os recursos léxicos, os recursos morfológicos, os recursos sintáticos e no plano da construção do texto podemos observar os marcadores discursivos, os parênteses, os recursos expletivos, e a tematização como forma de ressaltar determinados elementos que são inseridos no texto. Durante a coleta de dados, verifiquei que o gerúndio pode exercer essa função de proeminência ou rebaixamento de partes do texto, tanto como item do plano da gramática ou como elemento do plano do discurso, levando-se em conta os contextos discursivos em que aparece. Adiante destaco como sua morfologia e sua sintaxe atuam no seu funcionamento como estratégia de inserção (parênteses e tematizações) e colaboram assim para evidenciar o grau de saliência de determinados elementos em um texto.

\section{VI.1.1 O relevo em parênteses}

No capítulo anterior demonstrei como construções de gerúndio podem servir como marcas que colaboram para a organização dos tópicos através da inserção de parênteses. Preocupei-me ali em demonstrar como se dá a organização inter-tópica no processo de construção do texto (continuidade e descontinuidade). Nesta seção, procuro mostrar como os gerúndios, ao introduzir parênteses, também exercem uma outra função concomitante, de organização intra-tópica, que é a de promover a proeminência ou o rebaixamento de informações e, assim como ficou dito acima, construções com gerúndio podem desempenhar funções de caráter mais argumentativo como enfatizar, intensificar, marcar sentido especial, marcar contraste, inserir um reforço argumentativo, marcar importância para a estrutura ideacional/informacional, ou marcar foco informacional sobre determinados elementos do texto em construção (Travaglia, 1999:78 in Neves, org.). Vamos verificar isto através de alguns exemplos:

(3) (D2 255 SP:763-768) 
Doc. $\quad$ muito bem ... acho que nós ... já tivemos ótimas ... apresentações sobre parte do... do rádio... televisão ... nós queríamos modificar um pouquinho agora ... a área falando um pouco sobre comunicação e difusão ... então nós gostaríamos que o professor C. falasse sobre o problema do correio ...

(4) (D2 333 SP:1164-1169)

L2 lembra-se do caso do Flávio ... que que acabou ...

L1 que por sinal agora ... que por sinal agora [

L2 acabou ()

L1 em falando em Flávio Cavalcante por sinal agora ... é um novo contratado do Sílvio Santos ... então

(5) (D2 SP 62:642-45)

L1 agora:: ... ((pigarreou)) inclusive falando um pouco da Medicina aí você veja como é que está a situação hoje em dia ela está:: socializada né? ...

Nas ocorrências acima, verifica-se que a utilização do verbo falar deu-se em função de sua natureza como verbo típico da conversação. Assim como vimos no capítulo anterior, permanecem preservadas muitas das propriedades propriedades semânticas do radical dos verbos, embora sintataticamente lhes faltem os sujeitos. A morfologia do gerúndio dá conta de demarcar um uso formulaico, típico das intervenções sob forma de digressão ou parêntese:

(6) [C 182 Seb 22 5] eCo= mo opiCador me aSegura estar para Câ daSerra al- guâ distanSia parage mais alta que aSerra donde de viraõSe as agoas; pareSendo ser de JustiSa aquela de paraibuna, aestrema dos noSos destritos; eComo Sem Sem Ser este asento feito nolugar do agrado devossa Excelencia puriSo, epara mesaber aver nesta obra dezejo aonRa deque vossa Excelencia medeSida esta duvida pelomesmo por tador desta [OM].

(7) [M 191 RDN 36] (b) vendo oGovernador Geral que as Aldeas estavaõ despovoadas; [sendo] alia[s] os Indios taõ neceSsarios para todo oServiço, que [se empreendia] afavor daCoroa, determinou a 18de8[outu]bro dodito anno, que todos osque fossem aoSertaõ buscar Indios, paga[ss]em 05.o, pondo nas Aldeas deSua Magestade a5.a parte della[[e]]s, eque metade deste 5.o seRemetesse áBahia para lá fundar huma Aldea.

Nos exemplos acima, encontramos marcas que confirmam o estatudo de inserção da construção de gerúndio. No exemplo (6), observa-se a retomada da estrutura eComo após o parêntese encabeçado pelo gerúndio. Em (7), o item alias dá suporte à idéia de interrupção.

O gerúndio é selecionado nestas estruturas por motivações semânticas associadas a essa forma nominal. Sabemos que o gerúndio é portador do aspecto imperfectivo e é justamente essa propriedade que atua conjuntamente nesse processo. Vejamos isto na próxima seção. 


\section{VI.1.2 $O$ aspecto nas construções de gerúndio}

$\mathrm{O}$ aspecto atua sobretudo no estabelecimento do relevo do tipo fundo e figura e, pelo que pudemos verificar no corpus analisado, isso acontece em textos narrativos. Nesse caso os trechos com aspecto perfectivo aparecem em primeiro plano como figura e os trechos com aspecto imperfectivo aparecemem segundo plano como fundo, constituindo um quadro em que a ação característica da narrativa se desenvolve (Travaglia, 2006:191).

Em textos que apresentam mais trechos narrativos e dissertativos como as memórias e as cartas, as sequiências que representam o fundo aparecem em partes chamadas de orientação e de avaliação. A orientação é o trecho da narrativa em que se descrevem os cenários e participantes da ação ou "se monta um quadro de acontecimentos com o qual a ação da narrativa coincide temporalmente” (Travaglia, 2006:191). A avaliação aparece em trechos em que o falante registra suas impressões sobre a ação de forma avaliativa ou justificando-a, tal recurso aparece com freqüência em seqüências dissertativas.

A questão de figura e fundo tem sido tema primordial daqueles que trabalham com a Semântica Cognitiva (Talmy, 2000).

Os exemplos abaixo demonstram como o aspecto imperfectivo expresso tanto nas perífrases com o gerúndio, como nas construções absolutas, exercem a função apontada por Travaglia. Os trechos em itálico representam o fundo os trechos sublinhados referem-se à figura:

(8) (D2 SP 343:663-8)

L1 outro dia aí então o (Fábio) contando umas histórias de um:.... de um de um boy barato aí né?...carro envenenadíssimo... então temos que quando o cara vai acelerar assim::... ele aGArra a direção assim:: pisa no acelerador:.... e faz um movimento assim como estivesse caval/ cavalgando

(9) (DID SP 161, 1-5)

Doc. C. A.... você estava dizendo pra gente sobre umas representações teatrais... daria para você contar alguma coisa assim sobre essas representações que você fez... que tipo de pe::ças e $\underline{\text { tal?... }}$

(10) (D2 SP 343:61-70)

L2 mas que

L1 todo mundo na rua... ah não sei... deve ter uns:.... [

L2 tamaho quantos habitantes tem lá?

L1 cinqüenta cem mil...

L2 éh São Paulo acho assim uma vez o Franck sabe aquele que... que é arquiteto?

L1 uhn...

L2 ele estava falando que a topografia da cidade é muitobonita... e eu inclusive gosto né? cheio de... montes e:: né?

(11) (D2 SP 343:1212-1221) 
L1 não muda por exemplo... se você tem uma Idade Média que não tem na::da prático (não dá nada) é tudo obscuro... você pega uma família::...éh::agora

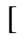
pois é... mas eu estava...

L2

L1 uma família duzentos anos antes é:: é tudo mais ou menos do mesmo jeito né? aparentemente pode ser diferentemas no fundo é igual né?... só mudou

falando de mudanças de forma... acho que no fundo as coisas continuam a mesma... as mesmas este texto que eu estava lendo...

Nestes exemplos, percebe-se que a opção pelo gerúndio promove uma debreagem enunciativa, ou seja, o tópico narrado é interrompido e uma nova informação é agregada. Na língua escrita a relação de fundo e figura aparece na constituição dos cenários e seus participantes. A partir deste recurso estabelece-se o ponto de vista a partir do qual deve ser visualizada a cena. Talmy (2000) fala de um processo chamado windowing, uma espécie de emolduramento projetado pelo falante/autor sobre um ponto específico da cena dada:

(12) [M 191 BON 1] Tendo vizitado a Real Fabrica de ferro de Saõ João do Ypane_| Ma e apanhado da boca doshomens, que ahi rezidiaraõ e trabalharã̃ to- I das as noticias mais importantes que pude recolher, passo agora a ex_ I pôr oseu estado actual eos melhoramentso que deve ter. Naõ me_ | hé poSivel pelo pouco tempo, que dei asemelhante exame entrar em- | todas as suas miudezas, nem referir todos os abuzos de Administra- $\mid$ çaõ, e os erros das suas manipulaçoens; mas oque disser, hé mais que | suficiente para se fazer hûa idea clara do estado deste utillissimo | Estabelecimento. (XIX - Memória - Bonifácio)

(13) [M 201 WLC 4] Comandando uma expedição, partida de Corunha em 1526, com o fim de explorar o Rio da Prata, Diogo Garcia chegou a S. Vicente a 15 de Janeiro de 1527 - "cinco anos antes de Martim Afonso", - e, narrou ter encontrado o bacharel e seus genros, aí moradores "mucho tiempo há que há bien 30 años". Deles comprou um bergantim, se abasteceu de água, lenha e todo o necessário para a viagem, contratou um dos genros por língua (intérprete) até o Rio da Prata. (XX - Memória - WL)

Nos exemplos acima, as construções encabeçadas pelo gerúndio devem ser entendidas como o ponto de partida para a compreensão do que vai ser descrito em seguida. Muitas vezes essa estratégia é utilizada para ordenar a seqüência dos fatos, mas notadamente pode-se perceber o matiz proposicional que estas estruturas encerram, tempo-causal em (12) e, temporal-final em (13).

\section{VI.1.3 O papel das orações de gerúndio na construção do relevo}

A opção pelo uso de orações de gerúndio parece mesmo estar associado à construção do relevo. No exemplo (14), a oração gerundial agrega uma informação secundária que o anunciante quer ressaltar. Nesta estrutura parece acumularem-se a função sintática de oração adjetiva, introduzida pelo pronome relativo que, e a 
função de oração adverbial introduzida pelo verbo no gerúndio escapando. A somatória "que escapando" faz sobressair no trecho o valor adjetivo:

(14) [A 191 SP 8] Na Cadêa da Villa de Sanctos se acha ainda| um escravo, que diz chamar-se João, e ser de na-|ção rebollo. Este escravo, que escapando á expe-|dição dirigida contra o Quilombo existente na Serra| do Cubatão, se veio entregar obrigado pela fome,| e medo, tem ultimamente declarado pertencer á um| Senhor de nome Luiz Antonio morador de Mogi-Gaussú.| Quem for realmente seu dono, o venha logo buscar,| aliás se executará o que manda a Lei a este respeito. $O$ Farol Paulistano, 09 de agosto de 1828

Esta característica já tinha sido ressaltada por Travaglia (1999:116): “As orações reduzidas e as orações adjetivas normalmente veiculam informação que o falante vê como secundária ou que, por alguma razão, quer apresentar como tal ao seu interlocutor. Este é o caso em diferentes tipos de texto". Discordo em parte deste raciocínio, pois, embora seja secundária, o fato de o falante deslocar essa informação, interpolando-a ou antepondo-a, justamente eleva o seu status semântico.

\section{VI.1.4 O relevo como processo de focalização de partes do texto}

Na coesão do texto, o processo de focalização tem por função básica a tarefa de organizar o texto, oferecendo ao interlocutor elementos que funcionam como apoios para o processamento textual. Tais itens servem como indicações dêiticas (para cima, para baixo, para a frente e para trás) e estebelecem a organização entre os segmentos textuais. Ingedore Koch prefere enumerar estes itens dentro de um quadro de "dêixis textual", pois essas "expressões dêiticas permitem ao falante obter uma organização da atenção comum dos interlocutores com referência ao conteúdo da mensagem" (Koch, 1988:3,4, apud Travaglia, 1999:120). Para conseguir o seu objetivo, o falante focaliza a atenção do interlocutor sobre objetos, entidades e dimensões de que faz uso na sua formulação. ${ }^{358}$

Visto por esta perspectiva, o gerúndio pode compor construções focalizadoras de partes do texto. Em todos os exemplos citados no capítulo anterior desempenham essa função de focalização. Neles o gerúndio atua como item que introduz a retomada de tópico abandonado e o início de novo tópico. Quero valer-me aqui apenas de alguns desses exemplos:

(15) (D2 255 SP:314-316)

\footnotetext{
${ }^{358} \mathrm{O}$ termo focalização é aqui utilizado da mesma forma como o fizeram os pesquisadores do grupo de organização textual-interativa da Projeto Gramática do Português Falado.
} 
Doc. agora mudando um pouquinho de assunto além das atividades profissionais no no no fim de semana ... vocês vão ao assim algum lugar para se distrair?

(16) (D2 SP 396:557-560)

Doc. (agora)vocês Acham que os::tecidos --voltando ao...ao assunto--...éh:::os tecidos se adaptavam eram adequados ao nosso clima...naquela época?

Nestas ocorrências, o marcador conversacional agora atua como operador discursivo e dêitico, reorientando o foco de atenção sobre o objeto de formulação, ele demarca o fim de uma unidade textual e apresenta uma nova parte, as expressões introduzidas pelo gerúndio mudando um pouquinho de assunto e voltando ao assunto confirmam o relevo sobre o tópico em curso. As construções perifrásticas com o gerúndio são mais ricas nessa função de orientação textual, pois a explicitação do aspecto imperfectivo desnuda o caráter incompleto de tópicos em curso, como demonstram os seguintes exemplos:

(17) (D2 SP 343:1183-1292)

L2 acho que vai acelerar um processo que já está acontecendo né?

L1 de?

L2 isso tudo isso que a gente estava falando né?... assim contradições e:.... ahn... coisas co::mo... a poluição...o conhecimento do ( ) populacional inclusive tal vão... se acentuar mais você pode inclusive dizer que o nível geral de... sei lá de ansiedade das pessoas vai aumentar... eu acho provável isso... estou vendo em termos bem amplos assim civilização ocidental::...

(18) (D2 SP 62:420-1)

L1 bom nós estávamos só só retomando:. ... você estava falando sobre ... sobre o problema do

O recurso do relevo de partes do texto está naturalmente condicionado à natureza do texto. É muito comum encontrar esta estratégia em elocuções formais. Nelas, o professor, por uma preocupação didática, chama a atenção de seus alunos para segmentos do texto em construção, de modo a tornar mais clara a sua exposição:

(19) (EF SP 405) então nós vamos fazer uma diferença aqui olha... uma coisa é dizer que a arte na época... tinha fun-ção... pragmática... porque é isso que a gente vem dizendo até agora certo? se ela foi criada... para um FIM... OUtro... que NÃO... a contemplação estética... ela é pragmática... então ela foi criada com uma função pragmática... outra coisa... é eu falar em es-TI-lo... naturalista...

(20) (EF RJ 379) hoje vou dar uma introdução, tentando localizar as principais diferenças práticas do início da industrialização no Japão e dos Estados Unidos atualmente bom...então, voltando um pouquinho atrás, nós vimos que o início da industrialização nos Estados Unidos se deu de uma maneira direta, né?, decorrente...de uma aplicação de excedente...europeu,

Em todos os casos, outros elementos dêiticos aparecem na focalização em questão, tal como pronominais co-referenciais do tipo isto, isso e aquilo, além de locativos dêiticos como atrás, acima, abaixo, dêiticos temporais do tipo agora, então e marcadores do tipo bom, perfeito, legal. O morfema do gerúndio contribui nesse 
"conglomerado" de dêiticos com seu caráter imperfectivo, promovendo a progressão textual, e permitindo a apresentação de verbos de determinada categoria como os anunciados acima (verbos de movimento, verbos dicendi, verbos ligados a processos de referenciação, verbos ligados à atividade mental,entre outros).

A posição não-marcada desses elementos que promovem o relevo é naturalmente a anteposição, pois é nesse plano que o falante aloca os conteúdos informacionais que considera mais importantes e que servem de pano de fundo (no sentido Talmyano) para a compreensão do que irá ser dito em seguida (a figura de Talmy).

A questão da posição remete-nos agora à estratégia discursiva em que o recurso do relevo mais se sobressai: a tematização. Na seção seguinte, discuto primeiramente a diferença entre tematização de seqüências tema-rema e construções de tópico. Em seguida, aplico essa diferenciação, exemplificando com tematizações encabeçadas por gerúndios que funcionam como fatos de focalização em narrativas orais e escritas, na dissertação e na injunção.

\section{VI.1.4 O relevo em tematizações}

Nas seções anteriores demonstramos como a focalização pode recair sobre determinadas partes do texto e verificamos que o gerúndio contribui nessa atividade com sua morfologia e na seleção de verbos de determinada classe semântica, que operam sobre a formulação do texto em curso. Ali se explicou como o foco da atenção recai sobre a atividade lingüística tanto do ponto de vista discursivo, quando atua na organização inter-tópica e intra-tópica, como do ponto de vista semântico. Nesta seção procuro demonstrar como o gerúndio atua na construção dos sentidos de um ponto de vista de organização textual, ou seja, em que tipos de construções ele se encaixa e coatua para exercer a focalização sobre determinado conteúdo informacional.

Os estudos sobre a estratégia da tematização Ingedore Koch (2006) e a ela estão associados os conceitos de tema e rema postulados pelos autores da Escola Funcionalista de Praga (Daneš, Firbas, Sgall, entre outros). Segundo esse ponto de vista funcional, os enunciados estão divididos em duas partes: o tema consiste no 
segmento sobre o qual recai a predicação trazida pelo rema. O tema seria um segmento comunicativamente estático, enquanto o rema se caracteriza por ser dinâmico. Enquanto o primeiro é visto como o núcleo, o segundo funciona como comentário, um é dado, e outro é o elemento novo no processo de formulação dos enunciados. Cabe lembrar que esse é um critério funcional e não posicional, muito verificado na fala e marcado especialmente pela prosódia. A articulação tema-rema pode se dar em duas modalizades: a) em seqüências não-marcadas em que ocorre a integração sintática entre elementos temáticos e remáticos e b) em seqüências com temas ou remas marcadas que apresentam graus mais reduzidos de integração sintática. Chamam-se de tematização e rematização o processo de extração de constituintes do enunciado para uma posição marcada, inicial ou final.

Koch (2006) aplicou o modelo de Koch \& Oesterreicher (1990) na verificação dos graus de integração de constituintes sintáticos em sequiências temarema e rema-tema (v. quadro 22). A autora notou que estas estratégias de construção da coerência textual seguem um determinado padrão: a posição inicial é preferida quando o falante tem o objetivo de para o seu interlocutor o assunto de que se vai falar e a posição final é mais reservada aos esclarecimentos, complementações e adendos.

\begin{tabular}{|c|c|}
\hline \multicolumn{2}{|c|}{ Seqüências tema-rema } \\
\hline Grau de integração sintática & Exemplo \\
\hline 1. Adjuntos preposicionados & $\begin{array}{l}\text { L1 - e nós temos boas orquestras também ( )... } \\
\text { inclusive na Tupi temos boas orquestras e temos } \\
\text {... e no que tange à nossa música popular eu acho } \\
\text { que:: agora a televisão está abrindo as portas... } \\
\text { para a nossa música popuLAR coisa que o rádio } \\
\text { não faz... (D2 SP 333:336-39) }\end{array}$ \\
\hline $\begin{array}{l}\text { 2. Anteposição de complemento com presença de } \\
\text { elemento de retomada }\end{array}$ & $\begin{array}{l}\text { L1 - ele vai ao jogo de futebol com o tio... } \\
\text { porque o Nelson... fins de semana ele estuda } \\
\text { então:: quase não sei com a gente ... (D2 SP } \\
360: 1356-58 \text { ) }\end{array}$ \\
\hline $\begin{array}{l}\text { 3. Anteposição de complemento sem retomada } \\
\text { pronominal }\end{array}$ & $\begin{array}{l}\text { Inf. - bebida alcoólica ... eu gosto muito }(0) \ldots \\
\text { sabe) (DID RJ 328:773) }\end{array}$ \\
\hline $\begin{array}{l}\text { 4. Construções com tema livre sem explicitação } \\
\text { do nexo sintático e/ou lógico-semântico }\end{array}$ & $\begin{array}{l}\text { L2 - agora H. ah:: filme ... água-com-açúcar -- } \\
\text { digamos assim -- para a gente ver certas coisas } \\
\text { que a gente vê:: americanas principalmente ... } \\
\text { antes A Moreninha né? (D2 SP 333:779-81) }\end{array}$ \\
\hline 5. Deslocamentos para o final, antitópicos & $\begin{array}{l}\text { L1 - e... depois volto para casa mas chego já } \\
\text { apronto o outro para ir para a escola... o } \\
\text { menorzinho... e fico naquelas lides domésticas } \\
\text { (D2 SP 360: } 157-59 \text { ) }\end{array}$ \\
\hline 6. Justaposições sem qualquer ligação sintática & e os amigos ... nada ... (exemplo criado) \\
\hline
\end{tabular}

Quadro 22. Seqüências tema-rema, baseado em Koch (2006a:361-66) 
Castilho (2003) propõe uma diferenciação entre tematizações e construções de tópico (CTs). Em seu estudo sobre o processo de discursivização das expressões preposicionadas ele alerta para o fato de que CTs são expressões que "tomam por escopo toda a sentença e não apenas um de seus constituintes", dessa forma, elas estão alocadas fora das fronteiras sentenciais:

Isto quer dizer que distinguiremos 'topicalização ${ }^{359}$ (= [i] mecanismo discursivo de seleção de um tópico textual; [ii] deslocamento de constituinte para a esquerda da sentença) de 'construção de tópico' (= estruturação de um constituinte extra-sentencial). Adjuntos se movem na sentença, mas as CTs já são produzidas em sua periferia” (Castilho, 2003).

Para o autor, as CTs predicam toda a sentença, enquanto (i) os SNs anacolúticos (O ônibus ! e não é que eu esqueci minha carteira outra vez!), (ii) os SNs movidos para a esquerda, coindexados a um constituinte da S (A minha carteira ela está cheia de contas) e (iii) os outros constituintes deslocados para a esquerda (Banana eu não como mesmo) são expressões nominais que não modificam a sentença.

O autor diz que através do expediente de mover as CTs para dentro da sentença é possível reconhecer que se modifica o significado proposicional da sentença: ${ }^{360}$

(21) Com respeito à globalização, eu gostaria que o senhor falasse sobre o significado da globalização no mundo moderno

(21b') Eu gostaria que o senhor falasse com respeito sobre o significado da globalização,

(21b") Eu gostaria que o senhor falasse respeitosamente sobre o significado da globalização,

Segundo o autor, estas alterações claramente não representam paráfrases de (21), mas elas são provas suficientes de que com respeito à globalização em (21) seja uma CT, pois, ao apagar tanto a locução prepositiva com respeito a como o núcleo de sua predicação globalização, o autor propõe modificações que alteram não só a própria estrutura sintática desses constituintes extra-sentenciais como altera o conteúdo proposicional da enunciado fonte. A resultante são advérbios que modificam única e exclusivamente o verbo falar. A verdadeira paráfrase de (21) talvez resultasse do movimento dessas CTs para outras posições, e mesmo assim,

\footnotetext{
359 A partir da publicação do primeiro volume da Gramática do Português Falado Culto no Brasil (Jubran \& Koch, 2006), o fenômeno que vinha sendo chamado de topicalização a que se refere Ataliba Castilho neste trecho passou a ser diferenciado com os termos tematização e rematização, a fim de evitar o choque terminológico com o termo topicalização, um fenômeno também pesquisado pelos estudiosos da sintaxe (Tarallo et al., 1990 [PGPF, vol. I]; Tarallo \& Kato, 1992 [PGPF, vol. II]; Kato et al., 1993 [PGPF, vol. III] ; Callou et al., 1996 [PGPF, vol. IV]; Silva et al., 1996; Moino, 1996; Kato \& Nascimento, 1996; Galves \& Abaurre, 1996; Leite et al., $1996 \mathrm{e}$ Rocha, 1996).

${ }^{360}$ Exemplos de Castilho, 2003.
} 
apesar da posição interna ou final, esses enunciados continuam exibindo o mesmo caráter modalizador do tipo hedge (delimitador):

(21c) Eu gostaria que o senhor falasse com respeito à globalização sobre o significado da globalização no mundo moderno.

(21c') Eu gostaria que o senhor falasse sobre o significado da globalização no mundo moderno com respeito à globalização.

Tarallo e Kato (Kato et al.,1993) apontam ainda que neste particular certos adjuntos, funcionando como preenchedores de fronteiras argumentais (margens, na acepção de Castilho, 1987 apud Tarallo, 1990:36), muitas vezes vêm acompanhados de pausas, hesitações e marcadores conversacionais, o que a nosso ver patenteia o seu estatuto extra-sentencial. Essa idéia parece confirmar o raciocínio de Castilho, quando diz que CTs são produzidas na periferia da sentença, ao contrário dos outros “adjuntos" que podem mover-se livremente na sentença. Mas é preciso reconhecer que a periferia sintática de que fala Castilho também pode ser verificada nos espaços (marcados a partir daqui com reticências:...) \pm anterior, \pm posterior e entre constituintes argumentais da sentença matriz. ${ }^{361}$ Em resumo, as CTs de Castilho devem ser vistas, portanto, como uma sorte de advérbios de sentença deslocados para a posição de tópico. ${ }^{362}$ Conclui-se, desse modo, que (36c) e (36c') são exemplos de preenchedores de duas posições de fronteiras sintáticas SV...Co e SVCo..., respectivamente.

Além disso, Kato (1987b apud Tarallo, 1990: 36) reconhece nesses elementos funções como as de tópico, de foco e de modalizador. Esta idéia foi melhor desenvolvida em trabalhos posteriores a respeito dos preenchedores sintáticos nas fronteiras de constituintes estudados por Tarallo e Kato (1993:239-40):

Em relação à possibilidade de variação posicional de certos tipos de constituintes, supomos que ela advém de princípios de canonicidade em níveis diferentes: semântico (agente antes do paciente, animado antes do inanimado, premissa antes da conclusão, etc.); discursivo/textual (novo antes do velho, fundo antes de figura, orientação antes de complicação e resolução), conforme sugerido em Kato (1986). Assim, embora uma função semântica tenha uma certa tendência a aparecer canonicamente em uma posição X, o mesmo constituinte pode estar sinalizando uma função textual (por exemplo, figura vs. fundo), que prefere dar a ele outra posição sintática. Dar uma pista de como se dá a interação entre esses diversos níveis ou módulos cognitivos poderá ser um dos tipos de discussão na conclusão deste trabalho.

\footnotetext{
${ }^{361}$ Estes espaços seriam referentes ao padrão sentencial SVCo: S...VCo, SV...Co, (S)...VSCo, SV... (Co), ...(S) ou (S)... .

${ }^{362}$ A discussão a que me refiro aqui também remete aos estudos de Ilari et al. (1990), Ilari (1992) e Castilho/Morais de Castilho (1992) sobre os advérbios focalizadores e modalizadores.
} 
A esse raciocínio argumentativo proposto por dois sintaticistas vale a pena contrapor a perspectiva discursivo/textual de uma pesquisadora dos processos de construção do texto falado, quando explica as funções que a tematização de elementos pode promover:

ao recorrer às construções com tema marcado, o falante seleciona um elemento (estado de coisas, propriedade, relação, coordenada espacial ou temporal, indivíduo ou grupo de indivíduos etc.) que deseja ativar ou reativar na memória do interlocutor, e sobre o qual seu enunciado deverá lançar nova luz, para apresentar a seguir algo que considera desconhecido por este, algo que deseja enfatizar ou com que pretende estabelecer algum tipo de contraste. É por essa razão que o elemento tematizado desempenha papel relevante no processamento pragmático-cognitivo do sentido, na medida em que essa forma de organização é determinada quer por questões ligadas à continuidade ou mudança de tópico, quer por fatores como facilitação do processamento do texto, interesse, relevância, expressividade, necessidade de se ganhar tempo para o planejamento da parte restante do enunciado, entre outros (Koch, 2006a:372-73, grifos meus).

Estas duas considerações confirmam a validade do questionamento de Castilho (1997:56-7) apresentado anteriormente sobre o fato de que determinados fatos sintáticos podem ser avaliados pelo "ângulo do ganho de propriedades discursivas", e que não se deve procurar explicações sintáticas quando estas estão "mais claramente identificáveis no limite da sentença", e que não se deve "supor que propriedades discursivas excluem propriedades gramaticais, e finalmente de que isso tudo é "a gramática convivendo com o discurso.

Tarallo \& Kato e sua equipe já apontavam para a necessidade de diferenciar entre dois tipos de "adjuntos", uns um tanto mais integrados sintaticamente e outros mais agregados, de valor discursivo/textual, como é o caso dos próprios marcadores conversacionais e os advérbios de sentença:

A configuração do 'fundo' [na terminologia Givóniana], após apurada em sua formalização, deverá definir posições estruturais bem determinadas para os 'adjuntos', a partir de novos núcleos e novos especificadores, com cada posição bem interpretável em forma lógica e quiçás na Representação Semântica, de tal sorte que os preenchedores poderão restringir-se aos discursivos, esses mesmos merecendo uma análise quanto a sua posição na frase e função na fala (Kato et al.1993:269).

Os exemplos abaixo (22-25) demonstram que além de estabelecer o relevo no processamento do sentido do texto, as tematizações indicam o início de um novo tópico, ou a sua retomada, o que dá suporte à idéia de que certos itens que pendulam entre o discurso e a sintaxe desempenham bem essas funções cumulativas: a) de organização textual e b) de marcação de conteúdo proposicional:

(22) (DID SP 137:523-33)

Doc. $\quad$ o senhor chegou a falar em... lojas shopping center e tal como é que é o comércio nessas cidades da Europa e no caso nas cidades dos Estados Unidos? 
Inf.

bom para a gente gastar dinheiro... ((risos)) ( ) a gente já viaja (mesmo) com essa... ( ) ainda que você faça intenção de não gastar... acaba-se gastando muito né?... mas:: ((pigarro))... bom o comércio... é:.... falando assim sob um aspecto muito::: simples a respeito do comércio de de nós que vamos LÁ quem vamos ver vitrines coisa que eu deTESto fazer aqui... em São Paulo e que lá eu acompanhei minha mulher em... todas as::... a:: as vitrines ou todas as lojas onde ela quis ir né?...

Em (22) a tematização é iniciada com a anteposição do termo o comércio. O gerúndio é ativado pelo informante como uma estratégia de reformulação do seu enunciado, ao mesmo tempo, o falante confirma a tematização do núcleo tópico proposto pelo documentador "O comércio nas cidades da Europa", além de colaborar na estratégia de rebaixamento do relevo, negociando com o documentador a centração em assim sob um aspecto muito simples. $\mathrm{O}$ mesmo acontece nos exemplos abaixo, em que o falante especifica o ponto de vista, o domínio de conhecimento ao qual o raciocínio está ligado:

(23) (D2 SP 343:1462-1483)

L1 então minha pergunta é a seguinte... pensando em futuro... por enquanto parece que... tem alguma coisa sempre acertando... de cá e de lá... é dois mil mesmo que vai ( )... você não enxerga isso não?

(24) (D2 SP 62:1335-1349)

L1 ... nós realMENte ainda não não não conseguimos ... éh:: ... ter assim uma uma bagagem cultural para poder assistir uma peça de teatro ... gostar ... DIScutir essa peça ... olhando em termos muito práticos para nós não não não nos interessa e a divulgação do teatro onde é que fica? não há divulgação ... nunca houve ...

A tematização pode ser verificada também na negociação entre documentador e informante, em torno da centração tópica a ser seguida, como em um dos exemplos do capítulo anterior:

(25) (DID 235:277-86)

Doc. $\quad$ se você fosse vegetaria::na como é que você se alimentaria?

Inf. partindo de uma:...de uma:...--como é que a gente fala?--..de uma definição...vegetaria::na eu iria comer vegetais né?((riu))

Doc. $\quad$ mas é só vegetais que come não?...

Inf. bom...acho que sim né?...pensando em vegetais num termo abrangente::acho que tem que ser só vegetais não?...ou:: o vegetariano como também::éh peixe...e essas coisas? acho que não né?...

\section{VI.1.4.1 A tematização do gerúndio como estratégia de relevo}

Quanto à sua natureza, além de estabelecer o contraste entre o primeiro e o segundo planos na relevância temática (figura e fundo), organizando o conteúdo informacional em termos de informações importantes e secundárias, e de indicar a 
relevância pragmática de uma determinada situação discursiva, o relevo também pode ser expresso através de estratégias de focalização.

\section{VI.1.4.2 Fatos de focalização na narração, na descrição, na dissertação e na injunção}

Como anunciado nas seções anteriores, a escolha do falante/autor pela anteposição parece estar associada a uma escolha discursiva que envolve a modalização do discurso, confirmando o que se tem pesquisado em Análise da Conversação sobre os tópicos, quando se diz que as posições mais exteriores dos enunciados são ocupadas por argumentos semanticamente mais significativos. No caso da anteposição das reduzidas de gerúndio, o raciocínio parece estar orientado para a idéia de "condição prévia para o entendimento do enunciado". Esse argumento deve ser entendido como uma interface sintaxe-semântica-discurso no processo de gramaticalização das orações gerundiais. Assim, as orações reduzidas de gerúndio em cabeça de sentença (anteposição) indicam ou apresentam o ponto de vista a partir do qual deve-se processar a informação que se segue. Trata-se de um processo de discursivização e de semanticização em cuja realização acumulam-se os traços de lugar no tempo e condição. Não é raro encontrar nessas construções, exemplos de locativos, às vezes mais concretos (26-27), às vezes mais abstratos (28), indicando o ponto de referência a partir do qual o interlocutor deve processar o enunciado. ${ }^{363}$

(26) (C 191 CL 512) Passando pela freguezia do Arujá, tive oc- | casião de ver ali funccionando a escola pu- | blica regida pelo senhor Caetano Nunes de $\mathrm{Si}$ - | queira, ha pouco para ali removido.

(27) (C 191 CL 526) Deparando com uma noticia in- | serta nesta folha, em que se disse | que disparei 2 tiros de revólver em | Alfredo Raul, tenho a declarar que, | si assim procedi, foi po que esse in- | dividuo seduziu minha mulher, des- | honrando minha reputação, a ponto | de encontral-a em casa do sobredito | cujo Alfredo Raul.

(28) (C 191 CL 531) Indo o collega destacado a primeiro periodo do segundo, que lhe é complementar e contem a illação a inferir-se das phrases que transcrevemos, evidentemente deixou nosso pensamento incompleto e assim exposto ás interpretações que deu, mas que não se compadecem com a nossa intenção, claramente expressa nos referidos periodos, acima reproduzidos.

$\mathrm{Na}$ descrição feita aqui, amplio a noção de tematização a construções oracionais que servem de expressão delimitadora de domínios. Também entendo que

${ }^{363}$ Exemplos retirados de Simões (2006). 
um texto não pode ser rotulado unicamente como sendo composto de uma única estratégia discursiva, seja ela a narração, a descrição, a dissertação e a injunção. Um mesmo texto pode apresentar porções de distintas estratégias. É possível, portanto, descrever os fatos de focalização nos textos, levando-se em conta em que porção do texto recai o foco. Na narração o foco incide sobre o participante e seus estados, sobre os acontecimentos e sobre o próprio narrador. Na descrição a estratégia focalizadora do relevo pode fazer ressaltar diferentes características do elemento descrito (pessoas, objetos ou eventos), como as psicológicas e físicas, as transitórias e as permanentes, os elementos e seus atributos, etc. Finalmente, nas dissertações o foco recai sobre conceitos, relações, argumentos e não argumentos. Na injunção, o foco recai sobre a ação a executar, no executante, no ato de determinar a realização de algo e na justificativa. ${ }^{364}$

Na documentação epistolar que reuni é possível encontrar alguns documentos de caráter híbrido entre carta e processo jurídico, algo como uma carta denúncia, como é o caso de uma carta de 1807 na qual um escrivão descreve todo o cenário e os seus participantes em orações iniciadas pelo gerúndio (orientação ou fundo), para depois, com verbos em sua forma finita (avaliação ou figura), apresentar o crime cometido por Manoel Coelho. Na segunda parte do texto o autor registra sua impressão sobre o fato de forma avaliativa (se abalansou aLevala daSua honra, para Colorar oSeugrande delicto, passou afinjir que Sequeria despozar Comella):

(29) [C 191 Lor 1] Diz Joaquim Joze da Costa da Villa deLorena que tendo hua filha de nome Gertrudes Maria da Conceiçaõ aindamenor, eidade de 18 annnos etendo procurado todos os meios de fazer viver adita Sua filha Com toda ahonra recato, ehoneStidade, como vivia, acontece que na auzencia delle Supplicante, ecompromessaS de Cazamento hum Manoel Coelho abuzando daSimplicidade daquelle menina, eSeduzindoa Com aquellas apparentes, efinjidas promessas, Se abalansou aLevala daSua honra, evirgindade; mas Entretanto para Colorar oSeugrande delicto passou afinjir que Sequeria despozar Comella

A denúncia parece ser um contexto bastante propício a este uso do gerúndio, como mostra um anúncio publicado em 1830 no jornal Farol Paulistano. Nele, uma esposa, incriminada pelo marido que a abandonou, alerta os leitores do jornal para que não comprem ao marido os bens comuns do casal. Também aqui a autora preferiu tematizar o cenário "Condição de mulher abandonada e falsamente denunciada", para em seguida apresentar o comentário acerca dos defeitos do marido (tem fingido dívidas e querer passar-se ao Rio de Janeiro):

${ }^{364}$ Para detalhes sobre os fatos de focalização v. Travaglia (2006). 
(30) [A $191 \mathrm{SP}$ ] Dona Emilia Carolina Ri-|veres da Silva, mulher do Tenente José| Antonio Martins, faz sciente ao publico| que tendo seu Marido denunciado em jui-|zo a Anunciante de um falso e supposto cri-|me do que s'está ella livrando depo-|sitada em casa honesta e capaz, e tendo| exigido de seu Marido os alimentos que| lhe são devidos, este para não cumprir es-|te dever tem fingido, dividas que nunca| existirão e tracta de vender tudo quanto $\mid$ tem para passar-se ao Rio de Janeiro ou| outra qualquer parte o que sendo sabido| pela Annunciante participa ella isto mes-|mo ao público a fim de que nem-nma pes-|soa compre ao dicto seu Marido cousa al-|guma ou faça com elle qualquer transacção| sem que a Annunciante seja ouvida. Farol Paulistano, 16 de março de 1830.

Assim como o anúncio acima, nas cartas, o gerúndio muitas vezes encabeça a porção inicial do texto, o que prova mais uma vez que este item sintático é bastante produtivo na construção da interlocução escrita. Primeiramente, os autores instauram o cenário que provocou a instância da enunciação e, ao delimitar o tópico informacional, marcam a tradição discursiva que orienta a constituição desse texto. Isso define (29) como uma carta-denúncia e (30) como um anúncio público de denúncia. O mesmo recurso foi utilizado no início de uma carta de reclamação e de uma carta de prestação de contas, respectivamente:

(31) [C 181 Seb 2] Tendo avizado porvarias vezes a Vossa Excelencia da chegada de tres navios olandezes no porto desta villa, inthe ao preZente naõ tenho tido Resposta, e [hoie] que Se contaõ vinte e sete do Corrente meti taõ emportunado Com o ofisial olandes que veio a terra por mandado do seu Comandante e me fes hum protesto de quereicha que Comtra mim,

(32) [C 181 Seb 15] Movendoçe nesta villa em meu Juizo huã Contenda deCauza Sivel entre partes Agravou demim huã dellas para omeo ouvidor Geral

Parece circular a afirmação de que um texto pode ser composto pela reunião de propriedades lexicais, semânticas, discursivas e gramaticais. De uma perspectiva de tradição textual, tanto leitores como autores reconhecem o caráter convencional que define um texto como carta ou anúncio, mas essa interpretação também tem suporte na apreensão que os falantes ou leitores têm das propriedades específicas que determinados recursos lexicais, sintáticos, semânticos e gramaticais são portadores.

Há uma alta ocorrência de gerúndios demarcando o foco através de construções com valor de modalização deôntica na vasta documentação administrativa de caráter epistolar do período colonial:

(33) [C 182 BAN 6] ObedeSendo orespeitaveu despacho devossa enxelencia enformo Naforma Seguinte OS[oplicante] Padre Joaõ Barboza deSumCam Sendo Naturar Naferguezia deja vari PaSou Acazade Naoscal dacompanha torio verde onde Tem deSua Molher dois filhos

(34) [C 19 1 Ald 26] Satisfazendo aCarta que por Ordem deVossa Excelenca escreveome o Sargento-mor ajudante de Ordens, Joaquim Joze Pinto de Morais Leme, respondo que nos suburbios desta Aldeia CirCunstanciado Com al gumas qualidades eactividade para Director dos Indios pareceme suficiente Salvador Pereira de Pontes, do destricto da Com CeiCam dos Guarulhos.

(35) [C 182 Seb 2] Equerendo Vossa Excelencia por osbenignosolhos nesta cauza, pode como Senhor, mandar que otalprezo pague adivida, enaReincidencia, Sirva aEl Rei. 
(36) [C 182 Seb 22] edis o dito picador que achou boa Saida para aSerra, elogo que sairaõ osditos meus picadores fis aviZo ao dito Capitam mor para ele entrar delá ComoCaminho qui eu naõ per tendo sair des tes matos Sem Com Cluir oque me pertenSer, naõ mandando oContrario vossa Excelencia que Deos guarde Com Saude muitos annos

(37) [C10 Seb 1 18] E com as Razoins de hû, e outro acodiraõ os sobreditto ReligioZos, pedindo ao dito Capitam largaSse do homem: o que elle naõ quizera.

(38) [C 19 1 Ald 29] anada meexponho sem obeneplacito de VossaExcelencia por serem estes [[índios]] daquelles Certoens de Rezende, exigindo eu acompetente authoridade para proseguir esta Deligencia por meio de Ordem de VossaExcelencia para obom exito visto queremse reunir volluntariamente aesta Aldea.

(39) [C6 BNRJ 1 19] Recebi ainformaçaõ do Capitam Mor de Porto feliz, etendo ja falado sobre esta materia, determino de novo naõ aprezentar ao Governo determinando fazelo em tempo mais oportuno, e proprio.

Na interação face a face o recurso da injunção é mais fácil de ser identificado, como nos exemplos retirados deste entremez do séc. XVIII:

(40) [Tea FE 2 18] Hiráõ as Comadres deitando as filhozes na frigideira, e os Compadres passandoas pela calda, e deitando-as no alguidar, e neste tempo estaráõ todos conversando no que quizerem.

\section{VI.2. As propriedades semânticas específicas das orações de gerúndio}

Nas seções anteriores, procurei demonstrar de forma geral como as construções de gerúndio desempenham papel discursivo-semântico ao projetarem o relevo sobre determinados conteúdos que compõem estas estruturas. A partir daqui, descrevo as propriedades semânticas específicas de cada tipo de oração de gerúndio.

A análise leva em conta a classificação sintática proposta no capítulo IV e está fundamentada nos dados colhidos nos dois corpora analisados. Sempre que possível, farei uma associação entre o valor semântico dessas estruturas e o contexto específico em que aparecem, ou seja, retomo o tópico das tipologias textuais para verificar em que ambiente determinados valores semânticos dos gerúndios são ativados, reativados ou desativados.

\section{VI.2.1 A semântica das orações adverbiais de gerúndio (dependente e independente)}

A revisão da literatura a respeito do gerúndio nas línguas românicas feita no capítulo I dá conta de que, no que se refere à sua semântica, há duas posturas metodológicas em relação às orações adverbiais (aqui OGadvs e CAs): (i) há um 
grupo que defende a idéia de que a construção com gerúndio adverbial é uma estrutura semanticamente ambígua (Cf. Pusch, 1980) e (ii) há outra corrente que prefere seguir pistas sintático-pragmáticas para desvendar um valor semântico específico (Cf. Reese, 1991). Neste trabalho assumo parcialmente o conceito defendido em (i), por entender que em determinados contextos o objetivo do falante/autor é justamente o de atenuar o seu enunciado através do uso de uma oração de gerúndio, coisa que não seria possível através de um item conjuncional que é a lexicalização plena de um conteúdo semântico específico. As cartas oficiais escritas por autores em relação de ascendência com seus interlocutores estão recheadas deste tipo de estratégia, como veremos a seguir. Também considero válida a postura (ii), por acreditar que é possível resgatar algum sentido de base nas construções gerundiais a partir de sua estrutura sintática, pelo radical do verbo projetado pelo gerúndio e também por conta do contexto em que estas construções aparecem.

Tradicionalmente usa-se classificar a semântica das orações adverbiais gerundiais, dividindo-as em causais, temporais, condicionais, consecutivas, concessivas etc. Pelo exposto nas seções anteriores, a estes valores proposicionais somam-se as demais propriedades semânticas acima descritas. Neste trabalho, procuro mostrar, para todos os tipos de orações de gerúndio, que sentidos de base podem ser ativados ou não na instância da enunciação.

Em seu trabalho sobre as técnicas de junção, Raible (1992) estabelece dois eixos: o eixo sintático, que delimita os graus de sentencialidade dos itens que compõem as sentenças simples ou complexas, e o eixo semântico, no qual ele reconhece 18 grandezas de valores proposicionais (quadro 23) que podem ser expressos pela junção de itens, sejam eles sentenças ou constituintes. O autor oferece um quadro geral com as diversas possibilidades para o francês, do qual se pode depreender que nas línguas em geral nem sempre se pode projetar todos os valores semânticos através de todas as técnicas de junção, p. ex., segundo ele, para o francês não se pode obter o sentido de modo/instrumento através dos recursos sintáticos dos níveis (I), (III), (IV) e (VIII), mas tal relação entre eventos pode ser expressa através de (V), (VI) e (VII). Adaptando-se esse esquema ao português e ao tema desta tese, verifica-se que essa língua não tem uma conjunção lexicalizada para a expressão de modo. Exatamente por este motivo é que outras técnicas são utilizadas para expressar 
esse valor proposicional e, no português, como é o caso de várias línguas românicas, isso se faz através de orações reduzidas de gerúndio.

\begin{tabular}{|c|c|c|c|c|c|c|c|c|c|c|c|c|c|c|c|c|c|c|}
\hline & \multicolumn{18}{|c|}{$\leftarrow$ EIXO SEMÁNTICO $\rightarrow$} \\
\hline I & \multirow{6}{*}{\multicolumn{18}{|c|}{$\begin{array}{l}\text { junção por justaposição } \\
\text { junção pronominal } \\
\text { junção com conectivo } \\
\text { junção com conjunção } \\
\text { junção com gerúndios e particípios } \\
\text { junção com grupos preposicionais }\end{array}$}} \\
\hline II & & & & & & & & & & & & & & & & & & \\
\hline III & & & & & & & & & & & & & & & & & & \\
\hline IV & & & & & & & & & & & & & & & & & & \\
\hline $\mathrm{V}$ & & & & & & & & & & & & & & & & & & \\
\hline VI & & & & & & & & & & & & & & & & & & \\
\hline \multirow{3}{*}{ 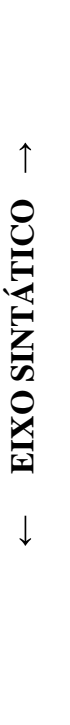 } & $\begin{array}{l}\tilde{\Xi} \\
\tilde{J} \\
\tilde{\Xi} \\
\Xi \\
0\end{array}$ & 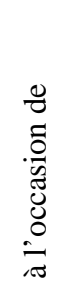 & $\begin{array}{l}\widehat{\tilde{E}} \\
\hat{\tilde{\theta}}\end{array}$ & 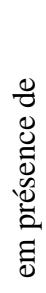 & 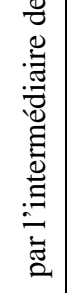 & $\begin{array}{l}\tilde{D} \\
\tilde{U} \\
\tilde{\Xi} \\
\tilde{J} \\
\tilde{\Theta}\end{array}$ & 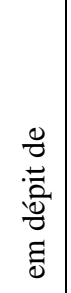 & 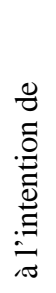 & 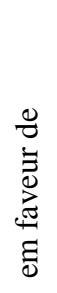 & & 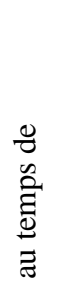 & 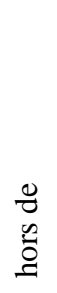 & 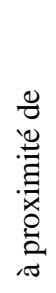 & 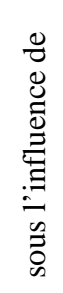 & $\begin{array}{c}\tilde{\theta} \\
\tilde{v} \\
. \mathscr{J} \\
\tilde{\sigma} \\
\tilde{v}\end{array}$ & 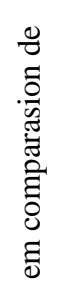 & 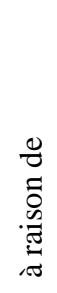 & 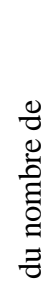 \\
\hline & 胥 & 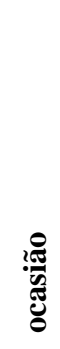 & 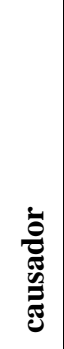 & 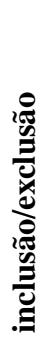 & 㟒 & 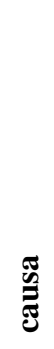 & 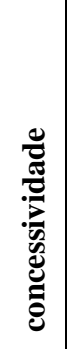 & & 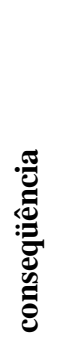 & 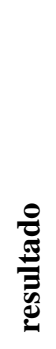 & 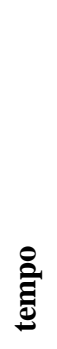 & 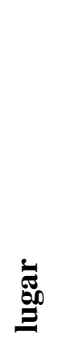 & 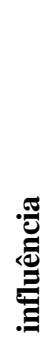 & 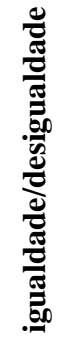 & 宽 & 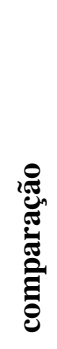 & 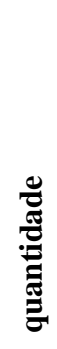 & \\
\hline & 1 & 2 & 3 & 4 & 5 & 6 & 7 & 8 & 9 & 10 & 11 & 12 & 13 & 14 & 15 & 16 & 17 & 18 \\
\hline $\begin{array}{l}\text { VII } \\
\text { VIII }\end{array}$ & & & & & ерс & & & & & & & & & & & & & \\
\hline
\end{tabular}

Quadro 23. As técnicas de junção segundo Raible (1992), adaptado.

O quadro de Raible (1992) exibe uma gama muito ampla de relações proposicionais que podem ser expressas através das várias técnicas de junção, o que demonstra que as línguas são bastante criativas, ou melhor, os seus falantes, pois procuram encontrar meios de reproduzir nas línguas em particular o sentido específico que querem atribuir a determinados conteúdos informacionais. É de suporse, portanto, que o elenco de valores proposicionais de Raible possa ser ampliado, pois as relações entre enunciados não devem esgotar-se nas 18 possibilidades por ele arroladas. Talmy (2000) é um dos autores que também se preocuparam em verificar como as línguas desenvolvem estruturas que relacionam eventos. No capítulo que trata da relação de figura e fundo que se estabelece entre sentenças, o autor exemplifica para o inglês com uma lista de 15 valores semânticos, dentre eles alguns que Raible poderia ter incluído também para o francês em seu esquema, como o 
valor da adição (positiva e negativa), da contrafactualidade (adversatividade) e da substituição ${ }^{365}$ :

(41) He works at a sideline in addition to/besides/on top of/as well as holding down a regular job. (adição positiva)

(42) He takes odd jobs no more than he holds down a regular job. (adição negativa)

(43) I would have joined you, except (that) only I was busy. (contrafactualidade)

(44) He watched TV instead of studying. (substituição)

Talmy (2000:381) observa ainda que as línguas nem sempre desenvolvem conjunções para expressar uma determinada relação proposicional e é nesse momento que entra a criatividade que se verifica nas línguas, ou seja, outros mecanismos são ativados para expressar o valor almejado.

Nas seção que segue, a idéia é mostrar que as orações adverbiais de gerúndio podem expressar não só os valores que comumente se atribui a elas, mas também outros que as descrições do gerúndio no português até o momento haviam visualizado, mas classificado de um ponto de vista somente sintático ou somente semântico.

\section{VI.2.2 A distribuição semântica das orações adverbiais de gerúndio}

A cada ocorrência de OGadvs, CAs e de gerúndio ambíguo foi atribuído um valor semântico aproximado. A classificação que se apresenta a seguir não deve ser considerada estanque ou que determinadas ocorrências não sejam passíveis de outras interpretações. A ambigüidade semântica é parte característica das orações de gerúndio e muitas vezes acumulam-se nestas construções diversos valores semânticos. Assim, não é preocupação deste estudo estabelecer critérios definidos para a interpretação das orações de gerúndio, mas sim possibilitar uma compreensão da maneira como elas se comportam nos textos analisados.

Com o objetivo de contrastar qual a freqüência de orações adverbiais gerundiais em oposição a sua variante com conjunções ${ }^{366}$, a tabela 12 contém os

\footnotetext{
${ }^{365}$ Exemplos de Talmy (2000:373-6).

${ }^{366} \mathrm{O}$ levantamento estatístico de orações conjuncionais partiu de uma metodologia inicial de analisar orações adverbiais gerundiais e orações conjuncionais do ponto de vista da Teoria da Variação.
} 
resultados obtidos tantos para as orações de gerúndio como para as conjuncionais que ocorrem no Corpus Básico nos três séculos analisados. ${ }^{367}$

Tabela 12. Distribuição das orações adverbiais gerundiais (G) e conjuncionais (C) no Corpus Básico (séc. XVIII, XIX e XX)

\begin{tabular}{|c|c|c|c|c|c|c|c|}
\hline & & OGadvs & & CAs & & Total & Total \\
\hline & & & $\%$ & & $\%$ & & $\%$ \\
\hline \multirow[t]{3}{*}{ adição } & $\mathrm{G}$ & 82 & 100 & 27 & 100 & 109 & 100 \\
\hline & $\mathrm{C}$ & 0 & - & 0 & - & 0 & - \\
\hline & Total & 82 & & 27 & & 109 & \\
\hline \multirow[t]{3}{*}{ adversatividade } & $\mathrm{G}$ & 3 & 100 & 0 & 0 & 3 & 100 \\
\hline & $\mathrm{C}$ & 0 & - & 0 & - & 0 & - \\
\hline & Total & 3 & & 0 & & 3 & \\
\hline \multirow[t]{3}{*}{ causa } & $\mathrm{G}$ & 31 & 10 & 20 & 100 & 51 & 15 \\
\hline & $\mathrm{C}$ & 281 & 90 & 0 & - & 281 & 85 \\
\hline & Total & 312 & & 20 & & 332 & \\
\hline \multirow[t]{3}{*}{ concessividade } & $\mathrm{G}$ & 7 & 33 & 4 & 100 & 11 & 44 \\
\hline & $\mathrm{C}$ & 14 & 67 & 0 & - & 14 & 56 \\
\hline & Total & 21 & & 4 & & 25 & \\
\hline \multirow[t]{3}{*}{ condição } & G & 13 & 9 & 25 & 100 & 38 & 22 \\
\hline & $\bar{C}$ & 132 & 91 & 0 & - & 132 & 78 \\
\hline & Total & 145 & & 25 & & 170 & \\
\hline \multirow[t]{3}{*}{ conseqüência } & G & 22 & 71 & 27 & 100 & 49 & 84 \\
\hline & $\mathrm{C}$ & 9 & 29 & 0 & - & 9 & 16 \\
\hline & Total & 31 & & 27 & & 58 & \\
\hline \multirow[t]{3}{*}{ exclusão } & $\mathrm{G}$ & 2 & 25 & 1 & 100 & 3 & 33 \\
\hline & $\mathrm{C}$ & 6 & 75 & 0 & - & 6 & 67 \\
\hline & Total & 8 & & 1 & & 9 & \\
\hline \multirow[t]{3}{*}{ finalidade } & $\mathrm{G}$ & 13 & 19 & 2 & 100 & 15 & 21 \\
\hline & $\mathrm{C}$ & 56 & 81 & 0 & - & 56 & 79 \\
\hline & Total & 69 & & 2 & & 71 & \\
\hline \multirow[t]{3}{*}{ modo } & G & 99 & 100 & 18 & 100 & 117 & 100 \\
\hline & $\mathrm{C}$ & 0 & - & 0 & - & 0 & \\
\hline & Total & 99 & & 18 & & 117 & \\
\hline \multirow[t]{3}{*}{ tempo } & $\mathrm{G}$ & 82 & 33 & 44 & 100 & 126 & 43 \\
\hline & $\mathrm{C}$ & 169 & 67 & 0 & - & 169 & 57 \\
\hline & Total & 251 & & 44 & & 295 & \\
\hline \multirow[t]{3}{*}{ Total } & $\bar{G}$ & 354 & 35 & 168 & 100 & 522 & 44 \\
\hline & $\mathrm{C}$ & 667 & 65 & 0 & - & 667 & 56 \\
\hline & Total & 1021 & & 168 & & 1189 & \\
\hline
\end{tabular}

Pelos resultados obtidos na tabela 12, observa-se que há três relações proposicionais entre sentenças que só se realizam através de orações gerundiais, já que o português não desenvolveu uma conjunção subordinativa para elas: modo, adição e adversativididade. As duas últimas são tradicionalmente consideradas apenas na junção de sentenças por coordenação. A circunstância de conseqüência

Percebi ao longo da pesquisa que essa estratégia era inviável, uma vez que outras estruturas sintáticas estão envolvidas como variantes nas escalas de sentencialização propostas por Lehmann (1988) e Raible (1992). Os resultados obtidos na tabela 1 devem servir apenas como exemplificação da distribuição de orações adverbiais gerundiais e conjuncionais segundo a sua semântica.

${ }^{367}$ Não foram consideradas as orações reduzidas de infinitivo finais introduzidas pela preposição para + infinitivo. 
parece ser mais freqüente com as orações gerundiais (84\%). O alto índice está associado à questão que envolve as orações conclusivas, tradicionalmente descritas apenas em processos de junção por coordenação. Os critérios semânticos que adoto para considerar a existência das relações de adição e adversatividade e o procedimento metodológico de englobar às orações consecutivas àquelas que têm valor de conclusão serão esclarecidos mais adiante, quando apresento a exemplificação de cada circunstância adverbial encontrada nos corpora.

Essa tabela 12 mostra ainda que determinadas circunstâncias são expressas na maioria dos casos através de orações conjuncionais: causa (85\%), condição $(78 \%)$, finalidade (79\%) e exclusão (67\%), embora esta última relação apresente poucas ocorrências no corpus em questão. As relações de tempo e concessividade mostram um certo equilíbrio na distribuição entre orações gerundiais e conjuncionais. O baixo índice de ocorrência de orações concessivas não permite esclarecer adequadamente a relação entre as gerundiais e as condicionais.

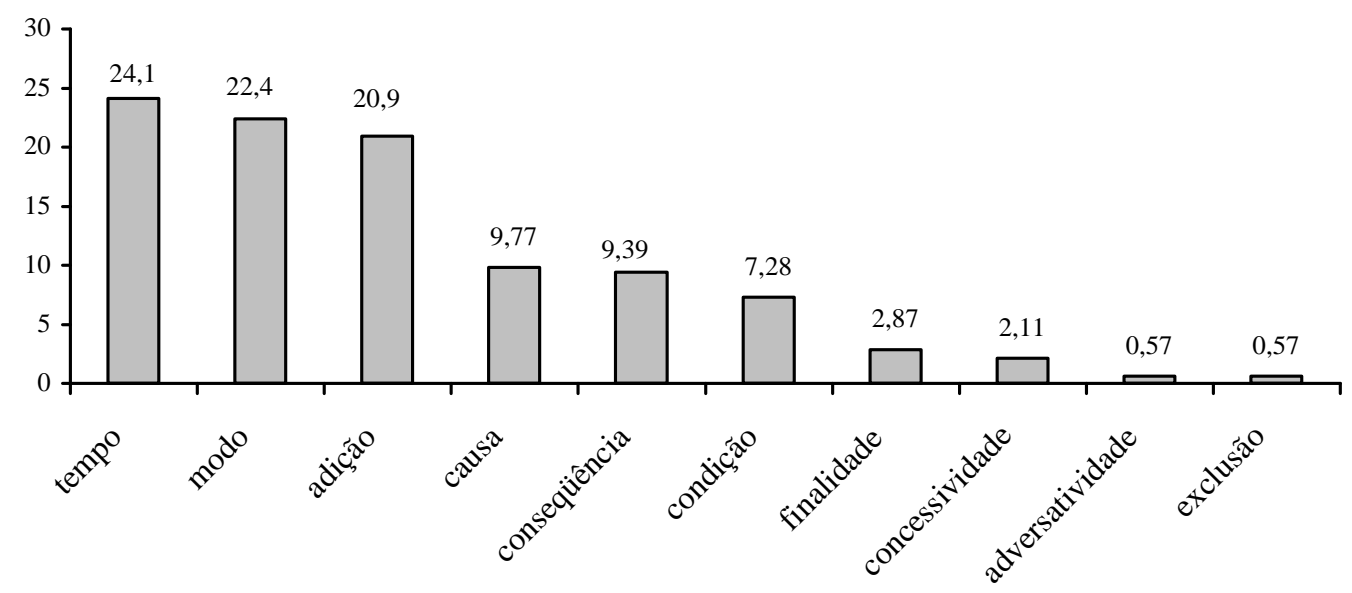

Gráfico 19. Distribuição geral das orações adverbiais gerundiais (OGadvs e CAs) por valor semântico no Corpus Básico (total de três séculos).

O gráfico 19 engloba todas as ocorrências de orações adverbiais gerundiais e através dele pode-se ver que circunstâncias realizam-se mais freqüentemente através de algum tipo de oração gerundial. Vê-se que as orações adverbiais gerundiais mais freqüentes são aquelas que expressam as circunstâncias de tempo, modo e adição, sendo menos frequientes as de finalidade, concessividade, adversatividade $\mathrm{e}$ exclusão: 
O gráfico 20 mostra como estão distribuídas as OGadvs e as CAs segundo os valores semânticos que denotam. Os resultados demonstram que essa distribuição não se dá de maneira equilibrada e essa disparidade está relacionada à finalidade discursiva que essas construções desempenham nos textos. Essa questão será retomada ao longo da descrição das OGadvs e das CAs.

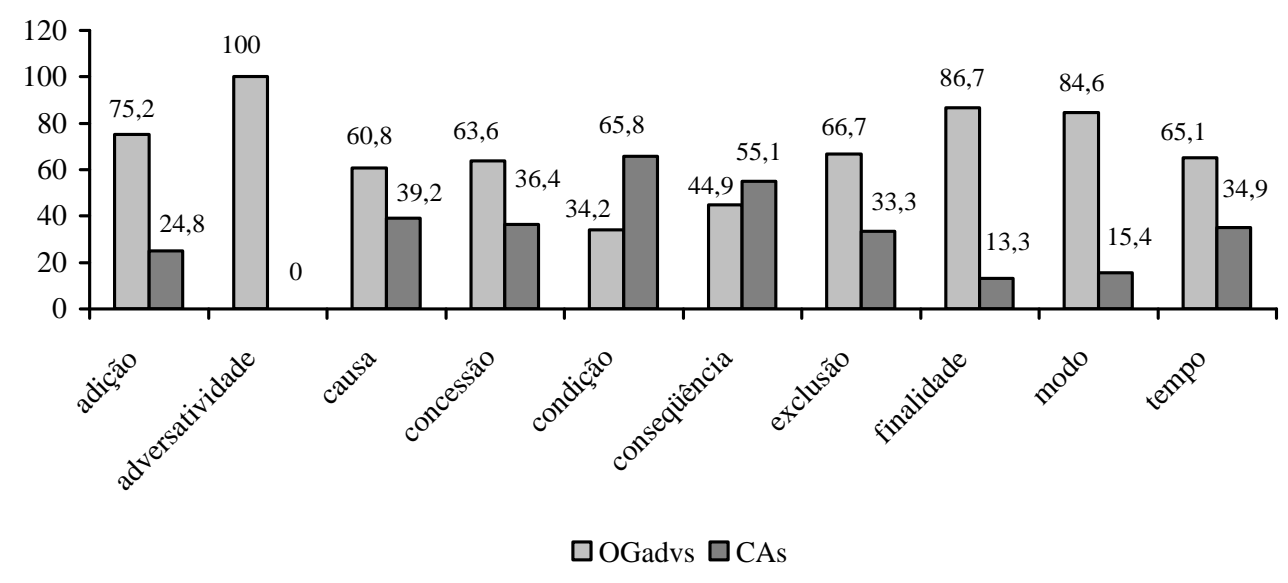

Gráfico 20. Distribuição de freqüências das circunstâncias adverbiais nas orações gerundiais (OGadvs e CAs) do Corpus Básico (séc. XVIII, XIX e XX).

\section{VI.2.3 As relações proposicionais das OGadvs e das CAs}

As tabelas 13 e 14 trazem o quadro geral da distribuição das OGadvs e das CAs, divididas pelos seus valores semânticos nos três séculos e conforme a tipologia textual analisada no Corpus Básico e no Corpus Diferencial. Como OGadvs e CAs exibem propriedades semânticas equivalentes, optei por uma descrição das mesmas em conjunto, procurando observar as especificidades de cada um dos tipos de orações adverbiais gerundiais. 

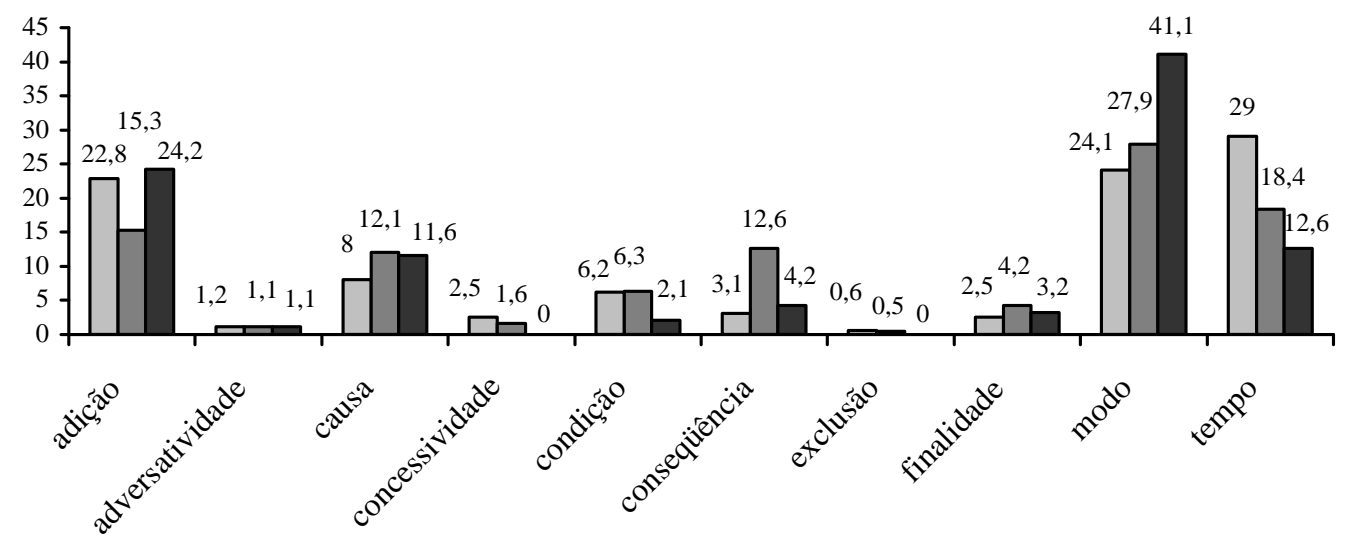

$\square$ séc. XVIII $\square$ Séc. XIX $\square$ Séc. XX

Gráfico 21. Freqüência das OGadvs nos séculos XVIII, XIX e XX (Corpus Básico e Corpus Diferencial).

A leitura dos totais obtidos para as OGadvs em cada século (gráfico 21) revela fatos interessantes relacionados à semanticização dos gerúndios adverbiais dependentes. Se acompanharmos a evolução das orações de modo $(24,1 \%>27,9 \%$ > 
Tabela 13. Distribuição semântica das OGadvs nos séculos XVIII, XIX e XX por tipologia textual.

\begin{tabular}{|c|c|c|c|c|c|c|c|c|c|c|c|c|c|c|c|c|c|c|c|c|c|c|c|c|c|c|c|c|}
\hline $\begin{array}{l}\text { OGadvs } \\
\text { séc. XVIII }\end{array}$ & A & $\%$ & CL & $\%$ & $\mathrm{CR}$ & $\%$ & $\mathrm{M}$ & $\%$ & CAP & $\%$ & $\mathrm{CO}$ & $\%$ & $\mathrm{CP}$ & $\%$ & TEA & $\%$ & D2 & $\%$ & DID & $\%$ & $\mathrm{EF}$ & $\%$ & $\mathrm{FB}$ & $\%$ & PBP & $\%$ & Total & $\%$ \\
\hline adição & & & & & & & 17 & 26,2 & 9 & 24,3 & 7 & 28,0 & 2 & 28,6 & 2 & 7,1 & & & & & & & & & & & 37 & 22,8 \\
\hline adversatividade & & & & & & & 1 & 1,5 & 1 & 2,7 & 0 & - & 0 & - & 0 & - & & & & & & & & & & & 2 & 1,2 \\
\hline causa & & & & & & & 5 & 7,7 & 3 & 8,1 & 1 & 4,0 & 2 & 28,6 & 2 & 7,1 & & & & & & & & & & & 13 & 8,0 \\
\hline concessividade & & & & & & & 1 & 1,5 & 0 & - & 1 & 4,0 & 2 & 28,6 & 0 & - & & & & & & & & & & & 4 & 2,5 \\
\hline condição & & & & & & & 1 & 1,5 & 3 & 8,1 & 1 & 4,0 & 0 & - & 5 & 17,9 & & & & & & & & & & & 10 & 6,2 \\
\hline conseqüência & & & & & & & 2 & 3,1 & 2 & 5,4 & 0 & - & 0 & - & 1 & 3,6 & & & & & & & & & & & 5 & 3,1 \\
\hline exclusão & & & & & & & 0 & - & 0 & - & 0 & - & 0 & - & 1 & 3,6 & & & & & & & & & & & 1 & 0,6 \\
\hline finalidade & & & & & & & 0 & - & 1 & 2,7 & 3 & 12,0 & 0 & - & 0 & - & & & & & & & & & & & 4 & 2,5 \\
\hline modo & & & & & & & 14 & 21,5 & 9 & 24,3 & 7 & 28,0 & 0 & - & 9 & 32,1 & & & & & & & & & & & 39 & 24,1 \\
\hline tempo & & & & & & & 24 & 36,9 & 9 & 24,3 & 5 & 20,0 & 1 & 14,3 & 8 & 28,6 & & & & & & & & & & & 47 & 29,0 \\
\hline Total & & & & & & & 65 & & 37 & & 25 & & 7 & & 28 & & & & & & & & & & & & 162 & \\
\hline & & & & & & & & & & & & & & & & & & & & & & & & & & & & \\
\hline $\begin{array}{l}\text { OGadvs } \\
\text { séc. XIX }\end{array}$ & A & $\%$ & $\mathrm{CL}$ & $\%$ & $\mathrm{CR}$ & $\%$ & $\mathrm{M}$ & $\%$ & CAP & $\%$ & $\mathrm{CO}$ & $\%$ & $\mathrm{CP}$ & $\%$ & TEA & $\%$ & D2 & $\%$ & DID & $\%$ & $\mathrm{EF}$ & $\%$ & FB & $\%$ & PBP & $\%$ & Total & $\%$ \\
\hline adição & 7 & 24,1 & 0 & - & 0 & - & 12 & 22,2 & 4 & 44,4 & 1 & 9,1 & 5 & 16,7 & 0 & - & & & & & & & & & & & 29 & 15,3 \\
\hline adversatividade & 0 & - & 0 & - & 1 & 11,1 & 1 & 1,9 & 0 & - & 0 & - & 0 & - & 0 & - & & & & & & & & & & & 2 & 1,1 \\
\hline causa & 2 & 6,9 & 8 & 25,0 & 4 & 44,4 & 4 & 7,4 & 0 & - & 1 & 9,1 & 4 & 13,3 & 0 & - & & & & & & & & & & & 23 & 12,1 \\
\hline concessividade & 0 & - & 0 & - & 0 & - & 3 & 5,6 & 0 & - & 0 & - & 0 & - & 0 & - & & & & & & & & & & & 3 & 1,6 \\
\hline condição & 9 & 31,0 & 1 & 3,1 & 0 & - & 0 & - & 0 & - & 0 & - & 1 & 3,3 & 1 & 6,3 & & & & & & & & & & & 12 & 6,3 \\
\hline conseqüência & 2 & 6,9 & 9 & 28,1 & 0 & - & 12 & 22,2 & 0 & - & 0 & - & 1 & 3,3 & 0 & - & & & & & & & & & & & 24 & 12,6 \\
\hline exclusão & 0 & - & 0 & - & 0 & - & 0 & - & 0 & - & 0 & - & 1 & 3,3 & 0 & - & & & & & & & & & & & 1 & 0,5 \\
\hline finalidade & 1 & 3,4 & 0 & - & 0 & - & 2 & 3,7 & 2 & 22,2 & 0 & - & 3 & $1-$ & 0 & - & & & & & & & & & & & 8 & 4,2 \\
\hline modo & 4 & 13,8 & 8 & 25,0 & 3 & 33,3 & 8 & 14,8 & 2 & 22,2 & 9 & 81,8 & 11 & 36,7 & 8 & 50,0 & & & & & & & & & & & 53 & 27,9 \\
\hline tempo & 4 & 13,8 & 6 & 18,8 & 1 & 11,1 & 12 & 22,2 & 1 & 11,1 & 0 & - & 4 & 13,3 & 7 & 43,8 & & & & & & & & & & & 35 & 18,4 \\
\hline Total & 29 & & 32 & & 9 & & 54 & & 9 & & 11 & & 30 & & 16 & & & & & & & & & & & & 190 & \\
\hline & & & & & & & & & & & & & & & & & & & & & & & & & & & & \\
\hline $\begin{array}{l}\text { OGadvs } \\
\text { séc. XX }\end{array}$ & A & $\%$ & $\mathrm{CL}$ & $\%$ & $\mathrm{CR}$ & $\%$ & $\mathrm{M}$ & $\%$ & CAP & $\%$ & $\mathrm{CO}$ & $\%$ & $\mathrm{CP}$ & $\%$ & TEA & $\%$ & D2 & $\%$ & DID & $\%$ & $\mathrm{EF}$ & $\%$ & $\mathrm{FB}$ & $\%$ & PBP & $\%$ & Total & $\%$ \\
\hline adição & & & & & & & 17 & 54,8 & 0 & - & 6 & 42,9 & 0 & - & 0 & - & 0 & - & 0 & - & 0 & - & 0 & - & 0 & - & 23 & 24,2 \\
\hline adversatividade & & & & & & & 0 & - & 0 & - & 0 & - & 0 & - & 0 & - & 0 & - & 0 & - & 1 & 100,0 & 0 & - & 0 & - & 1 & 1,1 \\
\hline causa & & & & & & & 5 & 16,1 & 1 & 12,5 & 2 & 14,3 & 1 & 14,3 & 0 & - & 2 & 25,0 & 0 & - & 0 & - & 0 & - & 0 & - & 11 & 11,6 \\
\hline concessividade & & & & & & & 0 & - & 0 & - & 0 & - & 0 & - & 0 & - & 0 & - & 0 & - & 0 & - & 0 & - & 0 & - & 0 & - \\
\hline condição & & & & & & & 0 & - & 0 & - & 0 & - & 0 & - & 1 & 8,3 & 1 & 12,5 & 0 & - & 0 & - & 0 & - & 0 & - & 2 & 2,1 \\
\hline conseqüência & & & & & & & 2 & 6,5 & 2 & 25,0 & 0 & - & 0 & - & 0 & - & 0 & - & 0 & - & 0 & - & 0 & - & 0 & - & 4 & 4,2 \\
\hline exclusão & & & & & & & 0 & - & 0 & - & 0 & - & 0 & - & 0 & - & 0 & - & 0 & - & 0 & - & 0 & - & 0 & - & 0 & - \\
\hline finalidade & & & & & & & 0 & - & 0 & - & 1 & 7,1 & 1 & 14,3 & 0 & - & 1 & 12,5 & 0 & - & 0 & - & 0 & - & 0 & - & 3 & 3,2 \\
\hline modo & & & & & & & 2 & 6,5 & 3 & 37,5 & 3 & 21,4 & 3 & 42,9 & 11 & 91,7 & 4 & 50,0 & 10 & 100,0 & 0 & - & 2 & 66,7 & 1 & 100,0 & 39 & 41,1 \\
\hline tempo & & & & & & & 5 & 16,1 & 2 & 25,0 & 2 & 14,3 & 2 & 28,6 & 0 & - & 0 & - & 0 & - & 0 & - & 1 & 33,3 & 0 & - & 12 & 12,6 \\
\hline & & & & & & & 31 & & 8 & & 14 & & 7 & & 12 & & 8 & & 10 & & 1 & & 3 & & 1 & & 95 & \\
\hline & & & & & & & & & & & & & & & & & & & & & & & & & & & & \\
\hline
\end{tabular}


Tabela 14. Distribuição semântica das CAs nos séculos XVIII, XIX e XX por tipologia textual.

\begin{tabular}{|c|c|c|c|c|c|c|c|c|c|c|c|c|c|c|c|c|c|c|c|c|c|c|c|c|c|c|c|c|}
\hline & $\mathrm{A}$ & $\%$ & $\mathrm{CL}$ & $\%$ & $\mathrm{CR}$ & $\%$ & $\mathrm{M}$ & $\%$ & CAP & $\%$ & $\mathrm{CO}$ & $\%$ & $\mathrm{CP}$ & $\%$ & TEA & $\%$ & D2 & $\%$ & DID & $\%$ & $\mathrm{EF}$ & $\%$ & FB & $\%$ & PBP & $\%$ & Total & $\%$ \\
\hline CAs séc. XVIII & & & & & & & $\mathrm{N}$ & & $\mathrm{I}$ & & $\mathrm{H}$ & & $\mathrm{J}$ & & $\mathrm{P}$ & & & & & & & & & & & & Total & \\
\hline adição & & & & & & & 5 & 12,2 & 1 & 4,5 & 2 & 25,0 & 2 & 25,0 & 0 & - & & & & & & & & & & & 10 & 11,4 \\
\hline causa & & & & & & & 3 & 7,3 & 2 & 9,1 & 1 & 12,5 & 0 & - & 1 & 11,1 & & & & & & & & & & & 7 & 8,0 \\
\hline concessividade & & & & & & & 0 & - & 1 & 4,5 & 0 & - & 0 & - & 1 & 11,1 & & & & & & & & & & & 2 & 2,3 \\
\hline condição & & & & & & & 6 & 14,6 & 5 & 22,7 & 1 & 12,5 & 1 & 12,5 & 5 & 55,6 & & & & & & & & & & & 18 & 20,5 \\
\hline conseqüência & & & & & & & 2 & 4,9 & 3 & 13,6 & 0 & - & 0 & - & 1 & 11,1 & & & & & & & & & & & 6 & 6,8 \\
\hline exclusão & & & & & & & 1 & 2,4 & 0 & - & 0 & - & 0 & - & 0 & - & & & & & & & & & & & 1 & 1,1 \\
\hline finalidade & & & & & & & 2 & 4,9 & 0 & - & 0 & - & 0 & - & 0 & - & & & & & & & & & & & 2 & 2,3 \\
\hline modo & & & & & & & 8 & 19,5 & 2 & 9,1 & 0 & - & 0 & - & 0 & - & & & & & & & & & & & 10 & 11,4 \\
\hline tempo & & & & & & & 14 & 34,1 & 8 & 36,4 & 4 & 50,0 & 5 & 62,5 & 1 & 11,1 & & & & & & & & & & & 32 & 36,4 \\
\hline Total & & & & & & & 41 & & 22 & & 8 & & 8 & & 9 & & & & & & & & & & & & 88 & \\
\hline CAs Séc. XIX & A & $\%$ & $\mathrm{CL}$ & $\%$ & CR & $\%$ & $\mathrm{M}$ & $\%$ & CAP & $\%$ & $\mathrm{CO}$ & $\%$ & $\mathrm{CP}$ & $\%$ & TEA & $\%$ & D2 & $\%$ & DID & $\%$ & $\mathrm{EF}$ & $\%$ & FB & $\%$ & PBP & $\%$ & Total & $\%$ \\
\hline adição & 8 & 42,1 & $\mathrm{~K}$ & & $\mathrm{~L}$ & & 6 & 16,2 & 1 & 33,3 & 0 & - & 2 & 18,2 & 0 & - & & & DID & & & & & & & & 20 & 22,2 \\
\hline causa & 4 & 21,1 & 2 & 20,0 & 1 & 25,0 & 4 & 10,8 & 0 & - & 1 & 20,0 & 5 & 45,5 & 0 & - & & & & & & & & & & & 17 & 18,9 \\
\hline concessividade & 0 & - & 1 & 10,0 & 2 & 50,0 & 2 & 5,4 & 0 & - & 0 & - & 0 & - & 0 & - & & & & & & & & & & & 3 & 3,3 \\
\hline condição & 4 & 21,1 & 1 & 10,0 & 0 & - & 3 & 8,1 & 0 & - & 0 & - & 2 & 18,2 & 0 & - & & & & & & & & & & & 11 & 12,2 \\
\hline conseqüência & 1 & 5,3 & 1 & 10,0 & 1 & 25,0 & 12 & 32,4 & 1 & 33,3 & 1 & 20,0 & 2 & 18,2 & 0 & - & & & & & & & & & & & 21 & 23,3 \\
\hline modo & 1 & 5,3 & 4 & 40,0 & 0 & - & 6 & 16,2 & 0 & - & 2 & 40,0 & 0 & - & 0 & - & & & & & & & & & & & 9 & 10,0 \\
\hline tempo & 1 & 5,3 & 0 & - & 0 & - & 4 & 10,8 & 1 & 33,3 & 1 & 20,0 & 0 & - & 1 & 100,0 & & & & & & & & & & & 9 & 10,0 \\
\hline Total & 19 & & 1 & 10,0 & 0 & - & 37 & & 3 & & 5 & & 11 & & 1 & & & & & & & & & & & & 90 & \\
\hline & & & 10 & & 4 & & & & & & & & & & & & & & & & & & & & & & & \\
\hline & & & & & & & & & & & & & & & & & & & & & & & & & & & & \\
\hline CAs sec. XX & $\mathrm{A}$ & $\%$ & CL & $\%$ & $\mathrm{CR}$ & $\%$ & $\mathrm{M}$ & $\%$ & CAP & $\%$ & $\mathrm{CO}$ & $\%$ & $\mathrm{CP}$ & $\%$ & TEA & $\%$ & D2 & $\%$ & DID & $\%$ & $\mathrm{EF}$ & $\%$ & FB & $\%$ & PBP & $\%$ & Total & $\%$ \\
\hline adição & & & & & & & 5 & 71,4 & 1 & 20 & 2 & 25 & 0 & - & 0 & - & & & & & 1 & 25 & 0 & - & 0 & - & 9 & 30 \\
\hline adversatividade & & & & & & & 0 & - & 0 & - & 0 & - & 0 & - & 0 & - & 0 & - & 0 & - & 0 & - & 0 & - & 0 & - & 0 & - \\
\hline causa & & & & & & & 0 & - & 0 & - & 3 & 37,5 & 0 & - & 0 & - & & & & & 1 & 25 & 0 & - & 0 & - & 4 & 13 \\
\hline concessividade & & & & & & & 0 & - & 0 & - & 0 & - & 0 & - & 0 & - & 0 & - & 0 & - & 0 & - & 0 & - & 0 & - & 0 & - \\
\hline condição & & & & & & & 0 & - & 1 & 20 & 0 & - & 0 & - & 1 & 100,0 & & & & & 2 & 50 & 1 & 50 & 0 & - & 5 & 17 \\
\hline consequiência & & & & & & & 0 & - & 3 & 60 & 2 & 25 & 0 & - & 0 & - & & & & & 0 & - & 0 & - & 0 & - & 5 & 17 \\
\hline exclusão & & & & & & & 0 & - & 0 & - & 0 & - & 0 & - & 0 & - & 0 & - & 0 & - & 0 & - & 0 & - & 0 & - & 0 & - \\
\hline finalidade & & & & & & & 0 & - & 0 & - & 0 & - & 0 & - & 0 & - & 0 & - & 0 & - & 0 & - & 0 & - & 0 & - & 0 & - \\
\hline modo & & & & & & & 0 & - & 0 & - & 0 & - & 0 & - & 0 & - & 0 & - & 0 & - & 0 & - & 0 & - & 0 & - & 0 & - \\
\hline tempo & & & & & & & 2 & 28,6 & 0 & - & 1 & 12,5 & 2 & 100,0 & 0 & - & & & & & 0 & - & 1 & 50 & 1 & 100 & 7 & 23 \\
\hline Total & & & & & & & 7 & & 5 & & 8 & & 2 & & 1 & & & & & & 4 & & 2 & & 1 & & 30 & \\
\hline
\end{tabular}


$41,1 \%)$ e de tempo $(29,0 \%>27,9 \%>12,6 \%)$, perceberemos que à medida que aumenta a frequiência de umas, diminui a das outras. Algumas circunstâncias mantêm-se estáveis e com pouca representatividade nos corpora (adversatividade, concessividade e exclusão), para algumas destas já não encontramos ocorrências no século XX (concessividade e exclusão). Outras exibem uma linha sinuosa, ora partindo de uma freqüência baixa no século XVIII, evoluindo para um freqüência mais alta no séc. XIX e voltando a cair no séc. XX (conseqüência e finalidade), ora mostrando uma freqüência mais alta no séc. XVIII, diminuindo no séc. XIX e voltando a subir no séc. XX. Nas seções seguintes procuramos esclarecer estes movimentos a partir da tipologia textual específica em que aparecem estas construções.

O quadro geral de distribuição das frequiências de cada tipo de circunstância expressa nas CAs (gráfico 22) mostra que as orações de tempo são muito freqüentes no séc. XVIII, 36,5\% em relação às outras circunstâncias, caem no séc. XIX (10\%) e voltam a subir no séc. XX (23\%). Esta oscilação não acompanha o ritmo linear de decréscimo que se pode observar para as OGadvs. Curiosamente, a relação de modo não acompanha o aumento de freqüência apontado para as OGadvs. No séc. XX não encontramos ocorrências de CAs de modo. Comparando-se a produtividade de OGadvs e CAs nos três séculos (gráfico 21 vs. gráfico 22), observamos que enquanto as OGadvs concentram o maior número de orações de modo, tempo e adição, mantendo no séc. XX muito pouca representatividade dos outros valores, as CAs parecem ter maior distribuição entre as várias circunstâncias ao longo dos três séculos. Talvez isto esteja relacionado ao fato de que as CAs, por serem constituídas de gerúndios independentes, são equivalentes a constituintes de sentença e aproximam-se mais dos advérbios, além de terem um estatuto mais autônomo no que se refere à sua semântica. Podemos arriscar a dizer por estes resultados que nas OGadvs o gerúndio se dessemanticiza - e o processo deve ter começado em sincronias mais passadas, pois nos três séculos aqui analisados vê-se que o processo de mudança já está bem avançado. Por outro lado, os gerúndios nas CAs mantêm preservados as suas propriedades semânticas de base, de expressar variadas circunstâncias proposicionais, denotar propriedades passageiras ou transitórias de um $\mathrm{SN}$, estabelecer o relevo, etc. 


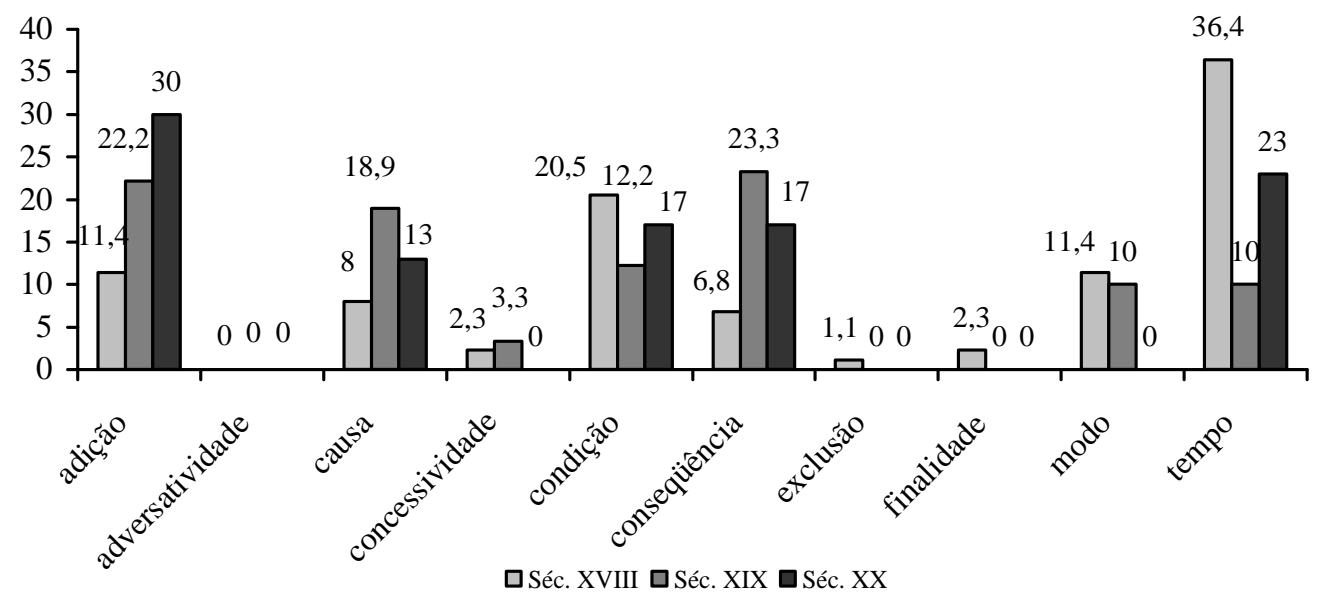

Gráfico 22. Freqüência das CAs nos séculos XVIII, XIX e XX (Corpus Básico e Corpus Diferencial)

Passo agora à exemplificação e comentário dos valores semânticos das OGAdvs e das CAs.

\section{VI.2.3.1 O valor temporal}

As OGs de tempo são as mais freqüentes nos corpora e encontram-se bem distribuídas nos três séculos:

(45) [M 182 MCA 14] Depois dedescobrir Christovaõ Colombo aAmerica noanno de1492, indo para asConquistas Portuguezas daAzia Pedro Alvarez Cabral, Senhor de = Azurara, por Capitaõ Mór de 13 Naoz, Cazualmente avistou terra des = conhecida aos 24 de Abril de 1500, aqual, noprincipio, lhepareceo Ilha;

(46) [TEA 192 SL 4] RAFAEL : Má virtude, essa em quem gosta de fabricar mexericos: não se descobrem com tanta facilidade. Mas vejam se tenho ou não razão de desconfiar. Ontem, à boca da noite, voltando para casa, vi a tia Onistalda que da porta da rua estava a conversar com um indivíduo que não pude reconhecer, por causa do capote em que estava embuçado. (Luísa presta grande atenção.)

(47) [C $201 \mathrm{WL} 1$ 13] Ha poucos dias, falando num | banquete de jornalistas, Getulio repetiu as ha| bitues declarações sobre a constituinte, sem pre- | cisar, todavia, a data da reunião.

A circunstância de tempo nas OGs pode-se dar através de uma relação de concomitância (45) com o evento expresso na OM, ou ainda uma relação de anterioridade. Brandão (1933) já havia observado que a circunstância de tempo posterior aproxima essas OGs de estruturas coordenadas, como mostra o exemplo abaixo encontrado no corpus:

(48) [C 181 Ald 19 45] Assim que logo Sepos asalvo hindo queixarse aVossa Excellencia antes que Eu ofizeSse.

Exemplos como (48) foram considerados aqui como casos em que está expressa a idéia de adição, uma vez que estruturas como essa podem ser comutadas em coordenadas aditivas, introduzidas pela conjunção "e". Esse procedimento tem como critério básico a idéia de que nessas construções a circunstância de tempo é um 
sentido de base que se verifica em todas as OGAdvs, se entendermos que a ligação entre dois eventos se dá numa relação de posição no tempo que cada uma ocupa em relação à outra. E já que falamos da ambigüidade, o exemplo acima poderia muito bem ser entendido como um caso de oração de modo (Como se pôs a salvo? - Indo queixar-se). Não é à toa que as três circunstâncias aparecem com igual produtividade segundo os resultados obtidos no gráfico 1, com 24,1\% para as OGs de tempo, 22,4\% para as de modo e $20,9 \%$ para as de adição, representando $67,4 \%$ do total de OGs encontradas no Corpus Básico.

As orações de tempo podem exibir ainda outros matizes como o temporalcausal:

(49) [C 181 Ald 6 1] Sem favor de vossa excelencia em aoCupaÇaõ em que aCisto naõ he poÇivel Satisfazer Como de zejo em obem, eaumento deS[ta] Aldea. - tendo notiÇia de que hua jndia CaZada que tem omarido emoCaminho doCu[y]aba por ordem de vossa excelencia, andava empeCadoCom outro jndio CaZado, Com jndiCios de que tinhaõ tenÇaõ defugirem; (...)Se me auZentou o dito jndio

(50) [C 192 CL 475 7] De repente estaca-se nessa carreira delirante: todos | os corpos soffrem uma commoção violenta: era uma | das locomotivas, que, desviando-se do trilho, rompeu | a terra por algum tempo com suas rodas e, ganhando | a beira do barranco, tombou n'um fosso de mais de 15 | pés de profundidade.

(51) [C 201 MA 340 5] Não sei se lhe contei, uma circunstância curiosa que me preocupou muito foi que depois de exames, diagnóstico de médico e tudo, tendo que escrever o estudo de introdução pro livro do Gallet, li toda a correspondência dele e topei inesperadamente com uma carta dele.

e ainda o temporal-condicional:

(52) [C 181 Ald 214 ] estegosto semedobra oje - empenas ponderando as que vossamerce ea Senhora minha Prima pade- se;

(53) [C 201 TA 5 2] Isto aqui está lindo. Por que você não resolve uma viagem? O brasileiro se engana, pensando que é preciso uma fortuna para vir a Paris.

A tabela 13 mostra que as OGadvs de tempo no séc. XVIII estão bem representadas na maioria dos textos, e em comparação às outras circunstâncias presentes nestes textos a relação de tempo é a mais freqüente nas memórias $(36,9 \%)$, nas cartas oficiais $(20,0 \%)$ e da administração privada (24,3\%), e também nos entremezes $(28,0 \%)$. Vale lembrar que os entremezes do séc. XVIII são de origem portuguesa, pois, como já expliquei anteriormente, não encontrei textos de teatro exclusivamente brasileiros para este século. As cartas particulares exibem apenas uma ocorrência entre as poucas OGadvs que compõem esse tipo de texto.

No séc. XIX, apesar de ampliada a tipologia textual com os anúncios e as cartas de jornal, percebe-se que a relação de tempo nas OGadvs diminui quantitativamente. Ela continua alta nas memórias $(22,2 \%)$ e se faz presente em 
outras tipologias textuais (anúncios, cartas de jornal e peças de teatro). Apesar de aumentar o número de OGadvs nas cartas particulares, um número reduzido delas traz a relação de tempo $(13,3 \%)$.

A partir do séc. XX, contamos apenas com 12 casos de OGadvs de tempo, que também se concentram em sua maioria nas memórias, estando as demais ocorrências distribuídas de maneira bem tímida nas outras tipologias textuais. $\mathrm{Na}$ língua falada ocorre apenas em um caso de OGadv, que também poderia ser interpretada como modal:

(54) [FB2 220 15] Inf. cobra tem né? o negócio é esse...ela nu quebrô a perna um dia descendo da cachoera nu quebrô a perna trupicô na perna quebrô a perna por que isso?...nu dá...( ) nu dá pa passá bem sem isso uma coisa qui nu é percisão por que qui vai fazê isso né?

Essas constatações levam a crer que desativou-se significativamente nas OGadvs de gerúndio a relação de tempo (dessemanticização), mantendo-se produtiva em textos escritos de maior formalidade como as memórias, nas quais a expressão de tempo é de vital importância para a seqüenciação dos fatos históricos narrados.

O valor temporal também é igualmente representativo para as CAs em todos os séculos, em várias classes de textos como provam as tabela 12 e 14:

(55) [C 181 Seb 15 6. preguntandolhes eu, Sehera al guã ordem ouCervico deSua Magestade que Deos guarde Responderaõme, oque vossaExcelencia nessas Duas Certidoins verâ que asmandej paçar pellos ofiçiaes de Justiça que prezentemente Seaxaraõ

\section{VI.2.3.2 O valor causal}

Apesar de menos freqüente que as orações de tempo e modo, as OGadvs causais ocorrem em todos os séculos:

(56) [C 181 Ald 13 14] Hua pobre viuva Grave mepedio RemetteSse aVossaExcelencia eSsa petiçaõ parecemdolhe que aSsim terâ milhor despacho, e todoConteudo nella hê verdade.

(57) [C 192 CL 512 3] Tendo de ir á côrte indaguei de alguns | amigos quando haveria vapor para lá e me | foi dito que sahia a 11 do corrente, o que por $\mid$ mim foi verificado tambem no Diario de San- | tos, na parte que trata da sahida e entrada | de navios naquelle porto.

(58) [M 201 PRO 10] Tendo em mira sempre assunto exclusivamente local direi em rápidas linhas algumas palavras sobre alguns homens ilustres, filhos de Santos, para depois me externar mais quando me referir às suas Igrejas e capelas e conventos da antigüidade.

OGadvs modais também podem exibir o matiz modo-causal. O particípio desenganado no exemplo (60) parece confirmar essa nuance:

(59) [M 182 MCA 25] Tambem quer persuadir omesmo Author (d) [ $\leftarrow$ (d) Ibidem ] que aviagem doCosmografo Florentino seRe $=$ tardou athé oanno seguinte de 1503. Nessa parte naõ selhe $=$ acha razaõ, porquanto de seequivocar Ozorio aRespeito donome, escre vendo |[p. 6] escrevendo 
Gonsallo Coelho emlugar deAmerico Vespucio, pornenhum modo seinfere que tambem errou aEpoca verdadeira doSucceSso relatado.

(60) [M 181 NP1 37] Desenganado o Anhangüera, marchou com a mais tropa e julgando, que indo sempre ao Norte, como até ali tinha feito, lhe ficavam já atrás os Guayases, que procurava, mudou de rumo, e seguiu a Nordeste 4 a do Norte.

No séc. XVIII, podemos encontrar o maior número de ocorrências nas memórias e nas cartas de administração privada. Já no séc. XIX, sua ocorrência é maior na cartas de leitores $(8 / 25, \%)$ e nas cartas de redatores $(4 / 44,0 \%)$. Nesse tipo de texto, o recurso parece ser utilizado por dois motivos: as cartas de leitores normalmente envolvem uma reclamação ou pedido e por conta desta finalidade o relação de causa pode aparecer com mais frequiência. A opção pelo gerúndio deve-se talvez a uma crença do seu autor de que este tipo de texto deve apresentar um estilo mais elaborado, arcaizante, como denotam os exemplos abaixo em que um leitor, ao reproduzir um diálogo fictício entre um brasileiro e um português, zomba da ostentação de certos alunos da Academia de Direito de São Paulo em relação a seus companheiros menos abastados:

(61) [C 191 CL SP 389 6] De | volta sentei-me a descançar na ponte franca | e ai estavão talvez ao mesmo fim dois su- | geitos, um dos quaes era um Portuguez | velho, e Brasileiro novo, digo Portuguez | velho, porque nasceu nas marges do Doiro, | e ja é avançado em annos, e Brasileiro no- | vo, porque vivendo entre nós, e adherin- | do á nossa causa tem tantos annos de Bra- | sileiro quanto o Brasil de Nação Indepen- | dente; o outro era um rapaz Paulista, e | segundo me persuado, estudante de Latim.

(62) [C 191 CL SP 389 9] Logo que cheguei encetavão elles uma con- | versação, e por me parecer interessante | apenas voltei a casa tractei d'escrevêl-a pa- | ra me não esquecer; e suppondo que pos- | sa alguem julgal-a tambem interessante | lh'a envio para que se digne publicar no seu | Farol.

No século XX, encontramos apenas 11 ocorrências, 5 delas nas memórias e as restantes distribuídas entre cartas oficiais, particulares e em diálogos do tipo D2. Na fala, este tipo de construção também aponta para um grau de maior formalidade, como mostra o exemplo seguinte:

(63) [D2 SP 360 113] L1 tinha-se esperanças...em que dona Ana Cândida tendo assumido a procuradoria geral do Estado...em ela sendo mulher...que ela defendesse um pouco mais a:: a classe não?

No exemplo (63) há outros índices de formalidade como o emprego do se indeterminador e o advérbio em acompanhando o gerúndio. ${ }^{368}$

As CAs seguem a mesma freqüência de ocorrência e de distribuição nos textos analisados. A maioria dos casos é de anteposição da OG:

\footnotetext{
${ }^{368}$ Moraes de Castilho (2005) defende que o item em que acompanha os gerúndios nestas construções são originários do antigo advérbio ende do português arcaico, um locativo.
} 
(64) [C 192 WL 13 5] Arrangei um emprego explendido: estou na repartição de Terras e Colonisação, como auxiliar de escripta; te- nho $150 \# 000$ reis mensa[e]s, mas havendo durante o o meu $1^{\circ}$ anno um imposto de $10 \# 000$ fico redusido a $140 \# 000$ o que já não é pouco;

(65) [A 192 SP 8] PROPAGADORA DA INSTRUÇÃO POPULAR|Tendo de se dar no dia 6 do corrente a festa da distribuição dos prêmios naquella escola, são convidadas as excelentíssimas famílias|que quizerem honrar com suas presença aquelle acto e para as quaes haverá lugares reservados; bem assim são convidados|todos os alunnos a comparecerem no referido dia às 7 horas da noite. Diário Popular, 03 de janeiro de 1879

(66) [C 202 CL 61 1] Ilustre Escritora: | Tencionando o Instituto Estadual do Livro dessa Diretoria de Letras lançar, ainda no corrente ano, na sua coleção de divulgação (Cadernos do Rio Grande), uma seção dedicada a textos de autores brasileiros modernos, vimos a sua presença solicitar o interesse no sentido de que a referida seção seja inaugurada por Vossa Senhoria.

Nota-se que no séc. XIX tanto OGadvs como CAs têm um aumento, e esta relação é bem alta para as CAs $(18,9 \%)$.

\section{VI.2.3.3 O valor condicional}

A circunstância de condição aparece pouco nos corpora analisados, mas pode ser encontrada nos três séculos:

(67) [TEA 182 FE 30] Mon. Pois Comadre, venha á cozinha, e lá verá no chaõ todas as cascas dos ovos, e contando-as, saberá a verdade, e livra-se da duvida que tem, mais meu Compadre.

(68) [A 191 SP 28] Este escravo já fugio da Cadeia com outros crimi-|nosos que alli se achavão; mas felizmente tornou al ser pegado; quem for seu dono dirija-se ao menciona-|do Juiz, que provando legalmente que the pertence| lhe sera' entregue. $O$ Farol Paulistano, 18 de julho de 1829

(69) [TEA 201 RV 22] ABELARDO II Não são não. Descanse. Eu entendo de socialismo. Olhe. A lei de férias só deu um resultado. Não há mais salário de semana ou de mês. É por dia de trabalho, ou por contrato. Somando bem, os domingos, feriados e dias de doença eram mais que as férias de hoje.

No séc. XVIII, as OGadvs condicionais concentram-se nas memórias e nas

cartas de administração privada. A circunstância de condição que se estabelece

entre a ação praticada pelo interlocutor/leitor e o julgamento dessa ação feito pelo

falante/autor é tida pragmaticamente como ofensiva. Dessa forma, nas cartas escritas

em grau de ascendência, parece que o escritor procura atenuar a expressão dessa

circunstância, optando pelo uso do gerúndio:

(70) [C 182 Seb 23 15] Ocontrario doque tenho ex posto aVossa Excelencia, naõ overá quen] diga, deque pode Vossa Excelencia in formar-Se das peSsoas deme lhor [conceito ?] destaVila, eaxando pello Contrario doque tenho refe- rido aVossa Excelencia, em mim Seja executado omerecido castigo- [espaço]

(71) [C 181 Ald 11 10] Eoutro Ssim por que hay huãs profeçias de Como vossaexelencia naõ hade hir a Cujaba SenoSso Senhor ouvir osRogos dospeccadores aSsim mesmo hadeSer por que me parece naõ há’ quem Sedescuide Com esta deligençia inda que Seria Com muito dispendio de vossaexelencia Seadita pro feçia sahir Certo eu Sobre todos devo Ser o mais Contante por ficar Soçegado mas $\mathrm{Su}$ ponho indo vossaexelencia Sempre ficarei aSombra dos Criados devossaexelencia

(72) [C 181 Ald 12 17] me foi nesesario dar Contas ao General Antonio dasilva Caldeira pimentel antes sesor de vossa excelenca oque me Respondeu emandou huã ordem cuio vai iunto Com 
aCarta inCLuza para vossa excelenca ver para que sendo servido me posacon firmar para comseguir

(73) [C 181 Ald 12 29] eComo tem faLesido o Cappitam mor da dita Aldea hé nesesario que vossa excelenca sendoser vido mande prover outro

Nos exemplos acima, os missivistas atenuam o pedido feito utilizando uma construção de gerúndio.

O maior número de ocorrências do séc. XIX concentra-se nos anúncios e também neles parece valer o argumento anterior:

(74) [A 191 SP 28] Este escravo já fugio da Cadeia com outros crimi-|nosos que alli se achavão; mas felizmente tornou a| ser pegado; quem for seu dono dirija-se ao menciona-|do Juiz, que provando legalmente que lhe pertence| lhe sera' entregue. $O$ Farol Paulistano, 18 de julho de 1829

(75) [A 191 SP 10] Em Novembro de 1825 fugio desta Cidade ao| Sargento Mór Joaquim Floriano de Godoi uma es-|crava parda de nome Maria (...) Quem d'ella lhe der noticia certe[r]a em| poder de quem existe será recompensado, e entregan-|do-lhe nesta Cidade receberá trinta mil reis de alviçaras. $\boldsymbol{O}$ Farol Paulistano, 22 de outubro de 1828

(76) [A 191 SP 12] Ao Coronel Ignacio de Sá da Villa de Cori-|ba lhe fugio um escravo preto, de nome João (...) qualquer pessoa que o pegar pode fazer con-|duzir a Sanctos a entregar ao Capitão Manoel de Alva-|renga Braga, ou a João Rodrigues Lima, que sa-|tisfará todo o trabalho, e despeza que se fizer com| esta diligencia levando o a entregar com toda se-|gurança. $O$ Farol Paulistano, 08 de novembro de 1828

(77) [A 191 SP 16] Para o pasto da Chacara do Tenente Coro-|nel Crispim a 3 mezes pouco mais ou menos forão| mandados por Amaro José Vieira 4 cavallos; e quan-|do os mandou tirar veio um trocado, o que faz pú-|blico para que o seu dono o receba dando a prova competente. O Farol Paulistano, 28 de fevereiro de 1829

No séc. XX ocorrem apenas dois exemplos na língua falada. Eles são representativos de situações em que o gerúndio condicional ainda parece bastante produtivo, ou seja, quando no enunciado está envolvida uma relação hipotética/contrafactual entre os eventos expressos na OM e na OG:

(78) [D2 SP 360 55] L2 porque::já pensou que que eu vou dizer para ele se ele não for eu não sei realmente eu chego na eu fico::indecisa...porque acho muito cedo para impor mas também se ele aprender a que dizendo que não quer ir não vai...eu estou criando um precedente muito sério...

(79) [TEA 201 Tel 21] GENI - Para mim não interessa que seja esse negócio, sendo bacana já me serve.

Assim como as OGadvs, as CAs condicionais são utilizadas em várias classes

de textos. Aparecem preferencialmente na anteposição (80), ou interpoladas dentro de outra subordinada (81) ou da própria OM, mas também podem estar posição final

(80) [C 181 Ald 11 10] Eoutro Ssim por que hay huãs profeçias de Como vossaexelencia naõ hade hir a Cujaba SenoSso Senhor ouvir osRogos dospeccadores aSsim mesmo hadeSer por que me parece naõ há' quem Sedescuide Com esta deligençia inda que Seria Com muito dispendio de vossaexelencia Seadita pro feçia sahir Certo eu Sobre todos devo Ser o mais Contante por ficar Soçegado mas $\mathrm{Su}$ ponho indo vossaexelencia Sempre ficarei aSombra dos Criados devossaexelencia

(81) [C 192 WL 14 5] Faço isso para minha tranquilidade, porque não merecendo fé minha palavra tenho satisfação em ver garantida [p. 2] em toda a plenitude a minha maior credora e mais ainda aos herdeiros da mesma. 
(82) [C 202 CLis 61 3] Frisamos, outrossim, que a nossa coleção não tem objetivos de lucro, sendo os seus volumes distribuídos por bibliotecas e instituições de cultura, e, por razões óbvias, colocados nas livrarias a preço popular.

\section{VI.2.3.4 O valor concessivo}

A relação de concessividade é pouco produtiva em OGadvs. No séc. XVIII, é utilizada em uma memória, em uma carta oficial e duas vezes em cartas particulares. No séc. XIX, ela só é detectada nas memórias, com três ocorrências e, no séc. XX, ela não ocorre nos corpora analisados:

(83) [C $18 \quad 1$ Ald 14 1] Nunca cuydey que os passatempos, dos divertimentos devossamerce meocazionace moles tias, enaõ há duvida que fazendome todas as Cabeleyras de graSa inda naõ mepaguava, oque t[enho o]zado. Sobre oSeofilho levado do emguano, dequem naõ esperava.

(84) [C 182 Seb 21 3] Acauza desteprocedimento hê, porter acerteza deotal Manuel vicente ter desonestado ahua pobre moça, evendoa sem forças eamparo, atem bandonado; eporque a Mai datal moça per- tende querelar pello facto eleivozia, esurdirem outras, pertur- baçoiñs aeste Republica, por evitarlas, tomei este espediente, naemtelligencia desermais util ao Real Serviço, evitando criminozos dosquais Senão Serve Deos, nem Sua Magestade.

(85) [M $191 \mathrm{RDN}$ 15] Noto neste procedimento duas incoherencias= a 1.a hé oerigir em Vila aAldea deSaõJozé, podendo contentar-se comfazela Freguezia, pois que ainda naõ tinha, nem hoje tem Capacidade para ser Vila. 2.a que tendo adita Povoaçaõ nome deVila com Pelourinho, eCamara, emque tem servido promiscuamente brancos, eIndios, ainda conServa onome deAldea, etenha Director.

São poucos os casos de CAs concessivas nos corpora, elas só aparecem no séc. XVIII e XIX:

(86) [M $191 \mathrm{RDN}$ 15] Noto neste procedimento duas incoherencias= a 1.a hé oerigir em Vila aAldea deSã̃Jozé, podendo contentar-se comfazela Freguezia, pois que ainda naõ tinha, nem hoje tem Capacidade para ser Vila. 2.a que tendo adita Povoaçaõ nome deVila com Pelourinho, eCamara, emque tem servido promiscuamente brancos, eIndios, ainda conServa onome deAldea, etenha Director.

\section{VI.2.3.5 O valor final}

Tradicionalmente o valor de finalidade não é reconhecido para as OGs nas gramáticas do português. Os únicos autores que mencionam a possibilidade de gerúndios com valor de finalidade são Claudio Brandão (1933) e Odette Campos (1972). Encontramos 15 casos nos quais se pode interpretar a circunstância final na OGadv.

Muitas vezes, quando na OM já foi introduzida uma noção de finalidade, existe a possibilidade de que uma OG assuma também o valor final, por empréstimo do valor semântico já introduzido anteriormente. O exemplo abaixo revela alguns 
mistérios a respeito deste tipo de estrutura:

(87) [M 182 MPC 51] 64. 20. Continuando nestes mesmos sentimentos por effeitos delles man- dou oprimeiro General daCapitania deSaõPaulo Antonio deAlbo- querque Coelho deCarvalho no anno de1700 por huma ordem Sua, que senaõ deichacem Saber [Sahir?] os moradores efamilias estabelecidas nas Vilas de beira-Mar para as Vilas de Serra aSima Sem licença Sua, nem ainda $\operatorname{com}>\mathrm{o}=[$ p. 10] $>\underline{9}>550$ Opretexto de negocio por ser muito prejeducial ao Serviço de Sua Magestade /5/ para naõ tirar osagricultores da Marinha, fazendo Soldados os seus povoadores, determinando SuaMagestade aoConde deSarzedas, que levantace mais duas Companhias deSoldados para forteficar aPraça deSantos, aodepois sou[bre] reprezen- taçaõ, que estalhe fez declarou por Provizaõ de 17 deDe- zembro de 1734 expedida pelo Concelho Ultramarinho /6/ que aoGovernador deRio deJaneiro lhemandou or- dem para dos passageiros, que fossem doRio semPasa- porte mandar para adita Praça, afim deSefazerem Soldados, naõ só sincoenta homens; mas todos osque fossem neces- sarios, eque das Ilhas selhe haviaõ de remeter mais cinco- enta.

O contexto em que a reduzida de gerúndio fazendo soldados os seus povoadores aparece, rodeada de tantas outras orações finais (v. grifos), confere-lhe um valor final-consecutivo, e talvez pudesse ser parafraseada por uma construção como a fim delde modo a. No trecho selecionado percebe-se que há um caráter volitivo envolvido que dá suporte a esta idéia:

(87a) O primeiro general da Capitania de São Paulo mandou uma ordem para não tirar os agricultures da Marinha ${ }^{369}$, fazendo soldados os seus povoadores.

(87b) Ele não quer que se tire os agricultures da Marinha, para fazer soldados os seus povoadores.

Isto parece ser um argumento para defender a idéia de que as OGs também assumem o valor proposicional por empréstimos semânticos do contexto em que aparecem, ou seja, na composição com os verbos da OM, ou através da semântica do próprio radical do verbo no gerúndio.

O raciocínio de Rudolph (1955 apud Böckle, 1983) a respeito desse fenômeno parece dar conta dessa idéia:

Die gedankliche Verbindung zwischen Haupt- und Nebensatz kann unter Umständen auch komplex sein. Der Sprechende wählt dann nicht eine Möglichkeit der Verknüpfung aus, sondern versucht, die Nebenaussage in doppelter Weise mit der Hauptaussage zu verbinden. Naheliegend ist die doppelte gedankliche Verknüpfung des Nebensatzes mit dem Hauptsatz, wenn dadurch zwei Satzarten verbunden werden, die einander gedanklich nahe kommen. Dieser Fall liegt vor bei der Verbindung eines Konsekutivsatzes mit einem Finalsatz, wenn nämlich die Wirkung oder Folge als beabsichtigt und nicht nur als Tatsache hingestellt wird. In solchen Verbindungen ist aber der konsekutive Gedanke zum finalen hinzugekommen, sondern der finale Gedanke hat sich in einen Konsekutivsatz hineingedrängt (Rudolph, Elisabeth, 1955, apud Böckle, 1983). ${ }^{370}$

\footnotetext{
${ }^{369}$ Marinha = litoral.

370 Tradução de Klaus Böckle em Böckle (1985 [1984]): “A ligação de ideias entre a oração principal e a subordinada pode, segundo o caso, verificar-se complexa. O locutor, então, não selecciona só uma possibilidade de ligação, mas tenta ligar, e maneira dupla [sic], a enunciação secundária à enunciação principal. Pensa-se, em primeiro lugar, na dupla ligação de ideias entre a oração subordinada e a oração principal, quando assim ficarem ligados entre eles dois tipos de
} 
Elisabeth Rudolph (1973) observa em um estudo posterior que as orações finais são portadoras de um complexo informativo [Informationskomplex], no qual a semântica de finalidade expressa na oração subordinada já foi liberada pela oração principal. Neste caso, na oração principal está expressa uma idéia de volição em relação a alguma ação a ser cumprida:

Im Finalgefüge wird ein kausales Verhältnis unter dem Aspekt des Willens gesehen. Wie im Konsekutivgefüge steht im Hauptsatz Ursache oder Grund; der Finalsatz enthält Wirkung oder Folge als die Vorstellung eines möglichen Geschehens, auf das sich der im Hauptsatz erkennbare übergeordnete Wille richtet. Unabhängig von der zeitlichen Position der Haupthandlung steht die des Finalsatzes nach dem Hauptsatz; die seltene Voranstellung dient keinem besonderen Ausdruck des finalen Gedankens. (...) Im Finalgefüge ist die Kausalkette sozusagen doppelt geknüpft: auf der Ebene des Handelns steht die Ursache im Hauptsatz und die Wirkung als Vorstellung im Finalsatz- auf der Ebene des Wollens ist das im Finalsatz stehende Ziel für den Willensträger die Motivierung und damit der Grund für das im Hauptsatz genannte Geschehen. Im Unterschied zum finalen Infinitiv ist der Handlungsträger im Finalsatz nicht mit dem der Haupthandlung identisch (Rudolph, 1973:58). ${ }^{371}$

Este parece ser o caso do exemplo acima mencionado, e dos seguintes, onde se pode ver na ação expressa na OG o resultado de uma ordem a ser seguida. Os agentes da ação expressa na oração final em (88) e (89) não são os mesmos que desencadearam o evento, o que não acontece em (90), no qual o agente da OM é idêntico ao da OG, o que a aproxima mais de uma oração conclusiva:

(88) [C 182 BAN 6 1] ObedeSendo orespeitaveu despacho devossa enxelencia enformo Naforma Seguinte OS[oplicante] Padre Joaõ Barboza deSumCam Sendo Naturar Naferguezia deja vari PaSou Acazade Naoscal dacompanha torio verde onde Tem deSua Molher dois filhos

(89) [C 182 Gen 6 1] Obedecendo ovenerando despacho deVossaExcelencia fi[s] toda adeligencia $\mathrm{poS}=$ sivel para informar avossaExcelencia pella minha propria maõ, como do= mesmo informe Seve, mas naõ pude continuar pella debilidade Comque meacho doente emCama:

(90) [C 182 Seb 21 6] Acauza desteprocedimento hê, porter acerteza deotal Manuel vicente ter desonestado ahua pobre moça, evendoa sem forças eamparo, atem bandonado; eporque a Mai datal moça per- tende querelar pello facto eleivozia, esurdirem outras, pertur- baçoiñs aeste Republica, por evitarlas, tomei este espediente, naemtelligencia desermais util ao Real Serviço, evitando criminozos dosquais Senão Serve Deos, nem Sua Magestade.

orações que estão logicamente perto um do outro. Tal caso realiza-se na ligação de uma oração consecutiva com uma oração final, justamente quando o efeito ou a consequência vierem apresentados como desejados e não pura e simplesmente como factos. Em tais construcções, porém não é a idéia consecutiva que veio associar-se à ideia final, é a ideia final que invadiu uma oração consecutiva".

${ }^{371}$ Tradução minha: "No enunciado final vê-se uma relação causal sob o aspecto da volição. Como nas orações consecutivas, a razão ou causa está na oração principal; a oração final contém o resultado ou a conseqüência como representação de um possível acontecimento, para o qual se orienta a vontade que se pode reconhecer na oração principal. Independentemente da posterioridade temporal do evento expresso na oração principal, a posição temporal da oração final é sempre subseqüente à da matriz, a rara anteposição temporal não confere à oração final nenhum sentido especial. (...) Na oração final a cadeia causal aparece, por assim dizer, duplamente interligada: no plano da ação a causa está na oração principal e a conseqüência, como representação, na oração final - no plano da volição, o objetivo contido na oração final é, para aquele que requer, a motivação e a razão para o acontecimento mencionado na oração principal. Ao contrário das construções infinitivas finais o agente expresso na oração principal não é idêntico àquele da oração principal" (Rudolph, 1973:58). 
Por estas características é que as OG finais aparecem mais em enunciados que se refiram a uma relação assimétrica entre os participantes da cena, como é próprio das cartas de administração privada, cartas oficiais e também de anúncios, como se lê da tabela 2.

(91) [M 182 MPC 16] aeste Respeito hu- ma só propoziçaõ aeste Respeito si parece evidentemente certo que Se a Capitania deSaõPaulo preciza deGeneral, no rio Grande aonde sempre tem sido, eseraõ as nossas contestaçoens com os Espanhoes, heatodas as Luzes mais necessario eindespençavel, athe segindo amesma razaõ porque os Espanhoes poseraõ ViceRey em Bou[y]nos Aires:

(92) [C 182 Seb 21 6] Acauza desteprocedimento hê, porter acerteza deotal Manuel vicente ter desonestado ahua pobre moça, evendoa sem forças eamparo, atem bandonado; eporque a Mai datal moça per- tende querelar pello facto eleivozia, esurdirem outras, pertur- baçoiñs aeste Republica, por evitarlas, tomei este espediente, naemtelligencia desermais util ao Real Serviço, evitando criminozos dosquais Senão Serve Deos, nem Sua Magestade.

\section{VI.2.3.6 O valor consecutivo}

Nas orações consecutivas, o evento expresso na oração matriz é a causa que provoca alguma mudança verificada na oração subordinada. Muitas vezes é possível comutar as orações consecutivas através de uma estrutura de correlação do tipo [dáse $X$, de modo que acontece $Y]$ ou do tipo [A é tão [X] que [Y]]. Nas OGadvs verifica-se ainda um suporte semântico de causa, expresso através de adjetivos intensificadores ou qualitativos, como nas seguintes ocorrências:

(93) [C 182 Seb 23 10] eprezentemente Sendo ac= tual Juis dos orfaons: por cujos fundamentos, naõ Só Seviaaba= tido omesmo Tenente Juliaõ, eSeus filhos oAlferes Juliaõ deMoura Ne= graõ, o Reverendo Padre Manoel Negraõ vigario da[Mera ?] e Igreja da[Tra?]= [g.a ?] deSanta Anna de Sapucahi deste Bispado, eoutros que existen nesta Vila, por Severen aniquilados depalavras tão rediculas, efalças inposturas, procurando deste modo ajurdiçaõ da= queles homens, Como taõ bem esta Republica, expostos todos oque omesmo faça aqualquer dos Senhores condecorados.

(94) [M 191 BON 20] Amistura das cargas hé mal feita, porque o mineral naõ hé devidamente queimado evai quaze crû aos pisoens; a pedra verde que se jun_ta na preparaçaõ de um quinto por 35 do mineral, hé mão fundente, por que hé dificil de queimar, pilar e fundir, dando escorias tenazes e muito ricas em ferro.

(95) [M 191 BON 33] Nesta ultima fundi_caõ, que durou mais de 6 mezes se obteve de ferro crû 13000 e _ tantas arrobas, segundo oque me d\{i\}sse o Administrador, mas creio que houve engano, porque comprando esta com aprimei_ra fundiçaõ, naõ hé provavel que desse mais de 9000 arrobas. Enquanto ao producto do mineral em ferro crû, e calculando- pela primeira fundiçaõ veio o mineral misturado, que dá 75 por 100 a dar 35 - perdendo-se 20 por cento, oque se colhe tambem do grande pezo das escorias.

Relativamente às orações consecutivas, Elisabeth Rudolph (1955:36) retoma

o raciocínio de Lerch em seu estudo sobre a sintaxe diacrônica do francês arcaico:

Eine Sicherheit, dass der Konsekutivsatz von vornherein mit dem Hauptsatz zugleich konzipiert war, ist nur dann gegeben, wenn das 'que' im Hauptsatz ein von ihm getrenntes 
Korrelat hat. Diese psychologische Unterscheidung deckt sich weitgehend mit der formalen Zweiteilung, wenn man nur die Konsekutivsätze im Hauptsatz ein getrenntes Korrelat haben, als mit dem Hauptsatz zugleich konzipiert ansieht. Obgleich Lerch diese Unterscheidung ebenfalls ablehnt, folgt er ihr in gewisser Weise doch, denn in seiner Darstellung der Konsekutivsätze behandelt er die Sätze, die ein Korrelat im Hauptsatz haben, getrennt von den übrigen“" (Rudolph, 1955:36). ${ }^{372}$

A autora ainda faz uma diferenciação entre oração consecutiva de efeito [Wirkunsgsatz] e oração consecutiva de resultado [Folgesatz]. Orações consecutivas de efeito são concebidas juntamente com a OM. Elas expressam o efeito da intensidade ou do modo, que já é indicado pelo correlato na oração principal. As orações consecutivas de resultado representam uma complementação posterior ao conteúdo da OM. Esse tipo de oração representa o resultado de uma ação nãointensificada que foi expressa na OM (Rudolph, 1955:37). Wirkungssätze são tratadas tradicionalmente na literatura gramatical como construções correlatas. Às margens das orações que formam o enunciado correlato surgem pares de expressões tais como: tanto...que, tão... que, tal... que e assim... que. Folgesätze podem ser entendidas como construções conclusivas [como X, deu-se $Y$ ]. Por este motivo é que foram incorporadas aqui as orações conclusivas apontadas por Brandão (1933) e Campos (1972).

Elisabeth Rudolph atenta ainda para a questão da processabilidade dos enunciados empreendida pelos ouvintes. Segundo esta autora, quando não há uma estrutura correlata muito clara, cabe ao ouvinte/leitor interpretar se um enunciado é consecutivo/conclusivo ou não (Rudolph, 1955:136) . O meio formal que denota essa circunstância muitas vezes realiza-se através do uso de adjetivos e advérbios, como nos primeiros exemplos acima.

Como se vê pela tabela 13, há um aumento significativo de OGadvs consecutivas no séc. XIX, e o contexto preferido por elas é novamente o das memórias, nas quais os eventos históricos se correlacionados através do binômio causa-consequiência. É de supor-se que na língua falada outros esquemas sintáticos são utilizados para relação de causa-conseqüência, como a justaposição com

\footnotetext{
${ }^{372}$ Tradução minha: "Só existe uma certeza de que a oração consecutiva já foi concebida de início com a oração principal, se o 'que' na oração matriz tiver um correlato separável dele. Essa distinção psicológica corresponde consideravelmente à divisão formal, somente se observarmos que as orações consecutivas têm um correlato na oração principal, ao contrário de ser concebido juntamente com a oração principal. Embora Lerch refute esta distinção, ele, de alguma forma, acaba seguindo-a, pois em sua descrição das orações consecutivas ele separa das demais as orações que têm um correlato na oração principal”.
} 
conectivos (O copo caiu, elpor isso quebrou/acabou quebrando).

O mesmo esquema de correlação também pode ser observado nas CAs consecutivas, as quais são comumente antecedidas de elementos intesificadores presentes na OM:

(96) [M $191 \mathrm{BON}$ 43] De mais os cavacos por serem muito grossose compridos e por se rem muito mais inflamaveis que acepa, deixaõ passar o mi- neral crûatravez athé orast ou encosto do bojo, e daõ hûa fusaõ rapida sem o devido aquecimento gradual, e carbonisa çaõ do ferro, precipitando-se agusa fria na caldeira, pouco liquida, e muito branca, sem adevida separaçaõ da escoria

(97) [M 191 BON 60] Detodos estes defeitos juntos vejo, que se perdiaõ dois terços da gusa em escorias, esó se aproveitava hum terço de ferro em barra, gastando-se a enormiSsima quantidade de 20 arrobas e - mais de carvaõ para dar huma de ferro refinado, quando nas bôas forjas estrangeiras naõ se perde se naõ 12 até 20 de ferro por 100 de gusa e combustivel naõ passa daproporçaõ 4 quando muito pa_ra hûa de ferro em barra.

(98) [M 191 BON 66] Igualmente acrescentarei para concluir com os defeitos da mani - pulaçaõ actual, que aproporçaõ do combustivel para o mineral na - fundiçaõ dos fornos hé em extremo grande, gastando-se superflua - mente muito carvaõ ecavacos.

(99) [M 192 HC 4] A Este apenas uma vereda quase intransitável levava à beira-mar, vereda fácil de obstruir, obstruída mais de uma vez, tornando a população sertaneja independente das autoridades da marinha,

Como se vê, a memória de José Bonifácio, um relatório sobre a fábrica de

ferro de Sorocaba, é responsável pelo alto índice de CAs consecutivas encontradas no séc. XIX. Nos outros dois períodos também aparecem em cartas de administração privada, porque também nelas muitas vezes a finalidade que move a escrita é a de prestação de contas.

\section{VI.2.3.7 O valor aditivo}

As OGs aditivas, junto com o grupo das temporais e das modais, representam um grupo bastante significativo nos corpora. O evento expresso nesse tipo de OG é utilizado para compor a sucessão de eventos que compõem a cena descrita pela oração complexa. Nelas está sempre envolvida uma relação de tempo posterior.

Podemos visualizar esta questão através dos exemplos abaixo:

(100)[C 182 Seb 22 9] Eu axome Jâ ComSeteLeoas emeia deestrada feita, e Com tinuando sem SoSego para dianteeC $[\bar{S}$-sobrescrito $]$ om forme oquemedis o meu piCador que emthe as deviZõis das agoas, ainda ave rá de dis tanSia tres Legoas, eque deSerta altura para diante tudo Saõ terras inutil;

(101)[M 191 RDN 64] OSenhor Artur de Sá eMeneses, deOrdem de Sua Magestade, deo hum Regimento para oGoverno dasAldeas, em 15 deJaneiro de1698, emque acautella muita coiza, dando huma ampla Jurisdiçaõ aoProcurador geral dosIndios, debaixo decujas Ordeñs estavaõ osCapitães dos mês $=$ mos (a).

(102) [C 202 CLis 18 3] Junto aqui o texto francês, rogando-lhe a fineza de devolvê-lo em prazo breve.

No exemplo (100), o autor da carta relata que já construiu SeteLe[g]oas de sua estrada "e" que continua sem Sosego para diante. Percebe-se aí uma relação de 
sucessão de fatos. Em (101), estebelece-se uma relação de adição temporal abstrata, quer dizer, ao mesmo tempo que OSenhor Artur de Sá eMeneses deo hum Regimento para oGoverno dasAldeas, Sá eMeneses deu huma ampla Jurisdiçã aoProcurador geral dosIndios. Note-se na OG ainda a reativação do verbo dar [ao mesmo tempo que $X, Y]$. Em (102), seria possível discutir-se, se não se trata de uma oração modal. Defendo que não, pois rogar a fineza não é o modo ou o instrumento pelo qual o missivista junta o texto francês. Percebe-se através dos três exemplos, que as OGs aditivas servem para colocar em "cena" eventos que acontecem em relação de subseqüência, mas que se apresentam somados no quadro oferecido ao ouvinte/leitor.

Aqui estão abrigados os casos em que os gerúndios aparecem em cascata, atuando para construir a figura e a relação de relevo em uma cena composta por vários eventos que são trazidos à tona pelo narrador. Campos (1972) e Brandão (1933) chamam-nos de gerúndios narrativos. Campos (1972) propõe ainda uma subdivisão entre os coordenados e os narrativos, que não assumo aqui, porque sintaticamente trata-se do mesmo caso. A análise semântica é que os separa nesses pólos, ou seja, são utilizados para exprimir a idéia de adição, conclusão/conseqüência ou contrafactualidade, que no português podem ser realizadas com conectivos em estruturas de coordenação.

(103) [M 202 ERN 5] Uma dessas estradas corria em direção ao vale do rio Paraíba do Sul até a atual cidade de Bananal, no trajeto para o Rio de Janeiro. Outra, avançando pela serra da Cantareira, alcançava Bragança, de onde era possível chegar ao sul de Minas. Uma terceira se dirigia até Franca seguindo o curso do famoso Caminhos dos Guaiases, que conduzia às minas de Goiás após atravessar o Triângulo Mineiro. Um quarto caminho avançava quase paralelamente ao rio Tietê até Piracicaba, passando por Itu e Porto Feliz. A quinta estrada do planalto estendia-se em direção a Sorocaba, de onde se podia alcançar a atual Itapeva, acesso às regiões meridionais.

(104) [C 191 Ald 28 5] Este motivo meobrigou aentregar Como de facto entreguey meya aRoba de polvora Com Seo xumbo a Hipolito Antonio Pinheiro, homem que naquele Sertaõ enContrey Com as melhores qualidades para Se lhe Cometer qualquer Coisa; enCarregando lhe de- entrar pelo Rio Sapucay the o Rio grande emdistancia de 15 legoas; e enca- rregando igualmente amesma deligencia a Joâo de Campos e a Manuel Vâs, aquelle para entrar pelos Batataes athe alagôa Rica, aeste descendo pe- las margens do Rio Pardo the a Sua Barra.

Em (103) os caminhos avançam, e enquanto avançam, seguem o curso, passam por Itu, etc. Novamente uma relação de subseqüência e não de modo. Em (104) temos um novo redobro do radical do verbo enCarregando, o que comprova a idéia de que os eventos expressos nas OGs somam-se uns aos outros e também à OM.

Observe-se ainda que no exemplo abaixo toda a cena descrita se deu no passado, mas é narrada com verbos no gerúndio. Ao fazer isso, o autor da carta 
presentifica essa cena, que é ressaltada e posta em relevo (foregrounded no sentido

Talmyano).

(105) [C 191 CL SP 390 5] Um po- | bre môço carreiro de 10 a 12 annos que | servia de arrimo a sua desgraçada familia, | tendo marchado 3 ou 4 leguas por entre | máos caminhos, chegou sem perigo | até as portas da Cidade; na continuação po- | rém da rua da Esperança quasi defronte | á casa do Conego Leão (sendo a rua prin- | cipal e unica para a entrada de todos os | carreiros \& que vem de Sancto Amaro) em | um lamaçal tremendo que alli existe ato- | la-se o carro, perde o equilibrio, e queren- | do o infeliz encostar a lenha ficou espedaçado | debaixo do peso enorme; e no mais lamentavel | estado hontem deu-se á sepultura, deixan- |do sua familia desolada, e sem este arrimo. | Bem poucas vezes se tem visto scena tão | tocante!!!

A maior ocorrência de OGadvs aditivas pode ser encontrada nas memórias, nas cartas de administração privada e nas cartas oficiais. Nas memórias, o percentual permanece bastante alto nos três séculos e nos outros tipos de textos diminui ao longo desse período. Não foram encontrados casos de OGadvs em textos de língua falada no séc. XX. Talvez os articuladores "aî", "daî" e "então" da oralidade expliquem essa ausência.

Nas CAs o valor aditivo cumpre uma função especial de estabelecer o relevo.

Nestes casos ocorrem com freqüência com os verbos ser, ficar, parecer, cujos complementos acrescentam uma informação secundária que o autor/falante julga relevante:

(106) [M 181 NP1 6] Neste pousos falhamos um dia, sendo a causa o requerer toda a Tropa a Anhangüera, e fizesse a resenha que lhe tinha prometido antes de fazer em Mogi, e a que tinha já faltado.

(107)[M 182 MPC 14] A requerimento dos Paulistas ou porque ja setemia aGuerra que veio adeclarar-se com os Espanhoes tornou a adop- tarse osistema antigo, enovamente seprencepiraõ á nome ar Generaes para esta Capitania, sendo oprimeiro Dom Luis Antonio Bo- telho deSouza Mouraõ esegundo oqual atualmente existe Mar- tim Lopes deSaldanha: qual destes dois sistemas he o- mais util nem digo nem poSodessidillo;

(108) [C 191 Ald 29 4] Outro sim sefor daaprova- de VossaExcelencia oaplicaremse os Meninos asprimeiras Letras, sendo eu emqualidade deDirector omesmo Professor comalgum Ordena do como osmais Professores Regios percebem daReal Fazenda para suavizar odito trabalho.

(109) [M 201 PRO 4] Nenhum historiador conseguiu precisar a data em que Santos foi elevada a categoria de Vila, porém pelo que consta de duas escrituras pelo Tabelião Pedro Fernandes e assinada por Braz Cubas, se deduz que foi entre 14 de agosto de 1546 a 3 de Janeiro de 1547; sendo elevada a categoria de cidade em 1836 por Lei Provincial daquele ano, sendo presidente o Doutor Venâncio José Lisboa.

(110) [M 181 NP2 38] Da Serra do Engano a esta Serra da Onça haverá 18 léguas, e no travessio 7 ribeirões grandes, mas tudo campos, ficando-lhe os matos da serra sempre à vista, os quais vem afocinhar no mesmo campo, formando outros quando rematam.

(111)[M 191 RDN 60] Em 1734 [[1739]] judicialmente, eperante oOuvidor daComarca, ojá relatado Campello, coñstrangeraõ aos innocentes Indios aaSsig= nar hum Termo, peloqual seobrigaraõ homeñs, emulheres atrabalhar para oseo Padre Supperior tres dias em cada Semana, ficando unicamente izentos daprestaçaõ destes Serviços osdoentes, easmulheres prenhas deseis mezes (a)

(112) [M 201 PRO 8] Do riacho do Caldeireiro, conhecido pelo dos Soldados a ponta do morro da Penha, fraldeando o morro de uma extremidade a outra até o mar, ficando compreendido o Mosteiro de São Bento, Santa Casa de Misericórdia, chácara de D. Angelina Martins Rodrigues e estabelecimento de costume de Henrique Porchat. 
(113) [C 201 WL 3 8] Os vencimentos de um | director por qua- | tro annos são suffici- | entes para, nesse prazo, tornar, licita e ho- || [7] nestamente indepen- | dente um homem des- | ambicioso e modesto $\mid$ como sou, parecendo- $\mid$ me que isso está em $\mid$ suas mãos e não fica- | rá mal a nenhum de $\mid$ nós.

Como se vê pela exemplificação acima, este tipo de construção é bastante freqüente nas memórias, pois através dessas estruturas apresentam-se os participantes da cena. O conteúdo expresso na OG é fundo e cognitivamente contém ambas as proposições da OM e da OG (Cf. Talmy, 2000, vol. 1, p. 379). As construções com os verbos ficar e parecer acima também exibem um matiz consecutivo por conta do valor reforçado de subseqüência temporal que adquirem com estes verbos.

\section{VI.2.3.8 O valor adversativo}

As OGadvs adversativas são a contrapartida contrafactual das aditivas. Nessas orações complexas, o evento expresso na OG restringe o sentido da OM $[\mathrm{X}=$ $\mathrm{X}-\mathrm{y}]$ :

(114) [C 181 Ald 129] odoutor aLeixandre marques dovaLe ovigitou e naõaChan do os ornamentos que opadre bispo ordenava e estar so mente empoder dos indios oquis fexar e deRubar epelo muito Rogo que lhe fis odeixou ficar mas deixando hû edital para que dentro de hû anno sefizese todos os ornamentos nesesarios

(115) [20 2 EF POA 278 46] bem, por exemplo na translação, o próprio nome já diz, pode ser uma tradução, o homem atua, o indivíduo ou aluno atua sobre a comunicação, o repre, ele permanece fiel a essa comunicação, mas utilizando as suas palavras, sem alterar o sentido.

Naturalmente não foram consideradas adversativas as construções em que o

mas funciona como articulador discursivo e cujo sentido não está contido na OG:

(116)[M 181 NP1 23] Com esta resposta desconfiados não só os Amboabas, mas ainda os poucos Paulistas, que nos acompanhava, determinaram voltar-se logo para São Paulo, mas acudindo a isto João Leite, os obrigou com rogos, e com promessas, e muito mais com seu natural agrado, a que o não desamparassem.

(117)[M 181 NP1 54] Na noite do terceiro dia da estamos as rancharias do Gentio, e seus fogos: emboscamo-nos no mato para lhe darmos na madrugada, mas sendo sentidos dos cachorros, que tinham muitos, e bons, quando os avançamos, nos receberam com seus arcos e flechas.

Às vezes, as construções adversativas podem realizar-se em estruturas em que o conectivo mas está distanciado do verbo no gerúndio como é o caso de (118) ou mesmo sem a presença do mas. Nesse caso, um outro item introduz a idéia adversativa, como em (119):

(118)[M 191 BON 27] Na segunda fundiçaõ que começou em Junho de 1819, efindou em fins deDezembro do mesmo anno, a mistura foi amesma, e as cargas foraõ de16 até 24 por dia, com mais alguma regularidade, que na antecedente: cada car_ ga destas levou tres cestos de cavacos ehum de carvaõ; mas isto variava se faltava oCarvaõ, levando as vezes cargas só de - cavacos. 
(119) [C 192 CR 532 4] De accôrdo com elles e com meu intimo sentimento, volto hoje a collaborar nesta folha, da qual, como eloquentemente exprimiu-se a sua illustrada redacção em artigo por demais benevolo para comigo - eu me havia separado tão sómente de corpo, deixando presa a elle minha alma.

As adversativas são muito pouco produtivas nos três séculos e só aparecem nos corpora sob a forma de OGadvs.

\section{VI.2.3.9 O valor modal}

Assim como as orações de tempo e adição, as OGadvs de modo são bastante produtivas nos corpora e aumentam significativamente ao longo dos três séculos no corpus mais homogêneo em tipologia textual (Corpus Básico). Se levarmos em conta os totais obtidos somando-se a este o Corpus Diferencial, notamos que há um decréscimo das OG modais. Não existe uma contrapartida conjuncional para as orações de modo. ${ }^{373}$

Uma vez que os eventos descritos por esse tipo de OG representam o modo como o evento da OM é executado, na maioria das vezes se realiza quando há identidade de sujeito (OGadvs):

(120) [M 181 NP1 13] Falhamos nele dois dias, pescando, e caçando por ter bons matos, e para provimento da viagem.

(121) [C 191 Gen 7 7] Debalde tenho tentado todos os meios os mais pru- dentes para refrear este accerrimo inimigo: já apaternal bon- dade de Vossa Excelencia, aquem confiadamente reccorro, pode tranquilizar omeu sensorio, dignandose informar-se exaustamente domeuproceder, edeterminar oque for servido, relativamente atão perniciozoescan- dalo.

(122) [TEA 201 Tel 11] RITA - Você não quer ter obrigação, só fica mofando dentro desse quarto, lendo livros sem utilidade nenhuma. Depois, quando seu pai se zanga, querem achar ruim. Geni! Geni! Venha me ajudar. Chega de conversa.

É interessante observar que há uma grande freqüência de verbos estativos que selecionam uma OGadv. Em certas estruturas, como em (122), a OGadv de modo aparece logo após uma perífrase.

Sua ocorrência está bem distribuída pela tipologia textual, aparecendo bastante na língua falada do séc. XX (v. tabela 13: Teatro, 91,7\%; D2, 50,0\%; DID, $100 \%$, FB, 66,7\% e FB, 100\%, com um única ocorrência de OGadv):

(123) [D2 SP 360 20] L2 é...((risos)) exatamente se a gente for parar para fazer as coisas calmamente não dá...pura e simplesmente não dá...então a gente corre depressa vai para o carro troca de roupa correndo faz isso faz (não sei que tá tá)

${ }^{373}$ Neste trabalho separo as construções de exclusão do tipo "sem que..." das orações modais, por acreditar que se trata de uma circunstância distinta, embora faça parte do universo semântico do modo. 
(124)[DID SP 234 83] Inf nem pagar é...e ficar em casa tomendo seu cafezinho comendo seu sanduíche e e...((risos)) e assistindo filme...

(125) [TEA 202 Per 24] VADO Sua mãe pegou num sono! Tá aqui do meu lado, dormindo tão gostoso...Tá tudo bem aí, filho?

(126) [FB2 220 36] Inf. é ajudava também mais agora (cuitadinha)...eu nu vô im parti ninhum...aqui pode perguntá pra essa turma do bairro aí...se eu vô na casa deles de domingo...de domingo (passo) o dia intero deitada aqui cuidando do servicinho deles...tempos atrais (tinha vaca) maiava a semana intera na manguera né? tirava leite (arrumava) ( ) (fazia tudo) agora vendemo o gado

A expressão de modo nas CAs aparece menos freqüentemente que nas

OGadvs e está restrita a alguns contextos como as memórias e as cartas:

(127)[M 182 MPC 9] 3.o Posta nesta cituaçaõ aCapitania podia restituirse Logo, cuidadandose nasua Povoaçaõ, ou mandandoselhe nova gente, ourepartindosse com ella, daque sempre chegava dePortugal, com animo de seestabalecer nas Minas, emedindo asforças daCapitania emeios deestabalecimento que ofrece pro curar que se aplicasem aelle osseus povoadores em utilidade propria eaumento daReal fazenda:

(128) [C 191 BNRJ 9 5] He verdade queSefariaõ grandes torturas Se Se puzesse em pratica amarcha dehum Regimento inteiro onde há muitos que teriaõ de perder grandes Lavouras, eCabedaes que giraõ no Comercio; mas este mal Se Remedeia fazendo partir hum Regimento Somente com as graças mais dezembaraçadas, eprehenchendo as faltas tanto deSoldados como mesmo de Officiaes com praças deoutros Regimentos que estejaõ nas mesmas Circunstancias.

No séc. XX não ocorrem CAs de modo.

\section{VI.2.3.10 O valor de exclusão}

A circunstância de exclusão é a menos produtiva de todas e é mais freqüentemente realizada através da variante conjuncional "sem que". Conta apenas com 3 ocorrências no corpus, sendo duas delas OGadvs:

(129) [TEA 182 DH 31] Beat. Longe, e bem longe de nós, continuarmos em mais enganos, baste para devertimento, os que temos seguido, daqui em diante viviremos seriamente, nunca atendendo aos obezequios de homem algum, que de antemaõ perparaõ os seus ardiz, e formaõ estes laços para ignocentemente cahirem as que sem conhecerem o percepcio, pençaõ que elles puras verdades lhes fallaõ; acabou-se, em fim, esta especia de lebertinagem.

(130) [C 192 MRI 3 3] No orçamento da Despeza, vossês podem cortar largo, não esquecendo padres, egrejas, diplomatas etc etc. Adeus eate sempre

Na única CA encontrada nos corpora é o radical do verbo que reforça a idéia de exclusão:

(131) [M 181 NP1 80] o que visto pelo Cabo se fez um forte em um dos ranchos, que lhe pareceu melhor, mandando recolher todo o milho, que se achou, a um paiol, a que pôs guardas, como o fez também a sete índios, que cativamos, mandando-lhe lançar a todos suas correntes, excetuando um índio do torto, também cativo, a que depois deu liberdade. 


\section{VI.2.4 A semântica das CAs segundo a natureza dos verbos}

A presença de verbos existenciais confere às CAs distintos valores proposicionais: pode ser concessiva (135), causal (64), conclusiva/consecutiva em (136), condicional (132) e (134), aditiva (133).

(132) [C 182 Ald 24 8] Havendo aprovidencia de serem obrigados os Indios, que sequizerem izentar dotrabalho aque unidos com osmais zelozos verifiquem os desman xos dos valos, eaque os vezinhos confinantes, que tiverem direito naqueles campos de fora por pro $=$ prios ou foreiros os naó queimem sem fazer sa bedor ao Director dodia para os Indios aserarem, ede fenderem oseo quintal noato dofogo, he sem duvida, que naó entraraó mais criaSsoens, nem deixaraó deplantar querendo trabalhar, para se remirem das suas necessidades

(133)[A $191 \mathrm{SP}$ 6] Os Cursos principiarão a 12 do cor-|rente havendo concurrencia sufficiente. $O$ Farol Paulistano, 06 de agosto de 1828

(134) [C 181 Ald 19 47] Esta, Meo Senhor excellentiSsimo Conde hê aSumma verdade; eSepode Vossa Excellencia informar doque digo, tendo em Sã Paulo o Padre Domingos Machado, que entaõ hera Subprior e na occaziaõ oqueria o Padre Vezitador mandar casti - gar, epr[e]nder, naõ obstante naõ Ser Indio dosSeos, pello atrevimento que entaõ uzou.

(135) [M 181 NP2 35] reparem que o morro que deles se avista a Loesnoroeste, e tendo o tempo claro não é o Taió, mas o Berimbau.

(136) [C 201 WL 1 9] O facto é que o projecto | de lei eleitoral, que elle elaborou com o João Cabral, | despertou mediocre enttusiasmo. Poucos o terão lido | na integra, dada a sua desmensurada extensão. | Mas todo mundo o censura por este ou por aquelle | motivo, havendo quasi sempre razão nas criticas | exaradas.

Observe-se ainda que o exemplo (134) traz uma ocorrência do verbo ter que tanto pode ser interpretado como existencial, como possessivo. Essa flutuação de valor semântico sempre esteve presente na gramaticalização de ter como verbo existencial. $^{374}$

Nas CAs com sujeito indeterminado: o falante/escritor compõe a cena descrita promovendo um enquadramento específico, depositando a atenção do ouvinte/leitor sobre um ponto de vista abstrato ou concreto a ser seguido (windowing):

(137) [M 182 MPC 34] Mais semostra evidentemente apropoziçaõ, deque aAgri- cultura na Marinha da Capitania deSaõPaulo he mais lucroza, que nas terras deSerra aSima, fazendo huma breve reflexaõ a respeito dos Dizimos.

(138) [M 182 MPC 16] aeste Respeito hu- ma só propoziçaõ aeste Respeito si parece evidentemente certo que Se a Capitania deSaõPaulo preciza deGeneral, no rio Grande aonde sempre tem sido, eseraõ as nossas contestaçoens com os Espanhoes, heatodas as Luzes mais necessario eindespençavel, athe segindo amesma razaõ porque os Espanhoes poseraõ ViceRey em Bou[y]nos Aires:

No exemplo (137) o verbo fazendo parece estar tanto orientado para um sujeito idealizado, que entenderá a idéia do autor se fizer huma breve reflexã̃ a respeito dos Dizimos.

${ }^{374}$ Cf. Mattos e Silva (1996 e 1997). 
Também são comuns os verbos no gerúndio que são utilizados nas indicações de caminho. Nelas o sujeito também é indeterminado, pois se trata da repetição de um caminho que já está traçado. Nessas construções ressalta-se o aspecto iterativo (habitual):

(139)[M 181 NP2 43] Légua e meia mais adiante chegamos ao alto da Lomba grande, da qual se vê próximo à parte do nascente uma largueza grande de mato, que segundo julgo vão fenecer na Serra do Mar: tem a dita Lomba grande um despenhadeiro para a parte do Nascente, e olhando dela para a parte do Sueste do feitio de uma cela:

(140) [M 181 NP2 47] Entrando nele caminho de nordeste, e distância de 2 léguas, fica o rio do mesmo nome do Campo, tem 5 braças de largo, e 3 de fundo, e deste a légua e meia, e sempre do mesmo rumo fica o ribeirão de Bartolomeu, com 8 braças de largo, e só 3 palmos de fundo no sítio em que o passamos,: mais adiante caminho de norte fica o rio Grande pequeno; terá de largo 12 braças, e pouco mais de 5 palmos de fundo, e distará do de São Bartolomeu 5 léguas.

Em todos estes casos verifica-se a estratégia de relevo descrita no início deste capítulo.

Ao longo desta descrição pudemos observar que as orações adverbiais de gerúndio exibem propriedades semânticas que atendem a determinadas finalidades discursivas. Associamos as relações proposicionais nelas identificadas às classes de textos em que mais freqüentemente aparecem. Notamos ainda que à medida que aumenta a freqüência do uso de OG de modo, diminuo o uso daquelas que expressam a noção de tempo. Além disso, dissociamos algumas categorias semânticas para obter um quadro mais nítido dessas estruturas e dos espaços que ocupam nos contextos discursivos estudados.

A partir da descrição acima, podemos reunir de forma sucinta as propriedades semânticas das OGadvs e das CAs: 
Propriedades semânticas da orações adverbiais (OGadvs e CAs)

- (i) OGadvs e CAs agregam uma informação secundária ao conteúdo da sentença complexa e têm um caráter parentético, funcionando como um aposto $\rightarrow$ [+adjetivo] e [+advérbio]

- (ii) A expressão de tempo e modo é adquirida pela relação semântica estabelecida entre oração matriz e sua dependente. $\mathrm{O}$ aspecto imperfectivo é o valor de base que o verbo no gerúndio exibe.

- (iii) Elas estabelecem uma relação proposicional com a OM, agregando uma circunstância que pode ser de tempo, causa, conseqüência, finalidade, etc. $\rightarrow$ [-adjetivo] e [+advérbio]

- (iv) Algumas palavras podem anteceder imediatamente a forma nominal do gerúndio para dar algum tipo de suporte semântico, como determinados advérbios: não, como, mesmo, meio, etc. e algumas preposições como sem, em, com, de: com os preços aumentando, não vamos viajar; chegou de mãos abanando.

- (v) OGadvs e CAs exprimem algum valor proposicional em relação ao evento descrito na OM, o qual pode ser de variada natureza semântica: tempo, condição, causa, modo, concessividade, conseqüência, finalidade, adição, adversatividade (contrafactualidade), etc.

- (vi) OGadvs e CAs são utilizadas como estratégia para estabelecer relevo sobre algum conteúdo.

Quadro 24. Propriedades semânticas das OGadvs e das CAs

$\mathrm{Na}$ seção anterior, observamos que as OGadvs apresentam-se num processo de dessemanticização, por exibirem menos relações proposicionais, se comparadas às CAs. Notamos que estas últimas mostram uma maior produtividade de relações proposicionais e que nelas mantêm-se mais preservadas as propriedades semânticas apontadas no quadro 24. É importante lembrar ainda que as CAs são as construções que estão mais dispostas ao processo de lexicalização. Outras podem gramaticalizarse em novas preposições (tirando esse fato, dependendo da chuva) ou conjunções. Müller-Lancé também observou isso para o francês:

Deutlich häufiger sind im Neufranzösischen absolute Konstruktionen, die sich in einem Grammatikalisierungsprozess befinden und mehr und mehr die Funktion von Präpositionen und Konjunktionen übernehmen. Sie sind also im Unterschied $\mathrm{zu}$ Formeln und Lexikalisierungen keine eigenständigen Informationsträger mehr, sondern dienen als Junktor dazu, weitere Informationen an die übergeordnete Proposition anzuschließen. Außerdem werden - im Unterschied zur Lexikalisierung - besonders häufig eingliedrige AK's bzw. AK-Prädikate grammatikalisiert (Müller-Lancé, 1994:301). ${ }^{375}$

\footnotetext{
375 Tradução minha: "No francês moderno são cada vez mais comuns construções absolutas que se encontram num processo de gramaticalização e cada vez mais assumem a função de preposições $e$ conjunções. Ao contrário de fórmulas e lexicalizações elas não são mais portadoras de informação independentes, ao contrário, como juntores, atuam para agregar informações suplementares à proposição principal. Além disso, ao contrário da lexicalização - construções absolutas compostas de um constituinte ou de um predicado gramaticalizam-se mais freqüentemente”.
} 
O fato é que não podemos dissociar o processo de dessemanticização das OGadvs da constatação de que, na contrapartida, aumentam as perífrases de gerúndio.Talvez seja arriscado falar-se aqui de uma mudança encaixada, mas fica a observação para uma pesquisa futura, que leve em conta não só as propriedades sintáticas dos itens envolvidos, mas também os traços semânticos desses itens. 
Tabela 15. Distribuição semântica das orações gerundiais ambíguas nos séculos XVIII, XIX e XX por tipologia textual.

\begin{tabular}{|c|c|c|c|c|c|c|c|c|c|c|c|c|c|c|c|c|c|c|c|c|c|c|c|c|c|c|c|c|}
\hline $\begin{array}{l}\text { G ambíguo } \\
\text { séc. XVIII }\end{array}$ & A & $\%$ & CL & $\%$ & CR & $\%$ & $\mathrm{M}$ & $\%$ & CAP & $\%$ & $\mathrm{CO}$ & $\%$ & $\mathrm{CP}$ & $\%$ & TEA & $\%$ & D2 & $\%$ & DID & $\%$ & $\mathrm{EF}$ & $\%$ & FB & $\%$ & PBP & $\%$ & Total & $\%$ \\
\hline adição & & & & & & & 3 & 50 & & & 4 & 80 & 0 & 0 & 2 & 33 & & & & & & & & & & & 9 & 50 \\
\hline causa & & & & & & & 0 & 0 & & & 0 & 0 & 0 & 0 & 0 & 0 & & & & & & & & & & & 0 & 0 \\
\hline condição & & & & & & & 0 & 0 & & & 0 & 0 & 0 & 0 & 2 & 33 & & & & & & & & & & & 2 & 11 \\
\hline conseqüência & & & & & & & 3 & 50 & & & 0 & 0 & 0 & 0 & 0 & 0 & & & & & & & & & & & 3 & 17 \\
\hline modo & & & & & & & 0 & 0 & & & 1 & 20 & 0 & 0 & 0 & 0 & & & & & & & & & & & 1 & 5,6 \\
\hline tempo & & & & & & & 0 & 0 & & & 0 & 0 & 1 & 100 & 2 & 33 & & & & & & & & & & & 3 & 17 \\
\hline Total & & & & & & & 6 & & & & 5 & & 1 & & 6 & & & & & & & & & & & & 18 & \\
\hline & & & & & & & & & & & & & & & & & & & & & & & & & & & & \\
\hline $\begin{array}{l}\text { G ambíguo } \\
\text { séc. XIX }\end{array}$ & A & $\%$ & CL & $\%$ & CR & $\%$ & M & $\%$ & CAP & $\%$ & $\mathrm{CO}$ & $\%$ & $\mathrm{CP}$ & $\%$ & TEA & $\%$ & D2 & $\%$ & DID & $\%$ & $\mathrm{EF}$ & $\%$ & FB & $\%$ & PBP & $\%$ & Total & $\%$ \\
\hline causa & 8 & 89 & 0 & 0 & & & 2 & 33 & & & 1 & 14 & 0 & 0 & & & & & & & & & & & & & 11 & 44 \\
\hline modo & 0 & 0 & 0 & 0 & & & 2 & 33 & & & 1 & 14 & 0 & 0 & & & & & & & & & & & & & 4 & 16 \\
\hline tempo & 0 & 0 & 0 & 0 & & & 2 & 33 & & & 1 & 14 & 0 & 0 & & & & & & & & & & & & & 3 & 12 \\
\hline adição & 1 & 11 & 0 & 0 & & & 0 & 0 & & & 2 & 29 & 0 & 0 & & & & & & & & & & & & & 3 & 12 \\
\hline finalidade & 0 & 0 & 0 & 0 & & & 0 & 0 & & & 0 & 0 & 1 & 50 & & & & & & & & & & & & & 1 & 4 \\
\hline condição & 0 & 0 & 1 & 100 & & & 0 & 0 & & & 0 & 0 & 1 & 50 & & & & & & & & & & & & & 2 & 8 \\
\hline conseqüência & 0 & 0 & 0 & 0 & & & 0 & 0 & & & 1 & 14 & 0 & 0 & & & & & & & & & & & & & 1 & 4 \\
\hline Total & 9 & & 1 & & & & 6 & & & & 7 & & 2 & & & & & & & & & & & & & & 25 & \\
\hline $\begin{array}{l}\text { G ambíguo } \\
\text { séc. XX }\end{array}$ & A & $\%$ & CL & $\%$ & $\mathrm{CR}$ & $\%$ & M & $\%$ & CAP & $\%$ & $\mathrm{CO}$ & $\%$ & CP & $\%$ & TEA & $\%$ & D2 & $\%$ & DID & $\%$ & $\mathrm{EF}$ & $\%$ & FB & $\%$ & PBP & $\%$ & Total & $\%$ \\
\hline adição & & & & & & & 1 & 100 & & & & & 1 & 20 & & & 0 & 0 & & & & & & & & & 2 & 25 \\
\hline causa & & & & & & & 0 & 0 & & & & & 4 & 80 & & & 1 & 50 & & & & & & & & & 5 & 63 \\
\hline finalidade & & & & & & & 0 & 0 & & & & & 0 & 0 & & & 1 & 50 & & & & & & & & & 1 & 13 \\
\hline Total & & & & & & & 1 & & & & & & 5 & & & & 2 & & & & & & & & & & 8 & \\
\hline & & & & & & & & & & & & & & & & & & & & & & & & & & & & \\
\hline
\end{tabular}




\section{VI.2.5 A semântica das orações de gerúndio ambíguo}

Como se pode ler da tabela 15 , o gerúndio ambíguo ocorre muito pouco nos corpora (51/1088). Essas ocorrências distribuem-se nas circunstâncias de adição, modo, condição, finalidade, causa e tempo. Para esclarecer melhor a sua utilização, vale a pena retomar algumas características sintáticas já apontadas no capítulo IV.

Durante a coleta de dados, deparei-me com casos interessantes em que o gerúndio ligado ao sujeito da OM, considerado aqui como categoria ambígua, ocorre com outras estruturas adverbiais:

(141) [C 182 BAN 6 2] ObedeSendo orespeitaveu despacho devossa enxelencia enformo Naforma Seguinte OS[oplicante] Padre Joaõ Barboza deSumCam Sendo Naturar Naferguezia deja vari PaSou Acazade Naoscal dacompanha torio verde onde Tem deSua Molher dois filhos

O primeiro exemplo (141) é o menos problemático de todos. Trata-se de uma resposta a um respeitaveu despacho em que um militar dá conta sobre a pessoa do padre João Barboza deSumCam [Assunção]. O escrivão-caipira, ou capira-escrivão, como queiram, informa na 2.a metade do séc. XVIII que o dito padre (a) é Naturar deja vari e (b) que paSou Acaza de não se sabe direito quem, onde tem deSua Molher dois filhos. O termo (a) é claramente uma oração relativa introduzida pelo gerúndio adjetivo sendo, que é o núcleo dessa predicação secundária.

(142)[C 181 Ald 14 3] Ofrancisco Pacheco EmbarCandose comtoda aSua gente, estan doSeo Pay navilla memandou dizer, emararitaguava, donde meacha va Com oexcelentissimo Senhor Conde adespedir atropa, que ofilho devossamerce vinha na Canoa, eotiraçe,

Já o exemplo (142) exibe duas OGs adjacentes ao SN sujeito da OM, o primeiro gerúndio, embarcandose, é claramente o núcleo de uma predicação secundária de Francisco Pacheco, o que não poderíamos dizer de estando, que toma como sujeito o Seo Pay, estabelecendo com ele uma predicação primária, devendo, portanto, ser interpretada como uma construção absoluta, que, na ausência da primeira OG, ficaria assim construída: Ofranscisco Pacheco, estan doSeo Pay navilla memandou dizer [isso]. Mas algo de estranho se passa aí: Que movimentos lingüísticos (cognitivos) estariam atuando neste caso, em que encontramos a aposição de dois tipos de gerúndio, um exercendo a função de núcleo de uma predicação secundária, e outro, como núcleo de uma predicação primária? As lições de sintaxe nos ensinam que a enumeração seqüencial de constituintes denotam identidade de propriedades. Ora, o que então além do morfema -ndo é idêntico nessas construções, já que em termos funcionais, à primeira vista, superficialmente, elas 
exerçam função distinta (predicação secundária vs. predicação primária)? Anote-se a pergunta. Ela vale para o exemplo (33), que já é nosso conhecido:

(33)[C 191 Lor 1 4] Diz Joaquim Joze da Costa da Villa deLorena que tendo hua filha de nome Gertrudes Maria da Conceiçaõ aindamenor, eidade de 18 annnos etendo procurado todos os meios de fazer viver adita Sua filha Com toda ahonra recato, ehoneStidade, como vivia, acontece que na auzencia delle Supplicante, ecompromessaS de Cazamento hum Manoel Coelho abuzando daSimplicidade daquella menina, eSeduzindoa Com aquellas apparentes, efinjidas promessas, Se abalansou aLevala daSua honra, evirgindade; mas Entretan= to para Colorar oSeugrande delicto passou afinjir que Sequeria despozar Comella fallando aoSupplicante para odito eff[eito],

Na denúncia contra hum Manoel Coelho, que Se abalansou a honra da filha de Joaquim José da Costa, encontramos duas OGs apostas ao dito Manoel Coelho: (a) abuzando daSimplicidade daquella menina e (b) eSenduzindoa Com aquellas apparentes, e finjidas promessas. Na sentença (a) abuzando é o núcleo de predicação secundária, de Manoel Coelho, uma espécie de aposto explicativo, sentido que tem apoio no estilo adotado pelo missivista - observe-se o caso de Diz Joaquim Jozé da Costa da Villa deLorena que tendo hua filha de nome Gertrudes. Em resumo, (a) é uma oração relativa. O gerúndio Seduzindo na sentença (b) é núcleo de predicação secundária do mesmo Manoel Coelho. Sim, e daí? Sintaticamente temos o caso de duas predicações secundárias de um gatuno chamado Manoel Coelho. Mas o escrivão ainda nos conta que Acontece que na auzencia delle Supplicante [o pai da moça] o dito Seabalansou aLevala daSua honra, evirgindade. E perguntamos: como fez isso? Responde-nos o escrivão: Seduzindoa Com aquellas apparentes, efinjidas promessas, ou seja, em (b) temos uma oração adverbial com valor temporal e matiz modal. Está ali ainda um articulador discursivo $e$ acompanhando o Seduzindoa que evidencia o salto narrativo, separando as duas predicações. O que nos dizem mesmo as lições de sintaxe? É possível apor uma relativa e uma adverbial dessa forma? Tanto é possível, que esse escrivão o fez. Continua a pergunta sobre a identidade de propriedades que os termos em aposição exibem na sentença. Ela se aplica também ao próximo exemplo:

(143)[A 192 SP 15] Typographia da Noticia|Esta bem montada officina, provisoriamente nesta povoação e que brevemente será transferida para Araraquara, dispont[d] ]o de peritos officiaes, apromta com nitidez e por modico preço todo e qualquer serviço.

A Typographia da Noticia parece ser uma empresa muito proba e eficiente, porque é uma (a) bem montada officina. O núcleo desse sujeito é o termo officina, que é modificado por um particípio, que por sua vez também é modificado, por um advérbio. Há o que se anunciar sobre esta empresa: embora (b) esteja 
provisoriamente nesta povoação, pois (c) que brevemente será transferida para Araraquara, no entanto, ainda continua ali naquela povoação e, (d) dispondo de peritos officiaes, ela apromta com nitidez e por modico preço todo e qualquer serviço. Há muito que se falar mesmo sobre essa Typographia: (a) o termo bem montada officina disputa com o título do anúncio a função de sujeito, (b) tem um constituinte com valor de locativo (adjetivo ou advérbio?), (c) tem uma oração relativa introduzida pelo pronome que, e, finalmente, (d) tem uma OG que agrega uma quarta informação não tão secundária assim para os propósitos daquele que contratou o anúncio, uma oração adverbial (?) com valor causal/explicativo (porque dispõe de peritos officiaes). Puxa! Que enumeração! Um sujeito modificado por qualificador, um locativo, uma oração relativa e outra adverbial! O que há de comum nestes itens? Talvez fosse o caso de enumerar as propriedadades desse tipo de construção.

O fato é que além das propriedades sintáticas apontadas para os gerúndios ambíguos no capítulo IV, podemos enumerar as suas regularidades semânticas, que podem ser a de expressar uma relação circunstancial específica, projetar o relevo sobre determinados enunciados e agregar informação secundária:

(144) [M 181 NP1 82] Nesse tempo se tinha humanizado já mais o gentio, buscando-nos, e servindonos sem arco e flecha, e admirando muito as nossas armas.

(145) [C 191 Lor 1 11] mas aponto de estarem promptificados para acontracçaõ domatrimonio, desappareceo fugitivamente oSupplicado mostrando o engano, efalsidade das Suas promessaS, e [pe]or tal modo que entrando oSupplicante nadiligencia deodescubrir, elle Supplicado lhedirigio acarta junta para total des engano doSupplicante; ecom o maiordesaforo qual Semostra docon- texto damesma Carta, e nesteS pungentes termos, humildemente prostrado aospezde VossaExcellencia; e implorando oSeu alto patrocinio.

(146) [C 192 WL 16 4] Comprehendes que a gente estando fóra, inda mais em cidade, augmentam assusta- doramente os extra; por menos que se queira gastar, lá se vae muito dinheiro e quasi tudo em futilida- des.

(147) [C 192 WL 6 2] e eu cumprindo um dever de Amigo tenho a participar-te que ha um mez tractei casamento com a Senhora Dona Candida Novaes filha do Coronel José Novaes de Aguiar residente em São Carlos.

Embora tradicionalmente esse tipo de construção possa ser reconhecido como uma oração relativa ligada ao sujeito, os exemplos acima mostram que nelas há alguma circunstância proposicional envolvida, e tanto podem ser comutadas em uma construção adjetiva introduzida pelo pronome relativo que, como em uma construção adverbial introduzida por alguma conjunção de valor circunstancial específico.

Em (144) é incontestável o valor consecutivo das três OGs que se apõem ao sujeito o gentio, embora possam ser comutadas em orações relativas explicativas: 
que nos buscava, que nos servia, que nos admirava, podendo serem até mesmo interpretadas como correlatas (já se tinham humanizado tanto que...), o que reforçaria ainda mais a idéia de conseqüência. O mesmo raciocínio serve para (145), que também exibe o matiz consecutivo: desapareceu tão fugitivamente que mostrou o engano e falsidade das suas promessas. Aliás, este é nosso Manoel Coelho lá de cima, que além de ter-se abalansado de valer-se da honra e virgindade de Gertrudes, fugiu sem casar com a moça. Vê-se que o autor deste texto gosta dos predicativos.

Já o exemplo de uma carta de Washington Luiz (146) mostra uma OG funcionando como CA - sujeitos distintos: a gente e os extra, este último, um absolutivo do verbo ergativo augmentam. A OG pode ser interpretada tanto como relativa, como adverbial temporal (quando a gente está fora).

O exemplo (147) denota um valor causal/final (como quero cumprir / para cumprir), mas também permite a conversão em um relativa do tipo eu que quero cumprir um dever de amigo. Aliás, o pronome eu parece ter sido extraído da OG. Veremos mais alguns casos de extração do sujeito no tópico seguinte.

As orações ambíguas também atuam como elementos que projetam relevo sobre uma informação secundária que se quer tornar relevante:

(148)[M 192 RL 11] Embora sem valor algum estratégico, tinha pelo menos o acampamento do Coxim uma altitude que lhe garantia a salubridade. Não tardou, porém, que a enchente havendoo ilhado e isolado, ali passasse a força pelas mais cruéis privações, sofrendo até fome.

(149) [A 192 SP 27] THEATRO SÃO JOSÉ|Companhia Lyrica Italiana|EMPREZA ANGELO FERRARI|O empresário Angelo Ferrari desejando corresponder ao graciozo convite de muitas pessoas d'essa culta cidade de São Paulo, resolveu dar uma série de 12 récitas apresentando n'este numero as operas mais applaudidas de seu repertorio, incluindo O GUARANY do distincto CARLOS GOMES. (...) A orchestra|contando habeis professores, e regida pelo distincto maestro|CAVALHEIRO N. BASSI |Rio de Janeiro, 26 de setembro de 1870|A. Ferrari A Constituinte, 01 de outubro de 1879

Os exemplos mostram OG do tipo fuzzy que parecem estabelecer o relevo,

presentificando uma cena vivenciada pelo falante e depositando foco sobre ela:

(150) [C 201 MA 340 8] Não sei se lhe contei, uma circunstância curiosa que me preocupou muito foi que depois de exames, diagnóstico de médico e tudo, tendo que escrever o estudo de introdução pro livro do Gallet, li toda a correspondência dele e topei inesperadamente com uma carta dele, duns cinco anos atrás, em que uma grafóloga aí do Rio, amiga dele, topando com uma carta minha na secretária dele, não sabendo de quem era nem me conhecendo pessoalmente, disse a ele que o indivíduo da carta iria em poucos anos sofrer dos rins e se tratasse muito porque o caso podia se tornar muito grave.

(151)[TEA 182 FE 23] Pant. Mas naõ gosto mais que vocè, porque o muito que bebo, quando como hum jantar forte, saõ tres canadas, e vocè já lhe tenho visto beber seis, e bem se lembrará que inda naõ ha dois mezes estando com aquelle seu primo o Carambola por alcunha, que apostando ambos dezaseis tostoens, a qual beberia hum pote de vinho de seis canadas, elle pondo-o á boca, 
naõ o pode acabar, e vocè rindo-se delle, mandando-o encher ó taberneiro, principiou a bebelo, e o acabou todo, ganhando áposta, e despois vindo-nos embora, vinha taõ direito, como se tivera bebido agoa.

A categoria fuzzy também é comum nos anúncios (89\%), nos quais procurase detalhar as qualidades do produto ou do serviço anunciado (152), ou mesmo nas declarações à praça (153):

(152)[A 192 SP 27] THEATRO SÃO JOSÉ|Companhia Lyrica Italiana|EMPREZA ANGELO FERRARI|O empresário Angelo Ferrari desejando corresponder ao graciozo convite de muitas pessoas d'essa culta cidade de São Paulo, resolveu dar uma série de 12 récitas apresentando n'este numero as operas mais applaudidas de seu repertorio, incluindo O GUARANY do distincto CARLOS GOMES. (...) A orchestra|contando habeis professores, e regida pelo distincto maestro|CAVALHEIRO N. BASSI |Rio de Janeiro, 26 de setembro de 1870|A. Ferrari A Constituinte, 01 de outubro de 1879

(153)[A 192 SP 20] A pedidos|Bilhete perdido|O abaixo assignado, tendo perdido o bilhete número 7443 da Loteria Rio Grandense, plano 1 - serie 11 A faz publico que fara valer o seu direito, a sorte distinga esse numero com algum premio.|Jahú, 28 de abril de 1897. José Ruffolo. Correio do Jahu, 29 de abril de 1897

As propriedades semânticas das orações gerundiais fuzzy encontram-se reunidas no quadro 25 .

Quadro 25. Propriedades semânticas das orações gerundiais ambíguas

- (i) agregam uma informação secundária ao conteúdo da sentença complexa e têm um caráter parentético, funcionando como um aposto $\rightarrow$ [+adjetivo] e [+advérbio]

- (ii) denotam uma atividade permanente ou passageira, atribuindo-se um modo de ser, uma qualidade ao nome a que estão ligadas ${ }^{376} \rightarrow$ [+adjetivo] e [+advérbio]

- (iii) exprimem um comentário do locutor acerca de uma entidade denotada por um $\mathrm{SN}^{377} \rightarrow$ [+adjetivo] e [+advérbio]

- (iv) estabelecem uma relação proposicional com a OM, agregando uma circunstância que pode ser de tempo, causa, conseqüência, finalidade, etc. $\rightarrow$ [-adjetivo] e [+advérbio]

Todos as outras propriedades podem ser encontradas tanto nas orações adverbiais como nas relativas, embora para algumas esse traço seja mais nítido do que para as outras, ou seja, a propriedade (iv) de estabelecer uma relação proposicional confere à oração subordinada um caráter [+adverbial], o que, no entanto, não exclui a possibilidade de interpretar alguma nuance circunstancial nas relativas.

\footnotetext{
${ }^{376}$ Cf. Bechara, 2003:517.

${ }^{377}$ Cf. Mateus, 2003:671.
} 


\section{VI.2.6 A semântica do gerúndio em orações relativas}

No capítulo IV observei que o gerúndio adjetivo passou a ser bastante utilizado a partir da $2^{\mathrm{a}}$. metade do séc. XIX. A tabela 16 mostra como estão distribuídos os gerúndios adjetivos, cruzando os tipos de complementos a que estão ligados e os tipos de textos em que aparecem. Através desse cruzamento é possível verificar que o gerúndio ligado ao OD é a categoria dos gerúndios adjetivos mais utilizada (48\%), em seguida o gerúndio ligado ao SN complemento da preposição em um SP (24\%), e por últimos os gerúndios ligados ao absolutivo ergativo e ao predicativo, ambos com 14\%. Apesar do número reduzido de ocorrências, é possível verificar que ele aparece em quase todas as tipologias textuais escolhidas para este século, menos nas cartas de administração privada, o que reforça a idéia de além do uso do gerúndio ligado ao $\mathrm{OD}$, plenamente aceito pelos gramáticos, as outras categorias de gerúndios adjetivos mostravam-se bastante disseminadas nessa época.

Tabela 16. O gerúndio adjetivo na $2^{\mathrm{a}}$. metade do séc. XIX

\begin{tabular}{|l|c|c|c|c|c|c|c|c|c|c|c|c|c|c|}
\hline $\begin{array}{c}\text { Gerúndio adjetivo } \\
2^{\text {a }} \text {. metade séc. XIX }\end{array}$ & $\mathrm{M}$ & $\%$ & $\mathrm{CP}$ & $\%$ & $\mathrm{TEA}$ & $\%$ & $\mathrm{CL}$ & $\%$ & $\mathrm{CR}$ & $\%$ & $\mathrm{~A}$ & $\%$ & Total & $\%$ \\
\hline $\begin{array}{l}\text { Complemento da OM a que } \\
\text { aparece ligado }\end{array}$ & & & & & & & & & & & & & & \\
\hline Objeto direto & 1 & 14 & 4 & 100 & 0 & 0 & 2 & 67 & 1 & 50 & 2 & 100 & 10 & 48 \\
\hline Absolutivo ergativo & 2 & 29 & 0 & 0 & 1 & 33 & 0 & 0 & 0 & 0 & 0 & 0 & 3 & 14 \\
\hline $\begin{array}{l}\text { Complemento da } \\
\text { preposição (SP) }\end{array}$ & 4 & 57 & 0 & 0 & 0 & 0 & 0 & 0 & 1 & 50 & 0 & 0 & 5 & 24 \\
\hline Predicativo & 0 & 0 & 0 & 0 & 2 & 67 & 1 & 33 & 0 & 0 & 0 & 0 & 3 & 14 \\
\hline Total & 7 & & 4 & & 3 & & 3 & & 2 & & 2 & & 21 & \\
\hline
\end{tabular}

As construções com gerúndio adjetivo exibem algumas particularidades semânticas que já foram apontadas no capítulo I. O gerúndio ligado ao OD, por exemplo, normalmente é selecionado por determinadas categorias de verbos expressos na OM. É o caso dos verbos de percepção visual e abstrata como ver, olhar, enxergar, assistir, sentir, achar, encontrar, etc:

(154)[TEA 191 Mac 23] SATÃ Não. Daqui a cinco minutos podemos estar à vista da cidade. Hás de vê-la desenhando no céu suas torres escuras e seus casebres tão pretos de noite como de dia, iluminada, mas sombria como uma essa de enterro.

(155)[DID SP 234 64] Inf (...) porque antigamente no tempo que eu estudava o o estudante quase não ligava para isso hoje você vê grupo de estudante grupos fazendo teatro e::organizando grupos

(156) [DID SP 234 89] Inf (...) ontem eu assisti...Carvalho Pinto falando com DOnas de casa...

(157) [C 192 CL 512 2] Vi no Diario uma defesa, em favor da com- | panhia, desmentindo a primeira queixa pu- | blicada na Provincia, e não soube como de- | cidir-me, o que acontece a quem vive no $\mid$ matto e não anda a par de todas as cousas.

Parece ser frequiente o uso do verbo receber: 
(158) [C 192 WL 19 1] Com praser recebi sua carta de 1.o do corrente trasendo-me boas noticias de meus queridos filhos, e espe- ro que continuem sempre com saude, e a minha boa, e queri- da Sophia naô sinta muito a mudança para esse logar; taô distante dos seus, mas em compensação tem por companheiro <um> <marido> que com seus carinhos, e dedi- cação fará que naô seja taô sencivel esta separação,

(159)[C 201 MA 323 20] Recebi ontem um anúncio do jornal indicando a venda do livro, dois dólares.

(160)[M 192 RL 10] Assim se adiantou em direção ao noroeste, até as margens do Paranaíba, quando ali recebeu peremptórias ordens do governo, levando-lhe instruções formais de marchar para o distrito de Miranda, então ocupado pelo inimigo.

(161)[A 192 SP 39] ATTENÇÃO\|Attenção [espaço] Attenção||Prospero Bellinfanti participa ao respeitavel publico campineiro que recebeu um grande e completo sortimento de generos norte americanos, constando de machinas de costira [costura] com todos os pertences linhas agulhas e oleos, arados completos, separadores de zinco para café, machinas para manteiga, ditas para café, gaiolas de arame e muitos outros artigos da mesma procedencia

Em todos os casos, a função principal do gerúndio adjetivo é de complementar o sentido do SN que o antecede. A opção pelo gerúndio e não por uma construção com o pronome relativo que está associada ao caráter nominalizador do gerúndio e também pelo fato de que também pode ser comutadas por uma oração de tempo introduzida pela conjunção quando. Ao utilizar o gerúndio, a cena vista é presentificada pelo falante/autor, de forma a dar mais vivacidade à descrição. Suas características estão reunidas no quadro 26.

Quadro 26. Propriedades sintáticas das orações relativas

- (i) exprimem um comentário do locutor acerca de uma entidade denotada por um SN $\rightarrow$ [+adjetivo] e [+advérbio]

- (ii) agregam informação secundária ao complemento dos verbos perceptivos (ver, olhar, assistir, encontrar,etc.)

- (iii) denotam uma atividade passageira, transitória, ou permanente atribuindo um modo de ser, uma qualidade que se atribui ao nome a que estão ligadas 


\section{VI.2.7 A semântica do gerúndio em nominalizações e do gerúndio imperativo}

As nominalizações aparecem muito pouco no quadro de ocorrências (10/1068) e aparecem com ocorrências únicas nas várias classes de textos nos três séculos. Do ponto de vista semântico, podem estar divididas em tres categorias: o gerúndio em construção nominalizada (162), o gerúndio exclamativo (163) e o gerúndio interrogativo (164):

(162)[TEA 192 SL 16] Em vão nasce um homem, à semelhança de Deus, possuindo inteligência, rico de vontade e esperanças. (...) Mártir de seus deveres, dando a vida pela pátria, seu destino, sua recompensa é o esquecimento; não haverá cruz humilde para fazer menção de sua morte. Não, Vitorino, eu nada pedirei.

(163) [TEA 202 Per 10] EMÍLIO Todos falando ao mesmo tempo... da esquina a gente já podia ouvir os gritos.

(164) Você chegando a essa hora? [exemplo criado]

Em todos os casos os verbos no gerúndio poderiam ser comutados na sua forma finita e a opção pelo gerúndio está associada ao grau de expressividade que se quer atribuir a um enunciado. Por suas propriedades semânticas talvez fosse o caso de considerar o gerúndio imperativo entre os gerúndios que indicam uma postura do falante em relação ao seu interlocutor. Esta postura pode ser avaliativa ou de ordem.

Segundo Brandão (1933), as perífrases com o verbo ir + gerúndio seriam a base do gerúndio imperativo. Os exemplos abaixo do séc. XVIII, parecem ser prova da gramaticalização do gerúndio como imperativo.

No canal de gramaticalização do gerúndio que vai de núcleo de perífrase verbal à forma nominal independente de um sujeito, é possível imaginar uma forma intermediária na qual o verbo ir já não forma mais uma perífrase com o verbo no gerúndio:

(165) [TEA 182 FE 31] Pant. Deichemos isso, vamos acabando as filhozes para merendarmos, que saõ mais de tres horas.

(166) [TEA 191 Nam 53] MARIA - Esta besta! O senhor a fazer-me roda, tão velho como é? Ai, que me rio desta! | MANUEL - Vai-te rindo, bestinha, até que chores.

(167)[TEA 192 SL 2b] VITORINO : Tarde, diz ela! Isso é coisa que já passou: vá rezando as AveMarias, tia Onistalda, que vossunçê já regula por aí.

(168)[TEA 192 SL 5a] RAFAEL : Cisma? Pois vão ouvindo. Hoje, ao levantar-me, fui direto à janela e abria

(169) [TEA 201 Tel 13] ADA - Fique a Senhora sabendo que estou com os olhos abertos. Não sou boba, não.

Num outro passo, a estrutura é quebrada e percebem-se dois verbos plenos: 
(170) [TEA 182 FE 16] Pant. Ora vamos Compadre trabalhando, que o verdadeiro entrudo, he comer bem, e beber-lhe melhor.

O estágio mais avançadao ocorre quando se dá a dessintaticização do verbo $i r$, decorrente da semanticização do gerúndio, o qual agora assume sozinho o valor de imperativo.

(171) Circulando! Circulando! [exemplo criado]

\section{VI.2.9 O aspecto nas perífrases de gerúndio}

Na seção 1.2 deste capítulo já expus de que modo o aspecto funciona para construir o relevo tanto nas construções adverbiais gerundiais como nas perífrases de gerúndio. Castilho defende que o termo aspecto "consiste em representar os graus do desenvolvimento do estado de coisas” codificado na predicação, e que se trata de "um ponto de vista sobre o estado de coisas", que por sua vez, "é uma entidade concitual, ao passo que as entidades reais podem ser retratadas lingüisticamente de várias maneiras, dependendo da angulação do falante” (Castilho, Gramática funcional do português, digitado). Ora, se o aspecto denota um ponto de vista, isto então confirma aquelas propriedades do gerúndio que já arrolamos para as outras categorias. Estenderam-se, assim, as propriedades inerentes desse item para outro domínio. Poderíamos dizer mesmo que nas perífrases o gerúndio é um advérbio de seu auxiliar, o qual apenas codifica o tempo, o modo e o aspecto que a morfologia do gerúndio não dá conta de marcar sozinha. Não era objetivo deste trabalho esgotar a questão das perífrases. Desta forma, apresentamos apenas uma ilustração sucinta das formas perifrásticas encontradas.

Segundo Castilho (Gramática funcional do português, digitado), o aspecto imperfectivo apresenta uma predicação dinâmica do sujeito que pode dividir-se em três fases: uma fase inicial (imperfectivo inceptivo), uma fase em curso (imperfectivo cursivo) e um fase final do estado (imperfectivo terminativo). Além disso, o aspecto imperfectivo "é altamente recursivo nas estruturas de fundo de narrativas, entendendo-se por isso as informações que compõem a moldura do evento central" (op. cit.).

Nos corpora, apresentam-se bem representadas as perífrases que exibem o aspecto imperfectivo cursivo: 
(172) [C 181 Seb 8 1] Cheguei a esta Vila aos vinte etres de Dezembro com bastantes molestias das muitas agoas mais deSsaude Seja Deus Louvado bem on de fico esperando muitas oCazioiñs doa grado denoSsa [ei]celencia para aellas naõ fal tar como devo

(173) [C 191 Seb 720 1] Tenho porSerteZa que Antonio nunes esta emma- cucuóCá [espaço] Anda travalhando aotenente Pires n[a?]s S[u?]- [a?]s Cano[a]s

(174) [C 201 MA 340 15] Estou passando mal dos rins outra vez, não dê risada. Depois da farra, uma semana atroz. Bom, fim do ano, Lindóia.

Algums semi-perífrases exibem este mesmo aspecto:

(175) [M 192 HC 9] Costumavam partir de madrugada, pousavam antes de entardecer, o resto do dia passavam caçando, pescando, procurando mel silvestre, extraindo palmito, colhendo frutos; as pobres roças dos índios forneciam-lhes os suplementos necessários, e destruí-las era um dos meios mais próprios para sujeitar os donos.

Outras semi-perífrases exibem o aspecto imperfectivo terminativo:

(176) [D2 SP 360 15] L2 não só de administração da casa...como de compras...tudo...de toda/ todas ad medidas a serem tomadas...é por conta da mae...quer dizer que então é::...fi/ acaba sendo uma loucura...

(177) [D2 SP 360 49]...porque se um tiver mais do que o outro sai um monte de briga na realidade não acabam tomando tudo não comendo tudo que tem

(178)[M 202 ZEQ 17] Com a expansão da ocupação do planalto, descendentes desses primeiros povoadores acabariam subindo a serra. Após a unificação da[s] coroas ibéricas, em 1580, muitos espanhóis o seguiram.

Também o aspecto iterativo é bastante comum nos corpora. O aspecto iterativo, ou habitual, denota uma quantificação do imperfectivo e do perfectivo e representa o ato repetido de uma ação. Normalmente colaboram para esta interpretação outros elementos como os advérbios ou construções que reforçam o caráter habitual:

(179) [M 182 MPC 22] e desde este tempo tem urigem quaze todas as dividas paSsivas, [a]que neta Capitania he obrigada aFazenda Real; falo das antigas; porque as modernas, eque atualmente sevaõ con- trahindo tem deferente razaõ.

(180) [M 191 RDN 12a] §. 4. Oexcelentissimo Senhor Dom Luis Antonio deSo[i]za, conheceo bem aneceSsidade deerigir Freguezias emAldeas, que fossem tomando m[aior] [calor] por offeito das suas deligencias esperançava-se muito nasdeSa õ Miguel, Pinheiros, eSaõ Joze.

(181)[D2 SP 360 26] L1 fez::arte demais no banheiro...porque às vezes...estão tomando banho e ficam jogando água pela janela quer dizer essa...é supervisora nata é assim....ah...toma conta...precocemente não? das::atividades dos irmãos ent/...é uma pena...

\section{Conclusões sobre a semanticização do gerúndio}

A partir da análise do gerúndio por suas propriedades semânticas, verifiquei que as orações de gerúndio muitas vezes são utilizadas como recurso que serve para estabelecer o relevo nos enunciados. Iniciei o capítulo estabelecendo um elo entre as propriedades discursivas e semânticas do gerúndio. Notei também que em textos mais narrativos e dissertativos como as memórias e as cartas, o aspecto imperfectivo inerente ao gerúndio desempenha um papel preponderante na construção da cena, ou 
nas estratégias de debregagem enunciativa, ou seja, como forma de interromper um tópico em curso para agregar uma informação nova ou secundária. A análise dos valores proposicionais das OGadvs mostrou que é preciso ampliar a lista de valores proposicionais atribuídos a estas construções.

A análise quantitativa que cruzou os valores semânticos segundo a tipologia das construções gerundiais acusou um decréscimo na variedade de valores semânticos das OGadvs ao longo do período analisado. Em contrapartida, as CAs mantiveram a amplitude de valores circunstanciais, por serem estruturas mais conservadoras, mais freqüentes em contextos formais. 


\section{CONCLUSÃO}

O resultados obtidos pela análise qualitativa e quantitativa dos dados mostrou que o modelo da Análise Multissistêmica da Língua foi proveitoso para o estudo das mudanças que envolvem as orações de gerúndio no português brasileiro. Embora nem sempre tenha sido possível segmentar as propriedades sociocognitivas envolvidas em cada subsistema (ativação, reativação e desativação), o procedimento metodológico mostrou que é bastante viável a separação da descrição por módulos, permitindo assim uma visualização mais nítida dos fatores condicionantes de eventuais mudanças.

No módulo da Gramática, foi estudado o processo de sintaticização do gerúndio na constituição de orações de gerúndio. Foram estabelecidos critérios para a classificação do gerúndio pelas suas propriedades sintáticas. A decisão de adotar o conceito de minioração, dividindo os gerúndios em dois grupos, pareceu acertada e foi suficiente para a análise proposta. O critério de classificação foi baseado, portanto, na relação do verbo no gerúndio com o sujeito, ficando assim divididos os seus usos: (i) os gerúndios dependentes do sujeito em minioração, como núcleo de predicação secundária, entre eles o gerúndio adverbial (OGadv), o gerúndio ambíguo e o gerúndio adjetivo, e (ii) os gerúndios independentes do sujeito da oração matriz, como núcleo de predicação primária, entre os quais o gerúndio adverbial independente em construções absolutas (CAs), o gerúndio em nominalizações, o gerúndio imperativo, o gerúndio como articulador discursivo e o gerúndio em perífrases verbais. A análise quantitativa envolveu fatores diacrônicos e os resultados apontaram uma significativa e progressiva redução dos gerúndios adverbiais (OGadvs e CAs) no decorrer dos três séculos. Através da comparação com as orações adverbiais conjuncionais, verificou-se que também diminuiu a freqüência deste tipo de construção ao longo dos três séculos, acompanhando o ritmo de redução das orações adverbiais gerundiais. Em contrapartida, notou-se um aumento progressivo das perífrases com gerúndio ao longo do três períodos. Os resultados obtidos para os gerúndios adjetivos mostram que houve um índice mais elevado dessas construções durante o século XIX, em comparação com os outros dois séculos. Os demais tipos não se mostraram significativos em questões numéricas, 
sendo encontrados com poucas ocorrências nos três períodos, não sendo possível identificar para este grupo se houve alguma mudança.

Pela análise do processo de discursivização do gerúndio iniciada já no capítulo III desta tese, observamos que foi bastante proveitoso ressaltar os mecanismos de incorporação do gerúndio ao quadro dos gêneros discursivos. Além disso, foi possível verificar que essa forma nominal é constantemente ativada e reativada como item que participa da organização dos quadros tópicos e da elaboração de paráfrases. Os resultados da análise quantitativa, que levou em conta os fatores diacrônicos e aqueles associadas às classes textuais, mostraram que as orações adverbiais (OGadvs e CAs) são pouco freqüentes em textos informais como as cartas particulares, os diálogos de teatro e os inquéritos de língua falada da $2^{\mathrm{a}}$. metade do século XX, sendo bastante produtivas em textos de maior formalidade como as memórias, as cartas da administração privada e as cartas oficiais. $\mathrm{O}$ contraste entre as orações adverbiais gerundiais e as orações conjuncionais indicou que no séc. XX há uma maior preferência por orações conjuncionais. Observei que as perífrases de gerúndio emergem em textos de menor formalidade e os menores índices foram encontrados nas memórias históricas, nas cartas de administração privada e nas cartas oficiais, contextos de maior formalidade e maior planejamento. As memórias continuam sendo o ambiente mais resistente às perífrases. Os demais tipos de gerúndio não se mostraram significativos de forma a que se pudesse observar algum tipo de mudança.

A análise do processo de semanticização do gerúndio verificou que os gerúndios adverbiais (OGadvs e CAs), os gerúndios ambíguos e as perífrases são utilizados como estratégias de emolduramento dos participantes e dos eventos de um determinado cenário, atuando aí como elemento que serve para demarcar o relevo, em decorrência da propriedade semântica do aspecto imperfectivo inerente ao gerúndio. A análise dos valores proposicionais das OGadvs mostrou que é necessário reconhecerem-se outros valores proposicionais além dos já tradicionalmente descritos nas gramáticas, entre eles o valor de adição, adversatividade e exclusão. A opção inicial em separar os gerúndios adverbiais em dois grupos mostrou-se bastante efetiva para a análise de sua semântica, uma vez que só assim foi possível detectar o ambiente em que houve o decréscimo previsto no início deste trabalho. Notei que diminui a variedade de relações proposicionais nas OGadvs, mostrando que nelas o 
gerúndio se dessemanticizou, ou seja, para determinadas relações, o gerúndio não é mais utilizado, e, portanto, outras estratégias sintáticas devem entrar em jogo para substituir esta possibilidade. Ao longo dos três séculos, as CAs mantiveram a maior variedade de valores semânticos, mostrando que estas estruturas são bastante conservadoras, o que por sua vez combina com a análise feita no capítulo sobre a discursivização do gerúndio, no qual observei que as CAs estão restritas a contextos formais como as memórias e as cartas de caráter mais oficial. Notou-se também naquele capítulo que as CAs são as estruturas mais dispostas aos processos de lexicalização e sintaticização de novas preposições e conjunções.

Não foi possível identificar pelos dados, se o aumento progressivo das perífrases de gerúndio ao longo dos séculos estaria associado ao decréscimo no uso adverbial do gerúndio. Este talvez seja um filão de pesquisas futuras para aqueles que estudam a emergência das perífrases no português brasileiro - ou manutenção, dependendo do ponto de vista assumido.

Outra questão que fica em aberto refere-se ao decréscimo no uso de construções gerundiais de valor adverbial. Tal fato merece atenção e serve como pista para trabalhos vindouros que analisem as estratégias de junção de enunciados no português brasileiro.

Finalmente, é importante ressaltar que a preocupação em constituir um corpus de análise segundo as propriedades discursivas específicas de cada gênero, atentando tanto para a forma como para o conteúdo, foi pertinente para a análise dos três processos envolvidos, o que prova que o modelo de TDs é bastante viável para a análise de processos de mudança lingüística. 


\section{Referências bibliográficas}

ALLWOOD, Jens (1998): Linguistica Communication as Action and Cooperation, a Study in Pragmatics. Goeteborg: Universidade de Goeteborg. Tese de Doutorado apresentada à Universidade de Goeteborg.

BARBOSA, Afrânio Gonçalves (1999): Para uma História do Português Colonial: aspectos lingüísticos em cartas de comércio. Rio de Janeiro: Faculdade de Letras, UFRJ, Rio de Janeiro. Tese de Doutorado em Letras, Área de Língua Portuguesa.

BARBOSA, Afrânio Gonçalves (2002): "O Contexto dos textos coloniais", em: Alkmin, Tânia Maria (Org.) (2002): Para a História do Português Brasileiro Volume III: novos estudos. Campinas: Humanitas/FFLCH/USP. p. 421-431.

BARBOSA, Afrânio / LOPES, Célia (Orgs., 2002). Queixumes e Bajulações na Imprensa Brasileira do séc . XIX. (digitado)

BARBOSA, Afrânio Gonçalves (2005). Normas cultas e normas vernáculas: a encruzilhada histórico-diacrônica nos estudos sobre português brasileiro. Rio de Janeiro: UFRJ/FAPERJ. (no prelo).

BECHARA, Evanildo (2003). Moderna Gramática Portuguesa. Edição revista e ampliada. Rio de Janeiro: Editora Lucena.

BIBER, Douglas (1993). "Using register-diversified corpora for general language studies". In: Computational Linguistics, Volume 19 , Issue 2. Special issue on using large corpora: II, p. 219- 241.

BITTENCOURT, Regina Lúcia C. L. (2006). No rastro do apagamento: pronomes clíticos nas funções recíproca, reflexiva, apassivadora $e$ indeterminadora. Salvador: UFBA/Instituto de Letras. Projeto de Pesquisa

BÖCKLE, Klaus (1985 [1984]). Para uma análise semântica do emprego dos modos nas orações ilativas iniciadas por DAÍ $Q U E$ e semelhantes correlativos em português contemporâneo. In: Herculano de Carvalho, José G. e SchmidtRadefeldt, Jürgen (1985 [1984], Org.). Estudos de Linguística Portuguesa.Coimbra: Coimbra Editora, p. 17-18. [Colecção Linguística "Coimbra Editora", vol. 1]

BÖCKLE, Klaus, 1983 in Schmidt-Radefeldt, Jürgen, 1983. Portugiesische Sprachwissenschaft. Tübingen: Gunter Narr Verlag. p. 134-135.

BRAGA, Maria Luiza (2002). Processos de redução: o caso das orações de gerúndio in Koch, Ingedore V. (2002). Gramática do Português Falado. Vol. VI. Campinas: Ed. da Unicamp.

BRANDÃO, Claudio (1933). O participio presente e o gerundio em português. Belo Horizonte: Imprensa Oficial do Estado de Minas Gerais.

BUENO, Franciso da Silveira (1958). Gramática Normativa da Língua Portuguesa. São Paulo: Edição Saraiva.

CAMPOS, Odette A. de Souza (1972). Gerundio no portugues : estudo historicodescritivo. São Paulo: FFLCH, USP, tese de doutoramento.

CAMPOS, Odette A. de Souza (1980). O gerúndio no português - estudo historico descritivo. Rio de Janeiro: Presença. 
CÂNDIDO LUSITANO, pseud (1746). O secretario portuguez compendiosamente instruido no modo de escrever cartas... / Francisco José Freire. - Lisboa : Off. de Antonio Izidoro da Fonseca.

CARDEIRA, Esperança (2005). Entre o português antigo e o portugês clássico. Lisboa: Imprensa Nacional / Casa da Moeda. (Filologia Portuguesa).

CASTILHO, Ataliba T. de e PRETI, Dino (Orgs. 1986). A Linguagem Falada Culta na Cidade de São Paulo. Materiais para seu estudo. São Paulo: TAQ/Fapesp, vol. I, Elocuções Formais.

CASTILHO, Ataliba T. de (Orgs. 1987). A Linguagem Falada Culta na Cidade de São Paulo. Materiais para seu estudo. São Paulo: TAQ/Fapesp, vol. II, Diálogos entre dois informantes.

CASTILHO, Ataliba T. de (1992). “Advérbios modalizadores”. In: R. Ilari (org.), Gramática do português falado. Campinas: Editora da UNICAMP, vol. II - Níveis de análise lingüística, p. 213-261.

CASTILHO, Ataliba T. de (1997). A gramaticalização. Estudos Lingüísticos e Literários 19: 25-63.

CASTILHO, Ataliba. T. (Org.) (1998). Para a História do Português Brasileiro: Primeiras Idéias. Vol.1. São Paulo: Humanitas/FAPESP.

CASTILHO, Ataliba T. (2003). Análise multissistêmica das preposições do eixo transversal no Português Brasileiro. Em: [Www.fflch.usp.br/dlcv/lport e 'www.alfal.org/comissaodehistoriadoportugues, acesso em 25.01 .2007 .

CASTILHO, Ataliba T. / RAMOS, Jânia (2003b). Perspectivas sobre a gramaticalização no Projeto para a história do Português Brasileiro. Em: A. T. Castilho (Org. 2003 b, Cap. I).

CASTILHO, Ataliba T. (Org. 2003c). Historiando o Português Brasileiro. Em: 'WwW.alfal.org/comissaodehistoriadoportugues, acesso em 25.01.2007.

CASTILHO, Ataliba T. (2004 a). Diacronia das preposições do eixo transversal no Português Brasileiro. Em: Lígia Negri et alii (Org. 2004). Sentido e Significação. Em torno da obra de Rodolfo Ilari. São Paulo: Contexto, pp. 11-47.

CASTILHO, Ataliba T. (2004 b). Reflexões sobre a teoria da gramaticalização. Contribuição ao debate sobre a teoria da gramaticalização no contexto do PHPB. Em: Wolf Dietrich / Volker Noll (Orgs. 2004). O Português do Brasil. Perspectivas da pesquisa atual. Madrid / Frankfurt: Iberoamericana / Vervuert, pp. 203-230.

CASTILHO, Ataliba T. (2004 c). O problema da gramaticalização das preposições no Projeto Para a História do Português Brasileiro. Estudos Lingüísticos 33 (2004), cd-rom.

CASTILHO, Ataliba T. (2005 em andamento). Funcionalismo, cognitivismo e mudança linguística.

CASTILHO, Ataliba T. (2006a). Abordagem da língua como um sistema complexo. Novas tendências da Lingüística Histórica. São Paulo: FFLCH-USP, digitado.

CASTILHO, Ataliba T. (2006b). "Proposta funcionalista de mudança linguística. Os processos de lexicalização, semanticização, discursivização na constituição das línguas". In: LOBO, Tânia; RIBEIRO, Ilza;CARNEIRO, Zenaide; ALMEIDA, 
Norma. (Orgs.). Para a história do português brasileiro: novos dados, novas análises. Salvador: EDUFBA.

CASTILHO, Ataliba T. de (2006). Abordagem da língua como um sistema complexo, no prelo.

CASTILHO, Ataliba T. de Castilho (no prelo). Gramática Funcional do Português. São Paulo: FFLCH-USP, digitado.

CIRÍACO, Larissa / CANÇADO, M. (2006). "Inacusatividade e Inergatividade no PB”. Cadernos de Estudos Linguísticos, UNICAMP, Campinas, v. 46, n. 2, p. $207-$ 225.

COSERIU, Eugenio (1981), Textlinguistik. Eine Einführung. Tübingen: Gunter Narr.

COSERIU, Eugenio (1988). Sprachkompetenz: Grundzüge der Theorie des Sprechens. Tübingen: Francke. (UTB für Wissenschaft: Uni -Taschenbücher; 1481).

CUNHA, Anna Carla de Oliveira Dini (2005). Uma historia de constituição de gênero discursivo em sala de aula: cartas / Anna Carla de Oliveira Dini Cunha. Campinas: Unicamp, dissertação de mestrado.

CUNHA, Celso / Cintra, Lindley (1985). Nova gramática do português contemporâneo. $2^{\mathrm{a}}$. edição. Rio de Janeiro: Nova Fronteira.

COMPANY COMPANY, Concepción (2005). "Gramaticalización, género discursivo y otras variables em la difusión del cambio sintáctico”. In: Colóquio Del Cid al Quijote. Tübingen: Universität Tübingen.

DIAS, Augusto Epiphanio da Silva (1918). Syntaxe Histórica Portuguesa. Lisboa. Livraria Classica Editora. pp. 247-259.

DUARTE, Maria Eugênia Lamoglia (2002). "Construções com se apassivador e indeterminador”. In: ALKMIN, Tania Maria (Org.). Para a história do português brasileiro. Vol. III: Novos estudos. São Paulo: Humanitas/FFLCH-USP, p. 155176.

DUARTE, Maria Eugênia Lamoglia e LOPES, Célia Regina dos Santos (2002). "Realizaram, realizou-se ou realizamos...?". In: DUARTE, M. E. L. e CALLOU, D. (Org.). Para a história do português brasileiro. Vol IV: Notícia de corpora $e$ outros estudos. Rio de Janeiro: UFRJ-Letras/FAPERJ, 155-166.

GARNER, Samuel (1887a). "The Gerundial Construction in the Romanic Languages". I. Modern Language Notes, Vol. 2, No. 3 (Mar., 1887), pp. 55-59.

GARNER, Samuel (1887b). "The Gerundial Construction in the Romanic Languages". II. Modern Language Notes, Vol. 2, No. 6 (Jun., 1887), pp. 136-141.

GARNER, Samuel (1887c). "The Gerundial Construction in the Romanic Languages”.III. Modern Language Notes, Vol. 3, No. 4 (Apr., 1888), pp. 93-96.

GARNER, Samuel (1887d). "The Gerundial Construction in the Romanic Languages". IV. Modern Language Notes, Vol. 3, No. 5 (May, 1888), pp. 132-135.

GARNER, Samuel (1887e). "The Gerundial Construction in the Romanic Languages". V. Modern Language Notes, Vol. 3, No. 7 (Nov., 1888), pp. 213-219.

GARNER, Samuel (1887f). "The Gerundial Construction in the Romanic Languages". VI. Modern Language Notes, Vol. 3, No. 7 (Nov., 1888), pp. 213-219. 
GARNER, Samuel (1887g). "The Gerundial Construction in the Romanic Languages". VII (Conclusion). Modern Language Notes, Vol. 4, No. 5 (May, 1889), pp. 129137.

HAHN, E. Adelaide (1943). Voice of Non-Finite Verb Forms in Latin and English. In: Transactions and Proceedings of the American Philological Association, Vol. 74, p. 269-306.

HEINE, Bernd / CLAUDI, U. / HÜNNEMEYER, F. (1991). Grammaticalization. A conceptual framework. Chicago: The University of Chicago Press.

HENNE, Helmut / REHBOCK, Helmut (1982): Einführung in die Gesprächsanalyse. Berlin: de Gruyter, (Sammlung Göschen).

HOPPER, Paul J. (1991). “On some principles of grammaticalization”. In: Traugott, Elizabeth Closs \& Heine, Bernd (eds.) Approaches to grammaticalization. Vol.I: Focus on theoretical and methodological issues. Amsterdam/ Philadelphia: John Benjamins Publishing, 1991, p. 17-35.

HUMBOLDT, Wilhelm von (1836 / 1990). Sobre la diversidad de la estructura del lenguaje humano y su influencia sobr el desarrollo espiritual de la Humanidad. Tradução de Ana Agud. Barcelona / Madrid: Anthropos / Ministerio de Educación y Ciencia.

Il secretario alla moda / [Jean Puget de LaSerre]. Portato dal francese da Livio Alessandri . Con un aggiunta di lettere morali e complimenti. All' ... Andrea Dolfino (1673). [S.1.] : Hertz.

Il secretario di corte, o le maniere di scrivere alla moderna / del Signor della Serre. Trasportati nel linguaggio Italiano da Girolamo Brusoni (1675). Venetia.

ILARI, R. et. al. (1990). "Considerações sobre a posição dos advérbios”. In: A. T. Castilho (org.), Gramática do português falado. Campinas: Editora da UNICAMP; São Paulo: FAPESP, vol. I - A ordem, p. 63-142.

ILARI, R. et. al. (1992). "Sobre os adverbios focalizadores". In: R. Ilari (org.), Gramática do português falado. Campinas: Editora da UNICAMP, vol. II - Níveis de análise lingüística, p. 193-212.

JUBRAN, Clélia C. A. S.; H. URBANO; L. L. FÁVERO; I. G. V. KOCH; M. S. RISSO et alii (1992) Organização tópica da conversação. In: R. ILARI (org.) Gramática do Português Falado, 2: Níveis de Análise Lingüística. Campinas: Edunicamp/Fapesp: 357-439.

JUBRAN, Clélia Cândida Spinardi / KOCH, Ingedore G. V. (Orgs. 2006). Gramática do Português Culto Falado no Brasil, vol. I, A construção do texto. Campinas: Editora da Unicamp.

JUBRAN, Clélia C. A. S. (2006a). "Tópicos Discursivos". In: JUBRAN, Clélia Cândida Abreu Spinardi; KOCH, Ingedore Grunfeld Villaça. (Org.). Gramática do Português culto falado no Brasil - Vol 1: Construção do texto falado. 1 ed. Campinas: Editora da UNICAMP, 2006, v. 1, p. 167-215.

KABATEK, Johannes (2003). Tradiciones discursivas y cambio lingüístico. Texto inédito apresentado ao Seminario de Historia de la Lengua Española : nuevas perspectivas. Soria, España, 7-11 de julio de 2003. 
KABATEK, Johannes (s/d). Zur Historizität von Texten. Tübingen: Universität Tübingen. (digitado).

KABATEK, Johannes (2005) "Sobre a historicidade de textos", tradução de José da Silva Simões, em: Linha d'água. 17. São Paulo: USP/APLL.

KABATEK, Johannes (2006): "Tradições discursivas e mudança lingüística". In: LOBO, Tânia, RIBEIRO, Ilza, CARNEIRO, Zenaide, ALMEIDA, Norma. (Orgs.). Para a história do português brasileiro: novos dados, novas análises. Salvador: EDUFBA, 2006.

KATO, Mary et. al. (1993). "Preenchedores sintáticos nas fronteiras de constituintes". In: Gramática do português falado. Campinas: Editora da UNICAMP; São Paulo: FAPESP, vol III - As abordagens, p.235-272.

KEWITZ, Verena (2001). Alguns aspectos da gramaticalização dos verbcos ser e estar no português arcaico. Anais do II Encontro de Estudos Diacrônicos do Português. Araraquara: Unesp, digitado.

KIRK, W. H. (1942). The Syntax of the Gerund and the Gerundive. In: Transactions and Proceedings of the American Philological Association, Vol. 73, p. 293-307.

KIRK, W.H. (1945). The Syntax of the Gerund and the Gerundive II. In: Transactions and Proceedings of the American Philological Association, Vol. 75, p. 166-176.

KOCH, Ingedore G. V. (2006). "Tematização e rematização". In: JUBRAN, Clélia Cândida Abreu Spinardi; KOCH, Ingedore Grunfeld Villaça. (Org.). Gramática do Português culto falado no Brasil - Vol 1: Construção do texto falado. 1 ed. Campinas: Editora da UNICAMP, 2006, v. 1, p. 167-215.

KOCH, Peter / OESTERREICHER, Wulf (1990). Gesprochene Sprache in der Romania: Französisch, Italienisch, Spanisch. Tübingen: Niemeyer. (Romanistische Arbeitshefte, 31).

KOCH, Peter / OESTERREICHER, Wulf (2006). Lengua hablada en la Romania: español, francés , italiano. Tradução de Araceli Lópes Serena.Madrid: Gredos.

LA SERRE, Jean Puget (1659). Le secretaire à la mode : avec un recueil de lettres morales et de nouveaux compliments de la langue française / par le Sieur de la Serre. Rouen: 1659

LA SERRE, Jean Puget (1747). Le secretaire à la mode par le Sieur de la Serre, 1747. Troyers: Garnier.(viseu)

Le Nouveu Secretaire du Cabinet (1739). Amsterdam: Pierre Paupiér.

Le sécrétaire incognu : contenant des letres sur diverses sortes de matières / par B. Pielat. - Amsterdam : Waesberge, 1671.

LEHMANN, Christian (1988). Towards a typology of clause linkage. In Haiman/Thompson (org.). Clause combining in gramar and discourse. Amsterdam/Philadelphia: John Benjamins [Studies in Language, vol. 18].

LEME, Luis Gonzaga Silva (1903-1905). Genealogia Paulistana. 9 vols. São Paulo: Ed. Duprat. versã o दlietrônica http://_www.geocities.com//scamargo/gp/ genpaulistana.htm, acesso em 21.01.2006.

LEME, Pedro Taques de A. Paes. (1980). Nobiliarquia Paulistana Histórica e Genealógica. Belo Horizonte / São Paulo: Editora Itatiaia / Editora da Universidade de São Paulo. 
LEROY, Christian (2005). "Lecture de Thomas Morus ou Le Triomphe de la foi et de la constance de Puget de La Serre (1641): la première tragédie en prose française. In Etudes Epistémè $\mathrm{n}^{\mathrm{o}}$. 2, Lectures Croisées: théâtre 17è - 18è siècles. novembro 2002, p. 250-68, ihttp://www.etudes-episteme.org/ee/articles.php?' lng=fr \&pg=14, acessado em 13.12.2006.

LOBO, Maria (2000). "Aspectos da sintaxe das orações gerundivas do português dialectal" in Actas do Congresso Internacional "500 Anos da Língua Portuguesa no Brasil", Évora: U. Évora.

LOBO, Maria (2001). "Para uma Sintaxe das Orações Causais do Português", in Actas do XVI Encontro Nacional da Associação Portuguesa de Linguística (Coimbra, Setembro 2000), Lisboa, A.P.L.

LOUREDA, Oscar (2006). "Fundamentos de una lingüística del texto real y funcional". In: Coseriu, Eugenio / Loureda, Oscar. Lenguaje y discurso. Pamplona: EUNSA, p. 127-151

LUFT, Celso Pedro (1978). Gramática resumida: explicação da Nomenclatura Gramatical Brasileira. 8a . edição. Porto Alegre: Globo.

LUÍS, Washington. (1980 [1918]) Na Capitania de São Vicente. Belo Horizonte / São Paulo: Ed. Itatiaia / Ed. da Universidade de São Paulo.

MARTINS, Ana Maria (2001). Documentos Portugueses do Noroeste e da Região de Lisboa - Da Produção Primitiva ao Século XVI. Imprensa Nacional - Casa da Moeda. Lisboa. Coleção Filologia Portuguesa.

MATEUS, Maria Helena Mira Mateus et alii (1989). Gramática da Língua Portuguesa. Lisboa: Caminho.

MATEUS, Maria Helena Mira et alii (2003). Gramática da Língua Portuguesa, 2a. ed. Lisboa: Caminho.

MEDINA, Joaquín Garrido (1994). Idioma e información, la lengua española de la comunicación. Madrid: Editorial Síntesis.

MILLER, D. G. (2000). “Gerund and gerundive in Latin”. In: Diachronica, Vol. 17, número 2, p. 293-349(57), John Benjamins Publishing Company. http://Lww.ingentaconnect.com/content/jbp/dia/2000/00000017/00000002/art0000 2 , acesso em 25.01.2007.

MORAES DE CASTILHO, Célia Maria (2005). O processo de redobramento sintático no português medieval. Campinas: Unicamp, tese de doutorado.

MOREIRA, Julio (1907). Estudos de lingua portuguesa. Lisboa. Livraria Classica Editora. 1907, pp. 92-101.

MOTTA, Othoniel (1934). "Um ensaio de syntaxe historica - A evolução do gerundio". In: Revista do Centro de Sciencias, Letras e Artes de Campinas. Ano XIII, fasc. II e III. Campinas, p. 36-49.

MÜLLER-LANCÉ, Johannes (1994). Absolute Konstruktionen vom Altlatein bis zum Neufranzösischen: ein Epochenvergleich unter Berücksichtigung von Mündlichkeit und Schriftlichkeit. Tübingen: Gunter Narr Verlag. (ScriptOralia; 64).

NARDI, Isidoro (1710). Il segretario principiante, ed instruto. Lettere moderne di D. Isidoro Nardi accademico arcade divise in due parti. Venezia. 
NEVES, Maria Helena Moura (2000). Gramática de Usos do Português. São Paulo: Editora da Unesp.

O Secretário Brazileiro, Contendo 306 Modelos de Cartas sobre Todos os Assuntos e um Formulário de Requerimentos e Memoriaes (s/d). Rio de Janeiro / Paris: Typographia H. Garnier.

OESTERREICHER, Wulf (1997). "Cajamarca 1532 - Dialogo y violencia. Los cronistas y la elaboración de una historia andina”. In: Lexis, vol. XXI, n.o 2, 1997.

PARIS, Luis (2003). Gramatical enconding of event relations. Buffalo: Faculty of the Graduate School of State University of New York at Buffalo. Tese de doutorado.

PERINI, Mário A. (2001). Gramática descritiva do português. $4^{\mathrm{a}}$. edição. São Paulo: Editora Ática.

PESSOA, Marlos de Barros (2002). "Da carta a outros gêneros textuais". In: Duarte, Maria Eugênia L. e Callou, Dinah (Org.). Para a história do português brasileiro: Notícias sobre corpora e outros estudos. Rio de Janeiro: UFRJ/FAPERJ, v. IV,

PONS RODRÍGUEZ, Lola (2006). "El peso de la tradición discursiva en un proceso de textualización". In: Colóquio Del Cid al Quijote. Tübingen: Universität Tübingen.

PRETI, Dino / URBANO, Hudinilson (Orgs. 1989). A Linguagem Falada Culta na Cidade de São Paulo. Materiais para seu estudo. São Paulo: TAQ/Fapesp, vol. III, Diálogos entre o Informante e o Documentador.

PUSCH, Claus D. I Andreas Wesch (2003, eds.): Verbalperiphrasen in den (ibero-) romanischen) Sprachen / Perífrasis verbals en les llengües (ibero-)romàniques / Perífrasis verbales en las lenguas (ibero-)románicas. Hamburg: Buske Verlag.

PUSCH, Luise F. (1980). Kontrastive Untersuchungen zum italienischen gerundio : Instrumental- und Modalsätze und das Problem der Individuierung von Ereignissen. Tuebingen : Niemeyer, 1980.

RAIBLE, Wolfgang (1992). Junktion - Eine Dimension der Sprache und ihre Realisierungsformen zwischen Aggregation und Integration. Heidelberg: Carl Winter. Sitzungsberichte der Heidelberger Akademie der Wissenschaften, Philosophisch-historische Klasse, Jg. 1992, Bericht 1.

RAVIZZA, João P.e (1958). Gramática Latina. 14a . edição. Niteroi: Escola Industrial Dom Bosco.

REESE, Susanne (1991). Gerundialkonstruktionen im Spanischen: Ansatz zu einer grammatisch-pragmatischen Beschreibung. Tübingen: Narr, 1991 (Tübinger Beiträge zur Linguistik; 349).

RENDON, José Arouche de Toledo (1842). "Memória sobre as aldeas de indios da província de S. Paulo”. In: RIHGB, Rio de Janeiro, t. 4, n. 13, 1842.

RUDOLPH, Elisabeth (1955). Zur Syntax der Konsekutivsätze im Spanischen und Portugiesischen. Tese de doutorado, Berlin: Freie Universität Berlin, Philosophische Fakultät. [mimeografado]

RUDOLPH, Elisabeth (1973. Das finale Satzgefüge als Informationskomplex : Analysen aus der spanischen Literatursprache. Tübingen: Niemeyer, 1973. (Zeitschrift für romanische Philologie : Beih. ; 138) 
SAID ALI, M (1975 [1920]). Investigações Filológicas. Com um estudo de Evanildo Bechara. Rio de Janeiro, GRIFO/MEC, pp. 45-52

SCHULTE, Kim (2004). Pragmatica Causation in the Rise of the Romance Preposicional Infinitive. A statistically-based study with special reference to Spanish, Portuguese and Romanian. Tese de doutorado. Cambridge: Trinity College, Departament o Spanish and Portuguese.

SILVA, R. V. M (1996). “A variação haver/ter”. In: SILVA, R. V. M. (org.) A carta de Caminha - Testemunho lingüístico de 1500, Salvador, EDUFBA.

SILVA, R. V. M. (1997). "Observações sobre a variação no uso dos verbos ser, estar, haver, ter no galego-português ducentista". In: Estudos Lingüísticos e Literários, 19. Salvador: UFBA.

SILVA, Rosa Virgínia Mattos (2002). "Reflexões e questionamentos sobre a constituição de corpora para o Projeto Para a História do Português Brasileiro". In: Dinah Callou; M. E. Duarte. (Org.). Para a história do português brasileiro: Notícias sobre corpora e outros estudos. Rio de Janeiro: UFRJ/FAPERJ, v. IV, p. 17-28.

SIMÕES, José da Silva (2006). "Variação das orações reduzidas de gerúndio e orações desenvolvidas conjuncionais. Sintaticização, semanticização e discursivização das orações reduzidas de gerúndio no português brasileiro". In: LOBO, Tânia, RIBEIRO, Ilza, CARNEIRO, Zenaide, ALMEIDA, Norma. (Orgs.). Para a história do português brasileiro: novos dados, novas análises. Salvador: EDUFBA, 2006.

SIMÕES, José da Silva / KEWITZ, Verena (2005a) . "A constituição de corpora diacrônicos do Português Brasileiro e seus traços lingüístico-discursivos". In: 6. Deutscher Lusitanistentag an der Universität Leipzig -15. bis 18. September 2005, digitado.

SIMÕES, José da Silva / KEWITZ (2006). "Traços lingüístico-discursivos em corpora do português brasileiro". In: Estudos Lingüísticos XXXV, p. 1018-1027.

SIMÕES, José da Silva / KEWITZ, Verena (2006a). Cartas paulistas dos séculos XVIII e XIX: uma contribuição para os corpora do PHPB (org., ed. e rev.). São Paulo: Humanitas / FFLCH / USP. (CD-Rom)

SKERLJ, Stanko (1926). Syntaxe du participe présent et du gérondif en vieil Italien. Avec une introduction sur l'emploi du participe présent et de l'ablativ du gérondif en Latin. Paris: Librairie Ancienne Honoré Champion.

SOBRINO, Francisco Secretario español enseñando la manera de escrivir cartas españolas, segun el estilo moderno, explicadas en francés. - Brusellas : Francisco Foppens, 1747. - $1 \mathrm{v}$.

SPINA, S. (1994): Introdução à edótica. 2. ed. rev. e aum. São Paulo: Ars Poética/Edusp.

TALMY, Leonard (2000). Toward a Cognitive Semantics. Cambridge / London: The MIT Press, 2 volumes.

TARALLO, Fernando et al. (1990). "Rupturas na ordem de adjacência canônica no português falado". In: A. T. Castilho (org.). Gramática do português falado. Campinas: Editora da UNICAMP / FAPESP, vol. I - A ordem, p. 29-62. 
TAUNAY, Affonso de E. (1975 [1920]). "Frei Gaspar da Madre de Deus (1715-1800) - Súmula Biográfica". In: Madre de Deus, Gaspar da, frei (1975 [1797]). Memórias para a História da Capitania de São Vicente. Belo Horizonte / São Paulo: Ed. Itatiaia / Ed. da Universidade de São Pualo, p. 7-23.

TIN, Emerson (2005, org). A arte de escrever cartas. Anônimo de Bolonha, Erasmo de Rotterdam, Justo Lípsio. Campinas, SP: Editora da UNICAMP.

TORREGO, Leonardo Gómez (2005). "La norma como herramienta para la reflexión gramatical". In Revista de Filología Española, Tomo LXXXV, fascículo $1^{\circ}$, Madrid, Consejo Superior de Investigaciones Científicas, Instituto de la Lengua Española.

TRAVAGLIA, Luiz Carlos . O relevo no processamento da informação (Cap. 5 - 2a parte). In: JUBRAN, Clélia Cândida Abreu Spinardi; KOCH, Ingedore Grunfeld Villaça. (Org.). Gramática do Português culto falado no Brasil - Vol 1: Construção do texto falado. 1 ed. Campinas: Editora da UNICAMP, 2006, v. 1, p. 167-215. 
This document was created with Win2PDF available at http://www.win2pdf.com.

The unregistered version of Win2PDF is for evaluation or non-commercial use only.

This page will not be added after purchasing Win2PDF. 